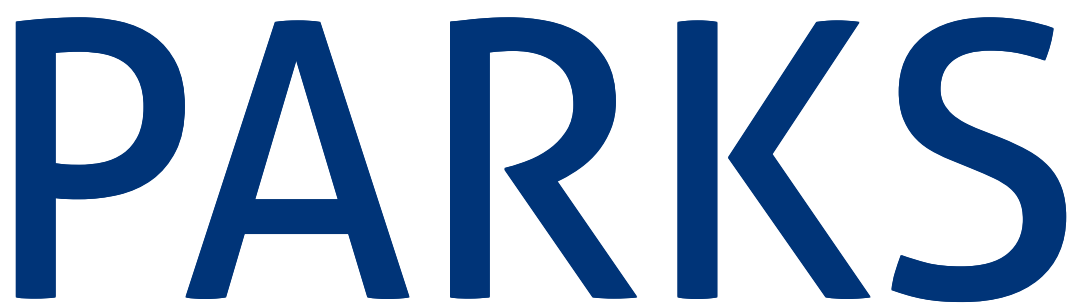

The International Journal of

\title{
Protected Areas and Conservation
}

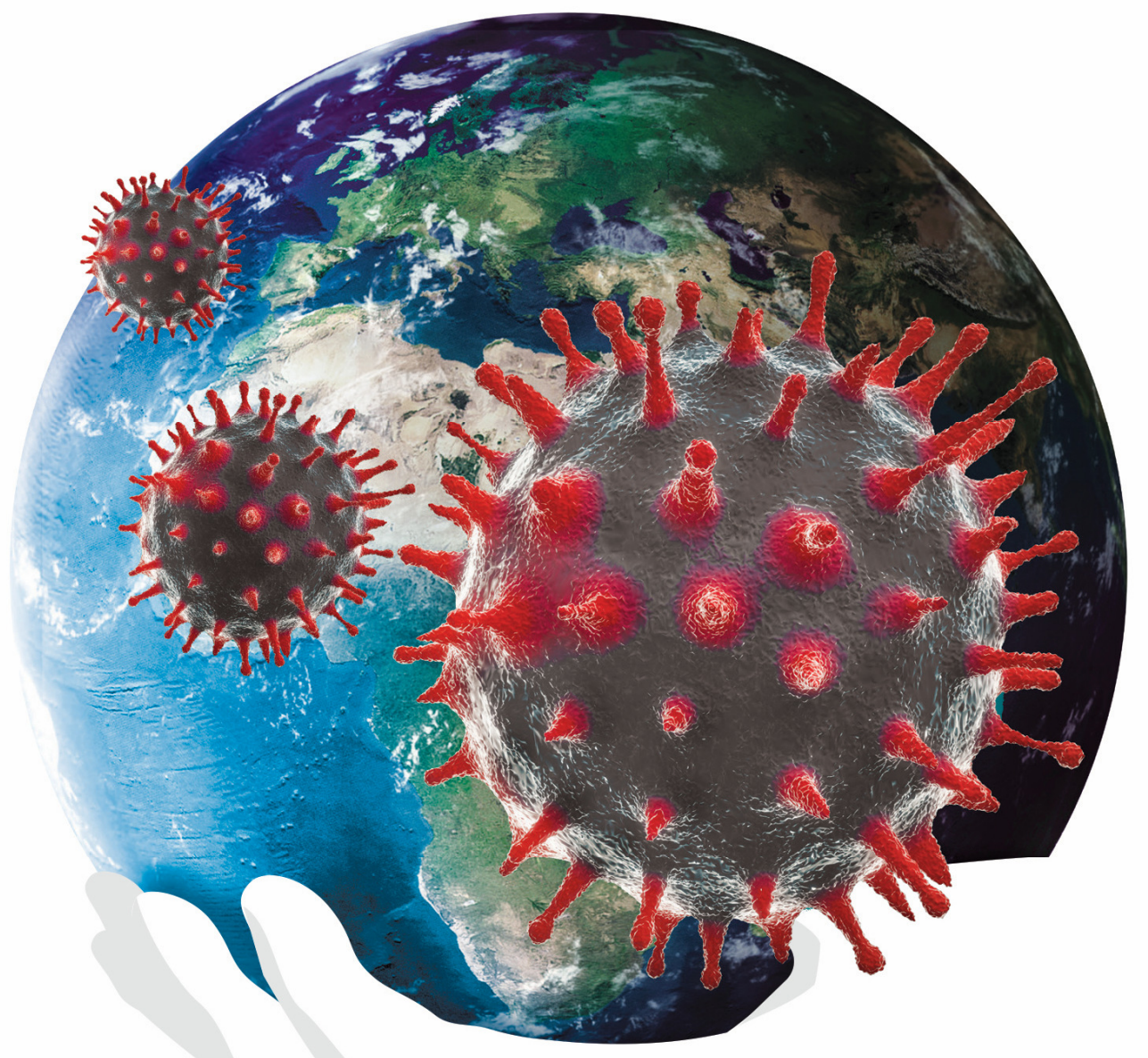

Developing capacity for a protected planet 


\section{IUCN PROTECTED AREA DEFINITION, MANAGEMENT CATEGORIES AND GOVERNANCE TYPES}

IUCN defines a protected area as:

A clearly defined geographical space, recognised, dedicated and managed, through legal or other effective means, to achieve the long-term conservation of nature with associated ecosystem services and cultural values.

The definition is expanded by six management categories (one with a sub-division), summarized below.

la Strict nature reserve: Strictly protected for biodiversity and also possibly geological/ geomorphological features, where human visitation, use and impacts are controlled and limited to ensure protection of the conservation values.

Ib Wilderness area: Usually large unmodified or slightly modified areas, retaining their natural character and influence, without permanent or significant human habitation, protected and managed to preserve their natural condition.

II National park: Large natural or near-natural areas protecting large-scale ecological processes with characteristic species and ecosystems, which also have environmentally and culturally compatible spiritual, scientific, educational, recreational and visitor opportunities.

III Natural monument or feature: Areas set aside to protect a specific natural monument, which can be a landform, sea mount, marine cavern, geological feature such as a cave, or a living feature such as an ancient grove.

IV Habitat/species management area: Areas to protect particular species or habitats, where management reflects this priority. Many will need regular, active interventions to meet the needs of particular species or habitats, but this is not a requirement of the category.

V Protected landscape or seascape: Where the interaction of people and nature over time has produced a distinct character with significant ecological, biological, cultural and scenic value: and where safeguarding the integrity of this interaction is vital to protecting and sustaining the area and its associated nature conservation and other values.

VI Protected areas with sustainable use of natural resources: Areas which conserve ecosystems, together with associated cultural values and traditional natural resource management systems. Generally large, mainly in a natural condition, with a proportion under sustainable natural resource management and where low-level nonindustrial natural resource use compatible with nature conservation is seen as one of the main aims.

The category should be based around the primary management objective(s), which should apply to at least three-quarters of the protected area - the 75 per cent rule.

The management categories are applied with a typology of governance types - a description of who holds authority and responsibility for the protected area.

IUCN defines four governance types.

Governance by government: Federal or national ministry/ agency in charge; sub-national ministry/agency in charge; government-delegated management (e.g. to NGO)

Shared governance: Collaborative management (various degrees of influence); joint management (pluralist management board; transboundary management (various levels across international borders)

Private governance: By individual owner; by non-profit organisations (NGOs, universities, cooperatives); by forprofit organsations (individuals or corporate)

Governance by indigenous peoples and local communities: Indigenous peoples' conserved areas and territories; community conserved areas - declared and run by local communities

For more information on the IUCN definition, categories and governance type see the 2008 Guidelines for applying protected area management categories which can be downloaded at: www.iucn.org/pa_categories

\section{IUCN WCPA'S BEST PRACTICE PROTECTED AREA GUIDELINES SERIES}

IUCN-WCPA's Best Practice Protected Area Guidelines are the world's authoritative resource for protected area managers. Involving collaboration among specialist practitioners dedicated to supporting better implementation in the field, they distil learning and advice drawn from across IUCN. Applied in the field, they are building institutional and individual capacity to manage protected area systems effectively, equitably and sustainably, and to cope with the myriad of challenges faced in practice. They also assist national governments, protected area agencies, nongovernmental organisations, communities and private sector partners to meet their commitments and goals, and especially the Convention on Biological Diversity's Programme of Work on Protected Areas.

A full set of guidelines is available at: www.iucn.org/ pa_guidelines

Complementary resources are available at: www.cbd.int/protected/tools/

Contribute to developing capacity for a Protected Planet at: www.protectedplanet.net/ 


\section{IUCN}

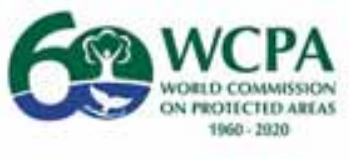

PARKS is published electronically twice a year by IUCN's World Commission on Protected Areas. For more information see: www.parksjournal.com

PARKS is published to strengthen international collaboration in protected area development and management by:

- $\quad$ exchanging information on practical management issues, especially learning from case studies of applied ideas;

- $\quad$ serving as a global forum for discussing new and emerging issues that relate to protected areas;

- $\quad$ promoting understanding of the values and benefits derived from protected areas to communities, visitors, business and others;

- $\quad$ ensuring that protected areas fulfill their primary role in nature conservation while addressing critical issues such as ecologically sustainable development, social justice and climate change adaptation and mitigation;

- changing and improving protected area support and behaviour through use of information provided in the journal; and

- $\quad$ publishing scientific research relevant to IUCN's work on protected areas.

Managing Editor: Marc Hockings, Australia: Emeritus Professor, University of Queensland; IUCN WCPA Vice-Chair for Science and Management of Protected Areas; Honorary Fellow, UNEP-World Conservation Monitoring Centre

Co-Editors: Helen Newing, Bas Verschuuren, Olivier Chassot, John Waithaka, Pamela Wright, Jonas Geldmann Statistical co-editor Allan Lisle

\section{Editorial Board Members}

IUCN

Trevor Sandwith, Switzerland: Director, IUCN Global Protected Areas Programme

Dr Tom Brooks, Switzerland: Head, IUCN Science \& Knowledge Unit

IUCN-WCPA Steering Committee Members

Cyril Komos, USA: IUCN WCPA Vice-Chair for World Heritage

Dr Kathy MacKinnon, UK: Chair IUCN WCPA

Dr John Waithaka, Kenya: Regional Vice-Chair for Eastern and Southern Africa

Nigel Dudley, UK: Vice-Chair for Natural Solutions

Dr Thora Amend, Peru: Vice-Chair for Governance

\section{External Experts}

Dr Ernesto Enkerlin Hoeflich, Mexico: Dean for Sustainable Development at Monterrey Tech; former Chair of IUCN WCPA

Nikita (Nik) Lopoukhine, Canada: Former Director General of National Parks, Parks Canada; former Chair of IUCN WCPA

Professor B.C. Choudhury, India: Retired Scientist (Endangered Species Management Specialist), Wildlife Institute of India; Coordinator of IUCN's National Committee in India

Dr Helen Newing, UK: Formerly of the Durrell Institute of Conservation and Ecology (DICE), University of Kent
Dr Kent Redford, USA: Former Director of the Wildlife Conservation Society (WCS) Institute and Vice President, Conservation Strategies at the WCS in New York; principal at Archipelago Consulting

Sue Stolton, UK: Partner Equilibrium Research, IUCN WCPA

Dr Bas Verschuuren, The Netherlands: Associate Researcher: Department of Sociology of Development and Change, Wageningen University ; Co-Chair, IUCN WCPA Specialist Group on Cultural and Spiritual Values of Protected Areas

Dr Eduard Müller, Costa Rica: Rector, Universidad para la Cooperación Internacional

Olivier Chassot, Costa Rica: Chief Operating Officer, Shellcatch Inc.

Dr Pamela Wright, Canada: Associate Professor, University of Northern British Columbia

Dr Jonas Geldmann, Denmark: Center for Macroecology, Evolution and Climate, University of Copenhagen

Thanks to: Mariart for layout advice and front cover picture production. Patricia Odio Yglesias and Sarah LaBrasca for abstract translations. Caroline Snow for proofreading. And to all the reviewers who so diligently helped in the production of this issue. 


\section{IUCN}

The designation of geographical entities in this journal, and the presentation of the material, do not imply the expression of any opinion whatsoever on the part of IUCN concerning the legal status of any country, territory, or area, or of its authorities, or concerning the delimitation of its frontiers or boundaries.

The views expressed in this publication do not necessarily reflect those of IUCN.

IUCN does not take any responsibility for errors or omissions occurring in the translations in this document whose original version is in English.

Published by: $\quad$ IUCN, Gland, Switzerland

Copyright: $\quad$ C 2021 International Union for Conservation of Nature and Natural Resources

Reproduction of this publication for educational or other non-commercial purposes is authorized without prior written permission from the copyright holder provided the source is fully acknowledged.

Reproduction of this publication for resale or other commercial purposes is prohibited without prior written permission of the copyright holder.

Citation:

IUCN WCPA (2021). PARKS. The International Journal of Protected Areas and Conservation, Volume 27 (Special Issue), Gland, Switzerland: IUCN.

ISSN:

ISSN 2411-2119 (Online), ISSN 0960-233X (Print)

DOI:

10.2305/IUCN.CH.2021PARKS-27SI.en

Cover image:

Mariart Design Studio

Back cover:

Little Red Flying Fox Pteropus scapulatus, Australia @ Gary Tabor

Editing:

Adrian Phillips and Brent A. Mitchell

Layout by:

Marc Hockings, IUCN WCPA

Available from:

IUCN (International Union for Conservation of Nature)

Global Programme on Protected Areas

Rue Mauverney 28

1196 Gland

Switzerland

Tel +41229990000

Fax +41229990002

parksjournal.com

iucn.org/theme/ protected-areas/ publications/ parks-journal 


\title{
PARKS: THE INTERNATIONAL JOURNAL OF PROTECTED AREAS AND CONSERVATION
}

\author{
Special Issue on COVID-19 and Protected and Conserved Areas \\ edited by Adrian Phillips and Brent A. Mitchell, IUCN World \\ Commission on Protected Areas
}

Managing Editor: Marc Hockings

editor@parksjournal.com

School of Earth and Environmental Sciences, University of Queensland, St Lucia,

Queensland 4072, Australia.

\section{CONTENTS}

A global tragedy in search of answers: Editors' introduction

Brent A. Mitchell and Adrian Phillips

Nature and humanity

Carlos Manuel Rodríguez

Drivers and causes of zoonotic diseases: an overview

Mariana Napolitano Ferreira, Wendy Elliott, Rachel Golden Kroner, Margaret F. Kinnaird, Paula R. Prist, Paula Valdujo and Mariana M. Vale

There's nothing new under the sun - lessons conservationists could learn from previous pandemics Olivier Hymas, Bruna Rocha, Natalia Guerrero, Mauricio Torres, Kevin Ndong and Gretchen Walters

Impacts of COVID-19 on protected and conserved areas: a global overview and regional perspectives John Waithaka, Nigel Dudley, Mónica Álvarez, Stanley Arguedas Mora, Stuart Chapman, Penelope Figgis, James Fitzsimons, Susan Gallon, Thomas N.E. Gray, Minsun Kim, M.K.S. Pasha, Scott Perkin, Paula Roig-Boixeda, Claudine Sierra, Allan Valverde and Mike Wong

COVID-19, Indigenous peoples, local communities and natural resource governance 57 Gretchen Walters, Neema Pathak Broome, Marina Cracco, Tushar Dash, Nigel Dudley, Silvel Elías, Olivier Hymas, Sangeeta Mangubhai, Vik Mohan, Thomas Niederberger, Christy Achtone Nkollo Kema Kema, Appolinaire Oussou Lio, Njaka Raveloson, June Rubis, S.A.R. Mathieu Toviehou and Nathalie Van Vliet

Urban parks and protected areas: on the front lines of a pandemic

Greg Moore and Jo Hopkins

Marine protected and conserved areas in the time of COVID 85

Carol Phua, Dominic A. Andradi-Brown, Sangeeta Mangubhai, Gabby N. Ahmadia, Shauna L. Mahajan, Kirk Larsen, Stephen Friel, Russell Reichelt, Marc Hockings, David Gill, Laura Veverka, Richard Anderson, Lovasoa Cédrique Augustave, Awaludinnoer, Tadzio Bervoets, Kitty Brayne, Rili Djohani, Joan Kawaka, Fabian Kyne, January Ndagala, Jenny Oates, Kennedy Osuka, Mosor Prvan, Nirmal Shah, Fabio Vallarola, Lauren Wenzel, Hesti Widodo and Sue Wells

Tourism in protected and conserved areas amid the COVID-19 pandemic 103 Anna Spenceley, Steve McCool, David Newsome, Ana Báez, James R. Barborak, Clara-Jane Blye, Kelly Bricker, Hery Sigit Cahyadi, Katherine Corrigan, Elizabeth Halpenny, Glen Hvenegaard, Delphine Malleret King, Yu-Fai Leung, Ante Mandić, Robin Naidoo, Dominik Rüede, James Sano, Mahmoud Sarhan, Veronica Santamaria, Thiago Beraldo Sousa and AnneKathrin Zschiegner

Impact of the COVID-19 pandemic on rangers and the role of rangers as a planetary health service 119 Rohit Singh, Chris Galliers, William Moreto, James Slade, Barney Long, Hamera Aisha, Andrew Wright, Falon Cartwright, Atul Deokar, Alexander Wyatt, Deepali Deokar, Rungnapa Phoonjampa, Eddie Smallwood, Rizwana Aziz, Amon Koutoua Benoit, Renata Cao, Sean Willmore, Deepani Jayantha and Sonali Ghosh 
COVID-era policies and economic recovery plans: are governments building back better for protected and conserved areas? 135

Rachel Golden Kroner, Edward B. Barbier, Olivier Chassot, Sunita Chaudhary, Lorenzo Cordova Jr, Annabelle CruzTrinidad, Tracey Cumming, Jennifer Howard, Charlotte Karibuhoye Said, Zoltan Kun, Angelique Ogena, Florence Palla, Rodrigo Samayoa Valiente, Sebastian Troëng, Allan Valverde, Ramitha Wijethunga and Michael Wong

Building sustainable finance for resilient protected and conserved areas: lessons from COVID-19 ..

Tracey Cumming, Andrew Seidl, Lucy Emerton, Anna Spenceley, Rachel Golden Kroner, Yvette Uwineza and Hugo van Zyl

Land use-induced spillover: priority actions for protected and conserved area managers

Jamie K. Reaser, Gary M. Tabor, Daniel J. Becker, Philip Muruthi, Arne Witt, Stephen J. Woodley, Manuel Ruiz-Aravena, Jonathan A. Patz, Valerie Hickey, Peter J. Hudson, Harvey Locke and Raina K. Plowright

Reframing the problem and solutions: twelve perspectives from around the world

Adrian Phillips, Brent A. Mitchell, Gilles Boeuf, Emily Bohobo N’dombaxe Dola, Yolanda Kakabadse, Ashok Khosla, Richard Louv, Freya Matthews, Elizabeth Maruma Mrema, Mark Poznansky, Fiona Reynolds, Mary Robinson, Richard Roberts, Juan Manuel Santos and Josefa Cariño Tauli

Vital sites: protected and conserved areas offer solutions for building back better .193 Bruno Oberle, Kathy MacKinnon and Trevor Sandwith

Editors' postscript

Adrian Phillips and Brent A. Mitchell 


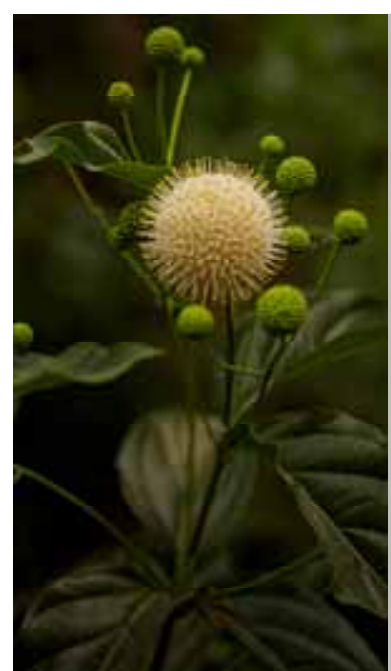

\title{
A GLOBAL TRAGEDY IN SEARCH OF ANSWERS: EDITORS' INTRODUCTION
}

\author{
Brent A. Mitchell1,2 and Adrian Phillips ${ }^{2}$ \\ bmitchell@qlf.org; adrian.phillips@gmx.com \\ ${ }^{1}$ QLF Atlantic Center for the Environment \\ ${ }^{2}$ IUCN World Commission on Protected Areas
}

\begin{abstract}
This introduction provides an overview and commentary on the papers in a special issue of PARKS, which is devoted to the impact and implications of COVID-19 on the world's protected and conserved areas. It describes how 11 peerreviewed papers and 14 essays have brought together the knowledge and findings of numerous experts from all parts of the world, supported by several wide-ranging surveys. The resulting global synthesis of experience answers some key questions: why did the pandemic occur? what has it meant for protected and conserved areas, and the people that depend on them? what were the underlying reasons for the disaster we now face? and how can we avoid this happening again? We applaud the international effort to combat the disease but suggest that humanity urgently needs to devote as much effort to addressing the root causes of the pandemic - our fractured relationship to nature. Unless we repair it, humanity will face consequences even worse than this pandemic.
\end{abstract}

Key words: Pandemic, COVID-19, protected and conserved areas, expert knowledge, global synthesis

\section{INTRODUCTION TO THE SPECIAL ISSUE}

After every personal tragedy - a sudden death, a car accident or a disastrous fire - we ask these questions: "What happened?", "Why did it happen?" and "How can we avoid it happening again"? We ask them too of larger scale disasters: a plane crash, a flood or the collapse of a community building. And, of course, they are the questions we have all been asking about COVID-19. People clamour to know more about the causes, consequences and implications of this devastating global pandemic.

Volumes have already been written in answer to these questions. We have learnt a remarkable amount about COVID-19 in a very short time. People working in many branches of science and all corners of the world have gathered and analysed information with astonishing speed. It is now abundantly clear that this worldwide tragedy has come about because of our neglect and abuse of nature. If we are to avoid repeated experiences of this kind, we will need to reconnect to the natural world. Hence the justification for focusing on how the COVID-19 pandemic, and the measures taken to combat it, have affected protected and conserved areas (PCAs). Such places are a practical expression of humanity's need for nature, and they should be at the heart of recovery plans for the future. This special issue of
PARKS looks at the pandemic from the point of view of those who work in this field, drawing on their experience to explain how the pandemic came about, what has been its impact and how we can make sure that something like it does not happen again.

\section{This special issue of PARKS}

The idea of a special issue of PARKS on COVID-19 emerged during the writing of an essay on this topic in the May number (Hockings et al., 2020). The essay provided a snap-shot of the impact of the pandemic on PCAs at that time, and concluded with a Call for Action. However, it could not do justice to the vast range of material that was rapidly emerging on the topic from dozens of perspectives. The Chair of IUCN's World Commission on Protected Areas (WCPA) suggested that an issue of PARKS should be dedicated to this topic alone - and we were honoured to be invited to edit it.

Working with leaders in WCPA, we set out to develop a structure and quickly decided that the issue should be built around three themes. Each theme is supported by several papers:

- The background to the pandemic. The first paper explains how the abuse of nature can give rise to zoonotic epidemics and pandemics like COVID-19. A 
second takes an historical perspective and reminds us that the current pandemic is not the first that raises questions about our relationship with the natural world;

- The impact of COVID-19 on PCAs, and on the people and livelihoods dependent on them. A global overview draws together several regional studies. Then five papers explore the impact of COVID-19 on the urban and marine environments, on protected area tourism as the most affected economic sector, and on Indigenous peoples and rangers - the communities that have found themselves in the frontline; and

- How we recover from the damage done to nature and avoid another catastrophe of this kind. Three papers address the policy, financial and scientific lessons we should learn, and the actions that are needed to create a more resilient future after the worst of the COVID-19 pandemic is put behind us.

For each of these eleven peer-reviewed papers, we identified lead authors, experts who are well known in their field, and invited them in turn to bring in a wide range of co-authors to reflect a diversity of perspectives from around the world. Some of the lead authors also drew together collections of case studies. Others were able to draw on regional surveys of PCA managers, and global surveys of rangers and of Indigenous peoples. In

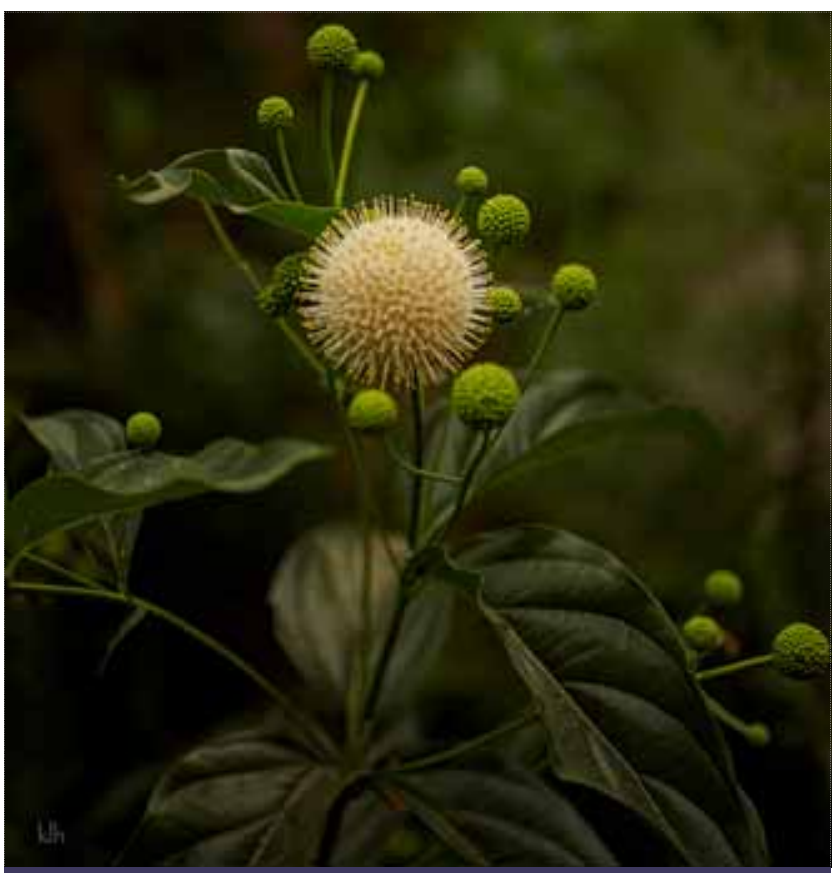

The SARS-CoV-2 virus came from nature, and only by restoring our relationship with nature can we reduce risk of such pandemics in future. Button Bush (Cephalanthus occidentalis) @ Ken Hassman all, nearly 150 lead authors and co-authors have contributed to this special issue; and each paper has benefited from two peer reviews.

We also invited a number of leading individuals from across the world, with very different backgrounds and perspectives, to reflect on the pandemic and its significance for life on Earth, challenging them to consider the deeper meaning of the COVID-19 disaster. Their 12 essays make fascinating reading. And finally, mindful of the role of international bodies and the importance of several international conferences to be held in 2021, we invited the new Chairperson and CEO of the Global Environment Facility and the incoming Director General of IUCN to introduce and round off respectively the whole issue with their own reflections.

As editors, we are deeply grateful to all those who have contributed so much time and effort to ensure the success of this project. This issue is the product of a team effort for a common purpose. It represents a global synthesis of current knowledge about a topic that reveals humanity's need to rebuild its relationship to nature. And it enables us to answer the key questions that follow.

\section{Why did COVID-19 happen?}

Like many pandemics, COVID-19 was caused by humanity's abuse of nature: Mariana Napolitano Ferreira brought together a group of experts to identify the drivers behind the pandemic. Their article describes how unregulated land use change, intensified agriculture, livestock production, the unregulated wildlife trade and wild meat consumption make it possible for zoonotic diseases (zoonoses) to emerge jumping from wildlife or domesticated livestock into human populations. The stresses brought about by climate change create the circumstances in which such 'spillover' events become more likely. The article also shows how PCAs have helped to avoid dangerous land use change and so reduce the probability that new zoonoses will emerge. However, controls on many aspects of the extraction, consumption and trade in wildlife are also essential.

There are many precedents for COVID-19: the current pandemic is often called 'unprecedented', but it is far from being the first such event in history. Outbreaks of smallpox, bubonic plague, influenza and other diseases have wrought havoc at a regional or global scale on many occasions in the past. Olivier Hymas and colleagues argue that past pandemics - of domesticated animals as well as diseases affecting humans - have shaped land use patterns in some countries to this day, 
especially in tropical countries. They point out that Europeans, often themselves carriers of diseases, failed to appreciate that many areas which they 'discovered' and believed to be pristine - and therefore suitable for dedicating to conservation - were in fact landscapes that still bore the mark of a disastrous disease that had previously driven out or destroyed the Indigenous human populations.

\section{What have been the impacts of COVID-19 on PCAs and the peoples and economies associated with them?}

The impacts of COVID-19 have been felt in PCAs all round the world: the paper by J ohn Waithaka and Nigel Dudley, prepared with the help of co-authors worldwide, draws together the results of surveys of COVID-19's impact on many hundreds of PCAs in all regions. It is the most complete digest of its kind. It is complemented by another, coordinated by Carol Phua, which draws on 15 case studies to review the impact of COVID-19 on marine protected areas. Although each terrestrial and marine region has had a distinctive experience, and the news is not universally bad, there are common themes: sudden and massive reductions in visitor numbers (except near cities); associated losses of income for PCAs and for the economies linked to them, as income from tourism collapsed and government support was cut; reports of more incursions and illegal extraction of natural resources; the diversion of protected areas managers from their usual duties; and destabilising relationships between PCAs and Indigenous and local communities.

The impacts occurring in PCAs near cities have been of a different kind: a set of nine case studies of PCAs, drawn together by Greg Moore and Jo Hopkins from their network of urban experts, tells a distinctive story for PCAs in or near major cities. Many such places experienced a surge in demand from urban dwellers who found there a refuge from the fear of the virus and the lockdown measures that came with it. Some visitors discovered nature for the first time; and some found it hard to adapt their behaviour to the needs of the parks. But most park managers were responsive and nimble, engaged with public health officials, experienced new levels of visitation, welcomed new visitors and implemented innovative management practices.

Tourism has borne the brunt of the economic impact of the pandemic: The way the pandemic has affected tourism in PCAs, and what this means for PCAs, is explored in greater detail in the article by Anna Spenceley and her team. This paper documents experience from eight country case studies, telling of the dramatic and often devastating effect of the pandemic on protected area tourism economies, especially those in developing countries where international tourism revenue had previously supported many jobs and conservation operations in remote places of great wildlife importance and scenic beauty.

Ranger services have been thrown into the frontline: Rohit Singh and colleagues from the International Ranger Federation describe the impact on the ranger service, based on a global survey and two national surveys, that tell a similar story but from the standpoint of a group who have been in the frontline fighting the pandemic. Some rangers lost their lives to the pandemic, some lost their jobs, and many found their health and their livelihoods had been put at risk. Many have had to take on new roles as public health advocates or field staff in their dealings with visitors and local people. Rangers, too, report increased pressures on many PCAs and the difficulty they have had in maintaining their normal duties and good relations with local communities living in or near park areas.

The pandemic has hit those who most depend on nature and natural resources the hardest: nearly all the papers report that local people living in and around PCAs have been worst affected: in health terms, many have been put at great personal risk as they often live far from lifesaving health services; employment and income opportunities have gone; and sometimes incomers have arrived or returned from cities to compete for the forest, wildlife and fishery resources upon which the resident communities depend. Gretchen Walters and her colleagues describe the experience of Indigenous people and local communities under the stress of the pandemic, as collected through a novel form of survey using the quantitative analysis of stories told by interviewees in eight case studies. They found that the most resilient societies in the face of the adverse impacts of the pandemic were those that depended least on external markets for their livelihoods, that were most empowered in terms of their rights and where strong social structures endured.

Necessity has been the mother of invention: the unexpected and often immense challenge that the pandemic has posed for PCAs, their staffs, and the economies and the people that depend on them, has meant that PCA employees, local communities and businesses have often had to adapt to survive. Many rangers have had to explore alternative ways of working, delivering interpretative messages remotely for example, and to take on a new role as advocates of public health measures. Many PCAs have delivered 
innovative ways of engaging visitors, opening up to new audiences and putting safety measures in place. Some governments and agencies have tapped into or created new sources of funding. Some tourist operators have been able to develop new products, even when numbers of visitors crashed. Some local communities have found new sources of work or income. While much of this is of a stop-gap nature designed to keep operations going through the crisis, many lessons have been learnt which can be applied when the pandemic recedes.

The pandemic has thrown into sharp relief many problems that were already well known: several articles point out that PCAs have long suffered from a lack of resources and weak political support. To that extent, the crisis has accentuated a pre-existing problem in many places. That is why a 'return to normal' is not in most cases the answer and recovery to the status quo ante is not enough. If any good is to come out of this disastrous experience, it would be a resolve to place PCAs on a more resilient footing.

But it has also revealed the need that people have for nature: the experience of COVID-19 has brought home to people that we all depend on nature. That may be self -evident in the case of Indigenous peoples and local communities living alongside remote PCAs who depend on natural resources to survive. But it is also true that millions who live in cities have become more aware of the natural world around them as lockdowns have stilled the hubbub of urban life. As Dame Fiona Reynolds put it: "If we ever questioned the dependence of the human spirit on nature, fresh air and beauty the coronavirus crisis has surely laid an end to it. This global experience has shown that humanity needs nature, a foundation upon which we can hope to build a renewed respect for it."

\section{How did it happen?}

A crisis of interconnected crises: The contents of this issue point to a simple fact: People and nature are at a crisis point. The word pandemic comes from the Greek pan, or "all", plus dèmos, "the people". While the impact of COVID-19 has been devastating, it takes place as other kinds of pan-demics are also sweeping the world: climate change, biodiversity loss and ecosystem change on a massive scale. While many papers and essays here speak to the biodiversity and ecosystem crises (particularly Reaser, Tabor, and colleagues), this issue of PARKS does not provide a lot of information on climate change. This is not to understate its importance but rather reflects the great many other topics we needed to cover in this volume. Our essayists point out again and again that all of these global crises are

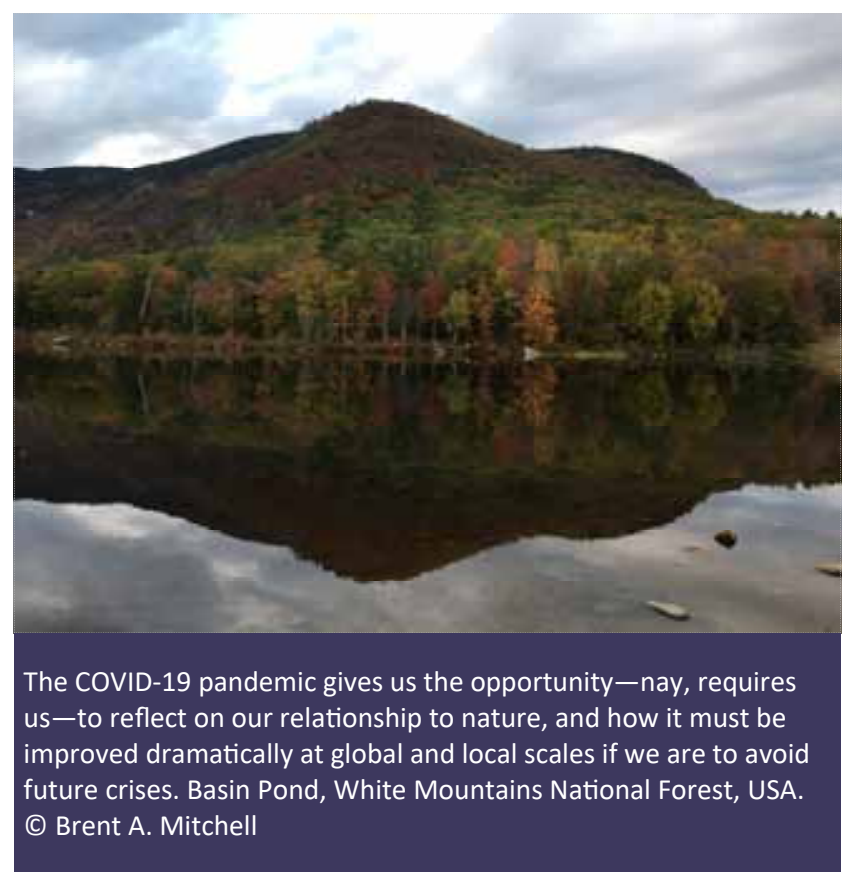

interconnected and the root cause is that our use and abuse of nature has reached the Earth's limits.

An economic system that is out of control: That overuse is a symptom of an economic system that largely ignores our place in the natural world. As Ashok Khosla puts it, the pandemic "results from the lopsided value systems and institutional arrangements that underlie our current economic policies and practices". The globalised, exploitative economic model based on relentless material growth and territorial expansion made the COVID-19 pandemic inevitable. It is almost as if our extraordinarily interconnected world was designed for SARS-CoV-2: once it had spilled over to humans, the global rapid transit system quickly expanded the epidemic to pandemic proportions.

A burgeoning human population: The sheer mass of humanity is felt in nearly every corner of the Earth, on land, in the oceans and in the atmosphere. Consider that it took over 200,000 years of human history for the world's population to reach 1 billion, and only 200 years more to reach 7 billion. There are currently 7.8 billion people on the Earth, projected to grow to 10.9 billion by the end of the century. Wildlife populations are squeezed into shrinking fragments of habitat, in ever closer proximity to humans, increasing the risk that pathogens will spill over from wild animals to people. As Mark Poznansky and Rich Roberts tell us, life scientists have understood this for decades. Illegal wildlife trade, estimated between US\$ 10-20 billion per year, increases the risk. 
A neglected conservation system: Conserved areas can provide protection, but they have been starved of resources, are not always truly protected and too often are treated as disposable. Rohit Singh and his colleagues document how "The Thin Green Line" of rangers is stretched to breaking point in many places. Even more depressing, Rachel Golden Kroner and coauthors document how the pandemic itself has been used as a cover to rollback many protections. And yet, as Yolanda Kakabadse reminds us, the COVID-19 crisis could be "the perfect opportunity" to re-evaluate the importance of PCAs and invest properly in programmes that guarantee their integrity.

The paradox of our relationship to nature: Until relatively recently, our species has lived as part of the natural world. But the global tragedy of COVID-19 has come about because much of humankind - as Mary Robinson tells us - has begun to see itself as "outside of nature". The result is a paradox. The modern world has become emotionally, economically and spiritually separated from nature; yet the pandemic has arisen precisely because of the close and often abusive interactions that many people routinely have with it. We have lost our respect for the natural world and, in doing so, we have exposed ourselves to the dangers it can harbour.

\section{How can we avoid it happening again?}

Use the power of the global community: Before the SARS-CoV- 2 epidemic burst onto the scene, 2020 was planned to be a 'Super Year for Nature', in which major new international targets to combat climate change and biodiversity decline would be set. That work has been delayed to 2021. This creates a unique opportunity to address all these pandemics with new resolve and commitment: a Year of Green Recovery'. The case for action is presented across this issue. It comes powerfully from former heads of States, Mary Robinson of Ireland and Juan Manuel Santos from Colombia. It specifically figures too in our opening essay by the GEF's Carlos Manuel Rodríguez, in comments by Elizabeth Maruma Mrema of the Convention on Biological Diversity, and in the closing essay by IUCN's Bruno Oberle, with Kathy MacKinnon and Trevor Sandwith.

Rethink economics: We have been humbled by COVID19. The experience requires us to develop new economic systems that value nature properly and really "build back better", as described in papers led by Rachel Golden Kroner (on a green recovery from the pandemic) and Tracey Cumming (on building sustainable finance for resilient protected and conserved areas).
Listen to the science: Scientists estimate that there are at least a half million viruses in wildlife populations with the potential to spill over to humans. We do not know how many would be likely to do so, under what circumstances, and which might cause disease. But we now know all too well that just one can be devastating. Jamie Reaser and Gary Tabor with their colleagues describe land-use induced spillover of pathogens from one species to another and warn us that the next pandemic is already in the making. To avoid a repeat of COVID-19, natural areas must be kept intact and made better connected, and degraded systems restored.

Listen to societies that retain deep cultural connections to nature: While science can show us one way of getting into a healthier balance with nature, Indigenous peoples also have wisdom and knowledge to lead us to that better path, says Josefa Cariño Tauli, an IbaloiKankanaey Igorot youth. Gretchen Walters et al. document some of the Indigenous experience with COVID-19. As Juan Manuel Santos notes, Indigenous peoples make up only 5 per cent of global population yet manage more than a quarter of all land and protect about 80 per cent of global biodiversity.

Listen to the next generation: Much of the work of recovery will fall to future generations. Emily Bohobo N'Dombaxe Dola says that she and other youth leaders are ready to take up the challenge in 2021. The question - she asks - is whether today's world leaders are ready too.

Listen to the voice inside us: Every one of us has work to do. Gilles Boeuf frames the problem not as a war against a virus, but against our own failings and irresponsibility towards the planet. Richard Louv boils it all down to a single existential threat with shared solutions, and sees the possibility of a nature-rich future if people galvanise the full powers of science, love and imaginative hope. Freya Mathews recognises that this will be articulated differently in different parts of the world, but all based around the idea that maintaining a living Earth should be part of our human purpose.

One day we will no longer need to wear a mask to prevent the spread of SARS-CoV-2. As liberating as that will feel, we must not replace the mask with blinkers and repeat mistakes that will trigger future crises. A defining characteristic of our species is our extraordinary ability to learn and adapt - and all the papers here document many lessons to be learned. But Homo sapiens is also the only species capable of heedlessly causing its own extinction. The pandemic is nature's warning that we have reached the limit of our planet's capacity to absorb 
abuse. We must act on what we have learned. We must adapt how we use the Earth, at scale, in fundamental ways.

People the world over made huge sacrifices to help contain the virus. Our science responded to COVID-19 by producing vaccines with record speed, a feat born of great resolve. The pandemic showed us heroes - in hospitals, emergency response, food supply lines and other essential services - that have been pushed to the limit of endurance. Once this immediate threat has passed, can we apply the same courage, discipline and commitment - socially, politically and economically to restore our balance with nature? Do we fully comprehend the larger threat connecting all these pandemics of human and planetary health? This is our ultimate test; our last chance perhaps; a worldwide reckoning. The question we must all ask ourselves is this: Will we act? Either we will re-discover our place within nature, or humanity will face consequences even worse than this pandemic.

\section{ABOUT THE AUTHORS}

Brent A. Mitchell is Senior Vice President of the Quebec-Labrador Foundation's Atlantic Center for the Environment. He chairs the IUCN WCPA Specialist
Group on Privately Protected Areas and Nature Stewardship, is a founding member of the US National Park Service Stewardship Institute, and is grateful to have had a skilled and simpatico co-editor in Adrian Phillips. ORCID 0000-0001-5305-1029

Adrian Phillips was formerly chair of IUCN WCPA, and Vice Chair of WCPA for World Heritage. He was previously employed by UNEP and IUCN, and for 11 years was the CEO of the UK's Countryside Commission. More recently, he was a trustee of several leading UK conservation NGOs. He was pleased to be dragged out of retirement to work with long-time colleague Brent Mitchell on this important publication.

\section{REFERENCES}

Hockings, M., Dudley, N., Elliott, W., Napolitano Ferreira, M. MacKinnon, K. et al. (2020). Editorial essay: COVID-19 and protected and conserved areas. PARKS 26 (1): 7-24. doi: 10.2305/IUCN.CH.2020.PARKS-26-1MH.en.

\section{RESUMEN}

Esta introducción ofrece una visión general y comentarios sobre los artículos publicados en un número especial de PARKS dedicado a los efectos y las repercusiones del COVID-19 en las áreas protegidas y conservadas del mundo. Describe cómo 11 artículos revisados por pares y 14 ensayos han reunido los conocimientos y conclusiones de numerosos expertos de todo el mundo, con el respaldo de varias encuestas de amplio alcance. La síntesis global resultante de la experiencia responde algunas preguntas clave: ¿Por qué se produjo la pandemia? ¿Qué ha significado para las áreas protegidas y conservadas y para las personas que dependen de ellas? ¿Cuáles fueron los motivos subyacentes del desastre al que ahora nos enfrentamos y cómo podemos evitar que se repita? Si bien encomiamos el esfuerzo internacional para combatir la enfermedad, sugerimos que la humanidad debe dedicar urgentemente el mayor esfuerzo posible a abordar las causas profundas de la pandemia - la fractura de la armonía entre la naturaleza y la humanidad. Si no la reparamos, la humanidad se enfrentará a consecuencias aún peores que esta pandemia.

\section{RÉSUMÉ}

Cette introduction donne un aperçu et des commentaires sur les articles dans un numéro spécial de PARKS qui est consacré à l'impact et aux implications de la COVID-19 sur les aires protégées et conservées du monde. Nous décrivons comment 11 articles revus par des pairs et 14 essais ont rassemblé les connaissances et les conclusions de nombreux experts de toutes les régions du monde, appuyés par plusieurs enquêtes de grande envergure. La synthèse globale de l'expérience qui en résulte répond à des questions clés: pourquoi la pandémie s'est-elle produite? qu'estce que cela signifie pour les aires protégées et conservées, et les personnes qui en dépendent? quelles sont les raisons sous-jacentes de la catastrophe à laquelle nous sommes aujourd'hui confrontés? et comment pouvons-nous éviter que cela ne se reproduise? Nous saluons l'effort international de lutte contre la maladie, mais suggérons que l'humanité doit de toute urgence consacrer autant d'effort à s'attaquer aux causes profondes de la pandémie - notre relation fracturée avec la nature. Si nous ne la réparons pas, l'humanité devra faire face à des conséquences encore pires que cette pandémie. 


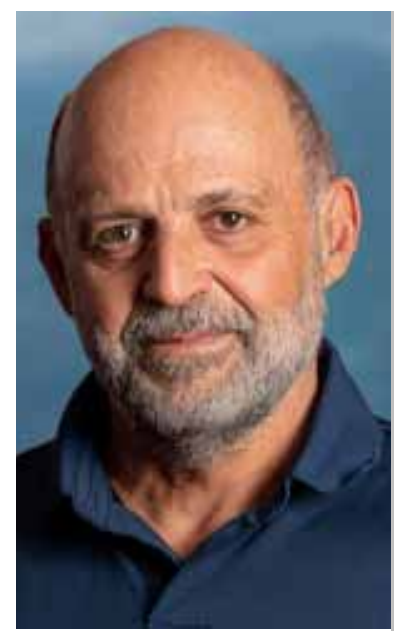

NATURE AND HUMANITY

\author{
Carlos Manuel Rodríguez
}

cmrodriguez@thegef.org

Global Environment Facility, Washington, DC

\title{
ABSTRACT
}

The SARS-CoV-2 virus, which has so far caused 103 million cases of COVID-19 and 2,250,000 deaths, has a zoonotic origin. The danger of new pandemics of a zoonotic origin is growing, partly because of poor land use management, especially in the tropics. We could greatly reduce this threat by investing in nature conservation for a tiny fraction of the cost of dealing with COVID-19. The Global Environment Facility supports and strongly advocates a green economic recovery post-COVID, in the form of sustainable and nature-based development.

Key words: SARS-CoV-2, COVID-19, Global Environment Facility

Perhaps at no time more than the present does the phrase "May you live in interesting times" embody its true meaning. We indeed find ourselves in a time of great uncertainty and disorder as opposed to the peace and tranquillity we all seek for ourselves, our families and the planet.

The SARS-CoV-2 virus - which (by early February 2021) had led to more than 103 million cases of COVID19 and nearly 2,250,000 deaths worldwide, while causing ongoing and extensive physical and economic suffering for countless more people - appears to have been transmitted from bats to humans in China. As is the case with the SARS-CoV- 2 virus, 75 per cent of all emerging infectious diseases are zoonotic in origin.

Experts no longer consider the occurrence of infectious diseases such as COVID-19 as unlikely, but rather as more likely to occur with increasing frequency if the negative way humans interact with nature does not change dramatically. In fact, every year, two new viruses are estimated to transfer from animals to humans.

Although changes in land-use practices have benefited people through economic and social development, they have had long-term negative impacts on human health and the provision of ecosystem services. Critically, there is increasing evidence that land-use change is a major driver of emerging infectious diseases (EIDs). Previous analyses demonstrate that over 30 per cent of EIDs affecting people are causally linked to land-use change. Deadly diseases such as HIV/AIDS, Ebola and Zika virus all originated in altered landscapes.
While the outbreaks of much infectious disease may be inevitable, the frequency, spread and damage they cause can be controlled and reduced through the adoption of biosecurity measures, sustainable agriculture, forest and protected areas management, and sound land-use planning - supported by the right institutional frameworks that aim to maintain intact forest habitats and limit the interface between fragmented forest habitats and livestock, food production and human settlements.

In addition to land conversion, the harvesting and transport of rodents, bats and primates that are viral reservoirs deliver potential zoonotic pathogens to human population centres through the wild meat trade. To reduce disease transmission of this type, we need to expand wildlife trade monitoring programmes, and to invest in efforts to end the wild meat trade by identifying alternative sources of protein for local communities.

Current evidence suggests that the highest risk of zoonotic transmission occurs in moderately fragmented habitats in tropical regions. Thus, building back better' must prioritise the conservation and sustainable use of ecosystems that maintain large intact habitats in the tropics as this will secure the direct and indirect economic value of this globally important biodiversity while reducing the risk of zoonotic spillover. Of course, protected and conserved areas will make a critical contribution to securing intact landscapes.

It is imperative that the biodiversity community should make connections with public health experts, and 
encourage the public health community to emphasise these linkages and help convey the importance of maintaining healthy ecosystems and habitats to reduce the risk of pandemics to a wider audience.

This approach will not only bring benefits for biodiversity, but also critical climate change mitigation, adaptation and land degradation benefits. The Global Environment Facility (GEF) is uniquely positioned to support countries, to work across sectors and collaborate with global multilateral environmental agreements to achieve these collective benefits for nature and humanity.

A recent article in Science estimated that significantly reducing the transmission of new diseases from tropical forests would cost, globally, between US\$ 22.2 and US\$ 30.7 billion each year. The COVID-19 pandemic will likely end up costing between US\$ 8.1 and US\$ 15.8 trillion globally - 500 times more than these preventative measures ${ }^{1,2}$.

As we have often noted in the biodiversity community, an ounce of prevention is worth a pound of cure. We have yet another opportunity in the upcoming Conference of the Parties to the Convention on Biodiversity to convey this message globally. This presents the GEF with a unique opportunity and responsibility to help countries build back better' after the COVID-19 crisis.

This crisis has highlighted to the world, in a way none of our institutions alone ever could, the need to understand and address the root causes of zoonotic diseases in a holistic and urgent way.

Recognising the dire consequences - but also the opportunities - of where we are today, governments, business and civil society have started to make plans for recovery from this crisis.
In J une 2020, the GEF released a set of immediate, medium- and longer-term actions to help address the current crisis and reduce the probability of new environmental crises emerging. The response spans measures to address wildlife trading, deforestation, urban sprawl and other pressures on ecosystems that increase the risk of zoonotic transmission.

The response also includes efforts to support a green economic recovery consistent with sustainable and nature-based development. These steps focus on the acceleration of needed transformations to economic and social systems to reduce their conflict with nature building on efforts already underway under the GEF- 6 Integrated Approach Pilots and the GEF-7 Impact Programs on: Food Systems, Land Use and Restoration; Sustainable Cities; and Sustainable Forest Management.

The mandate of the GEF, combined with its global vision and reach, places it in a unique position to work with the community of nations to ensure that the COVID-19 pandemic ceases to be a global threat and becomes an opportunity for lasting change. While the challenges are many, the current crisis can serve to reset humanity's relationship with the natural world by embracing norms and practices that lead to a more sustainable future for people and nature.

\section{ENDNOTES}

${ }^{1}$ https://science.sciencemag.org/content/369/6502/379

${ }^{2}$ To estimate the total financial cost of COVID-19, researchers included both the lost gross domestic product and the economic and workforce cost of hundreds of thousands of deaths worldwide.

\section{ABOUT THE AUTHOR}

Carlos Manuel Rodríguez is CEO and Chairperson of the Global Environment Facility. He is a former Environment and Energy Minister in Costa Rica.

\section{RESUMEN}

El virus SARS-CoV-2, que hasta ahora ha causado 103 millones de casos de COVID-19 y 2.250.000 muertes, tiene un origen zoonótico. El peligro de nuevas pandemias de origen zoonótico es cada vez mayor, debido - en parte- a la mala gestión del uso de la tierra, especialmente en los trópicos. Esta amenaza podría reducirse en gran medida invirtiendo en la conservación de la naturaleza por una pequeña fracción del costo de hacer frente al COVID-19. El Fondo para el Medio Ambiente Mundial aboga firmemente por una recuperación económica verde pos-COVID, en forma de desarrollo sostenible basado en la naturaleza.

\section{RÉSUMÉ}

Le virus SRAS-CoV-2 qui jusqu'à présent a causé 103 millions de cas de COVID-19 et 2250000 décès, est d'origine zoonotique. Le danger de nouvelles pandémies d'origine zoonotique risque d'augmenter, en partie à cause d'une mauvaise gestion de l'utilisation des terres, en particulier sous les tropiques. Nous pourrions réduire considérablement cette menace en investissant dans la conservation de la nature pour une infime fraction du coût de la gestion de la pandémie de COVID-19. Le Fonds pour l'environnement mondial soutient et préconise fortement une reprise économique verte après COVID, sous la forme d'un développement durable et axé sur la nature. 


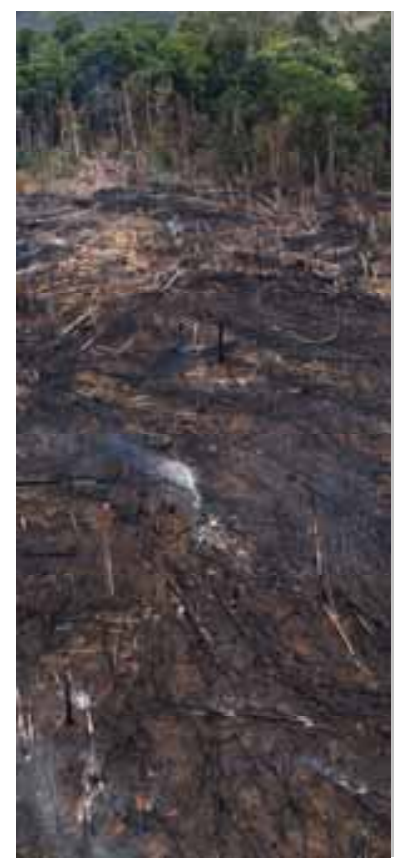

\title{
DRIVERS AND CAUSES OF ZOONOTIC DISEASES: AN OVERVIEW
}

\author{
Mariana Napolitano Ferreira ${ }^{*}$, Wendy Elliott ${ }^{2}$, Rachel Golden Kroner ${ }^{3}$, \\ Margaret F. Kinnaird ${ }^{4}$, Paula R. Prist ${ }^{5}$, Paula Valdujo ${ }^{1}$ and Mariana M. Vale ${ }^{6}$ \\ *Corresponding author: marianaferreira@wwf.org.br \\ ${ }^{1}$ WWF-Brasil, Brazil \\ ${ }^{2}$ WWF-International, Kigali Rwanda \\ ${ }^{3}$ Conservation International, USA \\ ${ }^{4}$ WWF-International, Nairobi, Kenya \\ ${ }^{5}$ Instituto de Biociências, Universidade de São Paulo, Brazil \\ ${ }^{6}$ Universidade Federal do Rio de Janeiro, Rio de Janeiro, Brazil
}

\begin{abstract}
Diseases transmitted between animals and humans are known as zoonotic diseases. The direct and indirect drivers that affect the emergence of zoonotic diseases are numerous and interacting, and their relative impact on the emergence of new diseases differs geographically with natural, cultural, social and economic conditions. In this article, we provide an overview of the concept, status and trends of zoonotic diseases. We focus on the direct drivers with the greatest potential influence on zoonotic disease emergence and which thereby increase the risk of epidemics and pandemics - land-use change, especially resulting from intensified agriculture and livestock production, the trade in wildlife, and wild meat consumption. We also explore evidence accumulated over recent decades that suggests that protected and conserved areas play a measurable and significant role in avoiding land-use change and thus potentially have a role in reducing the exposure to new zoonotic emerging infectious diseases.
\end{abstract}

Key words: COVID-19, emerging infectious disease (EID), EID drivers, land-use, protected and conserved areas

\section{INTRODUCTION}

Zoonotic diseases are those diseases or infections that can be transmitted between humans and wild and domestic animals (Slingerbergh et al., 2004). They have been linked to recent outbreaks that have threatened global health and economies, including Ebola, Severe Acute Respiratory Syndrome (SARS), Middle East Respiratory Syndrome (MERS), and now Severe Acute Respiratory Syndrome Coronavirus 2 (SARS-CoV-2), the virus causing COVID-19 (IPBES, 2020).

For years, scientists and policy actors have been warning about the risk of emerging infectious diseases (EIDs) and recommending how to avoid outbreaks (Dobson \& Carper, 1996; Morse et al., 2012). There is evidence of an increasing rate of emergence of novel EIDs. During the last century, on average two new viruses per year spilled from their animal hosts into human populations (Woolhouse et al., 2012). Zoonotic diseases have been receiving increased attention as a research topic, with overall rate of publications increasing from between 1 to 3 per annum in 2006, to more than 18 per annum in 2012, and more than 33 per annum in 2017 (White \& Razgour, 2020), contributing to a better understanding of pathogens, their hosts and factors affecting disease emergence.

Zoonotic disease emergence is a complex process. A combination of drivers provides conditions that allow pathogens to expand and adapt to new niches. The drivers are environmental, social, political and economic forces operating at local, national, regional and global levels (Institute of Medicine and National Research Council, 2009). In this article, we focus on direct drivers of zoonotic disease emergence, including land-use change, wildlife trade and wild meat consumption, and intensified livestock production.

\section{ZOONOTIC DISEASES: STATUS, TRENDS AND CORE CONCEPTS}

Zoonotic diseases are particularly important, as 60 per cent of the 1,407 human pathogen species are zoonotic (Woolhouse \& Gowtage-Sequeria, 2005), and of these, 72 per cent originated in wildlife (as opposed to domestic animals) (J ones et al., 2008). Moreover, 75 per cent of the 177 emerging or re-emerging pathogens (i.e., 
agents of an infectious disease whose incidence is increasing) are zoonotic (Woolhouse \& Dye, 2001; Taylor et al., 2001). These numbers may be underestimates, since new human pathogens are still being discovered at a rate of 3 to 4 species per year, with most of them being viruses (Woolhouse \&Antia, 2008). These have caused most recent human pandemics and represent a growing and significant threat to global public health and the economy (Parrish et al., 2008; J ones et al., 2008; Dobson et al., 2020).

Zoonosis may be viral, bacterial, parasitic or involve unconventional agents, such as fungi and protozoans (Cleaveland et al., 2001). However, the chance that a zoonotic pathogen is associated with emerging and reemerging infectious diseases depends on the pathogen group, being greatest for viruses and almost nil for helminths (worm-like parasites) (Woolhouse \& Gowtage-Sequeria, 2005). Among viruses, RNA types account for 37 per cent of all emerging and re-emerging pathogens; they are also well represented among emerging pathogens that have apparently entered human populations only in the last few decades. Examples are HIV and the group SARS-Coronavirus. The rates of nucleotide substitution (i.e., the replacement of one nucleotide to another) are much higher for this type of virus, so allowing rapid adaptation and greatly increasing the chances of successfully invading a new host population (Burke, 1998; Woolhouse et al., 2005).

Many of the diseases that exist today, such as influenza, diphtheria or HIV/acquired immune deficiency syndrome (AIDS), have a zoonotic origin (Diamond, 2002). Zoonoses fall into two categories: i) pathogens of animal origin which rarely transmit to humans, but, should it occur, human-to-human transmission will maintain the infection cycle for some time - examples include HIV, SARS-CoV-2, certain influenza A strains, Ebola virus and SARS; and ii) pathogens of animal origin in which direct or vector-mediated animal-tohuman transmission is the usual source of human infection - examples include Lyssavirus infections, Zika and Dengue virus, Hantavirus, yellow fever virus, Nipah virus (Bengis et al., 2004).

Zoonotic pathogens exist in many different animal hosts and there are many ways, both direct to indirect, in which transmission to humans occurs (Webster et al., 2017). Although the likelihood of transmission occurring through vector-borne and aerosol droplets is broadly similar (Loh et al., 2015), arboviruses (i.e. viruses transmitted by arthropod vectors, mostly mosquitoes) are less likely to generate pandemics than

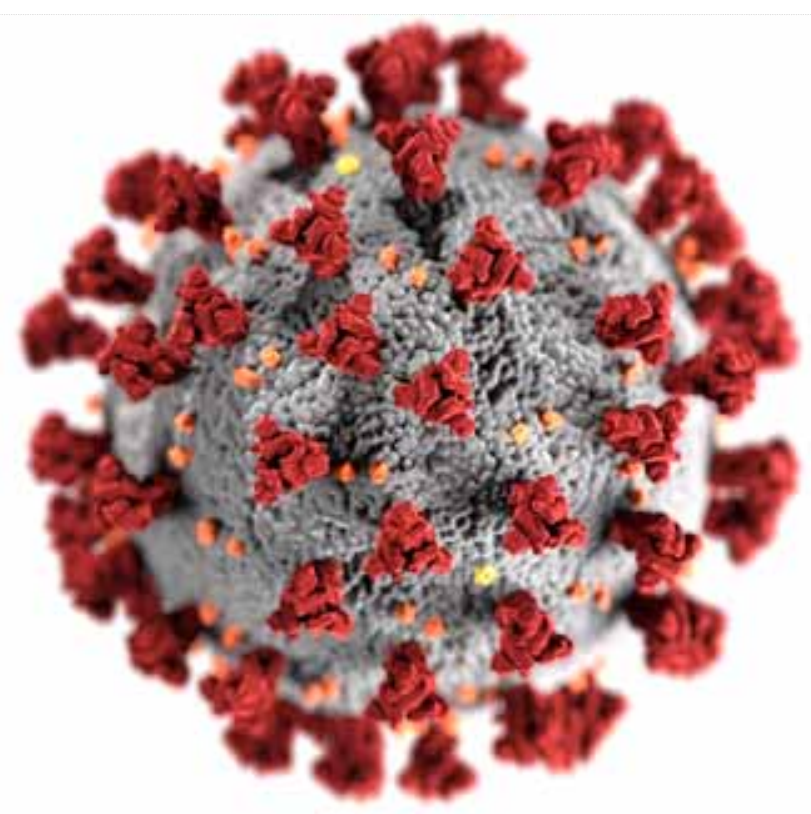

Ultrastructural morphology of a coronavirus Image: CDC, Alissa Eckert, MSMI; Dan Higgins, MAMS

those transmitted directly as aerosols. Arboviruses are partially constrained by having to pass sequentially through two hosts in their life cycle, their insect vector and then humans, or their reservoir host (Dobson, 2020). The ability of these viruses to expand their geographic range is also limited by climate and their dependence on suitable vectors. If a virus induces strong immunity in humans, its rate of spread will be rapidly curtailed, because uninfected vectors will have a harder time locating infectious hosts (e.g., Ferguson et al., 2016).

Generally, the infection of a human with a zoonotic pathogen represents a dead-end host. This means that most zoonotic pathogens are either not transmissible (directly or indirectly) or only minimally transmissible between humans (e.g., Rabies virus, Rift Valley fever virus, the Borrelia bacteria causing Lyme disease). Almost a quarter of all zoonotic pathogens are capable of some person-to-person transmission but do not persist without repeated reintroductions from a non-human reservoir (e.g., E. coli O157, Trypanosoma brucei rhodesiense). Less than 10 per cent spread exclusively from person to person (e.g., Mycobacterium tuberculosis and measles virus) or can do so once successfully introduced from a nonhuman source (e.g., some strains of influenza A, Yersinia pestis, or SARS coronavirus) (Woolhouse \& Gowtage-Sequeria, 2005).

Therefore, even if a pathogen is capable of infecting and causing disease in humans, most zoonotic pathogens are 
not highly transmissible within human populations and do not cause major epidemics. However, we currently have no way of predicting whether a pathogen will spillover from one host to another (e.g., species jump). Despite being rare, these events have led to some of the most devastating disease pandemics recorded, including HIV/ AIDS and COVID-19.

\section{DRIVERS OF ZOONOTIC DISEASE EXPOSURE Land-use change}

Because land-use change increases peoples' contact with wildlife and their potential pathogens that may be new to humans, it is believed to be the leading driver of emerging zoonosis (Loh et al., 2015), and has been linked to more than 30 per cent of new diseases reported since 1960 (IPBES, 2020). There are many direct and indirect drivers of land-use change, but very often this sequence occurs: roads are first driven into previously inaccessible natural areas, often to serve extractive activities like logging or mining; these facilitate more human incursions; and so lead to the conversion of further natural areas for settlements and subsistence and commercial agriculture. Land-use change and fragmentation processes increase the amount of natural edge habitat and the interface between wildlife and human-dominated areas. Edge length shows a positive correlation with the rate of contact between humans and wildlife, and consequent pathogen sharing (see Faust et al., 2018). Models of pathogen spillover from wildlife to domestic animals and humans predict that the highest spillover rates occur at intermediate levels of habitat conversion while the spillovers that lead to the largest epidemics are projected to occur less frequently at the extremes of either intact ecosystems or complete loss of ecosystems (Faust et al., 2018).

There are several well-documented examples of pathogen transmission between wildlife and humans linked with land-use change. An association has been shown between Ebola virus outbreaks and deforestation in Central and West Africa (e.g. ERM, 2015; Leendertz et al., 2016; Rulli et al., 2017), with an estimated time lag of two years between deforestation and outbreak occurrence (Olivero et al., 2017). The fragmentation process can stimulate the movement of wildlife into human-modified landscapes, especially when food for wild animals is no longer sufficient within the remaining

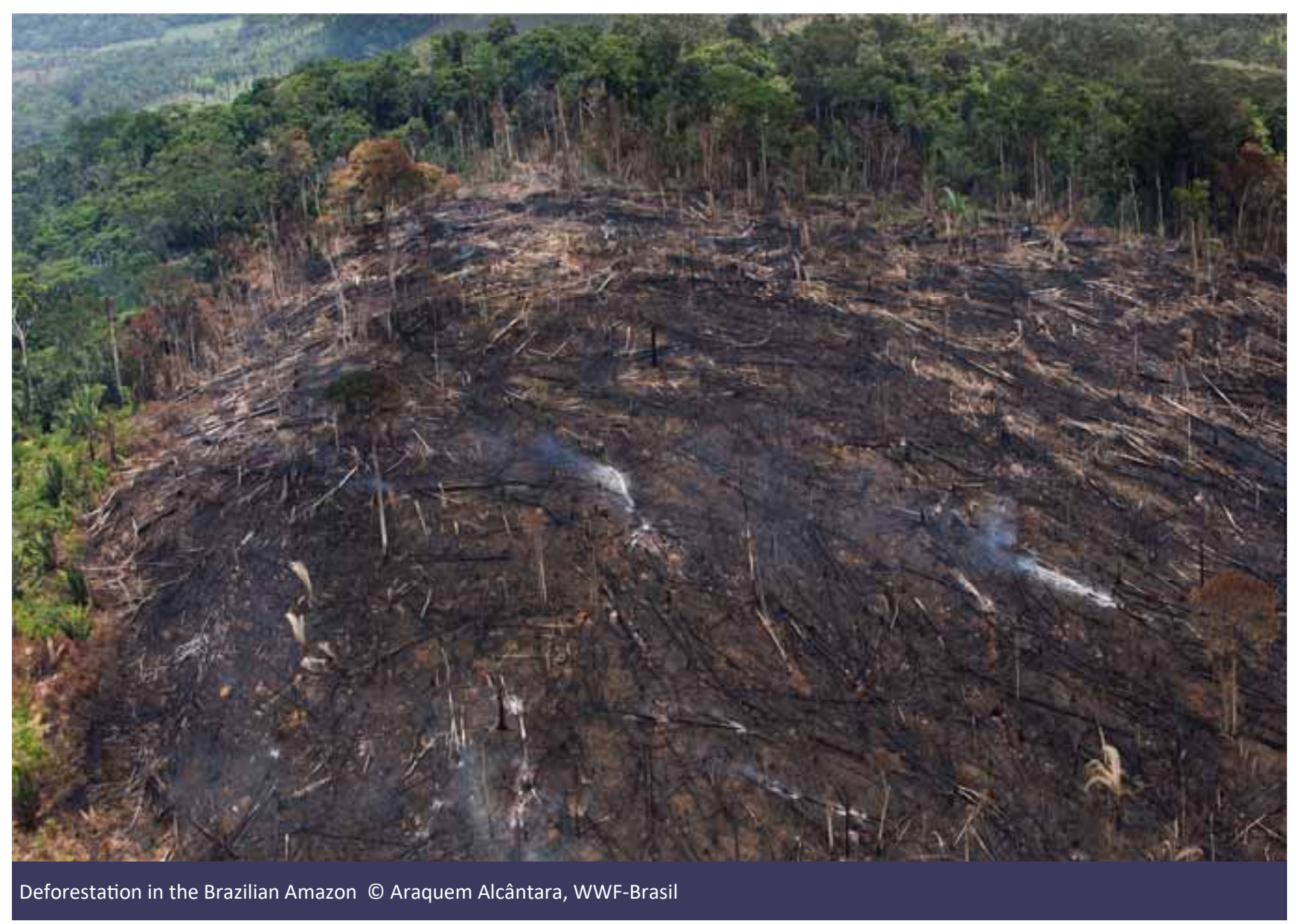


natural habitat. In disturbed forest habitats, for example, fruit bats are more likely to feed near human settlements, an important factor in a number of spillover events (Dobson et al., 2020). In Australia, Hendra virus spillover from flying fox fruit bats to domestic horses, and then to humans, has been associated with diminished nectar flows due to habitat loss or climate change; bats then switch to anthropogenic food sources, including fruiting trees planted in horse paddocks (Plowright et al., 2015). Similarly, Nipah virus spillover in Malaysia from bats to pigs, and eventually to humans, has been associated with reduced forest habitat, which - together with fruiting failure of forest trees during an El Niño-related drought - pushed flying foxes from natural habitats to cultivated orchards and pig farms (Looi \& Chua, 2007). Similar mechanisms have been suggested for Ebola outbreaks in Africa (Olivero et al., 2017). Although the vast majority of emerging infectious diseases come from wildlife, it is important to note that land-use change does not affect only the dynamics of wild animals. Land encroachment encourages the presence of domestic pets, which can be potential hosts of infectious diseases, within natural habitats. Dogs and cats, for example, share major vector-borne infectious diseases with man, such as rabies, leishmaniasis, Lyme disease and rickettsiosis (Day, 2011).

Transmission of pathogens driven by land-use change depends not only on increased contact between wildlife and humans (and their livestock), but also on the abundance of potentially infected wild hosts (Faust et al., 2018; Dobson et al., 2020). When natural habitat is transformed into agriculture, the available habitat is reduced for many wild species, creating less diverse wildlife communities. However, it can also increase the abundance of vectors and hosts, which are able to adapt to altered environments (Patz et al., 2004; Prist et al., 2016; Gibb et al., 2020), potentially intensifying transmission rates and the chance of spillover to humans.

While birds are an important source of zoonotic diseases (Boroomand \& Faryabi, 2020), the majority arise from mammals, with a particularly high proportion reported for rodents, bats and primates (Han et al., 2016; Olival et al., 2017; J ohnson et al., 2020): indeed, bats and primates are likely to share many viruses with humans (J ohnson et al., 2020). The impact made by zoonoses from these mammal groups is all the greater because they contain many different species (Han et al., 2016; Johnson et al., 2020; Mollentze \& Streicker, 2020). Bats have been implicated in many deadly emerging infectious viruses, including Ebola virus, SARS-CoV, MERS-CoV, Nipah virus, Hendra viruses (Han et al., 2015), and now probably SARS-CoV-2 (Platto et al., 2020; Zhou et al., 2020). Bats have been shown to have a higher proportion of zoonotic virus (Olival et al., 2017) than any other mammals, possibly due to their intrinsic social, biological and immunological features (Han et al., 2015). The close evolutionary links between humans and non-human primates may also contribute to a greater risk of pathogen spillover from this group (Han et al., 2016; Olival et al., 2017).

Tropical rainforests host a high diversity of rodents, primates and bats, with a particularly impressive bat richness in the Amazon (Jenkins et al., 2013). This explains, in part, why tropical forests are among the areas with the highest EID risk (once reporting effort is taken into account) (Allen et al., 2017). Other reasons include the current high rates of deforestation and fragmentation, the resulting simplification of ecosystems and proximity to expanding livestock production. Tropical forest loss and fragmentation is on the rise: approximately 70 per cent of remaining forest is within $1 \mathrm{~km}$ of the forest's edge, subject to the degrading effects of fragmentation (Haddad et al., 2015). It is no surprise, therefore, that land-use change in the tropical forest is expected to drive more pandemic emergence in the future (Loh et al., 2015; Murray \& Daszak, 2013; Faust et al., 2018).

\section{Wildlife trade and wild meat consumption}

Recent studies have found human-animal contact is a key risk factor for zoonotic disease emergence. Humananimal contact occurs in natural settings, live animal markets, wildlife farms and within the wildlife trade (Daszak et al., 2020; Li et al., 2020). The danger of spillover varies widely in such situations, though as yet there is a lack of data on the scale of these risks.

The wildlife trade has expanded dramatically recently. Although data are not fully available for domestic trade, the international legal wildlife trade has increased 500 per cent in value since 2005, and 2,000 per cent since the 1980s (UN Comtrade Database, 2020). It has been estimated that one in five terrestrial vertebrates is traded (Scheffers et al., 2019).

Wild meat complements and supports local diets and livelihoods in many regions (Fa et al., 2009), especially in some parts of the developing world. Wild meat often provides income in regions where few alternatives exist (Coad et al., 2019). Wild meat consumption in urban areas may be less due to the ready availability of alternative protein sources and more influenced by 
cultural influences, such as people's beliefs and social norms (Morsello et al., 2015). The legal and illegal wild meat trade feeds food markets and wider market networks beyond national boundaries.

Wildlife farming is the captive breeding of traditionally undomesticated animals to produce pets, food resources, traditional medicine and materials like leather, fur and fibre (Damania \& Bulte, 2007; Tensen, 2016). It too has grown rapidly in recent decades (Nijman, 2010). While wildlife farming in some instances can reduce consumption of wild individuals, alleviate poverty and improve welfare for farmers ${ }^{1}$, it can have negative impacts on wild populations ${ }^{2}$ and farms may function as spillover hotspots due to the intense human- wildlife interactions (Koopmans et al., 2004; Koopmans, 2020).

There is an urgent need to tackle live animal markets and any wildlife trade that is poorly regulated, particularly high risk trade. However, calls for complete bans on all wildlife trade risk exacerbating poverty, undermining human rights, damaging conservation incentives and harming sustainable development (Roe et al., 2020). A more nuanced call, endorsed by 380 experts from 63 countries, focused on the need to shut down high-risk wildlife markets (with priority given to those in high-density urban areas), scale up efforts to combat wildlife trafficking and trade in high-risk taxa, and strengthen efforts to reduce consumer demand for high-risk wildlife products?

Regulations are required for disease surveillance, veterinary care, sanitary transport, hygienic market conditions and control of the source of traded animals (Bell, 2004; Daszak et al., 2020; Li et al., 2020). Contact between humans and high-risk species, in particular, should be more strictly regulated, and accompanied by intensive disease surveillance (Betsem et al., 2011). Village-based alternatives that prevent communities from exposing themselves to potential risks should be encouraged.

\section{Intensification of livestock production}

By concentrating large numbers of animals in very small areas, livestock production intensifies humananimal and human-wildlife-livestock interaction (Chomel et al., 2007; J ones et al., 2013). This facilitates pathogen spillover from wildlife to livestock and has increased the likelihood that livestock become intermediate hosts in which pathogens are transmissible to humans (J ones et al., 2013).

Whereas the coevolution of hosts and pathogens in intact ecosystems favours low pathogenicity microorganisms, it is the opposite in intensive production systems where low genetic diversity and intense livestock management creates higher rates of contact and a greater number of opportunities for pathogens to transmit and amplify (J ones et al., 2013). Increasingly extensive transportation networks, the sale and transport of live animals, and the juxtaposition of agriculture and recreation with wildlife also contribute to the emergence and increasing virulence of zoonotic pathogens. Many wildlife species have thrived in this transitional landscape and have become reservoirs for disease in livestock and humans (J ones et al., 2013).

The expansion of livestock and poultry production, the greater size of farms and the increased number of individual animals at each farm create greater potential for transmission of pathogens to people (IPBES, 2020). Examples of zoonotic pathogens that circulate in livestock populations include the avian influenza viruses H7N9 and H5N1, both of which are highly lethal although with low transmission rates to humans; numerous bacterial, viral and parasitic pathogens in cattle, including the human coronavirus HCoV-OC43 (Cui et al., 2019); and several variants of swine flu including H1N1, H1N2 and H3N2 (Maldonado et al., 2006). The emergence of Middle Eastern Respiratory Syndrome (MERS) in people may have been due to transmission of a coronavirus of at origin (Yang et al., 2014), but which recently became endemic in domesticated camels (Elfadi et al., 2018), allowing repeated transmission to people (Azhar et al., 2014).

Other drivers of spillover risk include recreation which places people and high risk taxa in close proximity such as recreational caving (in caves with bat roosts) and some wildlife watching where humans come in relatively close proximity to wildlife (e.g., Gorilla viewing). In addition, actions that create unnatural concentrations of wildlife such as supplemental feeding of cervids also could potentially increase disease spread.

\section{THE ROLE OF PROTECTED AND CONSERVED AREAS}

The approach to EIDs has been largely reactive, focusing on pathogen control once it has already emerged from wildlife (Childs \& Gordon, 2009; Loh et al., 2015). A more proactive approach is needed to prevent disease emergencies (Dobson et al., 2020). Protected and conserved areas (PCAs) can play an important role in preventing future disease outbreaks by maintaining ecosystem integrity (Dobson et al., 2020).

PCAs are diverse and are managed through a range of governance types. PCAs include national parks and 
other protected areas, as well as other area-based conservation systems, including Other Effective areabased Conservation Measures, and Indigenous and Community Conserved Areas. All have the potential to play a measurable and significant role in avoiding landuse change (Ricketts et al., 2010; J usys, 2018; SoaresFilho et al., 2010). In a global analysis, J oppa and Pfaff (2010) found that protection reduces conversion of natural land cover for 75 per cent of the countries assessed. Even though there are important research gaps that need to be addressed in order to fully understand the overall health effects of PCAs (Terraube et al., 2017), it is clear that PCAs can buffer against the emergence of novel infectious diseases by reducing rapid changes in host/reservoir abundance and distribution, and limiting contact between humans, livestock and wildlife (Kilpatrick et al., 2017; Terraube et al., 2017; Terraube, 2019). Furthermore, PCAs offer significant opportunities for EID monitoring and surveillance: for example, in the Virunga National Park, monthly health checks are performed on habituated Mountain Gorillas 4 . In addition, PCAs can greatly reduce poaching and thus reduce one aspect of high-risk wildlife trade.

The main drivers of zoonotic diseases - rapid land-use change, high-risk wildlife trade and encroachment into natural areas - also threaten the ecological integrity of many PCAs (Gibb et al., 2020; Guo et al., 2019). With a rapidly accelerating human footprint and biodiversity in fast decline (WWF, 2020), we can no longer take for granted the role that PCAs have historically played in regulating the dynamics of zoonotic diseases (Lafferty \& Wood, 2013).

The cost of preventing future spillover pandemics by avoiding deforestation and regulating wildlife trafficking (which can at least partially be done through PCA establishment and implementation) is a minor fraction of the vast economic and societal costs of coping with a pandemic (Dobson et al., 2020).

There are many calls for PCAs to be better funded, more equitably managed, protected, scaled up and strengthened as part of post-COVID recovery plans (Hockings et al., 2020). Not only would this reduce the loss of biodiversity, help sequester carbon and support livelihoods, but it would also diminish the risk of future zoonotic diseases emerging. It would be an affordable and sensible insurance policy against future pandemics.

\section{CONCLUSION}

The COVID-19 pandemic was not the first, nor will it be the last, zoonotic disease to undermine economies and take human lives. Indeed, scientists warn that this may just be the beginning of a new cycle of emerging infectious diseases capable of gaining worldwide traction. A growing body of scientific evidence is helping us understand the complex interconnections between the health of people, wildlife and our shared environment. The most important drivers of emerging infectious diseases, such as land-use change, high risk wildlife trade and the intensification of livestock production, are also among the most significant causes of the destruction of nature.

There are many policy interventions we can take to avoid the occurrence and spread of new zoonotic diseases. Effectively and equitably managed PCAs will be a crucial element. Put them in place and manage them effectively, and we can reduce land-use change and fragmentation of natural habitats, and thereby reduce risks of EID spillovers, better control poaching, and minimise the worst impacts of the unregulated wildlife trade. Many of the priority actions that are needed in respect of PCAs are set out in greater detail in another paper in this special issue (Reaser et al., 2021).

Beyond that, PCAs will also protect us from the dangers of climate change and support livelihoods and enhanced well-being, income, clean water, clean air and green spaces for everyone's physical and mental health (Hockings et al., 2020). The benefits of PCAs have never been more clear, and the COVID-19 pandemic reminds us of yet another reason to invest in their protection for now and in the long term.

\section{ENDNOTES}

${ }^{1}$ https://www.cites.org/eng/prog/livelihoods
${ }^{2}$ https://wwf.panda.org/discover/our_focus/wildlife_practice/
species_news/tiger_farming/
${ }^{3}$ https://preventpandemics.org/
${ }^{4}$ https://www.gorilladoctors.org/saving-lives/gorilla-health-
monitoring-and-interventions/

\section{ACKNOWLEDGEMENTS}

We thank Andrew P. Dobson for input on arbovirus pandemic potential. Mariana M. Vale was funded by the National Council for Scientific and Technological Development (CNPq Grant no. 304309/2018-4) and the Chagas Filho Foundation for Research Support of the State of Rio de J aneiro (Grant no. E-26/ 202.647/ 2019); she had the support of the National Institute for Science and Technology in Ecology, Evolution and Biodiversity Conservation (CNPq Grant no. 465610/2014-5 and FAPEG Grant no. 201810267000023).

\section{ABOUT THE AUTHORS}

Mariana Napolitano Ferreira is Head of Science (WWF-Brasil) and coordinator of the Protected and Conserved Areas Community with WWF. 
Margaret Kinnaird is Global Wildlife Practice Leader at World Wildlife Fund International. Orcid: 00000002-5189-2817

Wendy Elliott is Deputy Leader, Wildlife Practice at WWF International.

\section{Rachel Golden Kroner is Environmental} Governance Fellow at Conservation International. Orcid: 0000-0003-1844-3398

Paula Prist has a Ph.D. in Ecology from the University of São Paulo and is a PAHO/WHO technical advisor.

Paula Valdujo is conservation specialist at WWFBrasil.

Mariana Vale is Associate Professor at the Federal University of Rio de Janeiro and a researcher at the Brazilian National Institute for Science and Technology.

\section{REFERENCES}

Allen, T., Murray, K.A., Zambrana-Torrelio, C., Morse, S.S., Rondinini, C., Di Marco, M., Breit, N., Olival, K.J. and Daszak (2017). Global hotspots and correlates of emerging zoonotic diseases. Nature Communications, 8(1): 1-10. DOI: 10.1038/ s41467-017-00923-8

Azhar, E.I., El-Kafrawy, S.A., Farraj, S.A., Hassan, A.M., AlSaeed, M.S., Hashem, A.M. and Madani, T.A. (2014). Evidence for camel-to-human transmission of MERS coronavirus. New England Journal of Medicine, 370(26): 2499 -2505. DOI: 10.1056/NEJMoa1401505

Bell, D., Roberton, S. and Hunter, P. R. (2004). Animal origins of SARS coronavirus: possible links with the international trade in small carnivores. Philosophical Transactions of the Royal Society of London. Series B: Biological Sciences, 359, 11071114.

Bengis, R.G., Leighton, F.A., Fischer, J.R., Artois, M., Morner, T. and Tate, C.M. (2004). The role of wildlife in emerging and reemerging zoonoses. Revue Scientifique et Technique-Office International des Epizooties, 23(2): 497-512.

Betsem, E., Rua, R., Tortevoye, Froment, A. and Gessain, A. (2011). Frequent and recent human acquisition of simian foamy viruses through apes' bites in central Africa. PLoS Pathogens, 7(10): e1002306. DOI: 10.1371/ journal.ppat. 1002306

Boroomand, Z. and Faryabi, S. (2020). Bird Zoonotic Diseases. Journal of Zoonotic Diseases, 4(3): 20-33.

Burke, D.S. (1998). Evolvability of emerging viruses. In: A.M. Nelson and C.R. Horsburgh (Eds) Pathology of emerging infections 2, pp. 1-12. Washington: American Society for Microbiology.

Childs, J.E. and Gordon, E.R. (2009). Surveillance and control of zoonotic agents prior to disease detection in humans. Mount Sinai Journal of Medicine, 76: 421-428. https:// doi.org/10.1002/msj.20133

Chomel, B.B., Belotto, A. and Meslin, F.X. (2007). Wildlife, exotic pets, and emerging zoonoses. Emerging Infectious Diseases, 13(1): 6-11. DOI: 10.3201/eid1301.060480
Cleaveland, S., Laurenson, M.K. and Taylor, L.H. (2001). Diseases of humans and their domestic mammals: pathogen characteristics, host range and the risk of emergency. Philosophical Transactions of the Royal. Society of London, Series B, Biological Sciences, 356(1411): 991-999.

Coad, L., Fa, J., Abernethy, K., van Vliet, N., Santamaria, C., Wilkie, D., El Bizri, H., Ingram, D., Cawthorn, D. and Nasi, R. (2019). Towards a sustainable, participatory and inclusive wild meat sector. Bogor, Indonesia: CIFOR. DOI: 10.17528/ cifor/007046

Cui, J., Li, F. and Shi, Z.L. (2019). Origin and evolution of pathogenic coronaviruses. Nature Reviews Microbiology, 17: 181-192. https://doi.org/10.1038/s41579-018-0118-9

Damania, R. and Bulte, E.H. (2007). The economics of wildlife farming and endangered species conservation. Ecological Economics, 62(3-4): 461-472. DOI: 10.1016/ j.ecolecon.2006.07.007

Daszak, P., Olival, K.J. and Li, H. (2020). A strategy to prevent future epidemics similar to the 2019-nCoV outbreak. Biosafety Health, 2: 6-8. DOI: 10.1016/j.bsheal.2020.01.003

Day, M.J. (2011). One health: the importance of companion animal vector-borne diseases. Parasites Vectors, 4: 49. DOI: 10.1186/1756-3305-4-49

Diamond, J. (2002). Evolution, consequences and future of plant and animal domestication. Nature, 418(6898): 700-707. DOI: doi.org/10.1038/nature01019

Dobson, A.P. and Carper, E.R. (1996). Infectious diseases and human population history. Bioscience, 46(2): 115-126. DOI: 10.2307/1312814

Dobson, A.P., Pimm, S.L., Hannah, L., Kaufman, L., Ahumada, J.A., Ando, A.W., Bernstein, A., Busch, J., Daszak, P., Engelmann, J., Kinnaird, M.F., Li, B.V., Loch-Temzelides, T., Lovejoy,T., Nowak, K., Roehrdanz: R. and Vale, M.M. (2020). Ecology and economics for pandemic prevention. Science, 369(6502): 379-381. DOI: 10.1126/science.abc3189

Dobson, A.P. (2020) Complex Life Cycles. In 'Unsolved Problems in Ecology', Ed A.P.Dobson, R.D.Holt \& D. Tilman, Princeton University Press

Elfadil, A.A., Ahmed, A.G., Abdalla, M.O., Gumaa, E., Osman, O.H., Younis, A.E., Al-Hafufi, A.N., Saif, L.J., Zaki, A., AlRumaihi, A. and Al-Harbi, N. (2018). Epidemiological study of Middle East respiratory syndrome coronavirus infection in dromedary camels in Saudi Arabia, April-May 2015. Revue Scientifique et Technique de l'Office Internationale des Epizooties, 37(3): 985-997.

ERM (Environmental Resources Management) (2015). Ebola Virus Disease and Forest Fragmentation in Africa: A Report by the ERM Foundation and the Environmental Foundation for Africa. London: The ERM Foundation. Available at: http:// www.efasl.org/site/wp-content/uploads/2015/09/Ebola-VirusDisease-and-Forest-Fragmentation-in-Africa_Report.pdf

Fa, J.E., Wright, J.H., Funk, S.M., Márquez, A.L., Olivero, J., Farfán, M.Á., Guio, F., Mayet, L., Malekani, D., Louzolo, C.H. and Mwinyihali, R. (2019). Mapping the availability of bushmeat for consumption in Central African cities. Environmental Research Letters, 14(9): 094002. DOI: 10.1088/1748-9326/ab36fa

Faust, C.L., McCallum, H.I., Bloomfield, L.S., Gottdenker, N.L., Gillespie, T.R., Torney, C.J., Dobson, A.P. and Plowright, R.K. (2018). Pathogen spillover during land conversion. Ecology Letters, 21(4): 471-483. DOI: 10.1111/ele.12904 
Ferguson, N.M., Cucunubá, Z.M., Dorigatti, I., Nedjati-Gilani, G.L., Donnelly, C.A., Basáñez, M.G., Nouvellet, P. and Lessler, J. (2016). Countering Zika in Latin America: Epidemic dynamics are key and data gaps must be addressed. Science 353 (6297): 353-354. DOI: 10.1126/science.aag0219

Gibb, R., Redding, D.W., Chin, K.Q., Donnelly, C.A., Blackburn, T.M., Newbold, T. and Jones, K.E. (2020). Zoonotic host diversity increases in human-dominated ecosystems. Nature, 584(7821): 398-402. DOI: 10.1038/ s41586-020-2562-8

Guo, F., Bonebrake, T.C. and Gibson, L. (2019). Land-use change alters host and vector communities and may elevate disease risk. EcoHealth, 16(4): 647-658. DOI: 10.1007/s10393-0181336-3

Haddad, N.M., Brudvig, L.A., Clobert, J., Davies, K.F., Gonzalez, A., Holt, R.D., Lovejoy, T.E., Sexton, J.O., Austin, M.P., Collins, C.D. and Cook, W.M. (2015). Habitat fragmentation and its lasting impact on Earth's ecosystems. Science Advances, 1(2): e1500052. DOI: 10.1126/sciadv.1500052

Han, B.A., Kramer, A.M. and Drake, J.M. (2016). Global patterns of zoonotic disease in mammals. Trends in Parasitology, 32 (7): 565-577. DOI: 10.1016/j.pt.2016.04.007

Han, H.J., Wen, H.L., Zhou, C.M., Chen, F.F., Luo, L.M., Liu, J.W. and Yu, X.J. (2015). Bats as reservoirs of severe emerging infectious diseases. Virus Research, 205: 1-6. DOI: 10.1016/ j.virusres.2015.05.006

Hockings, M., Dudley, N., Elliott, W., Ferreira, M.N., Mackinnon, K., Pasha, M.K.S., Phillips, A., Stolton, S., Woodley, S. et al. (2020). Editorial essay: Covid-19 and protected and conserved areas. PARKS, 26(1): 7-24. DOI: 10.2305/ IUCN.CH.2020.PARKS-26-1MH.en

Institute of Medicine and National Research Council (2009). Sustaining Global Surveillance and Response to Emerging Zoonotic Diseases. Keusch, G.T., Pappaioanou, M., Gonzalez, M.C., Scott, K.A. and Tsai, P. (Eds). Washington, DC: National Academies Press.. DOI: $10.17226 / 12625$

IPBES (Intergovernmental Platform on Biodiversity and Ecosystem Services) (2020). Workshop Report on Biodiversity and Pandemics of the Intergovernmental Platform on Biodiversity and Ecosystem Services. Daszak, P., das Neves, C., Amuasi, J., Hayman, D., Kuiken, T., Roche, B., Zambrana-Torrelio, C., Buss, P., Dundarova, H., Feferholtz, Y., Foldvari, G., Igbinosa, E., Junglen, S., Liu, Q., Suzan, G., Uhart, M., Wannous, C., Woolaston, K., Mosig Reidl, P., O'Brien, K., Pascual, U., Stoett, P., Li, H. and Ngo, H.T. (Eds). Bonn, Germany: IPBES Secretariat.. DOI:10.5281/ zenodo. 4147318

Jenkins, C.N., Pimm, S.L. and Joppa, L.N. (2013). Global patterns of terrestrial vertebrate diversity and conservation. Proceedings of the National Academy of Sciences, 110(28): E2602-E2610. DOI: 10.1073/ pnas. 1302251110

Johnson, C.K., Hitchens, P.L., Pandit, P.S., Rushmore, J., Evans, T.S., Young, C.C. and Doyle, M.M. (2020). Global shifts in mammalian population trends reveal key predictors of virus spillover risk. Proceedings of the Royal Society B: Biological Sciences, 287(1924): 20192736. DOI: 10.1098/ rspb.2019.2736

Jones, B.A., Grace, D., Kock, R., Alonso, S., Rushton, J., Said, M.Y., McKeever, D., Mutua, F., Young, J., McDermott, J. and
Pfeiffer, D.U. (2013). Zoonosis emergence linked to agricultural intensification and environmental change. Proceedings of the National Academy of Sciences, 110(21): 8399-8404. DOI: 10.1073/ pnas. 1208059110

Jones, K.E., Patel, N.G., Levy, M.A., Storeygard, A., Balk, D., Gittleman, J.L. and Daszak, P. (2008). Global trends in emerging infectious diseases. Nature, 451(7181): 990-993. DOI: 10.1038/nature06536

Joppa, L.N. and Pfaff, A. (2010). Global protected area impacts. Proceedings of the Royal Society B: Biological Sciences, 278(1712): 1633-1638. DOI: 10.1098/ rspb.2010.1713

Jusys, T. (2018). Changing patterns in deforestation avoidance by different protection types in the Brazilian Amazon. PloS One, 13(4): e0195900. DOI: 10.1371/journal.pone.0195900.

Kilpatrick, A.M., Salkeld, D.J., Titcomb, G. and Hahn, M.B. (2017). Conservation of biodiversity as a strategy for improving human health and well-being. Philosophical Transactions of the Royal Society B: Biological Sciences, 372(1722): 20160131. DOI: $10.1098 /$ rstb.2016.0131

Koopmans, M. (2020). SARS-CoV-2 and the human-animal interface: outbreaks on mink farms. The Lancet Infectious Diseases, 21(1), 18-19.

Koopmans, M., Wilbrink, B., Conyn, M.,Natrop, G., van der Nat, H., Vennema, H., van Steenbergen, J., Fouchier, R., Osterhaus, A. and Bosman, A. (2004). Transmission of H7N7 avian influenza $A$ virus to human beings during a large outbreak in commercial poultry farms in the Netherlands. The Lancet, 363 (9409), 587-593.

Lafferty, K.D. and Wood, C.L. (2013). It's a myth that protection against disease is a strong and general service of biodiversity conservation: Response to Ostfeld and Keesing. Conservation Biology, 14: 722-728. DOI: 10.1016/j.tree.2013.06.012 T.

Leendertz, S.A.J., Gogarten, J.F., Düx, A., Calvignac-Spencer, S. and Leendertz, F.H. (2016). Assessing the evidence supporting fruit bats as the primary reservoirs for Ebola viruses. EcoHealth, 13(1): 18-25. DOI: 10.1007/s10393-0151053-0

Li, Q., Guan, X., Wu, P., Wang, X., Zhou, L., Tong, Y., Ren, R., Leung, K.S., Lau, E.H., Wong, J.Y. and Xing, X. (2020). Early transmission dynamics in Wuhan, China, of novel coronavirus -infected pneumonia. New England Journal of Medicine, 382: 1199-1207. DOI: 10.1056/NEJMoa2001316

Loh, E.H., Zambrana-Torrelio, C., Olival, K.J., Bogich, T.L., Johnson, C.K., Mazet, J.A., Karesh, W. and Daszak, P. (2015). Targeting transmission pathways for emerging zoonotic disease surveillance and control. Vector-Borne and Zoonotic Diseases, 15(7): 432-437. DOI:10.1089/ vbz.2013.1563

Looi, L.M. and Chua, K.B. (2007). Lessons from the Nipah virus outbreak in Malaysia. Malaysian Journal of Pathology, 29(2): 63-67.

Maldonado, J., Van Reeth, K., Riera, P., Sitja, M., Saubi, N., Espuna, E. and Artigas, C. (2006). Evidence of the concurrent circulation of H1N2, H1N1 and H3N2 influenza A viruses in densely populated pig areas in Spain. The Veterinary Journal, 172(2): 377-381. DOI: 10.1016/j.tvjl.2005.04.014

Mollentze, N. and Streicker, D.G. (2020). Viral zoonotic risk is homogenous among taxonomic orders of mammalian and avian reservoir hosts. Proceedings of the National Academy 
of Sciences, 117(17): 9423-9430. DOI: 10.1073/ pnas. 1919176117

Morse, S.S., Mazet, J.A., Woolhouse, M., Parrish, C.R., Carroll, D., Karesh, W.B., Zambrana-Torrelio, C., Lipkin, W.I. and Daszak, P. (2012). Prediction and prevention of the next pandemic zoonosis. The Lancet, 380(9857): 1956-1965. DOI: 10.1016/S0140-6736(12)61684-5

Morsello, C., Yagüe, B., Beltreschi, L., Van Vliet, N., Adams, C., Schor, T., Quiceno-Mesa, M.P. and Cruz, D. (2015). Cultural attitudes are stronger predictors of bushmeat consumption and preference than economic factors among urban Amazonians from Brazil and Colombia. Ecology and Society, 20(4): 21. DOI: 10.5751/ES-07771-200421

Murray, K.A. and Daszak, P. (2013). Human ecology in pathogenic landscapes: two hypotheses on how land use change drives viral emergence. Current Opinion in Virology, 3 (1): 79-83. DOI: 10.1016/j.coviro.2013.01.006

Nijman, V. (2010). An overview of international wildlife trade from Southeast Asia. Biodiversity and Conservation, 19(4): 11011114. DOI: 10.1007/s10531-009-9758-4

Olival, K.J., Hosseini, P.R., Zambrana-Torrelio, C., Ross, N., Bogich, T.L. and Daszak, P. (2017). Host and viral traits predict zoonotic spillover from mammals. Nature, 546(7660): 646-650. DOI: 10.1038/nature22975

Olivero, J., Fa, J.E., Real, R., Márquez, A.L., Farfán, M.A., Vargas, J.M., Gaveau, D., Salim, M.A., Park, D., Suter, J. and King, S. (2017). Recent loss of closed forests is associated with Ebola virus disease outbreaks. Scientific Reports, 7(1): 1 -9. DOI: 10.1038/s41598-017-14727-9

Parrish, C.R., Holmes, E.C., Morens, D.M., Park, E.C., Burke, D.S., Calisher, C.H., Laughlin, C.A., Saif, L.J. and Daszak, P. (2008). Cross-species virus transmission and the emergence of new epidemic diseases. Microbiology and Molecular Biology Reviews, 72(3): 457-470. DOI: 10.1128/MMBR.00004 $-08$

Patz, J.A., Daszak, P., Tabor, G.M., Aguirre, A.A., Pearl, M., Epstein, J., Wolfe, N.D., Kilpatrick, A.M., Foufopoulos, J., Molyneux, D. and Bradley, D.J. (2004). Unhealthy landscapes: policy recommendations on land use change and infectious disease emergence. Environmental Health Perspectives, 112(10): 1092-1098. DOI: 10.1289/ehp.6877

Platto, S., Zhou, J., Yanqing, W., Huo, W. and Carafoli, E. (2020). Biodiversity loss and COVID-19 pandemic: The role of bats in the origin and the spreading of the disease. Biochemical and Biophysical Research Communications (in press). DOI: 10.1016/j.bbrc.2020.10.028.

Plowright, R.K., Eby, P., Hudson, P.J., Smith, I.L., Westcott, D., Bryden, W.L., Middleton, D., Reid, P.A., McFarlane, R.A., Martin, G. and Tabor, G.M. (2015). Ecological dynamics of emerging bat virus spillover. Proceedings of the Royal Society B: Biological Sciences, 282(1798): 20142124. DOI: 10.1098/rspb.2014.2124

Prist, P.R., Uriarte, M., Tambosi, L.R., Prado, A., Pardini, R., D'Andrea, P.S. and Metzger, J.P. (2016). Landscape, environmental and social predictors of Hantavirus risk in São Paulo, Brazil. PloS One, 11(10): e0163459. DOI: 10.1371/ journal.pone.0163459

Reaser, J.K., Tabor, G.M., Becker, D.J., Muruthi, P., Witt, A., Woodley, S.J., Ruiz-Aravena, M.,Patz, J.A et al. (2021) Land use-induced spillover: priority actions for protected and conserved area managers. PARKS 27(Special Issue): 161178 DOI: 10.2305/IUCN.CH.2021.PARKS-27-SIJKR.en

Ricketts, T.H., Soares-Filho, B., da Fonseca, G.A., Nepstad, D., Pfaff, A., Petsonk, A., Anderson, A., Boucher, D., Cattaneo, A., Conte, M. and Creighton, K. (2010). Indigenous lands, protected areas, and slowing climate change. PLoS Biology, 8 (3): e1000331. DOI: 10.1371/journal.pbio.1000331

Roe, D., Dickman, A., Kock, R., Milner-Gulland, E.J. and Rihoy, E. (2020). Beyond banning wildlife trade: COVID-19, conservation and development. World Development, 136: 105121. DOI: 10.1016/j.worlddev.2020.105121.

Rulli, M.C., Santini, M., Hayman, D.T. and D'Odorico, P. (2017). The nexus between forest fragmentation in Africa and Ebola virus disease outbreaks. Scientific Reports, 7: 41613. 10.1038/srep41613

Scheffers, B.R., Oliveira, B.F., Lamb, I. and Edwards, D.P. (2019). Global wildlife trade across the tree of life. Science, 366 (6461): 71-76. DOI: 10.1126/science.aav5327

Slingenbergh, J., Gilbert, M., Balogh, K.D. and Wint, W. (2004). Ecological sources of zoonotic diseases. Revue Scientifique et Technique-Office International des Epizooties, 23(2): 467484.

Soares-Filho, B., Moutinho, P., Nepstad, D., Anderson, A., Rodrigues, H., Garcia, R., Dietzsch, L., Merry, F., Bowman, M., Hissa, L. and Silvestrini, R. (2010). Role of Brazilian Amazon protected areas in climate change mitigation. Proceedings of the National Academy of Sciences, 107(24): 10821-10826. DOI: 10.1073/ pnas. 0913048107

Taylor, L.H., Latham, S.M. and Woolhouse, M.E. (2001). Risk factors for human disease emergence. Philosophical Transactions of the Royal Society of London. Series B: Biological Sciences, 356(1411): 983-989. DOI: 10.1098/ rstb.2001.0888

Tensen, L. (2016). Under what circumstances can wildlife farming benefit species conservation? Global Ecology and Conservation, 6: 286-298. DOI: 10.1016/j.gecco.2016.03.007

Terraube, J. (2019). Can protected areas mitigate Lyme disease risk in Fennoscandia? EcoHealth, 16(2): 184-190. DOI: 10.1007/s10393-019-01408-4

Terraube, J., Fernández-Llamazares, Á. and Cabeza, M. (2017). The role of protected areas in supporting human health: a call to broaden the assessment of conservation outcomes. Current Opinion in Environmental Sustainability, 25: 50-58. DOI: 10.1016/j.cosust.2017.08.005

UN Comtrade Database. (2020). https://comtrade.un.org/. Accessed on 9 November 2020.

Webster, J.P., Borlase, A. and Rudge, J.W. (2017). Who acquires infection from whom and how? Disentangling multi-host and multi-mode transmission dynamics in the 'elimination' era. Philosophical Transactions of the Royal Society B: Biological Sciences, 372(1719): 20160091. DOI: 10.1098/ rstb.2016.0091

White, R.J. and Razgour, O. (2020). Emerging zoonotic diseases originating in mammals: a systematic review of effects of anthropogenic land use change. Mammal Review, 50: 336352. DOI: $10.1111 / \mathrm{mam} .12201$

Woolhouse, M. and Antia, R. (2008). Emergence of new infectious diseases. In: S.C. Stearns, and J.K. Koella, (Eds) Evolution in Health and Disease, $2^{\text {nd }}$ ed. Oxford: Oxford University Press. pp. 215-228. 
Woolhouse M.E.J. and Dye, C. (2001) Population biology of emerging and re-emerging pathogens - preface. Philos. Trans. R. Soc. Lond. Ser. B, 356: 981-982

Woolhouse, M., Scott, F., Hudson, Z., Howey, R. and ChaseTopping, M. (2012). Human viruses: discovery and emergence. Philosophical Transactions of the Royal Society of London Series B Biological Sciences 367: 2864-2871. DOI: 10.1098/rstb.2011.0354

Woolhouse, M.E. and Gowtage-Sequeria, S. (2005). Host range and emerging and reemerging pathogens. Emerging Infectious Diseases, 11(12): 1842-1847. DOI: 10.3201/ eid1112.050997

Woolhouse, M.E., Haydon, D.T. and Antia, R. (2005). Emerging pathogens: the epidemiology and evolution of species jumps. Trends in Ecology \& Evolution, 20(5): 238-244. DOI: 10.1016/j.tree.2005.02.009
WWF (2020). Living Planet Report 2020 - Bending the curve of biodiversity loss. Almond, R.E.A., Grooten M. and Petersen, T. (Eds). Gland, Switzerland: WWF. 161p. Available at: https://www.zsl.org/sites/default/files/LPR\%202020\%20Full\% 20report.pdf

Yang, L., Wu, Z., Ren, X., Yang, F., Zhang, J., He, G., Dong, J., Sun, L., Zhu, Y., Zhang, S. and Jin, Q. (2014). MERS-related betacoronavirus in Vespertilio superans bats, China. Emerging Infectious Diseases, 20(7): 1260-1262. DOI: 10.3201/eid2007.140318

Zhou, H., Chen, X., Hu, T., Li, J., Song, H., Liu, Y., Wang, P., Liu, D., Yang, J., Holmes, E.C., Hughes, A.C., Bi, Y. and Shi, W. (2020). A novel bat coronavirus closely related to SARS-CoV2 contains natural insertions at the S1/S2 cleavage site of the spike protein. Current Biology, 30(11): 2196-2203. DOI: 10.1016/j.cub.2020.05.023

\section{RESUMEN}

Las enfermedades que se transmiten entre animales y humanos se conocen como enfermedades zoonóticas. Los generadores directos e indirectos que afectan la aparición de las enfermedades zoonóticas son numerosos e interactúan entre sí, y su impacto relativo en la aparición de nuevas enfermedades difiere geográficamente en función de las condiciones naturales, culturales, sociales y económicas. En el presente artículo se ofrece un vistazo general del concepto, la situación y las tendencias de las enfermedades zoonóticas. Nos centramos en los generadores directos con el mayor potencial de influencia en la aparición de enfermedades zoonóticas y que, por lo tanto, aumentan el riesgo de epidemias y pandemias: los cambios en el uso de la tierra, especialmente como resultado de la intensificación de la agricultura y la ganadería, el comercio de animales salvajes y el consumo de carne silvestre. También exploramos las pruebas acumuladas en los últimos decenios que sugieren que las áreas protegidas y conservadas desempeñan una función importante y cuantificable para evitar el cambio en el uso de la tierra y, por lo tanto, pueden contribuir a reducir la exposición a nuevas enfermedades infecciosas zoonóticas.

\section{RÉSUMÉ}

Les maladies transmises entre animaux et humains sont connues sous le nom de maladies zoonotiques. Les facteurs directs et indirects qui affectent l'émergence des maladies zoonotiques sont nombreux et interagissent les uns avec les autres. Leur impact relatif sur l'émergence de nouvelles maladies diffère géographiquement selon les conditions naturelles, culturelles, sociales et économiques. Dans cet article, nous présentons un récapitulatif du concept, de l'état actuel et des tendances des maladies zoonotiques. Nous visons les facteurs directs ayant la plus grande influence potentielle sur l'émergence des maladies zoonotiques et qui augmentent ainsi le risque d'épidémies et de pandémies, c'est-à-dire le changement d'affectation des terres résultant en particulier de l'intensification de l'agriculture et de la production animale, le commerce des espèces sauvages, et la consommation de viande sauvage. Nous explorons également les données accumulées au cours des dernières décennies qui suggèrent que les aires protégées et conservées jouent un rôle mesurable et significatif pour éviter les changements d'utilisation des terres. De cette manière elles ont potentiellement un rôle à jouer dans la réduction de l'exposition aux nouvelles maladies infectieuses émergentes zoonotiques. 


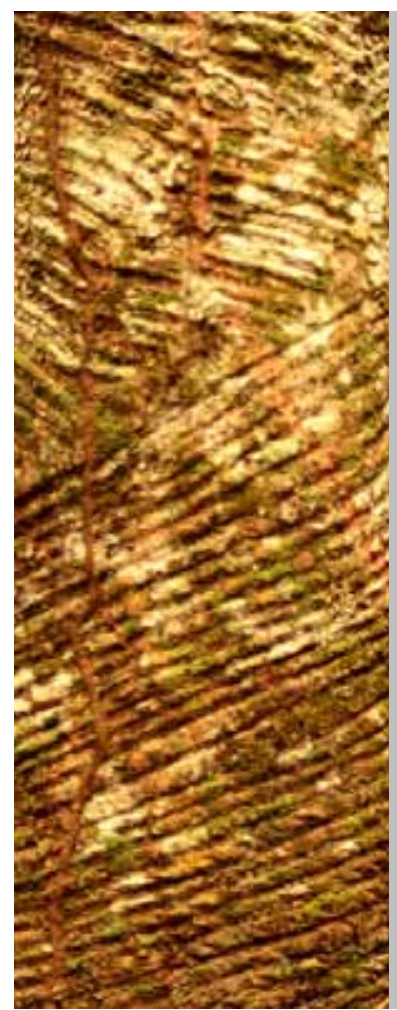

THERE'S NOTHING NEW UNDER THE SUN LESSONS CONSERVATIONISTS COULD LEARN FROM PREVIOUS PANDEMICS

\author{
Olivier Hymas ${ }^{1}$, Bruna Rocha², Natalia Guerrero³, Mauricio Torres ${ }^{4}$, Kevin \\ Ndong 5 and Gretchen Walters ${ }^{* 1,6}$
}

*Corresponding author: gretchen.walters@unil.ch

${ }^{1}$ University of Lausanne, Faculty of Geosciences and Environment, Institute of Geography and Sustainability, Lausanne, Switzerland

${ }^{2}$ Programa de Antropologia e Arqueologia, Universidade Federal do Oeste do Pará, Brazil; Grupo de Estudos em Ecologia Histórica e Política das bacias dos rios Trombetas, Tapajós e Xingu

${ }^{3}$ University of São Paulo, São Paulo, Brazil; Grupo de Estudos em Ecologia Histórica e Política das bacias dos rios Trombetas, Tapajós e Xingu

${ }^{4}$ Instituto Amazônico de Agriculturas Familiares, Federal University of Pará, Brazil

${ }^{5}$ Agence National pour les Parcs Nationaux, Kalikak, Libreville, Gabon, BP 20379

${ }^{6}$ University College London, Department of Anthropology, London, United Kingdom

\title{
ABSTRACT
}

In many industrialised societies, the COVID-19 pandemic has been painted as an unprecedented moment caused by human abuse of nature. Responses to it have, in turn, temporarily slowed down human impacts upon nature. This has led to a rallying cry against human encroachment into what are claimed to be pristine wildernesses. Reflecting upon historic, archaeological and palaeoecological evidence relating to the impacts of past epidemics within a wider historical timeframe from Africa and South America, we show that though COVID-19 is a novel disease, the pandemic itself does not represent a novel event, since diseases brought by Europeans have previously decimated the peoples living in these areas. The 'pristine wilderness' is a myth, which falsely held that these places had always been empty of people, thus helping to legitimate the creation of protected areas, and their political control by both colonial and national administrations. We therefore question the assumption behind what has been termed the 'anthropause' - that the supposed reduction in anthropogenic activities caused by the current pandemic presents a new opportunity to study anthropogenic impacts on nature: numerous previous occasions exist where depopulation resulted in anthropauses. Such responses to COVID-19 suggest further interdisciplinarity is needed in the field of conservation, in spite of advances in this direction.

Key words: epidemics, pristine wildernesses, protected areas, history, archaeology, Africa, Brazilian Amazonia

“...the unhealthiest period in all African history was undoubtedly between 1890 and 1930" (Hartwig \& Patterson, 1978, p.4)

"The white man brought measles and many people died" (Munduruku man in Melo \& Villanueva, 2008, p.40)

\section{DISEASES AND THE PRISTINE WILDERNESS \\ MYTH}

"Surprise" is the title of a 2014 paper on emerging infectious diseases that asks why predictable new diseases, such as SARS, Ebola and HIV, catch us unprepared (Stephen et al., 2015); and why recent pandemics, such as the 1918 Influenza pandemic (Saunders-Hastings \& Krewski, 2016) or the HIV/ AIDS pandemic (Snowden, 2008) have been so quickly forgotten in Western societies. Yet previous pandemics are remembered in the oral histories of many local communities around the world. Epidemiologists, such as the current US Director of the National Institute of Allergy and Infectious Diseases, Dr Anthony Fauci (in Morens et al., 2004) have also long warned of such a possibility.

While the development of new infectious diseases into pandemics is not novel, a publication often cited ${ }^{1}$ by ecologists that numbers "335 emerging infectious disease (EID) 'events'... between 1940 and 2004" has encouraged a belief that the number of EID events is escalating (J ones et al., 2008; Kilpatrick et al., 2017). But this dataset lacks historical depth, since the period it looks at excludes the consideration of the global spread of infectious diseases caused by empire building (e.g. Curtin, 1998; Hartwig \& Patterson, 1978), the influenza 
outbreak of 1918 (Patterson, 1979, 1986) and other pandemics that took place in the past (e.g. sleeping sickness - 1915-1926, cholera pandemics - 1817-1923, influenza pandemics - 19th century, bubonic plague pandemics - 6th to 20th century (see infographics in LePan, 2020; Byrne, 2008; Cunningham, 2008)). With greater historical context, it becomes harder to justify the claim by both media and some scientists that the emergence of new diseases and their impacts on "the environment and wildlife is a novel and understudied topic" (Manenti et al., 2020, p.2). This is best exemplified in a recent publication by WWF that uses the Jones et al. 60-year dataset to state that "over the last century, there has been an alarming increase in the number and frequency of new zoonotic disease outbreaks. The frequency of zoonotic disease outbreaks caused by a spillover of pathogens from animal hosts to people may have more than tripled in the last decade" (WWF, 2020, p.10), arguing that this "increase in zoonotic outbreaks is a symptom of a broken relationship between humans and nature, and is likely to worsen" (WWF, 2020, p.11), whereby the "devastating health impacts of recent pandemics including COVID-19 are a stark illustration of the human costs of the encroachment on nature" (WWF, 2020, p.24).

The idea that land use change constitutes a broken relationship with nature, which is driving infectious diseases, is evident too in the claim that the number of "published peer reviewed articles on land use change and diseases from the 1970s to the present increased markedly in the last decade" (Gottdenker et al., 2014). Land use change follows from the encroachment of "human activities (logging, mining, agricultural expansion, etc.) into wild areas and forests [...] and the commodification of wild animals (and natural resources in general) and an expanding demand and market for wild meat and live wild animals" (Volpato et al., 2020, p.1). Alarm at the speed and widespread nature of land use change - especially in tropical countries - is a key reason why conservationists and others argue for a more environmentally friendly world once the COVID19 pandemic is over (Gatti, 2020; Khoury, 2020), and for a "transition to more sustainable societies" (Stegeman et al., 2020, p.1).

While few would argue against a more environmentallyfriendly world, the discourse of a broken relationship is misleading, unless it acknowledges that the impacts upon the environment wielded by capitalist interests and industrial societies are very different to those of Indigenous peoples and traditional and local communities who depend directly upon these landscapes for their livelihoods and who may be negatively impacted by industrial and capitalist forces as they often live at these frontiers of encroachment. There is indeed a vast corpus of interdisciplinary literature, including historical ecological approaches (see Szabó \& Hédl, 2011), which shows how the presence of Indigenous peoples and traditional and local communities is not necessarily antagonistic to nature; in fact, it can have an environmentally beneficial impact on landscapes through certain kinds of management and plant domestication.

It would be unfortunate if this discourse (Schultz, 2011; Volpato et al., 2020) were to reinforce myths of pristine landscapes and Eden-like wildernesses (Adams \& McShane, 1996; Denevan, 1992; Neumann, 2002) tabula rasas (Aristotle, 2016, pp.60-61, gloss 430a; Duschinsky, 2012) untouched by human hands. In fact, many ecologists and conservationists have accepted that in most cases the pristine wilderness is just that: a myth. The "concept of 'pristine' forest is hardly appropriate in an era of pervasive anthropogenic change" (Ghazoul et al., 2015, p.623). As conservation has been transformed into an interdisciplinary subject, such a view of nature in a primordial state has been shown to be untenable2. Of course, the coming of the Anthropocene epoch (Chua \& Fair, 2019) and its impacts on the environment (Malhi et al., 2014) constitute a crisis without precedent. But the cause of this does not lie with those people who live in these encroachment frontiers (Rudiak-Gould, 2015).

While 'pristine wilderness' is a term employed for popular use, similar thinking underpins the more scientific terms like intact, old growth, undisturbed and primary forest. These terms are defined by ecological theories and data (for example Ahlström et al., 2020; Hubau et al., 2019; Lopez-Gonzalez et al., 2012) rather than historical, archaeological or even anthropological data. For example, Bauters et al. use ecological theory and old growth forest to date anthropogenic activity for site selection in the Democratic Republic of Congo by using the "expert judgment of local foresters" to age "different stages of forest development" (Bauters et al., 2019, p.2). Meanwhile Poulsen defines "Primary, or old growth, forest [...] as having no recent obvious signs of disturbance" (Poulsen et al., 2020, p.5). Though these terms may be accurate for their specific uses, the employment of ecological methods and data alone, or the direct observation of current human disturbance to determine past anthropogenic activity, are poor substitutes for archaeological, historical and anthropological methods and evidence.

The introduction of the concept of the anthropause (Rutz et al., 2020) builds upon this historical disconnection by suggesting that the events following 
the current pandemic are, in some way, novel: that diseases such as COVID-19 bring about "an unusual decrease in human activity associated with partial and total lockdowns" (Silva-Rodríguez et al., 2020, p.1) allowing many animal species to enjoy "the newly afforded peace and quiet" (Rutz et al., 2020, p.1156). While this decrease in human activity may be true in some places, it is not universal (Walters et al., 2021). A now common saying in the Brazilian Amazon is that "Deforesters don't do lockdown", because loggers, wildcat goldminers and landgrabbers have intensified the invasions of protected areas at a time when monitoring operations have been suspended, with officials and communities unable to do any monitoring. Similar events have also occurred in various African countries, while the second 2020 lockdown in France does not apply to hunters.

\section{PLACING ENVIRONMENTAL ENCROACHMENT AND DISEASE OUTBREAKS INTO HISTORICAL CONTEXT}

Historians have long recognised the links between humans transitioning, or encroaching, into new environments and the subsequent emergence of diseases (e.g. McNeill, 1976; Morris, 2011). However, the results of past collaborative work between historians, ecologists and epidemiologists are insufficiently used because they are in books or older articles: today many scientists are disconnected from their own disciplines' histories, since they prefer to use "new techniques of extracting literature through electronic means which filters out older material" (Reiners \& Lockwood in Spinage, 2012, p.vi).

When hominid species left the forest and entered the savannas (ca. 2 million years ago), they encountered new tick and mosquito species and their associated diseases. The emergence of tuberculosis arose from an "assemblage of effects" (Herschel, 1831, p.166), which included the consumption of novel food sources and the increase in smoke-induced lung damage that arose from the social interaction of gathering around the fire (fire was mastered 300,000 - 400,000 years ago) (Chisholm et al., 2016, p.9053). When agriculturalists in the Fertile Crescent created permanent settlements $(5,000$ 10,000 years ago), they made homes for scavengers and their diseases. When people domesticated wolves and other animals in the Old World, they brought novel diseases into their houses (Penakalapati et al., 2017) and into their meals. During the 50,000 - 100,000 years of global migrations and bridging of continental barriers, the movements of Homo sapiens have been accompanied by epidemics and pandemics (McMichael, 2004). All of these events would have had novel impacts on "the environment and wildlife" (Manenti et al., 2020, p.2) both during the transition into new environments and after the emergence of the associated disease.

For conservationists, restricting our historical and environmental exploration of novel diseases to the last century $^{3}$ not only limits understanding of ecosystems and of conservation, but also restricts our ability to generate "effective conservation policy" (Young et al., 2017, p. 3). In its correct historical context, Rutz's call for the international research community to "use these extraordinary circumstances to gain unprecedented mechanistic insight into how human activity affects wildlife" (Silva-Rodríguez et al., 2020, p.1) is problematic, as it entails untangling the current effects of reduced human movement from previous historic "extraordinary circumstances", besides other mitigating factors ${ }^{4}$.

Below we present data to suggest an alternative hypothesis. First, we summarise how the introduction of Rinderpest disease in Africa led to the creation of important protected areas in eastern Africa, something documented by an interdisciplinary team including ecologists in the Serengeti. We then document two historical cases of encounters of Europeans with Africans and with South Americans that led to the introduction of novel diseases for local populations which decimated Indigenous peoples, traditional communities and local communities who once lived in what are now protected areas in Gabon and Brazil. The former concerns relatively recent history from the 1800s, and the latter dates to the start of the first European expeditions to the Amazon in the 1500s. We show the connections between these processes and the subsequent construction of pristine wilderness myths, especially during the colonial era; and contend that these have become part of the way many erroneously understand the ecology and landscapes in these areas today (Fairhead \& Leach, 1996; Walters et al., 2019).

\section{THE 1887-1900 RINDERPEST PLAGUE AND THE CREATION OF PROTECTED AREAS IN EASTERN AND SOUTHERN AFRICA}

Through popular wildlife documentaries, safaris and other Africa-oriented environmental education across the world, a myth has been formed that some African national parks have been created to protect the remaining bush that is still "teeming with wildebeest and elephants, lions and zebras" (Pearce, 2000), while elsewhere this "African Eden" (Adams \& McShane, 1996, pp. 5-6) has largely disappeared because of human activity. Though this myth has been discredited by many Africanist scholars, conservationists and 


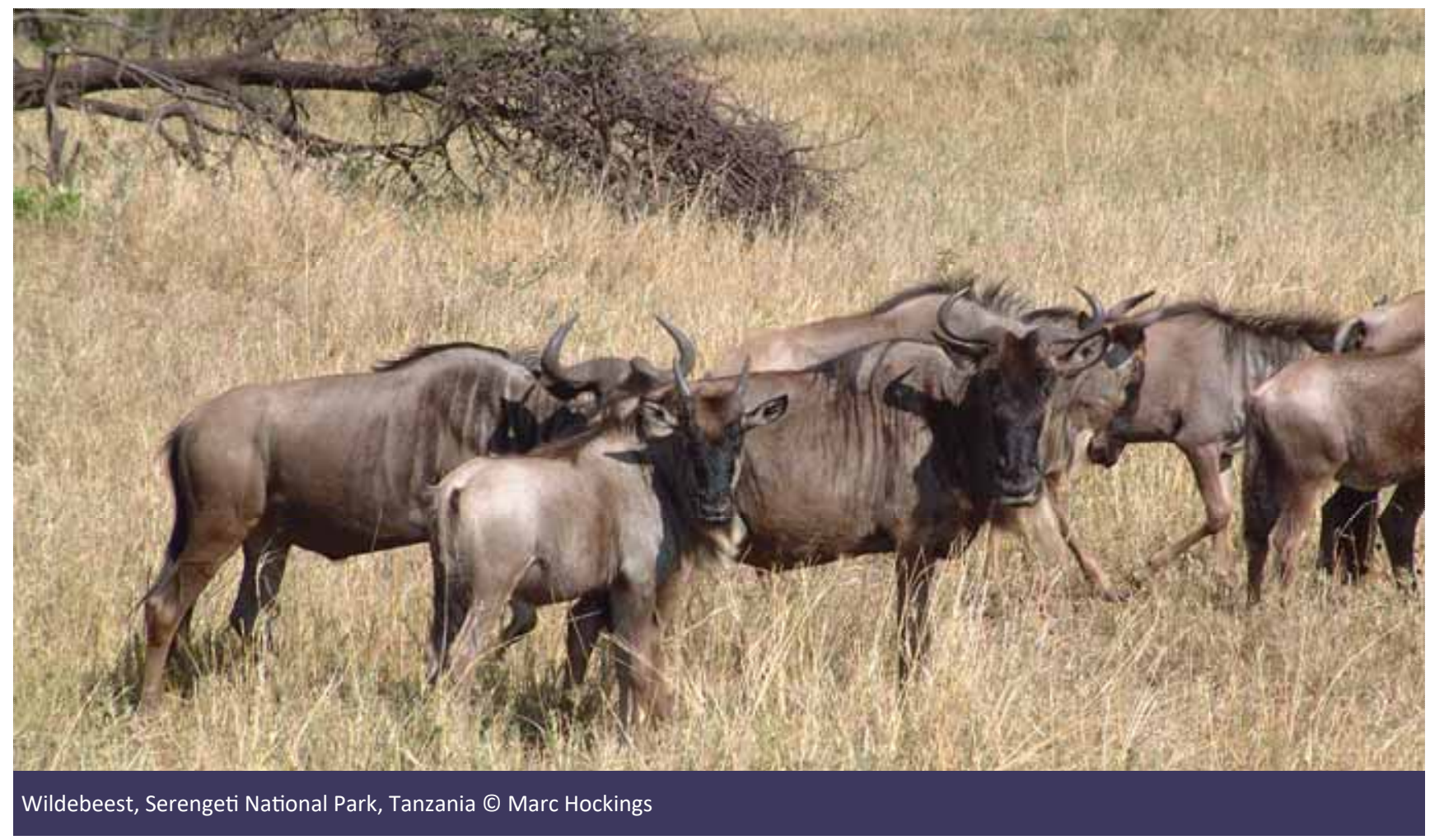

ecologists (Brockington, 2002; Homewood, 2008), it is worth summarising why this discourse is only a part of the story. Many renowned African National Parks, including the Serengeti (Sinclair et al., 2015), Maasai Mara, Ngorongoro, Tarangire, Tsavo, Selous, Kafue, Ruaha, Okavango, Luangwa and Kruger, result from a history of disease that led to the disappearance of people, their livestock and other anthropogenic activities, including fire, from these landscapes in the late 1800s.

Rinderpest, a viral disease of ruminants, originated when the British imported cattle into Egypt from India in 1868 (Spinage, 2012, p.1057) and later Eritrea (Ford, 1971, p. 138; Rowe \& Hødnebø, 1994, p. 155). Despite various unsuccessful colonial attempts to stop its dissemination, including quarantine and culling (Katzung Hokanson, 2019), the disease spread further (Marquardt, 2007). With a mortality rate of 90 per cent, cattle herds across the continent were devastated (Reader, 1998). It also impacted ruminant wildlife including Eland, Bongo, Wildebeest, Buffalo, Warthogs and Giraffes (Sinclair \& Arcese, 1995, p.488; Sinclair et al., 2015, p.17).

Whenever Rinderpest struck, pastoral and other farming livelihoods reliant on draught animals (e.g. for waterwheels, plough and transport) stopped. Weakened human populations were more vulnerable to famine, to other diseases such as smallpox, typhus, cholera and trypanosomiasis, and to natural disasters like locust plagues (Ford, 1971, p.141; Kjekshus, 1996, pp.126- 132). Human populations were devastated and their subsistence activities, like cultivation, burning, hunting and raising cattle, were abandoned (Ford, 1971, p.196; Sinclair et al., 2015, p.16).

Once grazing pressure of livestock and other herbivores was removed, trees became established (Sinclair et al., 2015, Chapter 3). Thus landscapes once described by colonial and pre-colonial explorers and hunters as savanna grasslands (Onselen, 1972; Sinclair \& Arcese, 1995, Chapters 4 and 23; Brockington, 2002, p.29) became dense thickets and woodlands. In turn, these thickets allowed the establishment of Tsetse fly (Glossina), carrying trypanosomiasis (Trypanosoma), a flagellated protozoic parasitic disease that kills cattle and causes fatal sleeping sickness in humans (Ford, 1971). This Tsetse fly-infested thicket discouraged the return of people and their livestock, but allowed populations of certain wild animal species to explode (Spinage, 2012, p.1092).

Till the mid-20th century, a vicious cycle of disease recurred in places such as the Serengeti, where Tsetse "flies multiplied, further lowering both human and cattle populations, leading to more habitat for Tsetse, and so on" (Adams \& McShane, 1996, p. 49). Colonial administrators who had, since the 1890s, been creating game reserves in which colonial elites could hunt, 
viewed these areas as pristine woodlands where many new reserves could be created. Later they became the protected areas of today (Pearce, 2000; Sinclair et al., 2015, Chapters 8 and 17).

In the 1940s and 1950s, colonial administrations started the first insecticide programmes against the Tsetse fly and cattle vaccination programmes against Rinderpest. As wildlife does not act as a long-term reservoir of Rinderpest, the vaccination of cattle brought about another explosion in wildlife populations (Sinclair \& Norton-Griffiths, 1979, Chapter 4; Sinclair \& Arcese, 1995, Chapters 4 and 23) and, at the same time, the return of pastoralists who felt it was safe to graze their livestock in these areas, setting up conflicts between pastoralists and conservationists (Brockington, 2002; Homewood et al., 2009; Sinclair et al., 2015, Chapters $4,8,16$ and 17). These conflicts continue today, especially when this disease history is forgotten, helping to discredit historical land use and land claims (Bluwstein, 2019).

This brief history, which historians have written about in detail (Marquardt, 2007), shows how a late 1800s pandemic created the colonial mind-set of pristine wildernesses, which were then established as protected areas in eastern and southern Africa. Taking the Serengeti as an example, collaboration between ecologists, conservationists, historians and social scientists (see the volumes edited by Sinclair from: 1979 to 2015) has shown how this savanna landscape is at disequilibrium (Behnke et al., 1993). A landscape that is not based on a simple succession/climax theory upon which a carrying capacity for livestock can be determined, but rather a highly dynamic system that reflects the complexities of climate variability. This understanding has improved its conservation (Adams \& McShane, 1996).

\section{PAST EPIDEMICS, FAMINE AND COLONISATION: CREATING THE MYTH OF GABON'S EDEN}

Waka National Park $(107,000$ ha.) is a mountainous park located in central Gabon, straddling the du Chaillu Massif (Map 1). It was created in 2002 in recognition of its rich culture, being the home of the Babongo Indigenous people (however see Hymas, 2015, Chapter 4 for how the Bantu speaking population fit into this rich culture), as well as endangered species such as Chimpanzees (Pan troglodytes), Gorillas (Gorilla gorilla) and Elephants (Loxodonta cyclotis). To its north lies the better-known Lopé National Park, which became a mixed UNESCO World Heritage site in 2007.

Within these parks, and in Gabon in general, diseaserelated human depopulation has a long history. The disappearance of iron workers between 1,400 and 800 BP from Lopé suggests that it was devoid of people for a 600-year period probably due to an epidemic (see Oslisly in Weber et al., 2001, pp.112- 113; Spinage, 2012, p.1194). From the mid-1800s, the scramble for natural

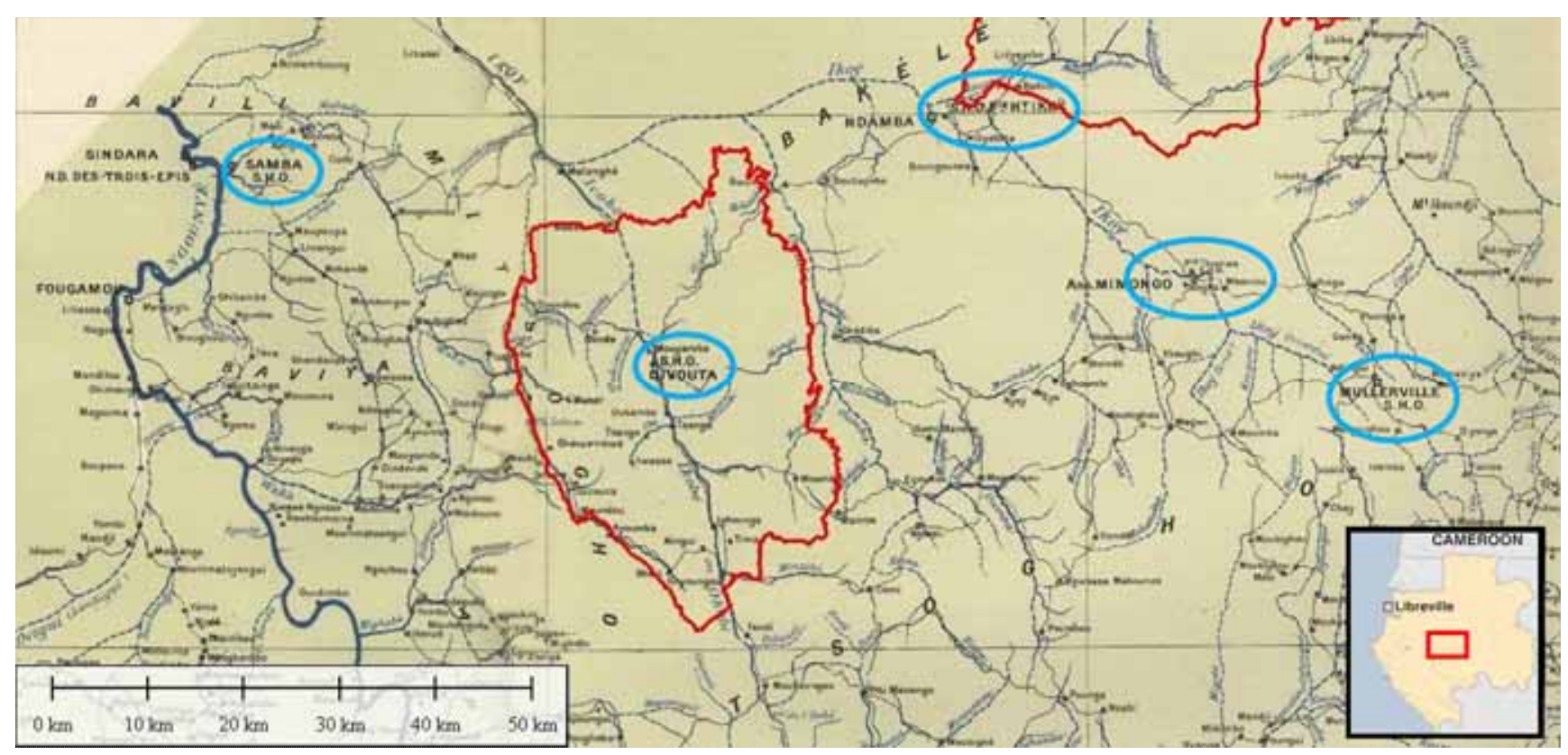

Map 1. Gabon - Old trade routes, villages and Société Commerciale, Industrielle et Agricole du Haut-Ogooué (SHO) trading posts in 1928, with the addition of the current Waka and Lopé National Park boundaries (in red), old SHO trading posts (in blue). Adapted from Mariol (1928) 
resources to trade with Europeans and the accompanying trade routes (see trade route map of Mariol, 1928), displacements, migration and forced labour intensified the spread of diseases (Sautter, 1966, p.625; Hartwig \& Patterson, 1978, p.12; Hymas, 2015, Chapter 3). Resulting population density maps show empty areas (Sautter, 1966, p.969) as entire villages disappeared, which were then claimed by forest.

Multiple outbreaks of diseases and famine occurred in colonial Gabon from 1910 to the 1930s. During this period, colonial administrators described seeing bodies and skeletons along well-established trade routes (Sautter, 1966, pp.860-861; Coquery-Vidrovitch, 1985, pp.54-56; Gray, 2002, p.158). The best known of the outbreaks was the 1918 Influenza pandemic, when it is estimated that half the population died (Patterson, 1975, 1979; Debusman, 1993; Rich, 2007)5, even though "severe [maritime] quarantine measures [which] had prevented the entrance of the flu into Gabon" had been established (Headrick, 1994, p. 173; see also Patterson, 1981, p. 407). This depopulation was reflected by a French forester who wrote in 1918:

\begin{abstract}
[d]ans toute la partie exploitable de la forêt du Gabon il devient de plus en plus rare de rencontrer des villages en plein forêt. La maladie du sommeil, l'alcoolisme, les maladies vénériennes ont fait disparaître une grande partie de la population et le reste, décimé, s'est rapproché petit à petit des points d'où il était facile d'aller aux factoreries européennes ${ }^{6}$ (Quillard in Chailley \& Zolla, 1920, p.645).
\end{abstract}

The Ikobey area, which is a corridor between Lopé National Park and Waka National Park (Map 1) off the main trade routes, was not spared. From the late 1890s until the early 1900s, this area was part of a commercial concession belonging to Société Commerciale, Industrielle et Agricole du Haut-Ogooué (SHO) (Coquery-Vidrovitch, 2001, p.380). In 1907 one of the first colonial French commercial agents for the SHO, Monsieur Quéru, set up trading posts in the middle reaches of the Ikoy and Ikobey Rivers (CoqueryVidrovitch, 2001, p.381). Via a network of caravan routes, he organised the buying and transport of rubber, ivory, raffia and palm kernels (Barnes, 1992, p.25; Coquery-Vidrovitch, 2001, pp.381-383; Gray, 2002, p.172). Later, new roads and caravan routes linked the trading posts at Sindara to the SHO trading posts and villages (Gray, 2002, pp.172-177). By 1928, the whole of the Ikobey area was criss-crossed with trading routes.

The trade activity of Europeans in the Ikobey region brought people in remote areas into contact with novel coastal diseases (Hartwig \& Patterson, 1978, pp.9- 10;
Headrick, 1994, p.42). The road building, carried out through a regroupement policy that relocated villages next to roads to provide forced labour, exacerbated the spread of various diseases, as did bringing porters and workers from greater distances. People fled the area as famine and disease spread. During the 1918 Influenza pandemic there was a 16.6 per cent mortality rate in the principal trading post of Sindara (Bruel, 1935, p.338).

By the 1930s, when the SHO lost the concession and was split up, the Ikobey area was completely depopulated, becoming a "dead zone" (Gray, 2002, p.160; Hymas, 2015, Chapter 4) which people feared was cursed (Choubert, 1954, p.37; Gray, 2002). For around thirty years, it was devoid of human presence, resulting in the growth of Okoumé (Aucoumea klaineana) trees and an increase in wild animal populations that had previously been hunted either for food or trade (Hymas, 2015, p.139). The network of trails and SHO trading posts fell into a state of disrepair and then disappeared altogether (Hymas, 2015).

With Gabon's independence from France in 1960, people started to return to the outskirts of the "dead zone". A timber company was granted a 100,000 ha concession (Gomez-J ordana, 1971), which attracted people fleeing regroupement and others seeking employment in the Société l'Okoumé de la N'gounié (La SONG). Only with the arrival of this company did the "dead zone" close completely. Local communities, still present in the area, found forest everywhere, some recalling that: "ici c'est la forêt tout ça c'était la forêt, Nyoe I et Nyoe II c'est la SONG qui a ouvert ça" and "il n'y avait pas des vieux villages"7 (Hymas, 2015, p.144).

This reforestation later made the area - presented at the time by the National Geographic Society as an African Eden (Quammen, 2003) - attractive both to timber companies (interested in larger timber trees) and conservationists, who created national parks for their biodiversity. The historical literature and oral histories presented here show that this so-called Eden was the product of earlier disease outbreaks linked to colonisation, when diseases spread from populated areas into rural areas.

The cycle of disease/ depopulation/forest regeneration described for Ikobey is not the first nor the last of its kind. Before the arrival of the Europeans at the start of the 20th century, the area had already gone through at least one similar cycle in the 1840-1880s, due to war (Hymas, 2015, pp.124- 125). From 2000, another cycle has started with people migrating out of the forest to 
roadside and urban areas (Hymas, 2015, pp.139- 143). Once again, depopulation of the landscape around Ikobey is underway (Photo 1).

\section{COLONISATION, EPIDEMICS AND THE PRISTINE MYTH IN BRAZILIAN AMAZONIA}

In contrast to the above examples, where epidemics led to the full (if temporary) abandonment of areas, in the Brazilian Amazon different lines of evidence show that forests have been continuously occupied and managed for millennia by Indigenous peoples and, from the eighteenth century, traditional communities - such as formerly enslaved Afrobrazilians who fled captivity in plantations, and rubber tappers who came from the country's northeast from the late 1800s (Photo 2). In this section we explore how the demographic collapses that occurred, largely as a result of epidemics that ensued from the European invasion of the Americas, fed into the creation of the Pristine myth (Denevan, 1992) the idea that the region was uninhabited until European arrival. This in turn was fundamental in shaping policies for the region, including the creation of strictprotection conservation units ${ }^{8}$. We focus here upon the establishment of the Amazônia National Park (Map 2),

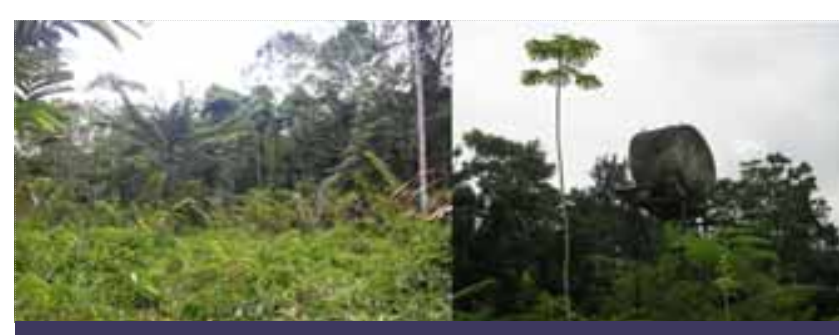

Photo 1. Forest taking over village site and logging camp that were abandoned around 2004, Gabon (C) Olivier Hymas

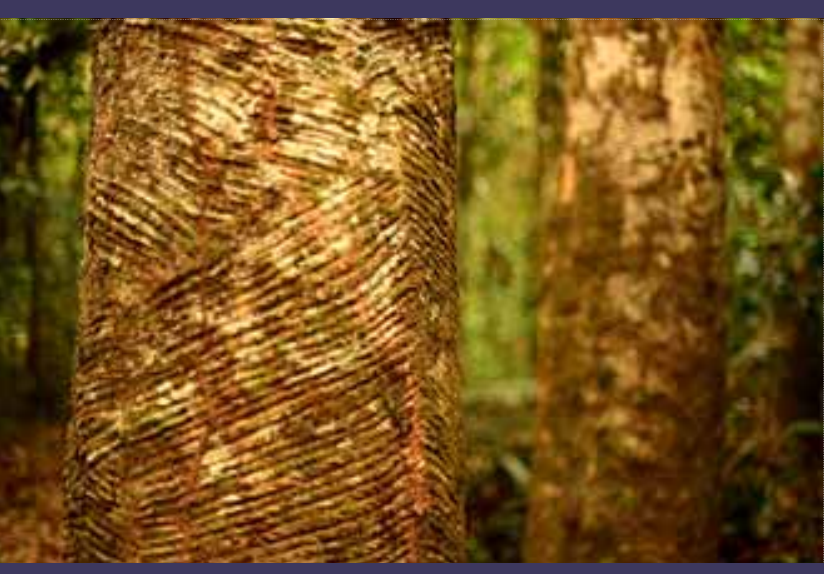

Photo 2. Trees that had previously been used for tapping rubber, Brazil (c) Natalia Guerrero

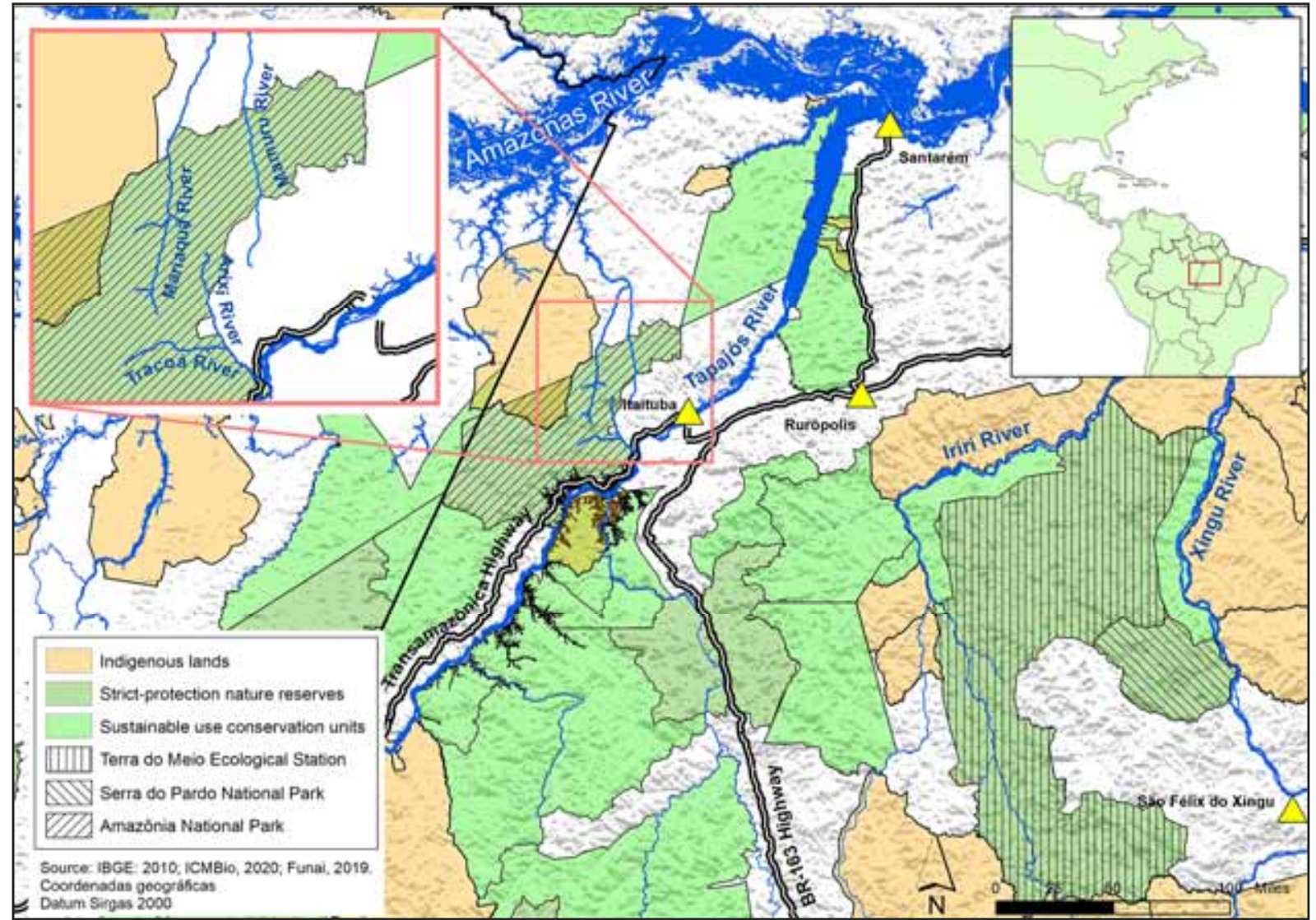

Map 2. Brazil - Amazônia National Park, by the Tapajós River 
which is located near the last rapids of the Tapajós River as it travels northwards.

In Amazonia, evidence of cumulative human transformations of the environment is available from the earliest archaeological sites, dated around 12,000 BP (Shock \& Moraes, 2019), involving plant use and management by Amerindian peoples. Formed from $\mathrm{C}$. 4,000 BP, Amazonian Dark Earths (ADEs), or anthrosols, are the unintentional consequence of human habitation and/ or the intentional result of past soil management (see Neves et al. in Lehmann et al., 2004, p. 35). They contain high levels of nutrients, organic matter and ceramic, lithic, faunal and botanical remains (see Kern et al. pp. 51-75 and Neves et al. pp. 29-50 both in Lehmann et al., 2004), and are extremely fertile. Studies have brought to light a "positive feedback process ... the long-lasting increase in productive capacity of soils for agricultural activities as a result of ancient habitation practices" (see ArroyoKalin in Pereira \& Guapindaia, 2010, p.378).

Fossil lake and terrestrial records taken near the right bank of the lower Tapajós River, dating from up to 8,500 years ago (Maezumi et al., 2018), clearly show the impact of these environmental management practices. In pre-Columbian times, lake cores indicate a closed canopy forest where growing signs of anthropogenic activity occur from 4,500 BP, including an increase in palm, edible plants and controlled fires, without there being any large-scale deforestation. Further upstream on the Tapajós River, in the vicinity of the Amazônia National Park in Itaituba, indirect evidence points to millennial human occupation of the region (Simões, 1976; Rocha, 2017), while archaeological research, focused primarily on sites containing Amazonian Dark Earths, obtained dates for past occupations ranging from $680 \pm 30 \mathrm{CE}$ to the 1800s (Perota, 1979; Rocha, 2017, pp.166-167). Within the park itself an archaeological survey located several former Amerindian sites (Oliveira et al., 2010).

The first European expeditions to the Amazon brought diseases that decimated Amerindian populations who had no prior exposure to them, either in practical or genetic terms (Myers, 1988). In close succession or simultaneously, smallpox, measles, influenza, tuberculosis and - in the wake of the Transatlantic Slave Trade - malaria, dengue, haemorrhagic and yellow fever devastated Amerindian societies. It is estimated that approximately 90 per cent of the Indigenous population in the Americas died in the first century following European invasion (Koch et al., 2019). The marked discrepancy between the descriptions by the first Europeans to travel along the banks of the Amazon River (1540-1570), who mention densely occupied areas (Carvajal, 1934), and later descriptions of Indigenous societies by colonial missionaries (Myers, 1988) indicates the intensity of this early demographic collapse in these areas.

But contact was "a temporally extended process, rather than a single instant or event that ruptures the otherwise pristine Garden of Eden into which colonial Europeans at first believed they had stumbled" (Whitehead, 1993, p.288) and could in fact happen prior to the physical encounter between Europeans and Amerindian peoples (Posey, 1987). Reports of Indigenous people fleeing missions (e.g. Biblioteca Pública de Évora, no date) indicate another way disease may have been transmitted to areas beyond Portuguese presence as "disease agents and vectors could spread from intrusive (white) carriers to aboriginal populations" (Cook, 1955, p.411). Thus in interior areas, such as Itaituba, peoples living beyond the reach of early colonial settlements could have become infected before the physical arrival of Europeans (Rocha, 2017).

The town of Santarém, a former pre-Columbian centre situated at the mouth of the Tapajós River, became a stop-off point for European vessels ascending and descending the Amazon River. The definitive establishment of Eurobrazilian presence here happened early on: Jesuits founded the headquarters for their activities in southern Amazonia from 1661. Mission settlements practised little quarantining of the sick (Crosby, 1976, p.296) and became "critical in creating stable pools for reinfection" (Whitehead, 1993, p.290) of Old World diseases, which would travel outwards along the trade networks that spanned from Santarém (Rocha, 2017).

The deadly effects of these "virgin soil epidemics" (Crosby, 1976) were compounded by warfare, slavery and descimentos, whereby missionaries uprooted Amerindian villages from different social groups and resettled them together in mission stations (aldeamentos). Large percentages ${ }^{9}$ of people aged fifteen to forty died (Crosby, 1976, p.294), which led to famine, and the collapse of traditional environmental management practices and polyculture agroforestry systems (Brierley, 1999; Koch et al., 2019). With the collapse in population after 1500, the core samples of the lower Tapajós River show a drop in fire use (see Figure 2d in Maezumi et al., 2018, p.18). However, areas were not completely abandoned as the territorial dynamics of Amerindian societies also changed, and new populations, such as rubber tapper communities, were brought to the Amazon by the early 1900s. 
The definitive establishment of Eurobrazilian presence further upstream in Itaituba, from the mid-1800s, would have started off new epidemic events. In contrast to frequent mentions of the effects of Old World diseases among Indigenous peoples living in Santarém and environs by Jesuits (e.g. Bettendorff, 1910), nineteenth-century travellers to the upper reaches of the Tapajós did not explicitly comment on the effects of diseases among the Indigenous population of that area. ${ }^{10}$ The Munduruku Indigenous people did not forget, however: "There were no illnesses here before the parïwat [whites; enemies] arrived" (Munduruku man in Melo \& Villanueva, 2008, p.40). Referring to the "plague", or "fever", the Sateré-Maué people today allude to an epidemic that some of them lived through as children, which was likely to have been yellow fever or malaria, and that occurred around 1940-50 in the vicinity of the Mariaquã and Mamuru Rivers. ${ }^{11}$ It is possible that this was an important element leading to an abandonment of these river valleys by the SateréMaué, though the rubber tapper communities remained. The Mamuru and the Mariaquã's headwaters are now part of the Amazônia National Park, as are some of the lands of the Munduruku.

In the 1950s, the Brazilian government determined that the "vocation" of the Amazon region was as a repository of natural resources that needed to be "integrated" into the rest of the country (Bueno, 2002; Arbex Jr., 2005, pp.21-67). From 1964, the military dictatorship continued these policies by promising "a land without people to people without land" (the people referred to being peasants pressuring for land reform in other parts of the country). The integration project led to the opening of roads, with massive incentives given to industrial agriculture and cattle-rearing enterprises in the region. The result was great devastation and a new genocide of Indigenous peoples (Brasil. Comissão da Verdade, 2014). At the same time, though, there was heightened conservation action, with the creation of 20 strict-protection reserves, covering almost 10 million hectares. Barretto Filho (2001, pp.158-159) argues that there is no contradiction here, as the creation of these numerous conservation units was made possible because they too reflected a top-down and hegemonically economic perspective.

The Amazônia National Park is a case in point. Created in 1974, based on the Yellowstone model (Torres, 2005), this is the area for which we observed ample evidence of previous human occupation - firstly by Indigenous peoples and later, straddling the nineteenth and twentieth centuries, by rubber-tapper communities. Yet the park's Management Plan claimed that it was "the country's largest national park, with over a million hectares of rainforest, which is almost entirely unaltered" (IBDF \& Polamazônia, 1978, p.83). In another passage, the plan states that a visit to "its unexplored dense rainforest, and the Tapajós River's primitive beauty, could satisfy the desire [of tourists], through the contact with the Amazon's primeval environment" (IBDF \& Polamazônia, 1978, p.33). The plan clearly ignored the existence of places along the Tracuá River, which were completely within the park's limits, and where, according to people who once lived in the area, there was pasture for cattle. Interviews with people whose land was expropriated always told of the same experiences: subjection to intimidation, and violence to force them to leave their territories. Entire communities left. Ironically, a decade later, an area within the Amazônia National Park was removed from it to make way for mining.

As elsewhere in the Amazon basin, archaeological and palaeoecological evidence points to protracted human occupation of the Tapajós River, while historic documents and indirect palaeoecological data indicate the collapse in Amerindian populations following the European invasion of Amazonia in the 1500s. But despite the depopulation caused by past epidemics, surviving Amerindian peoples continued to occupy forest areas, which in the case of the Amazônia National Park would also come to be inhabited by traditional communities. Naturalists' portrayals of the forest and its peoples would bring about the creation of the Pristine myth of lands supposedly unaltered by anthropogenic activity. This fed into a narrative that helped legitimise territorial expropriation throughout the basin with the super-imposition of strict-protection conservation units over traditionally occupied territories, with repercussions today.

\section{CONCLUSION}

By looking at past pandemics, we show that the impact of COVID-19 on the environment is not novel. Events like it have occurred since hominids started to migrate out of forests. Interdisciplinary conservationists, working with historians, archaeologists, anthropologists and others, have long studied the impacts of such events and the anthropauses they have brought about. Through three case studies, we have shown how past pandemics have set in motion a chain of events (Figure 1) that led to the creation of protected areas in landscapes that were, at the time, considered to be pristine wilderness.

We argue that it is misleading to use industrial society's values and perspectives on history as an adequate basis for shaping effective conservation policies in places 

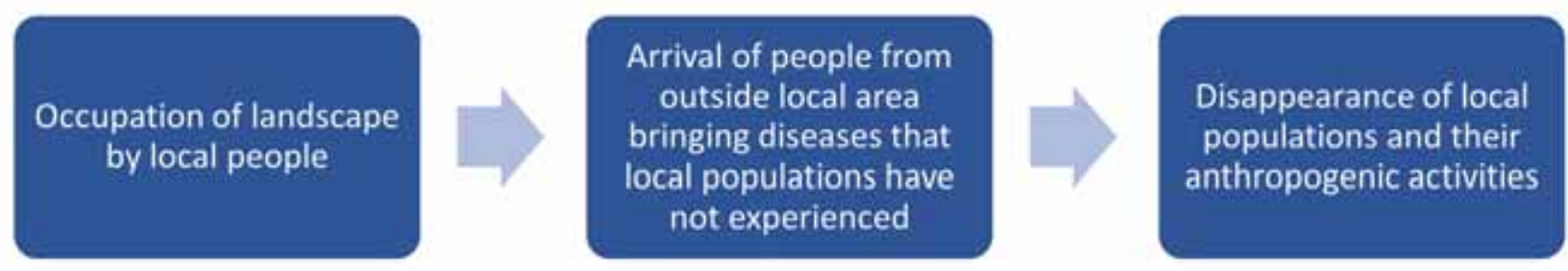

Disappearance of local

populations and their

bringing diseases that

cal populations have

anthropogenic activities
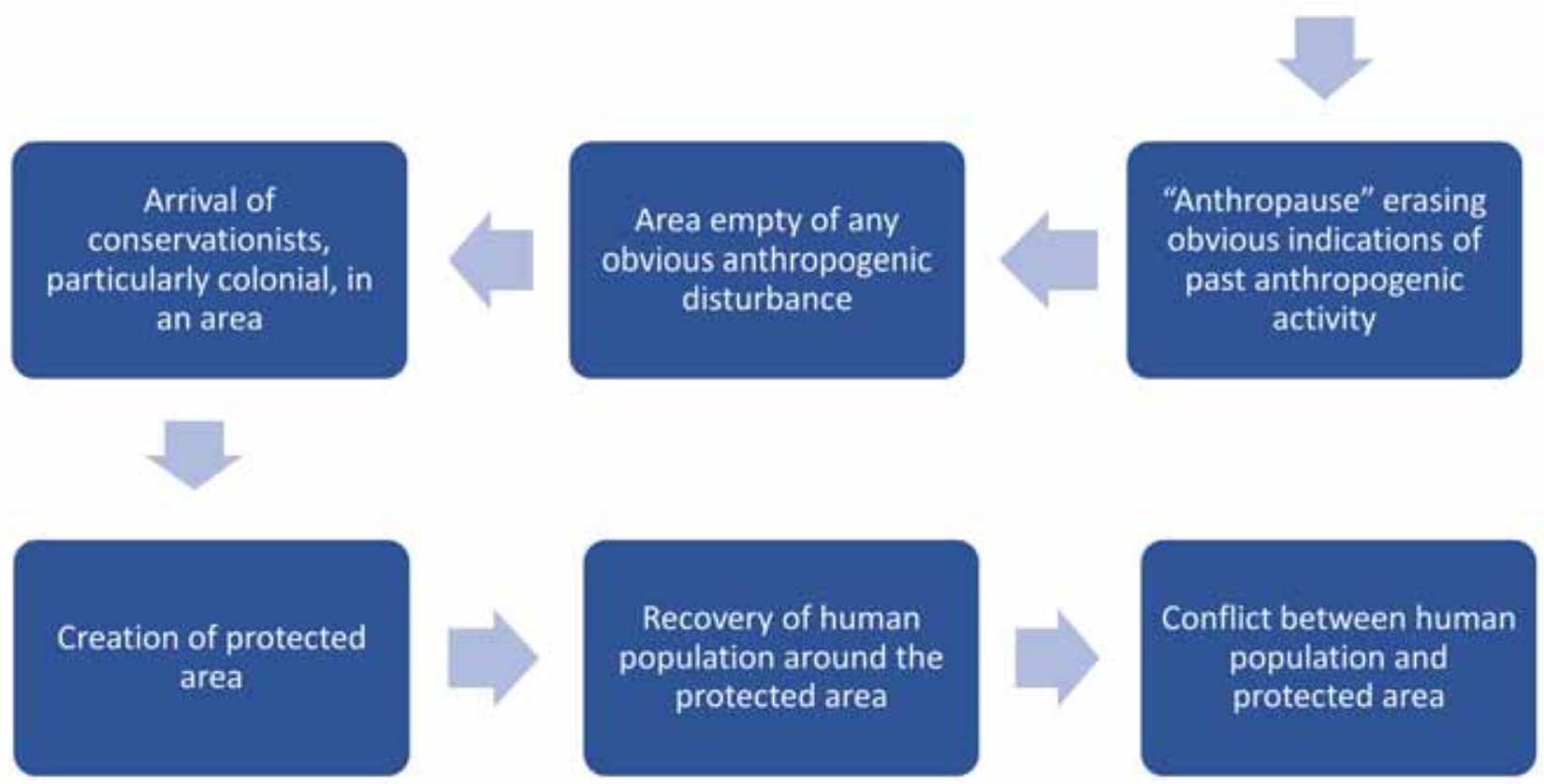

Figure 1. Chain of events following pandemics in the colonial era and how it impacts the perception by colonial conservationists of landscapes and ecology of protected and conserved areas

where these values and perspectives do not prevail and that it is mistaken to remove humans from conceptualisations of the environment (Pretty, 2011). Interdisciplinary scholars have repeatedly shown (e.g. Fairhead \& Leach, 1996; Walters et al., 2019) that apparently pristine wildernesses hide a much more complicated history of large-scale depopulation caused by outbreaks of diseases that were spread by European colonisation, exploration and trade.

We have seen how disturbances in the human/disease relationship are, within a longer historical timeframe, relatively common. The depopulation caused by such disturbance events is often followed by a regeneration of vegetation - particularly in tropical environments that conceals evidence of past anthropogenic activities. For the casual observer, without archaeological, historical or anthropological knowledge that would allow them to identify indicators of past human occupation, the vegetation succession creates the impression of a pristine wilderness. This tabula rasa (Aristotle, 2016, pp.60-61, gloss 430a; Duschinsky, 2012) has been used, particularly during the colonial period, to justify the creation of protected areas to the detriment of the ecology, conservation and the peoples who have long lived in these landscapes.

Archaeological, historical and anthropological literature can help conservationists better understand the factors shaping many of the landscapes and ecologies of protected and conserved areas (Szabó, 2010; Pooley, 2013). It is increasingly being shown that current Indigenous peoples' and traditional communities' management practices in anthropogenic landscapes support the aims of conservation (Levis et al., 2017, 2018; e.g. Balée et al., 2020). It would be useful to carry out such studies for all protected and conserved areas in the world, including future ones, in order to better understand the role of local populations, disease and historical events in shaping such landscapes and by doing so improve protected and conservation area management, in particular recognising the role that Indigenous peoples and local communities have played in shaping today's conservation landscapes. Though interdisciplinary research is becoming common, carrying it out is easier said than done (various difficulties are described in Adams, 2007; Drury et al., 2011; Fox et al., 2006; Pooley et al., 2014). Too often, it 
consists of little more than each discipline working separately on various aspects of the same project (Lowe et al., 2009). ${ }^{12}$ Also it is susceptible to 'garbage in/ garbage out' errors (GIGO) (Babbage, 1864, p.67; Hinde, 2004; Little et al., 2017). The interdisciplinary researcher must learn to be wary of their social, cultural and educational baggage, and accept that they may have to unlearn some fundamental assumptions in their own discipline. In effect, the interdisciplinary researcher "must also look inward to ensure that their own special interests do not undermine the usefulness of science" (Ascher, 2004, p.437).

While much progress has been made in both conservation and ecological science in accepting that pristine wilderness is very often a myth, current talk of the anthropause and use of ecological methods to substitute archaeological, historical and anthropological methods, suggests otherwise. We need to go further in our mindset change and assume that the great majority of protected and conserved areas have had some past anthropogenic activity until demonstrated otherwise. The first step in this process would be to accept that the anthropause is not new and redefine it to include any past event that has led to reduced anthropogenic activity (Figure 1). Only when ecologists and conservationists systematically integrate archaeological, historical and anthropological methods into their research and management of protected and conserved areas can it be said that we have finally de-bunked the myth of the pristine wilderness.

\section{ENDNOTES}

${ }^{1}$ As of the 4 December 2020 it has been cited over 5,308 times.

${ }^{2}$ For an example of this progress, see the four volumes on the Serengeti edited by Sinclair from 1979 to 2015.

${ }^{3}$ For example, Jones et al. only analysed 'EID events' since 1940 and included yellow fever (Jones et al., 2008, p.993) and does not refer to any of the cases in the comprehensive 1979 bibliography of infectious diseases of Africa in the twentiethcentury by Patterson (1979).

${ }^{4}$ Factors such as confined ecologists recording wildlife out of their windows at home. For instance Silva-Rodríguez uses idle camera traps to record the presence of Otters (Lontra provocax) in the urban areas of the city of Valdivia, in Chile, where they have "not been documented in the scientific literature, [though] its presence near the civic center of the city has been anecdotally reported before" (Silva-Rodríguez et al., 2020, p.8).

${ }^{5}$ The early twentieth century particularly impacted the Fang people, just like the mid-nineteenth century had impacted the Mpongwe. The Fang had continued to migrate to new trading centres on the coast to participate in trade, and with this the mortality rate of the Fang increased (Sautter, 1966, pp.860872). Missionaries estimated that during the influenza pandemic of 1918, 10 per cent of the population of Kango (east of Libreville) died (Rich, 2007, p.249), while by 1930 the Fang population had reduced by a half (Coquery-Vidrovitch, 1985, pp.54-56).

${ }^{6}$ "in all the exploitable areas of the Gabonese forest, it is becoming more and more rare to find villages in the middle of the forest. Sleeping sickness, alcoholism, venereal diseases have resulted in the disappearance of a large part of the population and the rest, decimated, have slowly come closer to places where they can get easy access to European factories".

7"here everything was forest, all that was forest, Nyoe I and Nyoe II, it was La SONG that opened it up". Makoko, Babongo Ghebondgi 24/02/10 [recording DS400043; 17:15] (Hymas, 2015 , p.144). "there were no old villages". Nyoe II, Akele 22/05/10 [recording DS400078; 16:25] (Hymas, 2015, p.144).

${ }^{8}$ In Brazil, strict-protection conservation units, which include National Parks, Ecological Stations and Biological Reserves, are one modality of protected area that does not permit human occupation. Sustainable use conservation units, on the other hand, are another modality that allows for human occupation, though in accordance with stipulated norms.

${ }^{9}$ It is hard to be more specific than this as it varies from people to people, over time and geographical location.

${ }^{10}$ Administrative documents and naturalists' accounts dating from the turn of the nineteenth to twentieth century testified to the continued occupation by Indigenous peoples and traditional communities of the area. Land titles issued by the Itaituba Intendancy between 1892 and 1904 recognised lands belonging to the Sateré-Maué people who lived inland, while the presence of Munduruku Indigenous peoples close to the banks of the Tapajós is noted.

${ }^{11}$ This living memory heavily influenced Sateré-Maués' reaction to news of the arrival of SARS-CoV-2, leading them to autonomously isolate themselves when they heard of the pandemic's approach.

${ }^{12}$ One of the pitfalls of interdisciplinarity is replacing longestablished method protocols of one discipline with protocols designed for another discipline, a form of 'Special Interest Error' (Little et al., 2017, p.280).

\section{ABOUT THE AUTHORS}

Olivier Hymas is a conservation practitioner / researcher, trained in biology and anthropology, specialising on long-term impacts of industries and conservation on rural communities and their environment, especially in Africa.

Bruna Rocha is an archaeologist and works along the middle and upper reaches of the Tapajós River, researching its peoples' long duration history .

Natalia Guerrero is a $\mathrm{PhD}$ candidate in Social Anthropology at University of São Paulo, with research experience in socioenvironmental conflicts involving traditional peoples in Brazilian Amazonia.

Mauricio Torres studies territorial conflicts in Amazonia from the perspective of peasants, Indigenous peoples and traditional communities. 
Kevin Ndong is a Gabonese social scientist working on integrating local communities into the communication of the Gabonese National Parks.

Gretchen Walters is an anthropologist and botanist who focuses on interdisciplinary approaches to understanding conservation landscapes in their historical contexts.

\section{REFERENCES}

Adams, J. and McShane, T. (1996) The myth of wild Africa: conservation without illusion. Berkeley: University of California Press.

Adams, W. (2007) Editorial, Oryx, 41(03). doi: 10/d7nj7b.

Ahlström, A., De Jong, G., Nijland, W. and Tagesson, T. (2020) Primary productivity of managed and pristine forests in Sweden, Environmental Research Letters, 15(9), p. 094067. doi: 10/ghm7rn.

Arbex Jr., J. (2005) 'Terra sem povo', crime sem castigo Pouco ou nada sabemos de concreto sobre a Amazônia, in Torres, M. (ed.) Amazônia revelada: os descaminhos ao longo da BR163. Brasília, Brazil: CNPq: DNIT, pp. 21-67. http:// philip.inpa.gov.br/publ_livres/Livros\%20inteiros/Amaz\%C3\% B4nia\%20Revelada.pdf.

Aristotle (2016) De anima. Translated by C. Shields. Oxford, United Kingdom : New York, NY: Clarendon Press (Clarendon Aristotle series).

Ascher, W. (2004) Scientific information and uncertainty: challenges for the use of science in policymaking. Science and engineering ethics, 10(3), pp. 437-455. doi: 10/fp44pp.

Babbage, C. (1864) Passages from the life of a philosopher. London: Longman.

Balée, W., de Oliveira, V., dos Santos, R., Amaral, M., Rocha, B., Guerrero, N. et al. (2020) Ancient Transformation, Current Conservation: Traditional Forest Management on the Iriri River, Brazilian Amazonia, Human Ecology, 48(1), pp. 1-15. doi: $10 /$ ghfbqx.

Barnes, J. (1992) Gabon: Beyond the Colonial Legacy. Boulder, San Francisco, Oxford: Westview Press.

Barretto Filho, H. (2001) Da nação ao planeta através da natureza: uma abordagem antropológica das unidades de conservação de proteção integral na Amazônia Brasileira. Ph.D. University of São Paulo. https://www.teses.usp.br/ teses/disponiveis/8/8134/tde-28072017-162458/ publico/2001_HenyoTrindadeBarrettoFilho.pdf.

Bauters, M., Vercleyen, O., Vanlauwe, B., Six, J., Bonyoma, B., Badjoko, H. et al. (2019) Long-term recovery of the functional community assembly and carbon pools in an African tropical forest succession, Biotropica, 51(3), pp. 319-329. doi: 10/ ghm7qz.

Behnke, R., Scoones, I. and Kerven, C. (eds) (1993) Range ecology at disequilibrium: new models of natural variability and pastoral adaptation in African savannas. London: Overseas Development Institute.

Bettendorff, J. (1910) Crônica da missão dos padres da Companhia de Jesus no Estado do Maranhão. Brasília: Senado Federal (Edições do Senado Federal, volume 115).

Biblioteca Pública de Évora (no date) Breve Noticia do Rio Topajôs, cujascabeceyras ultimò se descobrirão no anno de
1742 por huns certanejos ou Mineiros do Matto Grosso. CXV/2-15 a $\mathrm{n}^{\circ} 7$, fols $51 \mathrm{r}-54 \mathrm{r}$. Portugal.

Bluwstein, J. (2019) Resisting Legibility: State and Conservation Boundaries, Pastoralism, and the Risk of Dispossession through Geospatial Surveys in Tanzania, Rural Landscapes: Society, Environment, History, 6(1), p. 1. doi: 10/ghp6qk.

Brasil. Comissão da Verdade (2014) Relatório da CNV: textos temáticos, v. II, texto 5. Brasília. http:// cnv.memoriasreveladas.gov.br/images/pdf/relatorio/Volume $\%$ 202\%20-\%20Texto\%205.pdf.

Brierley, C. (1999) 1492 and the loss of Amazonian crop genetic resources. The relation between domestication and human population decline, Economic Botany, 53(2), pp. 188-202. doi: 10/b4mhqb.

Brockington, D. (2002) Fortress conservation: the preservation of the Mkomazi Game Reserve, Tanzania. Oxford: James Currey (African issues).

Bruel, G. (1935) La France Equatoriale Africaine: le pays, les habitants, la colonisation, les pouvoirs publics. Paris: Larose.

Bueno, M. (2002) O imaginário brasileiro sobre a Amazônia. M.Sc. Human Geography.

Byrne, J. P. (ed.) (2008) Encyclopedia of pestilence, pandemics, and plagues. Westport, Conn: Greenwood Press.

Carvajal, G. de, (1934) "Discovery of the Orellana River". In: H.C. Heaton, ed., The Discovery of the Amazon According to the Account of Friar Gaspar de Carvajal and Other Documents. Translation by Bertram T. Lee. New York: American Geographical Society.

Chailley, M. and Zolla, D. (eds) (1920) Congrès D’Agriculture Coloniale 21-25 Mai 1918. Compte Rendu des Travaux. Tome IV. Paris: Augustin Challamel.

Chisholm, R., Trauer, J., Curnoe, D. and Tanaka, M. (2016) Controlled fire use in early humans might have triggered the evolutionary emergence of tuberculosis, Proceedings of the National Academy of Sciences, 113(32), pp. 9051-9056. doi: 10/f86vbn.

Choubert, B. (1954) Recherches Géologiques au Gabon Central, Bulletin de la Direction des Mines et de la Géologie, 6, pp. 581.

Chua, L. and Fair, H. (2019) Anthropocene, Cambridge Encyclopedia of Anthropology. Edited by F. Stein, M. Candea, H. Diemberger, S. Lazar, A. Sanchez, and R. Stasch. doi: 10/ ggnbsg.

Cook, S. (1955) The Epidemic of 1830-1833 in California and Oregon. http://digitalassets.lib.berkeley.edu/anthpubs/ucb/ text/ucp043-004.pdf.

Coquery-Vidrovitch, C. (1985) Afrique noire: permanences et ruptures. Paris: Payot (Aux origines de notre temps).

Coquery-Vidrovitch, C. (2001) Le Congo au temps des grandes compagnies concessionnaires 1898-1930. Paris: Edition de l'EHESS

Crosby, A. (1976) Virgin Soil Epidemics as a Factor in the Aboriginal Depopulation in America, The William and Mary Quarterly, 33(2), p. 289. doi: 10/bzqm9q.

Cunningham, A. (2008) Epidemics, Pandemics, and the Doomsday Scenario, Historically Speaking, 9(7), pp. 29-31. doi: 10/ghqb38.

Curtin, P. (1998) Disease and empire: the health of European troops in the conquest of Africa. Cambridge, U.K. ; New York: Cambridge University Press. 
Debusman, R. (1993) Santé et population sous l'effet de la colonisation en Afrique équatoriale, Matériaux pour l'histoire de notre temps, 32(1), pp. 40-46. doi: 10/c7639d.

Denevan, W. (1992) The Pristine Myth: The Landscape of the Americas in 1492, Annals of the Association of American Geographers, 82(3,), pp. 369-385. doi: 10/fnzj4w.

Drury, R., Homewood, K. and Randall, S. (2011) Less is more: the potential of qualitative approaches in conservation research: Qualitative approaches in conservation research, Animal Conservation, 14(1), pp. 18-24. doi: 10/czn8wb.

Duschinsky, R. (2012) Tabula Rasa and Human Nature, Philosophy, 87(4), pp. 509-529. doi: 10/ghfq26.

Fairhead, J. and Leach, M. (1996) Misreading the African landscape: society and ecology in a forest-savanna mosaic. Cambridge; New York: Cambridge University Press (African studies series, 90 ).

Ford, J. (1971) The role of the trypanosomiases in African ecology: a study of the tsetse fly problem. Oxford [Eng.]: Clarendon Press. https://www.fulcrum.org/concern/ monographs/v692t637h.

Fox, H., Christian, C., Nordby, J., Pergams, O., Peterson, G. and Pyke, C. (2006) Perceived Barriers to Integrating Social Science and Conservation, Conservation Biology, 20(6), pp. 1817-1820. doi: 10/bqkfdj.

Gatti, R. (2020) Coronavirus outbreak is a symptom of Gaia's sickness, Ecological Modelling, 426, p. 109075. doi: 10/ ggv48q.

Ghazoul, J., Burivalova, Z., Garcia-Ulloa, J. and King, L. (2015) Conceptualizing Forest Degradation, Trends in Ecology \& Evolution, 30(10), pp. 622-632. doi: 10/f7vht7.

Gomez-Jordana, R. (1971) El Okoume, ABC, 24 April, pp. 12-13.

Gottdenker, N., Streicker, D., Faust, C. and Carroll, C. (2014) Anthropogenic Land Use Change and Infectious Diseases: A Review of the Evidence, EcoHealth, 11(4), pp. 619-632. doi: $10 / g g 9725$.

Gray, C. (2002) Colonial rule and crisis in Equatorial Africa: Southern Gabon, c. 1850-1940. Rochester N.Y.: University of Rochester Press.

Hartwig, G. and Patterson, K. (eds) (1978) Disease in African history: an introductory survey and case studies. Durham, N.C: Duke University Press ([Publication] - Duke University Center for Commonwealth and Comparative Studies ; no. 44).

Headrick, R. (1994) Colonial Health and Illness in French Equatorial Africa, 1885-1935. Edited by D. Headrick. Atlanta Georgia: African Studies Association Press.

Herschel, J. (1831) A Preliminary Discourse on the Study of Natural Philosophy. Philadelphia: Carey and Lea.

Hinde, S. (2004) The transmutation of GIGO and the cult of assumption, Computer fraud \& security, 2004(4), pp. 12-13. doi: 10/d6j2sh.

Homewood, K. (2008) Ecology of African pastoralist societies. Oxford: Athens, $\mathrm{OH}$ : Pretoria: James Currey.

Homewood, K., Kristjanson, P. and Trench, P. (eds) (2009) Staying Maasai? Livelihoods, Conservation and Development in East African Rangelands. New York, NY: Springer (Studies in Human Ecology and Adaptation). doi: 10.1007/978-0-38787492-0.

Hubau, W., De Mil, T., Van den Bulcke, J., Phillips, O., Angoboy Ilondea, B., Van Acker, J. et al. (2019) The persistence of carbon in the African forest understory, Nature Plants, 5(2), pp. 133-140. doi: 10/ggbj6h.
Hymas, O. (2015) L'Okoumé, fils du manioc: Post-logging in remote rural forest areas of Gabon and its long-term impacts on development and the environment. Ph.D. University College London. https://discovery.ucl.ac.uk/id/eprint/1473718/.

IBDF Instituto Brasileiro de Desenvolvimento Florestal and Programa de Poios Agropecuários e Agrominerais da Amazônia - POLAMAZÔNIA (1978) Plano de Manejo do Parque Nacional da Amazônia (Tapajós). Brasília. https:// www.icmbio.gov.br/portal/images/stories/docs-planos-demanejo/parna_amazonia_pm.pdf.

Jones, K., Patel, N., Levy, M., Storeygard, A., Balk, D., Gittleman, J. et al. (2008) Global trends in emerging infectious diseases, Nature, 451(7181), pp. 990-993. doi: 10/cbxh9h

Katzung Hokanson, B. (2019) Best of Intentions?: Rinderpest, Containment Practices, and Rebellion in Rhodesia in 1896, The Gettysburg Historical Journal, 18(1). https:// cupola.gettysburg.edu/ghj/vol18/iss1/8.

Khoury, B. (2020) The Root Causes of COVID-19 Screech for Compassion, Mindfulness, 11(8), pp. 1910-1913. doi: 10/ gg92nw.

Kilpatrick, A., Salkeld, D., Titcomb, G. and Hahn, M. (2017) Conservation of biodiversity as a strategy for improving human health and well-being, Philosophical Transactions of the Royal Society B: Biological Sciences, 372(1722), p. 20160131. doi: 10/ghcdcb.

Kjekshus, H. (1996) Ecology control \& economic development in East African history: the case of Tanganyika 1850-1950. London: Athens: James Curry (Eastern African studies).

Koch, A., Brierley, C., Maslin, M. and Lewis, S. (2019) Earth system impacts of the European arrival and Great Dying in the Americas after 1492, Quaternary Science Reviews, 207, pp. 13-36. doi: 10/gftzwm.

Lehmann, J., Kern, D., Glaser, B. and Wodos, W. (eds) (2004) Amazonian Dark Earths. Dordrecht: Kluwer. doi: 10.1007/14020-2597-1_4.

LePan, N. (2020) Visualizing the History of Pandemics, Visual Capitalist. https://www.visualcapitalist.com/history-ofpandemics-deadliest/.

Levis, C., Costa, F., Bongers, F., Peña-Claros, M., Clement, C., Junqueira, A. et al. (2017) Persistent effects of pre-Columbian plant domestication on Amazonian forest composition, Science, 355(6328), pp. 925-931. doi: 10/cmt2.

Levis, C., Flores, B., Moreira, P., Luize, B., Alves, R., FrancoMoraes, J. et al. (2018) How People Domesticated Amazonian Forests, Frontiers in Ecology and Evolution, 5, p. 171. doi: $10 / \mathrm{cwtm}$.

Little, T., Widaman, K., Levy, R., Rodgers, J. and Hancock, G. (2017) Error, Error in My Model, Who's the Fairest Error of Them All?, Research in Human Development, 14(4), pp. 271286. doi: 10/gdqbtw.

Lopez-Gonzalez, G., Burkitt, M., Lewis, S. and Phillips, O. (2012) ForestPlots.net - managing permanent plot information across the tropics, p. 10. doi: 10/ghm9nb.

Lowe, P., Whitman, G. and Phillipson, J. (2009) Ecology and the social sciences, Journal of Applied Ecology, 46(2), pp. 297305. doi: 10/bxvbz2.

Maezumi, S., Alves, D., Robinson, M., de Souza, J., Levis, C., Barnett, R. et al. (2018) The legacy of 4,500 years of polyculture agroforestry in the eastern Amazon, Nature Plants, 4(8), pp. 540-547. doi: 10/gd9kvs. 
Hymas et al.

Malhi, Y., Gardner, T., Goldsmith, G., Silman, M. R. and Zelazowski, P. (2014) Tropical Forests in the Anthropocene, Annual Review of Environment and Resources, 39(1), pp. 125-159. doi: 10/f25nxx.

Manenti, R., Mori, E., Di Canio, V., Mercurio, S., Picone, M., Caffi, M. et al. (2020) The good, the bad and the ugly of COVID-19 lockdown effects on wildlife conservation: Insights from the first European locked down country, Biological Conservation, 249, p. 108728 . doi: 10/ghk46k.

Mariol, F. (1928) La Nyanga et la Ngounyé d'après les itinéraires de G. Le Testu, M.A. De Pompignan et H. Charbonnier. Administrateurs des Colonies. J. Lacombe et V.E. Eymard, Adjoints Principaux des Services Civils. Paris: Les Procedes Dorel.

Marquardt, G. (2007) Open Spaces and Closed Minds A SocioEnvironmental History of Rinderpest in South Africa And Namibia, 1896-1897. D.Phil. University of WisconsinMadison. https://www.academia.edu/download/58994492/ Marquardt_Dissertation.pdf.

McMichael, A. (2004) Environmental and social influences on emerging infectious diseases: past, present and future, Philosophical Transactions of the Royal Society of London. Series B: Biological Sciences, 359(1447), pp. 1049-1058. doi: $10.1098 /$ rstb.2004.1480.

McNeill, W. (1976) Plagues and peoples. New York: Anchor Books Doubleday. http://hdl.handle.net/2027/heb.03218.

Melo, J. and Villanueva, R. (2008) Levantamento etnoecológico Munduruku: terra indígena Munduruku. Brasília: FUNAI/ PPTAL/GTZ. https://acervo.socioambiental.org/sites/default/ files/documents/MUL00005.pdf.

Morens, D., Folkers, G. and Fauci, A. (2004) The challenge of emerging and re-emerging infectious diseases, Nature, 430 (6996), pp. 242-249. doi: 10/ff5w22.

Morris, I. (2011) Why the West rules-for now: the patterns of history, and what they reveal about the future. London: Profile books

Myers, T. (1988) El efecto de las pestes sobre las poblaciones de la Amazonía Alta, Amazonia peruana, 8(15), pp. 61-81.

Neumann, R. (2002) Imposing wilderness: struggles over livelihood and nature preservation in Africa. Berkeley, Calif.: University of California Press (California studies in critical human geography, 4)

Oliveira, W., Barbosa, L. and Silva, W. (2010) Diagnóstico Arqueológico do Parque Nacional da Amazônia (PNA), Itaituba (PA). Unpublihed Report. Inside Consultoria Científica.

Onselen, C. van (1972) Reactions to Rinderpest in Southern Africa 1896-97, The Journal of African History, 13(3), pp. 473 -488. doi: 10/djnt2z.

Patterson, K. (1975) The northern Gabon coast to 1875. Oxford: Clarendon Press.

Patterson, K. (1979) Infectious diseases in twentieth-century Africa: a bibliography of their distribution and consequences. Waltham, Mass.: Crossroads Press (The Archival and bibliographic series).

Patterson, K. (1981) The Dempographic Impact of the 1918-19 Influenza Pandemic in Sub-Saharan Africa: A Preliminary Assessement, in. African Historical Demography, Centre of African Studies. University of Edinburgh., pp. 403-431.

Patterson, K. (1986) Pandemic influenza, 1700-1900: a study in historical epidemiology. Totowa, N.J: Rowan \& Littlefield.
Pearce, F. (2000) Inventing Africa, New Scientist, 167(2251), pp. 30-33.

Penakalapati, G., Swarthout, J., Delahoy, M., McAliley, L., Wodnik, B., Levy, K. et al. (2017) Exposure to Animal Feces and Human Health: A Systematic Review and Proposed Research Priorities, Environmental Science \& Technology, 51(20), pp. 11537-11552. doi: 10/gcjcb6.

Pereira, E. and Guapindaia, V. (eds) (2010) Primeiro Encontro Internacional de Arqueologia Amazônica. Museu Goeldi.

Perota, C. (1979) Pesquisas de campo realizada na bacia do rio Tapajós como parte do Programa Nacional de Pesquisas Arqueológicas da Bacia Amazônica (PRONAPABA). CNPq IPHAN: Universidade Federal do Espírito Santo.

Pooley, S. (2013) Historians are from Venus, Ecologists are from Mars, Conservation Biology, 27(6), pp. 1481-1483. doi: 10/ ghfjsj.

Pooley, S., Mendelsohn, J. and Milner-Gulland, E. J. (2014) Hunting Down the Chimera of Multiple Disciplinarity in Conservation Science, Conservation Biology, 28(1), pp. 2232. doi: 10/f5qm4v.

Posey, D. (1987) Contact before contact: typology of postcolombian interaction with northern kayapó of the Amazon basin, Boletim do Museu Paraense Emílio Goeldi. Série Antropologia, 3(2), pp. 135-154. http://repositorio.museugoeldi.br/handle/mgoeldi/565

Poulsen, J., Medjibe, V., White, L., Miao, Z., Banak Ngok, L., Beirne, C. et al. (2020) Old growth Afrotropical forests critical for maintaining forest carbon, Global Ecology and Biogeography. Edited by B. Poulter, 29(10), pp. 1785-1798. doi: 10/ghm9rv.

Pretty, J. (2011) Interdisciplinary progress in approaches to address social-ecological and ecocultural systems, Environmental Conservation, 38(02), pp. 127-139. doi: 10/ fjbm74.

Quammen, D. (2003) Saving Africa's Eden, National Geogrphic, 204(3), pp. 50-77

Reader, J. (1998) Africa: a biography of the continent. London: Penguin Books.

Rich, J. (2007) Hunger and Consumer Protest in Colonial Africa During the First World War: The Case of the Gabon Estuary, 1914-1920, Food, Culture and Society: An International Journal of Multidisciplinary Research, 10(2), pp. 239-259. doi: 10/dvpq95.

Rocha, B. (2017) Ipi Ocemumuge: A Regional Archaeology of the Upper Tapajós River. Ph.D. University College London. https://discovery.ucl.ac.uk/id/eprint/1558734/7/ Rocha_2017_Ipi\%200cemumuge_A\%20Regional\% 20Archaeology\%20of\%20the\%20Upper\%20Tapajos $\%$ 20River\%20v1\%20\%28edited $\% 20$ online $\% 20$ version $\% 29 \%$ 20and\%20v2.pdf.

Rowe, J. and Hødnebø, K. (1994) Rinderpest in The Sudan 18881890: The Mystery of The Missing Panzootic, Sudanic Africa, 5, pp. 149-178. http://www.jstor.org/stable/25653249.

Rudiak-Gould, P. (2015) The Social Life of Blame in the Anthropocene, Environment and Society, 6(1). doi: 10/gfx3z7.

Rutz, C., Loretto, M.-C., Bates, A., Davidson, S., Duarte, C., Jetz, W. et al. (2020) COVID-19 lockdown allows researchers to quantify the effects of human activity on wildlife, Nature Ecology \& Evolution, 4(9), pp. 1156-1159. doi: 10/ghfbwc.

Saunders-Hastings, P. and Krewski, D. (2016) Reviewing the History of Pandemic Influenza: Understanding Patterns of 
Emergence and Transmission, Pathogens, 5(4), p. 66. doi: 10/ggx94j.

Sautter, G. (1966) De l'Atlantique au Congo: une géographie du sous-peuplement République du Congo; République Gabonaise. Paris: La Haye, Mouton.

Schultz, P. (2011) Conservation Means Behavior, Conservation Biology, 25(6), pp. 1080-1083. doi: 10/br43x8.

Shock, M. and Moraes, C. (2019) A floresta é o domus: a importância das evidências arqueobotânicas e arqueológicas das ocupações humanas amazônicas na transição Pleistoceno/Holoceno, Boletim do Museu Paraense Emílio Goeldi. Ciências Humanas, 14(2), pp. 263-289. doi: 10/ ghfbt6.

Silva-Rodríguez, E., Gálvez, N., Swan, G., Cusack, J. and Moreira -Arce, D. (2020) Urban wildlife in times of COVID-19: What can we infer from novel carnivore records in urban areas?, Science of The Total Environment, p. 142713. doi: 10/ ghk5mt.

Simões, M. (1976) Nota sobre duas pontas-de-projétil da bacia do Tapajós (Pará). Belém, Pará, Brasil: Conselho Nacional de Desenvolvimento Científico e Tecnológico, Instituto Nacional de Pesquisas da Amazônia, Museu Paraense Emílio Goeldi. https://repositorio.museu-goeldi.br/bitstream/mgoeldi/632/1/ B\%20MPEG\%20Ant\%20n62\%201976\%20SIMOES.pdf.

Sinclair, A. and Arcese, P. (eds) (1995) Serengeti II: dynamics, management, and conservation of an ecosystem. Chicago: University of Chicago Press.

Sinclair, A., Metzger, K., Mduma, S. and Fryxell, J. (2015) Serengeti IV: Sustaining Biodiversity in a Coupled HumanNatural System. University of Chicago Press. doi: 10.7208/ chicago/9780226196336.001.0001.

Sinclair, A. and Norton-Griffiths, M. (eds) (1979) Serengeti, dynamics of an ecosystem. Chicago: University of Chicago Press.

Snowden, F. (2008) Emerging and reemerging diseases: a historical perspective, Immunological Reviews, 225(1), pp. 926. doi: $10 / \mathrm{d} 75 \mathrm{v} 2 \mathrm{j}$.

Spinage, C. A. (2012) African Ecology. Berlin, Heidelberg: Springer Berlin Heidelberg. http:// link.springer.com/10.1007/978-3-642-22872-8.

Stegeman, I., Godfrey, A., Romeo-Velilla, M., Bell, R., Staatsen, B., van der Vliet, N. et al. (2020) Encouraging and Enabling Lifestyles and Behaviours to Simultaneously Promote Environmental Sustainability, Health and Equity: Key Policy
Messages from INHERIT, International Journal of Environmental Research and Public Health, 17(19), p. 7166. doi: 10/ghnjjd.

Stephen, C., Berezowski, J. and Misra, V. (2015) Surprise is a Neglected Aspect of Emerging Infectious Disease, EcoHealth, 12(2), pp. 208-211. doi: 10/gg92cj.

Szabó, P. (2010) Why history matters in ecology: an interdisciplinary perspective, Environmental Conservation, 37 (04), pp. 380-387. doi: 10/dt3pjn.

Szabó, P. and Hédl, R. (2011) Advancing the Integration of History and Ecology for Conservation: History, Ecology, and Conservation, Conservation Biology, 25(4), pp. 680-687. doi: $10 / \operatorname{ch} 9 x \mathrm{dh}$.

Torres, M. (ed.) (2005) Amazônia revelada: os descaminhos ao longo da BR-163. Brasília, Brazil. http://philip.inpa.gov.br/ publ_livres/Livros\%20inteiros/Amaz\%C3\%B4nia\% 20Revelada.pdf.

Volpato, G., Fontefrancesco, M., Gruppuso, P., Zocchi, D. and Pieroni, A. (2020) Baby pangolins on my plate: possible lessons to learn from the COVID-19 pandemic, Journal of Ethnobiology and Ethnomedicine, 16(1), pp. 19, s13002-02000366-4. doi: 10/ggs2z4.

Walters, G., Broome, N., Cracco, M., Dash, T., Dudley, N., Elias, S. et al. (2021) COVID-19, Indigenous peoples, local communities and natural resource governance, PARKS.

Walters, G., Fraser, J., Picard, N., Hymas, O. and Fairhead, J. (2019) Deciphering African tropical forest dynamics in the Anthropocene: How social and historical sciences can elucidate forest cover change and inform forest management, Anthropocene, 27, p. 100214. doi: 10/gg3kxf.

Weber, W., White, L., Vedder, A. and Naughton-Treves, L. (eds) (2001) African Rain Forest Ecology and Conservation. An Interdisciplinary Perspective. Yale University.

Whitehead, N. (1993) Ethnic Transformation and Historical Discontinuity in Native Amazonia and Guayana, 1500-1900, L'Homme, 33(126), pp. 285-305. doi: 10/bszcc5.

WWF (2020) Covid 19: Urgent Call To Protect People And Nature. https://www.worldwildlife.org/publications/covid19-urgent-callto-protect-people-and-nature.

Young, H., Wood, C., Kilpatrick, A., Lafferty, K., Nunn, C. and Vincent, J. (2017) Conservation, biodiversity and infectious disease: scientific evidence and policy implications, Philosophical Transactions of the Royal Society B: Biological Sciences, 372(1722), p. 20160124. doi: 10/gg92h5. 


\section{RESUMEN}

En muchas sociedades industrializadas, la pandemia del COVID-19 ha sido descrita como un momento sin precedentes causado por el abuso humano de la naturaleza. Sin embargo, las reacciones a la pandemia también han frenado temporalmente los impactos humanos sobre la naturaleza. Esto ha dado lugar a una lucha contra la ocupación humana en las llamadas áreas vírgenes intactas. Al reflexionar sobre las pruebas históricas, arqueológicas y paleoecológicas relativas a los impactos de las epidemias pasadas dentro de un marco histórico más amplio de África y América del Sur, mostramos que, aunque el COVID-19 es una enfermedad nueva, la pandemia en sí misma no constituye un acontecimiento nuevo, habida cuenta de que las enfermedades traídas por los europeos ya habían diezmado a los pueblos que habitaban en estas áreas. La "naturaleza prístina" es un mito, que afirmaba con falsedad que estos lugares siempre habían estado deshabitados, ayudando así a legitimar la creación de áreas protegidas, y su control político por parte de las administraciones tanto coloniales como nacionales. De ahí que cuestionamos lo que se ha venido denominando la "antropausa" - que la supuesta reducción de las actividades antropogénicas provocada por la actual pandemia constituye una nueva oportunidad para estudiar los impactos antropogénicos en la naturaleza: existen numerosas ocasiones anteriores en las que la despoblación dio lugar a antropausas. Tales respuestas al COVID-19 sugieren que, a pesar de los avances en esta dirección, se necesita una mayor interdisciplinariedad en el campo de la conservación.

\section{RÉSUMÉ}

Dans de nombreuses sociétés industrielles, la pandémie COVID-19 a été dépeinte comme un moment sans précédent causé par l'abus humain de la nature. Les réactions à la crise ont, à leur tour, ralenti temporairement les impacts humains sur la nature. Cela a conduit à un cri de ralliement contre l'empiétement humain sur ce que l'on prétend être des étendues sauvages vierges. En se basant sur l'évidence historique, archéologique et paléoécologique relative aux impacts d'épidémies passées sur une période historique plus longue en Afrique et en Amérique du Sud, nous montrons que si la COVID-19 est une maladie nouvelle, la pandémie elle-même ne représente pas un événement nouveau, puisque les maladies apportées par les Européens ont déjà décimé les populations vivant dans ces régions. La «nature sauvage vierge» est un mythe, qui prétend à tort que ces lieux ont toujours été vides de personnes, contribuant ainsi à légitimer la création d'aires protégées et leur contrôle politique par les administrations coloniales et nationales. Nous remettons donc en question l'hypothèse que l'on appelle «l'anthropause» - selon laquelle la réduction supposée des activités anthropiques causée par la pandémie actuelle présente une nouvelle opportunité d'étudier les impacts anthropiques sur la nature. En effet de nombreuses occasions antérieures existent où le dépeuplement a entraîné des anthropauses. De telles réponses à la COVID-19 suggèrent qu'une plus grande interdisciplinarité est nécessaire dans le domaine de la conservation, malgré les progrès déjà réalisés dans cette direction. 


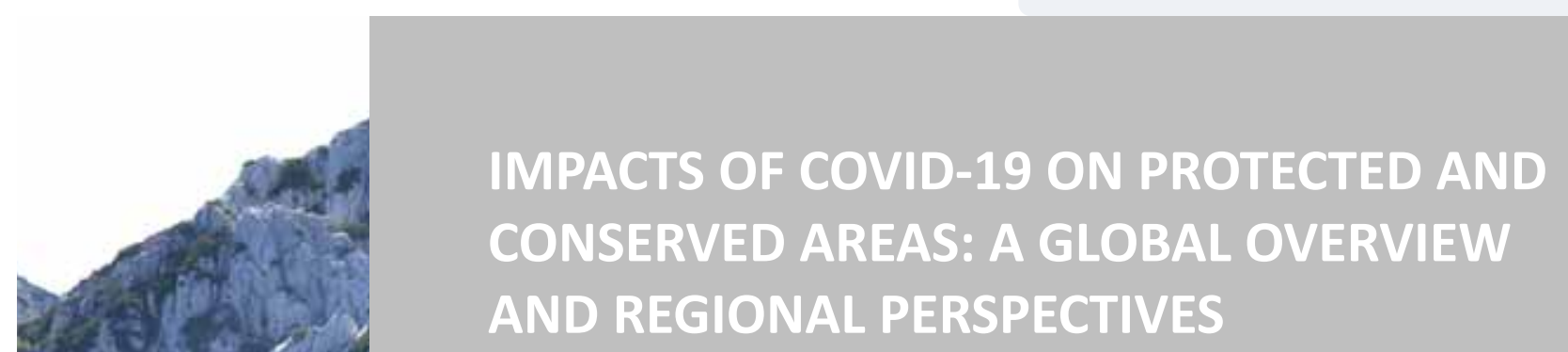

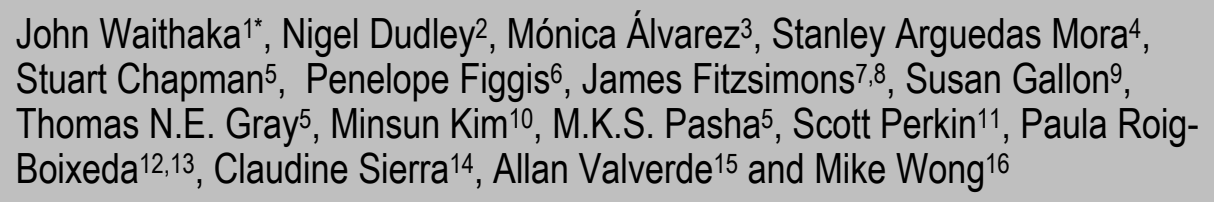

* Corresponding author: john.m.waithaka@gmail.com

${ }^{1}$ IUCN-WCPA East and Southern Africa, P.O. Box 14368-00100, Nairobi, Kenya

${ }^{2}$ Equilibrium Research, 47 The Quays, Cumberland Road, Bristol BS1 6UQ, UK

${ }^{3}$ Punto Focal Coordinación Regional REDPARQUES, Comisión Nacional de Áreas Naturales Protegidas, Mexico

${ }^{4}$ Casa 51, Condominio Bosque Verde, Granadilla Norte. C.P. 11802, Curridabat, San José, Costa Rica

${ }^{5}$ WWF Tigers Alive Initiative, Singapore

${ }^{6}$ IUCN World Commission on Protected Areas, 4 Woolcott St. Waverton, NSW 2060, Australia

${ }^{7}$ The Nature Conservancy, Suite 2-01, 60 Leicester Street, Carlton VIC 3053, Australia

${ }^{8}$ School of Life and Environmental Sciences, Deakin University, Burwood VIC 3125, Australia

${ }^{9}$ MedPAN, 58 Quai du Port, 13002 Marseille, France

${ }^{10}$ Korea National Park Service, 22, Hyeoksin-ro, Wonju-si, Gangwon-do, Republic of Korea

Author affiliations continue on page 55

\begin{abstract}
Protected and conserved areas (PCAs) throughout the world face huge challenges as a result of the COVID-19 pandemic. We give a global overview of impacts and responses. Protected area agencies, NGOs and research groups, together with the communities that support the management of PCAs, have conducted online studies to understand the overall impacts of COVID-19 containment measures on PCAs at regional and global levels. This paper summarises results from ten surveys, eight regional and two global, from 90 countries representing all continents except Antarctica. It draws lessons from different regions and contexts, and synthesises information on impacts and responses, particularly with regard to conservation and management activities, visitor services, revenue, stakeholder engagement, capacity, threats, illegal activities and neighbouring communities. Results vary; generally impacts have been most severe in Africa and Latin America, although many protected area agencies have evolved coping strategies and impacts are apparently not quite as severe as first thought. The paper also identifies future opportunities for PCAs in the post-COVID-19 era and proposes strategic decisions that may help cope with the current pandemic and prevent future ones.
\end{abstract}

Key words: Coronavirus, pandemic, protected areas, conserved areas, lessons learned

\section{INTRODUCTION}

The coronavirus disease (COVID-19) was first brought to global attention in December 2019 and declared a pandemic by the World Health Organization on 11 March 2020. The outbreak brought the world to a crisis posing unprecedented health, economic, environmental and social threats. Immediate action was required to minimise infections and control the spread of this zoonotic disease, suspected to be caused by humanwildlife contact (White \& Razgour, 2020). As in most sectors, protected and conserved area (PCA) operations were scaled down or suspended, visitor facilities closed, workplaces shut, many staff withdrawn from duty stations and supply chains disrupted (Hockings et al., 2020). These measures were often instituted in the absence of emergency response guidelines and without 
the necessary financial information, capacity, skills and technologies. While some PCAs may have benefitted from reduced visitation and pollution, others have seen increased illegal activity (Bennett et al., 2020). Impacts spread beyond PCA boundaries and concerns have been expressed about Indigenous people and local communities living inside and around PCAs (IUCN, 2020). Drawing inferences from recent outbreaks of zoonotic diseases such as Ebola, bird flu (H1N1), Middle East respiratory syndrome (MERS), Rift Valley fever, severe acute respiratory syndrome (SARS), West Nile virus and Zika virus - all of which have been linked to various forms of ecosystem degradation (Plowright et al., 2017) - it is clear that the underlying causes of these and other potential diseases need to be addressed to prevent future pandemics (Kavousi et al., 2020).

To understand how measures to control COVID-19 were impacting on PCAs, several online regional and global surveys were undertaken by a range of PCA practitioners, partners and stakeholders. The surveys were carried out within four months of the pandemic being declared, in Africa, Asia, Europe, Latin America and the Caribbean (LAC), Oceania and North America. They covered terrestrial and marine PCAs under various governance models (state, private, community/ Indigenous and collaborative).

This paper summarises the results. It draws lessons from different regions and contexts, synthesising information on the experience of dealing with the pandemic, the consequences for conservation and management of PCAs, lessons learned and emerging recovery strategies. It identifies opportunities for PCAs in the post-COVID-19 era and proposes strategies to reduce the risks of zoonotic pandemics and cope with any future outbreaks.

\section{METHODS}

Ten online surveys were independently prepared to help understand the impacts of the pandemic on PCAs at regional or global levels, the measures undertaken to address them, and to identify future opportunities for PCAs in the post-COVID-19 era (Table 1). The respondents included directors of PCA agencies, owners and managers of privately protected areas and community conserved areas, and other partners and stakeholders. Most questionnaires sought information on the impacts of COVID-19 on visitor services, revenue, PCA staff, conservation and management activities and neighbouring communities, with some also reporting changes in threats and illegal activities. Some questionnaires asked about innovations, strategies and actions taken to address the challenges posed by the pandemic, the success of such measures and lessons learned. One, which is reported separately because it adopted a rather different approach, looked explicitly at wildlife responses. Reports on the regional surveys are contained in supplementary online material. Ideally, identical surveys would have been used, but the spontaneous and rapid initiation of the surveys meant that this was not possible. Nonetheless, a rich array of material was collected quickly, during the first peak of the pandemic. While the surveys differed so much that direct statistical comparison was difficult, we have analysed each in turn and drawn overall conclusions and recommendations. Most surveys collected lessons learned, many in the form of recommendations.

The ten surveys comprised eight regional and two global assessments. Africa's survey was conducted by the IUCN -World Commission on Protected Areas (IUCN-WCPA) in collaboration with the African Wildlife Foundation and completed by the directors of protected area agencies in April 2020. IUCN carried out a similar survey for the Asia Protected Areas Partnership (APAP) targeting PCA agencies in the region in J une 2020. A survey in Tiger range countries was conducted in MayJ une 2020. MedPAN, the network of marine protected area managers in the Mediterranean countries, launched a survey focusing on marine protected areas (MPAs) in the region in May. The rest of the surveys were carried out between J une and August 2020. They include the Oceania survey that focused on public, private and Indigenous protected areas, along with community managed areas and locally managed marine areas. The North American questionnaire conducted by IUCN-WCPA was sent to all protected area agencies and related bodies in Canada and the USA, while the LAC survey, carried out by REDPARQUES and targeting its

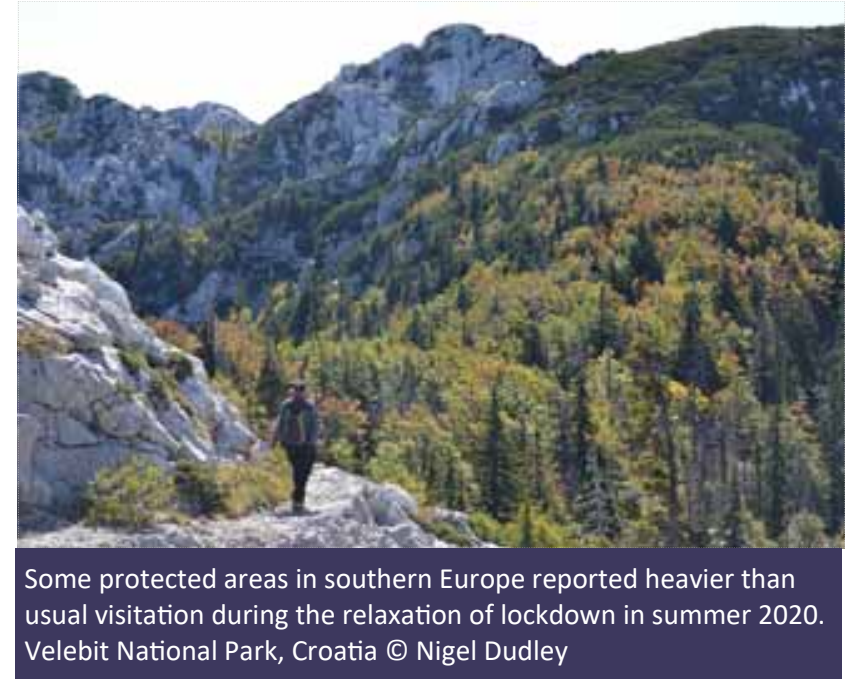


Table 1. Characteristics of the ten independent surveys on the impacts of COVID-19 on protected and conserved areas

\begin{tabular}{|c|c|c|c|}
\hline Region & Countries & Organisational lead & $\begin{array}{l}\text { Number of } \\
\text { responses }\end{array}$ \\
\hline Africa & $\begin{array}{l}\text { Algeria, Benin, Cameroon, Chad, Ethiopia, Ghana, Guinea-Bissau, } \\
\text { Madagascar, Malawi, Mozambique, Niger, Nigeria, Rwanda, Sao } \\
\text { Tome and Principe, Seychelles, Somalia, Sudan, Swaziland, Uganda }\end{array}$ & IUCN and AWF & 19 \\
\hline Asia & $\begin{array}{l}\text { Bangladesh, Bhutan, Cambodia, Japan, Myanmar, Republic of } \\
\text { Korea, Malaysia, Singapore and Sri Lanka }\end{array}$ & $\begin{array}{l}\text { IUCN on behalf of the } \\
\text { Asia Protected Areas } \\
\text { Partnership }\end{array}$ & 9 \\
\hline $\begin{array}{l}\text { Tiger range } \\
\text { states }\end{array}$ & $\begin{array}{l}\text { Bangladesh, Bhutan, Cambodia, China, India, Indonesia, Malaysia, } \\
\text { Myanmar, Nepal, Russian Federation, Thailand and Viet Nam }\end{array}$ & Tigers Alive & $\begin{array}{l}77 \text { responses } \\
\text { from } 40 \text { PCAs }\end{array}$ \\
\hline Oceania & $\begin{array}{l}\text { Australia, New Zealand, Palau, Samoa, Tuvalu, Solomon Islands, } \\
\text { Papua New Guinea, Kiribati and Fiji }\end{array}$ & IUCN & 44 \\
\hline North America & $\begin{array}{l}\text { Canada and the USA (Mexico was included in the Latin America } \\
\text { survey) }\end{array}$ & IUCN & 9 \\
\hline $\begin{array}{l}\text { Latin America } \\
\text { and the } \\
\text { Caribbean }\end{array}$ & $\begin{array}{l}\text { Argentina, Bolivia, Chile, Costa Rica, Cuba, Ecuador, El Salvador, } \\
\text { Guatemala, Mexico, Paraguay, Peru, Dominican Republic, Uruguay } \\
\text { and Venezuela }\end{array}$ & REDPARQUES & 14 \\
\hline $\begin{array}{l}\text { Latin America } \\
\text { species survey }\end{array}$ & $\begin{array}{l}\text { Argentina, Bolivia, Brazil, Colombia, Costa Rica, Ecuador, Mexico, } \\
\text { Peru and Venezuela }\end{array}$ & $\begin{array}{l}\text { Fundaciòn Tropos and } \\
\text { Escuela } \\
\text { latinoamericana de } \\
\text { Areas Protegidas }\end{array}$ & 40 \\
\hline $\begin{array}{l}\text { Mediterranean } \\
\text { marine } \\
\text { protected areas }\end{array}$ & $\begin{array}{l}\text { Albania, Algeria, Croatia, Cyprus, France, Greece, Israel, Lebanon, } \\
\text { Monaco, Northern Cyprus, Slovenia, Spain, Tunisia and Turkey }\end{array}$ & MedPan & 35 \\
\hline $\begin{array}{l}\text { Privately } \\
\text { protected areas } \\
\text { (PPA) }\end{array}$ & $\begin{array}{l}\text { Argentina, Australia, Brazil, Canada, Chile, Colombia, Costa Rica, } \\
\text { Falklands (UK), Namibia, Nepal, Oman, Peru, Puerto Rico (USA), } \\
\text { South Africa, Spain and the USA }\end{array}$ & $\begin{array}{l}\text { WCPA PPA and Nature } \\
\text { Stewardship Specialist } \\
\text { Group }\end{array}$ & 48 \\
\hline $\begin{array}{l}\text { Frankfurt } \\
\text { Zoological } \\
\text { Society (FZS) } \\
\text { supported } \\
\text { protected areas }\end{array}$ & $\begin{array}{l}\text { Germany, Ukraine, Belarus, Poland, Kazakhstan, Indonesia, Viet } \\
\text { Nam, Ethiopia, Democratic Republic of Congo, Tanzania, Zambia, } \\
\text { Zimbabwe, Brazil, Colombia, Guyana and Peru }\end{array}$ & FZS & 29 \\
\hline
\end{tabular}

members, was completed by the focal point for each country. A survey coordinated from Costa Rica looked at wildlife impacts in Latin America. Finally, we report on two surveys that sought global views. The first, conducted by the WCPA Privately Protected Areas and Nature Stewardship Specialist Group focused on privately protected areas (PPAs); the second carried out by the Frankfurt Zoological Society, targeted PCAs supported by that organisation. All surveys were completed by September 2020.

\section{RESULTS}

Given the diverse geographical, eco-climatic, economic, social, cultural, historical, religious, ethnic, racial, political and demographic environments within and between continents, the results of the surveys predictably differ in many ways. Some provided detailed information, including raw data, while others only released summarised highlights. This paper does not attempt to provide a detailed analysis of the surveys but rather regional and global overviews. Below we summarise each survey in turn before extracting key points, leading into the discussion section.

\section{Africa}

This regional survey assessed 23 basic activities normally carried out in PCAs, broadly focusing on biodiversity conservation, security operations, revenue generation and collaboration with stakeholders. Responses were received from directors of PCA agencies from 19 countries spread out across all African regions. The effect of COVID-19 on any PCA activity was rated 'high' if its impact on any of these activities was considered to be between 60 and 100 per cent, 'medium' (40-59 per cent), low' (20-39 per cent) and 'not important' (0-19 per cent). Ninety-four per cent of participating countries reported impacts of 20 per cent and above, although only high impacts (i.e., 60-100 per cent) are presented in this paper.

Most countries reported significant impacts on all operations. More than 70 per cent noted the effects on 


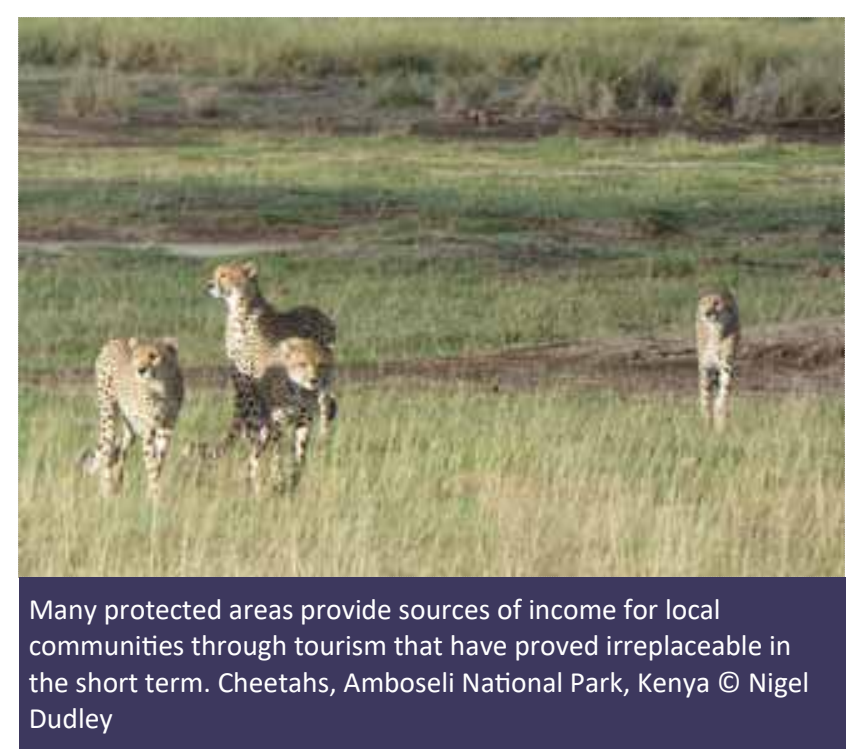

revenue generation from tourism and other sources, monitoring the illegal wildlife trade, and security intelligence. More than 60 per cent noted impacts on investigations of suspected illegal activities, training programmes, research and monitoring, the security of tourists and tourism-related facilities, and conservation work outside PCAs. Impacts on the protection of endangered species, conservation education and outreach, regular field patrols and anti-poaching operations were reported in more than 50 per cent of cases. Between 50 and 70 per cent of countries also reported high impacts on collaboration with stakeholders: these affected work with governmental bodies and local communities in more than 60 per cent of cases; whilst collaboration with private landowners, researchers and non-governmental organisations was affected in more than 50 per cent of cases.

Fewer than half the countries reported a high impact on the handling of emergency wildlife incidents. The maintenance of critical infrastructure was affected in fewer than a third of all cases and internal communications in a fifth.

Following heavy losses in revenue, just over a quarter of all countries reported that they expected to maintain basic PCA operations for up to one month; roughly the same number expected to keep going for several more months, but barely 20 per cent felt they would be able to operate beyond a basic minimum for 6-12 months. This level of impact was reported within one month of COVID-19 being declared a pandemic.

Over 80 per cent of countries attributed their reduced capacity to cope with the pandemic to insufficient funding, 67 per cent to COVID-related restrictions and 50 per cent to insufficient human resources due to chronic understaffing, and many of those available being sent home as a result of the pandemic. These were also identified as among the areas that needed urgent support to fight the impact of the pandemic. Eighty per cent of countries said diversification of income was a way to reduce overreliance on tourism and enhance the sustainability of PCAs. Other strategies included broadening partnerships, enhancing capacity and skills, reducing rural poverty and greater use of technology. All countries said that local communities and private landowners needed to be assisted economically in order to safeguard their livelihoods and reduce their reliance on PCAs.

\section{Lessons learned}

- The pandemic has the potential to reverse conservation gains already achieved, so urgent safeguarding measures should be put in place, such as emergency funding and support;

- $\quad$ Standardised emergency guidelines are needed on preventing, detecting, responding to and recovering from this and future pandemics;

- $\quad$ An emergency African Wildlife Crisis Fund should be established to support critical conservation activities and protect the livelihoods of the poor and vulnerable groups;

- There is a need to up-skill and resource the capacity of PCAs, and equip them with appropriate tools and technology to support research, monitoring, law enforcement, communications and partnerships;

- Diversification of revenue sources is needed to reduce overreliance on international visitors;

- A strong lobby is needed to encourage African governments to provide greater budgetary and policy support for PCAs;

- A strong partnership should be established between the conservation and health sectors at a national level to prevent or cope with future pandemics;

- Countries must invest in the restoration of degraded ecosystems to prevent future pandemics;

- $\quad$ Sustained support and economic empowerment is needed to help local communities and private landowners better conserve nature.

\section{Asia}

The Asia Protected Areas Partnership (APAP) survey was sent to protected areas agencies in 18 countries in J une 2020. It was completed by 12 agencies in nine countries. 
Three-quarters of respondents reported that PCAs had been fully or partially closed in response to the pandemic. The remainder reported that they remained open largely as usual, but with social distancing rules in place. New online activities, such as virtual tours, were introduced in some countries to compensate for reduced physical access to PCAs.

Three-quarters of respondents reported that conservation activities, such as patrols, anti-poaching, habitat enrichment, research and monitoring, had been largely unaffected, but one-quarter observed that some of these activities had been partially stopped. One respondent reported that their conservation budget had been reduced by half, affecting patrols, research and monitoring.

Fifty-eight per cent of respondents reported that engagement with local communities had been fully or partially stopped. Many events, including festivals and official meetings with local communities, had been cancelled, held under strict COVID-19 protocols or carried out virtually. Several respondents reported that special measures had been put into place to assist affected communities. These included donations of emergency supplies and the introduction of new and innovative mechanisms, such as 'drive-through' farmers' markets, where visitors could purchase locally grown produce from their cars (thus reducing the risk of exposure to Coronavirus).

Eighty-three per cent of respondents stated that staff numbers in their respective PCA agencies had remained unchanged, whilst 17 per cent reported staff reductions. However, there were concerns in some agencies about impacts on staff well-being, not only through direct exposure to Coronavirus, but also from the loss of opportunities for training and capacity building, as well as increased workloads. For example, some respondents observed that staff had been required to carry out extra duties, such as advising park visitors to abide by COVID -19 prevention measures, implementing pandemic prevention measures, carrying out additional patrolling and maintaining park facilities in areas with reduced visitation. Furthermore, lockdown and curfew had made reporting to duty a challenge for some officers. No staff recruitments, salary increments or additional budgets were reported.

\section{Lessons learned}

- Use of technology should be embraced more broadly, to address both conservation requirements (e.g. drones for surveillance) and visitor needs (e.g. virtual tours);
- Local communities should be more economically empowered to reduce their dependence on park resources;

- Rules and regulations related to social distancing (between people, and between people and wildlife) should be drawn up and disseminated;

- Procedures to prevent the spread of infectious diseases among visitors should be prepared and made available;

- Information and case studies should be shared among PCAs on all aspects of zoonotic diseases, their impacts on wildlife and their socio-economic consequences;

- Staff capacity in relation to safety and health issues should be enhanced;

- Sustainable funding sources for PCAs should be put in place.

\section{Tiger range states}

This survey was completed by protected area managers, rangers, and civil society supporting protected area management in government-managed protected areas. A total of 77 responses covering 40 PCAs were received from 12 out of the 13 Tiger range countries. Many reported that COVID-19 had impacted on funding and staff responsibilities and welfare, thereby compromising the ability of PCAs to achieve their conservation goals. It was reported that rangers were stretched and their jobs had become more difficult, with new duties allocated, including unfamiliar ones such as community health checks (see also Singh, in this issue). The provision of key supplies and equipment was disrupted in 60 per cent of PCAs, budget cuts were experienced in nearly half of them and community engagement activities stopped in 75 per cent. Nonetheless, the level of patrol coverage was reported to be stable and there was no

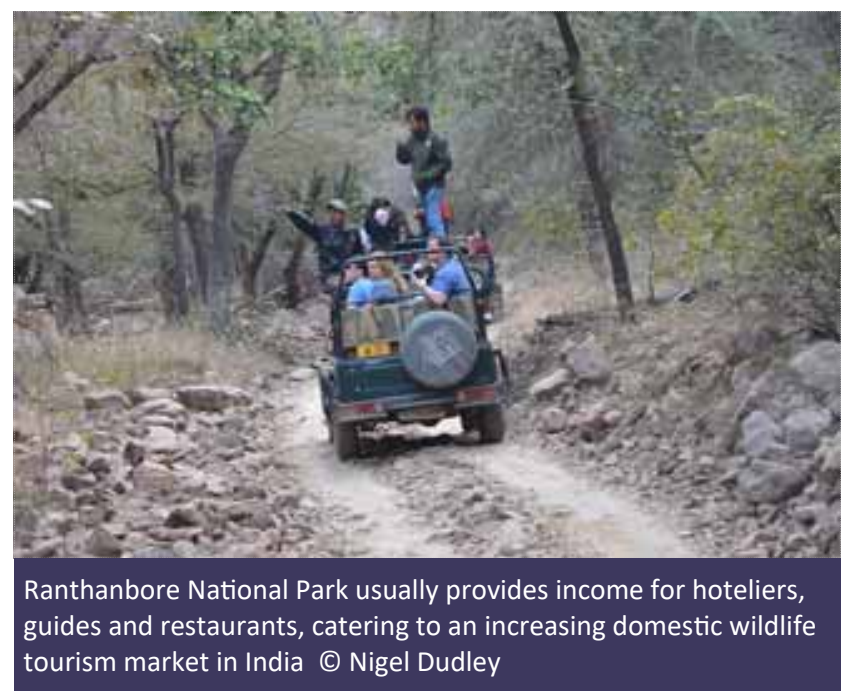


consistent evidence that threats had grown since the pandemic. Looking ahead, most respondents (76 per cent) were pessimistic about future budget allocations while 62 per cent were concerned about their ability to manage PCAs because of the pandemic.

\section{Lessons learned}

- Governments and donor agencies need to ensure funding levels remain or are increased in tiger PCAs across the region;

- Threats to PCAs, Tigers and Tiger prey are likely to decline if funding, effectiveness of legal systems and levels of community engagement are improved;

- Effectively managed PCAs will allow the protection of wildlife and wild places and help maintain an essential buffer between zoonotic disease pools and people.

\section{Oceania}

The results are based on feedback from 44 respondents, 26 from governments and 9 each from national and international NGOs. 31 responses were from Australia. The core operations most affected by COVID-19 were: maintaining relationships with stakeholders and volunteers; training; maintaining relationships with Indigenous landholders and managers; and carrying out research and monitoring. Core resource management activities, such as protecting species and fire management, were much less impacted. About one in five respondents said that at least 60 per cent of their visitor management work had been negatively impacted.

60 per cent of respondents reported that COVID-19 had only a minor impact on their law enforcement operations. Moreover, half of them reported that there had been at least a 60 per cent reduction in the delivery of environmental education. While a similarly large reduction took place in local employment from tourism, most respondents indicated that their ability to maintain or enhance visitor facilities had not been so heavily impacted.

Government funding was reported to be the most important source of revenue for most respondents and had not been significantly impacted. Other revenue sources included philanthropic support to communities and income from tourism. More than 60 per cent of respondents indicated that tourism-derived revenue was very or extremely important to local businesses, the local economy and the state/national economy. As expected, this revenue source had been significantly negatively affected.
The partnership activities most affected were conservation education, outreach and working with communities on issues such as invasive species management. Work with NGO partners, other government bodies and researchers was relatively little affected.

Nearly two-thirds of the non-government respondents indicated that they would not be able to maintain current operations for more than a year if current COVID-19 restrictions persisted. The rest of the respondents indicated that their ability to maintain normal operations was not at risk.

\section{Lessons learned}

- Agencies need to enhance their online presence and social media skills to maintain communication with the general public during closures, and to say when parks are reopened, especially for new park users;

- $\quad$ PCA visitor capacity should be assessed to avoid overload on some sites and enable better management of visitor flows; staff need training in online platforms;

- Cooperation between sectors of government must be enhanced to ensure good communication and cooperation, especially in emergency situations;

- Agencies can utilise the high use of protected areas in Oceania during the pandemic to increase the public and political understanding of the high value of natural areas to human health and well-being.

\section{North America}

Responses were received mainly from the federal agencies responsible for protected areas in Canada and the USA, with additional contributions from state, provincial and other jurisdictions in those countries. Initially, 44 per cent of visitor services were closed and 33 per cent partially closed; the rest remained open with social distancing. In the US, parks adjusted their visitation based on the local conditions of COVID-19 outbreaks. Some parks in areas with high outbreak rates closed completely while those in areas with low outbreak rates enforced social distancing, heightened hygiene measures and shut down visitor centres and other public facilities. In Canada, the national government closed all public spaces including protected areas, to visitors. A staged and gradual re-opening is being undertaken under public health direction and subject to social distancing rules.

The closures allowed some natural habitats to recover from the effects of historic use levels, whilst some park- 
based wildlife moved into nearby developed areas causing human-wildlife conflict. Loss of revenue and shifting operational priorities presented management with significant financial and capacity challenges.

Some PCAs introduced new web-based and social media activities to compensate for reduced physical access. These include live programming, self-guided interpretive packs, virtual outreach programmes and tours, and podcasts.

During the initial lockdown, almost half the sites were fully or partially closed, with the rest remaining open with minor modifications. However, activities relating to visitor safety, monitoring, public compliance and animal welfare resumed shortly thereafter, in accordance with health and safety guidelines. Conservation activities have been resuming in a phased manner.

Nearly 80 per cent of public engagement, outreach and services to local communities ceased or were reduced. Nearly as many reported reduced staffing, mainly due to not hiring temporary summer staff, students and volunteers. This reduced visitor services, resource protection and restoration. Most staff had to work from home, while those few on site were required to adhere to disease-prevention protocols such as social distancing, repeated sanitising, face coverings and use of plexiglass barriers.

The large majority of PCAs had introduced steps to respond to COVID-19. These were mainly technological and included greater accessibility to digital media for

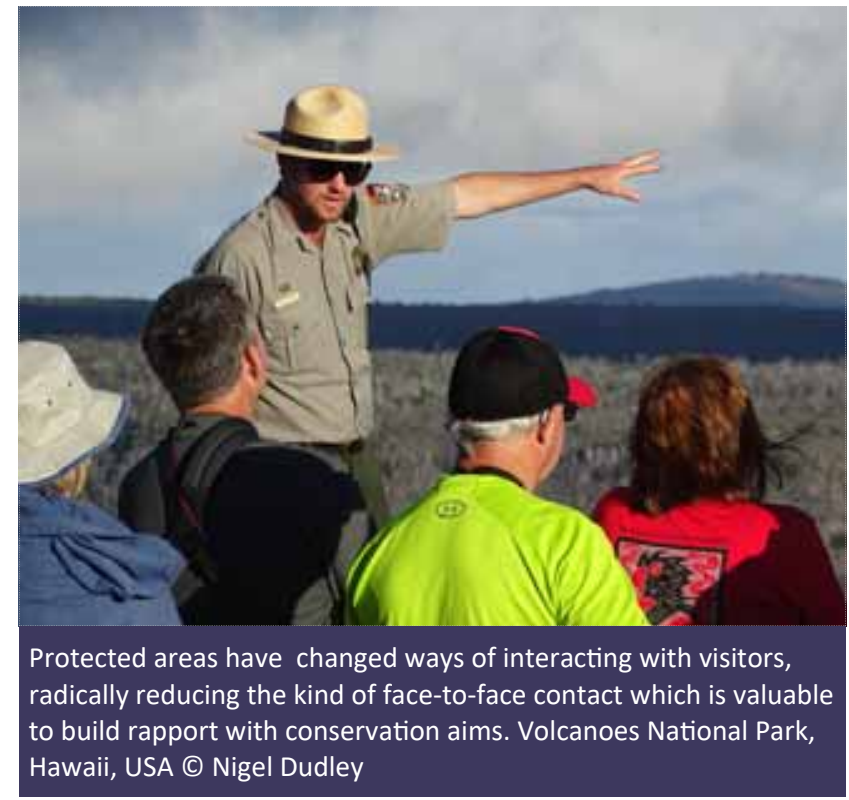

meetings, public interaction and telework. Over half reported that their organisations were holding discussions in preparation for future outbreaks, covering topics such as codifying remote working arrangements, enhanced development of online resources, updating pandemic response and management plans, and adopting more remote data collection measures.

\section{Lessons learned}

- Appropriate systems should be put in place to enable quick communication;

- Establish emergency preparedness plans;

- $\quad$ There is a need to provide more support to local communities and privately protected areas;

- Conservation partners should provide guidance on how systems of PCAs can work together to manage this and future pandemics.

\section{Latin America and the Caribbean}

Responses from the LAC survey were received from the REDPARQUES focal points from 14 out of the 19 member countries, 12 from Latin America and two from the Caribbean. They reported that all visitor services were initially fully or partially closed, but gradual reopening started subsequently, based on local conditions. Reduced visitation resulted in reduced income for PCAs and local communities and, in some cases, cuts in staff numbers and salaries; which (presumably) contributed to an increase in illegal activities such as logging, poaching, fires and settlements in some PCAs.

Conservation activities such as patrolling, antipoaching, monitoring, research, control of invasive species and habitat restoration continued largely as usual in most PCAs. Remote surveillance and interventions against direct threats were prioritised to compensate for reductions in staffing and budgets. Drones, satellite images and other technologies were used to enable PCAs to do more with less.

In 57 per cent of reported cases, engagement, outreach and the provision of services to local communities in and around PCAs remained in place, but these were partially stopped in the rest. Reduced numbers of visitors greatly reduced income to local communities. Increase in community engagement through online platforms was reported. PCA authorities provided COVID-19-related support to local communities, including implementing government social assistance policies, food distribution, delivery of personal protective equipment and training in hygiene and safety measures. 
Fifty per cent of all respondents reported that PCA staffing levels remained unchanged, the other 50 per cent reported a decrease that was attributed to safety measures and budget cuts, resulting in some of the remaining park staff being overworked. Greater use was made of phones, radio and internet communication. Most parks made more use of remote sensors, such as satellites and drones, and introduced virtual tours for 'visitors'. See also Box 1 for responses to a survey on wildlife behaviour change in Latin America.

\section{Lessons learned}

The survey identified that parks needed: sustainable financing; technology to allow remote surveillance and monitoring; strengthened capacities; increased education on the importance of PCAs for the well-being of society; and to disseminate the results of surveys to health-related organisations. The following steps were suggested:

- Cut out unnecessary face-to-face meetings in future and enhance use of technology;

- $\quad$ PCA visitor capacity should be assessed to avoid overload on some sites and enable better management of visitor flows;

- Emergency plans and safety protocols for staff and visitors should be developed;

- Managing present and future pandemics calls for development of adequate and appropriately trained and equipped human capital, including the use of technology to meet various needs;

- PCAs need improved waste management and sanitation, and enhanced access to basic services in order to cope with future emergencies and health protocols for the safety of the staff;

- PCAs will require adequate and sustainable funding;
- All citizens need to be educated on the importance of PCAs in supporting the well-being of society;

- PCAs of the various governance types are needed, and collaboration with local actors should be strengthened to compensate for the current budget deficits and staff cuts in publicly funded protected areas.

\section{Mediterranean marine protected areas}

Responses were received from 35 sites in 15 Mediterranean countries. Not all sites answered every question, making calculation of percentages difficult, but the survey revealed a rich variety of experience regarding marine protected areas, which had been poorly represented in several other surveys (see also Phua et al., 2021).

Most sites had closed at the time of the survey, although 11 remained open, some with restrictions. Twenty of the remainder had plans to re-open once the most severe restrictions had been lifted, while a few reported that future plans remained uncertain. The extent to which the public complied with restrictions sometimes changed over time, with increased illegal fishing. There were reports of fears of floods of visitors once restrictions were ended and differences between MPAs near cities and smaller communities, with people in the latter more likely to break the rules.

Only a few sites faced immediate reductions in funding, mainly due to reduced tourism but also sometimes from government cuts, with one MPA suffering a 60 per cent budget reduction. Nine sites had staff cuts but only two reported that they were currently unable to pay staff. Most MPAs had most people working from home, although some had partial or complete staff on site. Monitoring activities were affected in 25 sites.

\begin{abstract}
Box 1: Wildlife behaviour changes in Latin America
A survey of 40 people in 32 PCAs in Latin America looked at observed changes in the prevalence and behaviour of wildlife (specifically mammals, land and water birds and reptiles). Those responding varied from field rangers to directors of PCA agencies. The survey focused on the impacts of COVID-19, particularly reduced numbers of visitors and vehicles. People from 23 PCAs reported changes in wildlife distribution, including species moving into new zones or returning to areas that had previously been abandoned, and new species moving into the area. A further 12 PCAs recorded more observations of key species, while in only one case did observations decline (the Giant River Otter, Pteronura brasiliensis, due to increased hunting and fishing). While many of the increases occurred among commoner species, positive changes were also observed in vulnerable species like the Spectacled Bear (Tremarctos ornatus) and some listed as endangered, including the Mountain Tapir (Tapirus pinchaque) and Grey-cheeked Parakeet (Brotogeris pyrrhoptera). One site reported changes in the pattern of daytime and night-time activity in the South American Tapir (Tapirus terrestris) and two reported behavioural changes in birds. This survey is the first continent-wide snapshot of behavioural changes in named species and confirms what had been suspected: that a decline in visitor numbers gave many PCA species valuable breathing space.
\end{abstract}


The survey sought information about whether the absence of staff and visitors had allowed rare species to colonise new areas, leaving them exposed once lockdown ended. While there were few reports of this happening, there were many concerns that a sudden boost in tourism at the end of lockdown might affect vulnerable species, including cetaceans, turtles, Monk Seals and the Kentish Plover.

\section{Lessons learned}

- There was great variation in the ability of sites to cope with the pandemic: some found productivity actually increased with people working from home, whilst others felt such systems failed to work. Training in remote working would be useful;

- Although some sites had contingency plans for sudden emergencies (such as earthquakes), these generally did not address pandemics;

- A temporary dramatic reduction in visitation had beneficial impacts, with reports of reduced pollution and a boost in fish numbers, but perhaps less dramatic than might have been expected;

- Governance and management bodies should facilitate the implementation of timely and adaptive management measures to allow MPAs to cope with the impact of a pandemic;

- MPAs relying heavily on tourism funding need to plan contingency sources of funding to cope with a pandemic;

- The network of MPAs provided a way to quickly share best practices among practitioners during the pandemic.

\section{Privately Protected Areas}

This summary of the impacts of COVID-19 on PPAs is drawn from 48 responses from 16 countries covering all continents. It provides a global snapshot of the situation faced by PPA owners and managers. Over 80 per cent of visitor services and facilities were fully or partially closed, causing significant reduction in revenues. Other funding sources dried up, including sponsorship contracts as many PPA supporters were also affected by the pandemic. As a result, some planned activities and investments were abandoned or postponed, with priority given to maintaining staff, paying salaries and supporting critical conservation activities. Fifty-seven per cent of the respondents reported reductions in staff numbers, mostly affecting temporary staff and volunteers. A few PPAs with endowment funds were somewhat cushioned from the worst impacts of the pandemic.

Due to financial hardship, 67 per cent of the respondents reported that conservation activities, including patrols, anti-poaching, monitoring, research, control of invasive species and habitat restoration, had ceased or been curtailed. Seventy-three per cent of the respondents reported that public engagements, outreach and the provision of services to local communities partially or fully ceased. To keep visitors engaged without physical access to PPAs, 33 per cent of respondents introduced new online services, including virtual tours, workshops, seminars and webinars, live Facebook activities and videos.

Forty-two per cent of respondents reported that they were engaged in discussions on how to prevent and/or cope with future pandemics. Among the measures discussed were: developing protocols for staff, visitors and researchers during pandemics; replacing face-toface meetings with virtual meetings where possible; developing emergency management plans and guidelines; diversifying income to reduce overreliance on tourism; enhancing self-guided tours to reduce congestion on trails; developing high quality video clips to keep visitors engaged; and preparing guidelines to sensitise people on the role that natural areas play in human health and preventing pandemics.

\section{Lessons learned}

- The use of technology needs to be enhanced to enable improved remote monitoring;

- Best practice guidelines for developing virtual tools and educational materials for PPAs need to be established and made available;

- $\quad$ All people should be educated on the importance of PPAs and the connection between healthy nature, healthy people and sustainable living;

- The global community should be put on the alert and encouraged to prepare for the worst-case scenario in case of an even more deadly future pandemic;

- Guidelines on interactions between people and wildlife should be developed to prevent future Coronavirus-like zoonotic disease outbreaks;

- Visitor carrying capacities for PPAs should be established to ensure that economic pressures are not used to justify unsustainable visitor levels.

\section{Frankfurt Zoological Society (FZS)}

The survey targeted FZS project managers who forwarded the questions to PCA staff or discussed the survey with them. In total, the survey was completed for 29 individuals (9 in Europe, 8 in Africa, 10 in South America and 2 in South-East Asia) working in 16 countries. 
PCA budgets remained, on average, unchanged in European and South-East Asian PCAs, but reductions of up to 60 per cent and 70 per cent were reported in African and South American PCAs, respectively. Half of the PCAs reported reductions in government funding, whilst planned reductions had been announced in Viet Nam. Income from entry fees and tourism operations were reported as falling across all regions, with a couple of exceptions in Eastern Europe. Some of the budget gaps left by these cuts and reductions were covered through emergency funds, reshuffling budgets, and from the core funds of the FZS. However, these were not enough for those PCAs that suffered massive budget losses and had to reduce operations or salaries. There were no major changes reported in funding by public donors, but there were concerns that reductions could occur due to the global economic crisis and a shift in donor priorities. Some private donors feared difficulties in maintaining financial support if their own finances were impacted.

About 65 per cent of PCAs reported negative impacts on staff: reduced salaries and allowances, being furloughed, working longer shifts, and fears of falling sick with COVID-19. Temporary staff were laid off, especially in South American and African PCAs. Staff in many PCAs struggled to complete their work remotely, which was particularly challenging in places with poor or no internet access and for staff without computers at home. Morale was adversely affected among at least 50 per cent of staff.

Respondents reported that PCAs were able to implement 80 per cent of their regular operations, but there were substantial regional differences. Whereas European PCAs were able to implement 90 per cent of their operations, South American ones could only undertake 40 per cent, mostly due to the strict containment measures implemented by governments. The most affected operations were: engagement with local communities (cuts affecting 79 per cent of PCAs); staff training (reduced/stopped in 76 per cent of cases) and biomonitoring (reduced in 52 per cent of cases). However, whereas regular community engagement was consistently reported as negatively impacted, some PCAs provided food and health support to local and Indigenous communities to prevent or minimise the impacts of COVID-19. Reductions in patrols occurred in 35 per cent of the PCAs, mostly in South America: all patrols ceased in Guyanese and Brazilian PCAs. However, a few African, European and Vietnamese PCAs (21 per cent in total) increased patrol efforts to counteract expected or observed increases in illegal activities.
An increase in bushmeat hunting was reported in 48 per cent of PCAs, an upsurge that was attributed to COVID19 related unemployment, increased migration to rural areas and general economic hardship. Drug cultivation and trafficking, and gold mining increased in most South American PCAs already affected by these threats, caused by economic difficulties at national and local levels, and the absence of government and PCA staff. Threats associated with recreation were reported to decrease in 29 per cent of the cases but increased in some European PCAs.

A few PCAs in Peru and Tanzania reported changes in wildlife behaviour, with some species being observed in unusual places, presumably resulting from less visitation and human disturbance. Some of these reports were based on the analysis of camera trap data.

\section{Lessons learned}

- Capacity must be built to allow remote communication and implementation;

- Funding streams need to be diversified and resilience to shocks enhanced using contingency planning and reserves. Reliance on short-term funding agreements and single fragile sources like tourism is risky;

- Support to PCAs in times of crisis has been invaluable;

- $\quad$ Remote risks need to be identified and PCAs must plan accordingly, including developing guidelines and protocols for dealing with risks;

- Increased surveillance is needed in times of crisis, as threats may increase;

- Local communities are key PCA stakeholders and must be supported throughout this crisis, thereby strengthening relations with PCA and conservation staff.

\section{DISCUSSION}

The surveys reported above came from 152 reports, from 90 countries with every continent except Antarctica represented in the survey (although see Box 2). Some countries which did not respond to their own continent survey are at least partially covered by some of the specialist surveys, which covered 26 African countries, 21 from Asia, 17 from LAC, 13 from Europe, 9 from Oceania and 2 from North America.

Impacts: There were many commonalities in the impacts reported via the different surveys, but some regional differences emerged. It is encouraging that despite many difficulties, most PCAs are continuing to function; indeed, several reports are that the reduction 


\section{Box 2: Surveying impacts on protected areas in Antarctica}

Forty members of the Scientific Committee on Antarctic Research's Standing Committee on the Humanities and Social Sciences are examining how the pandemic is impacting work on the continent. The study is organised into five thematic units: futures and governance, research and decision-making, tourism, perceptions of Antarctica, and wildlife-human interactions. It will involve horizon-scanning, interviews, surveys, social media analysis and deskbased surveys, and one key aim is to identify the most vulnerable research. Observed changes to date include cancellation of high-level meetings affecting governance and impacts on the Antarctic. Initial results are expected in the first half of 2021 (Lorenzo et al., 2020). Other impacts are projected, such as a downturn in research funding and activity, a long-term dip in cruise tourism and, if food security is impacted, increased pressure for fishing in the region at a time when it is more difficult for regulatory bodies to meet (Frame \& Hemmings, 2020).

in visitation has provided a chance for some level of species and ecosystem recovery. Predictably, PCAs in the richer countries seem to be coping better than those in poorer countries. Least affected are countries in Europe, Oceania and North America. Medium impacts occurred across Asia; the most severe problems arose in Latin America, Africa and particularly in Eastern and Southern Africa. Many countries shut down their PCAs completely to visitors during the height of the first wave of the pandemic, particularly in LAC, although this was approached more regionally in North America (e.g. USA) depending on local prevalence of infection. Problems in Africa, in contrast, were due particularly to lack of finance. Some Asian countries listed rangers and wildlife protection as 'essential services' and thus these were permitted to continue.

The economic impacts of these closures, coupled with a collapse in international tourism and trade restrictions, have been significant for PCA agencies and individual PCAs in many countries. Reductions in government budgets and tourism revenues have had huge and immediate implications: PCA conservation and management functions have been disrupted, some staff cannot be paid, and some have lost their jobs and related benefits. As a result, several respondents felt the budgetary allocation for their PCAs would not last more than a few months under the conditions they found themselves in, with a risk of serious financial collapse. However, most countries have relaxed controls somewhat since then, so it will be interesting to see if these places have started to recover. The collapse of tourism and associated income had also hit people in local communities, who, in normal times, were able to generate an income from guiding, the hospitality trade, product sales, etc. - indeed in some cases they depend fully on tourism. Now many are left with little by way of support. This shows clearly the risks of relying so heavily on tourist income, particularly non-domestic tourism. The tourism sector is already vulnerable to political shocks and isolated terrorist attacks; now it has also been shown to be exposed to pandemics. Many respondents, particularly in countries of the Global South, where ecotourism finances much conservation and sustains many local communities, emphasised the need for alternative and diversified funding.

Government funding had been mostly unaffected at the time of reporting, although there are concerns about maintaining budgets in the face of a global recession, and there have been announcements of planned budget cuts for 2021. Some PCAs are reported to have lost their entire budgets already.

Despite the financial losses, there were efforts to maintain staff numbers and salaries. Not all surveys provided insights on the impacts of COVID-19 on the human resources of PCAs, but there were some reports of lay-offs, particularly of temporary staff. The payment of salaries had been secured, except in some cases where tourism revenue collapsed. Some PCAs and countries reported changes in staff duties and workload increases.

PCA operations have been affected as a result of COVID19 containment measures and financial losses. Although most but not all PCAs seem to have maintained some level of management, there has been a widespread reduction and even total halt of community engagement and monitoring and evaluation work, as well as notable reductions in law enforcement and capacity building. Indeed, monitoring and evaluation has been one of the most widely reported victims of COVID-19 (e.g. Corlett et al., 2020), leading to a gap in monitoring data that probably affects conservation everywhere, potentially compromising trend analysis and reducing the ability to report on management outcomes. Virtually all government PCA systems and many others have switched many of their activities to remote, online engagement, with an inevitable impact on fieldwork, patrolling and enforcement in many but by no means all countries. However, most African and some Latin American countries lacked the resources, equipment, 
training, connectivity and appropriate technology to support online platforms in the office and the field.

Concerns about potential threats to PCAs were raised from the onset of the pandemic (e.g. Hockings et al., 2020; Lindsey et al., 2020). Encouragingly, there were relatively few reports of major increases in threats or illegal activities, although some incidents are reported. Denser populations in surrounding areas, particularly where people returned to their home villages from cities, is expected to result in an increase in pressure on natural resources inside PCA boundaries. In some countries, wildlife crime for commercial purposes may have been prevented by restrictions in domestic and international travel and trade (e.g. see Hockings et al., 2020).

Coping strategies: Given the restrictions on movement and the collapse of international tourism, some countries have put a great deal of effort into developing opportunities for experiencing PCAs remotely (e.g. through online materials, video blogs and static cameras) and developing interactive learning sessions. Some institutions have been examining the scope for self-guided exploration of PCAs to reduce risks to rangers from close contact with numerous visitors. Others are using emergency funds to keep going or are prioritising actions so that they can maintain core functions with reduced inputs.

The absence of emergency response guidelines, poor levels of preparedness and limited capacity to deal with a pandemic were recognised as key weaknesses. Many PCA agencies are now planning for the next pandemic, or other major, unexpected catastrophe.

Many changes instituted under COVID-19, or highlighted for development, were already either underway or recognised as necessary before the pandemic. The main long-term effect of the pandemic may have been to accelerate these changes. Principal among these is a switch to greater reliance on remote or home working, which many PCA agencies say will continue to some extent. There are clear limitations in terms of fieldwork and patrolling but opportunities in other areas, although even remote field working is becoming more practicable, with electronic monitoring and surveillance systems becoming cheaper and better all the time. A switch to online learning, including

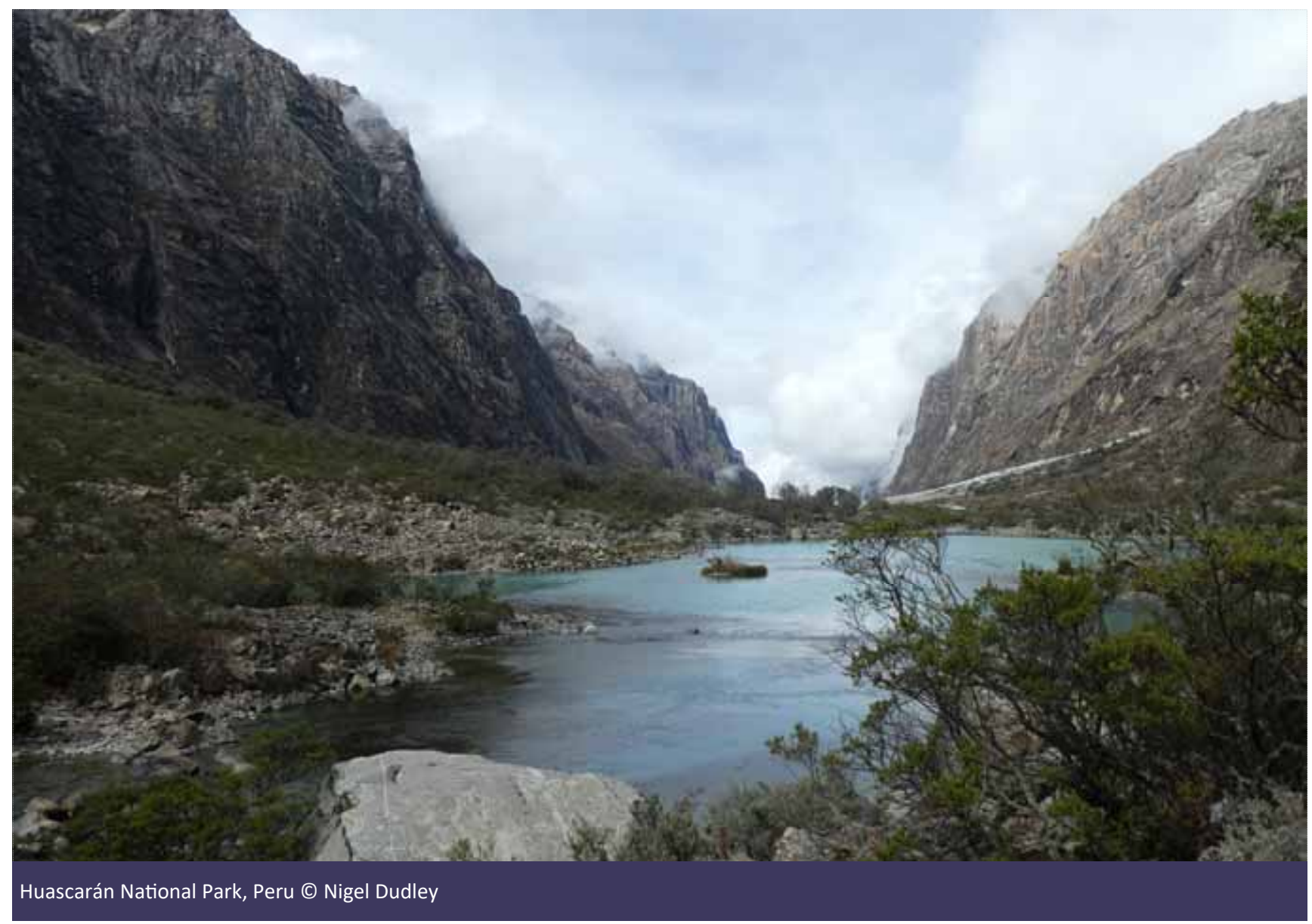


MOOCs (Massive Open Online Courses), is providing opportunities for many rangers and other staff, who would previously have been unable to afford the fees and travel costs of face-to-face training. Though these changes are almost certainly here to stay, many PCA activities will still require boots on the ground.

Lessons learned: Despite the huge problems that the world continues to face as a result of the pandemic, there are cautious grounds for optimism. Many PCAs seem to be coping with the additional challenges, one way or another, although almost all have experienced serious challenges. There were more complaints about monitoring failure than major increases in wildlife crime; the former is something that can be responded to at least in part by increased use of technological solutions. But virtually no PCAs were fully prepared; there were no contingency plans for a major pandemic, including at national levels, even though something of this sort has been predicted by health experts for years.

If PCAs were poorly prepared for this pandemic, a more serious health emergency would have devastating effects unless present shortcomings are addressed. The pandemic has thus created an opportunity to argue that these critical needs must be urgently addressed. A postCOVID-19 strategy will need to invest in better planning, capacity development, appropriate technology to enable remote work, and sustainable and diversified financing. Local communities and private landowners must be meaningfully engaged and adequately supported.

These measures will not bear fruit unless efforts to protect healthy ecosystems and to re-establish an ecologically healthy relationship between people and nature are given priority as part of the One Health initiative. The Healthy Parks Healthy People initiative (Townsend et al., 2015) and other studies have already demonstrated the fundamental link between healthy ecosystems and human health and well-being, and more specifically, the role that PCAs can play in this respect. Undoubtedly, this will cost a lot, but it pales in comparison with the price humanity has paid, and continues to pay since the lockdown. Failure to act is not an option: "future pandemics are likely to happen more frequently, spread more rapidly, have greater economic impact and kill more people if we are not extremely careful about the possible impacts of the choices we make today" (Settele et al., 2020).

Recommendations: There are some actions that national governments, PCA agencies and institutions like the IUCN World Commission on Protected Areas, could take in response to the results of this survey. Our surveys tell us this is what is required:

\section{Planning and research}

- $\quad$ Strategic guidance, including use of scenarios, for PCAs and agencies to help prepare for future unforeseen events, including pandemics and other major disruptions;

- Clear guidelines on managing PCAs during a pandemic (drawing on experience during 2020);

- Technical and strategic guidance on minimising risks from the spread of zoonotic diseases;

- Collaboration between international organisations, governments, the private sector and others to develop new funding models for PCAs;

- Research and some practical advice on carrying capacities for PCAs, both in terms of visitor impacts and also from a health perspective in the medium term.

\section{Funding}

- Better and sustainable funding, including diversification of income sources;

- A global effort to help build diversified and sustainable funding pathways, including emergency allocations, for those PCAs which have been over-reliant on tourism;

- Emergency funds to support critical conservation activities and safeguard the livelihoods of the poor and vulnerable sectors of society.

\section{Adequate capacity}

- Capacity building for remote work and communications, particularly for poorer countries but also more generally (e.g. on teleworking, online training and use of more remote working technologies, such as drones for monitoring and surveillance);

- A global effort to recognise and improve the working conditions for rangers and staff while coping and adapting to new challenges.

\section{Partnerships with the health sector and others}

- Collaborations and joint initiatives between PCAs and other relevant sectors, including those responsible for land use planning and health, with the aim to develop inclusive strategies, policies and guidelines to reduce transmission and spread of zoonotic diseases;

- Establishment of a platform for sharing lessons on handling future pandemics and for reaching out to the broader global community to create awareness 
of the link between healthy people and healthy nature.

\section{Putting local people first}

- Recognition of local communities and private landowners as critical allies for conservation of biodiversity who sometimes require economic and other kinds of support;

- Addressing rural poverty and safeguarding the livelihoods of local communities and private landowners. By creating space for conserving biodiversity, it is they who normally bear a disproportionate burden for the benefit of all humanity.

Finally, many respondents highlighted the importance of promoting the message that well-funded and effectively managed and governed PCA systems provide vital ecosystem services for human health and survival, and for tackling climate change, biodiversity loss and future pandemics. The OECD's recent policy brief rationalised why governments need to integrate biodiversity needs into their COVID-19 response and pandemic recovery plans (http:// www.oecd.org/ coronavirus/ policy-responses/ biodiversity-and-theeconomic-response-to-covid-19-ensuring-a-green-andresilient-recovery-d98b5a09/). It includes a call to scale up investments in biodiversity conservation, sustainable use and restoration.

\section{SUPPLEMENTARY ONLINE MATERIAL \\ Reports on regional surveys}

\section{ACKNOWLEDGEMENTS}

The authors would like to acknowledge all the busy managers, rangers and other conservationists who took the time to answer the questionnaires in these surveys.

\section{ABOUT THE AUTHORS}

John Waithaka is the IUCN-WCPA Regional Chair for East and Southern Africa, Co-Chair of the IUCN Wilderness Specialist Group and Member of the IUCN World Heritage Panel.

Nigel Dudley is a consultant and WCPA member, currently thematic vice-chair for natural solutions. He is based in Wales, UK, and works broadly on protected area policy.

Mónica Álvarez Malvido is based in Mexico. She is a WCPA member, a UNDP Consultant at CONAN and the Inter-institutional Affairs Coordinator for REDPARQUES.
Stanley Arguedas Mora is Costa Rican, and specialises in governance, management and planning of protected areas, and promotion of the Ecosystem Approach, throughout the Latin American Region.

Stuart Chapman is WWF's Tigers Alive Initiative Leader and previously led WWF's Heart of Borneo campaign and the WWF Greater Mekong's Programme.

Penelope Figgis AO is WCPA Vice Chair for Oceania, and has worked with many conservation organisations in Australia.

James Fitzsimons is the Director of Conservation and Science for The Nature Conservancy's Australia Program and Adjunct Professor at the School of Life and Environmental Sciences, Deakin University.

Susan Gallon is the scientific officer at MedPAN, the network of MPA managers in the Mediterranean that supports an efficient network of MPAs.

Thomas NE Gray is Tiger Landscape and Recovery Lead, WWF Tigers Alive Initiative. Has over 20 years of experience in wildlife conservation and management of species and habitats.

Minsun Kim is with the Korea National Parks Service and recently completed a secondment with the IUCN Asia Regional Office.

Scott Perkin is the Head of the Natural Resources Group at the IUCN Asia Regional Office. He provides the Secretariat for the Asia Protected Areas Partnership.

M.K.S. Pasha is the CA|TS Manager and is working on Conservation Assured across South and Southeast Asia, Russia, China and Latin America, and is a member of WCPA.

Paula Roig-Boixeda is a Research Fellow at the Frankfurt Zoological Society. She is coordinating a study on the impacts of COVID-19 on protected areas and conservation.

Claudine Sierra is based in Costa Rica and is involved in conservation projects related to invasive species and participatory protected area planning.

Allan Valverde is a Costa Rican conservationist, specialised in capacity building processes for protected areas management effectiveness with emphasis on Latin America. 
Mike Wong is WCPA vice-chair for North America, and was formerly with Parks Canada, based in Ottawa.

\section{REFERENCES}

Bennett, N.J., Finkbeiner, E.M., Ban, N.C., Belhabib, D., Jupiter, S.D. et al. (2020). The COVID-19 pandemic, small-scale fisheries and coastal fishing communities. Coastal Management 48: 336-347. doi: 10.1080/08920753.2020.1766937.

Corlett, R.T., Primack, R.B., Devictor, V., Maas, B., Goswami, V.R., Bates, A.E. et al. (2020). Impacts of the coronavirus pandemic on biodiversity conservation. Biological Conservation 246: 108571 . doi:10.1016/ j.biocon.2020.108571

Frame, B. and Hemmings, A.D. (2020). Coronavirus at the end of the world: Antarctica matters. Social Sciences and Humanities Open 2: 100054 . doi: 10.1016/ j.ssaho.2020.100054.

Hockings, M., Dudley, N., Elliott, W., Napolitano Ferreira, M., MacKinnon, K., Pasha, M.K.S., Phillips, A., Stolton, S., Woodley, S. et al. (2020). Editorial essay: COVID-19 and protected and conserved areas. PARKS 26 (1): 7-24. doi: 10.2305/IUCN.CH.2020.PARKS-26-1MH.en.

IUCN. (2020). Amplifying indigenous voices: IUCN Indigenous members' solutions and challenges relating to the COVID-19 crisis. Gland, Switzerland: IUCN.

Kavousi, J., Goudarzi, F., Izadi, M. and Gardner, C.J. (2020). Conservation needs to evolve to survive in the post-pandemic world. Global Change Biology 26: 4651-4653. doi:10.1111/ gcb.15197.

Lindsey, P., Allan, J., Brehony, P., Dickman, A., Robson, A. et al. (2020). Conserving Africa's wildlife and wildlands through the COVID-19 crisis and beyond. Nature Ecology \& Evolution 4 (10): 1300-1310. doi.org/10.1038/s41559-020-1275-6.

Lorenzo, C., Ligget, D., Frame, B., Herbert, A, Kelman, I. et al. (2020). Antarctica and the COVID-19 Pandemic: Taking a social sciences and humanities perspective. Environmental, Coastal and Offshore (ECO) Polar Special Issue: 116-119.

Phua, C., Andradi-Brown, D.A., Mangubhai, S., Ahmadia, G.N., Mahajan, S.L., Larsen, K., Friel, S. et al. (2021) Marine protected and conserved areas in the time of COVID. PARKS 27(Special Issue):85-102. doi:10.2305/IUCN.CH.2021.PARKS -27-SICP.en

Plowright, R., Parrish, C.R., McCallum, H., Hudson, P.J., Ko, A.I. et al. (2017). Pathways to zoonotic spillover. Nature Reviews: Microbiology 15: 502-510. doi: 10.1038/nrmicro.2017.45.

Settele, J., Sandra, D., Brondizio, E. and Daszak, P. (2020). IPBES Guest Article: COVID-19 Stimulus Measures Must Save Lives, Protect Livelihoods, and Safeguard Nature to Reduce the Risk of Future Pandemics. https://ipbes.net/ covid19stimulus.

Townsend, M., Henderson-Wilson, C., Warner, E. and Weiss, L. (2015). Healthy Parks Healthy People: The State of the Evidence 2015. Parks Victoria, Melbourne. https:// parkweb.vic.gov.au/about-us/healthy-parks-healthy-people/the -research.

Author affiliations (continued)

${ }^{11}$ IUCN Asia Regional Office, 63 Sukhumvit Soi 39, Bangkok 10110, Thailand

${ }^{12}$ Frankfurt Zoological Society, Bernhard-Grzimek-Allee 1, 60316 Frankfurt Am Main, Germany

${ }^{13}$ Institute of Environmental Science and Technology, Universitat Autònoma de Barcelona, 08193 Bellaterra, Spain

${ }^{14}$ Casa 7 G, Residencial Danza del Sol, La Unión de Cartago, Costa Rica

${ }^{15}$ P.O. Box 504-2050 San Pedro, San José, Costa Rica

${ }^{16}$ IUCN World Commission on Protected Areas, 845 rue Des Saisons, Gatineau, Québec, Canada, J9J 3B9 


\section{RESUMEN}

Las áreas protegidas y conservadas en todo el mundo se enfrentan a enormes desafíos como resultado de la pandemia del COVID-19. Ofrecemos un vistazo general de los impactos y las respuestas a nivel mundial. Los organismos encargados de las áreas protegidas, las ONG y los grupos de investigación, junto con las comunidades que apoyan la gestión de las áreas protegidas y conservadas, han realizado estudios en línea para comprender los impactos generales de las medidas de contención del COVID-19 en las áreas protegidas y conservadas a nivel regional y mundial. En el presente artículo se resumen los resultados de ocho encuestas regionales y dos mundiales, que abarcan 90 países de todos los continentes, excepto la Antártida. Se extraen enseñanzas de diferentes regiones y contextos, y se sintetiza la información sobre los efectos y las reacciones, en particular en lo que respecta a las actividades de conservación y gestión, los servicios de visitantes, los ingresos, la participación de los interesados, la capacidad, las amenazas, las actividades ilegales y las comunidades vecinas. Los resultados varían: en términos generales, los impactos han sido más graves en África y América Latina, aunque muchos organismos encargados de las áreas protegidas han elaborado estrategias de respuesta y los impactos no parecen ser tan graves como se pensaba en un principio. En el artículo también se identifican las oportunidades futuras de las APC en los años posteriores al COVID-19 y se proponen decisiones estratégicas que pueden ayudar a hacer frente a la pandemia actual y a prevenir otras futuras.

\section{RÉSUMÉ}

A travers le monde entier, les aires protégées et conservées sont confrontées à d'énormes défis en raison de la pandémie de COVID-19. Nous donnons un aperçu global de leurs impacts et leurs réactions. Les agences des aires protégées, les ONG et les groupes de recherche, ainsi que les communautés qui soutiennent la gestion des aires protégées et conservées, ont mené des études en ligne pour comprendre les impacts globaux des mesures de contention de la COVID-19 sur les aires protégées et conservées aux niveaux régional et mondial. Cet article résume les résultats de huit enquêtes régionales et de deux enquêtes mondiales, englobant 90 pays sur tous les continents, à l'exception de l'Antarctique. Nous tirons des leçons de différentes régions et contextes, et synthétisons l'information sur les impacts et les réponses, en particulier en ce qui concerne les activités de conservation et de gestion, les services aux visiteurs, les revenus, l'engagement des parties prenantes, les capacités, les menaces, les activités illégales et les communautés voisines. Les résultats varient: les impacts dans l'ensemble ont été plus graves en Afrique et en Amérique latine, bien que de nombreuses agences d'aires protégées aient développé des stratégies d'adaptation et que les impacts ne soient apparemment pas aussi graves que ce qui était initialement craint. Le document recense aussi des opportunités futures pour les aires protégées et conservées pour l'ère post-COVID-19 et propose des orientations stratégiques qui pourraient les aider à faire face à la pandémie actuelle et à en prévenir de futures. 


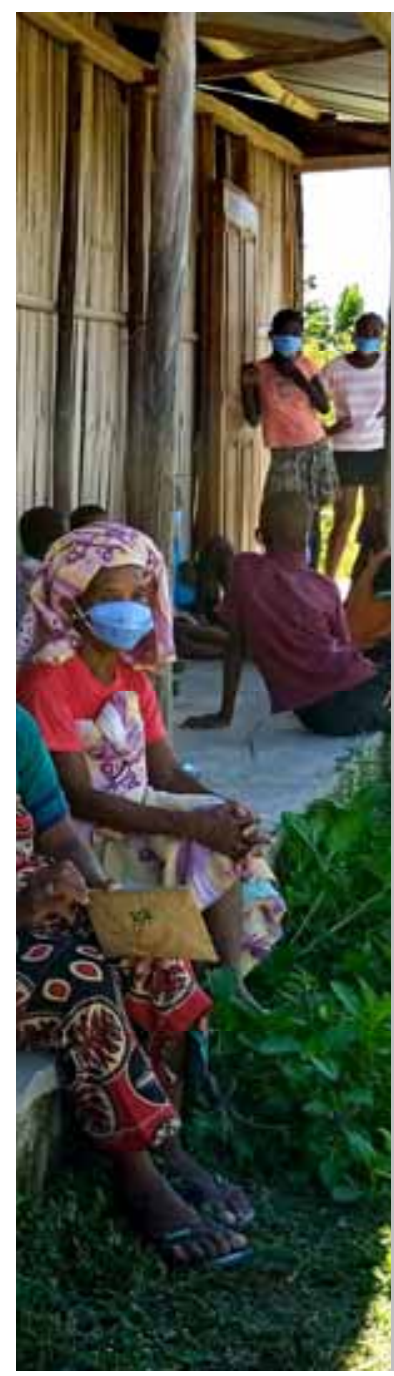

\title{
COVID-19, INDIGENOUS PEOPLES, LOCAL COMMUNITIES AND NATURAL RESOURCE GOVERNANCE
}

\author{
Gretchen Walters ${ }^{1,2}$, Neema Pathak Broome ${ }^{3}$, Marina $\mathrm{Cracco}^{1}$, Tushar \\ Dash $^{4}$, Nigel Dudley ${ }^{5}$, Silvel Elías ${ }^{6}$, Olivier Hymas ${ }^{1}$, Sangeeta \\ Mangubhai ${ }^{7}$, Vik Mohan ${ }^{8}$, Thomas Niederberger ${ }^{9}$, Christy Achtone \\ Nkollo-Kema Kema ${ }^{10}$, Appolinaire Oussou Lio ${ }^{11}$, Njaka Raveloson ${ }^{8}$, June \\ Rubis $^{12}$, S.A.R. Mathieu Toviehou ${ }^{11}$ and Nathalie Van Vliet ${ }^{13}$ \\ *Corresponding author: gretchen.walters@unil.ch \\ ${ }^{1}$ Institute of Geography and Sustainability, University of Lausanne, Lausanne, Switzerland \\ ${ }^{2}$ Department of Anthropology, University College London, United Kingdom \\ ${ }^{3}$ Kalpavriksh, Apt No. 5, 908 Deccan Gymkhana, Pune 411004, Maharashtra, India \\ ${ }^{4}$ Independent researcher and consultant, Odisha, India \\ ${ }^{5}$ Equilibrium Research, 47 The Quays, Cumberland Road, Bristol BS1 6UQ, UK \\ ${ }^{6}$ Facultad de Agronomía, Universidad de San Carlos de Guatemala, San Carlos, Guatemala \\ ${ }^{7}$ Wildlife Conservation Society, Fiji Country Program, 11 Ma'afu Street, Suva, Fiji \\ ${ }^{8}$ Blue Ventures, The Old Library, Trinity Road, Bristol, BS2 ONW, UK \\ ${ }^{9}$ ICCA Consortium; Institute of Social Anthropology, University of Bern, Switzerland \\ ${ }^{10}$ Université Omar Bongo, Laboratoire de Géomatique, de Recherche Appliquée et de \\ Conseils, Université Omar Bongo 680, Avenue Léon MBA, Libreville, Gabon \\ ${ }^{11}$ Groupe de Recherche et d'Action pour le Bien-Etre au Bénin, BP: 13 Avrankou, Benin \\ ${ }^{12}$ ICCA Consortium Co-Chair for Documenting Territories of Life; Sydney Environment \\ Institute, University of Sydney, Camperdown, NSW Australia \\ ${ }^{13}$ Center for International Forestry Research, Jalan CIFOR, Situ Gede, Bogor Barat, Bogor \\ 16115, Jawa Barat, Indonesia
}

\begin{abstract}
We report on how the COVID-19 pandemic is affecting Indigenous peoples and local communities (IPLCs), especially those who govern, manage and conserve their lands and waters. We explore the themes of access and use of natural resources, solidarity, decision-making, the role of governments and IPLCs in managing COVID-19, and the uptake of traditional medicine. These themes are explored through a global online survey in English, Spanish and French. We collected and analysed 133 surveys from 40 countries, using SenseMaker ${ }^{\circledR}$, a software that enables analysis of micronarratives based on how respondents classify their own stories. We explore the themes further through case studies from Benin, Fiji, France, Gabon, Guyana, Guatemala, India and Madagascar, highlighting challenges and opportunities in how IPLCs responded to COVID-19. Our study underscores the importance of selfempowerment and recognition of IPLC rights, which allows them to use traditional medicines, meet subsistence requirements during lockdowns, help community members and neighbours to sustain livelihoods, and to govern, defend and conserve their territories. We propose key actions to support IPLCs navigate future pandemics while protecting their lands and waters.
\end{abstract}

Key words: Coronavirus, pandemic, disturbances, resilience, rights, traditional medicine, natural resources, biodiversity conservation

\section{INTRODUCTION}

The COVID-19 pandemic is having an unprecedented impact across the globe. Although we frequently hear the perspectives of governments, business and the health sector, less is known about impacts on Indigenous peoples and local communities (IPLCs). The World Bank estimates there are 476 million Indigenous people in over 90 countries, 6 per cent of the global population (World Bank, 2020). Recent estimates for IPLCs living in important biodiversity conservation areas are 1.65 billion-1.87 billion people (Rights and Resources Initiative, 2020). Local communities in rural areas are harder to define and quantify but are likely to be even more numerous. IPLCs occupy and often protect 
and conserve large territories, with tenure rights over at least 38 million $\mathrm{km}^{2}$ in 87 countries (Garnett et al., 2018), although many still hold no formal title.

Indigenous peoples and some local communities have a distinct relationship with the environment that is fundamental to their social, cultural and spiritual lives. They often possess cultures and laws based on mutual reciprocity between humans and nature, and on the principles of safeguarding the environment for future generations. Indigenous and local knowledge, laws and principles form the basis of customary governance and management practices and are closely related to common rights over land, sea and natural resources, on more or less clearly defined territories and areas. These practices are enduring, widespread, diverse and dynamic, and have many different manifestations and names globally, but are also known under the umbrella term 'ICCAs - territories of life' - an abbreviation for "territories and areas governed, managed and conserved by custodian Indigenous peoples and local communities" (Sajeva et al., 2019).

As well as facing increased threats from climate change and the expansion of extractive and polluting industries and large-scale monocultures, IPLCs may have high rates of pre-existing health problems and poorer nutrition that leave them more susceptible to the COVID-19 pandemic (IWGIA and ILO, 2020; UN InterAgency Support Group on Indigenous Issues 2020). In Brazil (Santos et al., 2020; Conde, 2020) and the United States, IPLCs are suffering more from the disease than other people. Elsewhere, they appear less affected, and may sometimes be better placed to resist COVID-19 due to strategies adopted after previous epidemics (Banning, 2020; Bayha \& Spring, 2020; Crooks et al., 2020; The Lancet, 2020).

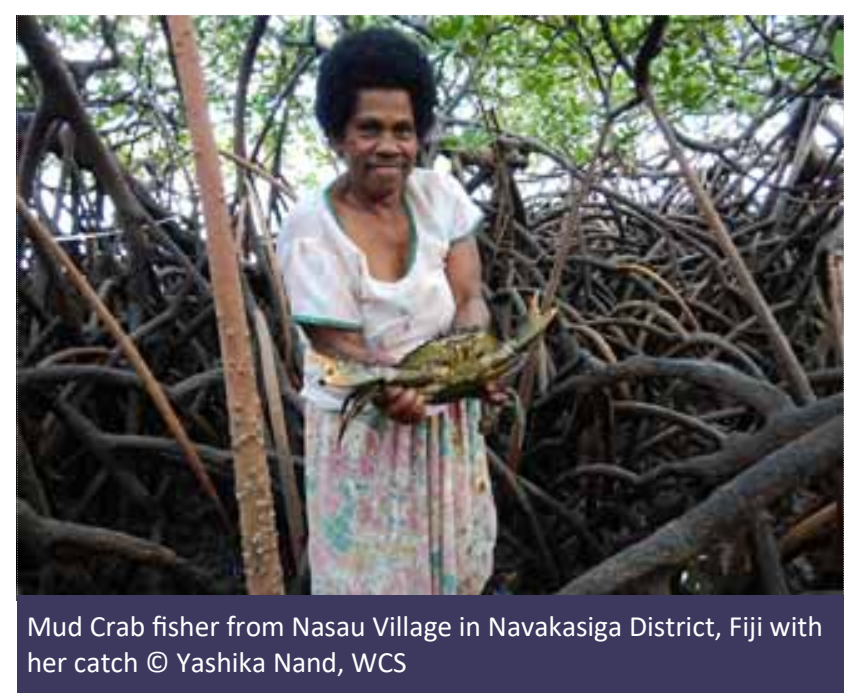

Much of the work published to date on COVID-19, in scientific papers or the media, is anecdotal, due to the difficulty of conducting fieldwork. Early in the crisis, publications summarised reports from the media or policy organisations (Belaïdi \& Koubi, 2020; Bennett et al., 2020), proposed experience-based recommendations (Meneses-Navarro et al., 2020; Power et al., 2020), or shared stories about how IPLCs were dealing with COVID-19 (Curtice \& Choo, 2020). In terms of nonpublished material, many IPLC groups held webinars about COVID-19, which explored some of the themes of this paper. However, these webinars are not always recorded, or notes are not made available, making examination of their content and long-term reference to their conclusions difficult.

Researchers have been encouraged to redirect work with community partners to support the COVID response (Bennett et al., 2020) and to combine anecdotal observations, systematic assessments and quantitative monitoring to produce new insights (Bates et al., 2020). This paper is an attempt to understand what is happening globally, beyond single territories, through a preliminary analysis of an online survey and case studies. We consider how COVID-19 has affected IPLCs, as reported by themselves and related organisations. We focus on resilience and health responses and what this may mean for access to, use of and defence of their territories, lands and waters.

\section{METHODS}

COVID-19 required that distant methods of survey be adopted. Online surveys have become more common, but have their own challenges including uneven internet access, limited language translation, unrealistic expectations of literacy and computer savviness, and poor response rates (Bernard, 2017).

We used SenseMaker ${ }^{\circledR}$, a tool enabling rapid, quantitative analysis of stories (Milne, 2015; Van der Merwe et al., 2019; Omoding et al., 2020). SenseMaker ${ }^{\circledR}$ helps analyse multiple perspectives of complex situations through identification of patterns around topics of interest and allows for meta-analysis of qualitative data bridging the gap between case studies and large-sample survey data. Through SenseMaker ${ }^{\circledR}$, respondents were encouraged to:

Please share an experience about the COVID-19 disease that shows how it has affected or is affecting Indigenous peoples' and local communities' use and relationship with their territories, lands and waters. This experience can be about you, your family, your community, or a community you work with. It could be a good, bad or neutral experience. It can be long or short. 
Sub-questions enabled respondents to add meaning to their story, signifying its importance and reducing the risk of imposing researchers' bias. Sub-questions focused on resource use and access, decision-making about COVID-19, economic, environmental and social impacts, traditional medicine, solidarity and conflict with families, communities and outsiders, community rights, community leaders and lessons from past epidemics. COVID-19 health measures and restrictions (e.g. lockdown, social distancing) were recorded, as were emotions related to stories shared. Before participating in the survey, respondents were told its objective and their consent secured. Only adults participated ${ }^{1}$. The analysis below presents triangle diagrams (e.g. Fig. 1), where respondents classified their story by placing a dot representing their story content in relation to the labels at the triangle endpoints; these triangles were further classified by other categories, such as emotional tone, gender and country. The closer the dot is to a corner, the stronger the statement is for the respondent's experience. A dot placed in the center of the triangle shows that the three elements in the corners of the triangle are equally important to the respondent. In the histograms, respondents rated their story by placing a dot along a line of opposing ideas.

The survey was developed by ICCA Consortium Members, Secretariat and Honorary Members, through online meetings in French, English and Spanish between May and July 2020. The questionnaire was developed in these three languages and tested, and further informed by a webinar series by ICCA Consortium Members ${ }^{2}$. It was promoted to ICCA Members and Honorary Members via email and social media and sent to other organisations working with IPLCs, notably through IUCN's Commission on Environmental, Economic and Social Policy and World Commission on Protected Areas, and the International Land Coalition. Some authors further circulated the survey at the community level in France, Gabon and Guyana. When researchers were living in communities, face-to-face interviews were conducted (e.g. Gabon) following protocols to protect interviewees and researchers. The survey opened on 7 August 2020 and the results presented here were collected until 9 November 2020. The survey remains open into 2021, when a second, in-depth analysis will be made.

The survey specifically sought replies from IPLCs, notably, as expressed in the survey form, from respondents who: identify as an Indigenous person; are from a community with close connections to their territories, lands and waters; or are from an organisation working with these communities.

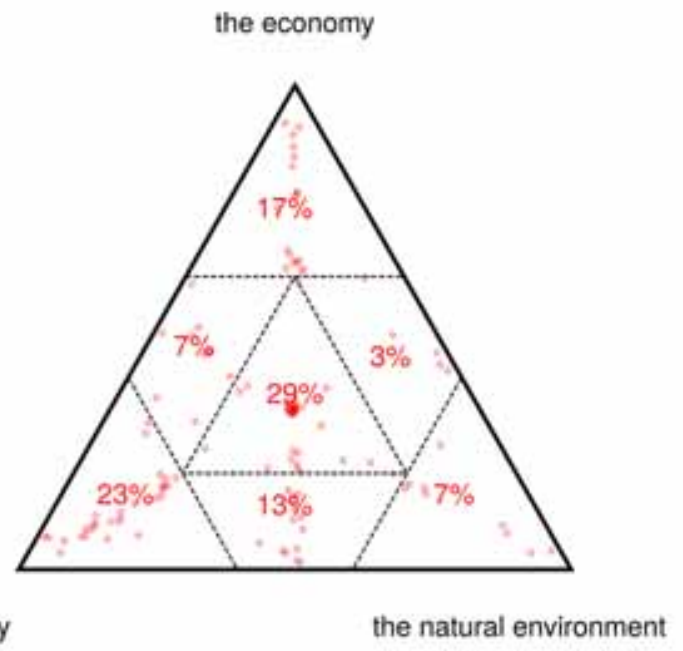

Figure 1. Percentage of responses that reflect the importance respondents placed on economic, societal or environmental factors. The percentages represent the proportion of answers in each sub-shape in the triangle.

\section{RESULTS}

Results are based on 133 answers, obtained to date, from 40 countries, 86 male and 45 female respondents, with two preferring not to say. Answers came from 30 members of the ICCA Consortium, and with a similar number of respondents who self-identified as belonging to an ICCA-territory of life. Sixty-one respondents are from organisations working with IPLCs, while 69 come from community members, including healers, leaders, governmental and conservation authorities; three preferred not to say. Of these 69 answers, 18 were from Gabon and 21 from Guyana, while other responses came from the 38 other countries. Geographically for all respondents, 51 are from Africa, 43 from Central and South America and the Caribbean, 15 from Europe, 13 from Asia and the Middle East, 6 from North America, 3 from Oceania, and 2 preferring not to say. We acknowledge that the response rate is low, which is typical of remote surveys. We note that IPLCs live in a variety of legal contexts, have different coping mechanisms and medicines, so we consider this to be a preliminary study. However, the survey results may help raise awareness of the issues surrounding IPLCs and COVID-19.

\section{Survey results and case studies}

Summary of key survey findings

In general, respondents felt that COVID-19 impacted them more in terms of social (23 per cent) and economic issues (17 per cent) than environmental ones (7 per cent); however, 29 per cent give equal importance to social and environmental issues (Fig. 1). The following 
sections report on the survey results, illustrated by case studies.

\section{COVID-19 and traditional medicine use}

Survey results

Overall, the usage of traditional medicine was perceived to be high (Fig. 2a), with the emotion of pride being particularly associated with 50 per cent of stories related to traditional medicine (Fig. $2 \mathrm{~b}$ ). The case from Guatemala shows ways in which traditional medicine has been used.

Case study 1: Use of traditional medicine by Indigenous peoples in Guatemala

The Indigenous peoples of Guatemala have counteracted the impacts of COVID-19 by mobilising knowledge and health practices inherited from their ancestors. This is not the first time they have faced these phenomena: diseases brought by the European invasion killed 80 per cent of the original population relying on traditional medicine since governmental health assistance has historically discriminated against them, a situation which continues in the current pandemic with assistance that is scarce and late (IACHR, 2020). According to one man from a Guatemalan Indigenous community, "Doctors in the hospitals complained that they do not have the necessary tools to care for the patients". Given the lack of access to conventional medicine, the traditional therapies of Guatemala's Indigenous peoples, used to

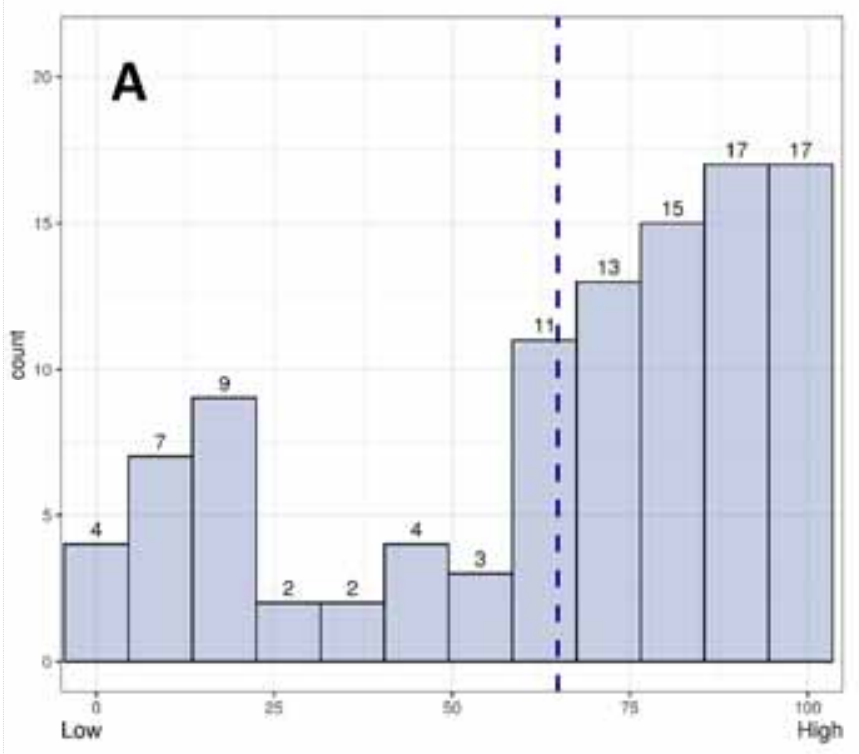
(Cook \& Lovell, 1991). Indigenous peoples are again

face diseases in the past, have been widely adopted to reduce the spread and impact of COVID- 19 .

In Guatemala, there are many Indigenous medical graduates from universities, some of whom combine scientific knowledge with traditional knowledge in the therapies they recommend. Indigenous medicine has been important in strengthening people's immune systems (also referred to as "taking care of the body and mind"), controlling fever and reducing respiratory congestion (Comunidad Maya Los Chenes, 2020). It includes mainly native plants found in ancestral territories, both in backyard gardens and in natural areas protected by communities. Steam baths - called tuj, chuj or temascal - are used by the K'iché, Mam, Kaqchikel and Ixil peoples with native plant species to improve the respiratory system. Most rural, Indigenous households have baths of this type. The Q'eqchí people used infusions of wild Guava leaves (Psidium guajava); the Ch'orti, use Quina (Cinchona offinalis), a plant from which the malarial treatment quinine is extracted. Q'eqchi, Ch'orti and other communities use Tres Puntas (Neurolaena lobata) for its antibiotic, anti-malarial, anti -ophidian and anti-inflammatory properties. Plantain (Plantago major), a naturalised species known for its expectorant properties, is also used.

Mayan Indigenous peoples have developed therapies that include ginger, garlic, eucalyptus and honey, sometimes complemented with conventional medicines depending on symptom severity. Although there are no

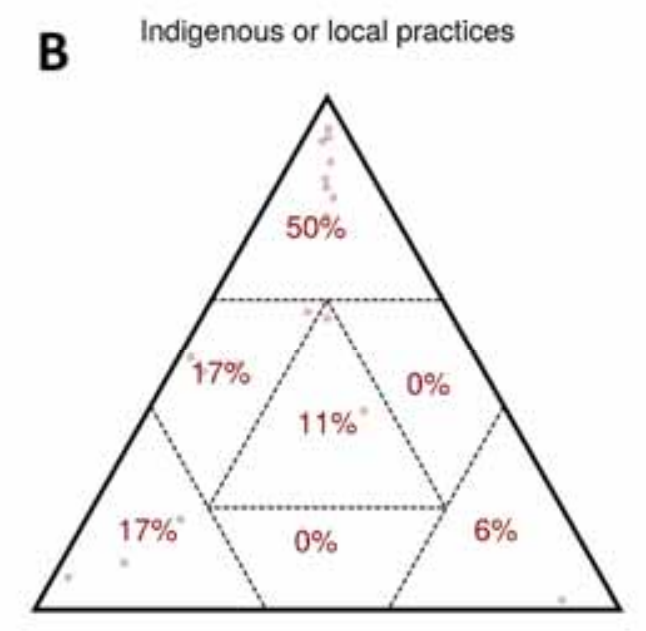

government non-profit organisations

Figure 2. Use of traditional medicine to counteract symptoms of COVID-19. (A) The number of stories: totals are given above each bar, the dashed vertical line is the median; traditional medicine was often considered to be "highly used'. (B) Stories concerning traditional medicine: in the case of Indigenous and local practices, 50 per cent of stories were associated with pride. 


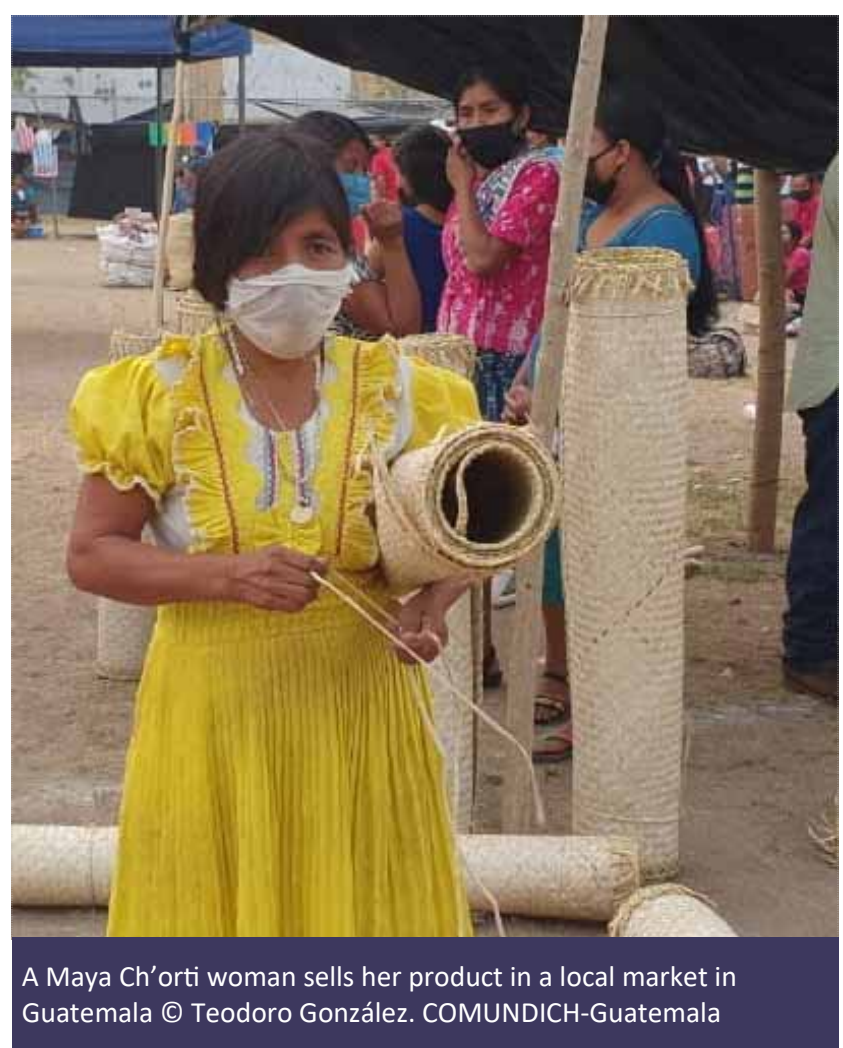

known Guatemalan Indigenous therapies capable of curing COVID-19, such medicines have been widely used to reduce the contagion and impact by strengthening immune system response.

\section{Solidarity}

COVID-19 was considered to have increased community solidarity (Fig. 3). A male Maasai community member from Tanzania reported that when the youth lost their tourism jobs, they returned home and, despite reduced family income, "helped my community to reclaim pieces of lands which have been taken forcibly by cultivators following their absence. The youth who came back to their ancestral land, united in numbers and claimed their land."

Case study 2: iTaukei communities in Fiji resilient in the face of COVID-19 but vulnerable to natural disasters

Fiji recorded its first COVID-19 case on 19 March 2020 and has had a total of 32 cases and 2 deaths (as of 15 October 2020). Telephone interviews in May 2020 with key informants from 20 rural Indigenous Fijian (iTaukei) communities across four provinces found that, while most people interviewed listed COVID-19 as a major event, there is little evidence of this affecting food security or fisheries livelihoods (WCS and LMMA, 2020). Over 90 per cent of all respondents had enough,

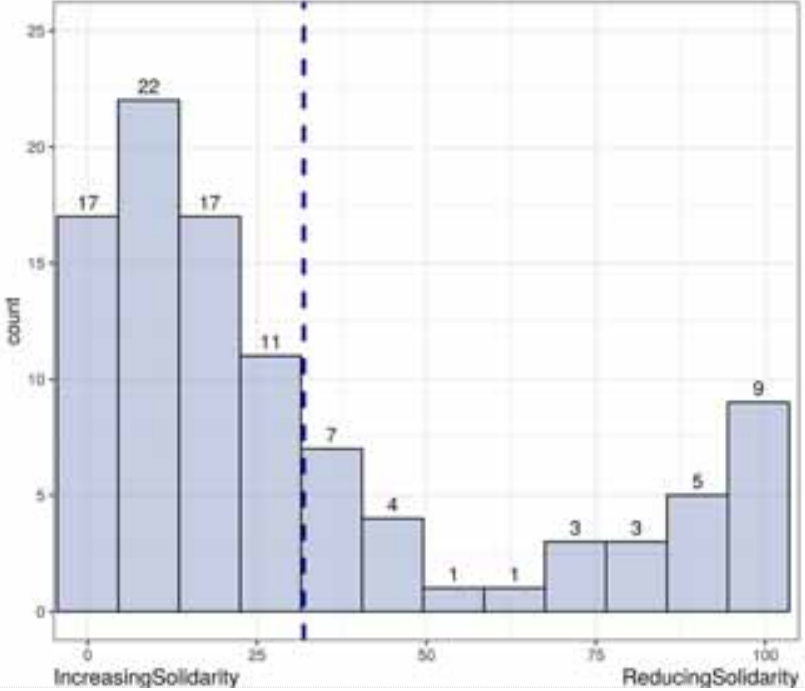

Figure 3. Stories reported increases of solidarity; the dashed, vertical line indicates the median. Numbers on top of each bar notes the number of stories.

more than enough or lots of food, from gardens and local fishing grounds. Just under a fifth of people stated their communities had suffered damage to crops from cyclone Harold which passed through Fiji in April 2020, affecting local livelihoods and household income. It appears that the iTaukei communities have been resilient to the shocks of the pandemic in the initial months of border closure and restrictions, but more affected by cyclones. Many villagers made decisions to close their village to self-isolate themselves from the rest of the country.

Land and marine tenure systems underpin natural resource management in Fiji, with 88 per cent of the land legally owned by iTaukei clans (Mangubhai et al., 2019). There were reports of support for family members returning to their villages. A woman working for an organisation in Fiji reported that "solesolevaki, a form of cultural social capital" had allowed returning villagers who had "lost their jobs in hotels when the international borders closed" to have access to food while they waited to harvest their plantations. Some concerns were raised that those returning to villages were breaking customary rules, including catching turtles and undersized fish, fishing or selling fish without a license, and poaching in the village tabus (traditional closures) (WCS and LMMA, 2020). These are commonly reported issues and offences even during normal times.

\section{Capacity of communities to govern their lands}

In the survey, COVID-19 was found to both reinforce and undermine community rights (Fig. 4a). Twentythree per cent of stories involved access, and 21 per cent 
concerned the use of natural resources (Fig. 4b). Restrictions sometimes prevented communities from protecting their lands. Some communities reported that their own movement was restricted, while private sector activities continued. An employee of an organisation working with IPLCs in Gabon, noted: Our project had begun facilitating a formal MOU [memorandum of understanding] between a logging company and villages on the co-management of hunting, but when COVID-19 arrived in the country the loggers stopped progress on this collaboration, citing the pandemic as the reason, while continuing to open roads further and further into the forest without controlling access and cutting down trees outside the knowledge of the villages. In Cameroon, another such employee said: "During this same period, they have witnessed the conversion of forest land to non-forest land, especially for the establishment of palm trees, which has led to the massive arrival of employees (including those carrying the virus) in the communities..." Similar observations were made elsewhere in Cameroon and the Democratic Republic of Congo.

An employee of an organisation working with fishing communities living outside a national park in Gabon, reported that "... park managers... banned ... residents from fishing in the park" during COVID-19, even though these fishing rights had been retained since the park was first established. As this situation has persisted for several months, the community "has initiated a process with the managers of the park without success. The inhabitants ... have taken the case to the courts and ... provincial authorities."

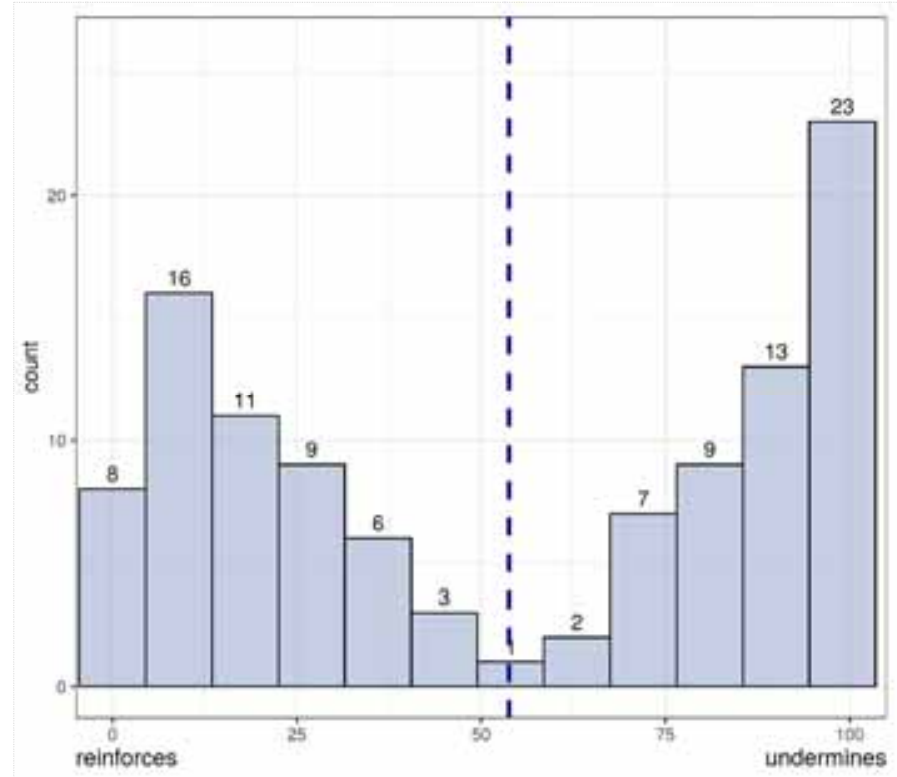

In other places, communities were able to effectively protect and use their lands, or were closed off from their lands, as explored in the case studies from India and France.

Case study 3: Empowered local communities are better equipped to deal with crisis in India ${ }^{3}$

India continues to be one of the worst-affected countries. The pandemic and lockdown have had a drastic impact on poor and marginalised communities, with the Adivasi and other traditional communities particularly affected. These have long faced disempowerment, but where they enjoy de facto or legal rights, hundreds of Adivasi communities have shown remarkable resilience in coping with the crisis. This has

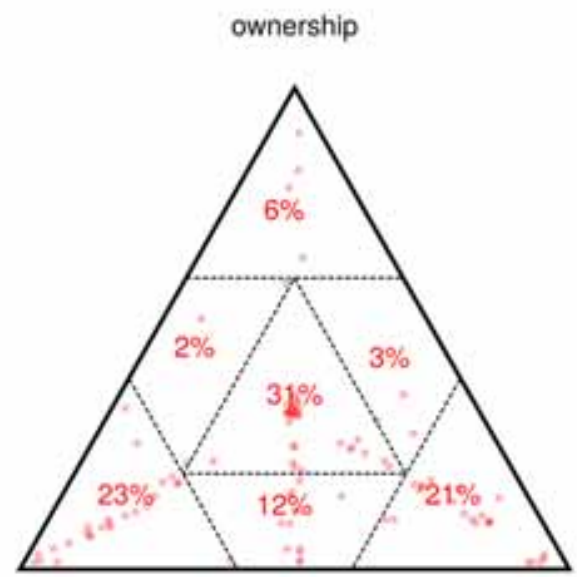

access

Figure 4b. COVID-19 stories focused largely on access or resource use, or a combination of all factors
"The restrictions that have been established in the country, especially in indigenous communities, affected the mobilization of people causing the loss of their jobs. They were also unable to attend to their crops in the established timeframes,

generating losses in their harvests and affecting food security. Similarly, people could not carry out the patrols against illegal logging and fires could not be adequately prevented, which directly affected the forests."

Member of an Indigenous organisation in Guatemala

Figure 4a. COVID-19 was perceived to both reinforce and undermine community rights 
been most evident where land and forest rights are recognised under The Scheduled Tribes and Other Traditional Forest Dwellers (Recognition of Forest Rights) Act 2006 (FRA) and Panchayat Extension to Scheduled Areas Act 1996. New rights to manage community forests allowed communities to quickly address COVID-19 and the lockdown before any outside agency reacted. Key lessons emerged (Vikalp Sangam and CFR-LA, 2020), based on interviews with the community members and others:

1. Local actors understand local complexities and can act faster when empowered.

2. Secure tenure and empowerment helped gram sabhas (village assemblies) to address distress and reduce out-migration prior to the lockdown, by creating local ecosystem-based livelihoods. Consequently, community members did not face the acute crisis suffered by many migrant workers.

3. Healthy and diverse ecosystems resulting from long-term conservation helped community resilience by supplying basic needs when other options closed, including where pastoralist communities had restored and managed grazing territories.

4. Access and control over resources helped community collectives and village assemblies strengthen themselves financially. Money was invested in meeting immediate local needs before outside financial help could be mobilised.

5. Forest ownership ensured better livelihood opportunities during lockdown as communities continued to collect forest produce for sale and pay community members a daily wage.

These examples show that when local institutions have resources and power, they can help the most vulnerable and weak in society, including women, children and poor people. Long-term protection of biodiversity and agro-biodiversity helps communities be more resilient in crises.

Case study 4: Community rights in France

Mont Mourex is a hill in France overlooking Geneva, Switzerland. Since the Middle Ages, part of it has belonged to, and is managed by, the inhabitants of the hamlet of Mourex, part of the village of Grilly. This form of land management, a section de commune, is rare in France as communal lands are usually owned by the village town hall. Today this area serves agricultural and forest livelihoods, but is also an important place for recreation. In Mourex, local people identify strongly with their lands (Smith, 2020).
When COVID-19 struck France, according to one female community member, people felt "very fortunate to have access to our community lands, where we typically collect firewood, exercise our dogs, walk or collect mushrooms". However, outsiders started using the area, despite a $1 \mathrm{~km}$ restriction on movement. The mayor then closed access to communal lands to community members and outsiders, without consulting the local community of Mourex, the legal owners. This was considered a "usurpation of authority" by one community member. Many others were angered, one woman noting that it "concentrated people into other areas of the territory" so that - as another community member noted - "we met MORE people after the closure of our area (Mont Mourex) than when it was open", thus increasing the potential for COVID-19 transmission.

However, some good has emerged from these restrictions. Being forced onto other paths meant that community members discovered new areas of the village lands. Restricting people to their gardens and the street created a new sense of community. Members supported each other through a WhatsApp group. People met neighbours that they did not know. For some, it became a learning opportunity, for example gardening for the first time.

\section{Economic effects}

The survey indicated that economic impacts were mixed between livelihood loss (21 per cent), changes in movement (19 per cent), and disruption of selling goods (8 per cent). We found 36 per cent of the stories were combinations of all three (Fig. 5). Job loss, especially

$$
\text { changes in movement of people }
$$

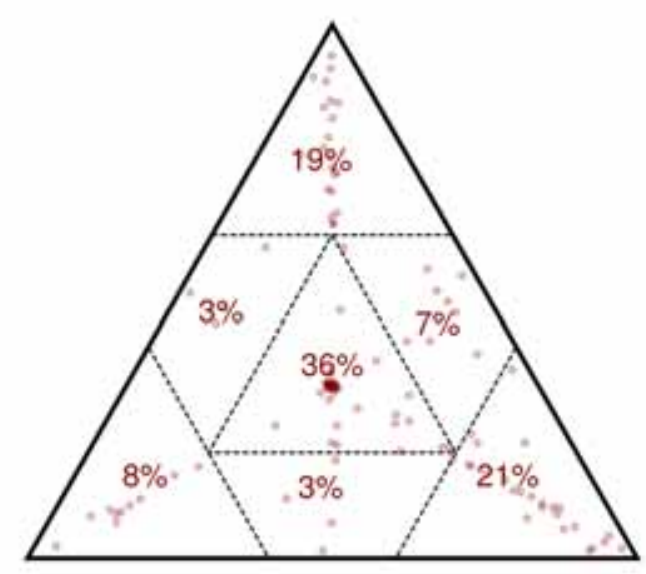

disruption of selling goods

Figure 5. In many stories, people reported loss of livelihoods and changes in movement of people, or combinations of several factors 
from the collapse of tourism, was mentioned in Fiji, Gabon, Hawaii, Pakistan and Tanzania. Elsewhere, communities were affected when NGOs cut back their work to minimise COVID-19 transmission (e.g. reducing gorilla survey teams); with less work, people, mainly youth, returned to their home communities. The case from Benin shows how closing markets can have a negative impact on the ability of IPLCs to provide basic needs, including buying and selling products.

Case study 5: Food security in Benin

In Benin, COVID-19 has significantly affected local food production systems, which were already weak. Avrankou, one of the 77 communes, is inhabited by 17 IPLCs including the Torri, Goun, Yoruba and Nago. Each community has forests, natural sites, sacred water sources and other natural resources - places for celebrating and perpetuating community ties. The government imposed enormous restrictions on communities. According to one respondent, "We carry out income-generating activities such as gardening, fish farming, beekeeping. Its activities allowed us to meet certain subsistence needs and given ... the arrival of the confinement we found ourselves unable to resell our products which leads us today to have no more financial and material resources."

From March to May 2020, communities did not have access to markets to sell or buy basic necessities. Thus, to avoid famine, they were forced to consume traditional seeds from their seed banks (for example Phaseolus vulgaris, Zea mays, Dioscorea alata, Dioclea hexandra, Abrus precatorius, Caesalpinia bonduc). These have not been genetically modified (and are used as food, for cultural and religious ceremonies and in traditional medicine). During this time, the Groupe de Recherche et d'Action pour le Bien-Etre au Bénin helped more than 2,200 community members to respect social distancing measures and discussed with them the challenges of food sovereignty during a pandemic. Today, markets have reopened, and agricultural production, community dialogue and training in agroecology have slowly resumed.

Case study 6: From tourism to school closure in a coastal Gabonese community

Gabon contains 13 land and 17 marine protected areas, with the ecotourism sector at the heart of its conservation model. Loango is considered an exemplary park for tourism, generating jobs and income, and avoiding dependence on the oil-rich economy. Ecotourism has become central to the debate between "conserve or exploit" (Méral, 2011).
COVID-19 has been a major blow to tourism, especially for local communities, such as the Ngové people in Loango National Park. The Ngové settled at Iguéla lagoon long before the arrival of the Portuguese at Pointe Catherine in 1474 (Deschamps, 1962). Before the creation of the modern parks, they lived mainly from traditional fishing, gathering, hunting and agriculture. Today, the forest and lagoon provides for subsistence, medicinal and cultural needs (Agondjo-Okawe, 1982).

The introduction of travel restrictions led to a drop in international tourists and a drastic loss of income to both tourist operators and the people that they hire. Some tourist operators were forced to lay-off staff and even to cease work permanently, affecting community projects funded by tourism. An example is the village school of Tchangorovié, which provides free schooling for the children of the Indigenous community living in the park. It is a private school, founded in 2007 through a project between the local communities and the Gabonese Parks Agency. Teachers' salaries were paid from community tourism revenues 4 . Nearly 1,000 children have attended the school, with a success rate in national exams of 90 per cent over 13 years. With the closure of the lodge, the school also risks closure if governmental support cannot be found, illustrating the dangers of over-dependence on tourism. The local community needs other sources of income to fund its educational needs reliably.

Indigenous or local practices

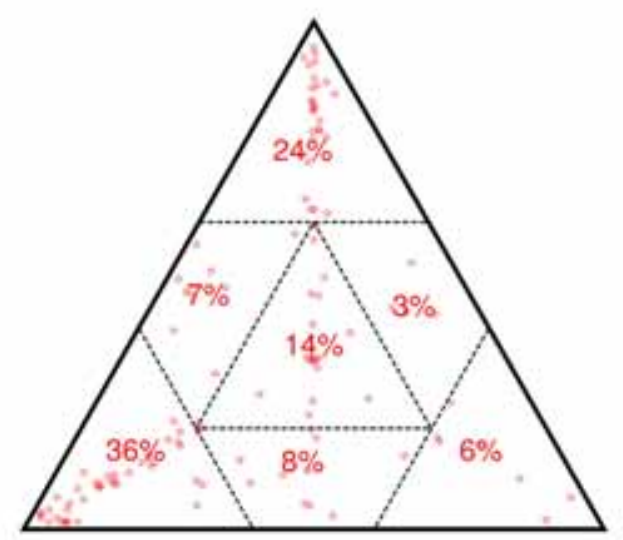

government

non-profit organisations

Figure 6. Respondents reported a mixture of management of COVID-19 responses from the government, Indigenous or local practice, but less often from non-profit organisations 


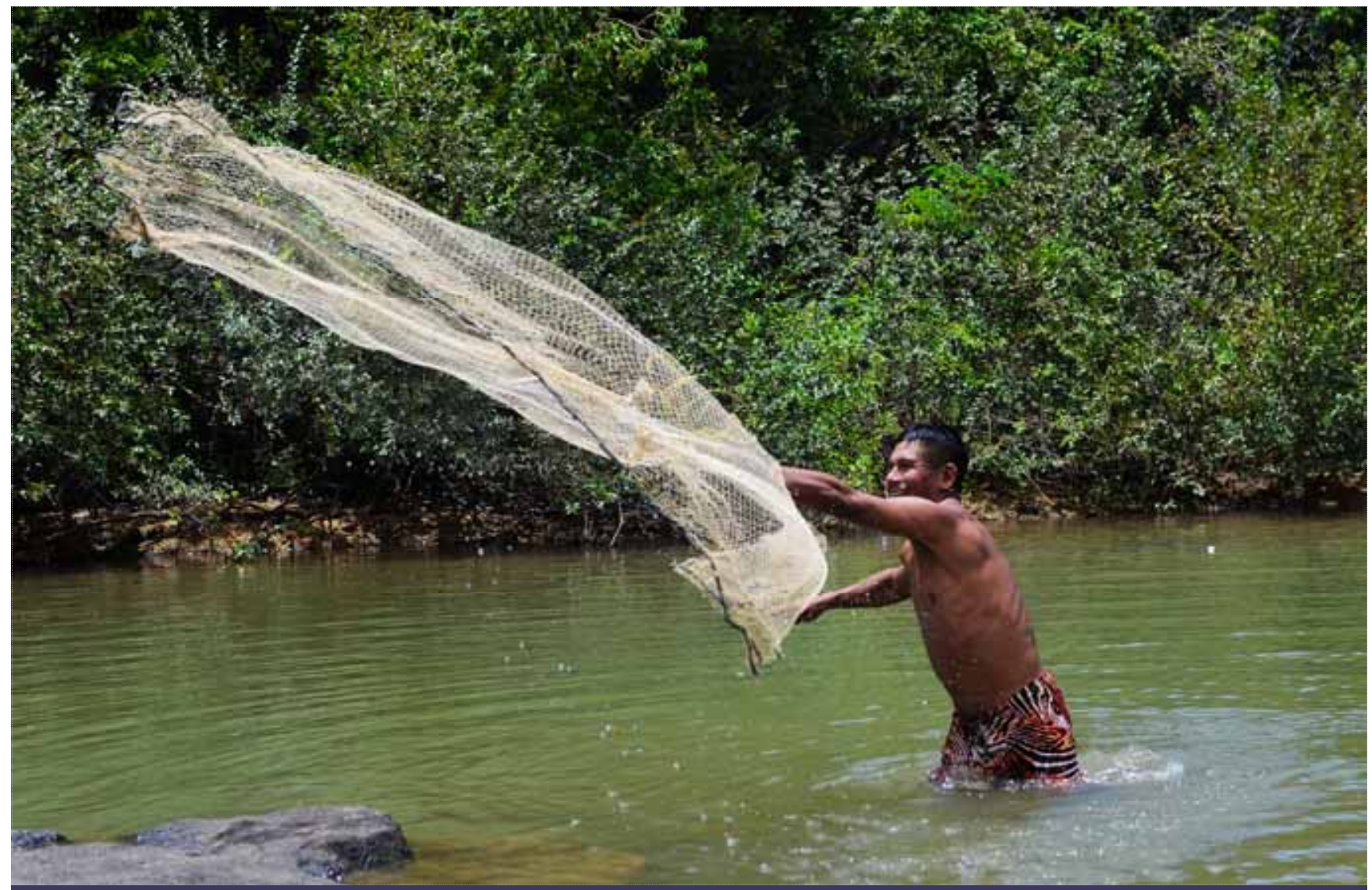

Wapichan man fishing on the Rupununi River, Guyana. Fish and wildlife are key sources of food (c) Quadad De Freitas

\section{Roles of communities and governments in dealing with COVID-19}

In 36 per cent of cases, the government was perceived as important in managing COVID-19 responses; 24 per cent thought Indigenous and local practices were more important; in 6 per cent of cases non-profit organisations were perceived to be managing COVID-19 (Fig. 6). In India, Bangladesh, Democratic Republic of Congo, Finland, France, Cameroon, Australia and Guatemala, stories stressed the failure of states to provide medical care. One Sami female reported that the intangible values of relationships in community and families had "been negatively affected" amongst reindeer herders.

Case study 7: Wapichan Wiizi response to COVID-19 in Guyana

The Wapichan Wiizi territory covers 2.8 million hectares, containing many globally rare or endangered animals and cultural heritage sites (Wapishan, 2012). It is managed by the South Rupununi District Council, an Indigenous overarching organisation, representative of 57 Indigenous communities. Wapichan Indigenous groups maintain traditional subsistence lifestyles of hunting, fishing and farming, but are increasingly involved in tourism, cattle ranching and commercialisation of farm and nature products (Conservation International Guyana and IDB, no date).

In the South Rupununi Region, the first concerns about COVID-19 arose in early April 2020 and the government swiftly closed all borders and banned gatherings of more than 10 persons. In the absence of medical facilities, local Indigenous leaders established a voluntary lockdown. Checkpoints were set up to control movements. Social control was effective in ensuring that all complied with safety measures. Movements of people between Guyana and Brazil were forbidden and movements of goods were only possible once a week at the Lethem border. The lockdown affected employment and income, particularly in tourism, transportation and trade. The trade of food products was particularly affected, and prices increased steadily. Local leaders took measures to raise awareness about the pandemic, distribute food to vulnerable households (e.g. elderly, disabled persons), and mainstream safety measures in public places.

From a food security perspective, households were generally well prepared: since schools were closed, 
people moved back to their old farming grounds deep in the forest, and relied on fishing, hunting and gathering. They increased farm size and started rearing chickens. Rapid adaptation was possible in households where knowledge of traditional practices had been maintained. Many leaders recognise the importance of maintaining traditional subsistence knowledge as adaptation capital during crises. Family cohesion, access to farming grounds, rivers and forests, and local knowledge gave households the capacity to adapt.

The pandemic also had social and cultural impacts. One man from the Annai group reported that it had ".. made an impact that caused families and friends to separate and die, community members that were accustomed to living with one another closely had to find new ways to live with each other, self-help and other activities that require being together were no longer accepted by villages."

Traditional festivities that represent bonding opportunities for remote communities did not take place. The lockdown highlighted the importance of family cohesion, but also sometimes caused depression, drinking and intra-family violence. Local leaders have learnt to react quickly by raising awareness of the dangers and avoiding them. Traditional medicine and traditional fishing, hunting, farming and gathering have regained importance.

\section{Case study 8: COVID-19 response in Madagascar -} NGOs and governments

Vezo fishing communities, living on the arid southwest coast of Madagascar, are among the most remote and poorly served communities in the country. They rely almost entirely on the sea for food and income. Since 2003, the marine conservation organisation Blue Ventures has worked with these communities to help rebuild their fisheries. This community population of 12,000 relies on a network of community health workers and basic community health clinics for its health care needs, alongside support from traditional healers.

In close collaboration with community leaders and the Ministry of Health, Blue Ventures worked to reduce transmission of COVID-19, protect the most vulnerable and strengthen health systems. Actions included: providing accessible health information; establishing a community-based COVID-19 surveillance system; constructing handwashing stations and distributing washing equipment and soap; supporting local women's associations to manufacture reusable face masks; and developing new clinical protocols that minimise health worker- client transmission. Observations suggest social distancing guidelines are observed, 65 per cent of households are washing their hands with soap or ash, and 60 per cent wear a mask when leaving the home. At the time of writing (October 2020), all community health workers continue to provide services and clinics remain open, ensuring that essential health care delivery continues.

This work runs in parallel with efforts to ensure fishers can continue to earn a livelihood and manage their resources sustainably. Challenges are exacerbated by falling fish prices: a male Malagasy reports: "the sale of fishery products decreased significantly in quantity and price because the fish merchants/collectors slowed down their activity due to barrier measures". Successful adaptation by Vezo communities provides clear evidence of the effectiveness of a locally-led response to the pandemic which effectively coordinates input from all local stakeholders.

\section{DISCUSSION}

This initial analysis of the SenseMaker ${ }^{\circledR}$ surveys and case studies shows that COVID-19 has impacted communities in different ways. Though it is impossible to generalise, there are common themes. Based on the survey and cases studies, the following insights emerge: rapid adaptation was possible in households where knowledge of traditional practices had been maintained; there was a paradoxical increase in solidarity but also of separation of people who used to work and live together; traditional festivities that represent bonding opportunities for remote communities did not take place; local leaders have learnt to react quickly by raising awareness of the dangers and avoiding them; traditional medicine and traditional fishing, hunting, farming and gathering have regained importance; many villages made decisions to self-isolate from the rest of the country; and restrictions sometimes prevented communities from protecting their lands. Many stories centred on resource use and access, with community governance of their lands being at times reinforced and at times undermined. The interactions between governments, local people, the private sector and community leaders led both to innovations in dealing with COVID-19, and to restrictions that increased vulnerability of IPLCs. In this discussion, we focus on two themes: IPLC responses, and resilience and rights.

\section{IPLC responses}

Our study found the responses to COVID-19 varied across IPLCs and geographies, and were shaped by: (a) government responses to the health crisis; (b) impact of 
further crises or disturbances on top of COVID-19; (c) engagement in the formal economic sector; and (d) access to resources, especially food and traditional medicines. Health responses involved both NGOs partnering with communities, and communities acting alone. In Madagascar and Benin, international and national NGOs collaborated with communities to increase health services, providing critical support to communities in adopting governmental measures.

In many cases, the government was absent or unable to react quickly, and communities and their leaders stepped in. In Guyana, community leaders were able to act fast, despite a lack of medical facilities. In India, Adivasi communities with more rights could respond quickly, deciding to self-quarantine before governmental measures were enacted. In Guatemala, traditional medicine was used to counteract some COVID-19 symptoms. In other cases, such as Fiji, some were frustrated with the lack of leadership from their community leaders (e.g. to address poaching), while in France, the authoritarian shut-down of access to community lands angered the community and rendered them more vulnerable to disease transmission as they were forced into smaller outdoor spaces.

Our results are borne out elsewhere, largely from media reports in the early phases of the pandemic. Many

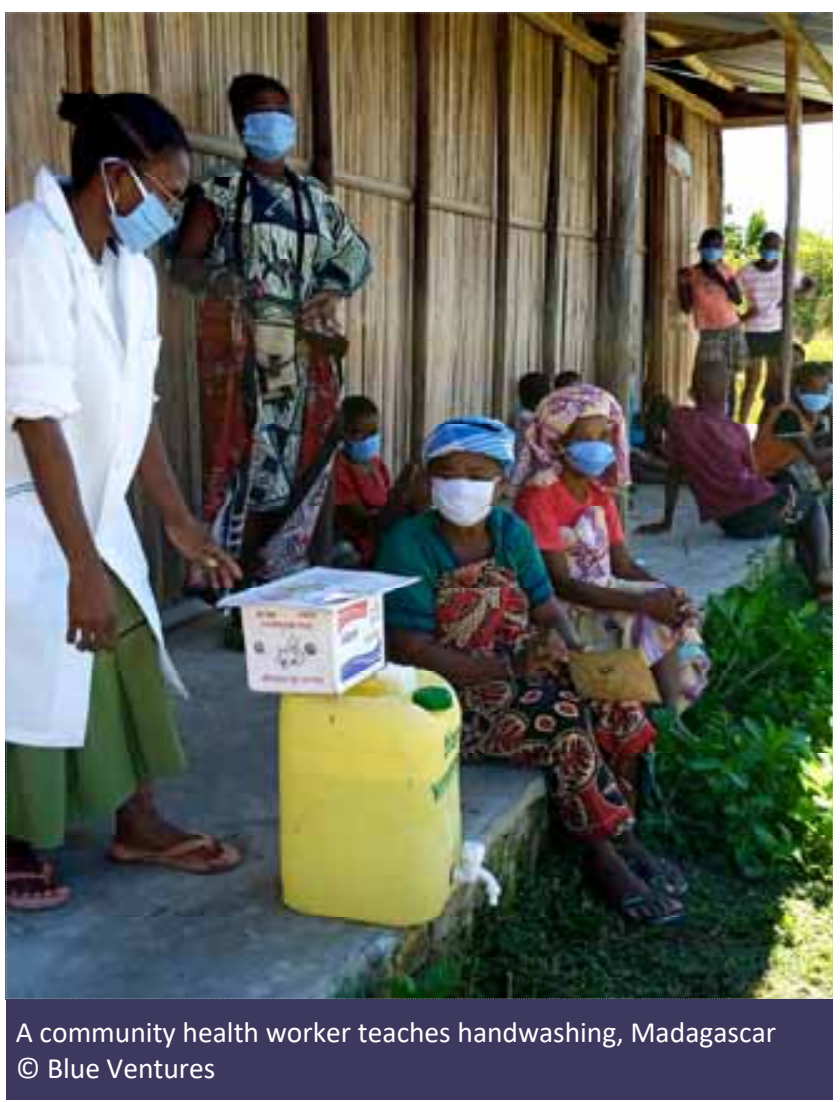

people returned to traditional practices and mutual selfhelp (Banning, 2020; The Lancet Diabetes \& Endocrinology, 2020). Some Canadian First Nations made extended stays on their lands to avoid COVID-19 and became more engaged in traditional practices (Banning, 2020). In the United States, Navajo youth helped elders (Gable, 2020) and Native Americans used traditional seeds and planted new gardens (Hoover, 2020). In Peru, the Autonomous Territorial Government of the Wampis Nation declared their territory to be a natural hospital, hosting plants for traditional medicine that can be used to stem COVID-19 symptoms (Carillo, 2020). The pandemic has renewed interest in traditional medicine and culturally relevant approaches to treatment of COVID-19 symptoms, and has emphasised the importance of locally led responses (Curtice \& Choo, 2020; United Nations, 2020). COVID19 responses should not be copied and pasted from elsewhere, or favour the elite, and traditional medicine should be supported (Iwuoha \& Aniche, 2020). Partnerships between governments and Indigenous peoples, which build on local knowledge, show good results in dealing with COVID-19 in Australia (Moodie et al., 2020), New Zealand (Carr, 2020) and Bolivia (Kaplan et al., 2020).

\section{Resilience and rights}

The survey and cases studies here demonstrate that IPLCs that are able to govern and access their lands and waters appeared to be more resilient. Through access, they were able to secure food and medicine for themselves and for outsiders and returning emigrants in need. With recognised tenure rights, they were able to enforce internal resource use regulations and often defend their territories from misuse by outsiders.

Tauli Corpuz, former United Nations (UN) Special Rapporteur on the rights of Indigenous peoples, notes that the absence of recognised rights over resources, isolation and small population size make them more vulnerable to the pandemic's economic and social impact (Hansen, 2020), so reducing their ability to safeguard their territories and monitor sites of concern, such as nearby mining concessions. But the news is not wholly negative, for example, some small-scale fishing communities have engaged in food sharing (Bennett et al., 2020); reduced movement by people has given nature a chance to recover; and while some countries have experienced a spike in poaching and other illegal activities, others have seen a reduction.

In Guyana, accessing fishing, hunting and gathering grounds and returning to traditional food production helped people survive. In India, Adivasi communities 


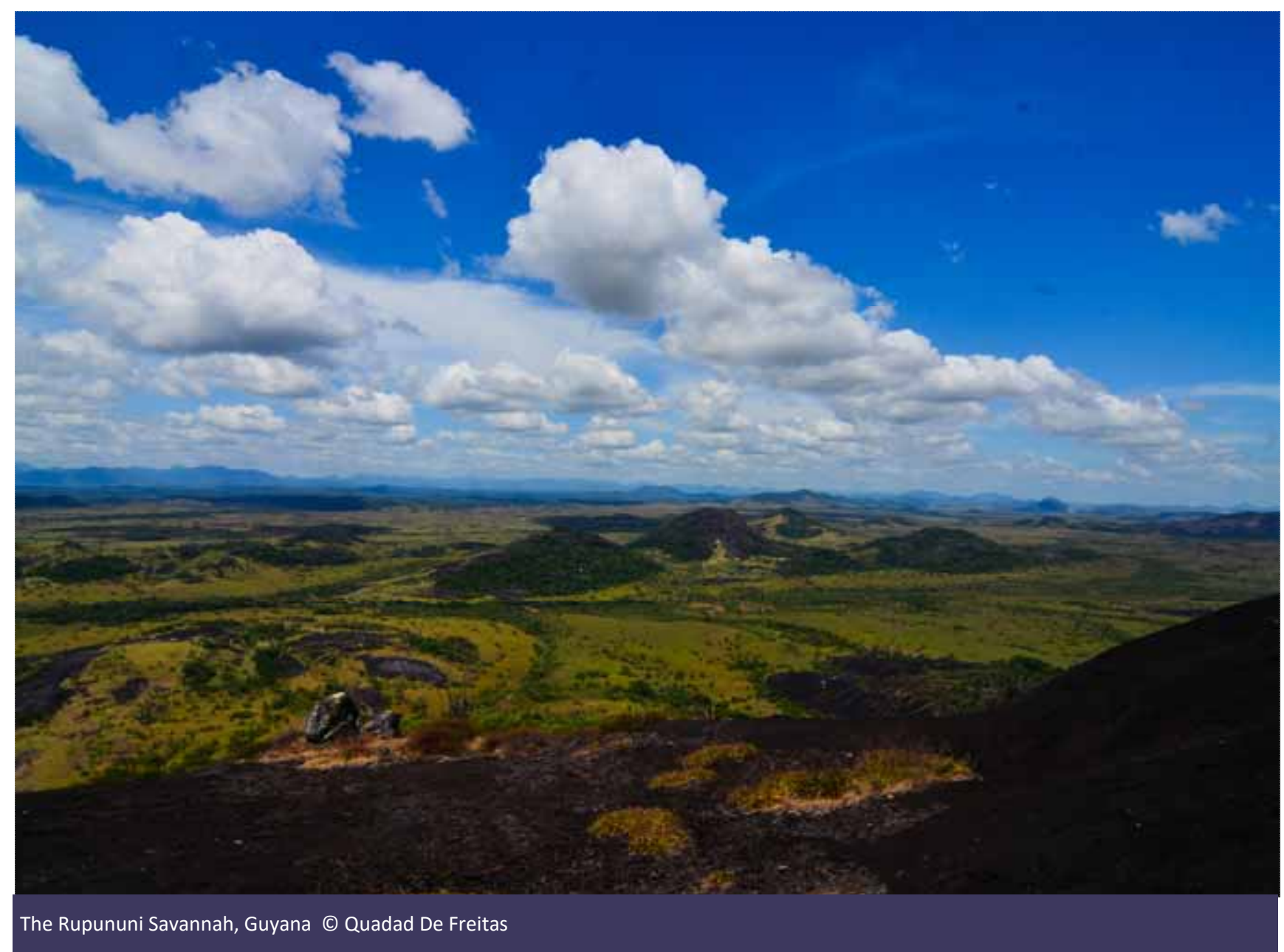

with forest rights continue to collect forest produce during the lockdown, enabling them to help outsiders. In Fiji, the practice of solesolevaki helped returning community members obtain shelter and food, while some community leaders were able to ensure compliance with customary rules for resource use and access. However, when a community outside a Gabon national park lost its fishing rights in the park, it was made more vulnerable to the pandemic.

Access to markets, much promoted by the development community, has both strengths and weaknesses in a situation like this. The communities in India, Fiji and Guyana did not depend solely on global markets; they appeared to fare better through self-reliance. However, resilience may break down under multiple crises: for example, the Fijian communities impacted by both COVID-19 and cyclones. Communities that were heavily dependent on markets for buying and selling, or jobs, generally fared worse. In Benin, communities had to eat their seed reserves since they did not have access to markets to purchase other food. Fisherfolk in
Madagascar suffered from falling fish prices; in Gabon, a local school, funded by tourism, is risking closure.

Lockdowns affected the ability of IPLCs to defend their lands. In Gabon, Guatemala, Cameroon and the Democratic Republic of Congo, people who were locked down noted that this policy did not apply to the extractive sectors - mining, logging and palm oil - even though these continued to operate, sometimes at the expense of community lands and helping to transmit COVID-19.

Resilience matters critically. There have been many reports that protected and conserved areas have been less well protected, and more vulnerable to poaching, during the pandemic. This study shows that where tenure is secure, there is resilience in IPLC communities, they have their own sources of food and they can take care of their territories within ICCAs. This is consistent with the observed linkages between ICCAs and increased food sovereignty (Pimbert et al., 2019). 
The COVID-19 pandemic demonstrates the limitations of the current funding model for protected and conserved areas and local peoples that depend on them, since this favours mainly states and operators, and may not directly fund local communities. Communities living near protected and conserved areas, who invested in wildlife tourism and rely on income from visitors, are now struggling (Corlett et al., 2020; Evans et al., 2020; Lindsey et al., 2020). There is a need to find alternative funding for protected and conserved areas (Rakhmatova, 2015; Cumming, 2021). The varied responses have challenged the narrative that only international tourism and aid can support IPLCs.

The survey offers evidence that people are not only surviving but, in some cases, thriving in part due to their reliance on customary knowledge, systems and practices. New models should consider the rights of communities while respecting and protecting nature. This requires their involvement as rightsholders in the governance and management of protected and conserved areas, as well as partners in revenue-sharing activities (e.g. Fabry \&Zeghni, 2012).

Communities need rights to land. Resilience of IPLCs is determined by their access to and use of nature, and an ability to govern and defend their lands and waters. The resources and the associated traditional knowledge which are being accessed during COVID-19 are invaluable in times of crisis and will continue to be an important safety net.

In some communities, over-reliance on NGOs or the government seems to reduce resilience, creating dependence on external funding or knowledge; however, effective collaboration between communities and NGOs can also lead to long-term capacity building and sustainability.

\section{Key actions to support IPLCs in pandemics and beyond}

How can IPLCs, managers of protected and conserved areas, NGOs, governments and companies work together respectfully in crises and beyond to encourage and protect resource rights and access to traditional crisis foods and medicines? Based on the results of this paper, we propose the following actions for dealing with the current and future pandemics:

1. A rights-based approach to crisis responses is needed, in which priority is given to tenure and rights as they pertain to communities governing their lands and territories.

2. Governments and development workers should recognise and protect the rights of IPLCs to govern their lands and territories because that is where the resources (water, food and medicine) needed to cope with pandemics are to be found.

3. Companies must not use crises as reasons to stop engaging with IPLCs or to move into their lands.

4. Crisis response measures to COVID-19 should: be jointly conceived with IPLCs; value diverse perspectives and approaches; and recognise the actions that many IPLCs undertake independently.

5. Governments and NGOs should learn from and disseminate COVID-19 success stories carried out by IPLCs.

6. Greater diversity of funding is needed for conservation initiatives that engage with IPLCs, with priority given to direct funding of ICCAs and local communities.

7. Long-term partnerships between protected and conserved areas and IPLCs are needed, which ensure that IPLCs' access to natural resources is not put at risk in times of crisis.

\section{ENDNOTES}

1. Adults were self-declared individuals who were considered of an adult age according to their country's laws.

2. https://www.iccaconsortium.org/index.php/category/covid19-en/

3. This section is written by Neema Pathak Broome, entirely based on and taken sometimes verbatim or summarised from the introduction section of Vikalpa Sangam and CFR-LA (2020). This has been done with due permission of all her colleagues and co-authors of the document.

4. Although Gabon has a small population of 1.8 million, the population is concentrated in the cities of Libreville and PortGentil, leaving the hinterland underpopulated by comparison. The priority areas for investment are de facto urban centres, thus causing most educational funding to be distributed to urban schools. The school of Iguéla functions entirely by income resulting from tourism paid by the lodge concessionaire; however, this situation is currently being reviewed by the government.

\section{ACKNOWLEDGEMENTS}

We would like to acknowledge the following people and Indigenous organisations who contributed to the development and testing of the survey: Holly J onas, Natividad Quillahuamán, Eleonora Fanari, Samuel Nnah, Teri Tuxson, Amy Maling, Felipe Gomez, Anna Panagiotou, Ellie Snowden, South Rupununi Conservation Society, North Rupununi District Development Board, South Rupununi District Council. We thank the people who took the time to respond to the questionnaire. The University of Lausanne funded this study. We thank two anonymous reviewers and the two editors of the Special Issue for their comments that improved this paper. 


\section{ABOUT THE AUTHORS}

Gretchen Walters, French community rightsholder. Assistant Professor, University of Lausanne. Member WCPA, CEESP, SSC, SULi.†

Neema Pathak Broome - Programme Coordinator Conservation and Livelihoods Programme, and ICCA Consortium South Asia Regional Coordinator.

Marina Cracco, Researcher at the University of Lausanne; member WCPA and CEM.

Tushar Dash - researcher on forest rights and governance issues in India with tribal and forest dwelling communities and the Forest Rights Act.

Nigel Dudley, freelance ecologist, based in Wales, UK. Member of WCPA, CEESP, CEM†.

Silvel Elías, Maya Kíché, Professor, University of San Carlos, Guatemala†.

Olivier Hymas - Conservation practitioner/ researcher, biologist and anthropologist. specialising on impacts of industries and conservation on rural communitiest.

Sangeeta Mangubhai, Member Fiji Locally Managed Marine Area network, Pew marine conservation fellow*.

Vik Mohan is a UK-based doctor and Director of Community Health at Blue Ventures*.

Thomas Niederberger, Coordinator for Research and Publications, ICCA Consortium; PhD (des) University of Bern, Switzerland.

Christy Achtone Nkollo-Kema Kema, Technical Research Assistant, Department of Geography, Omar Bongo University, Gabon.

Appolinaire Oussou Lio, geographer-naturalist, Expert in Earth J urisprudence, President of GRABEBENIN ONG*.

Njaka Ravelosonn the National Technical Advisor for Health at Blue Ventures Madagascar*.

June Rubis, a Bidayuh woman from Sarawak, and coChair of ICCA Documenting Territories of Life.

Mathieu S.A.R. Toviehou, Geographer-naturalist, Engineer of development and planning, Executive Director, GRABE-BENIN ONG*.

Nathalie van vliet, CIFOR associate researcher, focusing on wildlife and livelihoods in Africa and Latin Americat.

† Honorary members of ICCA Consortium

* Member of ICCA Consortium

\section{REFERENCES}

Agondjo-Okawe, P.L. (1982). Représentations et organisations endogènes de l'espace chez les Myènès du Gabon (Nkomi et Mpongwè) in Enjeux foncier en Afrique Noire. Karthala.

Banning, J. (2020). 'How Indigenous people are coping with COVID-19', CMAJ, 192(27), E787-E788. doi: 10.1503/ cmaj.1095879.

Bates, A.E., Primack, R.B., Moraga, P. and Duarte, C.M. (2020). 'COVID-19 pandemic and associated lockdown as a "Global Human Confinement Experiment" to investigate biodiversity conservation', Biological Conservation, 248, 108665. doi: 10.1016/j.biocon.2020.108665.

Bayha, M. and Spring, A. (2020). 'Response to COVID in Délinę, NT: reconnecting with our community, our culture and our past after the pandemic', Agriculture and Human Values, 37 (3), 597-598. doi: 10.1007/s10460-020-10059-z.

Belaïdi, N. and Koubi, G. (2020). 'Covid-19 et peuples autochtones : Des «faits informatifs » sur une relation au monde (Enquête de mars à juin 2020)', Revue des droits de l'homme. doi: 10.4000/revdh.10441.

Bennett, N.J., Finkbeiner, E.M., Ban, N.C., Belhabib, D., Jupiter, S. and Kittinger, J.N. (2020). 'The COVID-19 Pandemic, SmallScale Fisheries and Coastal Fishing Communities', Coastal Management, 48(4), 336-347. doi: 10.1080/08920753.2020.1766937.

Bernard, H.R. (2017). Research Methods in Anthropology: Qualitative and Quantitative Approaches. 6th edition. Rowman \& Littlefield.

Carillo, K. (2020). The Wampis Nation declares its integral territory as a natural hospital, ICCA Consortium. Available at: https:// www.iccaconsortium.org/index.php/2020/09/19/wampisdeclares-integral-territory-natural-hospital/.

Carr, A. (2020). 'COVID-19, indigenous peoples and tourism: a view from New Zealand', Tourism Geographies, 22(3), 491502. doi: 10.1080/14616688.2020.1768433.

Comunidad Maya Los Chenes (2020). Plantas medicinales del Pueblo Maya en tiempos de COVID-19. Los Chenes, Campeche, México. Available at: https:// www.educaoaxaca.org/wp-content/uploads/2020/05/PlantasMedicinales-del-Pueblo-Maya-May20.pdf.

Conde, M. (2020). 'Brazil in the Time of Coronavirus', Geopolítica (s), 11(Especial), 239-249. doi: 10.5209/geop.69349.

Conservation International Guyana and Inter-American Development Bank (no date). The State of Food and Agriculture in the Rupununi, Guyana.

Cook, N.D. and Lovell, W.G. (eds) (1991). Secret judgments of God: Old World disease in colonial Spanish America. 1st ed. International Congress of Americanists, Norman: University of Oklahoma Press (The Civilization of the American Indian series).

Corlett, R.T., Primack, R.B., Devictor, V., Mass, B., Goswami, B., Bates, A. et al. (2020). 'Impacts of the coronavirus pandemic on biodiversity conservation', Biological Conservation, 246, 108571. doi: 10.1016/j.biocon.2020.108571.

Crooks, K., Casey, D. and Ward, J.S. (2020). 'First Nations peoples leading the way in COVID-19 pandemic planning, response and management', Medical Journal of Australia, 213 (4), 151-152.e1. doi: 10.5694/mja2.50704.

Cumming, T., Seidl, A., Emerton, L., Spenceley, A., Golden Kroner, R., Uwineza, Y. and van Zyl, H. (2021) Building 
sustainable finance for resilient protected and conserved areas - lessons from COVID-19. PARKS 27 (Special Issue): 149-160. doi: 10.2305/IUCN.CH.2021.PARKS-27-SITC.en

Curtice, K. and Choo, E. (2020). 'Indigenous populations: left behind in the COVID-19 response', The Lancet, 395 (10239),1753. doi: 10.1016/S0140-6736(20)31242-3.

Deschamps, H. (1962). Traditions orales et archives au Gabon. Paris: Berger-Levrault.

Evans, K.L., Ewen, J.G., Guillera-Arroita, G., Johnson, J.A., Penteriani, V., Ryan, S.J., Sollman, R., Gordon, I.J. (2020). 'Conservation in the maelstrom of Covid-19 - a call to action to solve the challenges, exploit opportunities and prepare for the next pandemic', Animal Conservation, 23(3), 235-238. doi: $10.1111 /$ acv.12601.

Fabry, N. and Zeghni, S. (2012). 'Tourisme et développement local: une application aux clusters de tourisme', Mondes en

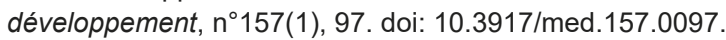

Gable, M. (2020). As Covid-19 tears through Navajo Nation, young people step up to protect their elders. Statnews, 26 May. Available at: https://www.statnews.com/2020/05/26/ navajo-nation-covid-19-youth-response-elders-health/.

Garnett, S.T., Burgess, N.D., Fa, J.E., Fernández-Llamazares, A., Molnár, Z., Robinson, C.J., Watson, J.E.M et al. (2018). A spatial overview of the global importance of Indigenous lands for conservation. Nature Sustainability, 1(7), 369. doi: 10.1038/s41893-018-0100-6.

Hansen, T. (2020). How Covid-19 could destroy indigenous communities. Available at: https://www.bbc.com/future/ article/20200727-how-covid-19-could-destroy-indigenouscommunities.

Hoover, E. (2020). Native food systems impacted by COVID. Agriculture and Human Values, 37(3), 569-570. doi: 10.1007/ s10460-020-10089-7.

IACHR (2020). IACHR Warns of the Specific Vulnerability of Indigenous Peoples to the COVID-19 Pandemic, Calls on States to Adopt Targeted, Culturally Appropriate Measures that Respect These Peoples' Land. Available at: http:// www.oas.org/en/iachr/media_center/ PReleases/2020/103.asp.

Iwuoha, V.C. and Aniche, E.T. (2020). Covid-19 lockdown and physical distancing policies are elitist: towards an indigenous (Afro-centred) approach to containing the pandemic in suburban slums in Nigeria. Local Environment, 25(8), 631-640. doi: 10.1080/13549839.2020.1801618.

Kaplan, H.S., Trumble, C.B., Stieglitz, J., Mamany, R.M., Cayuba, M.G., Moye, L.M. et al. (2020). Voluntary collective isolation as a best response to COVID-19 for indigenous populations? A case study and protocol from the Bolivian Amazon. The Lancet, 395(10238), 1727-1734. doi: 10.1016/S0140-6736 (20)31104-1.

Lindsey, P., Allan, J., Brehony, P., Dickman, A., Robson, A., Begg, C., et al. (2020). Conserving Africa's wildlife and wildlands through the COVID-19 crisis and beyond. Nature Ecology \& Evolution, 4(10), 1300-1310. doi: 10.1038/s41559020-1275-6.

Mangubhai, S., Sykes, H., Lovell, E., Brodie, G, Jupiter, S., Morris, C. et al. (2019). Fiji: Coastal and marine ecosystems. In C. Sheppard (ed.) World Seas: An Environmental Evaluation Volume II: The Indian Ocean to the Pacific. London, United Kingdom: Elsevier, 765-792.

Meneses-Navarro, S., Freyermuth-Enciso, M.G., PelcastreVillafuerte, B.A., Campos-Navarro, R., Melendez-Navarro, D.M. and Gomez-Flores-Ramos, L. (2020). The challenges facing indigenous communities in Latin America as they confront the COVID-19 pandemic. International Journal for Equity in Health, 19(1), 63. doi: 10.1186/s12939-020-01178-4.

Méral, P. (2011). Tourisme et conservation: tentations africaines. In G. Froger (ed.) Tourisme durable dans les Suds? Paris, France: PIE Peter Lang - coll. EcoPolis.

Milne, K.M.G. (2015). Can sense-making tools inform adaptation policy? A practitioner's perspective. Ecology and Society, 20 (1). doi: 10.5751/ES-06791-200166.

Moodie, N., Ward, J., Dudgeon, P., Adams, K., Altman, J., Casey, D. et al. (2020). Roadmap to recovery: Reporting on a research taskforce supporting Indigenous responses to COVID-19 in Australia. Australian Journal of Social Issues, (n/ a), 1-13. doi: 10.1002/ajs4.133.

Omoding, J., Walters, G.M., Edward, A., Carvvalho, S., Colomer, J., Cracco, M., et al. (2020). Analysing stakeholder perceptions to improve protected area governance in Ugandan conservation landscapes. Land, 9, 207-231.

Pimbert, M.P. and Borrini-Feyerabend, G. (2019). Nourishing lifeterritories of life and food sovereignty, Policy Brief of the ICCA Consortium no. 6. ICCA Consortium, Centre for Agroecology, Water and Resilience at Coventry University and CENESTA, Tehran.

Power, T., Wilson, D., Best, O., Brockie, T., Bourque Bearskin, R.L., Millender, E. and Lowe, J. (2020). COVID-19 and Indigenous Peoples: An imperative for action. Journal of Clinical Nursing, 29(15-16), 2737-2741. doi: 10.1111/ jocn. 15320.

Rakhmatova, Z.M. (2015). Tourisme et autonomisation des communautés locales. Le cas de la région du Pamir Tadjik. Téoros, 34(34, 1-2). Available at: http:// journals.openedition.org/teoros/2792 (Accessed: 27 October 2020).

Rights and Resources Initiative (2020). Rights-Based Conservation: The path to preserving Earth's biological and cultural diversity? Washington, DC: Rights and Resources Initiative.

Sajeva, G., Borrini-Feyerabend, G. and Niederberger, T. (2019). Meanings and more... 7. Available at: https:// www.iccaconsortium.org/wp-content/uploads/2019/11/ICCABriefing-Note-7-Final-for-websites.pdf.

Santos, V.S., Souza Araújo, A.A., Ribeiro de Oliveira, J., Quintans-Júnior, L.J. and Martins-Filho, P.R. (2020). COVID-19 mortality among Indigenous people in Brazil: a nationwide register-based study. Journal of Public Health. doi: 10.1093/pubmed/fdaa176

Smith, G. (2020). The section de commune of Mourex, France. A "power to be heard, to defend what is precious to us". Série Développement, Sociétées, Environnements, Université de Lausanne, 2e, p. 30.

The International Work Group for Indigenous Affairs (IWGIA) and International Labour Organization (ILO) (2020). The impact of COVID-19 on indigenous communities: Insights from the Indigenous Navigator. Available at: https://www.ilo.org/gender/ Informationresources/Publications/WCMS_757475/lang--en/ index.htm.

The Lancet (2020). Self-determination and Indigenous health. The Lancet, 396(10248), 361. doi: 10.1016/S0140-6736(20)316822. 
The Lancet Diabetes \& Endocrinology (2020). Indigenous peoples: resilience in the face of adversity. The Lancet Diabetes \& Endocrinology, 8(9), 731. doi: 10.1016/S2213-8587(20)30273 -4 .

United Nations (2020). The Impact of COVID-19 on Indigenous Peoples. Department of Economic and Social Affairs Policy Brief, 70.

Van der Merwe, S.E., Biggs, R., Preiser, R., Cunningham, C., Snowden, D.J. and Jenal, M. (2019). Making Sense of Complexity: Using SenseMaker as a Research Tool. Systems, 7(2), 25. doi: 10.3390/systems 7020025.

Vikalp Sangam and CFR-LA (2020). Community forest rights and the pandemic: Gram Sabhas lead the way. Volume 2 of the extraordinary work of 'ordinary people - beyond pandemics and lockdowns' series and Bulletin 5 of COVID-19 and forest rights. India. Available at: http://vikalpsangam.org/static/ media/uploads/Perspectives/

cfr_and_the_pandemic_gs_lead_the_way_bulletin_5_oct202 0. pdf.
Wapishan, P. (2012). Baokopa'o wa di'itinpan wadauniinao ati'o nii (Thinking together for those coming behind us: An outline plan for the care of Wapichan territory in Guyana). South Rupununi, Guyana: South Central and South Rupununi Districts Toshaos Councils. https://www.lifemosaic.net/ images/uploads/Territories_of_Life/TOL_Resources/ Plan_de_Vida/ Thinking_Together_For_Those_Coming_Behind_Us.pdf Wildlife Conservation Society and LMMA Network (2020). COVID19 Update \#1: Fiji. Available at: https:// Immanetwork.org/wp-content/uploads/2020/08/WCS-Fiji-andLMMA-Network.-Covid-Update-1-Fiji.-26.05.2020.pdf.

World Bank (2020). Indigenous peoples. Available at: https:// www.worldbank.org/en/topic/ indigenouspeoples\#: :text=There\%20are\%20approximately\% 20476 per cent20million, $\% \% \% 20$ of $\% 20$ the $\% 20$ extreme $\%$ 20poor (Accessed: 28 October 2020).

\section{RESUMEN}

Informamos sobre la forma en que la pandemia del COVID-19 está afectando a los pueblos indígenas y las comunidades locales, especialmente a los que gobiernan, gestionan y conservan sus tierras y aguas. Exploramos los temas de acceso y uso de los recursos naturales, la solidaridad, la toma de decisiones, el papel de los gobiernos y los IPLC (pueblos indígenas y comunidades locales - PICL) en la gestión del COVID-19, y la adopción de la medicina tradicional. Estos temas se examinan a través de una encuesta mundial en línea en inglés, español y francés. Recopilamos y analizamos 133 encuestas de 40 países, utilizando SenseMaker ${ }^{\circledR}$, un software que permite el análisis de micronarrativas basadas en la forma en que los entrevistados clasifican sus propias historias. Exploramos más a fondo los temas mediante estudios de caso de Benín, Fiyi, Francia, Gabón, Guyana, Guatemala, India y Madagascar, destacando los desafíos y oportunidades en términos de la forma en que los pueblos indígenas y las comunidades locales reaccionaron ante el COVID-19. Nuestro estudio subraya la importancia de la autonomía y el reconocimiento de los derechos de los PICL, que les permite utilizar la medicina tradicional, satisfacer las necesidades de subsistencia durante los cierres, ayudar a los miembros y vecinos de la comunidad a mantener los medios de vida, y a gobernar, defender y conservar sus territorios. Proponemos medidas clave para apoyar a los pueblos indígenas y las comunidades locales a defenderse de futuras pandemias, protegiendo al mismo tiempo sus tierras y aguas.

\section{RÉSUMÉ}

Nous rendons compte de la façon dont la pandémie de COVID-19 affecte les peuples autochtones et les communautés locales (PACL), en particulier celles qui gouvernent, gèrent et conservent leurs terres et leurs eaux. Nous explorons les thèmes de l'accès et de l'utilisation des ressources naturelles, de la solidarité, de la prise de décision, du rôle des gouvernements et des PACL dans la gestion de la COVID-19, et de l'adoption de la médecine traditionnelle. Ces thèmes sont explorés à travers une enquête mondiale en ligne en anglais, espagnol et français. Nous avons recueilli et analysé 133 enquêtes dans 40 pays, à l'aide de SenseMaker ${ }^{\circledR}$, un logiciel qui permet d'analyser les micro-narrations en fonction de la façon dont les répondants classent leurs propres histoires. Nous explorons les thèmes plus en détail à travers des études de cas provenant du Bénin, des Fidji, de la France, du Gabon, de la Guyane, du Guatemala, de l'Inde et de Madagascar, mettant en évidence les défis et les opportunités dans la manière dont les peuples autochtones et les communautés locales ont répondu à la COVID-19. Notre étude souligne l'importance de l'autonomisation et de la reconnaissance des droits des PACL qui leur permet d'utiliser des médicaments traditionnels, de répondre aux besoins de subsistance pendant les confinements, d'aider les membres de la communauté et les voisins à maintenir leurs moyens de subsistance et de gouverner, défendre et conserver leurs territoires. 


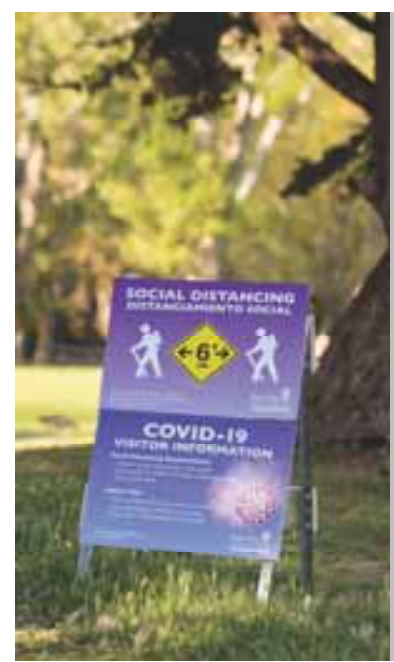

\title{
URBAN PARKS AND PROTECTED AREAS: ON THE FRONT LINES OF A PANDEMIC
}

\author{
Greg Moore ${ }^{1}$ and Jo Hopkins ${ }^{2}$ \\ mooregreg@comcast.net; jo.hopkins@parks.vic.gov.au \\ ${ }^{1}$ Golden Gate National Parks Conservancy, California, USA \\ ${ }^{2}$ IUCN WCPA Health and Well-being Specialist Group, Australia
}

\section{ABSTRACT}

Urban parks and protected areas are vital to the health and well-being of millions of urban dwellers across the globe. The COVID-19 pandemic has put this connection into urgent focus in major cities where most of the world's population live. Managers of urban parks and protected areas (green spaces in or at the edge of larger urban population centres) have been at the forefront of this international public health crisis since its onset - facing its challenges and impacts, adopting and adapting park responses, and testing new approaches. To inform this article, the experiences of urban parks and protected areas in 11 major cities in 10 different countries were gathered in surveys. The findings show that urban parks were closed and then often overwhelmed on reopening, and that managers faced novel and sometimes unmanageable situations. However, most were responsive and nimble, engaged with public health officials, dealt with new levels of visitation and new visitors, implemented innovative management practices and garnered lessons for the future. Huge challenges remain but there are hopeful signs of renewed public awareness and support for the critical role that nature and the outdoors play in the liveability and health of cities.

Key words: COVID-19, Health, Impact and Challenges, Snapshots, Innovations and Lessons

\section{CONTEXT AND PURPOSE OF ARTICLE}

Since the outbreak of COVID-19 in early 2020, park managers in our cities have been thrust into an unfamiliar world. Urban parks and protected areas exist in and near major cities where the virus has spread and often spiked. Because the virus is considerably less contagious in the outdoors than indoors (Nishiura et al., 2020), parks are under pressure to respond to the pandemic and provide their recreational, health, mental well-being and community benefits to larger numbers of people.

The questions we have tried to answer in this article are: what have been the impacts and challenges for urban parks and protected areas? How have park managers responded? Has the pandemic required new partnerships and innovations? And what are the lessons or hopes for the future?

\section{PARKS AND HEALTH: NOT A NEW CONNECTION} One thing is clear: the pandemic has intensified the connection between public health and public parks - a connection that began two decades ago with the launch of the Healthy Parks Healthy People movement. Initially created by Parks Victoria (Australia) in 2000, Healthy Parks Healthy People is an approach to managing parks and protected areas that has grown into a global movement. It recognises that people need access to parks and green spaces for the health benefits that nature provides; and that the health and well-being of people and societies depend on healthy natural environments. Over the years, International Union for Conservation of Nature (IUCN) has advanced this connection between human and natural health, which was highlighted at its World Parks Congress in 2014. Applying this approach to land management offers great potential to deliver a range of positive health outcomes as society recovers from the COVID-19 pandemic.

A 2015 review by Deakin University (Townsend et al., 2015) found parks provide significant physical, emotional and spiritual benefits to all age groups as well as fostering social connections which contribute to community cohesion. Now, in 2021, the pandemic has made these benefits even more evident and tangible to park managers and city residents across the globe. 


\section{METHODS}

The relatively short timeframe since the pandemic's inception did not easily allow for comprehensive research. Nonetheless, we have gathered a range of insights and perspectives from managers, consultants and experts from around the world, who have been engaged with urban parks and protected areas during the pandemic.

To understand the effects of COVID-19, a survey form was provided to urban parks and protected and conserved area managers, consultants and experts. The parks varied in size, urban proximity, management entity, visitation, economic context, community demographics and level of COVID-19 cases in surrounding communities. Four key topic areas were explored: impacts, challenges, innovations and future lessons. Direct conversations, interviews and email correspondence with attached materials and reports supplemented the form. We also reviewed research papers, articles, reports and media items about urban parks, public health and the pandemic.

\section{IMPACT AND CHALLENGES}

In March 2020, urban parks and protected areas found themselves on the front lines of a global pandemic. Park managers had to quickly pivot from their primary conservation and recreational mission to focus on ensuring the safety of park staff and visitors during a pandemic. Few parks had prepared for such a global emergency. Many parks struggled to manage visitation during COVID-19, especially with shortfalls in funding and park revenue caused by the pandemic. Some preliminary research by the NATURVATION ${ }^{1}$ project (Almassy et al., 2020) had suggested that "COVID-19 brought additional pressure on urban parks that local authorities managing them were not always able to absorb". To respond, most park managers had to seek expert advice outside of their normal experience and from beyond their borders. Yet quick decision-making was required.

For those parks contacted for this article, the most immediate impact was the uncertainty of how to respond to the pandemic and raising questions as to who was authorised to make COVID-related decisions on behalf of parks. Most parks and cities took the cautious approach, closing parks and their facilities until the level of threat could be assessed, jurisdictional issues were resolved and consultation with public health officials could occur. While there was wide variation (one large urban park system re-opened within 24 hours; another national park in a major city was closed for nine months), most urban parks and protected areas opened gradually, achieving significant reopening within four to six months.

Other significant challenges, brought to light by the snapshots in this article, included:

- Excessive demand for the outdoors, parks and open space. Strong demand from the public to have access to parks put managers under pressure to address the safety, resource protection, logistical and political questions associated with deciding when and how to open them. Most parks that were opened faced significant overcrowding. As a result, parking areas, trails and viewing points were used beyond capacity, staff resources were insufficient for maintenance and patrol, and visitors were unable to adequately social distance.

- Rapidly changing conditions. The changing levels of COVID-19 infection, and the public health guidelines required to respond to these changes, resulted in continually fluctuating conditions. Park managers had to adjust COVID-19 alert levels, with consequential impacts on visitor use of park grounds and facilities.

- Making the parks safe. Where parks remained open, or re-opened, managers had to quickly develop safety protocols for staff and visitors, produce signage and public communication campaigns to make those standards clear, and determine how to enforce social distancing and face mask standards.

- Poor visitor compliance. Issues with compliance with COVID-related protocols and other park rules arose most often on crowded urban beaches, in parks with low-capacity destinations that were highly sought-after locations (such as scenic viewing points, outdoor pavilions or picnic areas), and in parks with multiple access points.

- Reduced staffing levels. A range of impacts resulted from staff members being directly affected by COVID -19 as well as a decline in revenue to pay for staff.

- Forecasted funding declines. Parks with government funding models tended to fare better than parks with revenue-generating 'enterprise' models. However, even parks with more stable government funding are forecasting future funding declines as the full economic impacts of the pandemic are felt.

But while many problems were revealed, we also identified much innovation and indeed causes for optimism. We discuss these towards the end of the paper. At a time of pessimism, it is important to report that our survey also gave grounds for hope. 


\section{SNAPSHOTS: URBAN PARKS, PROTECTED AREAS, AND THE PANDEMIC}

Urban park and protected area managers, consultants and experts have emphasised that the pandemic is highly dynamic and that park managers have had to respond to fluctuating conditions. Recognising the changing course of the pandemic, we have gathered 'snapshots' from a number of urban parks and protected areas at one point in time - in October 2020 about seven months into the pandemic (Table 1: Participating parks and protected areas). In selecting these case studies, we wanted to include parks that varied in terms of their proximity to cities, size, visitor numbers, exposure to COVID-19, management types, geography, demographics and local economies, and we needed willing participants. Many of these factors are summarised in Table 1.

\section{Snapshot 1: Vancouver, British Columbia,} Canada - City, Regional and Provincial Parks ${ }^{2}$ The healing power of parks: now and forever

"As we speak of plans that will chart our way to economic recovery and health through COVID-19, included in these must be funding and policy to safeguard and grow our

Table 1. Participating parks and protected areas

\begin{tabular}{|c|c|c|c|c|c|c|}
\hline $\begin{array}{l}\text { SNAP- } \\
\text { SHOT }\end{array}$ & $\begin{array}{l}\text { URBAN } \\
\text { LOCATION }^{1}\end{array}$ & POPULATION & $\begin{array}{l}\text { PARK OR } \\
\text { PROTECTED } \\
\text { AREA(S) }\end{array}$ & $\begin{array}{c}\text { SIZE } \\
\text { (hectares) }\end{array}$ & $\begin{array}{c}\text { ANNUAL } \\
\text { VISITATION } \\
\text { (Approximate) }\end{array}$ & $\begin{array}{l}\text { MANAGEMENT } \\
\text { ENTITY/ENTITIES }\end{array}$ \\
\hline 1 & $\begin{array}{l}\text { VANCOUVER } \\
\text { METRO, British } \\
\text { Columbia, } \\
\text { Canada }\end{array}$ & 2.5 million & $\begin{array}{l}\text { Vancouver } \\
\text { municipal, regional } \\
\text { and provincial } \\
\text { parks }\end{array}$ & $\begin{array}{c}84,000 \\
\text { hectares }\end{array}$ & 33 million & $\begin{array}{l}\text { Municipal, Regional and } \\
\text { Provincial Park Agencies }\end{array}$ \\
\hline 2 & $\begin{array}{l}\text { SANTIAGO } \\
\text { METRO, Chile }\end{array}$ & 7 million & $\begin{array}{l}\text { Metropolitan Park } \\
\text { of Santiago }\end{array}$ & $\begin{array}{c}700 \\
\text { hectares }\end{array}$ & 6 million & $\begin{array}{l}\text { Parque Metropolitano de } \\
\text { Santiago (Parquemet) }\end{array}$ \\
\hline 3 & $\begin{array}{l}\text { HONG KONG } \\
\text { Special } \\
\text { Administrative } \\
\text { Region, China }\end{array}$ & 7.5 million & $\begin{array}{l}\text { Hong Kong } \\
\text { Country Parks and } \\
\text { Protected Areas }\end{array}$ & $\begin{array}{r}110,800 \\
\text { hectares }\end{array}$ & 12 million & $\begin{array}{l}\text { Country Parks and } \\
\text { Protected Areas in Hong } \\
\text { Kong, Special Administrative } \\
\text { Region }\end{array}$ \\
\hline 4 & $\begin{array}{l}\text { KAOHSIUNG, } \\
\text { Taiwan }\end{array}$ & 2.7 million & $\begin{array}{l}\text { Shoushan National } \\
\text { Nature Park }\end{array}$ & $\begin{array}{c}1,123 \\
\text { hectares }\end{array}$ & 2.6 million & $\begin{array}{l}\text { National Nature Park } \\
\text { Headquarters }\end{array}$ \\
\hline \multirow{2}{*}{$5^{3}$} & QUITO, Ecuador & 1.8 million & $\begin{array}{l}\text { AlER Pichincha- } \\
\text { Atacazo }\end{array}$ & $\begin{array}{c}9,932 \\
\text { hectares }\end{array}$ & $\sim 2$ million & $\begin{array}{l}\text { Various municipal and } \\
\text { federal entities }\end{array}$ \\
\hline & $\begin{array}{l}\text { RIO DE } \\
\text { JANEIRO, Brazil }\end{array}$ & 13 million & $\begin{array}{l}\text { Tijuca } \\
\text { National Park }\end{array}$ & $\begin{array}{c}3350 \\
\text { hectares }\end{array}$ & Not available & $\begin{array}{l}\text { Chico Mendes Institute for } \\
\text { Biodiversity Conservation }\end{array}$ \\
\hline 6 & $\begin{array}{l}\text { LIBREVILLE, } \\
\text { Gabon }\end{array}$ & 700,000 & $\begin{array}{l}\text { Arboretum } \\
\text { Rapando Walker }\end{array}$ & $\begin{array}{c}6,747 \\
\text { hectares }\end{array}$ & 11,500 & National Park Agency \\
\hline 7 & $\begin{array}{l}\text { MUMBAI, } \\
\text { India }\end{array}$ & 16 million & $\begin{array}{l}\text { Sanjay Gandhi } \\
\text { National Park }\end{array}$ & $\begin{array}{c}10,000 \\
\text { hectares }\end{array}$ & 1.5 million & $\begin{array}{l}\text { Ministry of Environment, } \\
\text { Forest and } \\
\text { Climate Change }\end{array}$ \\
\hline 8 & $\begin{array}{l}\text { AUCKLAND, } \\
\text { New Zealand }\end{array}$ & 4 million & Cornwall Park & $\begin{array}{c}172 \\
\text { hectares }\end{array}$ & 4 million & Cornwall Park Trust \\
\hline \multirow[b]{2}{*}{$9^{4}$} & $\begin{array}{l}\text { ALAMEDA and } \\
\text { CONTRA } \\
\text { COSTA } \\
\text { COUNTY, } \\
\text { California, USA }\end{array}$ & 2.8 million & $\begin{array}{l}\text { East Bay Regional } \\
\text { Park District }\end{array}$ & $\begin{array}{c}52,609 \\
\text { hectares }\end{array}$ & 25 million & $\begin{array}{l}\text { East Bay Regional } \\
\text { Park District }\end{array}$ \\
\hline & $\begin{array}{l}\text { LOS ANGELES } \\
\text { and VENTURA } \\
\text { COUNTY, } \\
\text { California, USA }\end{array}$ & 11 million & $\begin{array}{l}\text { Santa Monica } \\
\text { Mountains (SMM) } \\
\text { Conservancy zone } \\
\text { SMM National } \\
\text { Recreation Area }\end{array}$ & $\begin{array}{c}297,000 \\
\text { hectares } \\
\\
62,726 \\
\text { hectares }\end{array}$ & $\begin{array}{l}10 \text { million } \\
\text { (about } 30 \\
\text { million with } \\
\text { beaches) }\end{array}$ & $\begin{array}{l}\text { US National Park Service, } \\
\text { Santa Monica Mountains } \\
\text { Conservancy, and } \\
\text { California State Parks }\end{array}$ \\
\hline \multicolumn{7}{|c|}{$\begin{array}{l}\text { 1URBAN LOCATION: The individual parks and park systems in this survey vary in their proximity to cities - from within a city or metro area to being within a } \\
60 \text { km radius of an urban centre. } \\
{ }^{2} \text { ANNUAL VISITATION: Some parks have actual counts; others are a mix of counts, sampling and estimates based on the park's physical characteristics and } \\
\text { visitor access points. While data may not always have been collected on a strictly comparable basis, they indicate the general magnitude and varying scale } \\
\text { of visitation to the parks. These visitation counts and estimates are pre-COVID. } \\
{ }^{3} \text { SNAPSHOT 5: The information for this Snapshot came from a park expert deeply knowledgeable about parks in both countries, which faced similar } \\
\text { situations with the pandemic; therefore, these two cities and park areas were combined. } \\
\text { }{ }^{4} \text { SNAPSHOT 9: Because of similar context in the State of California, these two large park systems were combined into one Snapshot. }\end{array}$} \\
\hline
\end{tabular}


parks and urban green spaces - for this is where we will instinctively go to heal and stay healthy when the next crisis, personal or global, comes."

Dr Melissa Lem, Director, Park Prescriptions, British Columbia Parks Foundation

Vancouver Parks: A wide array of city, regional and provincial parks - from downtown parks to large natural protected and conserved areas within 60 kilometres of the city centre.

Impacts and challenges: When COVID-19 reached British Columbia in March 2020, many parks and park facilities closed to the public. Since then, a major impact was the increased demand for the outdoors, parks and open spaces. Visitation levels increased by over 40 per cent, with some parks experiencing 85 per cent increases in visitation over the same period in 2019. At the same time, car access increased as public transport use declined due to safety concerns, creating problems for the parks and adjacent communities.

Overcrowding became a problem at many park sites. Booking websites for park programmes, campgrounds and services were overwhelmed and many crashed. The parks experienced their highest ever demand for camping sites. Camping and hiking occurred in undesignated areas or without proper permits. New populations of visitors came to the parks - often people lacking experience in leave no trace' visits: for example, some people who were unfamiliar with bear-proof trash cans just left garbage on the ground.

Innovations and lessons: Faced with common challenges, park agencies instituted more planning and communication among their jurisdictions, as well as with public health officials; and with the public about effectively ensuring visitor safety while making the outdoors accessible during a pandemic. On the positive side, the public's increased demand and use of the parks encouraged action and innovation. Thus, public health officials recognised the value of people getting outdoors; and park agencies took measures to provide safe access, including one-way trails, social distancing, crowding controls, and using parks for childcare and public health needs.

The British Columbia Parks Foundation championed an innovative, experimental online portal which gave the public real-time information about park visitation levels so that people could better plan a safe time to visit. Based on its success, the Foundation is exploring a more ambitious technology connection, Discover Parks, which will keep park visitors and supporters more easily connected to their parks, aware of park needs, and involved as advocates, volunteers and donors.
Snapshot 2: Santiago, Chile - Metropolitan Park of Santiago (Parque Metropolitano de Santiago Parquemet)3

Together We Take Care of Ourselves

"We see the happy faces of the families who are visiting our parks after more than five months when many of these public spaces were closed due to the confinement of COVID-19. We are motivated, with more energy and passion than ever, to achieve our crucial mission to deliver happiness to people by connecting them with parks, nature, the outdoors and one another."

Martín Andrade Ruiz-Tagle, Director, Parque Metropolitano de Santiago

Metropolitan Park of Santiago: A large 'green lung' of parks, forests and gardens providing nature, recreation and environmental education within Santiago Metro.

Impacts and challenges: Responding to the pandemic, Parquemet initially closed many of its park areas, while working quickly and effectively to establish safe visitor capacity levels for their parks.

Innovations and lessons: Parquemet developed an innovative system of web-based information and QR codes that allowed people to see the number of visitors in each park in real time. Called Juntosdenuevo (Together Again), this application is designed to help visitors "maintain social distancing outside your home, avoiding crowds in public spaces" under the motto of "Together We Take Care of Ourselves". People can find the park to visit and "book their space" on the site or with a QR code on the phone. If park quotas are full, the system places people in a virtual queue, notifying them when it is their turn to visit.

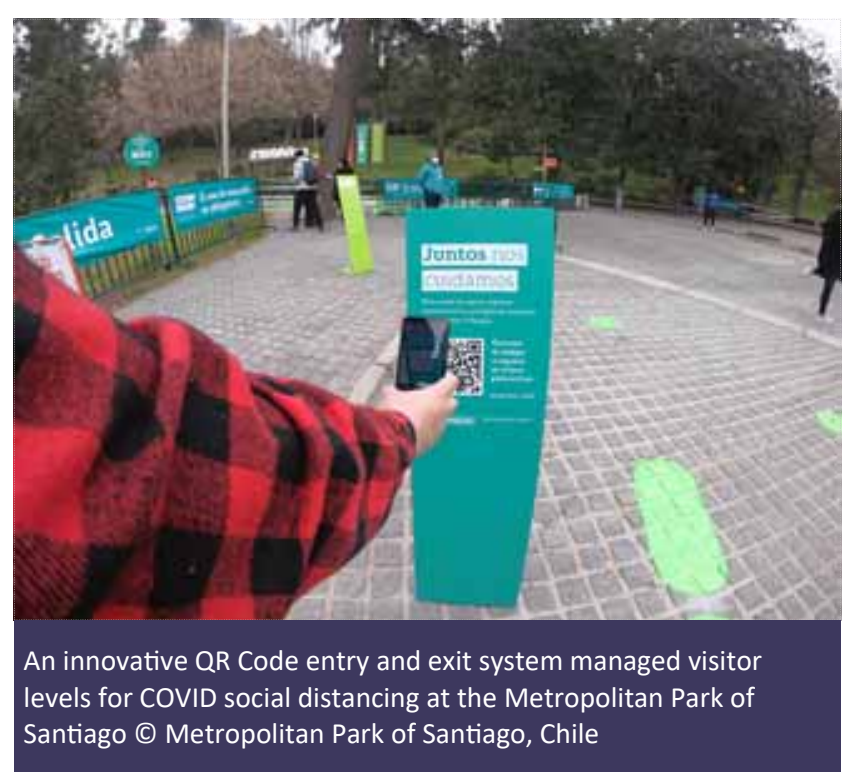


COVID-19 has made people more aware of equity issues in the public's access to green spaces and the outdoors. There are significant inequalities between rich and poor areas; some Santiago neighbourhoods have 20 square metres of park area per person, while others have less than 3 square metres.

Parquemet sponsored a beautiful artistic display that welcomed Santiago residents back to parks after the COVID-19 closure. At the entrance to the Metropolitan Park of Santiago, a Chilean artist created a walkway mural covering more than 1,000 square metres. In addition, Parquemet installed colourful, artistic demarcations to support social distancing in the park. These efforts give a message to cities, urban parks and protected areas - indeed to the world at large: Together We Take Care of Ourselves.

\section{Snapshot 3: Hong Kong Special Administrative Region, China - Hong Kong Country Parks and Protected Areas 4}

When parks become refuges, their importance grows.

"Protected areas are refuges for citizens in times of a pandemic. Hong Kong is not unfamiliar with pandemics, particularly the SARS epidemic in 2003-2004. That epidemic resulted in improvements to park programming and management, increased public interest in nearby ecology, and the provision of university courses on sustainable tourism and local heritage. The COVID-19 pandemic will foster new opportunities to enhance parks and expand recognition of the value and importance of urban protected areas and open spaces."

Dr Wong Fook-yee, Adjunct Professor, Geography and Resource Management Department, Chinese University of Hong Kong

Hong Kong Country Parks and Protected Areas: 24 country parks for conservation, recreation and outdoor education and 22 special areas for nature conservation within about 50 kilometres from the city of Hong Kong.

Impacts and challenges: COVID-19 affected Hong Kong most seriously from March to May and from mid-J une to early September 2020. During these periods, barbecue sites, camping areas and visitor centres were closed to the public. Generally, other areas of the country parks have remained open and become a refuge for people during the pandemic. Overall park visitation increased, along with various impacts on the parks. Many visitors are new to the parks and unfamiliar with various park regulations. This resulted in litter and in some cases careless fire handling caused hillside fires. The park management and associated NGOs organised staff and volunteers to pick up waste and alert visitors to the importance of keeping the countryside clean.
Innovations and lessons: Park managers encouraged visitors to use their own water bottles and established more than 20 water refilling stations within park lands. To support businesses inside country parks, including refreshment kiosks, cafeterias and souvenir shops, rents were reduced by 50 per cent for a six-month period.

In marine areas, where sea traffic has fallen during the pandemic, more sightings of local Chinese White Dolphins were reported. The absence of visitors provided a respite for wildlife in ecologically sensitive sites for butterflies and birds, such as Mai Po Nature Reserve.

An international conference for park managers, designed to exchange experiences and lessons learned during the pandemic, could be valuable, not only for the managers, but for health experts and other government officials charged with responding to future public health crises.

\section{Snapshot 4: Kaohsiung City, Taiwan - Shoushan National Nature Park ${ }^{5}$}

Open to visitors and to enhanced awareness of nature and health

\begin{abstract}
"The successful experience of the Taiwanese government in epidemic prevention will increase the public's awareness of the connection between parks and public health, the willingness of visitors to cooperate with the resource protection regulations of the park, and the openness to efforts to manage park visitation levels that reduce overcrowding and its impacts."
\end{abstract}

Lih-Der Ho, Professor, National Kaohsiung Normal University, Taiwan

Shoushan National Nature Park: A rare green space of seasonal tropical forest, limestone caves, endemic wildlife and archaeological sites about 13 kilometres from the city of Kaohsiung.

Impacts and challenges: Responding to COVID-19, park managers took immediate action for the safety of park visitors. They halved the number of available car parking spaces. Access was curtailed to indoor facilities, guided tours and on-site interpretation. The park developed online activities and communications to encourage safe visitor behaviour and enhance interpretation.

Visitors entering indoor facilities were required to follow epidemic prevention measures, such as measuring body temperature, wearing masks and filling in a personal information log. The park posted epidemic prevention notices indicating safe visitor capacity at park gathering areas. Even so, many visitors failed to maintain this 
social distancing at first but, with more promotion, the situation improved significantly. Some visitors were unhappy about the measures, especially as the park's popularity made it difficult to maintain social distancing at key outdoor pavilions.

Innovations and lessons: Major innovations include social media campaigns to introduce and promote park resources, so reducing the health risk caused by gatherings of tourists. The park visitor centre offered online interactive activities to encourage visitors to check in and take photos at designated places in the park, and then upload photos to a Facebook fan page. These social media campaigns allowed tourists to go to the park separately and avoid gatherings. The park also organised 'flash events', replacing the original longerterm activities with short-term ones to reduce contact time with the public.

As a protected area in Taiwan, Shoushan National Nature Park has benefitted from the effective containment of COVID-19 on this island of 23 million people. Management responses were focused on the safety and number of visitors rather than on closing parks. The pandemic activated a valuable dialogue and engagement between park and visitors - a positive platform for the future.

\section{Snapshot 5: Quito, Ecuador and Rio de Janeiro, Brazil - Urban Parks and Protected Areas ${ }^{6}$ \\ Future challenges and inequities}

\begin{abstract}
"The future poses many challenges for urban parks and protected areas in countries struggling economically. During an economic crisis resulting from COVID-19, the parks are affected disproportionally with reductions of government funding and other economic activity. Additionally, a divide exists between parks near wealthier and poorer communities. This inequity will affect the ability of the parks to be resilient after the pandemic."
\end{abstract}

Pedro da Cunha e Menezes, Member, IUCN Urban Conservation Strategies Specialist Group (currently a Brazilian Diplomat in Ecuador and former Manager of Tijuca National Park, Rio de J aneiro, Brazil)

Ecuador and Brazil Urban Parks: Large areas of urban parks, natural landscapes, protected and conserved areas and natural areas of special intervention and recovery (AIER) near the major city of Quito, Ecuador (35-50 kilometres) and Tijuca National Park near Rio de J aneiro, Brazil (17 kilometres).

Impacts and challenges: Both Ecuador and Brazil took a rapid and strict approach by closing parks and protected areas in March 2020. Most parks remained

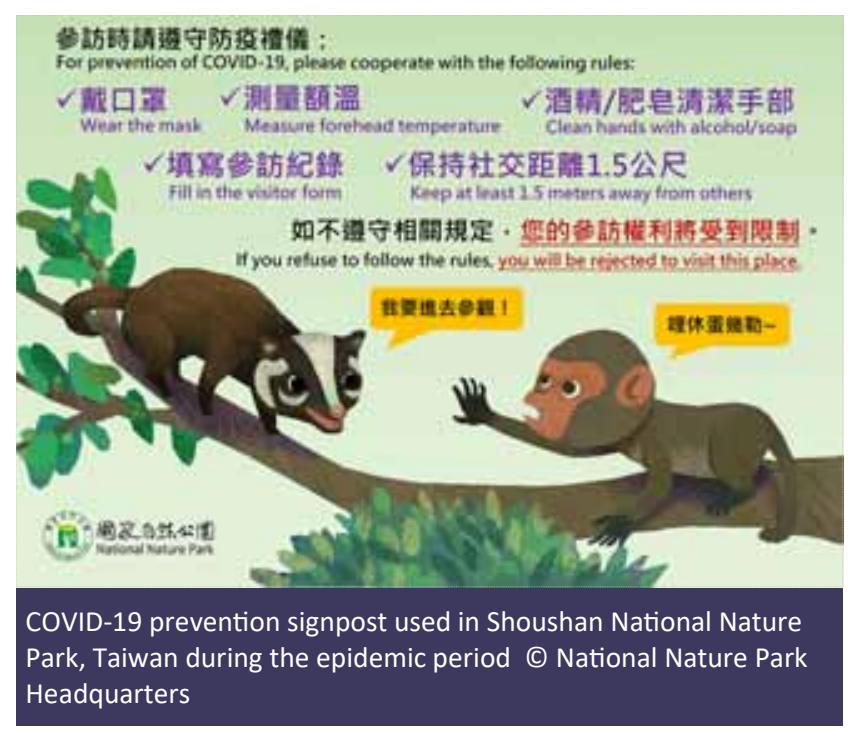

fully closed until re-opening in August 2020 with restrictions including social distancing, mask requirements and bans on gatherings. Some highly popular visitor features, such as scenic viewing points, remain closed.

Park managers faced many challenges because of COVID-19. The pandemic produced an increased demand for and visitation to parks. Once parks were open, people were eager to return to nature. Because other leisure options were limited or unavailable, there was more pressure on parks. Visitation levels were higher than before the pandemic, placing a burden on park management, especially parks with limited ranger presence.

Many new visitors were unaccustomed to nature-based parks and inexperienced in hiking, trail use and other nature-based activities. As a result, visitor behaviour, crowding and compliance were problematic. Most urban parks and protected areas have multiple entry points not a single, patrolled entrance gate. This made controlling visitor numbers and supervising visitor behaviour an added challenge.

Park closures led to reduced income from concessions and tourism, adversely affecting local community businesses as well as funding for the parks.

Innovation and lessons: Although innovation in the face of these challenges is desirable, the situation has been too unpredictable and under-resourced for the development of management innovations. Park managers were fortunate if they could just keep up with things on a day-to-day basis. Future challenges may be long-lasting and daunting, with a significant and longterm reduction of funding and staffing of park areas. 


\section{Snapshot 6: Libreville, Gabon - Arboretum Raponda Walker ${ }^{7}$}

\section{New wildlife and new visitors}

"When the complete lockdown concluded, the youth of Libreville experienced a new need and desire to discover nature. With the increase of youth and Gabonese urban residents visiting Arboretum Raponda Walker, we are hopeful that beyond COVID-19, the Gabon residents especially youth will invest more in nature protection for future generations."

Andrea Minkwe, Manager of Arboretum Raponda Walker protected area

The Arboretum Raponda Walker (ARW): Tropical rainforest managed for protection, restoration and the development of leisure activities, tourism, science and education, located just over 25 kilometres from the capital city of Libreville.

Impacts and challenges: Although the ARW did not immediately put measures in place to combat COVID19, the national government closed the park to all visitors for about four months between March and J une 2020, leading to a complete halt in ecotourism activity.

Innovations and lessons: In preparation for reopening, ARW widened visitor pathways to maintain social distancing between visitors walking in the forest. Since the modest resumption of park visitation, some visitors have had encounters with wildlife not frequently seen before, such as Sitatunga (antelope) and Forest Turtles, such species having moved into new areas of the park in the absence of visitors.

More Gabonese have been attracted to the site, especially young people. This has required improvements, including opening new picnic areas, increased visitor reception capacity, adjustments to staff working hours, more orientation and information panels, an increase in the number of eco-guides and the creation of car parking areas.

\section{Snaphot 7: Mumbai, India - Sanjay Gandhi National Park 8}

A simple walk in the park critical to urban dwellers

\begin{abstract}
"The future of the park is a key to our prosperity. COVID19 has heightened awareness that nature must be in balance with our urban communities. The forest needs better protection and vigilant monitoring. It is a critical national asset when it comes to exposing and engaging people with the natural world."
\end{abstract}

Shardul Bajikar, consultant and naturalist associated with Sanjay Gandhi National Park

Sanjay Gandhi National Park: A forest of rich biodiversity with over 35 species of mammals, 250 species of birds and 1,300 species of plants in the heart of Mumbai City.

Impact and challenges: The government closed the park in March 2020, at the onset of the pandemic. Though the closure remained in place during the survey period of this article, plans are being made for modest levels of public access to the park. The major impacts of COVID19 result from the lack of any visitors to this park. Daily revenue through ticket sales fell by about 200,000 INR (about US\$ 2,700). After the initial phase of lockdown, local communities of people who walk in the park (averaging 3,000 walkers daily) called for access to be re -established. By early October, the park was planning to re-open to walkers.

The pandemic also produced effects inside the park. Some park staff and people living inside the park contracted COVID-19; due to these outbreaks, various small settlements inside the park were designated as COVID "containment zones" by the municipal and health authorities to help prevent the pandemic's spread.

Innovations and lessons: With access to the park closed, park authorities developed educational films about the forest and the various protection initiatives and interventions. Their films on the park's biodiversity were aired on social media platforms. Some live Instagram sessions highlighted researchers working in the park, raising public interest and engagement.

Using this platform, the park ran a 65-day series of posts about the lockdown, social distancing and personal safety, pointing out how some wild species also employ these survival strategies. This social media effort resonated: there were more than 600,000 views and 200,000 people responded to the campaign, during which the park Facebook page gained 12,500 new followers. Leading newspapers also featured and relayed this campaign.

The pandemic has raised questions about the high visitation levels at the park. Many believe that the current high number of visitors is not in the best interests of the forest. The pandemic presents an opening for policy makers to reduce this burden and convert the park into a high-quality ecotourism experience.

\section{Snapshot 8: Auckland, New Zealand - Cornwall Park9}

\section{Temporary measures test future possibilities}

"We remain optimistic about our future with summer ahead and the park's visitor numbers increasing. The park 
has been a real strength in the community with many local people enjoying the benefits that a vast open space offers, even more essential in a time of stress and public concern."

Michael Ayrton, Park Director, Cornwall Park Trust Board

Cornwall Park: An urban oasis rich with history, nature and farm-life including 8,000 trees, numerous gardens and habitat for wildlife within the city of Auckland.

Impacts and challenges: With the arrival of COVID-19, the park management immediately developed safety plans for park staff and visitors, which responded to 'alert levels' from the New Zealand Ministry of Health. The Trust encouraged park visitors to follow physical distancing guidance; however, with limited staff and resources, these standards were challenging to enforce.

The Trust closed indoor facilities, closed park gates at times of high virus alerts and curtailed vehicle access, but pedestrian access to the park remained open as it was felt that this was needed more than ever during the pandemic. As alert levels fell, access to the park was increased. External gates were opened allowing the whole community to access the park again.

The park was more frequently visited, especially by city locals. It also experienced a high number of new visitors that had the time and the desire to get outdoors, exercise and experience nature; these new visitors may become more regular users.

The park's funding is predominantly from lease revenue from adjacent properties. Responding to the economic uncertainty about these revenues, the Trust implemented various budgetary measures and contingency plans. A more constrained COVID-oriented budget may result in more modest park aspirations, fewer park capital and repair projects, and less confidence in financial forecasting.

Innovations and lessons: Because changing pandemic alert levels required different management responses, public communication to park visitors was critical. The park capitalised on its online following using branded designs on its website and Facebook and Instagram channels, leading to more followers and views.

Park staff also tested ways of encouraging visitors to experience the park without cars - providing space to allow greater social distancing. The result: more families with small children were riding bikes and scooters in a larger and safer space. Many visitors supported the concept of road closures with more space for walkers and cyclists. Park management got a better indication of the number of people who would walk to the park rather than drive. This more pedestriancentred approach will be a lesson for future park planning.

Snapshot 9: Alameda and Contra Costa County, California - East Bay Regional Park District and Los Angeles and Ventura County, California Santa Monica Mountains Conservancy zone and National Recreation Area ${ }^{10}$

Partnerships across public parks and public health

"Our decade of experience with the Park District's Healthy Parks Healthy People program was a game changer when the pandemic hit. Because of that program, we had deep and trusted relationships with public health officials, and we could turn to these experts for their amazing expertise, guidance, and assistance. With their help, we were able to act quickly and effectively."

Robert Doyle, General Manager, East Bay Regional Park District

East Bay Regional Park District and the Santa Monica Mountains Conservancy zone: Two of the world's largest and most visited systems of urban parks and protected areas with parks on the doorstep of urban and suburban residents, ranging up to 50 kilometres from city centres.

Impacts and challenges: East Bay Regional Park District (EBRPD) closed their parks for an initial 24 hours but thereafter were able to keep 99 per cent of outdoor sites open and accessible. The County health department determined that the East Bay parks were 'essential services', allowing them to remain open, provided the

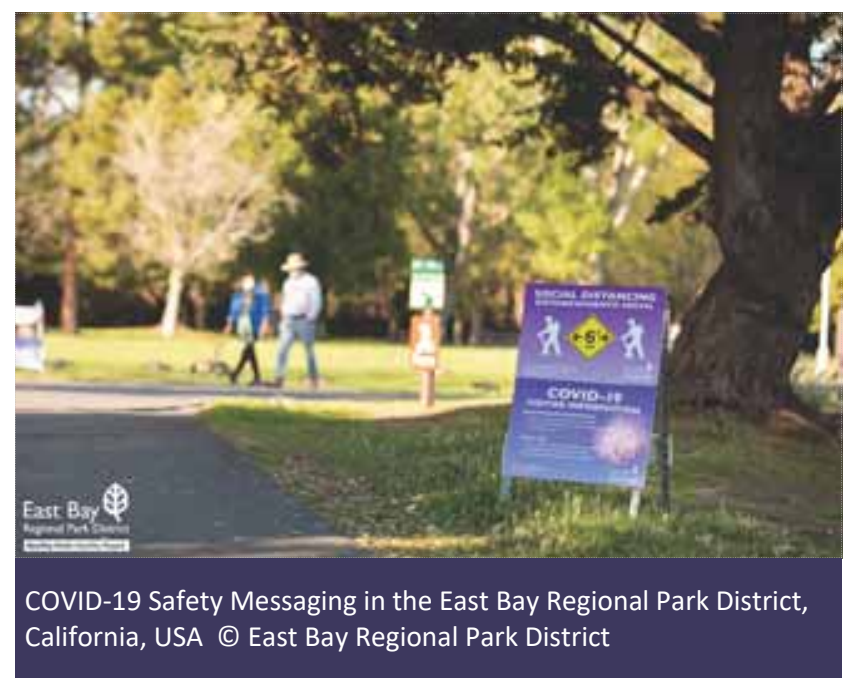


right public health measures were in place. Since reopening, park visitation has increased more than 50 per cent with many first-time visitors.

Across the Santa Monica Mountains, various park closures were implemented in March 2020, especially in places that attracted large numbers of visitors. They remained closed until May 2020. US National Park Service (NPS) and Santa Monica Mountains Conservancy staff worked with county health departments to develop a pandemic plan. Since the park has more than 300 points of entry, managing visitor access has been a challenge, but visitation is also dispersed. Once trails were opened, the Los Angeles County Parks Department oversaw coordination between local, state and federal entities.

Because the Santa Monica Mountains Conservancy relies heavily on income generated by park visits, events and concessions, the economic impacts of the pandemic have been extremely significant. A 66 per cent loss of Conservancy revenue to fund park operations has led to staff reductions, furloughs and reduced services.

Lessons and innovations: Robert Doyle, General Manager of EBRPD, attributes the ability to quickly open its parks - and keep them open - to its close working relationship and trust with public health officials and doctors. A recently commissioned EBRPD survey revealed that 96 per cent of East Bay respondents believe that accessibility to parks and trails has been significant in maintaining the mental and

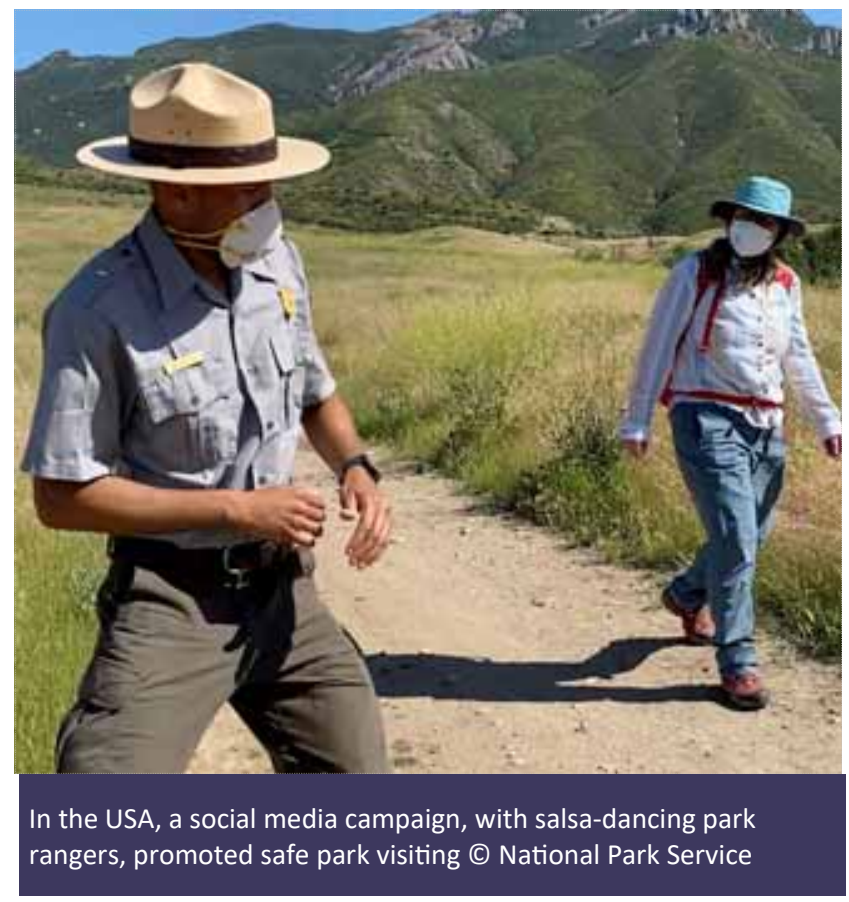

physical health of East Bay communities during the pandemic; 94 per cent of first-time visitors said they would visit the parks again.

In the Santa Monica Mountains, the NPS responded to the pandemic by adopting virtual programming, producing 72 park programmes with almost 250,000 views. The NPS also launched a creative social media campaign encouraging park visitors to wear face masks and social distance in the parks.

As a result of the coordination among park agencies because of the pandemic, new conversations about the future are occurring, including about more equitable access to recreation. The Santa Monica Mountains Conservancy is considering a new revenue model based on a pilot 'taxing district' to fund efforts to combat wildfire insecurity as well as more general park needs.

\section{INNOVATIONS}

Given the dynamic and pressing nature of the pandemic, some parks still found time to innovate during this major and unexpected crisis. Most innovations involved communications with the public, safely managing visitation and enhancing partnerships.

Various park areas found new ways to reach the public with technology playing a major role. East Bay Regional Park District launched a public communications campaign in traditional media outlets and through social media. The NPS at Santa Monica Mountains launched a social media campaign encouraging maskwearing with salsa dancing rangers. ${ }^{14}$ Almost all parks moved to virtual programming and communications with many using social media platforms to new levels of success.

Some park managers were creative and innovative in managing visitors prior to their park visit. Parquemet in Santiago, Chile, and the British Columbia Parks Foundation developed online portals where people could see real-time use of parks, decide to visit a less crowded park site, and even make a reservation for a particular time. Such portals have much potential for managing visitor levels and mitigating overcrowding in urban parks and protected areas, not only during a pandemic but for future park management.

Most parks made changes in access arrangements to promote social distancing. Some parks closed vehicle entrances, parking areas or roads to better control park use and dedicated closed roads as pedestrian and bicycle corridors. Many parks extended the width of trails and converted these walking paths into one-way access 
routes. A golf course in the Presidio of the Golden Gate National Recreation Area was temporarily converted to a large public green space for visitors. Many parks used demarcations to promote social distancing, including the very inventive artistic innovations at Santiago Metropolitan Park. Such innovations may now encourage a deeper look at how parks are affected by car use and how park spaces might be planned in the future.

Stronger partnerships also emerged, especially between park areas and public health officials. Parks with existing health-based partnerships, such as East Bay Regional Park District, were more able to secure the expertise, resources and support to face the pandemic. The Park District helped launch a regular webinar series, hosted by public health officials, hospitals and doctors, to support all San Francisco Bay Area park agencies in developing well-informed and ongoing responses to COVID. ${ }^{15}$ The NATURVATION project (Almassy et al., 2020) recently examined over 500 initiatives in urban parks, gardens and protected areas world-wide, and found 'health and well-being' issues were among the top three sustainability challenges being addressed by parks.

\section{THE FUTURE}

We believe the following trends and lessons learnt during the pandemic are especially relevant to the future of urban parks and management.

Lingering financial impacts: Many park managers are worried, even pessimistic, about the future. Most will face funding reductions and there is great uncertainty about future trends in the economy, travel and tourism and government funding. A report on financial impacts (Trust for Public Land, Parks and the Pandemic, 2020) summarised matters: "The consensus....is that the picture for parks will be bleak indeed."

Greater awareness of parks and their relevance: The pandemic put many urban parks and protected areas at the forefront of the public's mind, with greater media coverage and more visitors. Many surveys documented the public's growing recognition that parks and protected areas are important community, civic, health and economic assets. A national survey in the United States during the pandemic (LaPlaca Cohen, Culture Track and Sloverlinett, 2020) asked people: "What do you want more of in your life right now?" The top answer was "getting outdoors". An article on the impact of COVID-19 on public space (Honey-Rosés et al., 2020) suggested that the pandemic may "transform our relationship with public space" and asked "optimistically, will this global experience lead us to rethink the way we develop and (re)design our cities?" Other indications "highlight that access to urban nature is important to urban resilience in the short- and longterm" (Samuelsson et al., 2020). For park managers, these are hopeful questions and responses.

New audiences to the parks: In most parks, there were new audiences coming to visit. In many cities, the pandemic motivated people to seek the benefits of the outdoors and nature. In some cases, local visitors filled parks that once mainly served national or international visitors. More young people and local people discovered what parks offered; many have been exposed to nature for perhaps the first time in their lives. If the profile of future park visitors changes, it has implications for the level of public support, local advocacy and funding.

Equity in park access and benefits: In many cities, the pandemic highlighted inequitable access to medical treatment and disproportionate rates of infection in poorer communities. This 'equity lens' affected park managers and their perspectives. The Trust for Public Land (2020) reported that 100 million people in the United States do not have a park within a 10-minute walk from home. In many cities, wealthier communities have more access to parks and the outdoors than poorer ones. A study of green spaces during COVID-19 completed by Urban Systems Lab (Lopez et al., 2020) identified these inequities and advocated "reframing urban parks and open spaces as a form of critical urban infrastructure to leverage the multiple health, social, economic, and environmental benefits they provide". The pandemic has reinforced a growing discussion among park managers and the public on whether urban parks and protected areas provide benefits equitably and, if not, what should be done about it. This dialogue - and the actions it may propel - might be one of the positive things that could come from this global tragedy.

\section{HOPE ILLUMINATED}

COVID-19 shone a light on our global community where the health of nature and people are intertwined across borders and continents. On 18 March 2020, demonstrating the international nature of the pandemic, the iconic Christ the Redeemer statue in Tijuca National Park in Rio de J aneiro was illuminated with all the flags of countries affected by the pandemic. The challenges for our parks and nature are global in scope - and the pandemic reminds us of our common plight and shared hopes for the future.

\section{ENDNOTES}

${ }^{1}$ NATURVATON: Link: https://www.naturvation.eu/home

${ }^{2}$ Andrew Day, CEO, British Columbia Parks Foundation: Provided 
information on case study form, by email exchange, review of written materials and phone conversations for the Vancouver Parks Snapshot.

${ }^{3}$ Martín Andrade Ruiz-Tagle, Director, Parque Metropolitano de Santiago: Provided information on case study form, by email exchange, and review of written materials for the Metropolitan Park of Santiago Snapshot.

${ }^{4} \mathrm{Dr}$ Wong Fook-yee, Adjunct Professor, Geography and Resource Management Department, Chinese University of Hong Kong: Provided information on case study form, by email exchange, and review of written materials for the Hong Kong Country Parks and Protected Areas Snapshot.

${ }^{5}$ Lih-Der Ho, Professor, National Kaohsiung Normal University, Taiwan: Provided information on case study form, by email exchange, and review of written materials for the Shoushan National Natural Park Snapshot.

${ }^{6}$ Pedro da Cunha e Menezes, Member, IUCN Urban Conservation Strategies Specialist Group: Provided information on case study form, by email exchange, virtual meeting, and review of written materials for the Snapshot on urban parks and protected areas in Quito Ecuador and Rio de Janeiro, Brazil.

${ }^{7}$ Andrea Minkwe, Manager of Arboretum Raponda Walker protected area and Nelly Houtsa, Environmental lawyer and IUCN World Commission on Protected Areas Youth Professionals focal point in West and South Africa: Provided information on case study form, by email exchange, and review of written materials for the Arboretum Raponda Walker protected area Snapshot.

${ }^{8}$ Shardul Bajikar, consultant and naturalist associated with Sanjay Gandhi National Park: Provided information on case study form, by email exchange, and review of written materials for Sanjay Gandhi National Park Snapshot.

${ }^{9}$ Michael Ayrton, Park Director, Cornwall Park Trust Board: Provided information on case study form, by email exchange, and review of written materials for the Cornwall Park Snapshot.

${ }^{10}$ Robert Doyle, General Manager, East Bay Regional Park District: Provided information on case study form, by email exchange, telephone conversation, and review of written materials for the Urban Protected Areas, California Snapshot.

${ }^{11}$ Joseph T. Edmiston, Executive Director. Santa Monica Mountains Conservancy: Provided information on case study form, by email exchange, virtual meeting, and review of written materials for the Urban Protected Areas, California Snapshot.

${ }^{12}$ David Szymanski, Superintendent, Santa Monica National Recreation Area: Provided information on case study form, by email exchange, virtual meeting, and review of written materials for the Urban Protected Areas, California Snapshot.

${ }^{13}$ National Park Service Video/Social Media Campaign at Santa Monica Mountains Santa Monica Face Mask Video

${ }^{14}$ UCSF and East Bay Regional Park District: Webinar Series Guidance for Parks as an Essential Service During a Pandemic Links below:

https://www.youtube.com/watch?v=8XzMVTn80r0

https://www.youtube.com/watch?v=b3des27YDFk

https://www.youtube.com/watch?v=KU_g1jtY5bw

\section{ACKNOWLEDGMENTS}

The authors acknowledge the assistance that they received from Russell Galt, Head of IUCN Urban
Alliance; Ted Trzyna, Chair, IUCN WCPA Urban Conservation Strategies Specialist Group; Dr. Harriet Bulkeley, Professor, Department of Geography, Durham University, United Kingdom; Neil McCarthy, Chief Executive Officer, World Urban Parks Organisation and Dr. Robert McDonald, Lead Scientist for the NatureBased Solutions, the Nature Conservancy.

Those who contributed towards the preparation of the snapshots are listed in the endnotes.

\section{ABOUT THE AUTHORS}

Greg Moore is CEO Emeritus \& Special Advisor, Golden Gate National Parks Conservancy and a parks/ conservation consultant. Greg has four decades of experience with national parks and protected areas. As the founding $C E O$ of the Parks Conservancy, he grew this organisation to one of the country's most successful partners to the US National Park Service. During his career, he has advised conservation projects in Australia, Canada, Chile, China, Italy, New Zealand, and South Africa. He is a consultant to various international efforts including the Lincoln Institute of Land Policy's International Land Conservation Network and Amigos de Los Parques in Patagonia, Chile.

Jo Hopkins is Chair of the IUCN WCPA Health and Well-being Specialist Group. Jo has extensive experience in protected area management - and is passionate about the health benefits derived from nature. She was part of the team that established the Healthy Parks Healthy People initiative and has continued that work for over 20 years. Jo collaborates with individuals and organisations to influence local, national, and international policy promoting parks as a nature-based solution to the world's most pressing challenges.

\section{REFERENCES}

Almassy, D., Maia, S., Xie, I. and Bulkeley, H. (2020), Naturvation Project Team, personal communication, www.naturvation.eu

Honey-Rosés, J., Anguelovski, I., Chireh, K., Daher, C., Konijnendijk van den Bosch, C., Litt, J., Mawani, V., McCall, M., Orellana, A., Oscilowicz, E., Sánchez, U., Senbel, M., Tan, X., Villagomez, E., Zapata, O. and Nieuwenhuijsen, M. (2020). The impact of COVID-19 on public space: an early review of the emerging questions - design, perceptions and inequities, Cities \& Health, DOI: 10.1080/23748834.2020.1780074 https:// doi.org/10.1080/23748834.2020.1780074

Nishiura, H., Kobayashi, T., Saito, T., Sunagawa, T., Matsui, T., Wakita, T., MHLW COVID-19 Response Team, Suzuki, M. (2020). Closed environments facilitate secondary transmission of coronavirus disease 19) https:// doi.org/10.1101/2020.02.28.20029272 
LaPlaca Cohen, Culture Track \& Sloverlinett Audience Research (2020). Culture + Community in a Time of Crisis. https:// culturetrack.com/research/covidstudy/

Lopez, B., Kennedy, C. and McPhearson, T. (2020). Parks are Critical Urban Infrastructure: Perception and Use of Urban Green Spaces in NYC during COVID-19. Preprints 2020, 2020080620 (doi: 10.20944/preprints202008.0620.v1). http:// urbansystemslab.com/urban-parks-survey

Samuelsson, K., Barthel, S., Colding, J., Macassa, G. and Giusti, M. (2020). Urban Nature as a source of resilience during social distancing amidst the coronavirus pandemic https:// www.stockholmresilience.org/publications/artiklar/2020-05-10 -urban-nature-as-a-source-of-resilience-during-socialdistancing-amidst-the-coronavirus-pandemic.html
Townsend, M., Henderson-Wilson, C., Warner, E. and Weiss, L. (2015). Healthy Parks Healthy People: the state of the evidence review 2015. https://www.iucn.org/sites/dev/files/ content/documents/hphpstate-evidence2015.pdf

Trust for Public Land (2020). A Trust for Public Land Special Report: Parks and the Pandemic. https://www.tpl.org/sites/ default/files/Parks\%20and\%20Pandemic\%20-\%20TPL\% 20special\%20report.pdf

\section{RESUMEN}

Los parques urbanos y las áreas protegidas son vitales para la salud y el bienestar de millones de habitantes urbanos en todo el mundo. La pandemia del COVID-19 ha puesto de manifiesto el carácter apremiante de esta relación en las grandes ciudades donde habita la mayor parte de la población mundial. Los administradores de parques urbanos y áreas protegidas (espacios verdes en los grandes centros de población urbana o en sus bordes) han estado al frente de esta crisis internacional de salud pública desde su inicio, haciendo frente a sus desafíos y repercusiones, adoptando y adaptando las respuestas de los parques y poniendo a prueba nuevos enfoques. PPara fundamentar este artículo, se realizaron encuestas para recopilar las experiencias de los parques urbanos y las áreas protegidas en 11 grandes ciudades en 10 países diferentes. Las conclusiones muestran que los parques urbanos fueron cerrados y al reabrirlos se desbordaron, y que los administradores se enfrentaron a situaciones nuevas y a veces inmanejables. Sin embargo, la mayoría de ellos fueron receptivos y ágiles, se comprometieron con los funcionarios de salud pública, se ocuparon de los nuevos niveles en el número de visitas y de nuevos visitantes, aplicaron prácticas innovadoras de gestión y generaron importantes enseñanzas para el futuro. Si bien persisten enormes retos, hay señales esperanzadoras de una renovada conciencia pública y de apoyo al papel fundamental que la naturaleza y las actividades al aire libre desempeñan en la habitabilidad y la salud de las ciudades.

\section{RÉSUMÉ}

Les parcs urbains et les aires protégées sont cruciaux pour la santé et le bien-être de millions de citadins à travers le monde. L'importance de ce lien a été mise en évidence de façon urgente par la pandémie de COVID-19 dans les grandes villes où vit la majeure partie de la population mondiale. Les gestionnaires d'aires protégées et de parcs urbains (espaces verts dans, ou à la périphérie, des grands centres urbains) sont à l'avant-garde de cette crise de santé publique internationale depuis son apparition - ils font face à ces défis et ces impacts, adoptent et adaptent les réponses du parc et testent de nouvelles approches. Pour éclairer le present document, des enquêtes ont été menées auprès de parcs urbains et d'aires protégées dans 11 grandes villes, dans 10 pays différents, afin de recueillir leurs expériences. Les résultats montrent que les parcs urbains ont été fermés, puis souvent débordés lors de leur réouverture, et que les gestionnaires ont été confrontés à des situations nouvelles et parfois ingérables. Cependant, la plupart se sont montrés réactifs et agiles, ont collaboré avec les responsables de la santé publique, se sont adaptés aux nouvelles jauges de visites et aux nouveaux visiteurs, ont mis en œuvre des pratiques de gestion innovantes et ont tiré des leçons pour l'avenir. D'énormes défis demeurent, mais il y a des signes encourageants d'une prise de conscience et d'un soutien renouvelé du public pour le rôle essentiel que jouent la nature et le plein-air dans la qualité de vie et la santé des villes. 


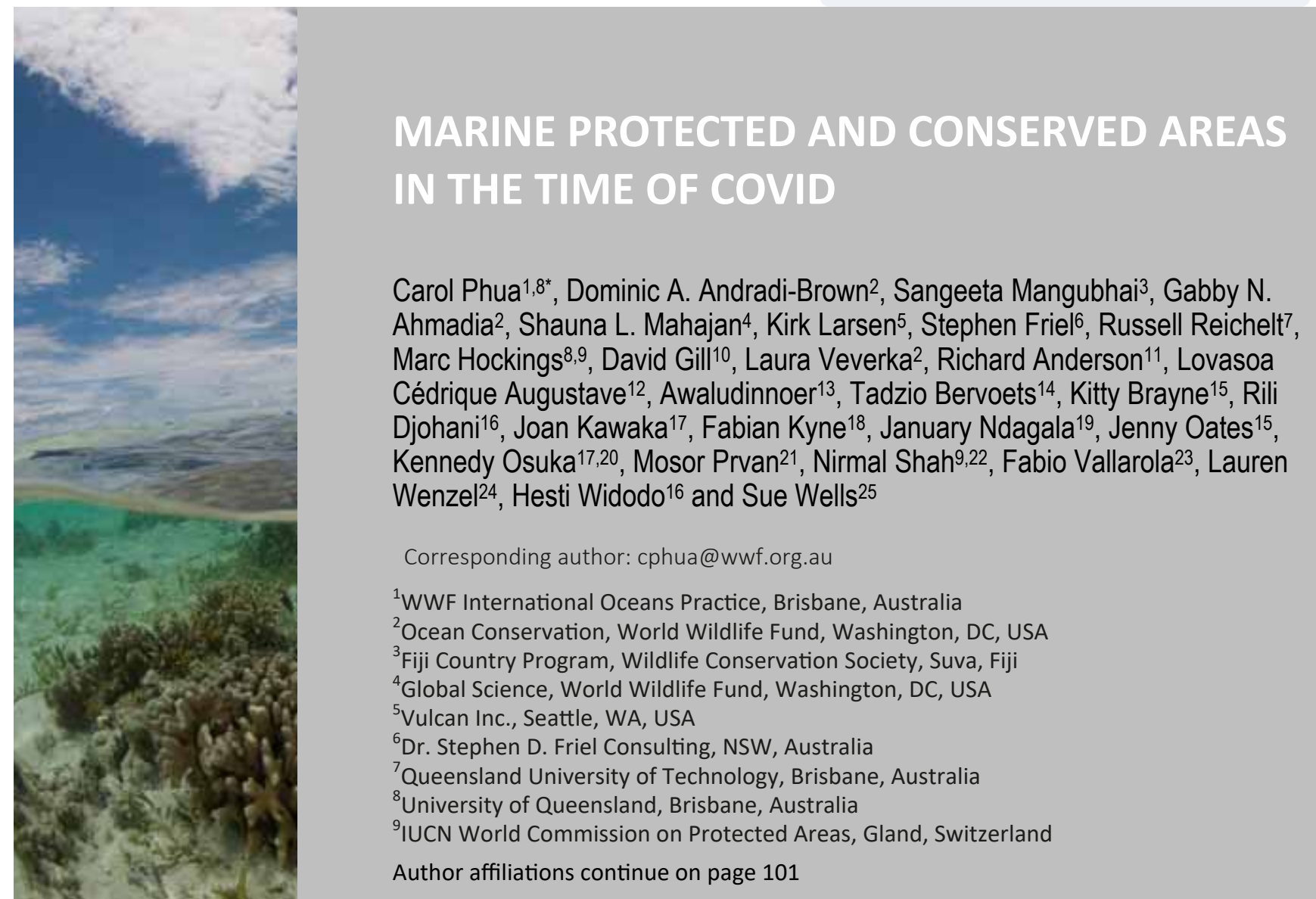

\begin{abstract}
The intersection of potential global targets and commitments for ocean conservation with the COVID-19 pandemic in 2020 has resulted in an opportunity to rethink the future of marine area-based conservation tools, particularly for marine protected and conserved areas (MPCAs). As MPCAs continue to provide essential ecological, social and economic services, current approaches to establishing and managing these areas require an understanding of the factors that drive the pressures they face. We briefly review their status pre-pandemic and provide an overview of the impacts of COVID-19 informed primarily by 15 case studies. Impacts are of two kinds: those affecting livelihoods and well-being of local communities and stakeholders that depend on the MPCA; and those which affect management and governance of the MPCA itself. Responses from managers and communities have addressed: the management of resources; income and food security; monitoring and enforcement; seafood supply chains; and communication amongst managers, community members and other stakeholders. Finally, we discuss innovative approaches and tools for scaling and transformational change, emphasising synergies between management for conservation and management for sustainable livelihoods, and how these relate to the principles of equity and resilience.
\end{abstract}

Key words: communities, resilience, innovation, pandemic, coronavirus, sustainable financing, impacts and response, technology, blockchain

\section{INTRODUCTION}

The COVID-19 pandemic caused by a novel coronavirus, SARS-COV-2, is a symptom of the much larger crises of climate change, a burgeoning global population and growing inequity - that affect both humanity and the natural world (Díaz et al., 2019). Its impacts on the support given to nature are already apparent, with many governments redirecting resources towards healthcare and economic development (Hockings et al., 2020). The negative effects are being especially felt in protected and conserved areas, a key tool in biodiversity conservation and sustainable use of natural resources, including in the marine environment. This is despite the fact that a new found appreciation for green and natural spaces has occurred during lockdowns in many countries, giving hope that the true value of nature will be better captured during recovery from the pandemic.

For MPCAs, this moment is critical, given the growing understanding of the essential contributions they make towards biodiversity conservation, sustainable fisheries and human well-being (Brander et al., 2020). The year 2020 came with high expectations that countries would 


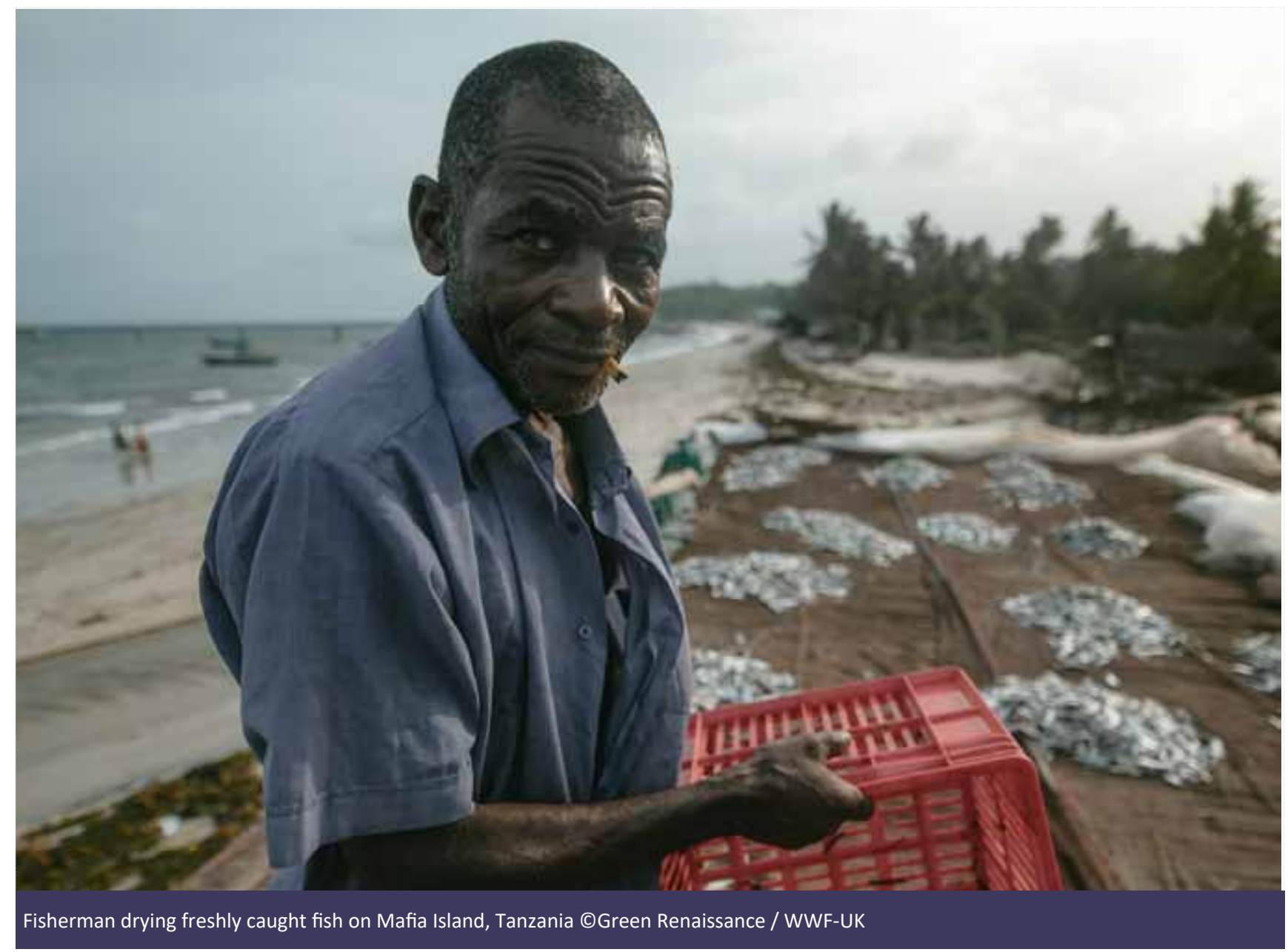

agree to ambitious commitments to make ocean-based economies more sustainable, protect marine biodiversity and create ecologically and socially resilient MPCAs, and manage the oceans to help address climate change. Instead, the pandemic changed the course of the global policy calendar: meetings were postponed or held virtually, and progress dramatically slowed. However, the crisis provides an opportunity to reexamine mechanisms, interventions, management and governance structures so that we can better manage future 'shocks', such as pandemics, extreme climate events or financial crises.

Adapting current approaches to establishing and managing MPCAs in a changing world requires a reflection on the successes and failures of marine conservation, and on how different approaches have been affected by the pandemic. Our paper aims to: (1) review the status of MPCAs pre-pandemic; (2) provide an overview of the impacts of COVID-19, using 15 case studies (Table 1) and other sources; and (3) propose innovative approaches for scaling-up and transformational change to secure a more effective, ethical and resilient future for MPCAs in a post-COVID world. We use the term MPCAs throughout this paper to include all forms of marine protected areas (MPAs) (whether highly protected or multiple use), as well as Other Effective Area-based Conservation Measures (OECMs) such as Locally Managed Marine Areas (LMMAs), in line with current and more inclusive thinking on area-based management.

\section{WHERE WE WERE PRE-PANDEMIC}

There is global consensus that the health of the marine environment is declining due to multiple anthropogenic pressures, including climate change, unsustainable fisheries and growing coastal and ocean development (Northrop et al., 2020), with most MPCAs failing to effectively address these stressors. Aichi Target 11 calls for the effective protection of 10 per cent of coastal and marine areas, a target which has not been met either globally (currently 7.77 per cent of marine waters are within MPCAs; www.protectedplanet.net/en), or, in most cases, nationally. Countries have also largely failed to meet the qualitative aspects of Aichi Target 11, namely that MPCAs should be well-connected, ecologically 
representative, and equitably and effectively managed. There are numerous obstacles to achieving success, including poor governance, lack of political will, weak institutions and limited management capacity (Bennett et al., 2017). Gill et al. (2017) found that 90 per cent of MPCAs surveyed reported below optimum or inadequate staff capacity, and 65 per cent reported insufficient budgets; only half of MPCAs stated that locals were directly involved in decision-making. The lack of consensus on suitable indicators or levels of protection needed for effective marine conservation (e.g. Agardy et al., 2016; Sala et al., 2018) have hindered MPCA evaluation, and are now under detailed discussion as the post-2020 Global Biodiversity Framework is developed (CBD, 2019; Geldmann et al., 2020).

Equitable governance of MPCAs and fair benefit sharing are of growing importance to stakeholders more generally, yet many MPCAs lack inclusive governance processes (Gill et al., 2017; Zafra-Calvo et al., 2019). Since the Sustainable Development Goals (SDGs) elevated the importance of joint social-environmental agendas, the need to address the main barriers to mainstreaming equity and inclusion within MPCAs has become clearer. Formal institutions for governing MPCAs are often separated from those responsible for social development, leading to siloed approaches.
Equitable forms of MPCA governance often require that power be devolved to local levels, which can be met with resistance from those in authority. Local actors often have limited capacity or regulatory support for their roles (Cudney-Bueno \& Basurto, 2009). And, while there is more research on the social dimensions of MPCAs, we still lack data on their social impacts (Ban et al., 2019), and on how best to design MPCAs so that they deliver more equitable benefits in diverse contexts (Gill et al., 2019). Ensuring equitable benefit sharing remains a key challenge to those working at the intersection of conservation and development, and specifically in relation to the role of fisheries in food security (e.g. Hicks et al., 2019).

\section{WHERE WE ARE NOW - THE IMPACT OF THE PANDEMIC}

To understand the effects of the pandemic on MPCAs and the subsequent responses of communities and managers, we gathered published studies from the literature, and compiled 15 new case studies from different geographies, with diverse management and governance structures. We refer to the new case studies throughout by superscript citation codes (Table 1). Due to the availability of information, these new case studies mostly focus on coastal or nearshore MCPAs (with the exception of Hawaii, USA ${ }^{\mathrm{CS}}$ ), which represent the majority of existing MPCAs (UNEP-WCMC et al., 2018).

Table 1. Marine Protected and Conservation Area (MPCA) case studies and their respective citation codes. Full case studies available in Supplementary Online Material.

\begin{tabular}{|c|c|c|}
\hline Code & MPCA & Authors \\
\hline CS1 & Papahānaumokuākea Marine National Monument, Hawaii, United States & Wenzel \& Clark \\
\hline CS2 & Galápagos Marine Reserve, Galápagos, Ecuador & Izurieta et al. \\
\hline CS3 & Northern Belize Coastal Complex, Belize & Kyne et al. \\
\hline CS4 & Florida Keys National Marine Sanctuary, Florida, United States & Wenzel \& Fangman \\
\hline CS5 & Dutch Caribbean, Netherlands & Bervoets \& Wells \\
\hline CS6 & Adriatic Sea Marine Protected Areas, Croatia and Italy & Vallarola \& Prvan \\
\hline CS7 & Kanamai-Mtwapa Co-Management Area, Kenya & Kawaka et al. \\
\hline CS8 & Mafia Island Marine Park, Tanzania & Ndagala \& Medard \\
\hline CS9 & Velondriake Locally Managed Marine Area, Madagascar & Oates et al. \\
\hline $\operatorname{cs} 10$ & Seychellois Marine Protected Areas, Seychelles & Shah \& Wells \\
\hline $\operatorname{cs} 11$ & Tun Mustapha Park, Sabah, Malaysia & Jomitol et al. \\
\hline CS12 & Nusa Penida Marine Protected Area, Bali, Indonesia & Sanjaya et al. \\
\hline CS13 & Raja Ampat Marine Protected Area Network, West Papua, Indonesia & Awaludinnoer et al. \\
\hline CS14 & Great Barrier Reef Marine Park, Queensland, Australia & Hockings \\
\hline CS15 & Vatu-i-Ra Conservation Park, Ra Province, Fiji & Mangubhai \\
\hline
\end{tabular}


Table 2. Observed impacts of, and responses to, COVID-19 on Marine Protected and Conservation Areas reported in case studies (Table 1) and recent literature. Framework adapted from Gill et al. (2017)

\begin{tabular}{|c|c|c|}
\hline Domain & Indicator & Impacts and responses drawn from the case studies \\
\hline \multirow{5}{*}{ 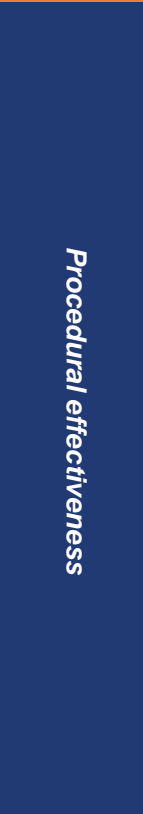 } & Budget capacity & $\begin{array}{l}\text { Decline in tourism income through MPCA user fees, sales, etc. created } \\
\text { significant budget shortfalls. } \\
\text { Changes in government priorities (i.e. focus on COVID-19) reduced some } \\
\text { MPCA budgets. Elsewhere, governments have made up shortfalls from lost } \\
\text { tourist revenue. } \\
\text { In some very select cases, trust funds and private foundations provided } \\
\text { emergency funding to retain management capacity. }\end{array}$ \\
\hline & Staffing capacity/presence & $\begin{array}{l}\text { Reduced staff capacity and presence due to layoffs because of budget cuts, } \\
\text { travel and quarantine restrictions and sickness preventing staff working. }\end{array}$ \\
\hline & $\begin{array}{l}\text { Implementation of planned } \\
\text { management activities }\end{array}$ & $\begin{array}{l}\text { - Reductions in MPCA management activities due to cuts in budget and } \\
\text { capacity in state-run MPCAs. } \\
\text { Timelines extended for planned activities due to slower rate of work. } \\
\text { Management facilities not available for original uses as repurposed for COVID- } \\
19 \text { health responses. }\end{array}$ \\
\hline & $\begin{array}{l}\text { Degree of monitoring } \\
\text { (management, resource } \\
\text { conditions, users) }\end{array}$ & $\begin{array}{l}\text { - Ecological monitoring programmes halted. } \\
\text { - Tourism operators or local community members trained to assist with } \\
\text { monitoring (and paid as a means of income support). }\end{array}$ \\
\hline & Level of enforcement & $\begin{array}{l}\text { Reduced frequency of patrolling and enforcement in some MPCAs. } \\
\text { Increased surveillance in some community MPCAs. } \\
\text { Increased time for training due to reduction in other management activities. }\end{array}$ \\
\hline \multirow{2}{*}{ 竞 } & $\begin{array}{l}\text { Degree of stakeholder } \\
\text { involvement in decision-making }\end{array}$ & $\begin{array}{l}\text { Changes in jurisdictional authority or priorities for local government bodies and } \\
\text { MPCA managers (primarily due to implementation of emergency guidelines } \\
\text { and protocols) have altered stakeholder engagement in MPCA management } \\
\text { activities. In some cases, this has led to more coordinated decision-making } \\
\text { and enforcement within MPCAs. }\end{array}$ \\
\hline & $\begin{array}{l}\text { Degree of devolution of } \\
\text { management authority }\end{array}$ & $\begin{array}{l}\text { Where staff capacity was reduced, some enforcement was devolved to local } \\
\text { communities. } \\
\text { MPCA community surveillance groups have increased collaboration and } \\
\text { information-sharing with State-led enforcement agencies. }\end{array}$ \\
\hline \multirow{3}{*}{ 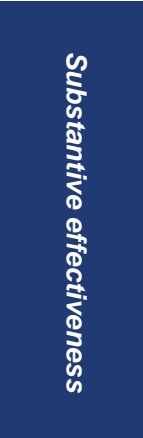 } & $\begin{array}{l}\text { Status or change in well-being } \\
\text { of affected communities }\end{array}$ & $\begin{array}{l}\text { Loss of livelihoods for many communities and stakeholders dependent on } \\
\text { MPCA tourism. } \\
\text { Seafood supply chains disrupted with reduced markets affecting fishing in } \\
\text { MPCAs. }\end{array}$ \\
\hline & $\begin{array}{l}\text { Status or change in threats to } \\
\text { resource conditions }\end{array}$ & $\begin{array}{l}\text { Reduced disturbance to species and habitats from visitor activities. } \\
\text { Increased pressure on resources due to return to subsistence livelihoods in } \\
\text { some places and increased coastal populations as people return from work to } \\
\text { home communities. } \\
\text { Increased illegal extractive activities in many MPCAs. }\end{array}$ \\
\hline & $\begin{array}{l}\text { Status or change in species or } \\
\text { habitat condition }\end{array}$ & $\begin{array}{l}\text { Perceived increase in abundance and behaviour change of certain species } \\
\text { due to reduced disturbance. }\end{array}$ \\
\hline$\stackrel{n}{5}$ & dativ & $\begin{array}{l}\text { Differential impacts on stakeholders dependent on MPCAs according to } \\
\text { livelihoods, geographical location and gender. }\end{array}$ \\
\hline
\end{tabular}

ecological and social costs and

benefits across social groups

The main impacts of, and responses to, COVID-19 on MPCAs as documented in recent publications and our case studies are summarised in Table 2. We recognise that impacts differ between MPCAs as well as between geographic regions. To structure the analysis, we adapted the framework provided by Gill et al. (2017) which distinguishes MPCA management and performance topics into four domains: (1) appropriateness of management activities and capacities (procedural effectiveness); (2) fairness or justness of management (procedural equity); (3) achievement of desired MPCA outcomes (substantive effectiveness) and: 
(4) distribution of MPCA costs and benefits (substantive equity).

COVID-19 has resulted in both negative and positive changes (Figure 1). The major impact for MPCAs where tourism is a key element has been the dramatic decline in tourism-related revenue (Hudson, 2020). Marine tourism alone, on which millions of people depend, was valued in 2016 at US\$ 390 billion globally (OECD, 2016) and has been growing rapidly. Its decline led to significantly reduced funds for management and for livelihoods dependent on MPCAs. This is visible across all four domains (Table 2), though we found no examples of MPCAs that ceased to operate in 2020. Nonetheless, several positive responses have emerged, providing new ways of working that may be retained into the future.

\section{Pandemic Impacts on procedural effectiveness}

Budget and staff capacity

The dramatic fall in tourism activity has severely affected many governments and MPCAs that relied on

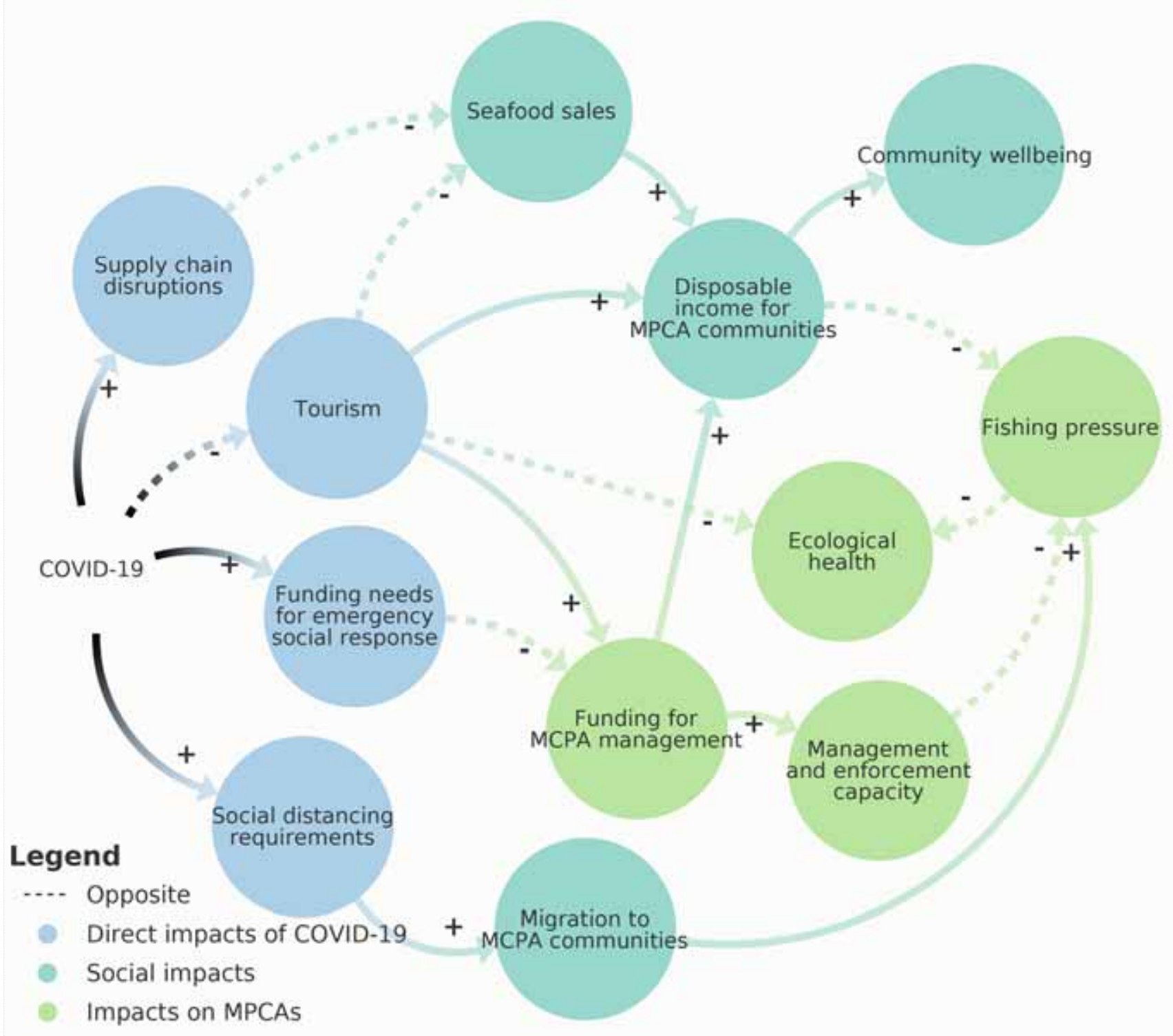

Figure 1. Impacts of COVID-19 on MPCAs and adjacent communities. This causal loop diagram shows the impacts documented in the case studies from COVID-19 on MPCAs and MPCA-dependent communities. Positive relationships (solid lines with a + sign) indicate variables that are reinforcing: when one goes up, the other goes up. Negative relationships (dotted lines with a - sign) indicate variables that have opposite relations: when one goes up, the other goes down. 
tourism to fully or partly finance MPCA budgets. For example, Mafia Island Marine Park (Tanzania) depends solely on tourism operators, visitor fees and issuance of fishing permits for income, which then provides revenue for other MPAs in the country. Reduced funding has virtually halted management throughout the national MPA network. CS8 The budget for Nusa Penida MPA (Indonesia) was significantly reduced by loss of tourism fees (there were 2,000 tourists/ day prepandemic and only 20-30 tourists/day in September 2020), and a 50 per cent cut in government funding which pivoted to prioritising COVID-19 responses. ${ }^{\text {CS12 }}$ Some governments made up lost revenue from tourism (e.g. the Australian Government provided the Great Barrier Reef Marine Park Authority (GBRMPA) with additional funds ${ }^{\mathrm{CS} 14}$ ); in other cases, private foundations or Trust funds stepped in to provide emergency funding. ${ }^{\mathrm{CS}}$, $\mathrm{CS} 13$

Loss of income led to reduced staff capacity or activity (Figure 1), often compounded by sickness, quarantine requirements and/ or travel restrictions preventing staff working (e.g. TanzaniaCs8, Raja AmpatCS13). In some cases, staff were laid off, though managers in some MPCAs tried to balance cuts across all activities to enable core management functions to be maintained (e.g. Raja Ampat(CS13). In the Galápagos, concerns about spreading COVID-19 between islands led to restrictions on staff movements between different parts of the MPA.CS2 Some MPCAs, however, took advantage of reduced field operations to focus on staff training (i.e. FijicS15).

\section{Implementation of management activities}

Management plan implementation has been delayed and effective implementation reduced in many cases. Concerns for staff well-being and government public health directives meant that work involving social contact was often dropped or postponed. In the Mediterranean, 78 per cent of MPAs surveyed adopted different working arrangements with staff often working from home. Many MPAs halted field work (MedPAN, 2020). In Malaysia, where all non-essential travel was stopped, NGO staff were unable to visit MPCAs.CS11 Invasive species management was disrupted in some MPCAs: on Midway Atoll, the mice eradication programme was suspended, leaving groundnesting seabirds vulnerable $\mathrm{CS}^{\mathrm{s}}$; and invasive lionfish culling was reduced in Belize.CS3 However, in the Galápagos, the Galápagos Biosecurity Agency, which was set up to prevent invasive species spread, converted its lab to conduct COVID-19 testing, emphasising the important role that the existence of such a biolab can play. CS2
The pandemic highlighted the need for MPCAs to have disaster and emergency response plans, in addition to existing ones such as those for oil spills and hurricanes. Such plans help managers decide how best to deploy resources during a crisis and minimise disruption. In the Dutch Caribbean, part of a protected area emergency response manual was rapidly adapted into a Pandemic Response Letter containing guidance for managers. CS5

In some cases, MPCAs with local community governance have shown greater resilience. In Fiji, the Vatu-i-Ra Conservation Park management committee resolved to maintain the traditional closure (tabu) of the park despite having no funding from tourism. CS15 In Velondriake (Madagascar), communities decided to continue with plans to expand permanent no-take zones within the LMMA.CS9

\section{Monitoring and enforcement}

Ecological monitoring programmes have been affected by the pandemic in many MPCAs, as illustrated in the case studies. For example, long-term governmentfunded monitoring was delayed in Hawaii ${ }^{\mathrm{CS} 1}$ and Florida. CS4 Ecological monitoring at MPCAs supported by international volunteer programmes was disrupted in the Philippines (People and the Sea, 2020), Belize and Madagascar, although in some cases local staff are continuing monitoring efforts. $\mathrm{CS3}, \mathrm{CS} 9, \mathrm{Cl} 5$

Enforcement was also affected in many MPCAs, although the pandemic had a variable impact on the need for it: in some places illegal activities decreased (e.g. where commercial fishing was disrupted) and in others they increased (see below). The GBRMPA has funded tourism operators to re-deploy their staff, once trained, to monitoring and resource management, benefiting both the park and the industry.CS14 Budget cuts, staff capacity reduction and restrictions on movement have reduced patrolling frequency and occurrence (e.g. Mafia Island ${ }^{\mathrm{CS} 8}$ and Nusa PenidaCS12) as well as staff presence (e.g. Seychelles ${ }^{\mathrm{CS} 10}$ ). However, in Velondriake LMMACS9, in response to perceived increases in infringements, the community surveillance group stepped up its patrolling and information sharing with State-led enforcement services. CS9

\section{Pandemic impacts on procedural equity}

In many countries, the sudden change in national priorities - towards healthcare and the economic emergency - had an immediate impact on MPCAs. Some established MPCA decision-making processes were overridden to prioritise COVID-19 responses. Despite global calls for a green recovery and to recognise conservation as essential work, MPCAs have often 
become lower priorities for government (e.g. Galápagos ${ }^{\mathrm{CS} 2}$ ). Occasionally, changed national priorities have had a positive effect. For example, the Malaysian National Security Council identified border security as a national pandemic priority, mandating that enforcement agencies prioritise this. In response, in Tun Mustapha Park - near the Malaysian border with the Philippines - coordination between enforcement agencies increased, so reducing illegal blast fishing. ${ }^{\text {Cs11 }}$ Reductions in management capacity have led some MPCA authorities to devolve certain operational aspects to local communities, as in Raja Ampat, where communities were given increased autonomy to patrol and enforce rules, allowing MPA staff to focus on enforcement in more remote areas. ${ }^{\mathrm{CS} 13}$

\section{Impacts of the pandemic on substantive effectiveness}

Pandemic impacts on MPCAs that affect human wellbeing

MPCAs are frequently essential to the livelihoods of adjacent coastal communities who, in some countries, are among the most vulnerable and marginalised peoples (Bennett et al., 2020). In many cases, tourism has been promoted by local authorities and MPCA managers to provide alternative livelihoods, and the pandemic has highlighted the insecurity of this approach. Many of the case studies illustrate the shift from fisheries to tourism prior to the pandemic, and the consequent negative impact of the pandemic (Figure 1) on local livelihoods (e.g. KenyaCS7, GalápagosCS2, TanzaniaCS8 and IndonesiaCs12,CS13). MPCA establishment is often accompanied by development of a hospitality industry involving accommodation, visitor facilities, guiding, seafood supply chains for restaurants, and water-based recreational activities. Such activities were widely halted or reduced, and many enterprises closed, as in the Mediterranean (MedPAN, 2020), IndonesiaCS12,CS13 and the Great Barrier Reef.CS14 Attempts have been made to relaunch domestic tourism in the Great Barrier Reef ${ }^{\mathrm{CS} 14}$ and Raja Ampat ${ }^{\mathrm{CS} 13}$, but have had limited success principally because of pricing barriers - domestic visitors being unwilling or unable to pay the same high prices as international tourists.

The closures of some seafood markets and widespread disruption to supply chains affected numerous MPCAs. In some cases, communities increased fishing intensity or resorted to illegal practices (see section on 'environmental threats' below). Examples include the Mediterranean (MedPAN, 2020), the Pacific (Bennett et al., 2020), KenyaCS7, MadagascarCS9, MalaysiaCs11, IndonesiaCS13 and the Great Barrier Reef.CS14 In Velondriake LMMACS9, communities dependent on

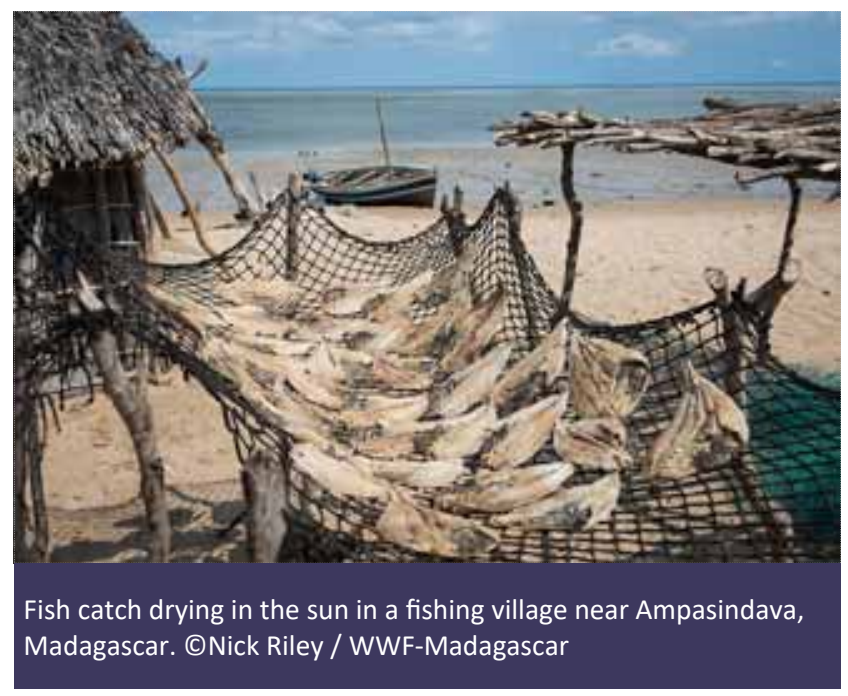

single supply chains (e.g. octopus fishery) have fared less well than those with more diverse income streams (e.g. sea cucumber and seaweed farming) which have provided revenue throughout the crisis. ${ }^{\text {CS9 }}$

\section{Pandemic impacts on environmental threats}

To slow COVID-19 spread, many nations imposed travel restrictions and limited access to MPCAs (e.g. 67 per cent of Mediterranean MPCAs were closed; https:// medpan.org/). This noticeably reduced disturbance from visitors, a significant threat to species and habitats in some MPCAs. Fewer cruise ships in the Florida Keys National Marine Sanctuary probably reduced noise and air pollution and sediment disturbance.cS4 Lack of visitors led to an 18 per cent increase in water clarity in Hanauma Bay Sanctuary, Hawaii (Severino et al., 2020). Plastic pollution, however, has built up in some MPCAs which would normally be cleared by agencies supporting the tourism business. ${ }^{\text {CS6 }}$

COVID-19 increased fishing pressure in many MPCAs. Illegal fishing by supertrawlers increased significantly in offshore MPCAs in the UK during the early months of the pandemic (Greenpeace, 2020). In many nearshore

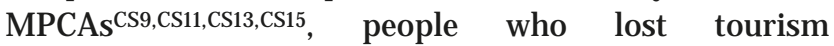
livelihoods had to fall back on fishing, and others returned from urban areas to their coastal communities following pandemic-induced loss of employment. Lost livelihoods and uncertain food security intensified illegal extractive activities including: fishing in no-take areas (e.g. KenyaCS7, IndonesiaCS13, Seychelles ${ }^{\mathrm{CS} 10}$ and AustraliaCs14); replacing or even adding to legal fishing gear with destructive illegal equipment (e.g. GalápagoscS2 and Madagascarcs9); and greater mangrove cutting (e.g. Madagascarcs9). MPCA compliance during the pandemic in some cases, such as Gokova Bay, 


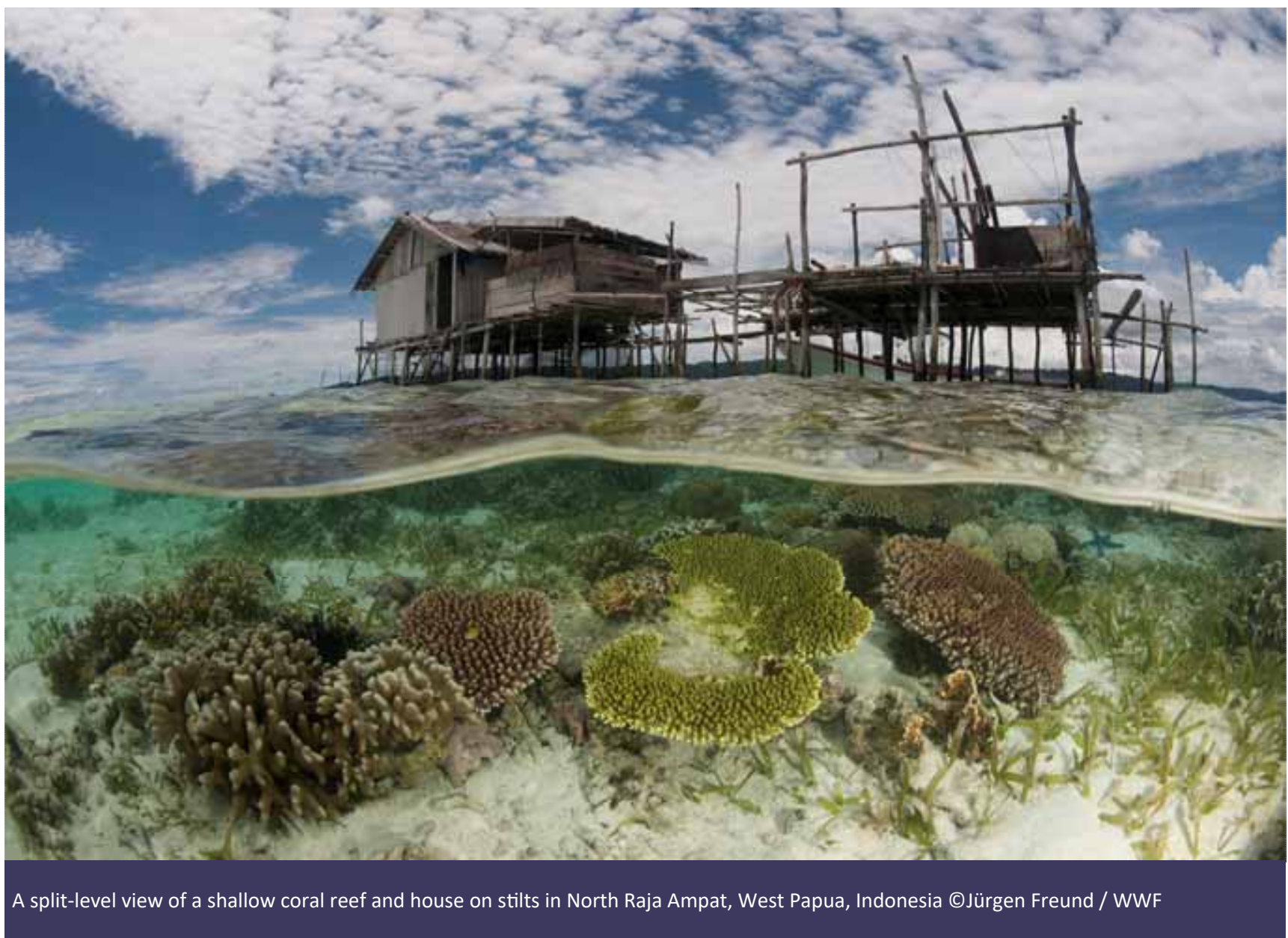

Turkey, depended on location, with increased illegal fishing in more rural areas, but regulations nearer urban areas continuing to be respected (MPA News, 2020a). For some MPCAs, both inshore and offshore, however, the overall reduction in commercial fishing that has been documented for several countries and regions (Clavelle, 2020; FAO, 2020), may have led to reduced incursions, although documentation is scarce.

Potential new threats to MPCA biodiversity emerged in some places during the pandemic. Increased farming next to or within MPCAs (e.g. Raja AmpatCS13) and expanded aquaculture activities within MPCAs (e.g. Nusa PenidaCs12) have offered livelihood opportunities in the absence of tourism; but, when not managed, both can cause pollution.

Pandemic impacts on biodiversity and resource condition

Anecdotal reports and some initial studies suggest variable ecological responses within MPCAs due to the pandemic. In some cases, species have increased in abundance or their distribution has changed, presumably due to reduced human disturbance; for example, nesting areas of Kentish Plover (Charadrius alexandrinus) on the Italian Adriatic coast expandedCs6; marine mammal and large fish sightings increased near to shore in GalápagosCS2, Hawaii (Severino et al., 2020) and Raja AmpatCS13; manta rays appeared less wary in Nusa Penidacs12; and sea turtle nesting on beaches in Kenya increased.CS7

Negative effects on biodiversity may become apparent as monitoring activities resume post-pandemic. Increased fisheries pressure within MPCAs may exceed sustainable levels. Reduced access to, and tourism in, MPCAs may also have perverse biodiversity outcomes. In Kenya, a curfew limited fishing to nearshore areas and led to more trampling of corals.CS7 While plastic pollution build-up on beaches in Adriatic MPCAs may have hindered turtle nesting, the reduced disturbance from cleaning actually benefited nesting birds. CS6

\section{Pandemic impacts on substantive equity}

Stakeholders and communities dependent on MPCAs have been affected in different ways by COVID-19 (Figure 1). Greatest impacts have been felt by those 
reliant on tourism, as well as fishers reliant on MPCAs. For example, Malaysian fishers were uncertain whether continued fishing breached government movement restrictions that would be enforced by park authorities, thus undermining fisher food security. ${ }^{\text {CS11 }}$ Declines in fish prices or closures of markets have forced some fishing communities into bartering to maintain food security.CS2,CS11 In Raja Ampat, the pandemic has disproportionately affected fishers in more remote parts of the archipelago as transport connections to the main fish markets are reduced.cs13 Pandemic restrictions have particularly affected women: traditionally, women sell fish in the evenings in Kenya, but they have been disproportionately affected by a curfew (Kithia et al., 2020). CS7

\section{MPCAS POST-COVID-19-'BUILDING BACK BETTER'}

The case studies show at least five main areas where MPCAs illustrate either vulnerability or resilience to the pandemic: (1) sustainable financing, (2) devolved and equitable management, (3) seafood supply chains, (4) adaptive MPCA monitoring and enforcement, and (5) communications capacity. For each of these five areas, we look at the opportunities for learning from the experience of the pandemic and thus ensuring more effective management in the future, with a notable emphasis on the increasing role of emerging and applied technology.

\section{Sustainable financing}

MPCAs were underfunded before the pandemic (Meyers et al., 2020), and highly vulnerable to global recessions and disruption of tourism. MPCAs often have higher financial needs than terrestrial sites, since enforcement, monitoring and research are logistically more complex in the marine environment, requiring boats, specialised equipment and particular expertise (Bohorquez et al., 2019). Efforts to diversify MPCA financing must accelerate, whilst ensuring that revenue generated contributes to on-going operations as well as short-term project needs. Financing mechanisms need to be resilient to stress events, like pandemics, climate change and financial crises. Further trialling and documentation of funding models are needed. Trust funds have often proved successful but those established for some MPCAs ${ }^{\mathrm{CS} 13, \mathrm{CS} 10}$ were unable to respond to budget shortfalls as they are designed to support project-based activities rather than operating costs. However, in the Dutch Caribbean, the Nature Conservation Trust Fund can provide emergency funding, and each protected area received an additional US\$150,000 this year.CS5
User fees (e.g. visitor entry, diving and other in-water activities, guided tours, food outlets) have been an easy option for generating revenue for both communities and MPCA management authorities. During the pandemic, some MPCAs were able to generate revenue from local tourism when international tourism ceased, and in some cases the sale of entry tickets and souvenirs was brought online $^{\mathrm{CS}}$, an approach that could be retained postpandemic. Virtual tourism may expand in the future, allowing overseas 'visitors' to maintain support for an MPCA. Multiple modalities exist for this, but it will be necessary to add value beyond videos and photographs, providing for example, virtual dives and fundraising opportunities (Guttentag, 2010; J ung and Claudia tom Dieck, 2018).

Numerous options for financing exist beyond tourism. The Blue Finance programme (http:/ / blue-finance.org) focuses on impact investors - that is, investors who seek positive environmental and social outcomes through their investments - using a model involving comanaged MPCAs: trials are underway in the Caribbean and South-East Asia. Crowdfunding was used for management activities in Seychelles before the pandemic (Shah, 2017), and in Malaysia during the pandemic where communities in Tun Mustapha Park used this to obtain food.cs11 The sale of carbon offset credits is an established financing mechanism for terrestrial protected and conserved areas and is now being applied to marine conservation (Howard et al., 2017; MPA News, 2020b), with multiple initiatives underway to integrate 'blue carbon' credits (from protection and restoration of mangroves, salt marshes and seagrass) into MPCAs (Moraes, 2019). Examples include Velondriake LMMA, where demand for Tahiry Honko carbon credits pre-pandemic outstripped supplycs9; and Nature Seychelles, which buys carbon credits to make Cousin Island Special Reserve carbon neutral.CS10 Despite challenges ahead (Howard et al., 2017) and concerns about potential unintended consequences of off-setting (MPA News, 2020c), the aviation and tourism industries provided most demand for carbon credits pre-pandemic (Gross, 2020). CS9 The protection of blue carbon stocks features in many nations' nationally determined contributions to the United Nations Framework Convention on Climate Change, and may thus provide further leverage for funding for MPCAs (Gallo et al., 2017).

In the current environment, any additional funding for MPCAs or other ocean and/or conservation initiatives will help improve outcomes and effective management of MPCAs. From the case studies we have observed, the one critical constraint is the ability of suppliers and 
buyers of blue carbon to meet and transact inexpensively. This bottleneck can be addressed through the creation of a secure and more easily accessible marketplace for carbon that leverages existing technology. This approach has already been demonstrated by the REDD+ initiative (Robinson, 2018) which utilises blockchain functionality to facilitate similar outcomes that can be used for MPCAs. As blockchain is still a new technology, there is a natural gap in knowledge between technological enthusiasts and natural resource managers as well as policy makers. A technical understanding is not essential for the purposes of this paper, but UNDP (2020) provides a succinct description of how blockchain is relevant for reaching the SDG goals.

Reducing funding requirements is as important as raising revenue. Costs can be much reduced by giving communities responsibility for management in exchange for secure access to resources. In Belize, the integration of MPCA and fisheries management through the Managed Access Program has given licensed fishers greater involvement in management of MPCAs, through monitoring of their catches and representation on Managed Access Committees, in exchange for rights to catch a controlled portion of fisheries stocks in the general use zones of some MPCAs (Martinez et al., 2018). Microfinance, such as community-led savings and loans schemes, have been set up alongside community-managed MPCAs in many places such as MadagascarCS9, the Philippines (Garcia, 2018), Kenya and Tanzania (Nicholas, 2019). These allow people to save money and access credit in exchange for playing an active role in management of the area. Such schemes have provided vital financial support during the pandemic and could be scaled up to ensure more resilient financial systems in future.

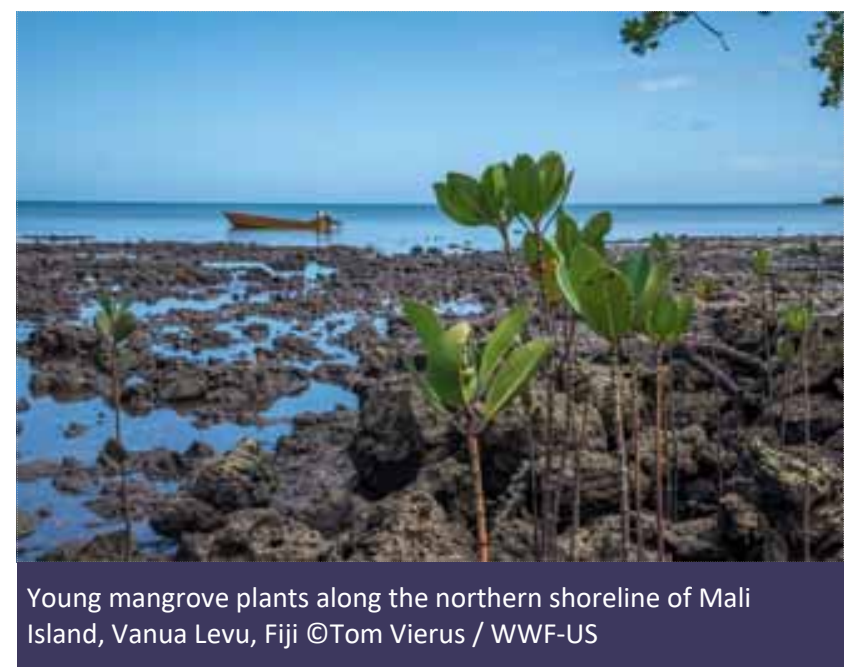

\section{Devolved and equitable management}

Building back post-COVID-19 will require coordinated actions across multiple scales. The case studies show that in many places, communities and communitybased or co-managed governance systems have some resilience and capacity to adapt (Folke et al., 2002) to unexpected circumstances such as the pandemic. For example, the loss of international tourism and its associated revenue in the Galápagos led to the emergence of new commerce enabled by local production and trade.CS2 MPCAs with strong local community governance structures in place were often better placed to weather the crisis and secure support from partner organisations and governmental services. ${ }^{\text {CS9 }}$ Several case studies show an increase in harmful fishing practices in response to economic and food insecurity caused by the pandemic. Ensuring that governance systems can withstand an increasingly uncertain future requires building on the momentum started pre-COVID-19 to mainstream equity and benefit sharing in MPCAs. Empowering and reinforcing local institutions to lead on MPCA management is vital.CS7, C15

\section{Improving the efficiency of seafood supply chains}

The resilience and sustainability of seafood supply chains are inextricably linked to their governance and the technology available. Supply chains were affected globally during the pandemic, with direct impacts on those who rely on trading marine resources for income, particularly where single source supply chains were involved. In some cases, modern communications infrastructure provided solutions; for example, fishers operating in and around MPCAs at Telascica and Lastovo Islands (Croatia), Tun Mustapha Park (Malaysia) and Raja Ampat found it difficult to get fish to market - with physical markets often closed or supply chains disrupted.CS6,CS11,CS13 As a result, ad hoc virtual markets on Facebook were set up to connect fishers and fish traders directly with consumers - a solution that could be scaled up elsewhere. This is an example of how technology can provide tangible new solutions to building the resilience of MPCAs and those who depend on them.

There is already a broad literature on supply chain resilience (Golan et al., 2020), and sustainable supply chains (Zavala-Alcívar et al., 2020) outlined as relevant for achieving the SDGs. Blockchain technology has been identified as a useful tool for achieving sustainability goals (Adams et al., 2018; UNDP, 2020) and can help address multiple emerging supply chain issues (Howson, 2020). Blockchain based marketplaces can 
give fishers low cost direct access to local and international markets and bypass the challenge of matching local demand for, and supply of marine products. For example, by-catch or parts of the fish typically seen as waste products can be sold, and this has already been explored through initiatives such as WWF-Australia's collaboration with OpenSC (WWFAustralia, 2020).

These initiatives demonstrate that blockchain technology can be used effectively to track the source of marine products, from line to plate, giving consumers more sustainable choices (Howson, 2020). Implemented in parallel with existing MPCA programme goals, blockchain can be a mechanism to lower costs of governance, monitoring and oversight while also enhancing fishers' businesses and community outcomes.

\section{Monitoring and enforcement}

Budget cuts and public health directives as a result of the pandemic have had a significant impact on certain MPCA activities, in particular research, monitoring and enforcement. Programmes that rely heavily on data collection by individuals or groups living outside MPCAs and their adjacent communities were badly impacted. There are several emerging technologies that can help to mitigate this. For example, mobile software $^{2}$, can be used to collect and analyse locallycollected data, which can support the kind of informed, rapid decision-making that is vital in a crisis while developing local monitoring capacity. Platforms are also improving rapidly for the remote collection and analysis of ship-borne tracking and monitoring data - including automatic identification system (AIS) and vessel monitoring systems ${ }^{3}$ - and for integrating those data with satellite-based synthetic aperture radar and multispectral data. Where expensive and complex AIS and VMS systems are not feasible, as in tracking smallscale fishing, simple self-contained systems are becoming available ${ }^{4}$ which also reduce requirements for individuals on site.

Satellite-based remote sensing, which allows the collection of data over large areas and at large volumes, is often freely available (e.g. Sentinel-2, Landsat 8) on open platforms that facilitate analysis (e.g. Google Earth Engine), and will play a key role in monitoring and enforcement in future. This technology makes it possible to map and monitor changes in important coastal habitats, such as mangroves (e.g. Global Mangrove Watch) and coral reefs (e.g. Allen Coral Atlas). Autonomous (e.g. https:// www.saildrone.com/) and remotely operated vehicles are another means of

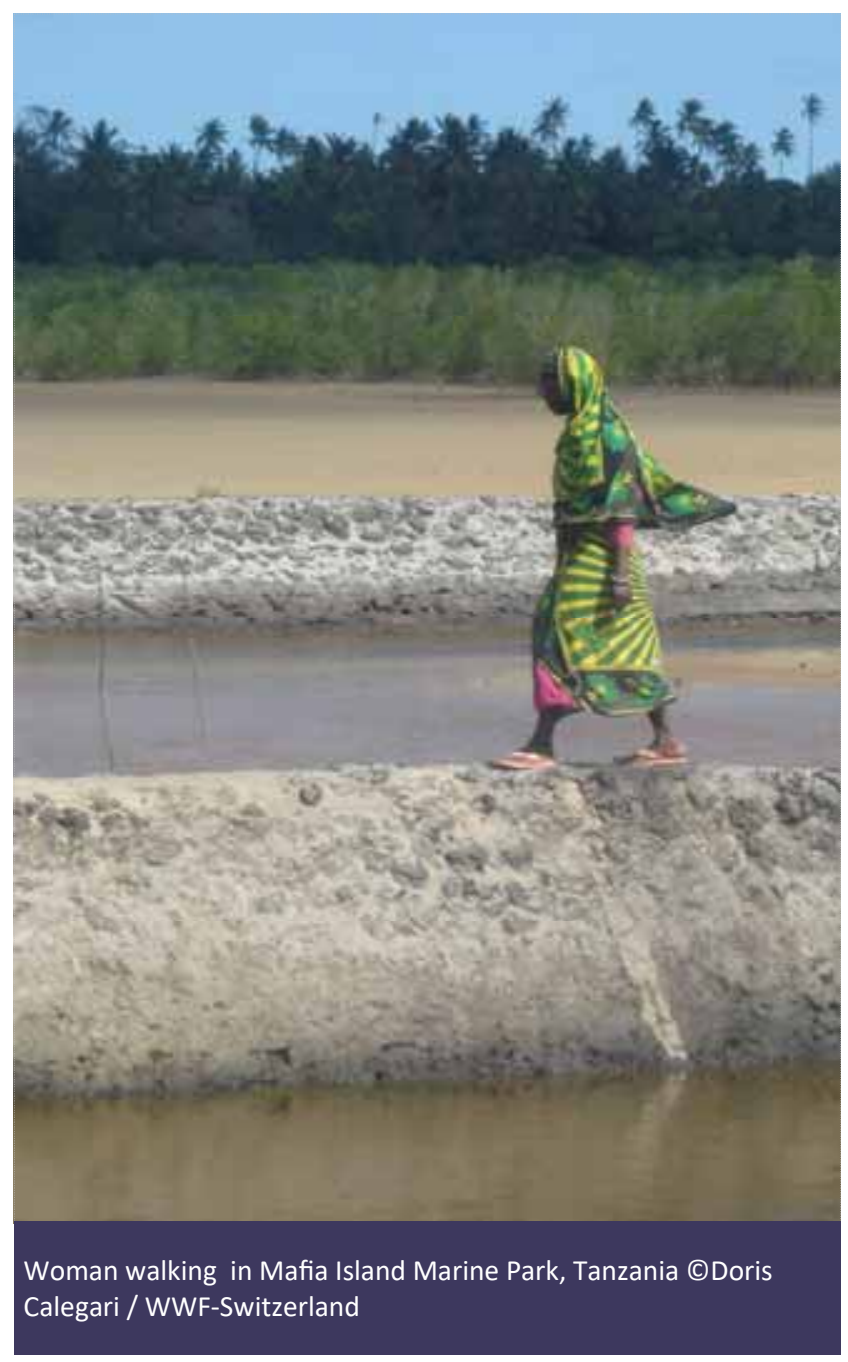

data collection and surveillance, and are becoming more affordable (Jiménez López \& Mulero-Pázmány, 2019). Such technology reduces the need for teams on the ground, a major asset in crises such as a pandemic. There will, nevertheless, be a continued need to build capacity for locally based monitoring, such as in Velondriake LMMACs9; this is essential for groundtruthing, but also provides employment and opportunities to engage local communities in park management. There is a level of technical sophistication necessary for analysis of the vast amount of data produced by drone cameras and other sensors, and so investment in capacity development is urgently needed to accelerate the use of these technologies in MPCAs.

Robust monitoring will not be enough on its own: greater attention was already being paid pre-pandemic to the need to embed the monitoring and assessment of MPCAs in management systems. The pandemic has demonstrated the need to ensure that social, economic and ecological monitoring is underpinned by user- 
friendly, robust and adaptive systems for data collection, storage and analysis and also that it is designed to be sustainable (and informative) in crises situations. This will involve the use of the newest technology and ensuring that the data collected will help MPCA decision-makers to identify risks from climate change, pandemics and other major events 5 .

\section{Communications, coordination and collaboration capacity}

A good communications infrastructure is critical to the resilience of MPCAs. In the Adriatic SeaCS6, the pandemic situation led to mobile and virtual communication technology being used extensively which improved the transparency and effectiveness of collaboration between MPCA practitioners, and will be retained in the future. Well-prepared and informed online meetings and email exchanges can lead to more objective discussion than physical in-person meetings, and often make it easier to track what was said, when and by whom. In addition, the Adriatic Protected Areas Network (AdriaPAN), which enabled collective reflection and sharing around preparations for a second lockdown, demonstrated the value of such social MPCA networking systems, many of which were being established pre-pandemic in different regions. CS6

Reliance on technology for virtual meetings and remote education also demonstrated the potential for the wider adoption of these tools for public engagement in remote or large-scale MPCAs (e.g. Hawaiics1, FloridaCS4 and the Great Barrier ReefCS14). However, in some countries, MPCAs may not have the 'economic density' for mobile network operators to invest in coverage (Cherry, 2003), making it difficult to achieve the kind of virtual collaboration and learning seen in the Adriatic Sea, USA and Australia. Nevertheless, Community Cellular Networks - low cost cellular radios managed locally by a community - have been deployed in Mexico, Philippines and Indonesia (e.g. Keleher et al., 2020), and provide the means by which experiences and learning can be shared. Such systems may also be used for income generation, for example, marketing fish (Ali \&Heimerl, 2018).

\section{CONCLUSION}

Recalling Heraclitus's wisdom, "there is nothing permanent except change", we argue that management of MPCAs needs to be adaptive to change in order to support nature and people, as demonstrated by the diversity of challenges as well as responses in the management of MPCAs during the pandemic. Extended exposure to major disturbance requires that more attention be given to resilience, and needs meaningful integration with, and attention to, the social, cultural, political and economic context of each site. The recent zoonotic disease outbreaks show how fundamentally broken human relationships have become with nature (IPBES, 2020). Yet COVID-19 has opened a window of opportunity for us to rethink and rebuild these relationships, and create MPCAs that are locally and collaboratively driven, and supported by innovative technologies, tools and ethical financing mechanisms. Such a transformation is essential if SDG 14 is to be achieved.

The length and the severity of disruption caused by the pandemic remains unclear, but efforts should be made to make MPCA management and governance more ethical and effective, putting the principles of equity and resilience at the forefront of building back better' (Leach et al., 2020). This means building on successes and ensuring that enabling conditions exist for grassroot adaptations. MPCAs must be designed and managed in such a way that social-ecological resilience is fostered. This will involve maintaining diversity and redundancy in systems, managing connectivity, ensuring adaptive system thinking, encouraging learning and broadening participation (see the seven principles of resilience outlined in Biggs et al., 2015). Similar recommendations for improving ocean resilience as a whole, post-pandemic, have been made by the High-Level Panel for a Sustainable Ocean Economy (Northrop et al., 2020), the World Economic Forum through its Virtual Ocean Dialogues (https:// www.weforum.org/ events/ virtual-ocean-dialogues2020) and others, such as Laffoley et al. (2020a; 2020b).

Strategies to improve the outcomes for MPCAs should support the people living in or near them - and vice versa. The pandemic, climate change and other rapidly growing pressures require that we strengthen synergies between conservation and resilient livelihoods, addressing the challenges of sustainable development in a more tangible way. Our case studies confirm the importance of building social-ecological resilience. We should learn this and other lessons from the pandemic, applying innovation in our efforts to safeguard the future of marine ecosystems and the people that depend on them, and manage better for uncertainty. One mechanism to do so could be through the establishment of an MPCA Futures Working Group, under the umbrella of the IUCN World Commission on Protected Areas' 'Protected Areas \& COVID Task Force'.

To achieve these changes and facilitate cross-learning and innovation, conservationists need to break down 
silos and work closely with diverse stakeholders and experts from beyond the MPCA community. Rebuilding a better future will depend on this.

\section{ENDNOTES}

${ }^{1}$ The term "'blockchain'" refers to the technology itself. It forms an immutable record of the transactions for all users, so that no external authority is needed to validate the authenticity and integrity of the data. It can be used with any kind of data and can facilitate direct transfer of asset ownership.

${ }^{2}$ SMART\# (https://smartconservationtools.org/ -- used widely for MPCA enforcement), Open Data Kit (https:// opendatakit.org/ -- software that allows for offline data collection with mobile phones -- e.g., Jeffers et al., 2019), and MERMAID software (https://datamermaid.org/ -- used for gathering and aggregating data from coral reef surveys).

${ }^{3}$ (VMS; $\quad$ https://globalfishingwatch.org/; https:// www.oceanmind.global/; https://vulcan.com/skylight)

${ }^{4}$ e.g. https://www.pelagicdata.com/

${ }^{5}$ Since 2006, MPCAs in the Dutch Caribbean have been using an assessment tool (Management Success) based on IUCN's framework for assessing management effectiveness, and this will be used to track the impact of the pandemic and the shortfalls it has created, in the same way that it previously addressed other crises such as hurricanes. ${ }^{\text {CS5 }}$

\section{SUPPLEMENTARY ONLINE MATERIAL}

Marine case studies compilation - CS1 to CS15

\section{ACKNOWLEDGEMENTS}

We would like to thank the following case study authors: J en Chapman (Blue Ventures, Belize), Athline Clark (NOAA Office of National Marine Sanctuaries), Sarah Fangman (NOAA Office of National Marine Sanctuaries), Mariuxi Farias (WWF-Ecuador), Tarsicio Granizo (WWF-Ecuador), Pablo Guerrero (WWFEcuador), Arturo Izurieta (Charles Darwin University; CEDENMA), Joannie J omitol (WWF-Malaysia), Modesta Medard (WWF-Tanzania), Defy Pada (CI, Indonesia), Purwanto (University of Papua, CTC), Fazrullah Rizally Abdul Razak (Sabah Parks), Maritza Rodriguez (Blue Ventures, Belize), Melita Samoilys (CORDIO East Africa), Wiral Sanjaya (CTC), J oel Verde (SACD).

We would also like to thank those who contributed to the inception process of this article and the workshop: Dirk Hulverscheidt, Aulani Wilhelm (CI), John Davis (OCTO), William Cheung (University of British Columbia), David Obura (CORDIO East Africa), Aya Mizumura (WWF-Australia), J ohn Tobin (University of Cornell), Mark Moran (University of Queensland), J on Day (J ames Cook University) and Chrisma Salao (WWF Philippines). We thank the editors and two anonymous reviewers for comments that improved this manuscript.

\section{ABOUT THE AUTHORS}

Carol Phua is the Global Coral Reef Initiative Leader and MPA Lead for WWF's Oceans Practice. 0000-00030407-1968

Dominic A. Andradi-Brown is senior marine scientist for WWF-US' Ocean Conservation Program. 0000-0001-5191-5225

Sangeeta Mangubhai is the director of WCS-Fiji, working on MPAs and LMMAs. 0000-0002-4728-4421

Gabby Ahmadia is director of Oceans science at WWF -US working on area-based/ community conservation in coastal ecosystems.

Shauna L. Mahajan is a senior social scientist with an interdisciplinary background in WWF's Global Science program. 0000-0003-1726-3117

Kirk Larsen is an engineer and program officer at Vulcan, Inc., focused on conservation science and technology. 0000-0003-1726-3117

Stephen Friel is an independent consultant and data scientist with a background in financial markets, development economics and blockchain technology. 0000-0002-8208-365X

Russell Reichelt is experienced in marine research, and management and chaired the Great Barrier Reef Marine Park Authority for 11 years. 0000-0002-80559351

Marc Hockings is Vice-Chair (Science \& Management) with the IUCN-WCPA. 0000-0003-4419-8963

David Gill is an Assistant Professor at Duke University Marine Lab, focused on conservation impact evaluation 0000-0002-7550-1761

Laura Veverka is a program officer for WWF-US' Ocean Conservation Program, focused on coastal habitat conservation priorities. 0000-0003-4198-5216

Richard Anderson is a professor in the Paul G. Allen School of Computer Science and Engineering at University of Washington.

Lovasoa Cédrique Augustave is a fisheries coordinator and FIP Lead, working closely with coastal communities to rebuild tropical fisheries. 
Phua et al.

Awaludinnoer works for the Indonesia Coasts and Oceans programme in the local NGO Yayasan Konservasi Alam Nusantara/The Nature Conservancy.

Tadzio Bervoets is the director of the Dutch Caribbean Nature Alliance (DCNA), the network of protected areas for the Dutch Caribbean.

Kitty Brayne is responsible for coordinating evidence generation and learning processes at Blue Ventures.

Rili Djohani is co-founder and executive director for the Coral Triangle Centre (CTC).

Joan Kawaka holds an Environment and International Development MSc, with expertise in establishing marine community conservation areas.

Fabian Kyne is the conservation science manager for the Blue Ventures Belize Program.

January Ndagala is a marine scientist currently leading the 'Save Our Mangroves Now' project at WWF Tanzania.

Jenny Oates is the knowledge development manager at Blue Ventures and has a $\mathrm{PhD}$ in Tropical Marine Ecology.

Kennedy Osuka is a fish and fisheries scientist at CORDIO East Africa.

Mosor Prvan is a biologist with over 15 years' experience in the Adriatic Sea and the Mediterranean.

Nirmal Shah is a Seychellois conservation biologist and sustainable development practitioner with almost 40 years' experience.

Fabio Vallarola has recently been the leading force in AdriaPAN, an MPA networking organisation associated with MedPAN.

Lauren Wenzel is the director of NOAA's Marine Protected Areas Center, focusing on US and international MPA programmes.

Hesti Widodo is a senior program manager at Coral Triangle Center (CTC), with a social science background.

Sue Wells has over 40 years' experience in global marine conservation, particularly MPAs, currently working as a consultant.

\section{REFERENCES}

Adams, R., Kewell, B. and Parry, G. (2018). Blockchain for good? Digital ledger technology and sustainable development goals. In: Handbook of sustainability and social science research, pp. 127-140. Cham: Springer. DOI: 10.1007/978-3-319-67122 $-2 \_7$

Agardy, T., Claudet, J. and Day, J.C. (2016). 'Dangerous Targets' revisited: Old dangers in new contexts plague marine protected areas. Aquatic Conservation: Marine and Freshwater Ecosystems, 26: 7-23. DOI: 10.1002/aqc.2675

Ali, K. and Heimerl, K. (2018). Designing sustainable rural infrastructure through the lens of OpenCellular. Communications of the ACM, 61(8): 22-25. DOI: $10.1145 / 3232037$

Awaludinnoer A, Pada D., Purwanto, Veverka, L. and AndradiBrown, D. (2021). Case Study 13: Raja Ampat Marine Protected Area Network, West Papua, Indonesia. In Phua et al. (2021) Marine protected and conserved areas in the time of COVID. PARKS 27(SI) Supplementary Online Material, p. 41.

Ban, N.C., Gurney, G.G., Marshall, N.A., Whitney, C.K., Mills, M., Gelcich, S., Bennett, N.J. et al. (2019). Well-being outcomes of marine protected areas. Nature Sustainability, 2(6): 524532. DOI: 10.1038/s41893-019-0306-2

Bennett, N.J., Finkbeiner, E., Ban, N.C., Belhabib, D., Jupiter, S.D., Kittinger, J.N., Mangubhai, S. et al. (2020). The COVID19 pandemic, small-scale fisheries and coastal fishing communities. Coastal Management, 48(4): 1-11. DOI:10.1080/08920753.2020.1766937

Bennett, N.J., Teh, L., Ota, Y., Christie, P., Ayers, A., Day, J.C., Franks, et al. (2017). An appeal for a code of conduct for marine conservation. Marine Policy, 81: 411-418. DOI: 10.1016/j.marpol.2017.03.035

Bervoets, T. and Wells, S. (2021). Case Study 5: Dutch Caribbean, Netherlands. In Phua et al. (2021) Marine protected and conserved areas in the time of COVID. PARKS 27(SI) Supplementary Online Material, p. 16.

Biggs, R., Schlüter, M. and Schoon, M.L. (eds.) (2015). Principles for building resilience: sustaining ecosystem services in social -ecological systems. Cambridge University Press. DOI: 10.1017/СВO9781316014240

Bohorquez, J.J., Dvarskas, A. and Pikitch, E.K. (2019). Filling the data gap - A pressing need for advancing MPA sustainable finance. Frontiers in Marine Science 6: 45. DOI: 10.3389/ fmars.2019.00045

Brander, L.M., van Beukering, P., Nijsten, L., McVittie, A., Baulcomb, C., Eppink, F.V. and Cado van der Lelij, J.A. (2020). The global costs and benefits of expanding Marine Protected Areas. Marine Policy, 116: 1-12. DOI: 10.1016/ j.marpol.2020.103953

CBD. (2019). Synthesis of views of Parties and observers on the scope and content of the Post-2020 Global Biodiversity Framework. Convention on Biological Diversity (Preparations for the Post-2020 Biodiversity Framework). <https:// www.cbd.int/doc/c/de9c/8c12/7c0cb88a47f9084e5d0b82eb/ post2020-prep-01-inf-01-en.pdf>

Cherry, S. (2003). The wireless last mile. IEEE Spectrum, 40(9): 18-22. DOI: 10.1109/MSPEC.2003.1228003

Clavelle, T. (2020). Global fisheries during COVID-19. Global Fishing Watch. (12 May 2020). Available at: <https:// 
globalfishingwatch.org/data-blog/global-fisheries-during-covid $-19 />$

Cudney-Bueno, R. and Basurto, X. (2009). Lack of cross-scale linkages reduces robustness of community-based fisheries management. PloS One, 4(7): e6253. DOI: 10.1371/ journal.pone.0006253

Díaz, S., Settele, J., Brondízio, E.S., Ngo, H.T., Agard, J., Arneth, A., Balvanera, P. et al. (2019). Pervasive human-driven decline of life on Earth points to the need for transformative change. Science, 366(6471). DOI: 10.1126/science.aax3100

FAO. (2020). How is COVID-19 affecting the fisheries and aquaculture food systems. Rome. 5 pp. DOI: 10.4060/ ca8637en

Folke, C., Carpenter, S., Elmqvist, T., Gunderson, L., Holling, C.S. and Walker, B. (2002). Resilience and sustainable development: building adaptive capacity in a world of transformations. AMBIO, 31(5): 437-440. DOI: 10.1579/00447447-31.5.437

Gallo, N.D., Victor, D.G. and Levin, L.A. (2017). Ocean commitments under the Paris Agreement. Nature Climate Change, 7(11): 833-838. DOI: 10.1038/nclimate3422

Garcia, F. (2018). Community Bank Environment Fund (EF) Engendering grassroots financing for marine protected areas. Panorama. (18 September 2018). Available at: <https:// panorama.solutions/en/solution/community-bank-environment -fund-ef-engendering-grassroots-financing-marine-protectedareas>

Gill, D.A., Cheng, S.H., Glew, L., Aigner, E., Bennett, N.J. and Mascia, M.B. (2019). Social synergies, tradeoffs, and equity in marine conservation impacts. Annual Review of Environment and Resources, 44(1): 347-372. DOI: 10.1146/ annurev-environ-110718-032344

Gill, D.A., Mascia, M.B., Ahmadia, G.N., Glew, L., Lester, S.E., Barnes, M., Craigie, I. et al. (2017). Capacity shortfalls hinder the performance of marine protected areas globally. Nature, 543: 665-669. DOI: 10.1038/nature21708

Golan, M.S., Jernegan, L.H. and Linkov, I. (2020). Trends and applications of resilience analytics in supply chain modeling: systematic literature review in the context of the COVID-19 pandemic. Environment Systems \& Decisions, 1. DOI: 10.1007/s10669-020-09777-w

Greenpeace. (2020). Bright Blue Seas: the need to properly protect our offshore marine protected areas. Available at: <https://www.greenpeace.org.uk/wp-content/ uploads/2020/09/Bright-Blue-Seas-Greenpeace-report.pdf>

Gross, A. (2020) Carbon offset market progresses during coronavirus. Financial Times. (28 September 2020). Available at: <https://www.ft.com/content/e946e3bd-99ac-49a8-82c9e372a510e87c>

Guttentag, D.A. (2010). Virtual reality: Applications and implications for tourism. Tourism Management, 31(5): 637651. DOI: 10.1016/j.tourman.2009.07.003

Hicks, C.C., Cohen, P.J., Graham, N.A., Nash, K.L., Allison, E.H., D'Lima, C., Mills, D.J. et al. (2019). Harnessing global fisheries to tackle micronutrient deficiencies. Nature, 574: 9598. DOI: 10.1038/s41586-019-1592-6

Hockings, M. (2021). Case Study 14: Great Barrier Reef Marine Park, Queensland, Australia. In Phua et al. (2021) Marine protected and conserved areas in the time of COVID. PARKS 27(SI) Supplementary Online Material, p. 45.
Hockings, M., Dudley, N., Elliott, W., Ferreira, M.N., Mackinnon, K., Pasha, M.K.S., Phillips, A., Stolton, S., Woodley, S. et al. (2020). Editorial essay: Covid-19 and protected and conserved areas. PARKS, 26(1). DOI: 10.2305/ IUCN.CH.2020.PARKS-26-1MH.en

Howard, J., McLeod, E., Thomas, S., Eastwood, E., Fox, M., Wenzel, L. and Pidgeon, E. (2017). The potential to integrate blue carbon into MPA design and management. Aquatic Conservation: Marine and Freshwater Ecosystems, 27: 100115. DOI: $10.1002 /$ aqc. 2809

Howson, P. (2020). Building trust and equity in marine conservation and fisheries supply chain management with blockchain. Marine Policy, 103873. DOI: 10.1016/ j.marpol.2020.103873

Hudson, D.S. (2020). COVID-19 and Travel. Oxford: Goodfellow Publishers. DOI:10.23912/9781911635703-4387

IPBES. (2020). IPBES Workshop on Biodiversity and Pandemics. Workshop Report. DOI: 10.5281/zenodo.4147318

Izurieta, A., Farias, M., Guerrero, P. and Granizo, T. (2021). Case Study 2: Galápagos Marine Reserve, Galápagos, Ecuador. In Phua et al. (2021) Marine protected and conserved areas in the time of COVID. PARKS 27(SI) Supplementary Online Material, p. 8.

Jeffers, V.F., Humber, F., Nohasiarivelo, T., Botosoamananto, R. and Anderson, L.J. (2019).Trialling the use of smartphones as a tool to address gaps in small-scale fisheries catch data in southwest Madagascar. Marine Policy, 99: 267-274. DOI: 10.1016/j.marpol.2018.10.040.

Jiménez López, J. and Mulero-Pázmány, M. (2019). Drones for conservation in protected areas: present and future. Drones, 3 (1): 10. DOI: 10.3390/drones3010010

Jomitol, J. Razak, F.R.A. and Andradi-Brown, D. (2021). Case Study 11: Tun Mustapha Park, Sabah, Malaysia. In Phua et al. (2021) Marine protected and conserved areas in the time of COVID. PARKS 27(SI) Supplementary Online Material, p. 34.

Jung, T. and Claudia tom Dieck, M. (2018). Augmented Reality and Virtual Reality. Empowering Human, Place and Business. Cham: Springer. ISBN 978-3-319-64027-3

Kawaka, J., Osuka, K. and Samoilys, M. (2021). Case Study 7: Kanamai-Mtwapa Co-Management Area, Kenya. In Phua et al. (2021) Marine protected and conserved areas in the time of COVID. PARKS 27(SI) Supplementary Online Material, p. 23.

Keleher, N., Barela, M.C., Blumenstock, J., Festin, C., Podolsky, M., Troland, E., Rezaee, A. and Heimerl, K. (2020). Connecting Isolated Communities: Quantitative Evidence on the Adoption of Community Cellular Networks in the Philippines. In Proceedings of Information and Communication Technologies and Development (ICTD '20). ACM, New York, NY, USA. DOI: 10.1145/3392561.3394645

Kithia, J., Wanyonyi, I., Maina, J., Jefwa, T. and Gamoyo, M. (2020). The socio-economic impacts of COVID-19 restrictions: data from the coastal city of Mombasa, Kenya. Data in Brief, 33: 106317. DOI: 10.1016/j.dib.2020.106317

Kyne, F., Chapman, J., Rodriguez, M. and Verde, J. (2021). Case Study 3: Northern Belize Coastal Complex, Belize. In Phua et al. (2021) Marine protected and conserved areas in the time of COVID. PARKS 27(SI) Supplementary Online Material, p. 12. 
Laffoley, D., Baxter, J.M., Amon, D.J., Claudet, J., Hall-Spencer, J.M., Grorud-Colvert, K., Levin, L.A., et al. (2020a). Evolving the narrative for protecting a rapidly changing ocean, postCOVID-19. Aquatic Conservation: Marine and Freshwater Ecosystems. DOI: 10.1002/aqc.3512

Laffoley, D., Baxter, J.M., Amon, D.J., Currie, D.E., Downs, C.A., Hall-Spencer, J.M., Harden-Davies, H. et al. (2020b). Eight urgent, fundamental and simultaneous steps needed to restore ocean health, and the consequences for humanity and the planet of inaction or delay. Aquatic Conservation: Marine and Freshwater Ecosystems, 30(1): 194-208. DOI: 10.1002/aqc.3182

Leach, M., MacGregor, H., Scoones, I. and Wilkinson, A. (2020). Post-pandemic transformations: How and why COVID-19 requires us to rethink development. World Development, 105233. DOI: 10.1016/j.worlddev.2020.105233

Mangubhai, S. (2021). Case Study 15: Vatu-i-Ra Conservation Park in Fiji. In Phua et al. (2021) Marine protected and conserved areas in the time of COVID. PARKS 27(SI) Supplementary Online Material, p. 47.

Martinez, V.I., Casteñada, A., Gongora, M., Wade, B. and Requena, N. (2018). Managed access: a rights-based approach to managing small-scale fisheries in Belize. FAO. $<$ http://www.fao.org/fishery/static/tenure-user-rights/root/ volume3/C311.pdf>

MedPAN. (2020). The lockdown seriously impacted Mediterranean MPAs - Results of our survey. Available at: <http:// medpan.org/the-lockdown-seriously-impacted-mediterraneanmpas-results-of-our-survey/>

Meyers, D., Alliance, C.F., Bohorquez, J., Cumming, B.F.I.B., Emerton, L., Riva, M., Fund, U.J.S. and Victurine, R. (2020). Conservation finance: a framework. Conservation Finance Alliance, pp.1-45. DOI: 10.13140/RG.2.2.14186.88000

Moraes, O. (2019). Blue carbon in area-based coastal and marine management schemes-a review. Journal of the Indian Ocean Region 15(2): 193-212. DOI: 10.1080/19480881.2019.1608672

MPA News. (2020a). MPAs, COVID-19, and the coming financial crisis: What impacts are practitioners already seeing, and how are they responding? (7 May 2020). Available at: <https://mpanews.openchannels.org/news/mpa-news/mpascovid-19-and-coming-financial-crisis-what-impacts-arepractitioners-already>

MPA News. (2020b). Funding MPAs by selling blue carbon credits: Practitioners from the first projects describe their experience so far (30 July 2020). Available at: <https:// mpanews.openchannels.org/news/mpa-news/funding-mpasselling-blue-carbon-credits-practitioners-first-projects-describe -their>

MPA News. (2020c). Selling carbon credits to fund MPAs, Part 2: Could MPAs sell credits based on their fish stocks? (5 October, 2020). Available at: <https:// mpanews.openchannels.org/news/mpa-news/selling-carboncredits-fund-mpas-part-2-could-mpas-sell-credits-based-theirfish>

Ndagala, J. and Medard, M. (2021). Case Study 8: Mafia Island Marine Park, Tanzania. In Phua et al. (2021) Marine protected and conserved areas in the time of COVID. PARKS 27(SI) Supplementary Online Material, p. 25.
Nicholas, T. (2019). Microcredit scheme benefits coastal communities and marine conservation in Tanzania. Fauna \& Flora International. (October 16, 2019). Available at: <https:// www.fauna-flora.org/news/microcredit-scheme-benefitscoastal-communities-marine-conservation-tanzania>

Northrop, E., Konar, M., Frost, N. and Hollaway, E. (2020). A Sustainable and Equitable Blue Recovery to the COVID-19 Crisis. Report. Washington, DC: World Resources Institute. $<$ https://oceanpanel.org/sites/default/files/202009/20_HLP_Report_COVID_Blue_Recovery.pdf>

Oates, J., Augustave, L.C. and Brayne, K. (2021). Case Study 9: Velondriake Locally Managed Marine Area, Madagascar. In Phua et al. (2021) Marine protected and conserved areas in the time of COVID. PARKS 27(SI) Supplementary Online Material, p. 28.

OECD. (2016). The ocean economy in 2030. Paris: OECD Publishing. DOI: 10.1787/9789264251724-en.

People and the Sea. (2020). The impact of COVID-19 on People and the Sea. Available at: <https://www.peopleandthesea.org/ the-impact-of-covid-19-on-people-and-the-sea/> Accessed 16 November 2020.

Robinson, J. (2018). REDD+ Unchained: Blockchain and Climate Change Mitigation. (5 November 2018). Available at: < https:// ecosphere.plus/2018/11/05/redd-unchained-blockchain-andclimate-change-mitigation-2/>

Sala, E., Lubchenco, J., Grorud-Colvert, K., Novelli, C., Roberts, C. and Sumaila, U.R. (2018). Assessing real progress towards effective ocean protection. Marine Policy, 91: 11-13. DOI: 10.1016/j.marpol.2018.02.004

Sanjaya, W., Widodo H., Currier K. and Djohani, R. (2021). Case Study 12: Nusa Penida Marine Protected Area, Bali, Indonesia. In Phua et al. (2021) Marine protected and conserved areas in the time of COVID. PARKS 27(SI) Supplementary Online Material, p. 39.

Severino, S.J.L., Rodgers, K.S., Stender, Y. and Stefanak, M. (2020). Hanauma Bay Biological Carrying Capacity Survey 2019-20 2nd Annual Report. University of Hawaii: Hawaii Institute of Marine Biology. Coral Reef Ecology Laboratory/ Coral Reef Assessment Monitoring and Programme. <http:// www.honolulu.gov/rep/site/dpr/hanaumabay_docs/ Hanauma_Bay_Carrying_Capacity_Report_August_2020.pdf $>$

Shah, N. (2017). Crowd funding for Marine Protected Area management. Panorama. (24 July 2017). Available at: $<$ https://panorama.solutions/en/solution/crowd-funding-marine -protected-area-management>

Shah, N. and Wells, S. (2021). Case Study 10: Seychellois Marine Protected Areas, Seychelle. In Phua et al. (2021) Marine protected and conserved areas in the time of COVID. PARKS 27(SI) Supplementary Online Material, p. 31

UNDP. (2020). Six things blockchain can do for the SDGs. Available at: <https://feature.undp.org/beyond-bitcoin/\#group5-things-blockchain-can-do-for-the-sdgs-CWDXIGEkKN> Accessed 16 November 2020.

UNEP-WCMC, IUCN and NGS (2018). Global Coverage. In: Protected Planet Report 2018. Cambridge, UK; Gland, Switzerland; and Washington, DC, USA: UNEP-WCMC, IUCN and NGS. Available at: <https://livereport.protectedplanet.net/ chapter-2> 
Vallarola, F. and Prvan, M. (2021). Case Study 6: Adriatic Sea Marine Protected Areas, Croatia \& Italy. In Phua et al. (2021) Marine protected and conserved areas in the time of COVID. PARKS 27(SI) Supplementary Online Material, p. 20.

Wenzel, L. and Clark, A. (2021). Case Study 1: Papahānaumokuākea Marine National Monument, Hawaii, United States. In Phua et al. (2021) Marine protected and conserved areas in the time of COVID. PARKS 27(SI) Supplementary Online Material, p. 5.

Wenzel, L. and Fangman, S. (2021). Case Study 4: Florida Keys National Marine Sanctuary, Florida, United States. In Phua et al. (2021) Marine protected and conserved areas in the time of COVID. PARKS 27(SI) Supplementary Online Material, $\mathrm{p}$. 14.
WWF-Australia. (2020). WWF-Australia and OPENSC. Available at: <https://www.wwf.org.au/get-involved/panda-labs/ opensc\#gs.Imokof> Accessed 16 November 2020.

Zafra-Calvo, N., Garmendia, E., Pascual, U., Palomo, I., GrossCamp, N., Brockington, D., Cortes-Vazquez, J.A., Coolsaet, B. and Burgess, N.D. (2019). Progress toward equitably managed protected areas in Aichi Target 11: A global survey. BioScience, 69(3): 191-197. DOI: 10.1093/biosci/biy143

Zavala-Alcívar, A., Verdecho, M.J. and Alfaro-Saíz, J.J. (2020). A conceptual framework to manage resilience and increase sustainability in the supply chain. Sustainability, 12(16): 6300. DOI: $10.3390 /$ su12166300

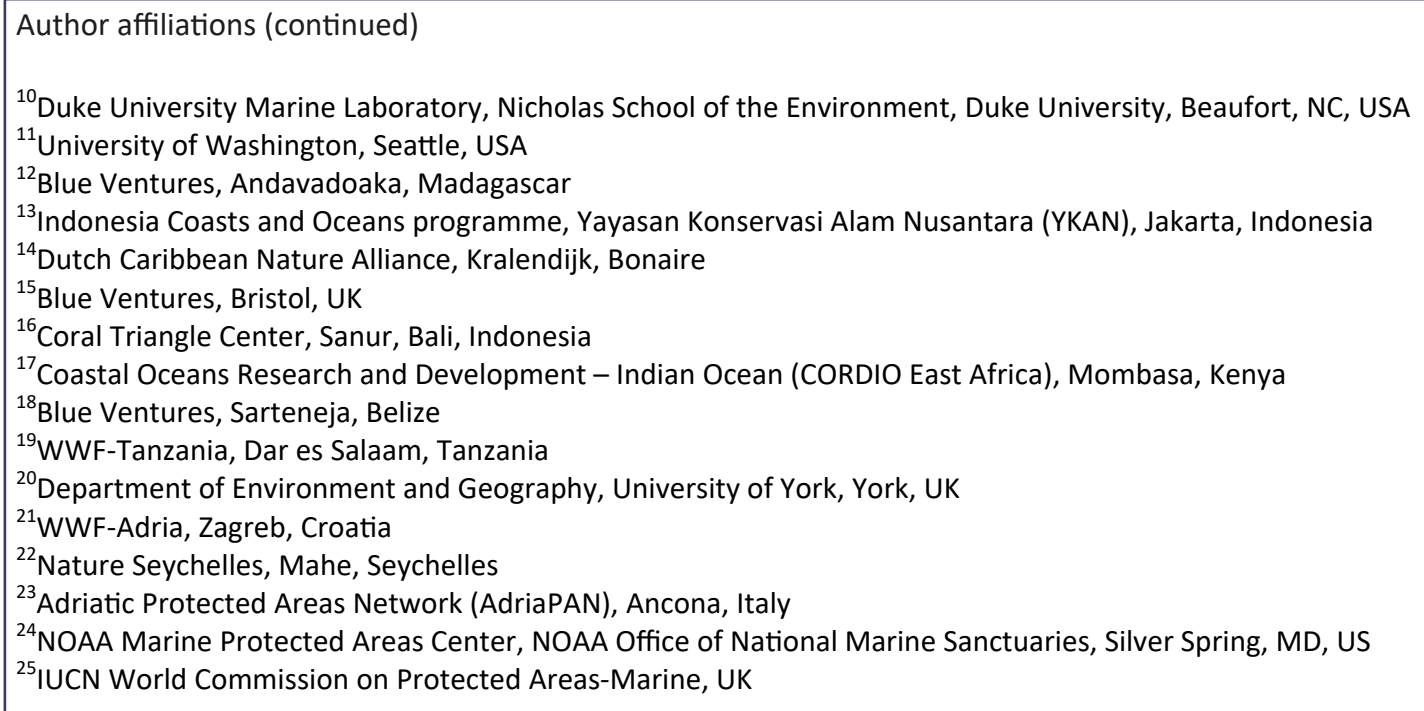




\section{RESUMEN}

La intersección de los posibles objetivos y compromisos mundiales establecidos para la conservación de los océanos con la pandemia del COVID-19 en 2020, ha permitido reconsiderar el futuro de los instrumentos de conservación basados en las áreas marinas, en particular para las áreas marinas protegidas y conservadas (AMPC). Dado que las AMPC continúan prestando servicios ecológicos, sociales y económicos esenciales, los enfoques actuales para establecer y gestionar estas áreas requieren una comprensión de los factores que impulsan las presiones a las que se enfrentan. Examinamos brevemente su estado prepandémico y ofrecemos una visión general de los impactos del COVID-19 mediante la presentación de 15 estudios de caso. Los impactos son de dos tipos: los que afectan los medios de vida y el bienestar de las comunidades locales y los interesados directos que dependen de las AMPC; y los que afectan la gestión y gobernanza de las AMPC. Las respuestas de los administradores y las comunidades han abordado: la gestión de los recursos; los ingresos y la seguridad alimentaria; la vigilancia y la aplicación de la ley; las cadenas de suministro de alimentos de origen marino; y la comunicación entre los administradores, los miembros de la comunidad y otras partes interesadas. Por último, examinamos las herramientas y enfoques innovadores para la ampliación y el cambio transformacional, haciendo hincapié en las sinergias entre la gestión para la conservación y la gestión de los medios de vida sostenibles, y su relación con los principios de equidad y resiliencia.

\section{RÉSUMÉ}

La rencontre en 2020 entre les objectifs et les engagements mondiaux pour la conservation des océans et la pandémie de COVID-19 a permis de repenser l'avenir des outils de conservation marine, en particulier pour les aires marines protégées et conservées (AMP). Dès lors que les AMP continuent de fournir des services écologiques, sociaux et économiques essentiels, il est crucial que les approches actuelles pour les créer et les gérer tiennent compte des facteurs de pression qu'elles subissent. Nous passons brièvement en revue leur état avant la pandémie et fournissons un aperçu des impacts de la COVID-19 à travers 15 études de cas. Les impacts sont de deux types: ceux qui touchent aux moyens de subsistance et au bien-être des communautés locales et des parties prenantes qui dépendent de l'AMP, et ceux qui concernent la gestion et la gouvernance de l'AMP elle-même. Les réponses des communautés et des gestionnaires ont porté sur la gestion des ressources, le revenu et la sécurité alimentaire, la surveillance et le contrôle, les chaînes d'approvisionnement des produits de la mer, et la communication entre les gestionnaires, les membres de la communauté et les autres parties prenantes. Pour conclure, nous discutons d'approches et d'outils innovants d'analyse et de changement transformationnel, en mettant l'accent sur les synergies entre la gestion de la conservation et la gestion des moyens de subsistance durables, et comment celles-ci sont liées aux principes d'équité et de résilience. 


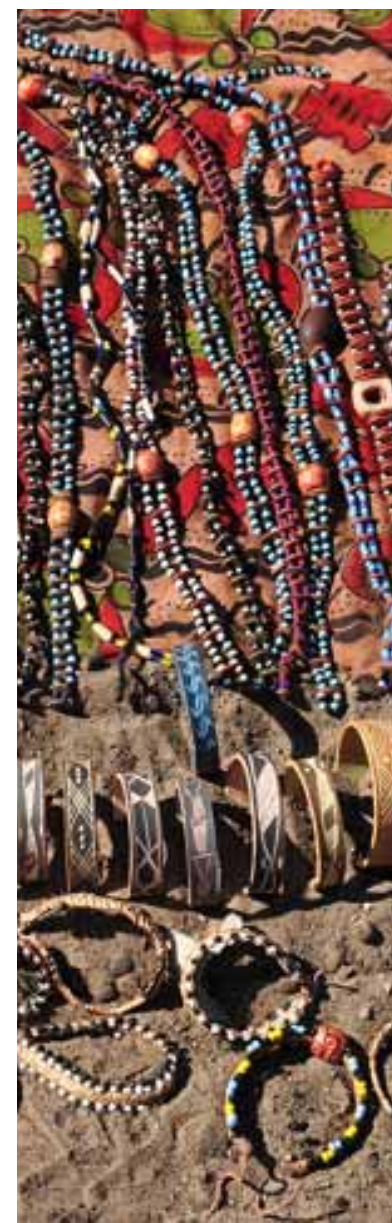

\title{
TOURISM IN PROTECTED AND CONSERVED AREAS AMID THE COVID-19 PANDEMIC
}

\author{
Anna Spenceley ${ }^{1 *}$, Steve $\mathrm{McCool}^{2}$, David Newsome ${ }^{3}$, Ana Báez ${ }^{4}$, James R. \\ Barborak $^{5}$, Clara-Jane Blye ${ }^{6}$, Kelly Bricker ${ }^{7}$, Hery Sigit Cahyadi ${ }^{8}$, Katherine \\ Corrigan $^{9}$, Elizabeth Halpenny 6 , Glen Hvenegaard ${ }^{10}$, Delphine Malleret King ${ }^{11}$, \\ Yu-Fai Leung ${ }^{12}$, Ante Mandić ${ }^{13}$, Robin Naidoo ${ }^{14}$, Dominik Rüede ${ }^{15}$, James \\ Sano ${ }^{16}$, Mahmoud Sarhan ${ }^{17}$, Veronica Santamaria ${ }^{18}$, Thiago Beraldo Sousa ${ }^{19}$ \\ and Anne-Kathrin Zschiegner20
}

\author{
Corresponding author: annaspenceley@gmail.com \\ ${ }^{1}$ School of Tourism and Hospitality, University of Johannesburg, South Africa \\ ${ }^{2}$ University of Montana, USA \\ ${ }^{3}$ Environmental and Conservation Sciences Group, Murdoch University, Australia. \\ ${ }^{4}$ Turismo \& Conservación Consultores S.A \\ ${ }^{5}$ Center for Protected Area Management, Colorado State University, Fort Collins, CO, USA \\ ${ }^{6}$ Faculty of Kinesiology, Sport, and Recreation, University of Alberta, Edmonton, $A B$, \\ Canada \\ ${ }^{7}$ Department of Parks, Recreation, and Tourism at the University of Utah, Salt Lake City \\ Utah, USA \\ ${ }^{8}$ Destination Tourism Studies, Bandung Institute of Tourism, Bandung, West Java, \\ Indonesia.
}

Author affiliations continue on page 117

\begin{abstract}
The COVID-19 pandemic has had a global impact on the tourism sector. With tourism numbers dramatically reduced, millions of jobs could be lost, and progress made in equality and sustainable economic growth could be rolled back. Widespread reports of dramatic changes to protected and conserved ${ }^{1}$ area visitation have negative consequences for conservation finances, tourism businesses and the livelihoods of people who supply labour, goods and services to tourists and tourism businesses. This paper aims to share experiences from around the world on the impacts of the COVID-19 pandemic on protected area tourism; and considers how to build resilience within protected area tourism as a regenerative conservation tool.
\end{abstract}

Key words: sustainable tourism, protected area, conserved areas, parks, COVID-19 pandemic, resilience, impacts, recovery

\section{OVERVIEW OF COVID-19 AND TOURISM}

The COVID-19 pandemic has impacted the tourism sector globally. Between J anuary and May 2020, every global destination imposed travel restrictions, and 45 per cent totally or partially closed their borders to tourists (United Nations World Tourism Organization UNWTO, 2020a). The World Travel and Tourism Council (WTTC) estimates that the COVID-19 pandemic has caused a global loss of up to 174 million direct tourism jobs and the elimination of US\$ 4.7 trillion from the sector's contribution to GDP (a 53 per cent loss compared to 2019) (WTTC, 2020a). With the tourism value chain rolled back, much progress made in sustainable economic growth is at risk (UNWTO, 2020b). This is the scale of uncertainty and change that now threatens tourism.

Before the COVID-19 pandemic, protected areas received roughly 8 billion visits ${ }^{2}$ annually, and generated approximately US\$ 600 billion per year in direct in-country expenditures and US\$250 billion per year in consumer surplus (Balmford et al., 2015). The WTTC (2019) calculated that 21.8 million jobs were supported by wildlife tourism globally, and in Africa over a third of all direct tourism GDP could be attributed to wildlife. Many operators working in protected areas have based their business models on sustainable development principles, and have actively 
contributed to biodiversity conservation and local economic development (Snyman \& Spenceley, 2019; Mitchell \& Ashley, 2010). However, it is difficult to say just how sustainable practices in this sector really are: some destinations suffered from excessive tourism before the pandemic (UNWTO, 2019; Peeters et al., 2018).

For many protected areas, the negative impacts of the COVID-19 pandemic on management capacity, budgets and effectiveness are significant, as are those on the livelihoods of communities living in and around these areas (Hockings et al., 2020). Furthermore, many staff and members of surrounding communities contracted COVID-19, and illness and deaths further reduced agencies' capacity to manage tourism.

This paper aims to: document the diversity of impacts through case studies; describe how protected area tourism is now operating in a COVID-19 pandemic world; and suggest that this opportunity be used to rethink, plan and implement a more holistic tourism. Attaining the UN Sustainable Development Goals is a priority, particularly for vulnerable communities living in or near protected areas (Spenceley \& Rylance, 2019).

\section{CASE STUDIES ON IMPACTS OF THE COVID-19 PANDEMIC ON PROTECTED AREA TOURISM}

The authors have contributed globally-distributed case studies describing the impacts of COVID-19 on protected area tourism. The first section describes the impacts of the pandemic on PCAs, and responses in different countries; the second illustrates the experiences of operators.

\section{Impacts on protected areas}

Brazil: The 334 federally managed protected areas, covering 170 million hectares, reported about 15.3 million visits in 2019. Though all were closed to visitation in March 2020, most reopened between August and October, but with a loss of about 5 million visits over the year (Breves et al., 2020). Re-opened protected areas apply strict health protocols and procedures, including the use of masks, alcohol for sanitising surfaces and social distancing. Based on an economic analysis of tourism's contribution to the Brazilian economy in 2018 (Souza et al., 2020), the reduced number of visitors will lead to a loss of US\$ 1.6 billion in sales for businesses working directly and indirectly with tourism around protected areas. It will also mean that 55,000 permanent or temporary jobs will be lost, employees and businesses will lose US $\$ 410$ million, and Brazil's GDP will be reduced by US $\$ 575$ million.
Namibia: Closure and prohibitions halted tourism in Namibia, which received 1.7 million international travellers in 2019 (Namibia Tourism Board, undated). Initial estimates suggested Namibia's communal conservancies could lose US\$ 10 million in direct tourism revenues, threatening funding for 700 game guards and 300 conservancy management employees, and the viability of 61 joint venture tourism lodges employing 1,400 community members (WWF-Namibia, 2020). This will reduce incomes substantially, increasing poverty among households living in conservancies and near protected areas (Naidoo et al., 2015; Naidoo et al., 2019), and forcing families to rely more heavily on natural resource extraction to sustain livelihoods (e.g. hunting wildlife for meat). While the worst of these immediate impacts have been avoided via emergency funds raised to cover critical conservancy shortfalls, poaching of Namibia's iconic Rhinos and Elephants may yet increase. Indeed, the first rhinos poached in a communal conservancy in over two years occurred in April 2020, possibly due to reduced tourism and/or conservation presence. It remains to be seen whether the long-term, cumulative effects of the pandemic lead to the collapse of Namibia's much-lauded communal conservancy programme.

Costa Rica: Nature-based tourism in Costa Rica's national park system is a mainstay of the economy. In 2018, tourism revenue generated 30 per cent of the budget of the National System of Conservation Areas. The COVID-19 pandemic hit Costa Rica during its high season, and visits to protected areas ended abruptly in March 2020. By mid-May, due to business sector pressure, 18 national parks reopened at 50 per cent capacity with strict health protocols. As of J une 2020, 27 protected areas had reopened, but visitation was down by nearly 80 per cent because of restrictions on international travel. Despite continued domestic visitation, conservation agency revenues will be reduced since citizens pay only 20 per cent of the national park entry fees that international visitors pay.

Ecuador: During 2019, over 270,000 tourists visited the Galapagos Islands Marine Reserve and National Park. 67 per cent of visitors were international, with tourism contributing 66 per cent of the Galapagos' GDP. Protected areas in the Galapagos were closed to tourism during the second trimester of 2020, but patrolling, exotic species eradication, infrastructure maintenance and monitoring continued, free of tourists for the first time in 60 years. However, economic impacts were dramatic as park operations depend on tourism revenues, as do 3,000 of the Galapagos' 30,000 inhabitants. The shutdown ended on 1 July, but the 


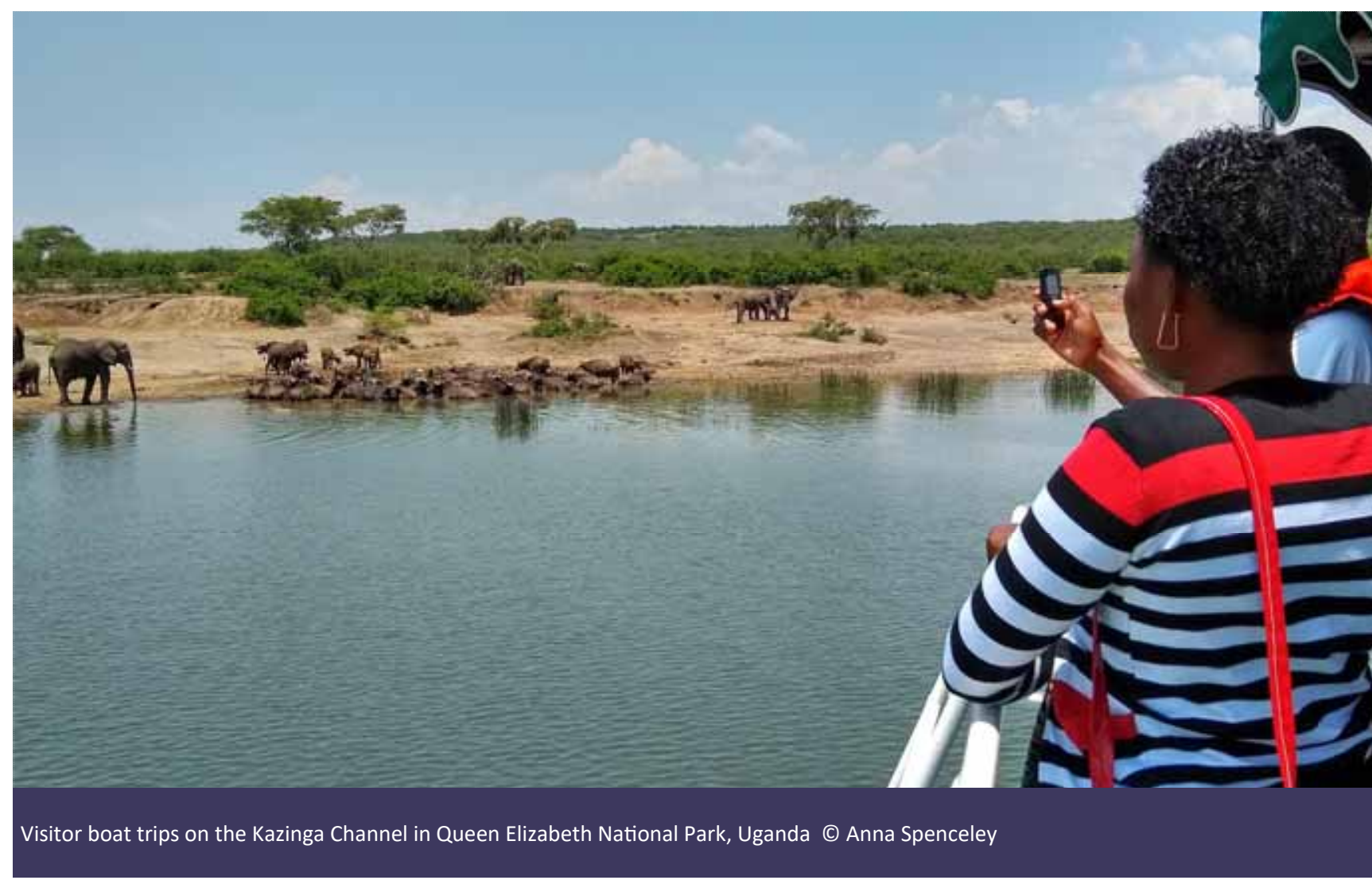

period without visitors gave park managers time to pause, reflect and plan for reopening. Guidelines for tourism reactivation were developed to reduce negative impacts, diversify products and services, and benefit local livelihoods. In future, local operators and guides will offer guided visits to tortoise breeding centres, and six new terrestrial visitor sites will be opened. Many locally based small tour boats will be allowed to operate new routes for day trip activities like snorkelling. Beaches will reopen to visitors and residents, but reservations will be required for sites that had high prepandemic visitation.

Indonesia: In 2019, the Rinjani Geopark in Indonesia received 700,000 visitors who spent 4 billion Rupiah (US\$ 283,000), while the Lake Toba Geopark had 12.1 million visitors and generated 942 billion Rupiah (US\$ 66.7 million) (Indonesian Geopark Commission, 2019). By April 2020, the government enforced total lockdown, and closed all tourist destinations. The tourism industry and local communities lost jobs (e.g. porters, mountain guides, homestay providers), though national park staff retained theirs. Environmental damage and congestion were reduced. In June, there was a gradual re-opening of natural area tourism sites, albeit with restrictions on visitor use, but congestion has re-emerged despite the COVID-19 pandemic.
Germany: In the Black Forest National Park, visitation increased by 100,000 visits between April and June 2020 compared with the same period in 2019 (a 50 per cent increase). Areas easily accessible from urban areas, and areas within the parks known for their tranquillity reported increased visitation. It is thought that the urban population's desire for nature and the preference for quiet places compared to crowded ones were factors. Many first-time visitors appeared unfamiliar with protected areas or even forests, and more people wanted to camp inside the protected area, which is not allowed. Some visitors justified their non-compliance with park rules as a wish to break free in nature during such restrictive times (Baden-Württemberg.de, 2020; Nationalpark Schwarzwald, 2020)

USA: The pandemic had a considerable impact on US protected areas. For example, in the case of Utah, its five national parks reported that 15.3 million visitors spent an estimated US\$ 1.2 billion in local gateway regions during 2019. This supported 18,900 jobs, generated US\$ 614 million in labour income, and added US\$ 1.1 billion in value and US\$ 1.9 billion in economic output to Utah's economy (National Park Service, 2020a). Economic impacts of COVID-19 closures have been significant. For example, Arches National Park reported about 404,000 fewer visitors between March and May 
2020; by August, though, visitation levels were near average. Communities living around national parks were the hardest hit, with the highest unemployment rates in Utah (DUDSE, 2020; DUDSW, 2020). At the same time, park managers adopted strategies to ensure safer visitation, such as timed entry, signage for social distancing, guidelines for responsible recreation and increased infrastructure cleaning (GNAR, 2020). Other popular national parks in the USA, such as Glacier, Yellowstone and J oshua Tree, reported rapid increases in visitation when they were re-opened.

Canada: Pandemic restrictions impacted provincial park visitors in Alberta, as COVID-19 restrictions changed the way people use parks (Hockings et al., 2020). A 2020 survey of people that had previously visited showed that 85 per cent intended to visit or had already visited a provincial park. Over 80 per cent agreed that parks were safe to visit during the pandemic; 23 per cent felt that provincial parks were safer than other destinations. Of the respondents who did not intend to visit a provincial park, 67 per cent were concerned about becoming infected with COVID19 and 60 per cent did not want to infect others. Only 40 per cent of respondents definitely wanted personal interpretation offered; of interpretive options, respondents preferred amphitheatre programmes (75 per cent) and guided hikes (56 per cent). The main reasons for not attending personal interpretation programmes were concerns about getting infected (37 per cent) and not wanting to infect others (34 per cent). Understanding visitor perceptions of COVID-19 can help parks foster the benefits of interpretation, which include enjoyment, learning and increased parkfriendly attitudes and behaviours (Hvenegaard \& Shultis, 2016; Cook et al., 2019).

\section{Impacts on tourism operators}

Research undertaken for the European Union by Spenceley (2020a) has demonstrated the dramatic effect of the pandemic on protected area tourism economies in Africa. Survey responses from 736 operators working in 41 African countries showed a 63 per cent decline in clients in March 2020 compared to the same time in 2019, with a 72 per cent drop in future bookings. 83 per cent of clients cancelled between March and J une 2020, with substantial impacts on local economies. 59 per cent of tourism employees are recruited locally, but because of the crisis 65 per cent are on reduced wages. Operators predict that if the crisis continues, over 17,000 of their local employees would be adversely affected. Local procurement of products, hospitality services and payments to community initiatives are predicted to be US\$ 81 million less than in the previous financial year (a 47 per cent decline). Compounding this is a likely reduction in operator expenditure on local environmental services by US\$ 26 million in 2020. Environmental crime is an immediate concern of 80 per cent of operators and 87 per cent predict that levels will increase because of the pandemic.

The Long Run is an NGO with nature-based tourism business members committed to sustainability ${ }^{3}$. Member experiences demonstrate how the pandemic is affecting individual operations. For example, in Kenya, 62 per cent of Cottar's Wildlife Conservation Trust's budget usually comes from visitor conservation fees, benefitting 6,000 Maasai families and 7,000 acres of wildlands. At Kicheche Mara Camp, communities mostly rely on tourism revenues earned from employment, land rental, local purchases, handicraft sales and for hiring vehicles. As a result of the pandemic, 74,000 acres of wildlife and ecosystems of the Mara North Conservancy are at risk, making the area vulnerable to poaching, bushmeat hunting and encroachment. A prolonged shut-down could cause irreversible damage because landowners are likely to return to different land uses, and tourism camps would close.

One of the most diverse reefs in the Indian Ocean, Chumbe Island Coral Park in Zanzibar (the first marine protected area in the world), is at risk. Since late March 2020, illegal fishing has been recorded within Chumbe's coral reef sanctuary, threatening nearly 30 years of protection and the nearby fishing grounds of local communities. A similar situation faces the 300,000-acre Misool Private Marine Reserve in Indonesia: without continued support from ranger patrols, the conservation gains made since 2005 could be lost.

A public-private-partnership ecotourism initiative is being implemented in Wadi el Gemal National Park (WGNP) in Egypt (Sarhan, 2016, 2017). The partners jointly operate ecotourism projects providing jobs for the local Ababda tribe, improving their living conditions, supporting tourism businesses, increasing park revenues and boosting the local economy (Sarhan, 2018). Responding to COVID-19, and a dramatic drop in visitation, partners in the WGNP in Egypt are implementing a Crisis Management Plan, financed through the partners' resources and an international donor (Abu Ghosoun NGO, 2020). A package of socioeconomic development programmes is helping to mitigate the social impacts (see Figure 1). These include the Village Savings and Loan Association micro-credit programme, five organic beekeeping projects and a local 


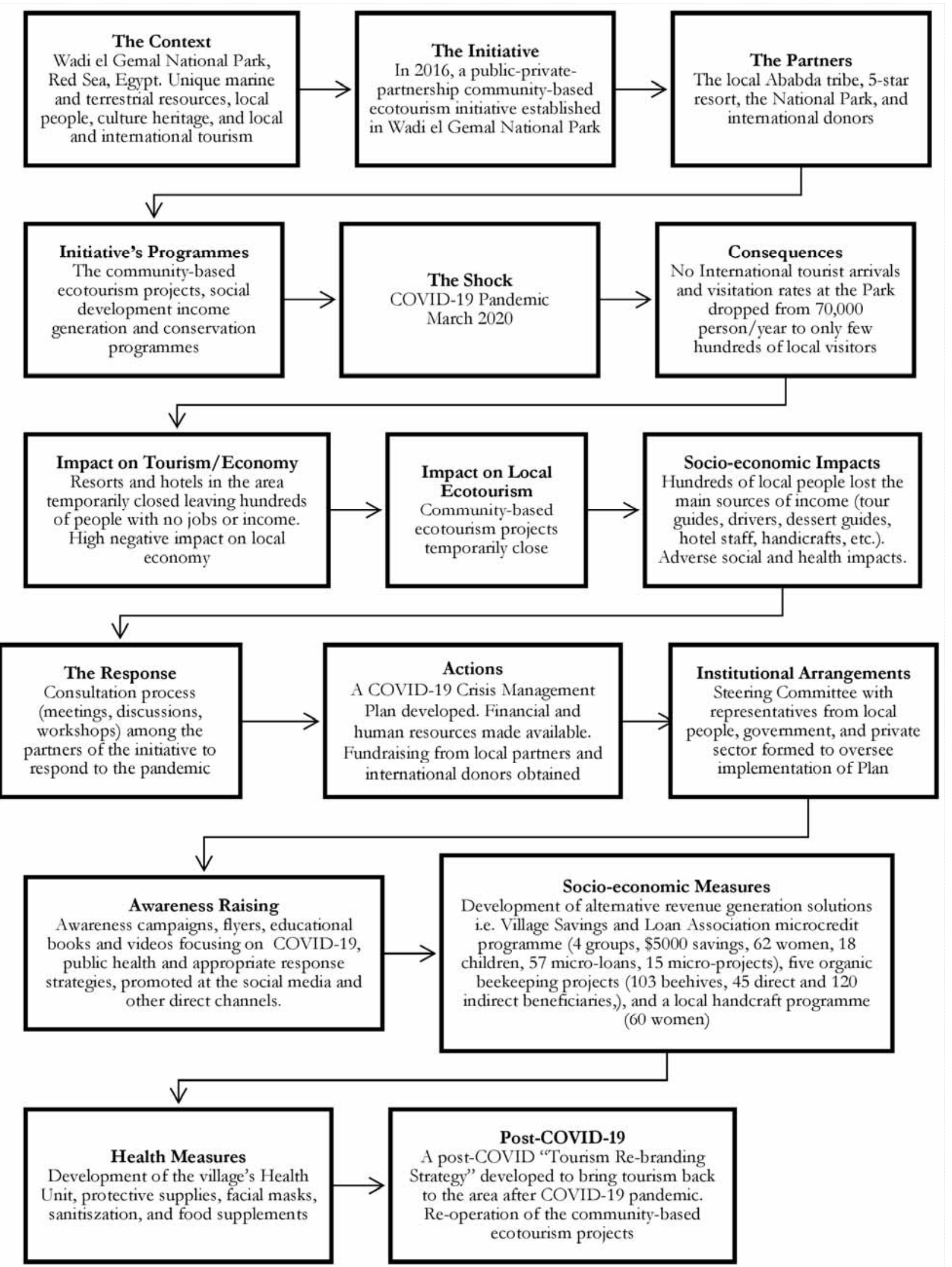

Figure 1. Responding to the Pandemic: The community-based ecotourism public-private partnership initiative in Wadi el Gemal National Park in Egypt 
women's handcraft programme (Elgebal, 2020; Soliman, 2020). Support is also given to the village's Health Unit, as well as supplies of protective equipment, face masks, sanitisation, food supplements, awareness raising materials and training. A post-COVID -19 pandemic 'Tourism Re-branding Strategy' was developed, employing several public relations agencies in Europe to help tourism recover after the pandemic.

The pandemic will probably have immediate and longer -term effects on protected areas. Reduced funds for conservation, and the challenges of reopening parks, may well hinder management efforts and postpone monitoring. Though our present understanding of the full extent of the impacts is limited, it is certain that, in the absence of a revival in international visitor numbers, many protected areas and private sector tourism enterprises will continue to experience devastating revenue and job losses - with consequential damage to conservation and the economy.

Amid the COVID-19 pandemic, there are numerous reports of wildlife and natural areas thriving in the absence of people (see Spenceley, 2020d), suggesting that nature is sending us a message (UN News, 2020). However, there are also challenges where wildlife has become dependent on tourists for food (e.g., Primates and Elephants in Asia: Kretchmer, 2020; Hamdi, 2020). More importantly, conservation and local antipoaching and conservation programmes have had to be cut as tourism revenue collapses (Spenceley, 2020a), resulting in increased levels of poaching in some locations (Hockings et al., 2020).

In response to this, governments, multilateral financial and development institutions and foundations, private equity/venture capital investors and NGOs are coming together to provide emergency liquidity for private sector tourism enterprises and to invest in supporting long-term sustainable recovery programmes that favour biodiversity and poverty alleviation (IUCN, 2020; Spenceley, 2020c, 2020d; Anon, 2020).

\section{MANAGING TOURISM BETTER AND BUILDING RESILIENCY}

This pandemic has highlighted the significant role that protected areas play in human health and wellbeing, "especially after a long period of lockdown or enforced isolation" (Hockings et al., 2020: pp. 16-17). It also demonstrates the interconnectedness between stakeholders and sectors, including private enterprise, public health, government and NGOs. Recovery cannot be achieved by any one sector alone: collaboration is fundamental if we want sustainable tourism and healthy ecosystems, where thriving business are linked to the
KEEP YOUR SOCIAL DISTANCE

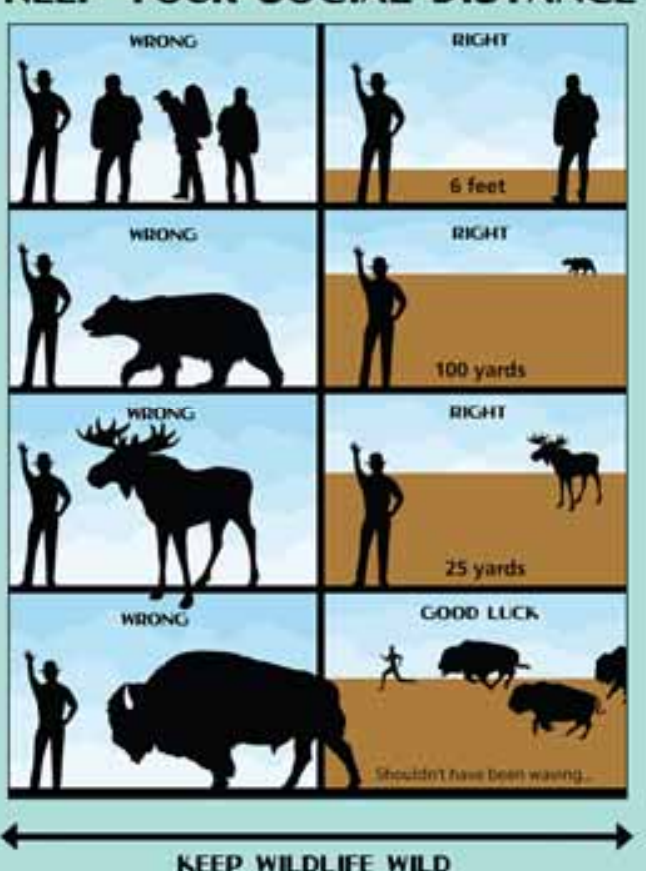

Communicating COVID-19 precautions to tourists in the USA (National Park Service, 2020b)

wellbeing of local people. This section provides examples of constructive responses to the COVID-19 pandemic and strategies for operating visitation amid these conditions.

Managers of protected areas are under pressure to provide facilities for visitors safely (Hockings et al., 2020), but there are challenges because of rapidly changing intelligence and new health and safety requirements. A guidance document developed under a European Union project provides information for protected areas on operating tourism amid the COVID19 pandemic (Spenceley, 2020b). It includes examples and links based on reputable international and national advice, and also protected area authority recommendations. There is information on health and hygiene standards, planning and distribution of visitors, consultation and coordination, managing interactions between wildlife and people (e.g. to avoid further zoonotic disease transmission), and risk assessment analyses (see Kingsford \& Biggs, 2012). The guidance includes suggestions on how to manage visitation safely - with recommendations for before, and when, visitors arrive, including in gateway communities. There is advice on training and equipment for staff, financing interventions and options for online-visits (i.e. where protected areas are not yet able to open). Reviewed by 
representatives of WCPA, UNESCO, WWF and others, this guidance should become a useful resource when reopening natural attractions, even in unique and remote global destinations (e.g. Antarctica: Falk, 2020).

\section{AN OVERVIEW OF TOURISM AND PROTECTED AREAS IN THE TIME OF COVID-19}

Drawing on the case studies and other evidence, we identify several key features of how protected area tourism has been affected by the pandemic (see Table 1 and below).

Visitor numbers fell sharply but have begun to recover: Agencies and the industry have long encouraged public use and outdoor recreation in protected areas, promoting access and inclusivity. While COVID-19 still impacts negatively on tourism, upbeat stories demonstrate the enduring passion for parks that makes outdoor recreation a major economic driver in many countries. After many tourism destinations closed in March 2020, news circulated of the relatively low risk of contagion outdoors and of the safety and health benefits of socially distanced outdoor pursuits in times of social isolation. Many high-density venues remain closed, or with restricted visitation, but COVID-19 has spurred innovation and encouraged dispersed recreation. In many countries, parks that closed have since cautiously reopened. Many governments and the outdoor industry

Table 1. The impact of the pandemic on protected area tourism - summary of experience from the case studies

\begin{tabular}{|c|c|c|c|c|c|c|c|c|}
\hline Effect or Action & $\begin{array}{l}\text { w } \\
\underline{N}\end{array}$ & 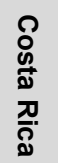 & 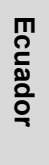 & $\begin{array}{l}z \\
\frac{z}{3} \\
\frac{\sigma}{n}\end{array}$ & $\begin{array}{l}\bar{\Xi} \\
\frac{0}{0} \\
\frac{0}{3} \\
\frac{\mathscr{B}}{2}\end{array}$ & 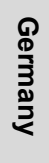 & $\stackrel{\complement}{\infty}$ & ช్ \\
\hline \multicolumn{9}{|l|}{ During lockdown } \\
\hline Reduced number of visitors & $\checkmark$ & $\checkmark$ & $\checkmark$ & $\checkmark$ & $\checkmark$ & & $\checkmark$ & $\checkmark$ \\
\hline Loss of tourism revenue/employment & $\checkmark$ & $\checkmark$ & $\checkmark$ & $\checkmark$ & $\checkmark$ & $\checkmark$ & $\checkmark$ & \\
\hline Increased number of visitors & & & & & & $\checkmark$ & & \\
\hline Conservation efforts maintained and scope for site restoration & & & $\checkmark$ & & & & & \\
\hline Reduced management effectiveness/conservation actions & $\checkmark$ & & & $\checkmark$ & & & & \\
\hline Increased poaching & & & & $\checkmark$ & & & & \\
\hline \multicolumn{9}{|l|}{ Easing of lockdown } \\
\hline Return to pre-lockdown visitation levels & & $\boldsymbol{\nabla}$ & & & $\checkmark$ & $\Delta$ & $\checkmark$ & \\
\hline Change in composition of visitors & & & & & & $\checkmark$ & $\checkmark$ & \\
\hline Non-compliance and anti-social behaviour & & & & & & $\checkmark$ & $\checkmark$ & \\
\hline Renewed concern about visitation and environmental damage & $\checkmark$ & & & & $\checkmark$ & & $\checkmark$ & \\
\hline \multicolumn{9}{|l|}{ Plans for post-COVID-19 recovery } \\
\hline Review of previous tourism/visitation situations & $\checkmark$ & & & & & & & \\
\hline Tourism reactivation guidelines & $\checkmark$ & & $\checkmark$ & & & & & \\
\hline \multicolumn{9}{|l|}{ Innovations } \\
\hline Reservation requirements for high visitation sites & & & $\checkmark$ & & & $\mathbf{x}$ & & $\checkmark$ \\
\hline Timed entry requirements & & & & & & $\mathbf{x}$ & $\checkmark$ & $\checkmark$ \\
\hline New site development & & & $\checkmark$ & & & & & \\
\hline Social distancing rules/education & $\checkmark$ & & & & & $\checkmark$ & $\checkmark$ & $\checkmark$ \\
\hline Cleaning of infrastructure & $\checkmark$ & & & & & & $\checkmark$ & $\checkmark$ \\
\hline
\end{tabular}


have implemented guidelines for staff and visitors to reduce COVID-19 risks, and domestic visitation has rebounded amid the collapse in international visitation. In many US protected areas, campgrounds are full, hiking and biking trails are busy, hunting and fishing license sales are up, and outdoor equipment sales are surging. Some protected areas are visited more now than before the pandemic, despite fear of travel by air and ship. Along with the shift in visitor profiles and decline in visitor spending, protected area visitors can enjoy the associated emotional and health benefits (Hockings et al., 2020; Buckley et al., 2019; Derrien et al., 2019).

Economic recovery is not straightforward: Even where visitor numbers have recovered, protected area revenues and local livelihoods are still suffering. For example, in the USA local and regional park systems that do not collect entrance fees, or charge less for local visitors, cannot recover the increased costs of coping with rising numbers of visitors. Visitors often avoid sitdown restaurants and densely packed tourism venues in gateway communities: so local sales tax revenue is lost and bankruptcies and layoffs may follow.

Safety considerations have been internalised into tourist management: For example, Alberta's provincial parks in Canada maintain their outdoor interpretive programmes but under new rules that require visitors to observe physical distancing (2 metres apart), to wear masks when people interact with others outside their social group, and to use hand sanitisers. They also turn away those who feel unwell or have been exposed to someone who tested positive, limit attendance and space out attendees (e.g. for amphitheatre programmes), and disinfect materials before and after use (Alberta Parks, 2020).

Some parks have developed online ways of sharing nature: Alberta Parks posts engaging webinars on its YouTube channel (Alberta Parks Nature Source, 2020), and 10 per cent of past park users access live webcams or digital tours of Alberta's parks. The Black Forest National Park in Germany put up an online format as a substitute for physical guided tours (Black Forest National Park, 2020).

Innovative ways of supporting tourist-dependent communities are emerging: For example, since the onset of the pandemic, members of The Long Run have held weekly brainstorming events to share lessons on how to help affected local communities. For example, Kualoa Ranch in Hawaii increased agricultural production and established a weekly farmers' market; Nikoi and Cempedak resorts in Indonesia brought back furloughed employees with the help of a community beach clean-up, Seven Clean Seas, to clear waste from beaches on Bintan Island; Caiman Ecological Refuge in Brazil developed tourism reopening protocols with the Brazilian government; Borana in Kenya channelled funds to its Mobile Clinic, visited by more than 700 people each month from vulnerable, remote communities; Kasiiya Papagayo in Costa Rica provided 100 per cent financing for an 'Eco carpentry Shop' to support local entrepreneurship, so creating new revenue streams; and in South Africa, Grootbos Private Nature Reserve's Football Foundation set up a food relief programme to feed more than 2,000 people daily since the pandemic started.

Innovation and product diversification are creating stronger alternative revenue streams in tourism destinations: For example, the Ku-Humelala Craft Group in South Africa have pivoted from making craft to sell to tourists to making face masks to protect people from coronavirus (andBeyond, 2020). In Kenya, the Ol Petjeja Conservancy has launched 'The Art of Survival' fund, which can be accessed through an art competition for children; winners get a fully paid trip there once the pandemic is over (Snyman, in DHDNR, 2020). In Alaska, Tutka Bay Lodge on the edge of Kachemak Bay State Park grows most of the produce used in the kitchen in greenhouses and gardens on site. While visitor rooms are empty, the employees are handmaking sausages, pickling and shrimping, learning new skills and developing new offerings (O'Brien, 2020).

The tourist market itself is adapting to the new circumstances: Market research demonstrates that amid COVID-19, people are seeking out adventure travel,

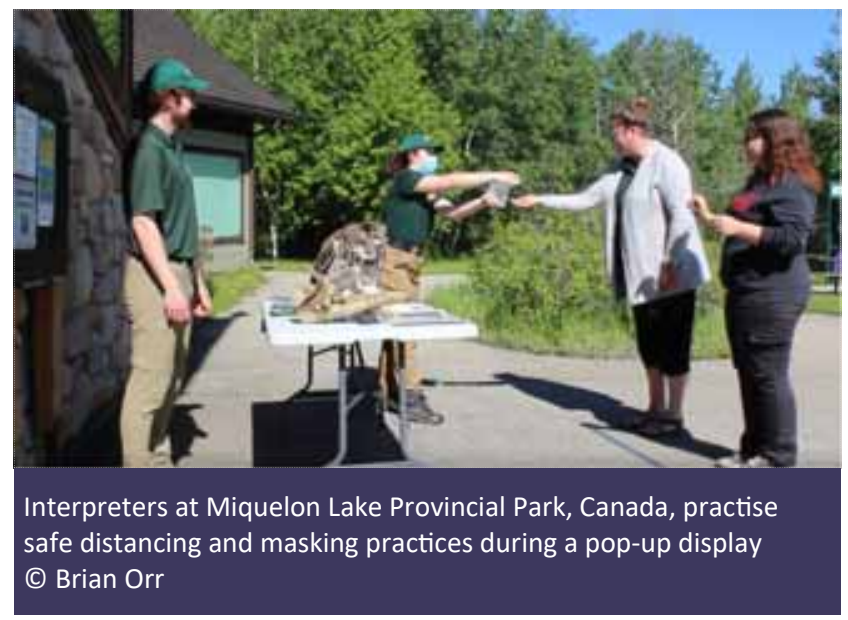


natural spaces and sustainable experiences (WTTC, 2020b; Tripadvisor, 2020; Bremner, 2020a; Galvani et al., 2020; Riley, 2020) (see Figure 2). The market segments of people that visit protected areas are becoming more diverse, with increased numbers of domestic and local travellers (e.g. APAP, 2020; SANParks, 2020). There is growing interest in staycations, micro-adventures and generally in domestic tourism rather than international travel (UNWTO, 2020c; Shoji, 2020; Kinsman, 2020). Domestic tourism can be encouraged through financial incentives, such as preferential pricing packages for local people and holiday vouchers, and through innovative marketing (for example, digital promotion and use of social media channels) (Lindsey et al., 2020; UNWTO, 2020c). However, it may be easier to bridge the financial gap in developed countries, because in many developing countries domestic travellers generate only a fraction of the revenue of internationals (e.g. 20-25 per cent in Kenya: J ames, 2020; J ohnson, 2020): the local market is smaller, often lower entrance fees are charged for local people, and generally locals will spend less on accommodation and activities.

\section{WHAT NEXT FOR PROTECTED AREA TOURISM?}

Before tourism recovery gains momentum, we need first to reflect on how protected areas were performing in the face of massive tourism pressure before the pandemic (e.g. Newsome, 2020). Often such a critical assessment of previous tourism scenarios will reveal opportunities for improvement.

Looking forward, there is much talk of building back better'. For tourism, this should not mean a return to business as usual but planning for forms of tourism that address climate change and biodiversity loss (GEF, 2020), and which are more inclusive, equitable and integrated with sustainable development principles. How can we learn from our experience with COVID-19 to ensure a more resilient and sustainable future for this industry? Nobody can predict how the pandemic will evolve, nor the recovery timeline, but stakeholders can identify plausible scenarios and create plans that work across these. Future directions need to build consensus on more sustainable pathways through best practice environmental management and encourage visitors to be more respectful of people, wildlife and the receiving environment. The United Nations World Tourism Organization (UNWTO) has developed a 'One Planet Vision for a responsible recovery of the tourism sector' indicating how a tourism recovery might help achieve a more resilient and sustainable future that works for people and planet (UNWTO, 2020d).

Our experience with COVID-19 shows that resilience is fundamental to the sustainability of protected area

\section{Travel in the new normal: recovery in domestic, intra-regional, then international}
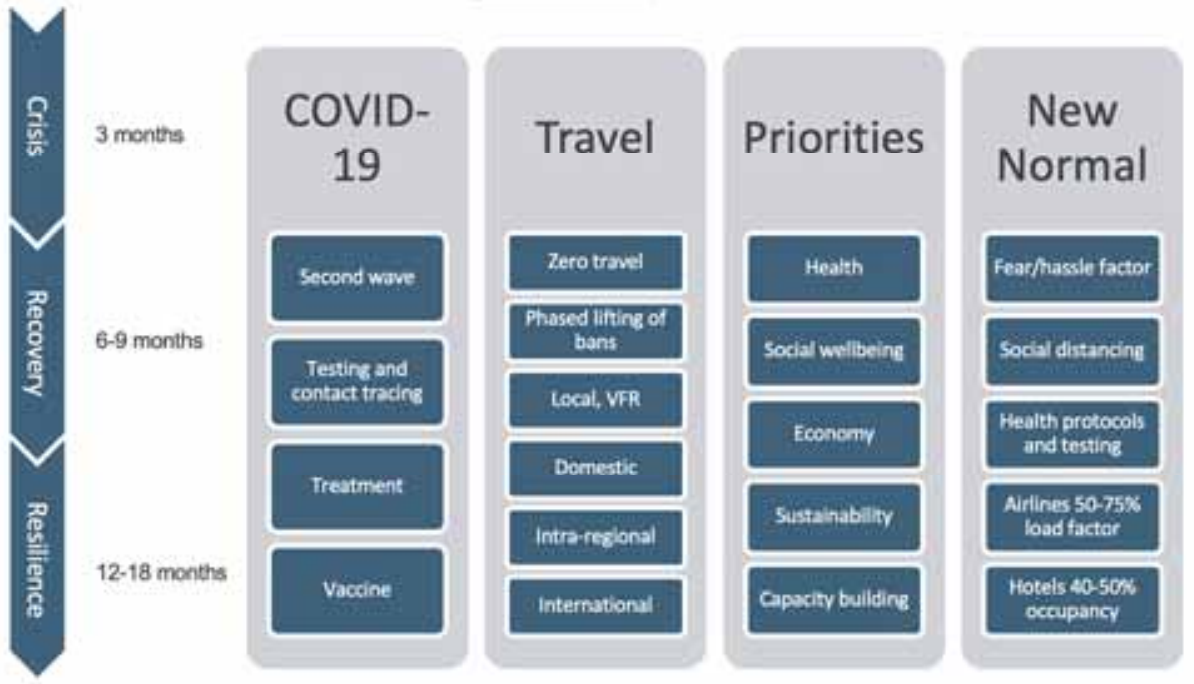

P turemantar intermational AFIIINTERNATIOHLLL

Figure 2. As travel recovers by stages the focus will be more on nature, adventure and sustainability (VFR = visiting friends and relatives) (Bremner, 2020b) 
tourism. 'Resilience' in terms of tourism means: safeguarding the health of visitors, local people and staff; creating more diverse income streams for the local economy; greater attention to equity and inclusiveness; and better understanding of the large-scale context for tourism, globally, such as changes affecting the airline industry (Nunes, 2020). Such challenges must be set in the context of addressing climatic issues and economic disparities.

Rebounding from the effects of the pandemic requires innovative thought about tourism experiences. Examples include: developing alternative land-based economic activities compatible with the destination's needs (e.g. Condor Valley, Argentina); small-scale regenerative agriculture businesses (e.g. Samara Reserve, South Africa); new products and guest experiences that include healthy practices and food; rethinking business models and engaging new markets (e.g. BatuBatu, Malaysia); expanding seasons and tailoring activities to new clients (e.g. Basecamp Oulanka, Finland); and creating virtual experiences such as 'the junior marine biologist programme' (e.g.
SixSenses Laamu, Maldives) and 'Safari Talks' (e.g. African Bush Camps, South Africa). Long-term resilience for protected areas also means strengthening the local economy, securing the financial viability of enterprises and considering the need for long-term investment (e.g. endowment funds) which will help achieve global conservation targets over the long term (Hvenegaard et al., 2012). Through a shift towards digital offerings, protected areas may increase the bonding between conservation and visitors and enable managers to educate people over long distances (Skinner, 2020; Cocks \& Tassiem, 2020).

We recommend that planning for tourism should become more holistic, inclusive, equitable and adaptable and focused on the question of what tourism can sustain. Many of the communities involved are particularly vulnerable to change because of distances from markets and their dependence on natural resources for livelihoods. The way forward for tourism could have five dimensions: (1) fostering openness to change, with a willingness to embrace new ways of thinking and acting; (2) developing a vision for the

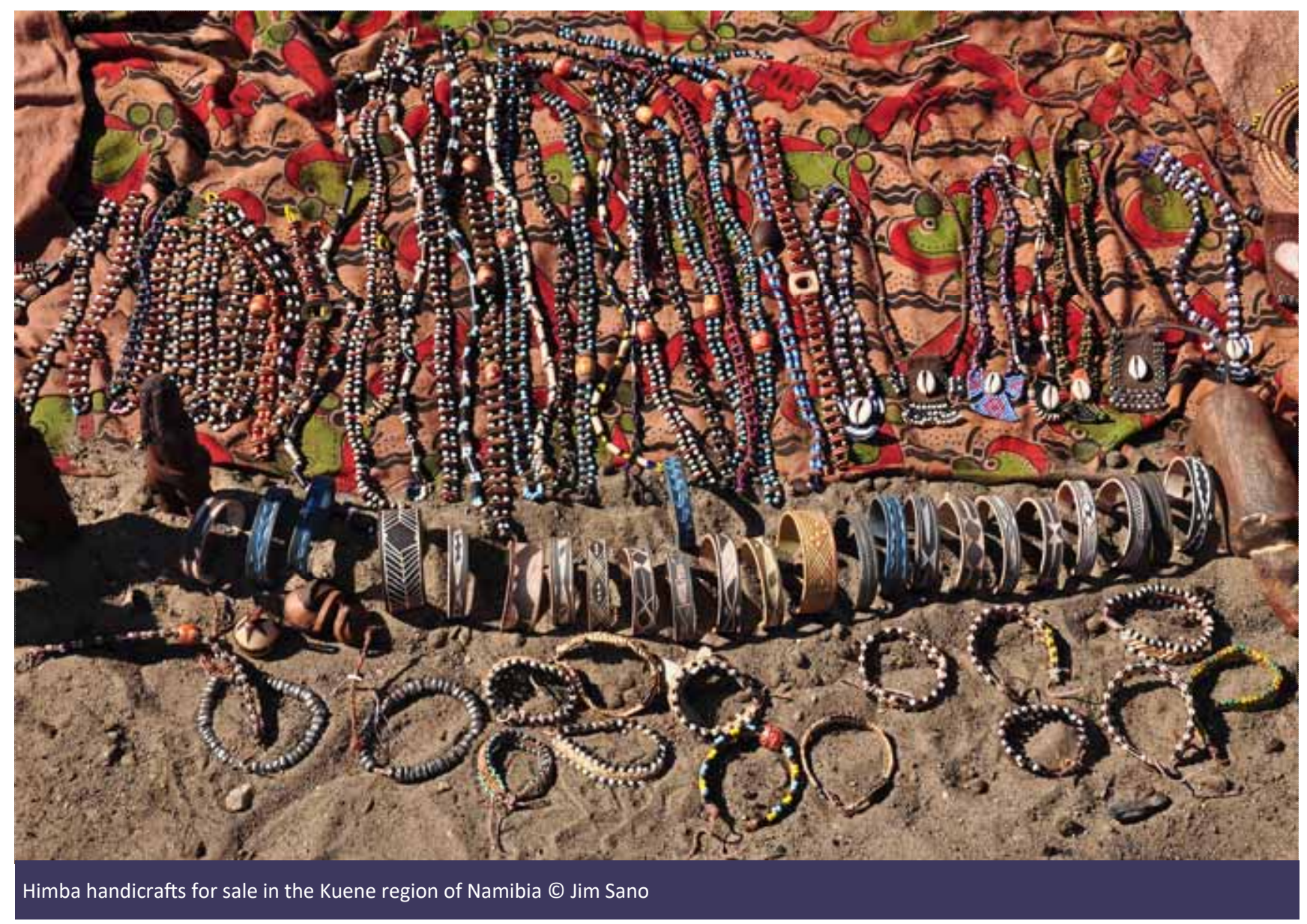


tourism offer of the future; (3) protecting biodiversity for its importance to the ecology of the area and peoples' dependency on tourism; (4) recovering and rebuilding local livelihoods and the health of residents and visitors; and (5) reframing tourism, including the resources it uses, to achieve productive and healthy livelihoods without degrading the biodiversity upon which it depends.

What we have learned from the COVID-19 experience reinforces time-tested principles and practices that have been developed over the years, such as those described in the 'IUCN Best Practice Guidelines' on sustainable tourism (Leung et al., 2018). For example, US federal agencies (National Park Service, US Forest Service, US Fish and Wildlife Service, etc.) have supported the adoption of a Visitor Use Framework which focuses on "managing visitor use to achieve or maintain desired conditions" (IVUM, 2020, p. 1). The experience of the COVID-19 pandemic requires us to see how tourism can promote human health and wellbeing in the destination communities, the health of ecosystems and a deeper visitor experience. The pandemic demonstrated that the most effective and resilient protected areas, particularly those experiencing increasing visitation, had put in place robust management frameworks. Monitoring is essential for professional management, especially during turbulent times when quick decisions must be made, as evidenced by experiences from Brazil and Germany, where monitoring quickly detected changed patterns of visitation, community impacts and ecosystem responses. Several cases suggest the importance of working with local communities and other affected groups to rebuild tourism planning and management. The IUCN Best Practice Guidelines online directory ${ }^{4}$, and major knowledge-sharing platforms, such as Panorama Solutions ${ }^{5}$ and the World Bank's Nature-based Tourism Tools and Resources Collection ${ }^{6}$ (World Bank, 2020), capture and share innovative ways in which the crucial role of protected area tourism in conservation and community development may be recovered in the post-pandemic world.

The COVID-19 pandemic has revealed how dependent some conservation areas and many local communities are on tourism, and also the physical and mental health benefits of nature for visitors. But it has also shown how vulnerable tourism is to forces beyond its control. Even if we can overcome the biggest challenges of the coronavirus, tourism may remain vulnerable to uncertainties and risks of subsequent health, security or economic shocks. The only way to make it more robust is to plan for a different type of tourism that is less exploitative, more sustainable and more in tune with the long-term needs of nature, the communities that depend on it, and the tourists themselves. Tourism will remain an economic activity that supports conservation, but more diverse and stable revenues are required to sustain protected area management. Tourism will only thrive if it is adaptable and functions as an essential environmental and social service. This will be possible if it fully integrates the principles of sustainable development, and focuses on equity, inclusiveness and integration better than it has done in the past.

\section{ENDNOTES}

${ }^{1}$ Hereafter referred to as 'protected areas' or as the specific type of protected or conserved area, as defined by IUCN categories and guidance

${ }^{2}$ Throughout the paper we used 'billion' to describe 'thousand million

${ }^{3}$ See http://www.thelongrun.org

${ }^{4}$ https://go.ncsu.edu/iucn-sustainabletourism-bpg

${ }^{5}$ https://panorama.solutions/en

${ }^{6} \mathrm{http}: / /$ appsolutelydigital.com/nbt/filters.html

\section{ABOUT THE AUTHORS}

Anna Spenceley, $\mathrm{PhD}$ is an independent consultant, and Chair of the IUCN WCPA Tourism and Protected Areas Specialist (TAPAS) Group.

Steve McCool is Professor Emeritus at the University of Montana USA and has authored or co-authored many publications on protected area management.

David Newsome is Associate Professor in the Environmental and Conservation Sciences Group, Murdoch University in Western Australia.

Ana L. Báez is a senior consultant and President of Turismo \& Conservación Consultores S.A., a pioneer company in sustainable development issues.

Jim Barborak is Codirector of the Center for Protected Area Management at Colorado State University. He has four decades' experience in nearly 30 countries.

Clara-Jane Blye is currently a $\mathrm{PhD}$ candidate at the University of Alberta, in the Faculty of Kinesiology, Sport, and Recreation.

Kelly Bricker is Professor, Chair, Department of Parks, Recreation, and Tourism at the University of Utah. Kelly coordinates the Capacity Building of the TAPAS Group.

Hery Sigit Cahyadi is Associate Professor of Destination Tourism Studies at the Bandung Institute of Tourism in Bandung, West J ava, Indonesia. 
Katherine Corrigan is an undergraduate student at the University of Alberta's Augustana Campus in Camrose taking Environmental Studies and Outdoor Education.

Elizabeth Halpenny, $\mathrm{PhD}$, teaches and conducts research in the areas of tourism, marketing, environmental psychology and protected areas management.

Glen Hvenegaard is a Professor of Environmental Science at the University of Alberta's Augustana Campus in Camrose, Alberta.

Delphine Malleret King, $\mathrm{PhD}$ heads The Long Run, an organisation which supports a global network of tourism based privately protected areas (PPAs), hosted by NEPCon.

Yu-Fai Leung is Professor, Department of Parks, Recreation and Tourism Management, North Carolina State University. He coordinates the Biodiversity Working Group within the TAPAS Group.

Ante Mandić, $\mathrm{PhD}$ is an Assistant Professor at the University of Split, Faculty of Economics, Business and Tourism, Croatia. Webpage: https://antemandic.com/ ORCiD: https:// orcid.org/ 0000-0002-2524-6387

Robin Naidoo, $\mathrm{PhD}$ is lead scientist for Wildlife Conservation at World Wildlife Fund (US) and an Adjunct Professor at the University of British Columbia.

Dominik Rüede has been working for Black Forest National Park (Germany) since 2016 on regional development and visitor monitoring.

Jim Sano is World Wildlife Fund's Vice President for Travel, Tourism and Conservation. He was formerly President of Geographic Expeditions at Yosemite National Park.

Mahmoud Sarhan is a conservation and development consultant with experience working with protected areas agencies, government, international nonprofit organizations, and local NGOs.

Verónica Santamaria is Director of the public use area of the Galapagos National Park. Ecuadorian. She has lived for more than 18 years in the Galapagos Islands.

Thiago Beraldo Souza, $\mathrm{PhD}$ works for the Chico Mendes Institute for Biodiversity Conservation
(ICMBio) and is Knowledge Development Coordinator of the TAPAS Group.

Anne-Kathrin Zschiegner, $\mathrm{PhD}$ is the Head of Technical Assistance at the LongRun, which supports a global network of tourism based Privately Protected areas.

\section{REFERENCES}

Abu Ghosoun NGO (2020). COVID19 Pandemic Crisis Management Plan Abu Ghosoun Community Development Association, Marsa Alam, Red Sea, Egypt. (Unpublished report). Available at: www.abughosoun.org (Accessed: 15 September 2020).

Alberta Parks Nature Source (2020). Alberta Parks Nature Source, Alberta Parks, Edmonton, AB. Available at: https:// www.youtube.com/channel/UCGQKe-Dy4EZs4GaZxJMA4nA. (Accessed 14 August 2020).

Alberta Parks (2020). Response to COVID-19. Available at: https:// albertaparks.ca/albertaparksca/news-events/response-tocovid-19/. (Accessed: 14 August 2020).

andBeyond (2020). From crafts to masks: South Africa. What do you do when there are no guests to buy your crafts? Turn your talents to a COVID necessity... Available at: https:// www.andbeyond.com/impact/our-impact-platforms/africafoundation/from-crafts-to-masks/? utm_campaign=339779_Indirect_No\%20room $\% 20$ for $\% 201 \%$ 20in\%20COVID-

19_13May2020\&utm_medium=email\&utm_source=Dotdigital \&dm_i=5BIT,7A6B,26Z1XH,S701,1 (Accessed: 9 October 2020).

Anon (2020) Investment platform for conservation economies and landscapes in Africa. International Finance Corporation, Space for Giants, Investors in Wildlife, and Dalberg.

Asia Protected Areas Partnership (APAP) (2020). Member update: Korea National Park Service responds to the COVID-19 pandemic, Available at: https:// asiaprotectedareaspartnership.org/index.php/newsarticle? id=140. (Accessed: 15 September 2020).

Baden-Württemberg.de (2020). Corona beschert Nationalpark Schwarzwald Besucherrekorde, 5 August 2020, Available at: https://www.baden-wuerttemberg.de/de/service/presse/ pressemitteilung/pid/corona-beschert-nationalparkschwarzwald-besucherrekorde-2/ (Accessed: 31 August 2020).

Balmford, A., Green, J.M.H., Anderson, M., Beresford, J., Huang, C., Naidoo, R., Walpole, M. and Manica, A. (2015). Walk on the wild side: estimating the global magnitude of visits to protected areas, PLoS Biology 13(2): e1002074.

Black Forest National Park (2020). Neuer Bildungskanal des Wildnisbildungsteams startet. Available at: https:// www.nationalpark-schwarzwald.de/de/nationalpark/blog/2020/ wibidigi/wibidigi-der-nationalpark-zu-hause/ (Accessed: 16 November 2020).

Bremner, C. (2020a). Travel and tourism: Embracing transformation to move beyond Coronavirus. Euromonitor International. Available at: https://hub.wtm.com/travel-andtourism-embracing-transformation-to-move-beyondcoronavirus/ (Accessed: 6 October 2020). 
Bremner, C. (2020b). Travel 2040: Sustainability and digital transformation as recovery drivers. Euromonitor International. Available at: https://go.euromonitor.com/wb-video-travel-2020 -travel-2040.html (Accessed: 5 October 2020).

Breves, G.S.S., Barbosa, E.F.P., Garda, A.B. and Souza, T.V.S.B (2020). Monitoramento da Visitação em Unidades de Conservação Federais: Resultados de 2019 e Breve Panorama Histórico. Brasilia, Brasil: ICMBio.

Buckley, R., Brough, P., Hague, L., Chauvenet, A., Fleming, C., Roche, E., Sofija, E. and Harris, N. (2019). Economic value of protected areas via visitor mental health. Nature Communications 10: 5005.

Cocks, T. and Tassiem, S. (2020). South Africa 'virtual safaris' liven up lockdown with jackals and leopard cubs. Reuters. 6 May 2020. Available at: https://www.reuters.com/article/ushealth-coronavirus-safrica-virtual-sa-idUSKBN22I14B. (Accessed: 26 November 2020).

Cook, K., Hvenegaard, G.T. and Halpenny, E.A. (2019). Visitor perceptions of the outcomes of personal interpretation in Alberta's provincial parks. Applied Environmental Education \& Communication. DOI:10.1080/1533015X.2019.1693309.

Department of Human Dimensions of Natural Resources (DHDNR) (2020). Protected areas for all. Webinar series part 1: Session 1A Protected area tourism beyond 2020. (Webinar). 26 August 2020. Available at: https:// www.youtube.com/watch? feature=youtu.be\&v=IOKS8M35cNE\&app=desktop (Accessed: 1 October 2020).

Derrien, M., Cerveny, L. and Wolf, K. (2019). The human health dimensions of sustainable tourism. In: S.F. McCool and $\mathrm{K}$. Bosack (eds.) A Research Agenda for Sustainable Tourism, pp. 150-158. Cheltenham, UK: Edward Elgar Publishing.

Division of the Utah Department of Workforce Services (DUDSSE): Research and Analysis Division (2020). Southeast's Labor Market and Economy. Available at: http:// utaheconomysoutheast.blogspot.com/2020/06/unemployment -insurance-claims-data-shed.html (Accessed: 24 August 2020).

Division of the Utah Department of Workforce Services (DUDSSW): Research and Analysis Division (2020). Southwest's Labor Market and Economy. Available at: http:// utaheconomysouthwest.blogspot.com/2020/05/

unemployment-insurance-claims-data-shed.html (Accessed: 24 August 2020).

Elgebal, D. (2020). Abu Ghosoun Village Savings and Loan Association Microcredit Program: A Progress Report for the period from March 2020 to July 2020. Marsa Alam, Red Sea, Egypt: Abu Ghosoun Community Development Association.. Available at: www.abughosoun.org (Accessed: 24 August 2020).

Falk, B. (2020). What will happen to the $7^{\text {th }}$ continent? BBC Travel. 12 October 2020. Available at: http://www.bbc.com/travel/ story/20201011-what-will-happen-to-the-7th-continent (Accessed: 17 October 2020).

Galvani, A., Lew, A.A. and Perez, M.S. (2020). COVID-19 is expanding global consciousness and the sustainability of travel and tourism. Tourism Geographies, 22 (3), 567-576.

Gateway and Natural Amenity Region Initiative (GNAR) (2020). Outdoor Recreation in Utah during the COVID-19 Pandemic.
Global Environment Facility (GEF) (2020). White paper on a GEF COVID-19 response strategy: The complexities and imperatives of Building Back Better, GEF/C59.Inf.14. 17 November 2020. 59 $9^{\text {th }}$ GEF Council Meeting, December 7-11. Virtual Meeting.

Hamdi, R. (2020). Coronavirus closures of Asian elephant camps offer respite to pursue reforms. Skift. 30 March 2020. Available at: https://skift.com/2020/03/30/coronavirus-closures -of-asian-elephant-camps-offer-respite-to-pursue-reforms/ (Accessed: 19 October 2020).

Hockings, M., Dudley, N., Elliott, W., Napolitano Ferreira, M., MacKinnon, K., Pasha, M.K.S., Phillips, A.et al. (2020). PARKS, 26 (1), 7-24.

Hvenegaard, G.T. and Shultis, J. (2016). The role of interpretation. In: P. Dearden, R. Rollins and M. Needham (eds.), Parks and Protected Areas in Canada: Planning and Management, pp. 141-169, $4^{\text {th }}$ Ed. Don Mills, ON,Canada: Oxford University Press.

Hvenegaard, G., Halpenny, E. and McCool, S. (2012). Protected area tourism and the Aichi targets. PARKS 18(2): 6-11.

Indonesian Geopark Commission (2019). Presidential Regulation Number 9 of 2019 concerning Development of Earth Parks (Geoparks).

Interagency Visitor Use Management Framework (2020). Available at: https://visitorusemanagement.nps.gov/VUM/Framework (Accessed: 15 November, 2020).

IUCN (2020). Conserving Nature in a time of crisis: Protected Areas and COVID-19. Available at: https://www.iucn.org/ news/world-commission-protected-areas/202005/conservingnature-a-time-crisis-protected-areas-and-covid-19. (Accessed: 3 September 2020).

James, H. (2020). Mara land owners weight options as Covid-19 bites. PDOnline, 11 June 2020. Available at: https:// www.pd.co.ke/business/economy-and-policy/mara-landowners-weigh-options-as-covid-19-bites-40160/? fbclid=IwAR1eqBQ09x4XRZLCiMaAWSLdH2I1 CiciztwwX7T5 312a3O0Hd49C2G0-xwA. (Accessed: 7 October 2020).

Johnson, K. (2020). Tourism helps wildlife conservation - but we need to be thinking much bigger. Independent. 27 September 2020. Available at: https://www.independent.co.uk/voices/ coronavirus-environment-wildlife-tourism-africa-conservationillegal-trade-b624014.html (Accessed: 5 October 2020).

Kinsman, J. (2020). What kind of holidays will we take when we can travel again? Conde Nast Traveller. Available at: 2020 from https://www.cntraveller.com/article/future-travel. (Accessed: 5 October 2020).

Kingsford, R.T. and Biggs, H.C. (2012). Strategic adaptive management guidelines for effective conservation of freshwater ecosystems in and around protected areas of the world. IUCN WCPA Freshwater Taskforce. doi: 10.1016/ j.bicon.2010.09.022.

Kretchmer, H. (2020). These locked-down cities are being reclaimed by animals. World Economic Forum. 17 April 2020. Available at: https://www.weforum.org/agenda/2020/04/covid19-cities-lockdown-animals-goats-boar-monkeys-zoo/ (Accessed: 1 October 2020).

Leung, Y.-F., Spenceley, A., Hvenegaard, G.T. and Buckley, R. (eds.) (2018). Tourism and Visitor Management in Protected Areas: Guidelines for Sustainability (Best Practice Protected Area Guidelines Series No. 27). Gland, Switzerland: IUCN. 
Lindsey, P., Allan, J., Brehony, P., Dickman, A., Robson, A., Begg, C., Bhammar, H., et al. (2020). Conserving Africa's wildlife and wildlands through the COVID-19 crisis and beyond. Nature Ecology and Evolution https:// doi.org/10.1038/s41559-020-1275-6

Mitchell, J. and Ashley, C. (2010). Tourism and poverty reduction: Pathways to prosperity. London: Earthscan.

Naidoo, R., Gerkey, D., Hole, D., Pfaff, A., Ellis, A.M., Golden, C.D., Herrera, D., Johnson, K., Mulligan, M.I., Ricketts, T.H. and Fisher, B. (2019). Evaluating the impacts of protected areas on human well-being across the developing world. Science Advances, 5 (4), DOI: 10.1126/sciadv.aav3006

Naidoo, R., Weaver, C.L., Diggle, R.W. and Matongo, G. (2015). Complementary benefits of tourism and hunting to communal conservancies in Namibia. Conservation Biology, 30 (3), DOI: $10.1111 /$ cobi. 12643

Namibia Tourism Board (undated). Over $1.6 \mathrm{~m}$ tourists visited in 2019. Available at: http://www.namibiatourism.com.na/ industrynews/over-1-6m-tourists-visited-in-2019 Accessed: 31 August 2020.

National Park Service (2020a). National Park Service Visitor Spending Report 2020. Available at: https://www.nps.gov/ subjects/socialscience/vse.htm. (Accessed 18 August 2020).

National Park Service (2020b). COVID-19 safety and social distancing graphics. Available at: https://www.nps.gov/media/ photo/gallery.htm?pg=4913675\&id=CF41B3F2-A93D-4F38A482-CD02DD7488BD (Accessed: 3 September 2020).

Nationalpark Schwarzwald (2020). Besuchsaufkommen und Corona, 5 August 2020. Accessed on 31 August 2020 at https://www.nationalpark-schwarzwald.de/fileadmin/ Mediendatenbank_Nationalpark/04_Forschen/ Sozialwissenschaftlich/20200805_Besuchsaufkommen_und Corona_Rueede_Versand.pdf

Newsome, D. (2020). The collapse of tourism and its impact on wildlife tourism destinations. Journal of Tourism Futures https://doi.org/10.1108/JTF-04-2020-0053

Nunes, A. (2020). 'How Covid-19 will change air travel as we know it', BBC. Available at: https://www.bbc.com/future/ article/20200709-how-covid-19-will-change-air-travel-as-weknow-it (Accessed on 15 September 2020).

O'Brien, M. (2020). These 5 eco-friendly resorts around the world have survived the pandemic without guests by focussing on sustainability, caring for their orchards and farms, and delivering fresh food to locals. Business Insider Australia. 19 July 2020. Available at: https://www.businessinsider.com.au/ how-eco-friendly-resorts-around-world-survived-pandemicwithout-guests-2020-7?r=US\&IR=T (Accessed: 5 October 2020).

Peeters, P., Gössling, S., Klijs, J., Milano, C., Novelli, M., Dijkmans, C., Eijgelaar, E., Hartman, S., Heslinga, J., Isaac, R., Mitas, O., Moretti, S., Nawijn, J., Papp, B. and Postma, A. (2018). Research for TRAN Committee - Overtourism: impact and possible policy responses. Brussels: European Parliament, Policy Department for Structural and Cohesion Policies

Riley, E. (2020). What the future of adventure travel looks like. Outside. 21 May 2020. Available at: https:// www.outsideonline.com/2413863/future-adventure-travel-after -coronavirus-pandemic (Accessed: 5 October 2020).
Sarhan, M. (2016). Public-Private Partnership for Ecotourism Development in Wadi el Gemal National Park in Egypt, CEESP Members Newsletter 1619 - Aug 2016, IUCN.

Sarhan, M. (2017). A Public-Private Partnership Model for Ecotourism Development in Wadi el Gemal National Park. Sustainable Tourism in Small Island Developing States, from 22- 24th Nov 2017, Mahe, Seychelles

Sarhan, M. (2018). From the resort to ecotourism and agritourism: the challenge in Wadi el Gemal National Park, Egypt. Marsa Alam, Egypt. 1st World Congress on Agritourism Bolzano/ Bozen (Italy) 07- 09/11/2018

Shoji, K. (2020). Can micro-tourism save Japan's ailing travel industry. The Japan Times. 12 September 2020. Available at: https://www.japantimes.co.jp/news/2020/09/12/national/media -national/micro-tourism-travel-industry-coronavirus/ (Accessed: 5 October 2020).

Skinner, T. (2020). Virtual worlds: Can we travel without travelling? BBC. 31 March 2020. Available at: http://www.bbc.com/travel/ story/20200330-covid-19-virtual-travel-during-coronavirus (Accessed: 26 November 2020).

Snyman, S. and Spenceley, A. (2019). Private sector tourism in conservation areas in Africa. CABI.

Soliman, M. (2020). Wadi El Gemal Honey Project: A Progress Report for the period from March 2020 to July 2020. Marsa Alam, Red Sea, Egypt: Abu Ghosoun Community Development Association.

South African National Parks (SANParks) (2020). COVID-19 Safety message. Available at: https://www.sanparks.org/ about/covid-19.php (Accessed: 15 September 2020).

Souza, T.V.S.B., Chidakel, A., Child, B., Chang, W. and Gorsevski, V. (2020). Economic Effects Assessment Approaches: Tourism Economic Model for Protected Areas (TEMPA) for Developing Countries. In: A. Spenceley, (ed.) Handbook for sustainable tourism practitioners: The essential toolbox: Edward Elgar Publishing (in press).

Spenceley, A. (2020a). COVID-19 and protected area tourism: A spotlight on impacts and options in Africa, Report to the EU, Eurata Consortium.

Spenceley, A. (2020b). Tourism and visitation in protected areas amid COVID-19: Guidance for protected area authorities and managers, Report to the EU, Eurata Consortium.

Spenceley, A. (2020c). Setting the scene: Impacts of the pandemic on the tourism sector and building back greener. Online side event of the $26^{\text {th }}$ Meeting of the UNECE Committee on Environmental Policy. 9 November 2020. Available at: https:// www.oneplanetnetwork.org/transforming-tourism-resilient-and -sustainable-post-covid-world-event-summary (Accessed: 22 November 2020).

Spenceley, A. (2020d). Building nature-based tourism back from COVID-19: Recovery, resilience and sustainability. Report to the Luc Hoffmann Institute. 12 November 2020.

Spenceley, A. and Rylance, A. (2019). The contribution of tourism to achieving the sustainable development goals. In: S. McCool and K. Bosak (eds.) A research agenda for sustainable tourism, pp. 107-125. Edward Elgar Publishing.

Tripadvisor (2020). Beyond COVID-19: The road to recovery for the travel industry. Available at: https://www.tripadvisor.com/ Covid19WhitepaperMay2020 (Accessed on 10 September 2020). 
UN News (2020). 'Devastated by pandemic, tourism sector must be rebuilt in a safe, equitable and climate friendly way - UN chief'. UN News 25 August 2020. Available at: https:// news.un.org/en/story/2020/08/1070902 (Accessed: 5 October 2020).

UN World Tourism Organization (UNWTO) (2019). 'Overtourism'? Understanding and managing urban tourism growth beyond perceptions. (Volumes 1 and 2).

UN World Tourism Organization (UNWTO) (2020a). Impact Assessment of the COVID-19 Outbreak on International Tourism. UNWTO Reports. Available at: https:// www.unwto.org/impact-assessment-of-the-covid-19-outbreakon-international-tourism (October 2020).

UNWTO (2020b). . UNWTO Reports. Available at: https:// www.unwto.org/news/covid-19-response-travel- restrictions? fbclid=IwAR3YJtncEvUpNjAAAQqYlaYwcMnQucqCsnBdVm9 19ILa968vWiv0UAlmVbk (Accessed: 21 April 2020).

UNWTO (2020c). Understanding domestic tourism and seizing its opportunities, UNWTO Briefing Note - Tourism and COVID19, issue 3. Available at: https://www.e-unwto.org/doi/ epdf/10.18111/9789284422111 (Accessed: 15 September 2020).
UNWTO (2020d). One Planet vision for a responsible recovery of the tourism sector. Available at: https://www.unwto.org/covid19-oneplanet-responsible-recovery-initiatives (Accessed: 10 October 2020).

World Bank (2020). Tools and Resources for Nature-Based Tourism. Washington, DC: World Bank. (c) World Bank. Available at: https://openknowledge.worldbank.org/ handle/10986/34433 License: CC BY 3.0 IGO

World Travel and Tourism Council (WTTC) (2019). Economic impact of global wildlife tourism._Available at:_https:// www.atta.travel/news/2019/08/the-economic-impact-of-globalwildlife-tourism-wttc/ (Accessed: 10 October 2020).

WTTC (2020a). '174 m travel and tourism jobs could be lost due to COVID-19 and travel restrictions, says WTTC'. 29 October 2020. Available at: https://wttc.org/News-Article/174m-Travel\&-Tourism-jobs-could-be-lost-due-to-COVID-19-and-travelrestrictions (Accessed: 27 November 2020).

WTTC (2020b). Recovery Dashboard. Available at: https://wttc.org/ Initiatives/Recovery-Dashboard (Accessed: 3 September 2020).

WWF-Namibia (2020). Mitigating the impacts of the COVID-19 virus to Namibia's communal conservancies. Unpublished report.

\footnotetext{
Author affiliations (continued)

${ }^{9}$ Environmental Studies and Outdoor Education, University of Alberta, Camrose, Alberta.

${ }^{10}$ University of Alberta's Augustana Campus, Camrose, Alberta.

${ }^{11}$ The Long Run, United Kingdom

${ }^{12}$ Department of Parks, Recreation and Tourism Management, North Carolina State University, USA

${ }^{13}$ University of Split, Faculty of Economics, Business and Tourism, Croatia.

${ }^{14}$ WWF-US, Washington, DC, USA; Institute for Resources, Environment and Sustainability, University of British Columbia, Vancouver, BC, Canada

${ }^{15}$ Nationalparkzentrum am Ruhestein, Germany

${ }^{16}$ WWF-US, Washington, DC, USA

${ }^{17}$ School of Hospitality, Tourism and Events, Auckland University of Technology, New Zealand

${ }^{18}$ Public Use Mananagement, Galapagos National Park Directorate, Ecuador

${ }^{19} \mathrm{Chico}$ Mendes Institute for Biodiversity Conservation (ICMBio), Brazil

${ }^{20}$ The Long Run, Kenya
} 


\section{RESUMEN}

La pandemia del COVID-19 ha tenido un impacto global en el sector del turismo. Al reducirse drásticamente el número de turistas, podrían perderse millones de puestos de trabajo, y los avances logrados en materia de igualdad y crecimiento económico sostenible podrían retroceder. Los informes generalizados de cambios drásticos en la visita a áreas protegidas y conservadas tienen consecuencias negativas para las finanzas de la conservación, las empresas turísticas y los medios de vida de las personas que suministran mano de obra, bienes y servicios a los turistas y a las empresas turísticas. El presente artículo tiene por objeto compartir experiencias de todo el mundo sobre los efectos de la pandemia del COVID-19 en el turismo de las áreas protegidas; y examina la forma de fomentar la capacidad de resiliencia del turismo de las áreas protegidas como instrumento regenerativo de conservación.

\section{RÉSUMÉ}

La pandémie de COVID-19 a eu un impact certain au niveau mondial sur le secteur du tourisme. Suite à la réduction spectaculaire du nombre de touristes, des millions d'emplois pourraient être perdus et les progrès réalisés en matière d'égalité et de croissance économique durable pourraient s'en trouver annulés. De nombreux rapports sur les chutes drastiques dans la fréquentation des aires protégées et conservées font état de ces conséquences négatives sur les finances de la conservation, les entreprises touristiques et les moyens de subsistance des personnes qui fournissent de la main d'oeuvre, des biens et des services aux touristes et aux entreprises touristiques. Le présent document vise à partager les expériences provenant du monde entier relatives aux conséquences de la pandémie de COVID-19 sur le tourisme des aires protégées, et examine comment renforcer la résilience du tourisme des aires protégées en tant qu'outil de conservation régénérative. 


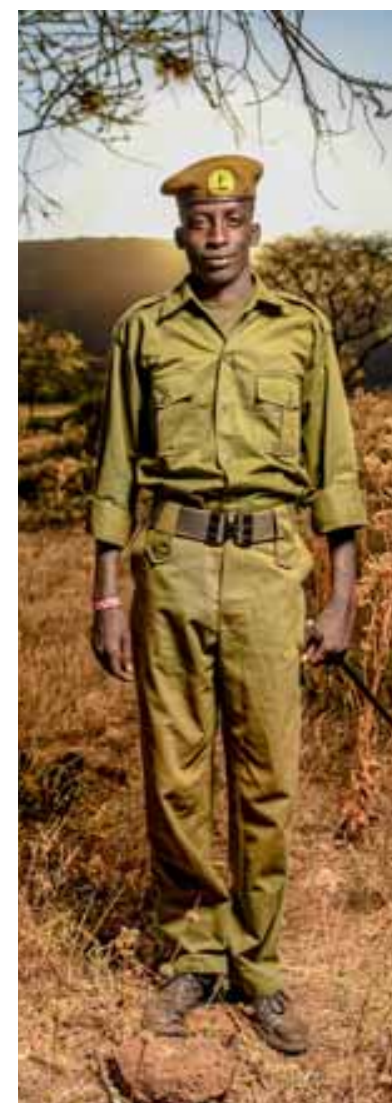

IMPACT OF THE COVID-19 PANDEMIC ON RANGERS AND THE ROLE OF RANGERS AS A PLANETARY HEALTH SERVICE

Rohit Singh ${ }^{1 *}$, Chris Galliers², William Moreto ${ }^{3}$, James Slade ${ }^{4}$, Barney Long ${ }^{4}$, Hamera Aisha ${ }^{5}$, Andrew Wright ${ }^{6}$, Falon Cartwright ${ }^{7}$, Atul Deokar ${ }^{8}$, Alexander Wyatt ${ }^{9}$, Deepali Deokar ${ }^{10}$, Rungnapa Phoonjampa ${ }^{11}$, Eddie Smallwood ${ }^{12}$, Rizwana Aziz ${ }^{13}$, Amon Koutoua Benoitt4, Renata Ca0 ${ }^{15}$, Sean Willmore ${ }^{16}$, Deepani Jayantha ${ }^{17}$ and Sonali Ghosh ${ }^{18}$

\title{
* Corresponding author: rsingh@wwfnet.org
}

${ }^{1}$ World Wildlife Fund, 1250 24th Street, N.W., Washington, DC 20037, USA

${ }^{2}$ International Ranger Federation, 11 Veronica Court, Leongatha, Victoria, 3953 Australia

${ }^{3}$ University of Central Florida, 4000 Central Florida Blvd, Orlando, FL 32816, United States

${ }^{4}$ Global Wildlife Conservation, PO Box 129, Austin, TX 78767, USA

${ }^{5}$ World Wide Fund for Nature, 46-K, PECHS Block 6, Shahrah-e-Faisal, Karachi, Pakistan

${ }^{6}$ International Ranger Federation, 116 State Park Lane, Counce, TN 38326, USA

${ }^{7}$ Bahamas National Trust, Bay Street Business Centre, Nassau, Bahamas

${ }^{8}$ Maharashtra Forest Service Association, Nagpur Maharashtra, India 440013

Author affiliations continue on page 134

\begin{abstract}
Rangers play an indispensable role in maintaining balance between people and the natural world by protecting and managing protected and conserved areas. Despite occupying this key role, rangers are facing many challenges across organisational, occupational and personal fronts that hinder the delivery of their duties. The COVID-19 pandemic has exacerbated these challenges and made the fight against the illegal killing of wildlife, illegal logging, illegal harvesting of non-timber forest products, encroachment, and other environmental crimes in protected and conserved areas even more difficult. 915 survey responses were generated from individual rangers from 60 countries in order to understand how they perceived the impact of COVID-19 on rangers and their work in protecting and conserving protected areas around the world. The findings indicate that different aspects of ranger work have been negatively impacted due to the pandemic and the associated actions of authorities and illegal actors. The study also reveals differing regional perceptions of the impact of the pandemic on protected and conserved areas and ranger work. The results of the survey, which provide useful insights into the challenges facing rangers during the current global crisis and indicate where actions may be required to mitigate an impending loss of biodiversity, are used to support four recommendations in the paper.
\end{abstract}

Key words: conservation areas, community, pandemic, protected areas, survey, rangers

\section{INTRODUCTION}

The COVID-19 pandemic is an example of the health repercussions that can result from imbalance between humans and nature caused by excessive exploitation (Thompson, 2013; Magouras et al., 2020). The driving forces behind outbreaks of this and similar zoonotic diseases are: destruction of, and encroachment into, wildlife habitats (Bloomfield et al., 2020; Gibb et al., 2020; Plowright et al., 2017; Loh et al., 2015; Butler, 2008; Goldberg et al., 2008; Ferreira et al., 2021 illegal wildlife trade (Aguirre et al., 2020); and consumption of wildlife meat sold in unregulated markets (Hockings et al., 2020; UNODC, 2020; UNEP \& ILRI, 2020; Bisson et al., 2015).

Rangers fulfil an indispensable role in maintaining the delicate balance between humans and nature by protecting and managing natural resources, moderating human interaction with nature and providing the primary deterrence to illegal activities within protected and conserved areas (PCAs) (Rowcliffe et al., 2004; Tranquilli et al., 2014). Their role in mitigating the risks of zoonotic disease spill-over may therefore be considerable (Bergen, 2020). Previous research has 
shown the organisational, occupational and personal challenges that rangers face in discharging their duties (Belecky et al., 2019; Moreto et al., 2019; Singh et al., 2020). The COVID-19 pandemic has exacerbated the struggle of rangers against the illegal killing of wildlife, illegal logging, unpermitted harvesting of non-timber forest products (NTFPs), encroachment and other environmental degradation in PCAs (Hockings et al., 2020; Waithaka, 2020; World Bank, 2020). In many parts of Asia, Africa and South America, there are reports that deforestation has increased during the pandemic (Fair, 2020), including a 77 per cent increase in global forest loss alerts recorded by Global Land Analysis and Discovery (GLAD) compared to the average from 2017-2019 (WWF, 2020).

In some countries, ranger services are considered to be essential or enabling services and rangers have therefore been expected to continue working unchanged throughout the pandemic; elsewhere, their activities have been sharply reduced because of staff cuts, reappropriation of operational budgets, limited access to health care equipment and re-allocation to other duties to control the spread of the disease. In some cases, patrols and similar services have been withdrawn because community support is no longer available (FFI, 2020). With increased workloads and reduced resources, rangers are even less able to address the threats facing PCAs (Bergen, 2020; Hockings et al., 2020).

Rangers, occupying this role as a planetary health service, are crucial in the implementation of the 'One Health' approach, a collaborative effort of multiple health and science professions, together with their

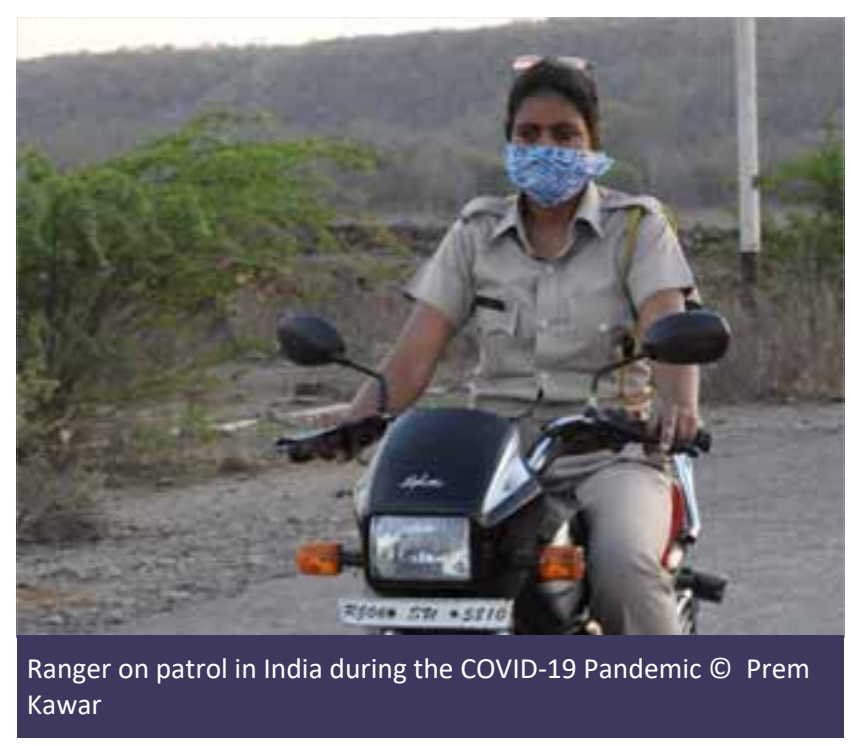

related disciplines and institutions - working locally, nationally and globally - to attain optimal health for people, domestic animals, wildlife, plants and our environment (Mackenzie \& J eggo, 2019). Given the importance of rangers in safeguarding PCAs, reducing the exploitation of wildlife and helping to maintain a healthy planet, and noting the high possibility of future pandemics, it is essential to understand the impacts of the COVID-19 pandemic on them. The purpose of this paper, the first of its kind, is to throw light on what the COVID-19 pandemic has meant for rangers and their day-to-day work through a global survey. We also provide case studies from two countries to show the impact of the pandemic at the site level. The paper provides broad recommendations and flags concerns that may arise in the future.

\section{METHODS}

Two primary data sources were used for this paper: a) a global survey; and b) case studies from independent surveys conducted in Pakistan and India.

\section{Global Survey}

This global survey was undertaken by World Wide Fund for Nature (WWF), Global Wildlife Conservation (GWC), International Ranger Federation (IRF) and the University of Florida ${ }^{1}$. The online survey consisted mainly of close-ended questions aimed at understanding the impact of the COVID-19 pandemic on the ranger workforce. It explicitly targeted rangers, defined as a "person involved in the practical protection and preservation of all aspects of wild areas, historical and cultural sites" (IRF, 2019). The survey was developed in English and translated into Spanish and French. The Spanish and French translations were verified by a third party. It contained 52 questions, grouped into seven areas.

Data were gathered between August and September 2020 using the online survey application 'Qualtrics'. The survey was shared through Facebook, Twitter and WhatsApp; and through emails to regional and national ranger associations, and conservation organisations that support rangers. It was also emailed to over 500 individual rangers that participated in the 9th World Ranger Congress (2019). 1,200 surveys were returned. After removing incomplete surveys from the data, 915 completed surveys were used for the present study (Figure 1).

\section{Limitations}

This global study is not without limitations. Many rangers do not possess the skills, equipment and connectivity necessary to complete an online survey. 
Though it was delivered in three major languages (English, Spanish and French), not all rangers are fluent in one of these languages. While the case studies provide greater detail on how aspects of ranger work have been affected, they need further evaluation to justify broad conclusions. Some of the initiatives or programmes that may have or are currently being affected by the COVID-19 pandemic, such as budget cuts, may not have been fully implemented at the time of the survey, and therefore may not be captured. The impact of mass migration and unemployment is yet to be fully felt in protected and conserved areas.

So, while the study provides a snapshot of the current global situation, it cannot be used to draw conclusions at national levels. Moreover, because the varied sample sizes in different geographic regions may have biased the results, or not be statistically significant, any extrapolation to the regional level - which has been done at some points in discussing the global survey results below - should be interpreted with caution.

\section{Case Study: Pakistan}

A case study from Pakistan, also conducted in May and June 2020 before the online survey, aimed to provide information separate to that of the primary survey. It utilised a questionnaire which was designed to establish: (1) rangers' involvement in additional tasks besides their designated jobs, such as relief support and maintaining law and order; and (2) support- or reliefrelated initiatives that rangers have undertaken in their individual capacities, such as donations and relief provision for nearby local communities. The survey, which was conducted in the local language (Urdu), was delivered to 157 rangers from 33 protected areas of all kinds across the country. The questionnaire was delivered through emails to individual rangers where possible, and email groups, Facebook and other social media-based wildlife and environmental groups of Pakistan. Responses were also captured via direct phone calls by the survey team; interviewees were informed of the purpose of the interview and their verbal consent obtained.

\section{Case Study: India}

A separate and independent case study was conducted in India to capture the responses of family members of rangers who were posted at outposts during the pandemic. This used four open-ended questions: What concerns do you have about your husband/wife/son/ daughter who is based in the forest during the COVID19 pandemic? What challenges are you facing in the absence of your husband/ wife/son/ daughter during the COVID-19 pandemic? How do you feel about the steps taken by the government to protect rangers and their families during the COVID-19 pandemic? What do you think the government/NGOs/public can do to help rangers and their families during the COVID-19 pandemic? Fifty-two interviews were conducted in 34 protected areas in 18 states of India in September 2020, using telephone enquiries in Marathi, Hindi or English. The surveyor was briefed on the purpose and interview protocols before the administration of the survey. Before each interview, the surveyor explained the purpose of

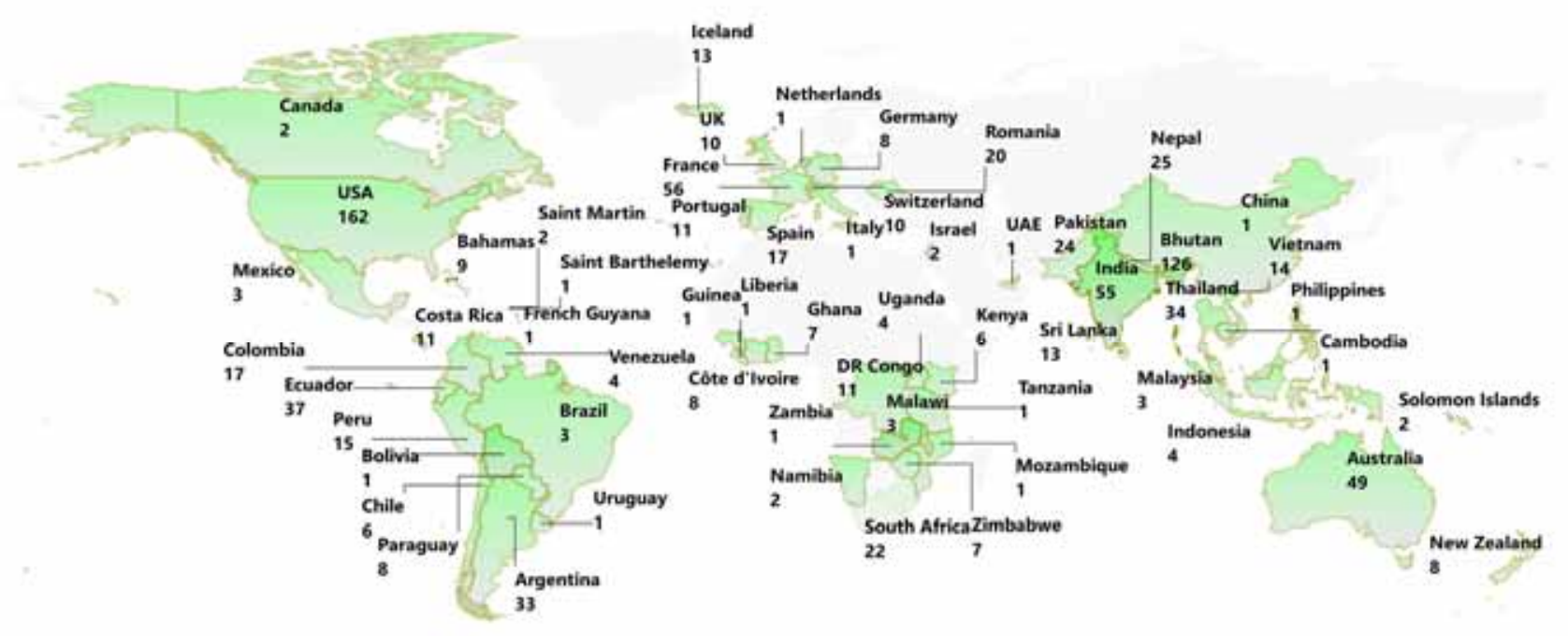

Figure 1. The countries where surveys were conducted with number of responses for each country ${ }^{2}$ 
the interview and sought the verbal consent of respondents.

\section{RESULTS FROM THE GLOBAL SURVEY}

Response rates: Responses were received from 62 countries with the USA having the most responses (Figure 1).

Demographic information: Of those respondents who indicated a gender, 79 per cent were male and 21 per cent female. The age of respondents was between 19 and 74 years-old, with ranger experience ranging from one to 40 years. The online survey was designed to target only rangers, with the very first question asking the respondent, "Are you a ranger or not?" If not, then the respondent was prevented from progressing with the survey. Therefore, 100 per cent of the responses are from rangers.

Locational information: Some 28 per cent of rangers were living and working at a remote outpost with no access to medical help during the time of the survey. More than half those in South America said they are based in a remote location, followed by Asia (40.5 per cent), Africa (38.6 per cent), Central America and Caribbean (26.9 per cent) and Europe (12.2 per cent). Very few reported being located remotely in North America and Australia / Oceania.
Threats to protected and conserved areas: While it is generally believed that threats and pressures to PCAs have increased due to the COVID-19 pandemic, respondents provided mixed responses to this question (Figure 2). Most respondents believed that the threat that had grown most was 'other pressures', for example the collection of non-timber forest products (NTFPs) and grazing: more than 58 per cent agreed that this had increased in their country of operation.

Sharp geographical variations were revealed by the data. For example, while more than half of respondents from South America, Africa, and Central America and Caribbean 'strongly agreed' or 'agreed' that subsistence and commercial hunting had increased (Table 1), fewer than 20 per cent of North American and European respondents accepted that proposition. Similar contrasts were shown in respect of illegal logging and encroachment, and other pressures. There is a stark contrast again between South America and other regions in respect of perceptions of increased rates of logging and encroachment. This reflects the different threats faced by different regions and the need for further research to understand the drivers of those threats.

Impact on protected and conserved area management activities: Key protected area conservation activities across all regions have been affected by the COVID-19

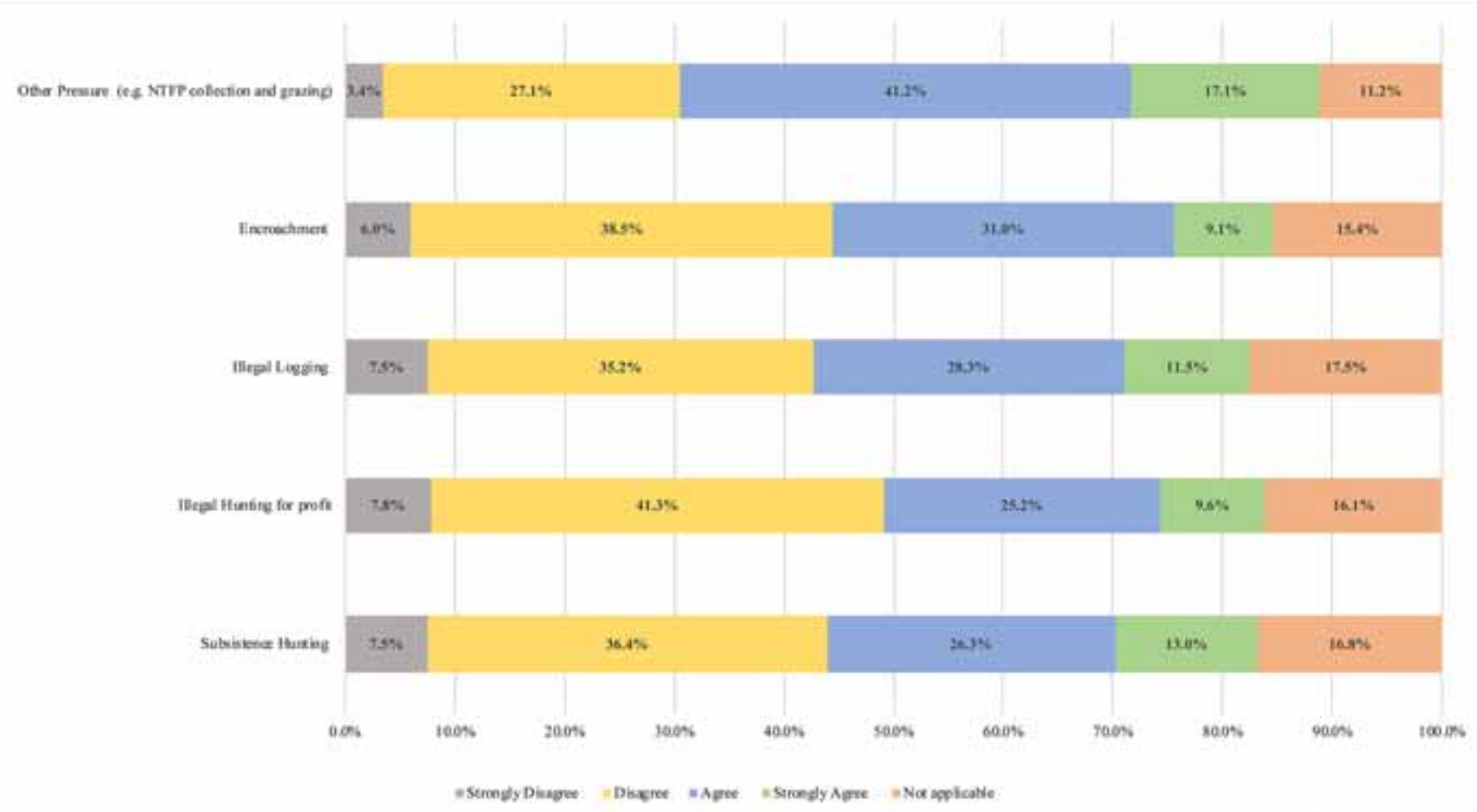

Figure 2. Responses to the question: "Since the start of the COVID-19 pandemic in your country, what threats have increased in your protected and conserved areas?" 
Table 1. Percentage of rangers by region that 'Strongly agreed' and 'Agreed' with the statement: "Since the start of the COVID-19 pandemic in your country, [threat/pressure] has increased."

\begin{tabular}{lccccc} 
Region & $\begin{array}{c}\text { Subsistence } \\
\text { Hunting }\end{array}$ & $\begin{array}{c}\text { Commercial } \\
\text { Hunting }\end{array}$ & $\begin{array}{c}\text { Illegal } \\
\text { Logging }\end{array}$ & Encroachment & $\begin{array}{c}\text { Other Pressure (e.g. } \\
\text { NTFP collection and } \\
\text { grazing) }\end{array}$ \\
\hline South America & $70.5 \%$ & $60.0 \%$ & $79.1 \%$ & $80.0 \%$ & $79.1 \%$ \\
\hline North America & $17.9 \%$ & $11.5 \%$ & $9.0 \%$ & $39.1 \%$ & $50.0 \%$ \\
\hline Asia & $48.1 \%$ & $38.5 \%$ & $47.3 \%$ & $31.6 \%$ & $60.8 \%$ \\
\hline Africa & $76.3 \%$ & $68.9 \%$ & $57.2 \%$ & $50.7 \%$ & $70.2 \%$ \\
\hline Europe & $8.2 \%$ & $15.7 \%$ & $15.7 \%$ & $18.7 \%$ & $41.8 \%$ \\
\hline Australia \& Oceania & $16.3 \%$ & $21.8 \%$ & $49.1 \%$ & $45.5 \%$ & $56.4 \%$ \\
\hline $\begin{array}{l}\text { Central America and } \\
\text { Caribbean }\end{array}$ & $56.0 \%$ & $64.0 \%$ & $44.0 \%$ & $36.0 \%$ & $52.0 \%$
\end{tabular}

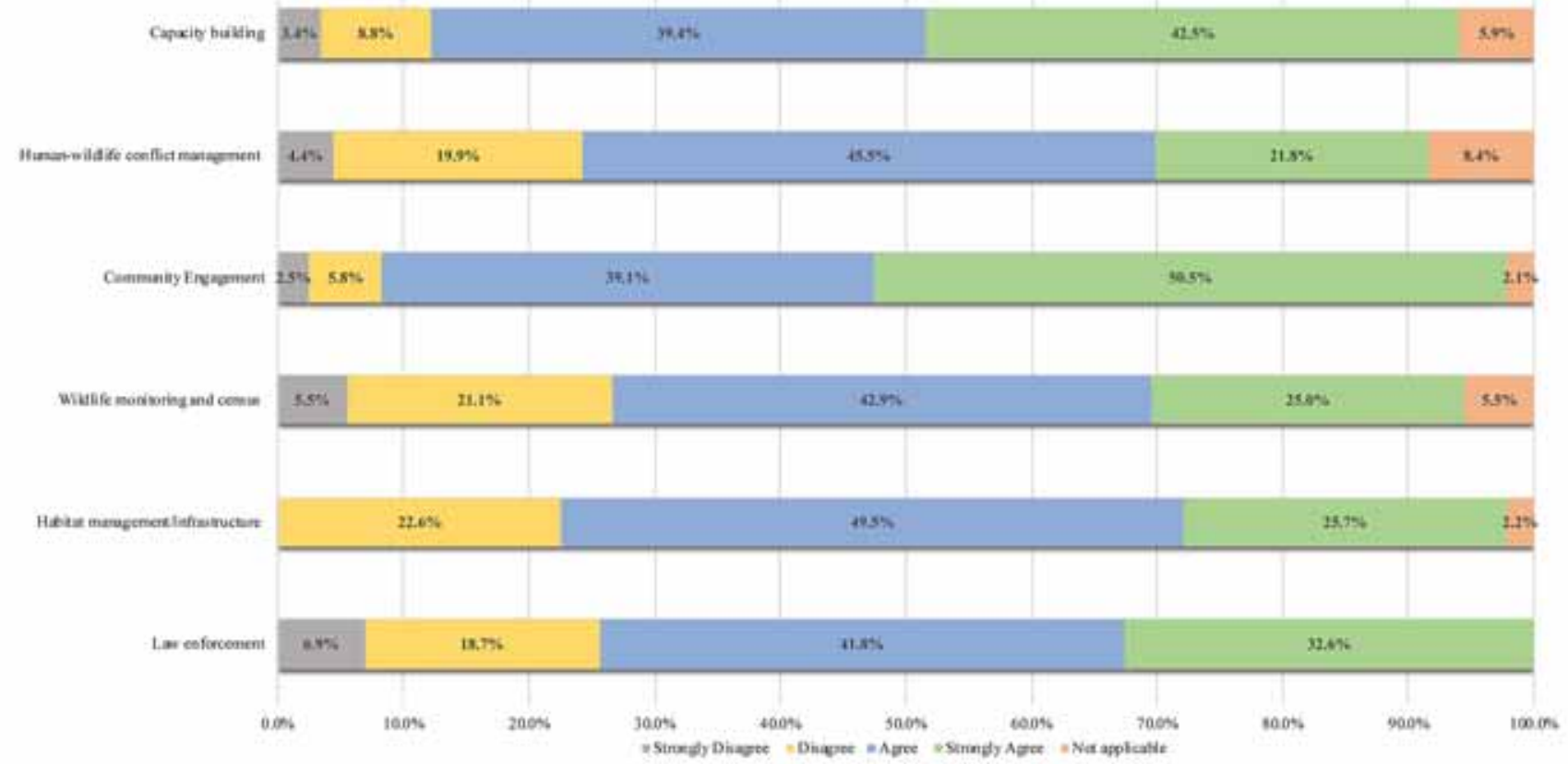

Figure 3. Responses to the statement: "COVID-19 has negatively impacted the daily operations of protected/ conservation area"

pandemic (Figure 3). Community engagement activities were often the most affected. Pandemic control measures have affected community outreach, awareness and community conservation activities. The fear among most rangers of contracting COVID-19 when interacting with members of the local community and visitors, has affected their work in community engagement. Lockdowns and movement control orders may have also had this effect. Many law enforcement activities may have been negatively impacted, with reductions in essential operation supplies needed for daily patrols, as well as the closure of courts. Wildlife monitoring is identified as the least impacted activity (Figure 3). This may be because there is seasonal variation in wildlife monitoring activities or because such monitoring is most often done in remote areas free of contact with non -rangers. It is also possible that respondents overlooked basic wildlife monitoring undertaken on regular patrols during the pandemic. Many rangers were re-assigned to other tasks related to addressing the pandemic. The additional tasks included:

- Conducting international border patrols to control the spread;

- Delivering essential goods (e.g. rations) to communities and vulnerable groups;

- Enforcement of social distancing and use of masks among park visitors and communities around the 
park;

- Enforcement of social distancing and gathering rules

- Supporting homeless populations;

- Creating awareness (e.g. posting signs, educating the public) among the communities;

- National disaster service assignments (e.g. enforcement of public health orders);

- Filling in on other labour/tasks due to lack of seasonal staff;

- Providing emergency medical assistance;

- Supporting authorities in track and tracing;

- Undertaking more frequent decontamination of public use areas in the park;

- Increasing patrols to ensure social distancing and use of face masks; and

- Distributing health kits (e.g. masks, sanitisers) to local communities.

Staffing and budgets: When asked whether the COVID19 pandemic had affected staffing and budgets, nearly a third of all rangers 'strongly agreed' that budget cuts due to COVID-19 had negatively affected their day-today work (e.g. less fuel and rations). This includes impacts on community engagement (over 75 per cent), law enforcement activities (over 60 per cent) and human- wildlife conflict management activities (nearly 60 per cent). Less than ten per cent of rangers from Australia / Oceania and Europe reported budget cuts; in Africa, more than half of all rangers did so.
In addition to the operational work, more than half of the rangers reported that their personal life has been impacted due to the budget cuts which led to salary delays, reductions in pay and subsequent impacts on living conditions. More than one in four rangers said that their salary has been reduced or delayed and nearly 20 per cent of rangers reported that colleagues had been laid off from their jobs due to COVID-19 related budget cuts. More than a third of all rangers in Central America and Caribbean countries reported being laid off, closely followed by South America and Africa. In Asia, the figure was one in five and in Europe less that one in ten. Respondents whose salaries had been reduced were asked to describe the reduction. Nearly a quarter $(\mathrm{n}=150)$ reported reductions in ranger salaries and some rangers $(n=32)$ reported reduced allowances and benefits; however, some of these reductions were temporary and may last only for a few months.

Many conservation sites, particularly in developing countries, depend on income provided by tourism and donations from conservation organisations. We enquired as to whether study participants believed that tourism positively contributed to PCA management and almost three-quarters of respondents agreed that it did. When asked whether tourism had been negatively impacted by the COVID-19 pandemic, nearly 85 per cent of rangers agreed (Figure 4). Most also reported the negative impact of the COVID-19 pandemic on other revenue sources such as donations (Figure 4).

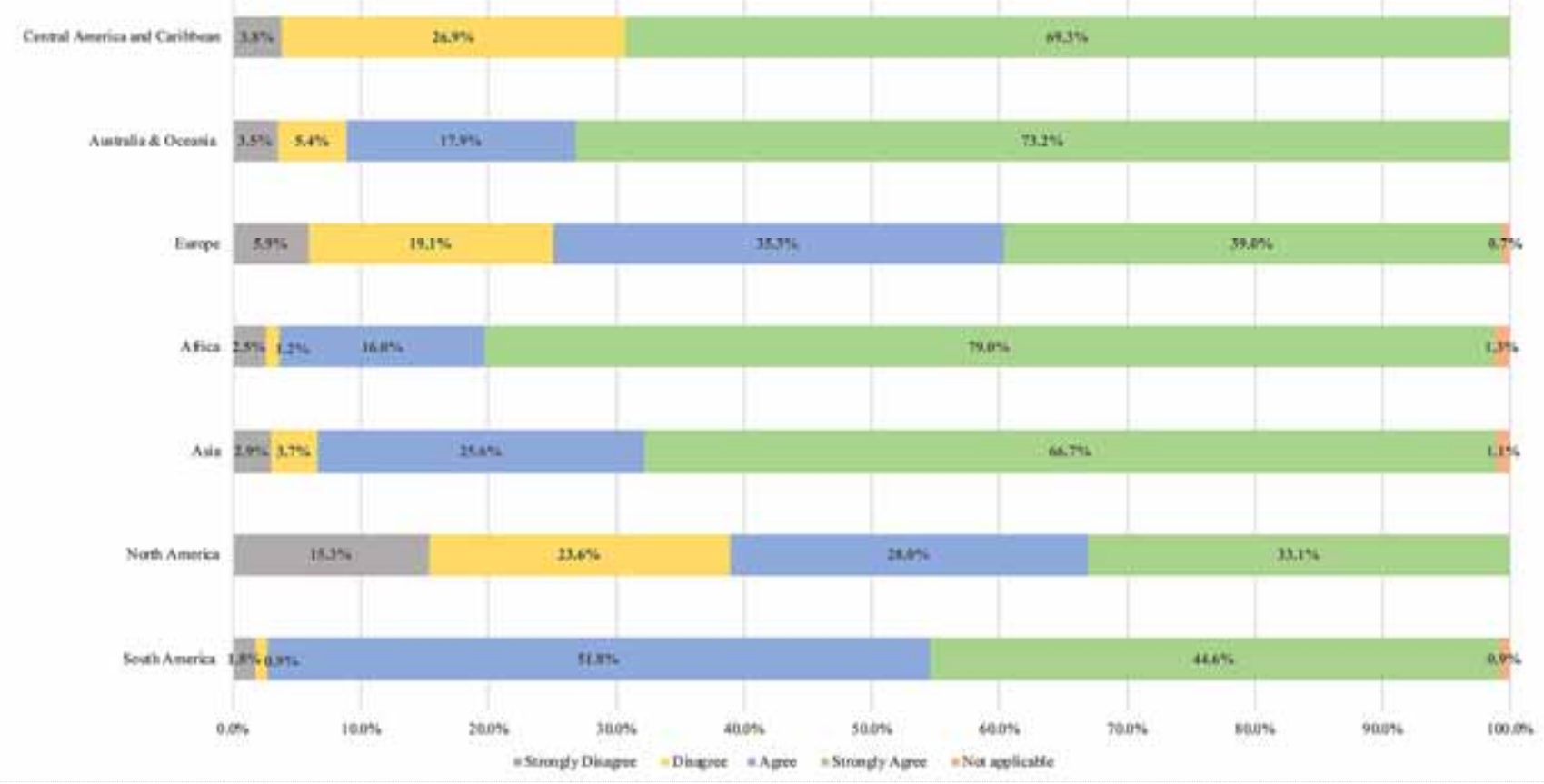

Figure 4. Responses to the statement: "In your opinion, tourism has been negatively impacted by COVID-19" 
Occupational welfare: To better understand the organisational elements that may have been impacted by the COVID-19 pandemic, we examined responses related to occupational welfare. The overwhelming majority believed they received adequate information about COVID-19 from their employers, governments or other organisations as well as adequate supplies of sanitation and hygiene equipment, such as clean water, soap, face masks. However, regional differences were recorded as highlighted in Figure 5.

Five ranger casualties due to COVID-19 have been recorded from the outset of the outbreak to $30 \mathrm{June}$ 2020 (IRF, 2020). More than one in four rangers said they do not have access to adequate insurance to cover the treatment of COVID-19. Africa was the region with the lowest coverage and North America reported the highest. Given the results of recent research (Belecky et al., 2019; Long et al., 2016), the low level of coverage in Africa and Asia is unsurprising (Figure 6).

Two-thirds of all rangers expressed concern about their financial well-being. This was most marked in the less wealthy regions of Africa, Asia and South America, where more than four out of five respondents were concerned about their financial well-being. This was a matter of less concern in the economically wealthier regions. However, more than three-quarters of all respondents felt that they were being supported by their organisations or employers during the pandemic.
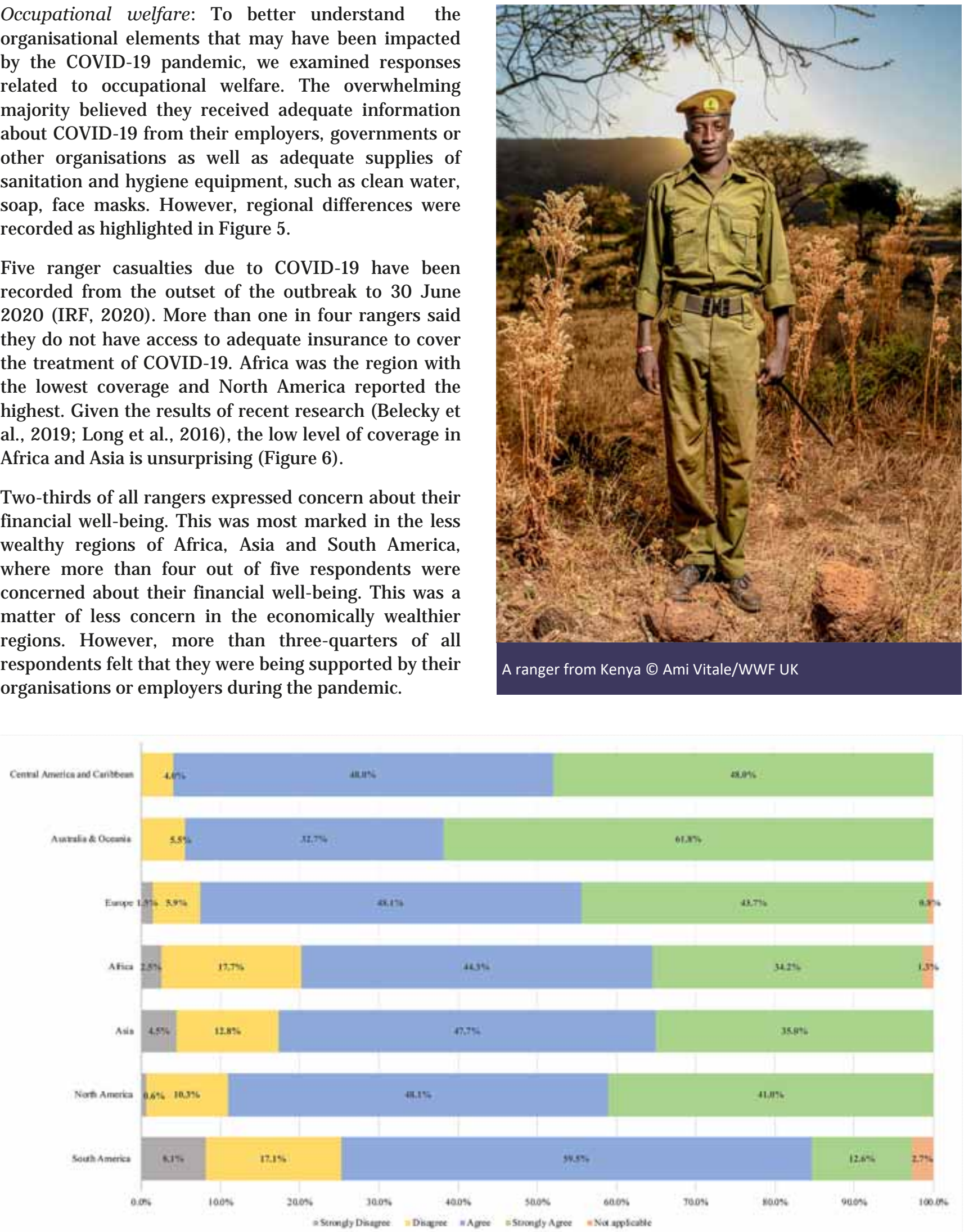

Figure 5. Responses to the question "Do you have access to adequate sanitation and hygiene equipment (e.g. clean water, soap, face masks) that is useful in preventing the spread of COVID-19?" 


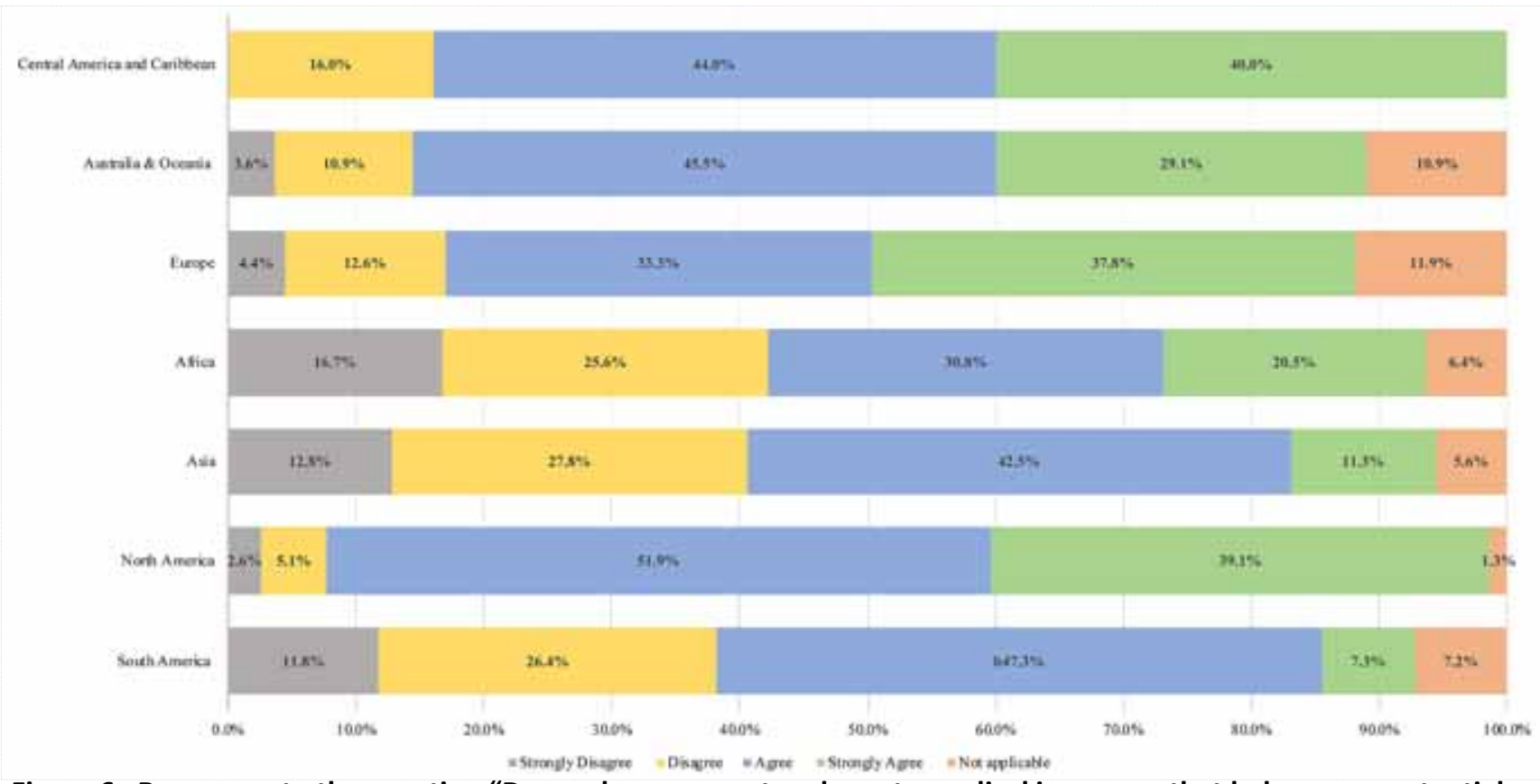

Figure 6. Responses to the question "Do you have access to adequate medical insurance that helps cover potential treatment for COVID-19?"

Rangers' personal lives appeared to have been impacted by the COVID-19 pandemic across all regions, with almost half of them agreeing that they were spending less time with their families as a result. More than 85 per cent were worried about family members contracting COVID-19 while they were away on duty. Respondents were also concerned about COVID-19 during their daily operations: more than 70 per cent of rangers reported being worried about contracting the virus during patrol and more than 80 per cent were concerned about contracting COVID-19 when they encountered suspects. Nearly 40 per cent of rangers were also worried about potentially transmitting COVID -19 to wildlife that they encountered during their work. Two-thirds of rangers had access to a COVID-19 test if needed. But, whilst more than three-quarters said that they did not have to pay for testing, access varied region by region: half of those in Africa, two-thirds of those in Asia but barely 30 per cent of those in South America were able to be tested.

The role of rangers in controlling COVID-19: When asked, "Do you believe that rangers have a role in controlling COVID-19?", four out of five respondents agreed. Ranger roles that were nominated by respondents included:

1. environmental conservation that reduces risk of zoonotic disease spillover;

2. awareness and education in relation to health guidelines (masks, social distancing etc) for:

a. local communities b. visitors

3. support for others provided by:

a. building visitor confidence to revive tourism

b. providing food for remote and vulnerable communities

c. assisting other agencies to protect provincial and international borders

4. providing access to natural areas to support mental and physical well-being

Those who do not believe that they have such a role in controlling COVID-19 considered that their primary role is nature protection, not health response because:

1. they do not have the right expertise, skills and legal mandate to be a respondent to health crisis;

2. their workload has significantly increased (e.g. in the USA huge influx in visitor numbers) and they do not have the time to take on additional duties;

3. Indigenous rangers have to stay away from any health risk to ensure that they do not take the virus back to their Indigenous communities;

4. rangers do not contact the public sufficiently to play a role in controlling the spread of the virus; and

5. involvement in such work should be voluntary and not mandated by managers.

There was, though, some variation between regions: the overwhelming majority of African rangers believed that they did not have any direct role in controlling the spread of COVID-19, whereas little more than half the European rangers took that view. This shows the pivotal 


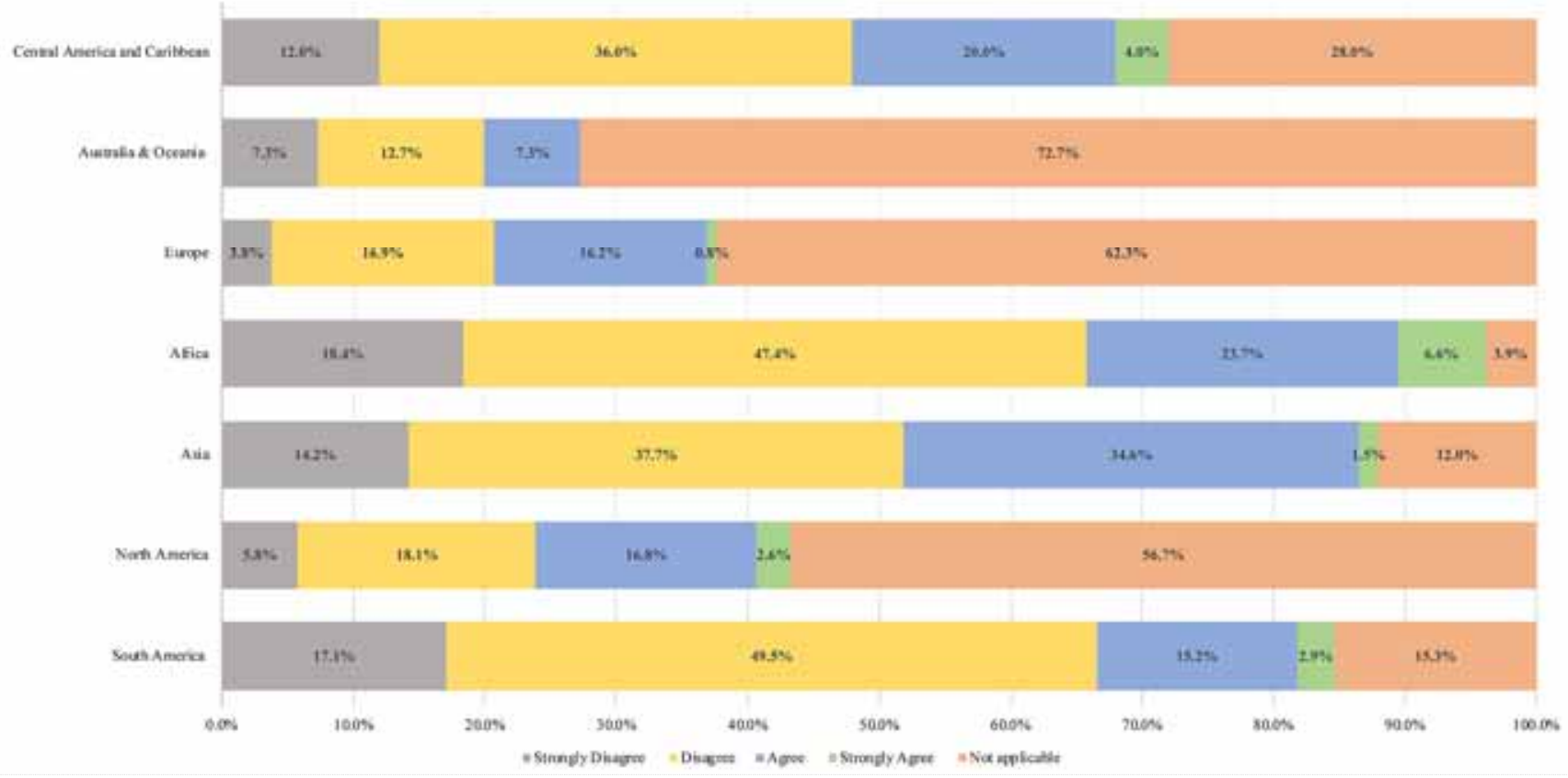

Figure 7. Responses to the statement: "Since the start of the COVID-19 pandemic, the conservation/protected area authority has sufficiently shared rations with the local communities."

need for clarity and understanding about the role of rangers, not only among the general public but also among rangers themselves.

Impact on ranger-community relationship: Half the respondents believed that the PCA authority they worked for had conducted sufficient awareness and education programmes about COVID-19 for local communities. However, nearly 90 per cent reported an impact on community engagement activities due to the COVID-19 pandemic. Lockdowns, movement control orders and fear of spreading COVID-19 may have been the reason behind the impact on community engagement activities. A quarter of all rangers interviewed have mentioned that their park authorities have shared their rations with local communities during the COVID-19 pandemic; in Asia more than a third have done this (Figure 7). Many also mentioned that they have done this in their personal capacity too.

\section{RESULTS FROM THE CASE STUDIES Pakistan}

Supporting other agencies: 58 of the 157 rangers interviewed were partially or fully assigned with additional duties to support other government departments. These included helping to implement lockdown measures (e.g. preventing public gatherings, prohibiting the public from entering protected and conserved areas) and raising awareness regarding COVID-19 related measures.
Supporting communities: Officially no tasks were assigned to rangers regarding community support. However, rangers have been doing so in a professional and personal capacity. 118 rangers provided a portion of their salary to COVID-19 relief efforts. 125 rangers said they also helped communities by providing food, 44 helped arrange access to doctors or health care facilities during lockdown periods and 3 taught children in local communities.

\section{India}

Out of 52 respondents, 39 were female and 13 were male. When rangers were required to be absent during the COVID-19 pandemic, their family members faced challenges in procuring food, medical equipment and other daily needs. Two-thirds of female rangers found their work-life balance very challenging during the pandemic. 45 of the families surveyed were concerned about rangers contracting COVID-19 in the field and about the lack of medical support available there. Threequarters of rangers interviewed said they received their salaries on time and were positive about the steps their respective departments were taking to support them during these challenging times. 49 of the 52 families were content that their rangers should spend more time in the field helping to control the spread of the virus.

\section{DISCUSSION}

COVID-19 has had an unprecedented impact on human health, society and the global economy, so a priority is to 
understand how this and other zoonotic diseases came into being and how to prevent future zoonotic spill-over events. This pandemic is believed to have arisen from the consumption or handling of wildlife meat from an unregulated market (Bisson et al., 2015; Hockings et al., 2020). While this may never be fully verified, similar disease outbreaks have been linked to the destruction of nature, especially encroachment into wild areas (Brancalion et al., 2020; Gibb et al., 2020; Goldberg et al., 2008). Therefore, a priority is to establish preventative measures such as the protection of wildlife habitats and the reduction of unregulated and illegal exploitation of wildlife. The most effective means of habitat protection is the establishment of protected and conserved areas and other effective area-based conservation measures. 15.4 per cent of terrestrial areas and 3.4 per cent of global ocean area is under some formal protective status (UNEP-WCMC and IUCN, 2016). The key to maintaining their value and reducing the exploitation of nature is effective management, enforcement of regulations and building strong community relations. These actions all rely heavily on rangers, who are on the frontline, protecting nature from many threats - notably illegal logging, land clearing (Sodhi et al., 2004; Wilcove et al., 2013), hunting and the illegal wildlife trade (Gray et al., 2017; Harrison et al., 2016). By performing this vital task, rangers are, in turn, helping to reduce the likelihood of future pandemics of zoonotic origin (Bergen, 2020), thus delivering a planetary health service.

The results from this study suggest that a significant proportion of rangers believe the current pandemic is exacerbating threats to PCAs and negatively impacting on them and their work, which was already fraught with various organisational, occupational and personal challenges before the pandemic (Belecky et al., 2019; Singh et al., 2020). On a personal level, rangers are already burdened with long working hours and job requirements that keep them away from their families for significant periods of time. Other studies on rangers from Asia, Africa and Latin America, for example, reported that they already work an average of 105.7 hours per week and more than a quarter (26.5 per cent) of rangers spend less than five days a month with their families (Belecky et al., 2019; Singh et al., 2020). On top of this, our survey found that half of all respondents reported that the pandemic is causing them to spend less time with their families, and is causing the added stress of employment and financial uncertainty. All of these factors put the welfare of rangers at risk.

The perceived increase in threats to PCAs in some regions, particularly in South America, is in line with other research that suggests that the pandemic has resulted in more illegal killing of wildlife, logging and other environmental crimes (Badola, 2020; Waithaka, 2020; World Bank, 2020). However, our data indicate strong regional differences in rangers' perceptions, with many disagreeing that threats have increased during this period. While previous reports have uncovered an increase in logging and poaching (Hockings et al., 2020; Waithaka, 2020; World Bank, 2020), the highest perceived threat by rangers globally was NTFP collection, grazing and other similar pressure - although this was the only type of threat increase that was not corroborated by most South American rangers.

An increase in NTFP collection and grazing was reported by most rangers in North America, Asia, Africa, Australia and Oceania. This can be a significant issue in some PCAs with varied impacts on different taxa (Broder et al., 2019; Soofi et al., 2018). However, this threat is often considered less serious than illegal logging and poaching, which can rapidly impact wildlife populations (Sodhi et al., 2004; Wilcove et al., 2013). The perception that NTFP collection and grazing are the greatest threats may be a result of the high number of responses from rangers in the USA and Asia, where grazing or land use intensification (Hanberry \& Abrams, 2018), and NTFP reliance (Das, 2005), are respectively common issues impacting PCAs. Despite this, the regions with the highest proportions of rangers reporting threat increases were South America and Africa, where the primary threats identified by rangers were illegal logging, encroachment and subsistence hunting - the latter more strongly reported by African rangers. These results are not surprising, given the existing reports of illegal logging and encroachment in South America (Brancalion et al., 2020; Escobar, 2020; Silva-Araújo et al., 2020) and the often poorly resourced or understaffed ranger forces in both regions. The high proportion of rangers in South America reporting an increase in encroachment (80 per cent) and the existing reports of deforestation in the region should provide renewed concern for the forests of South America. The strong link between the pandemic and increased hunting reported by African rangers is also concerning: even though the region has been the site of various zoonoses in recent decades (Marcotty et al., 2009; Asante et al., 2019), this does not seem to be deterring wildlife consumption, indeed it may even have increased. Interestingly, the responses from Asia, which has been the source of notable recent zoonoses, indicated that the pandemic had not led to more hunting, however, the threat posed by poaching and wildlife consumption is well documented in the region (Sodhi et al., 2004; Wilcove et al., 2013). 
The negative impact on PCAs may be due to deteriorating socio-economic conditions around PCAs. The long-term economic and environmental consequences of pandemic-related changes - increased poverty, displacement of populations, undermining of protection from risks such as unemployment and exclusion - are unclear and will require continued attention (UNDP, 2020). Reduced ranger services may also have played a part as more than half of rangers reported that they had been assigned to additional tasks, many of which were unrelated to their regular duties.

The social and economic fallout resulting from the pandemic has led to budget cuts for PCAs, which affect their ability to operate effectively and impact on the rangers as individuals. More than half of rangers reported adverse effects on their personal lives: a quarter reported salary reductions and payment delays; 20 per cent reported losing their jobs as a direct result of the pandemic. This loss of salary and staff will put further pressure on an already overstretched and underpaid workforce (Belecky et al., 2019) with negative impacts on PCAs which are already operating below the level required for effective protection (Leverington et al., 2010). The current situation also affects ranger welfare, directly through job losses and in other ways. Recent research has shown that rangers around the world often lack adequate health insurance (Belecky et al., 2019) and with the risk of disease transmission this concern is heightened. 27.9 per cent of rangers reported a lack of insurance coverage should they contract COVID-19 and previous research indicated that half of all rangers have no access to medical facilities (Belecky et al., 2019). 82.5 per cent of survey respondents indicated a fear of contracting

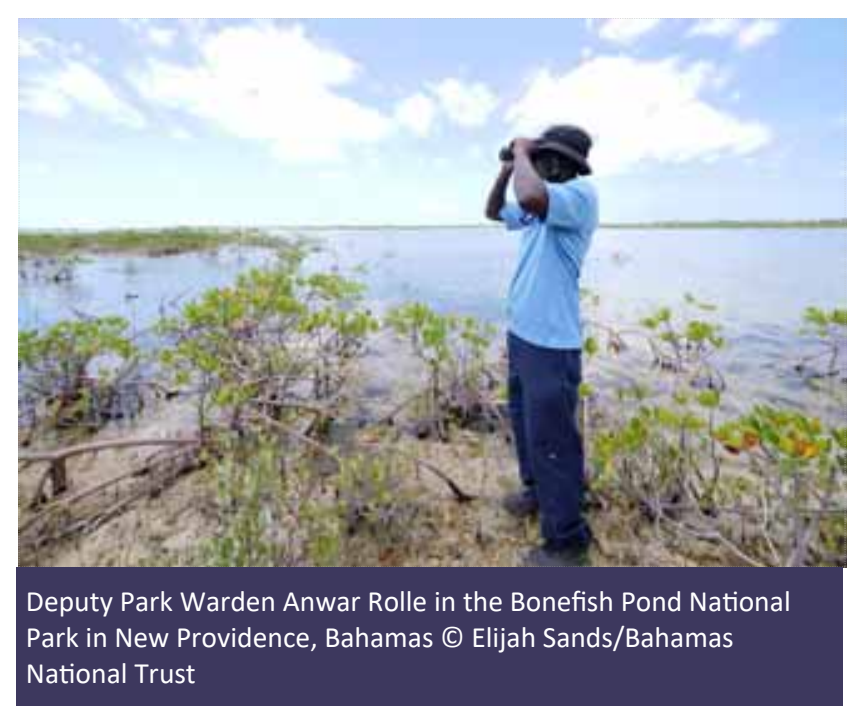

COVID-19 at work. Rangers who continue to deliver their duties in the field could be at significant risk.

While most rangers were fearful of contracting COVID19 while on patrol or encountering suspects, most believed that they have a role in controlling its spread. However, strong regional differences were reported which provide some insights as to the differing perceptions of rangers about their roles. Nearly all North American rangers felt they had a role to play, while practically none of the rangers from Africa felt they had a direct role in controlling the spread of the virus. There are clearly great differences in how the importance of rangers' work is perceived in each region. This could be a result of the way that rangers' work differs in different regions or it could demonstrate that many rangers themselves are unaware of the full potential of their role.

The survey results have provided some concerning results, most notably perhaps the impact on activities relating to community engagement. This could further complicate the already problematic relationship between communities and protected and conserved areas (Anaya \& Espirto-Santo, 2018), and between rangers and local communities (UN OHCHR, 2010). Given the increased rate of global unemployment (Bluestein et al., 2020), financial hardship (Nicola et al., 2020), internal migration (Dandekar \& Ghai, 2020) and reliance on wildlife for subsistence (McNamara et al., 2020), a positive and mutually supportive relationship between PCA authorities and communities is more important than ever.

\section{RECOMMENDATIONS}

Rangers are among those on the frontline in managing and protecting biodiversity, along with many other stakeholders, but especially Indigenous peoples and local communities. Despite the critical role that rangers play in conservation, their work is often underrecognised and under-resourced; they are often poorly trained and equipped to address the threats facing the world's biodiversity.

The COVID-19 pandemic has further highlighted the critical role that rangers should play in preventing disease by maintaining the balance between nature and humans - in effect acting as front-line health service workers on behalf of the planet. At the same time, it has revealed that many of them have been serving their local communities at this moment of crisis. However, the COVID-19 pandemic has also made their job more difficult. The surveys have provided insights into the challenges that rangers are facing during the pandemic and their role in alleviating its impacts. 
In light of our analysis, we suggest the following four recommendations to address the critical needs of rangers:

Raise the status of rangers: The unregulated harvest and trade in wildlife, illegal logging, human encroachment into wildlife habitat, unauthorised land clearance and other environmental crimes that destroy nature increasingly bring people into contact with wildlife which in turn contributes to an increased risk of zoonotic disease transmission. Through their work in protecting biodiversity, rangers play an indispensable role in limiting the likelihood that zoonotic diseases will endanger people. In countries such as India, Bhutan, Nepal and South Africa, rangers are already recognised as an essential service, meaning that their critical work continues despite lockdowns or other similar restrictions. This is not the case in many other countries, where ranger work is severely impacted during national emergencies. Recognition of rangers as an essential service by governments, to be set alongside comparable public servants such as the police, firefighters and medical health workers especially in Asia, Africa and Latin America, will benefit biodiversity conservation during the pandemic and help maintain public health.

Professionalise the job of a ranger: Recognition of the ranger profession as an essential service should lead to greater investment in professionalising the ranger sector, including through increased allocation of government resources, improved recruitment processes, better training opportunities when beginning service and throughout the duration of service. In many countries, the profession needs better career opportunities, improved working conditions and enhanced pay.

Put community relations at the heart of ranger work: More than four out of five rangers in Asia, Africa and Latin America believe that success in their jobs depends on the help of local communities, which was the aspect of ranger work most impacted by the pandemic according to this survey. While much of this may be due to a temporary reduction in contact between rangers and communities, this relationship must remain at the very top of the agenda for protected and conserved areas. Furthermore, livelihoods of local communities may have been so undermined by the pandemic that they will become more dependent on forest resources, leading to an increase of illegal activities, which could damage the often already precarious relationship between rangers and communities. The role of rangers in supporting communities and their livelihoods, by protecting the resources that communities depend upon, needs to be recognised. The current pandemic has demonstrated the crucial interdependence of these two vital partners in conservation, and consequently the mutually supportive roles of community and conservation stakeholders in the protection and management of PCAs.

Ensure sufficient resources on the ground: The pandemic has highlighted the role of rangers as planetary health workers and the crucial role they can play in supporting vulnerable communities in remote areas. Prevention of future pandemics is far less costly than managing future ecosystem service losses (IPBES, 2020; Waldron, 2020), or the pandemics and the public health crises they precipitate. In this light, the best precaution against another pandemic is to invest in the care of the natural environment so that it delivers stable ecosystem services, climate change mitigation, jobs and other benefits to society (OECD, 2020). Those making this case to governments should include the resourcing of rangers - in terms of ranger numbers, training, equipment and welfare - as a priority. Indeed, the three recommendations above all call for more support to rangers.

\section{ENDNOTES}

${ }^{1}$ The study, including its informed consent and anonymity protections, was approved by the University of Central Florida institutional review board (STUDY00002120)

${ }^{2}$ The authors of this paper do not endorse the borders of this map shown in this publication, nor any political position related to territorial claims.

\section{SUPPPLEMENTARY ONLINE MATERIAL}

Survey form - Impact of COVID-19 on ranger workforce

\section{ACKNOWLEDGEMENTS}

The survey was only possible with support from the many individuals and institutions that contributed to it. We would specifically like to thank Southern African Wildlife College, all regional chapters of the International Ranger Federation, and national and provincial ranger associations. We would also like to thank the field teams of World Wide Fund for Nature and Global Wildlife Conservation. Finally, we are also highly indebted to all the rangers who participated in the survey.

\section{ABOUT THE AUTHORS}

Rohit Singh has over 15 years' experience in wildlife law enforcement and anti-poaching. He currently leads the Zero Poaching Initiative of WWF Wildlife Crime Initiative. 
Chris Galliers is the current president of the International Ranger Federation (IRF), having been on the IRF committee since 2012.

William Moreto is an academic, working for the University of Central Florida, with a background in criminology and has studied rangers extensively across Asia and Africa.

James Slade is Global Wildlife Conservation's Wildlife Crime Prevention Officer with over a decade of experience in protected areas and anti-poaching.

Barney Long is the director of species conservation at Global Wildlife Conservation, focusing on the conservation and recovery of highly threatened mammals.

Hamera Aisha is associated with WWF-Pakistan. She has been working on wildlife conservation including poaching and illegal wildlife for over 10 years in Pakistan.

Andrew Wright is the Park Manager at Pickwick Landing State Park in Tennessee in the United States and North American Representative of the IRF.

Falon Cartwright is the Operations Manager for the Bahamas National Trust with over a decade of experience in national park management, grants and project management, and strategic planning.

Atul Deokar is associated with Maharashtra Forest Department, in the Government of India, as Assistant Conservator of Forest, Pench Tiger Reserve. He worked as General Secretary of the Forest Rangers Association of Maharashtra

Alexander Wyatt is a conservation professional contributing to WWF's Wildlife Crime Initiative supporting anti-poaching and ranger work primarily in Asia.

Deepali Deokar is working for empowerment of female staff of the forest department and also with the locals through various activities in Maharashtra, India

Rungnapa Phoonjampa is the Wildlife Practice Lead based in WWF-Thailand. Her interests are focused on gibbon population and ecology. She is currently in charge of tiger conservation in the Upper Western Forest Complex, Thailand.

Eddie Smallwood is an Aboriginal and South Sea Island man from the Townsville Region in Australia.

Rizwana Aziz is Assistant Director Wildlife at the Punjab Wildlife and Parks Department in Pakistan.
During her 13 years' experience, she has been involved in various aspects of wildlife crime prevention.

Amon Koutoua Benoit is the Western Africa Representative of the Game Rangers Association of Africa and the Africa Representative of the IRF.

Renata Cao is a passionate conservationist with more than 15 years of experience working with IPLC in Latin American Protected Areas. Currently her work relates to Latin American Wildlife.

Sean Willmore is a former Australian Park Ranger and now founder and Managing Director of the Thin Green Line Foundation, and the current President of the IRF.

Deepani Jayantha is a veterinarian and a conservationist from Sri Lanka, working closely with the local department of wildlife conservation for more than 15 years.

Sonali Ghosh is a practising forester and formerly a natural World Heritage site manager.

\section{REFERENCES}

Aguirre, A.A., Catherina, R., Frye, H. and Shelley, L. (2020). Illicit wildlife trade, wet markets, and COVID 19: preventing future pandemics. World Medical \& Health Policy, 12(3): 256-265. doi: 10.1002/wmh3.348

Anaya, F.C. and Espírito-Santo, M.M. (2018). Protected areas and territorial exclusion of traditional communities. Ecology and Society, 23(1). doi: 10.5751/ES-09850-230108

Asante, A. D., Ir, P., Jacobs, B., Supon, L., Liverani, M., Hayen, A., Jab, S. and Wiseman, V. (2019). Who benefits from healthcare spending in Cambodia? Evidence for a universal health coverage policy. Health policy and planning, 34 (Supplement_1), i4-i13. doi: 10.1093/heapol/czz011

Badola, S. (2020). Indian wildlife amidst the COVID-19 crisis: an analysis of status of poaching and illegal wildlife trade. TRAFFIC India office. Available at: https://www.traffic.org/site/ assets/files/12885/wildlife-amidst-covid-19-india-web.pdf

Belecky, M., Singh, R. and Moreto, W.D. (2019). Life on the frontline 2019: A global survey of the working conditions of rangers. WWF report, 70pp. Available at: https:// c402277.ssl.cf1.rackcdn.com/publications/1279/files/original/ wwf_rangers_survey_report_2019.pdf?1575295516

Bergen, M. (2020). How COVID-19 is impacting rangers worldwide. USA: Global Wildlife Conservation. Available at: https://www.globalwildlife.org/blog/how-covid-19-is-impactingrangers-worldwide/

Bisson, I., Ssebide, B.J. and Marra, P.P. (2015). Early detection of emerging zoonotic diseases with animal morbidity and mortality monitoring. EcoHealth 12: 98-103. doi: 10.1007/ s10393-014-0988-x

Bloomfield, L.S.P., McIntosh, T.L. and Lambin, E.F. (2020). Habitat fragmentation, livelihood behaviors, and contact between people and nonhuman primates in Africa, Landscape Ecology, 35(4): 985-1000. doi: 10.1007/s10980-020-00995-w 
Blustein, D. L., Duffy, R., Ferreira, J. A., Cohen-Scali, V., Cinamon, R. G., \& Allan, B. A. (2020). Unemployment in the time of COVID-19: A research agenda. doi: 10.1016/ j.jvb.2020.103436

Brancalion, P.H., Broadbent, E.N., de-Miguel, S., Cardil, A., Rosa, M.R., Almeida, C.T., Almeida, D.R., Chakravarty, S., Zhou, M., Gamarra, J.G. and Liang, J. (2020). Emerging threats linking tropical deforestation and the COVID-19 pandemic. Perspectives in Ecology and Conservation. doi: 10.1016/j.pecon.2020.09.006

Bröder, L., Tatin, L., Danielczak, A., Seibel, T. and Hochkirch, A. (2019). Intensive grazing as a threat in protected areas: the need for adaptive management to protect the Critically Endangered Crau plain grasshopper Prionotropis rhodanica. Oryx, 53(2): 239-246. doi: 10.1017/ S0030605318000170

Butler, C.D. (2008). Human health and forests: An overview. Human Health and Forests: 13-33.

Dandekar, A. and Ghai, R. (2020). Migration and reverse migration in the age of COVID-19. Economic \& Political Weekly, 55(19): 28-31. Available at: https://www.epw.in/ journal/2020/19/commentary/migration-and-reverse-migration -age-covid-19.html

Das, B.K. (2005). Role of NTFPs among forest villagers in a protected area of West Bengal. Journal of Human Ecology, 18(2): 129-136. doi: 10.1080/09709274.2005.11905820

Díaz, S., Settele, J., Brondízio, E., Ngo, H., Guèze, M., Agard, J., Arneth, A., Balvanera, P., Brauman, K., Butchart, S. and Chan, K. (2020). Summary for policymakers of the global assessment report on biodiversity and ecosystem services of the Intergovernmental Science-Policy Platform on Biodiversity and Ecosystem Services. Available at: https://uwerepository.worktribe.com/output/1493508

Escobar, H. (2020). Illegal deforestation in Brazil soars amid climate of impunity, Science Magazine. Available at: https:// www.sciencemag.org/news/2020/08/illegal-deforestationbrazil-soars-amid-climate-impunity

Fair, J. (2020). COVID-19 lockdown precipitates deforestation across Asia and South America, Mongabay, published on July, 2020. Available at: https:// news.mongabay.com/2020/07/covid-19-lockdown-precipitates -deforestation-across-asia-and-south-america/

FFI. (2020). How is Covid-19 affecting wildlife and rangers in Indonesia's tiger hotspot? Cambridge: Fauna and Flora International. Available at: https://www.fauna-flora.org/news/ covid-19-affecting-wildlife-rangers-indonesias-tiger-hotspot

Gibb, R., Redding, D.W., Chin, K.Q., Donnelly, C.A., Blackburn, T.M., Newbold, T. and Jones, K.E. (2020). Zoonotic host diversity increases in human-dominated ecosystems. Nature, 584(7821): 398-402. doi: 10.1038/ s41586-020-2562-8

Goldberg, T.L., Gillespie, T.R. and Rwego, I.B. (2008). 'Health and disease in the people, primates, and domestic animals of Kibale National Park: implications for conservation'. In Science and conservation in African forests: The benefits of long-term research (pp. 75-87). Cambridge University Press. doi: $10.1017 / C B O 9780511754920.010$

Gray, T.N., Billingsley, A., Crudge, B., Frechette, J.L., Grosu, R., Herranz-Muñoz, V., Holden, J., Keo, O., Kong, K., Macdonald, D. and Neang, T. (2017). Status and conservation significance of ground-dwelling mammals in the Cardamom Rainforest Landscape, southwestern Cambodia. Cambodian Journal of Natural History, 2017: 3848. Available at: https://assets.fauna-flora.org/wp-content/ uploads/2017/11/201706_Cambodian-Journal-of-NaturalHistory.pdf

Hanberry, B.B. and Abrams, M.D. (2018). Recognizing loss of open forest ecosystems by tree densification and land use intensification in the Midwestern USA. Regional Environmental Change, 18(6): 1731-1740. doi: 10.1007/ s10113-018-1299-5

Harrison, R.D., Sreekar, R., Brodie, J.F., Brook, S., Luskin, M., O'Kelly, H., Rao, M., Scheffers, B. and Velho, N. (2016). Impacts of hunting on tropical forests in Southeast Asia. Conservation Biology, 30(5): 972-981. doi: 10.1111/ cobi.12785.

Hockings, M., Dudley, N., Elliott, W., Ferreira, M.N., Mackinnon, K., Pasha, M.K.S., Phillips, A. et al.(2020). Editorial essay: Covid-19 and protected and conserved areas. PARKS, 26(1). doi: 10.2305/IUCN.CH.2020.PARKS-26-1MH.en

IRF (2019). Who Is A Ranger? Available at: https:// www.internationalrangers.org/

IRF (2020). Roll of Honour, 2020. Available at: https:// www.internationalrangers.org/meet-our-rangers/\#roll-ofhonour

ILRI (2020). Wildlife markets in the pandemic: Prohibit or preserve them? Ban or promote them? Available at: https:// clippings.ilri.org/2020/09/02/wildlife-markets-in-the-pandemicprohibit-or-preserve-them-ban-or-promote-them/

IPBES (2020). Pandemics Report: Escaping the 'Era of Pandemics'. Available at: https://ipbes.net/sites/default/ files/2020-12/IPBES\%20Workshop\%20on\%20Biodiversity\% 20and\%20Pandemics\%20Report_0.pdf

Leverington, F., Costa, K.L., Pavese, H., Lisle, A. and Hockings, M. (2010). A global analysis of protected area management effectiveness. Environmental Management, 46(5): 685-698. doi: $10.1007 / \mathrm{s} 00267-010-9564-5$

Loh, E.H., Zambrana-Torrelio, C., Olival, K.J., Bogich, T.L., Johnson, C.K., Mazet, J.A., Karesh, W. and Daszak, P. (2015). Targeting transmission pathways for emerging zoonotic disease surveillance and control. Vector-Borne and Zoonotic Diseases, 15(7): 432-437. doi: 10.1089/ vbz.2013.1563

Long, B, Grein, G., Boedicker, N. and Singh, R. (2016). Are rangers adequately protected by insurance schemes? PARKS 22(2): 83-93. doi: 10.2305/IUCN.CH.2016.PARKS-222BL.en

Mackenzie, J.S. and Jeggo, M. (2019). The One Health approach-Why is it so important? Tropical Medicine and Infectious Disease, 4, 88. doi: 10.3390/tropicalmed4020088

Marcotty, T., Matthys, F., Godfroid, J., Rigouts, L., Ameni, G., Gey van Pittius, N. et al. (2009). Zoonotic tuberculosis and brucellosis in Africa: neglected zoonoses or minor publichealth issues? The outcomes of a multi-disciplinary workshop. Annals of Tropical Medicine \& Parasitology, 103(5), 401-411. doi: : 10.1179/136485909X451771

Magouras, I., Brookes, V.J., Jori, F., Martin, A., Pfeiffer, D.U. and Dürr, S. (2020). Emerging zoonotic diseases: Should we rethink the animal-human interface? Frontiers in Veterinary Science, 7. doi: 10.3389/fvets.2020.582743 
McNamara, J., Robinson, E.J., Abernethy, K., Iponga, D.M., Sackey, H.N., Wright, J.H. and Milner-Gulland, E.J. (2020). COVID-19, systemic crisis, and possible implications for the wild meat trade in Sub-Saharan Africa. Environmental and Resource Economics, 76(4): 1045-1066. doi: 10.1007/s10640 $-020-00474-5$

Moreto, W. D. (2019). Provoked poachers? Applying a situational precipitator framework to examine the nexus between humanwildlife conflict, retaliatory killings, and poaching. Criminal Justice Studies, 32(2), 63-80. doi: 10.1080/1478601X.2019.1600816

Nicola, M., Alsafi, Z., Sohrabi, C., Kerwan, A., Al-Jabir, A., losifidis, C., Agha, M. and Agha, R. (2020). The socioeconomic implications of the coronavirus pandemic (COVID19): A review. International Journal of Surgery (London, England), 78, 185. doi: 10.1016/j.ijsu.2020.04.018

OECD (2020). Policy Responses to Coronavirus (COVID-19), From containment to recovery: Environmental responses to the COVID-19 pandemic, Version 20 April 2020 Available at: https://www.oecd.org/coronavirus/en/policy-responses

Plowright, R.K., Parrish, C.R., McCallum, H., Hudson, P.J., Ko, A.I., Graham, A.L. and Lloyd-Smith, J.O. (2017). Pathways to zoonotic spillover. Nature Reviews Microbiology, 15(8): 502510. doi: 10.1038/nrmicro.2017.45

Rowcliffe, J.M., de Merode, E. and Cowlishaw, G. (2004). Do wildlife laws work? Species protection and the application of a prey choice model to poaching decisions. Proceedings of the Royal Society of London. Series B: Biological Sciences, 271 (1557): 2631-2636. doi: 10.1098/rspb.2004.2915

Silva-Araújo, M., Silva-Junior, E.F., Neres-Lima, V., Feijó-Lima, R., Tromboni, F., Lourenço-Amorim, C., Thomas, S.A., Moulton, T.P. and Zandonà, E. (2020). Effects of riparian deforestation on benthic invertebrate community and leaf processing in Atlantic forest streams. Perspectives in Ecology and Conservation. doi: 10.1016/j.pecon.2020.09.004

Singh, R., Gan, M., Barlow, C., Long, B., Mcvey, D., De Kock, R., Gajardo, O.B., Avino, F.S. and Belecky, M. (2020). What to Rangers feel? Perceptions from Asia, Africa and Latin America. PARKS, 26: 63. doi: 10.2305/ IUCN.CH.2020.PARKS-26-1RS.en

Sodhi, N.S., Koh, L.P., Brook, B.W. and Ng, P.K. (2004). Southeast Asian biodiversity: an impending disaster. Trends in Ecology \& Evolution, 19(12): 654-660. doi: 10.1016/ j.tree.2004.09.006

Soofi, M., Ghoddousi, A., Zeppenfeld, T., Shokri, S., Soufi, M., Jafari, A., Ahmadpour, M., Qashqaei, A.T., Egli, L., Ghadirian, T. and Chahartaghi, N.R. (2018). Livestock grazing in protected areas and its effects on large mammals in the Hyrcanian forest, Iran. Biological Conservation, 217: 377-382. doi: 10.1016/j.biocon.2017.11.020

Thompson, R.A. (2013). Parasite zoonoses and wildlife: one health, spillover and human activity. International Journal for Parasitology, 43(12-13): 1079-1088. doi: 10.1016/ j.ijpara.2013.06.007
Tranquilli, S., Abedi-Lartey, M., Abernethy, K., Amsini, F., Asamoah, A., Balangtaa, C., Blake, S., Bouanga, E., Breuer, T., Brncic, T.M. and Campbell, G. (2014). Protected areas in tropical Africa: assessing threats and conservation activities. PloS One, 9(12): e114154. doi:10.1371/ journal.pone. 0114154

UNDP (2020). Brief 2: Putting the UN Framework for SocioEconomic Response to COVID-19 into Action: Insights. Available at: https://www.undp.org/content/undp/en/home/ coronavirus/socio-economic-impact-of-covid-19.html

UNEP-WCMC and IUCN (2016). Protected Planet Report 2016. Cambridge UK and Gland, Switzerland: UNEP-WCMC and IUCN. Available at: https://portals.iucn.org/library/sites/library/ files/documents/2016-051.pdf

UNEP (2020). There are no winners in the illegal trade in wildlife. Available at: https://www.unenvironment.org/news-andstories/story/there-are-no-winners-illegal-trade-wildlife

UNODC (2020). Preventing future pandemics of zoonotic origin by combating wildlife crime: protecting global health, security and economy. Available at: https://www.unodc.org/documents/ Advocacy-Section/

Wildlife_trafficking_COVID_19_GPWLFC_public.pdf

UN OHCHR (2010). Investigating allegations of extra-judicial killings in the Terai: OHCHR-Nepal, Summary of Concerns, July 2010. Available at: https://reliefweb.int/report/nepal/ investigating-allegations-extra-judicial-killings-terai-ohchrnepal-summary-concerns-

Waithaka, J. (2020). The impact of COVID-pandemic on Africa's protected areas operations and programmes. IUCN. Available at: https://www.iucn.org/sites/dev/files/content/ documents/2020/ report_on_the_impact_of_covid_19_doc_july_10.pdf

Waldron, A., Adams, V., Allan, J., Arnell, A., Asner, G., Atkinson, S., Baccini, A., Baillie, J., Balmford, A.et al. (2020). Protecting $30 \%$ of the planet for nature: costs, benefits and economic implications: Working paper analysing the economic implications of the proposed $30 \%$ target for areal protection in the draft post-2020 Global Biodiversity Framework. Available at: http://pure.iiasa.ac.at/16560 58pp.

Wilcove, D.S., Giam, X., Edwards, D.P., Fisher, B. and Koh, L.P. (2013). Navjot's nightmare revisited: logging, agriculture, and biodiversity in Southeast Asia. Trends in Ecology \& Evolution, 28(9): 531-540. doi: 10.1016/j.tree.2013.04.005

World Bank. (2020). Risking Lives to Protect Wildlife and Wildlands: Stories from Rangers in the Field. Washington, DC: World Bank. (c) World Bank. Available at: https:// www.worldbank.org/en/news/feature/2020/07/30/risking-livesto-protect-wildlife-and-wildlands-stories-from-rangers-in-thefield

WWF (2020). Mehr Wald geht durch Corona verloren, Berlin: WWF Germany, Available at: https://blog.wwf.de/waldcorona/?_ga=2.191480681.232588903.15900743151039827102.1590074315\&_gac $=1.225442152 .1590074315 . C$ j0KCQjwzZj2BRDVARIsABs3I9KYLYW7DJ-84Ksdx0sDJY69EZh37S104nlwYCPVCrWdVGSVGSARTgaAqs5 EALw_wcB 


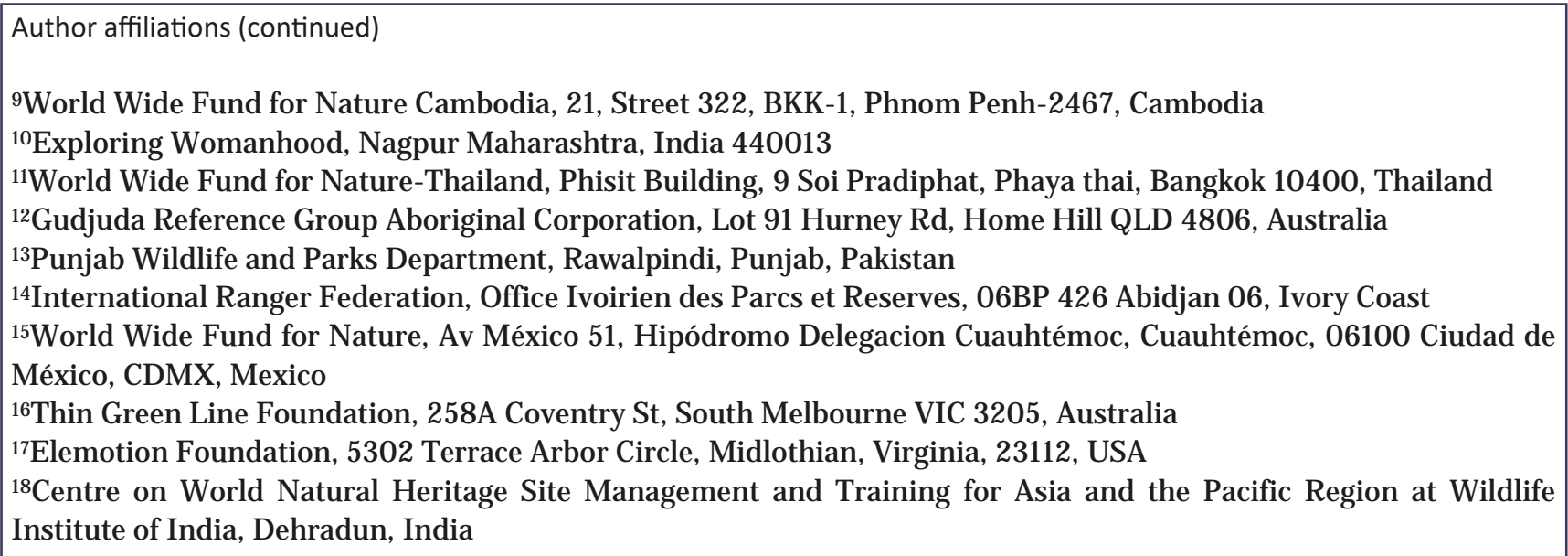

\section{RESUMEN}

Los guardaparques desempeñan un papel indispensable en el mantenimiento del equilibrio entre las personas y el mundo natural mediante la protección y la gestión de las áreas protegidas y conservadas. A pesar de desempeñar este importante papel, los guardaparques se enfrentan a muchos retos en el ámbito organizativo, ocupacional y personal que dificultan el cumplimiento de sus obligaciones. La pandemia del COVID-19 ha exacerbado estos retos y ha hecho aún más difícil la lucha contra la matanza ilegal de la vida silvestre, la tala ilegal, la recolección ilegal de productos forestales no madereros, la invasión y otros delitos ambientales en las áreas protegidas y conservadas. Se recibieron 915 respuestas al cuestionario de guardaparques de 60 países con el fin de comprender cómo percibían el impacto del COVID-19 en los guardaparques y su labor de protección y conservación de las áreas protegidas en todo el mundo. Las conclusiones indican que diferentes aspectos de la labor de los guardaparques han tenido efectos adversos como resultado de la pandemia y las acciones relacionadas de las autoridades y los actores ilegales. El estudio también revela diferentes percepciones regionales del impacto de la pandemia en las áreas protegidas y conservadas y en la labor de los guardaparques. Los resultados del estudio, que proporcionan una visión útil de los retos a los que se enfrentan los guardaparques durante la actual crisis mundial e indican dónde pueden ser necesarias las medidas para mitigar una inminente pérdida de biodiversidad, se utilizan en el documento para apoyar cuatro recomendaciones.

\section{RÉSUMÉ}

Les rangers jouent un rôle indispensable pour maintenir l'équilibre entre les populations et le monde naturel en protégeant et en gérant les aires protégées et conservées. Alors même qu'ils occupent un rôle clé, les rangers sont confrontés à de nombreux défis sur des fronts organisationnels, professionnels et personnels qui entravent l'exécution de leurs fonctions. La pandémie de COVID-19 a exacerbé ces défis et rendue encore plus difficile leur lutte contre l'abattage illégal de la faune, l'exploitation forestière illégale, la récolte illégale de produits forestiers non ligneux, l'empiètement et d'autres délits environnementaux dans les aires protégées et conservées. Les réponses à une enquête auprès de 915 rangers dans 60 pays ont permis de comprendre comment ils perçoivent l'impact de la COVID-19 sur eux-mêmes et sur leur travail de protection et de conservation des aires protégées à travers le monde. Ces données indiquent que de nombreux aspects du travail des rangers ont souffert de l'incidence de la pandémie et des actions connexes des autorités et des acteurs illégaux. Elles révèlent également des différences régionales dans la perception de l'impact de la pandémie dans les aires protégées et conservées et sur le travail des rangers. Les résultats de l'enquête apportent un éclairage utile sur les défis auxquels sont confrontés les rangers pendant la crise mondiale actuelle et permettent de déterminer quelles actions pourraient s'avérer nécessaires pour atténuer une perte imminente de biodiversité. Les conclusions viennent appuyer quatre recommandations contenues dans l'article. 


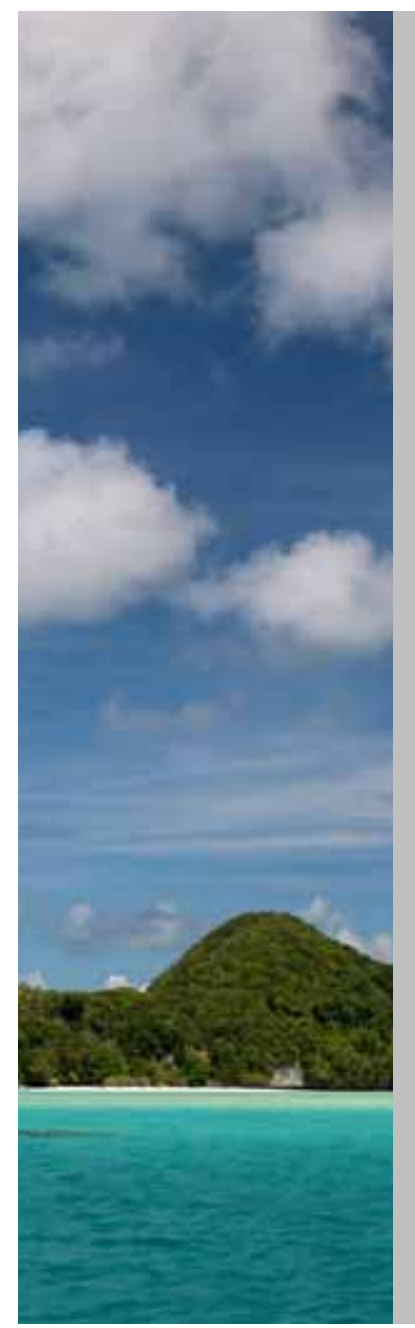

\title{
COVID-ERA POLICIES AND ECONOMIC RECOVERY PLANS: ARE GOVERNMENTS BUILDING BACK BETTER FOR PROTECTED AND CONSERVED AREAS?
}

\author{
Rachel Golden Kroner ${ }^{* 1}$, Edward B. Barbier ${ }^{2}$, Olivier Chassot ${ }^{3}$, Sunita \\ Chaudhary ${ }^{4}$, Lorenzo Cordova Jr5, Annabelle Cruz-Trinidad6, Tracey \\ Cumming ${ }^{6}$, Jennifer Howard 7 , Charlotte Karibuhoye Said8, Zoltan Kun', \\ Angelique Ogena ${ }^{5}$, Florence Palla ${ }^{10}$, Rodrigo Samayoa Valiente ${ }^{11}$, Sebastian \\ Troëng ${ }^{12}$, Allan Valverde ${ }^{3}$, Ramitha Wijethunga ${ }^{13}$ and Michael Wong ${ }^{14}$ \\ *Corresponding author: rgolden@conservation.org \\ ${ }^{1}$ Moore Center for Science, Conservation International, 2011 Crystal Drive, Arlington, VA, \\ 22202, USA \\ ${ }^{2}$ Department of Economics, Colorado State University, Fort Collins, CO, 80523, USA \\ ${ }^{3}$ University for International Cooperation, Avenida 15, Calle 35, Barrio Escalante, San José \\ 10101, Costa Rica \\ ${ }^{4}$ International Centre for Integrated Mountain Development (ICIMOD), Lalitpur 3226, \\ Kathmandu, Nepal \\ ${ }^{5}$ Biodiversity Finance Initiative, United Nations Development Programme, 1554 \\ Mandaluyong City, Philippines \\ ${ }^{6}$ Biodiversity Finance Initiative, United Nations Development Programme, 304 East 45th \\ Street, New York, NY 10017
}

Author affiliations continue on page 147

\section{ABSTRACT}

The COVID-19 pandemic is having a major impact on conservation policies and practice at multiple scales, including protected and conserved areas (PCAs). There is a need to understand the implications for PCAs of recent actions, enacted or promoted in the wake of COVID-19. To fill this knowledge gap, we reviewed economic stimulus packages and other government policies that were implemented or advanced between January and October 2020. We identified positive examples of support for PCAs in economic recovery packages (in 17 countries) and instances where commitments made before 2020 to scale up environmental protections were advanced (in 22 countries), but also rollbacks of protection measures (64 cases in 22 countries). On balance, post-COVID economic stimulus packages and policies to date have undermined more than supported environmental protections, including for PCAs; rollbacks may have long-term consequences where they authorise damaging infrastructure or undermine Indigenous rights. We suggest priority actions for a green economic recovery that include putting PCAs at the centre of such efforts, helping ensure the long-term prosperity of people and our planet.

Key words: economic recovery, conservation finance, COVID-19, regulations, rollbacks, IPLC

\section{INTRODUCTION}

Destruction of the natural environment is directly linked to outbreaks of pandemics. The zoonotic origin of COVID-19 demonstrates the complex links between the health of people and the health of nature, and underscores the importance of avoiding habitat loss and fragmentation to prevent future pandemics (Gibb et al., 2020; Shah et al., 2018). When well-designed and wellmanaged, PCAs not only protect intact ecosystems, they also offer economic and health benefits. Protected areas and areas conserved by Indigenous Peoples and Local Communities (IPLC); or Indigenous and Community Conserved Areas can play a significant role in maintaining intact ecosystems (Andam et al., 2008; BenYishay et al., 2017; Geldmann et al., 2013; Terraube \& Fernández-Llamazares, 2020). Recent analyses demonstrate a 5-to-1 return on environmental investments in protected areas (Waldron et al., 2020) based on the numerous ecosystem services they can provide, including climate mitigation and resilience 
building. When well-designed, and effectively and equitably managed, PCAs can assist vulnerable communities and support sustainable livelihoods (Naidoo et al., 2019) through food security and quality (Basurto, 2018; Cabral et al., 2020; Kawarazuka \& Béné, 2011). Cost-effective investments in PCAs to avoid ecosystem degradation, along with efforts to curb the illegal wildlife trade, have the potential to reduce the risk of future pandemics (ICIMOD, 2020). Billions spent in prevention means societies can avoid spending trillions on coping with the health and economic impacts of environmental degradation and associated pandemics (Dobson et al., 2020). Less straightforward to quantify but no less important are the existence, cultural and spiritual values provided by PCAs.

The COVID-19 pandemic has had a devastating impact on public health and the global economy. All nations are now focusing on economic recovery efforts to support health and livelihoods and to provide immediate relief. At the same time, in many countries, the public funds available for conservation have been cut. Yet the climate and nature crises are becoming ever more serious. Half of the world's GDP is moderately or highly dependent on nature and its services, but current funding for environmental protection is insufficient; the biodiversity financing gap' is estimated at around US\$ 700 billion (WEF, 2020; Deutz et al., 2020).

Notwithstanding this, the current period of economic recovery provides an unprecedented opportunity for nations to make rapid shifts towards green and sustainable investments, including through investments in nature protection. The protection of natural capital, including ecosystem resilience and regeneration, protects biodiversity and helps mitigate, and adapt to, climate change; it can also be an economic multiplier (Hepburn et al., 2020). Investments in nature-based solutions, including protecting and restoring PCAs, can foster long-term health, ecosystem services and biodiversity benefits, as well as promote job creation (Hockings et al., 2020). Although achieving equitable management of PCAs globally requires additional attention (Zafra-Calvo et al., 2019), well-managed protected areas can advance social development agendas, including fair employment, sustainable food production and safe drinking water access (Stolton et al., 2015).

The pandemic - and responses to it - also threaten some conservation efforts. Many national economies are in danger of collapse (Wren, 2020; McKibbin \& Fernando, 2020). Reduced government budgets and weakened enforcement have led to increased illegal deforestation (Brancalion et al., 2020), and more poaching. The loss of funding previously provided by tourism may further weaken PCA effectiveness (Corlett et al., 2020). At a time when the public is understandably preoccupied and unable to participate in decision-making processes, some governments may undermine, weaken or re-interpret environmental regulations and their implementation, in order to realise short-term economic gains. These risks compound historical underfunding of PCAs (Waldron et al., 2020). Therefore, economic recovery efforts should not only involve short-term expansion and support for PCAs (including management capacity (Gill et al., 2017)), but also institute safeguards to ensure long-term sustainability and effective performance.

There is a crucial need to understand how governments' decisions, plans and actions have affected PCAs during the COVID-19 pandemic, including through economic recovery packages, budgets, regulatory changes and other policies. This article takes stock of government actions that have been enacted or proposed between January and October 2020 and have affected or may affect PCAs including economic recovery plans and other policies. It considers the benefits and drawbacks for PCAs, and suggests lessons that can inform near and longer-term economic recovery efforts and ensure sustainable conservation financing for a post-COVID world. Information presented is necessarily illustrative, rather than comprehensive, and does not include information about distribution equity, as policies and economic recovery plans are evolving rapidly and most such plans have yet to be fully implemented.

\section{METHODS}

This essay draws from the principles which Hockings et al. (2020) believe should guide the first two phases of the PCA response to the pandemic, specifically: (1) Rescue (including maintain existing laws) and (2) Recovery (including adopt a sustainable and equitable recovery). We ask the following framing questions:

- Do countries pledge funding that directly supports, or has the potential to support, PCAs within COVID19 economic recovery packages? Which ones? How?

- Have countries scaled up policies or laws in support of PCAs, or increased PCA budgets, during the COVID-19 pandemic? Which ones? How?

- Have countries postponed, weakened or terminated environmental laws and regulations, or reduced PCA budgets during the COVID-19 pandemic? Which ones?

To address these questions, we synthesised information from the best available data, documents, literature and 
websites that described policies and national economic recovery plans which affect or may affect PCAs. We organise results in four sections: (1) Examples of economic recovery packages with likely direct support for PCAs; (2) Examples of economic recovery with the potential to support PCAs; (3) examples of advancements or continuations of pre-pandemic commitments during 2020 that support PCAs; and (4) Rollbacks to environmental protections (defined here as weakening or terminating environmental laws or regulations, and reducing budgets). The geographical scope of the review is global, aiming to include as wide and diverse representation of geographies as possible. The study includes policies and economic recovery plans that were proposed or advanced between J anuary and October 2020.

In our review of economic recovery packages 1,2,3, associated reports, websites (e.g. global and regional hubs and trackers ${ }^{4,5,6}$ ), news and other sources (see Supplementary Online Material - Methods for more details), we noted cases in which one or more of the following supportive provisions were adopted or proposed:

- Expansion, upgrade or improved connectivity of PCAs (we took an inclusive approach to ensure a variety of area-based conservation efforts were recognised);

- Increased funding to improve management;

- Support for the tenure, access and human rights of IPLCs, for co-management schemes, and for provisions to ensure equitable distribution of benefits;

- Investments in ecological restoration that include a focus on PCAs;

- Investments in monitoring zoonoses in and around PCAs, which may boost local employment and assist in pandemic prevention;

- Support for long-term sustainability of PCAs, including:

- Investments in community resilience to compensate for loss of tourism revenue (e.g. direct support, debt restructuring);

- Support for PCA-related employment (e.g. for improved visitor access, nature-based education and invasive species eradication);

- Other investments that support PCAs and their conservation.

After extracting relevant examples from economic recovery packages, we also determined whether these elements were likely to (1) directly, or (2) have the

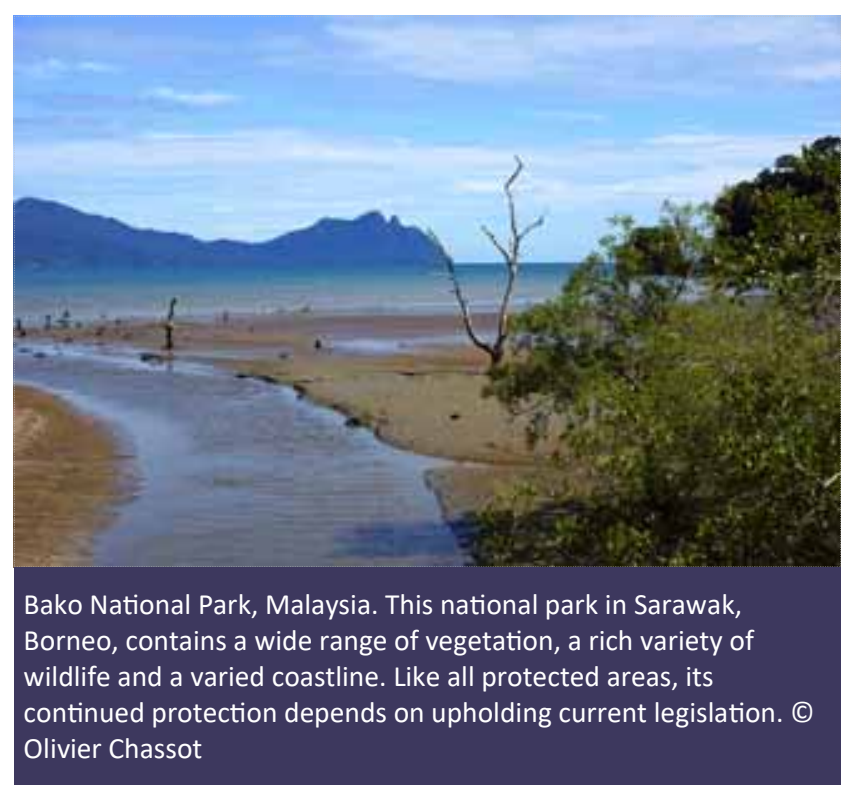

potential to directly, support PCAs. Since information was not always available on whether funds directly target PCAs, we used available details in recovery plans to categorise each example (e.g. as either direct or potential support), and only included examples in the direct category if details in recovery plans were sufficiently clear. We note that some examples provided describe a plan or broader package that involves not only support for PCAs but also other initiatives. When available, we provide information relevant for PCA support, but note that the level of detail available to segment this information is limited for most countries to date.

We also identified examples of advancements or continuations of pre-pandemic commitments that support PCAs, by reviewing relevant news and reports, from which we extracted illustrative examples. To identify rollbacks to PCA laws, regulations and budgets, we drew information from online trackers and reports7,8 and supplemented results with online searches. We recognise that our review of budget cuts is incomplete; other publications (Waithaka et al., 2021) provide more comprehensive information on this point. If needed, we reached out to regional experts (e.g. IUCN WCPA members, local NGO staff) to supplement and validate information, especially if documents were not available online. We provide more detailed explanation of research strategies in the Supplementary Online Materials - Methods.

A few caveats and limitations apply to this review. Some countries may have enacted both rollbacks and planned positive stimulus efforts for PCAs; we note both separately, but a measurement of the relative or net 
impacts of these opposing actions is outside the scope of this analysis. As we focus on countries where national economic recovery plans and policies have advanced, and for which information is available, this review is necessarily illustrative, rather than comprehensive, and does not indicate global trends. To focus the review, we do not cover an in-depth survey of enforcement or implementation of existing or new laws. To date, most economic recovery packages represent plans that are not yet detailed or implemented; assessment of the impacts of proposed or recently advanced economic recovery plans and other policies will require future research. Finally, the availability of information relies on transparency and press freedoms (if reported through news outlets), which is limited in some cases. ${ }^{9}$

\section{RESULTS}

Economic recovery efforts in response to the pandemic have been significant: trillions of dollars have been committed in a few short months, with near-term focus on relief and livelihoods. ${ }^{10,11}$ G20 nations have pledged US\$ 12.1 trillion, including stimulus funding of at least US\$ 3.7 trillion which could directly affect nature in one of three ways. It could lead to rollbacks of environmental protections; herald a return to business as usual; or initiate a transition to a greener economic model $^{1}$. At best, only 10 per cent of the US\$ $12-13$ trillion dedicated to COVID-19 stimulus can be considered additional 'green stimulus' (Barbier et al., 2020), and only a modest fraction of currently planned global stimulus will put the world on track to achieve the Paris Climate Agreement goals (Andrijevic et al., 2020). Most earmarked green funding in recovery packages supports renewable energy, green infrastructure and transport; less support has been pledged to support activities related to land use. ${ }^{12}$

A recent analysis finds that recovery efforts in 16 of 20 major economies invested in or focused more on activities that undermine environmental protections rather than support them. Examples of rollbacks to PCAs are highlighted below. A review of economic stimulus efforts in 11 Asia-Pacific region countries demonstrates similar results (Carnell et al., 2020). Limited reference to PCAs or biodiversity was found in recovery plans in Africa; for instance, Senegal is focusing on restoring and accelerating the pre-COVID growth trajectory by emphasising endogenous development and a strong private sector ${ }^{13}$, although the country is moving ahead with the designation of three marine protected areas. In Latin America and the Caribbean, some governments are considering limiting their spending in the environmental sector ${ }^{14,15}$, and resorting to international loans, while others have promoted local PCA-based tourism. ${ }^{16,17}$ Globally, while economic recovery plans from some countries support environmental protections more than they undermine them, most of them are heavily skewed towards unsustainable development (e.g. de-regulation, subsidies to polluting industries and easing permitting processes). On balance, the largest economies of the world are failing to 'build back better' in terms of support for green initiatives and nature protection in economic recovery packages.

We highlight here examples of stimulus plans that likely directly support PCAs (from 9 countries) or have the potential to directly support them (from 10 countries), pledging at least US\$ 31.918 billion (and furthering part of the efforts pledged in the US\$ 249 billion Next Generation EU package). In addition, we provide examples from 22 countries that are acting on and/or continuing to advance previous commitments to scale up and increase support for PCAs despite the pandemic (see Supplementary Online Materials - Results). All values are converted to US\$ for consistency, with original currency values where available to provide contextually appropriate information for each country; bolded numbers below indicate those used for summary statistics.

\section{Examples of economic recovery packages likely to directly support PCAs}

Eight countries and the EU earmarked support to expand and connect PCAs, including state and community governance systems; to manage PCAs (e.g. restoration, tourism); and to establish new PCA institutions.

- EU: The 'Next Generation EU' recovery package proposes to commit US\$ 249 billion of its stimulus funds (30 per cent of the total US\$ 830 billion) towards green initiatives, including US\$ $\mathbf{1 1 . 7 4}$ billion ( $€ 10$ billion) for "natural capital and circular economy"18 (other funds would support decarbonisation, green infrastructure and renewable energy). It also stipulates 'do no harm' environmental safeguards. The package supports the implementation of the EU Biodiversity Strategy for 2030 , which promotes the protection of at least 30 per cent of Europe's lands and seas in effectively managed and well-connected protected areas ${ }^{19}$, and supports sustainable agriculture, reversing the decline of pollinators and reducing the use of harmful pesticides..$^{20,21}$

- Finland: US\$ $\mathbf{1 5 . 3 8}$ million ( $€ 13.1$ million) has been pledged for state-run rehabilitation of nature sites and the development of nature tourism, as well 
as US\$ 62.23 million ( $€ 53$ million) for projects involving green areas, water services and forest conservation. US\$ 23.74 million ( $€ 20$ million) of this is appropriated for voluntary forest conservation and US\$ 15.2 million ( $€ 13.1$ million) for the rehabilitation of local recreation areas. ${ }^{22}$

- Iceland: US\$ $\mathbf{4 . 7 4}$ million (ISK 650 million) is committed for tourism infrastructure in protected areas. ${ }^{23}$

- Japan: A programme has been announced to promote tourism and 'workation' (telework and vacation) in national parks (level of funding unclear). ${ }^{24}$

- Kenya: Support pledged for conservation in PCAs through promotion of tourism, including employment of 5,500 community scouts under the Kenya Wildlife Service (US\$ 9.2 million, or 1 billion Ksh) and 160 community conservancies (US\$ 9.2 million, or 1 billion Ksh). ${ }^{25}$

- New Zealand: US\$ 850 million ( $\$ 1.245$ billion NZD) has been pledged to create 11,000 jobs in support of the following four initiatives: regional environmental projects to restore wetlands and riverbanks (US\$ 287.80 million or $\$ 433$ million NZD, 4,000 jobs over five years); pest eradication and management (US\$209.37 million or \$315 million NZD, 600 jobs annually); a J obs for Nature programme' to manage public lands, involving predator control, wetland restoration, regenerative planting, recreation and visitor improvements (US\$ 132.93 million or $\$ 200$ million NZD); and public and private land management to restore indigenous biodiversity and habitat, revegetation of conservation land and riparian planting (US\$ 102.36

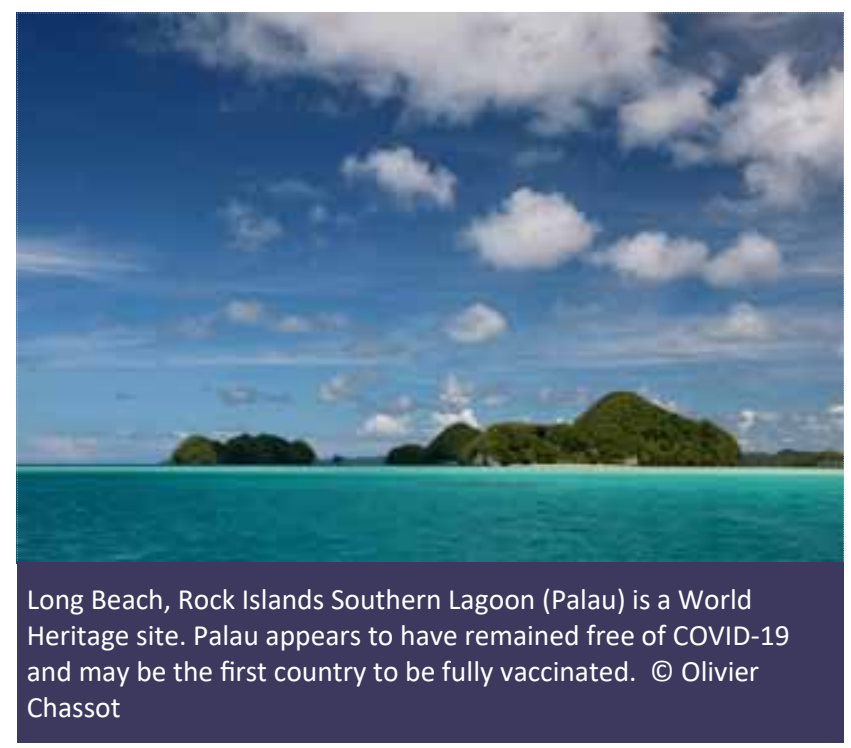

million, \$154 million NZD, 1,800 jobs).26,27,28,29,30

- Pakistan: Green Stimulus Initiative includes plans to expand protected areas, the addition of 15 national parks covering over 7,300 km2 (supported with Rs4 billion or US\$ 24 million); launch of Pakistan's first National Parks Service; and $\sim 5,000$ newjobs. 31

- Sweden: The Swedish government has proposed a 33 per cent increase in the 2021 budget for environment and nature protection. ${ }^{32}$

- United Kingdom: Local Nature Recovery Strategies initiative earmarks US\$ $\mathbf{1 . 2 9 7}$ million (£1 million) to connect protected areas, restore 500,000 hectares of wildlife habitat outside protected areas, and support urban green and blue infrastructure (e.g. floodplains, wetlands, rivers and forests). ${ }^{33}$

\section{Examples of economic recovery with the potential to support PCAs}

Ten countries earmarked support to invest in initiatives related to nature-based solutions, green infrastructure, international conservation, sustainable tourism and job creation in restoration.

- China: The Green Development Fund proposes to provide green investments worth US\$ 12.66 billion ( 88.5 billion yuan) in the Yangtze River economic belt, support environmental protection, ecological restoration, pollution control, clean energy and green transportation. ${ }^{34}$

- Ethiopia: US\$ $\mathbf{3 . 6}$ million (133.02 ETB) is pledged for nature-based solutions to tackle climate change and foster a green recovery, including support for ecological restoration and community management. 35

- Germany: US\$ 821.86 million ( $€ 700$ million) is earmarked for conservation and sustainable management of forests. Responding to COVID, the German Government's International Climate Initiative (IKI) dedicated US\$ 58 million (€68 million) in support of 29 projects in 25 countries to build economic, social and ecological resilience, and prevent future pandemics. ${ }^{36}$

- India: Approximately US\$ 817 million (Rs 6,000 crores) has been committed for jobs (including those available to tribal communities) in forest management, wildlife protection, afforestation and plantation work. $37,38,39$

- Ireland: US\$ $\mathbf{1 7 . 6 1}$ million ( $€ 15$ million) has been added to the existing peatland rehabilitation fund of US\$ 5.87 million ( $€ 5$ million) to restore 33,000 hectares of peatlands, thereby maintaining or 
creatingjobs. ${ }^{40,41}$

- Nepal: A province-level green recovery initiative has been initiated, providing jobs to hundreds of people staying at quarantine centres to plant trees; in four months, more than 7,000 trees were planted in and around public spaces. ${ }^{42}$

- Singapore: US\$ $\mathbf{3 . 8 7}$ billion (SG\$5 billion) for Coastal and Flood Protection Fund has been pledged for protection against rising sea levels with both hard infrastructure and nature-based solutions. ${ }^{43}$

- Sri Lanka: The Ministry of Tourism and Sri Lanka Tourism Development Authority introduced a sustainable destination development certification programme to promote sustainable tourism, and reduced the tourism development levy by 0.5 per cent while reinvesting that amount in biodiversityfriendly projects (pers. comm. Secretary of the Ministry of Tourism, Sri Lanka).

- Sweden: US\$ 16 million (SEK 150 million) is earmarked for nature conservation and forest management to provide jobs, increase recreation opportunities and reduce the spread of pests. ${ }^{44}$

\section{- United Kingdom:}

- The Green J obs Challenge Fund plans to invest US\$ 51.83 million ( $£ 40$ million), supporting up to 5,000 jobs, while "planting trees, restoring habitats, clearing waterways, and creating green space for people and wildlife." 45,46

- The pilot Natural Capital and Ecosystem Assessment is being launched with US\$ 6.48 million ( $₫ 5$ million) committed to "improve the baseline understanding of habitats and species abundance" for evidence-informed conservation decisions. ${ }^{47}$

\section{Examples of advancements or continuations of pre-pandemic commitments during 2020 that support PCAs}

At least 22 countries have advanced pre-pandemic commitments that support PCAs, including new legal frameworks and institutions for PCAs (e.g. Namibia, Uruguay); PCA establishment, upgrading and/or expansion (e.g. Belize, El Salvador, India, Saudi Arabia, Senegal, Seychelles, Turkey); commitments to expand and/ or strengthen PCAs (e.g. Canada, China, Peru, Romania, Russia); PCA management (Argentina, Nepal, the United States); and international PCA investments (e.g. Germany). Other ongoing activities include support for diverse forms of PCA governance (e.g. Canada, Cameroon) and research in PCAs to minimise risks of infectious zoonotic diseases (e.g. Guinea-
Bissau). A complete list with details is provided in Supplementary Online Material - Results.

\section{Rollbacks to environmental protections}

During the pandemic to date, the governments of at least 22 countries rolled back or weakened environmental protections for PCAs or reduced PCA budgets. We identified 64 examples of rollbacks that were advanced, enacted or proposed between J anuary and October 2020, which directly affect PCAs or the rights of IPLCs; or which involve legal changes that generally weaken environmental regulations and will likely affect PCAs (e.g. changes to the National Environmental Protection Act in the United States). Some were explicitly tied to economic recovery efforts, while others were not. Supplementary Online Material Results Table 2 and online trackers give more information. ${ }^{8,48}$ Most often, rollbacks that directly affect PCAs authorise new or expanded industrial and/or extractive activities, including: large-scale infrastructure (roads, airports, pipelines, hydropower plants, coal plants, housing developments, telecommunications infrastructure, space infrastructure) and extractive activities (coal, oil and gas development, other mining, logging, industrial fishing). Brazil, India and the United States are emerging hotspots of COVID-era rollbacks. However, the government of Cameroon reversed its plans to log the Ebo Forest after protests. ${ }^{49,50}$ There have also been other rollbacks to environmental protections that indirectly affect PCAs by weakening climate regulations, and species and air quality protection. For example, all G20 members (except for the EU) have included bailouts or tax relief to support fossil-fuel intensive industries (airlines, coal, natural gas, biofuels) in their economic stimulus packages, and/or amended environmental regulations and procedures, including weakening public comment processes, environmental impact assessments and reviews, permit approvals and enforcement. ${ }^{1}$ We provide illustrative examples below, especially those rollbacks that are likely to directly affect PCAs, and provide the full list in the Supplementary Online Materials - Results; additional information on these other rollbacks can be found through online trackers. ${ }^{51,52,53}$

\section{Brazil}

- Proposal to allow mining and oil and gas extraction within Indigenous reserves ${ }^{54}$;

- Proposal to allow land regularisation within Indigenous reserves, which would allow "squatters on public land to more easily receive deeds to their properties" and accelerate deforestation ${ }^{55}$; 
- Revivals of plans to build new large highways (BR163 and BR-319) 56,57 ;

- Decision to revoke 'permanent protection zones' which safeguard mangroves and other key ecosystems. ${ }^{58}$

Cameroon (rollback reversal):

- Approval of a logging concession in the Ebo Forest cancelled; the proposal would have affected more than 68,000 hectares of primary forest. 59,60

\section{Canada}

- Proposal to eliminate protective status for 175 provincial parks in Alberta (closure and/ or removal from Parks system and reversion to public land), following amendment that removed the requirement for public consultation in these types of decisions. ${ }^{61}$

\section{Cook Islands}

- Allowance of exploration of minerals, with plans to develop commercial mining within five years, was justified by decision-makers based on country's need to reduce dependence on tourism, following COVIDera travel restrictions. ${ }^{62}$

\section{Ecuador}

- Increasing road construction into Yasuní National Park, bringing oil development closer to the territory of Indigenous people in voluntary isolation ${ }^{63}$;

- Layoffs of 398 staff of the Ministry of Environment and Water, including 30 staff from the National System of Protected Areas. ${ }^{64}$

\section{El Salvador}

- Reduction of budget for Ministry of Environment and Natural Resources, which manages protected areas, by US\$ 1.4 million. ${ }^{65}$

\section{Greece}

- Approval of oil and gas exploration in protected areas. ${ }^{66}$

\section{India}

- At least 31 proposals ${ }^{67}$ to open up National Parks and Sanctuaries for infrastructure, extraction and development projects, including coal mining in Dehing Patkai Elephant Reserve. 68 Proposed change of rules to ease environmental clearance processes, for many projects like dams, mines, airports and highways (e.g. by removing public hearing requirements). ${ }^{69}$

\section{Kenya}

- Plans to construct a road70, eco-lodge, high-end restaurant and amphitheatre in Nairobi National Park. ${ }^{71}$

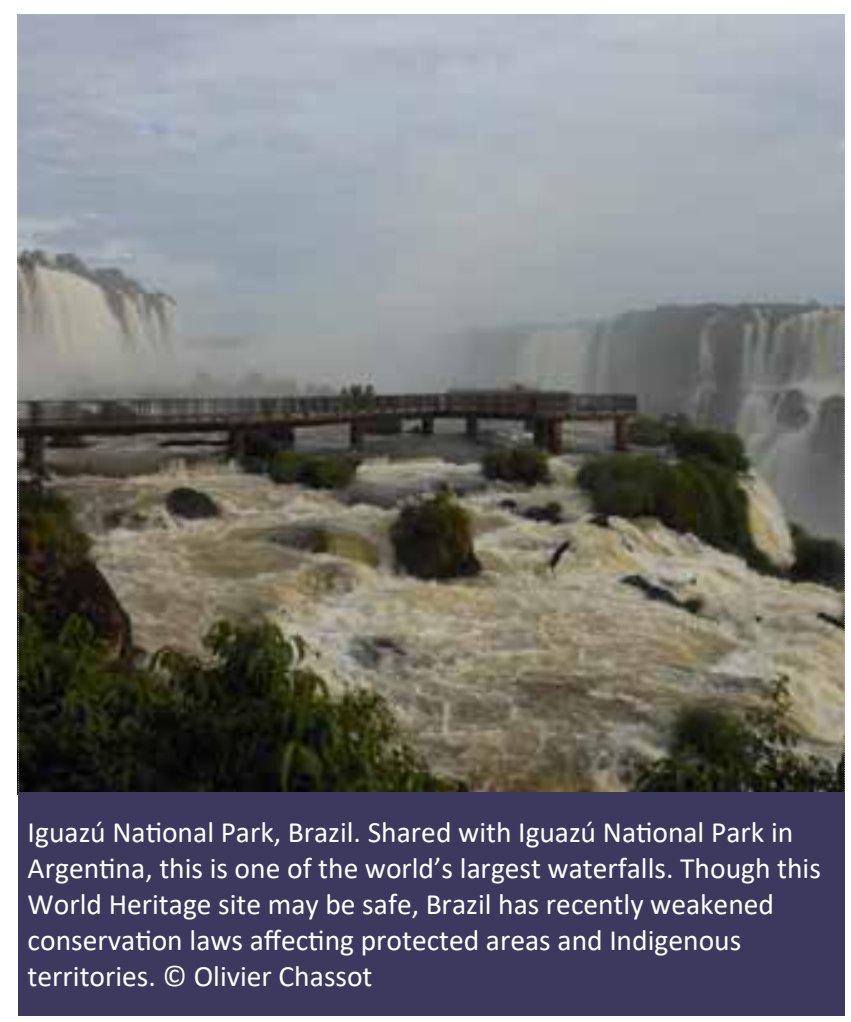

\section{Malaysia}

- Proposed reduction by 97 per cent of the Kuala Langat Forest Reserve, which supports traditional livelihoods of Orang Asli peoples. ${ }^{72}$

\section{Mexico}

- Budget cuts announced by the President to reduce the operational budget of almost all government entities by 75 per cent, including for the National Natural Protected Areas Commission (CONANP). 73,74

\section{Poland}

- Adjustment of the definition of the type of wood that can be burned in powerplants, including "deadwood and dying trees" and allowance of sanitary logging; may lead to forest harvest in protected Natura 2000 sites. $75,76,77$

\section{Russia}

- New law permits deforestation in specially protected natural areas to build or update transport infrastructure, and suspends requirements for environmental impact evaluations. ${ }^{78}$

\section{United Kingdom}

- Approval of housing development near proposed national park and Area of Outstanding Natural Beauty $^{79}$ and approval of spaceport in area protected under the Conservation of Habitats and Species Regulations ${ }^{80,81}$ 


\section{United States}

- Revision to management plans to allow increased development within the previously downsized Bears Ears and Grand-Staircase Escalante ${ }^{82}$ National Monuments;

- Advancement to plans to explore and drill for oil and gas in the Arctic National Wildlife Refuge: offering of oil and gas leases ${ }^{83}$; approval of seismic testing to measure oil and gas potential ${ }^{84}$; authorisation of incidental harming or killing of polar bears during oil and gas exploration ${ }^{85}$; auction of oil and gas leases 86 ;

- Allowance of hunting of bear cubs, baiting bears and killing swimming caribou from motorboats within national preserves in Alaska87;

- Authorisation of commercial fishing in the Northeast Canyons and Seamounts National Monument ${ }^{88}$;

- Weakening of environmental reviews under the National Environmental Policy ${ }^{89}$.

\section{DISCUSSION \\ Implications of near-term commitments that support or undermine PCAs}

Our review illustrates that recent policies and economic recovery plans around the world have a variety of implications for PCAs. There are some positive signs: some countries have adopted elements of a sustainable and equitable recovery, including a few that have earmarked direct support for PCAs and related activities (e.g. restoration, tourism). The EU's recovery plan stands out', with the largest amount of green investments, although the EU Green Deal could offshore environmental damage elsewhere (Fuchs et al., 2020). Also, some countries have continued to advance on environmental protection commitments and make new commitments despite the pandemic.

On the other hand, we report many examples of rollbacks to environmental protections, including those affecting PCAs. Environmental laws, regulations and initiatives have been weakened or abandoned and budgets cut in some countries. Rollbacks to protected areas are not new, and have been increasing over the last two decades, including protected area downgrading, downsizing and degazettement (PADDD) events (Golden Kroner et al., 2019). Most countries do not hold PADDD decisions to the same rigorous processes of public consultation and technical justification that are required for creating PCAs (Pack et al., 2016). Moreover, many recent rollbacks have been allowed at a time when the public cannot properly participate in decision-making processes.
Rollbacks to PCAs can undermine global efforts to conserve biodiversity, address climate change and protect ecologically important areas (Forrest et al., 2015; Golden Kroner et al., 2019). Moreover, they could exacerbate the conditions that favour a future pandemic by increasing ecosystem loss and fragmentation, and bringing wildlife in closer contact with human populations due to increased development (Gibb et al., 2020; Shah et al., 2018). Furthermore, rollbacks could set a precedent and offer moral license to other countries (Golden Kroner et al., 2019).

As some countries have engaged in both rollbacks and positive actions, it is vital to monitor and report on both progression and regression in PCAs, not only net change. The Post-2020 Global Biodiversity Framework provides an opportunity to encourage tracking of both positive and negative changes (Bacon et al., 2019; Maxwell et al., 2020; Qin et al., 2019), ensuring transparency and accountability. Whether rollbacks are enacted during a crisis or not, decisions that undermine environmental protections represent short-term thinking at the expense of long-term planetary and societal prosperity.

\section{Implications of recent policy changes and economic stimulus efforts for IPLCs}

Approximately 50 per cent of the world's lands are traditionally owned, managed, used or occupied by Indigenous peoples and local communities, which overlaps with significant biodiversity and intact forests (Fa et al., 2020; Schuster et al., 2019; Wily 2011). Lands stewarded by Indigenous communities have lower deforestation and carbon emissions (e.g. in Brazil) (BenYishay et al., 2017; Walker et al., 2020), and are home to equivalent biodiversity as state protected areas in some countries (Schuster et al., 2019). However, the voices of IPLCs have historically been marginalised in national and global biodiversity conservation policy contexts (FPP et al., 2020). During the COVID-19 pandemic, rollbacks to lands and waters stewarded by IPLCs have been proposed that could expand or fasttrack extractive activities (e.g. mining and oil and gas) in Australia, Brazil and the Philippines. ${ }^{90,91}$ IPLCs in Brazil face the simultaneous challenges of COVID-19, fires, and proposals to allow mining on their territories that would affect 222 culturally unique Indigenous groups, 863,000 $\mathrm{km}^{2}$ of Amazon forests, which provide more than US\$ 5 billion annually in ecosystem services (Siqueira-Gay et al., 2020; Villén-Pérez et al., 2020). In the Philippines, after languishing for more than two decades due to opposition from local Indigenous peoples and civil society groups, the Tampakan gold and 
copper mine was granted an extension to operate for 12 years $^{92}$ and subsequently received approval from the National Commission on Indigenous Peoples; its mine tailings will potentially impact the Liguasan Marsh, a key biodiversity wetland. COVID-related closures are also disproportionately affecting marginalised communities, including some IPLC groups, by restricting access to food and sources of income (Bennett et al., 2020). There is an urgent need for the PCA community to follow the lead of IPLCs, to empower them and collaborate with them, given their critical role as environmental stewards (FPP et al., 2020).

\section{Building forward beyond COVID-19}

Drawing from our results, existing best practices and literature ${ }^{93}$, and noting relevant recovery recommendations from other organisations (see Supplemental Table 2), we recommend the following priority actions for economic recovery from the COVID19 crisis, in addition to supporting current and future PCAs and fostering enabling conditions for long-term conservation. Our results demonstrating widespread rollbacks to budgets and restrictions for PCAs, including IPLC rights, provide fresh urgency to these recommendations. Any actions taken should follow the principles of good governance (participation, inclusion, transparency, and evidence- and rights-based decisionmaking) and equitable distribution of benefits (including women, youth and IPLCs). Details of specific approaches should be tailored to local circumstances.

\section{Near-term priorities for a sustainable recovery}

Do no harm and avoid rollbacks that undermine PCAs. Ensure that recovery efforts, including taxes, subsidies and other incentives, do not undermine nature protections, encourage fossil fuel emissions or exacerbate land-use change. Although PCA budgets are under pressure, efforts should be made to maintain budgets (e.g. as in the Philippines), keep staff on board, and prioritise the most important management actions (Hockings et al., 2020; Lindsey et al., 2020). Transparent decision-making and continued tracking of economic recovery efforts and commitments (including rollbacks) will be necessary as additional economic recovery plans emerge.

Create a supportive, enabling environment for PCAs. Recovery efforts should recognise the role of PCAs in rebuilding economies and societies, and maintain and enhance existing laws, regulations, funding, enforcement and other support for PCAs. Enabling conditions should include 'green strings', where bailouts are tied to strengthened regulations for nature protection (e.g. as in the EU's package, where recovery loans are conditional on pledges to align with sustainable investment and climate risk goals ${ }^{1}$ ). Further, recovery efforts can provide jobs in PCAs (e.g. for ecosystem restoration, patrols, management action) and support the tourism industry while favouring conservation.

\section{Recognise, support and protect IPLC territories and rights.}

Since many IPLCs face increasing rollbacks and are vulnerable to COVID-19, they require emergency relief (e.g. as earmarked for Indigenous peoples in Canada ${ }^{94}$ ). Their territorial and resource rights, as well as traditional knowledge systems need to be recognised, and they must be able to participate meaningfully in decision-making processes.

\section{Address the immediate PCA funding shortfall.}

'Green recovery' approaches should include tangible benefits for biodiversity and PCAs. The World Economic Forum estimates that it will take only US\$ 140 billion to protect 30 per cent of the planet ${ }^{95}$, a fraction of the more than US\$ 12 trillion that has been pledged for COVID relief. In addition to the current pledges, as listed in the results here, PCA-directed funding (e.g. from government budgets, official development assistance, philanthropy) should support staff to manage, monitor and enforce protections and restoration efforts, and can provide maximum conservation impact by targeting areas with high biodiversity and irrecoverable carbon (Goldstein et al., 2020; Hockings et al., 2020; Lindsey et al., 2020). Adequate funding should be administered within well-designed and well-managed institutional systems; the IUCN Green List for Protected Areas criteria $^{96}$ (good governance, sound design and planning, effective management, conservation outcomes) provides a standard to achieve, or at least aspire to.

\section{Longer-term needs for PCAs: sustainable financing, effective policies and enforcement, and transformative change}

Support for PCAs in the medium- to longer term requires sustainable financing for conservation, diversification and innovation. This could include 'rainy day' funds to bridge downturns in visitation financed from trust funds or other sources; private investments that compensate community conservancies that are paid back as tourism recovers (e.g. in Maasai Mara, Kenya ${ }^{97}$ ); and other domestic efforts that can generate revenue for conservation in the absence of external donations (Barbier \& Burgess, 2020). Innovative financing mechanisms, including debt-for-nature swaps ${ }^{98}$ and green and blue bonds, could support conservation and help to solve the sovereign debt crisis simultaneously. 
There are many additional finance mechanisms that can be used to support PCAs, suited to different environments and contexts. These include carbon credits, biodiversity offsets, payments for ecosystem services, nature linked endowments, natural infrastructure investments, conservation trust funds, taxing carbon to pay for natural climate solutions, carbon markets, incorporation of nature insurance and reinsurance schemes ${ }^{99}$, and certification schemes (Barbier et al., 2020; Barbier \& Burgess, 2020; Deutz et al., 2020; Lindsey et al., 2020; Claes et al., 2020; World Bank Group 2020).

Transformative changes in the mid- to longer term will be required to ensure the durability and performance of PCAs. These may include financial models that support PCAs rather than cause harm, embracing diverse PCA governance systems including: guaranteeing meaningful leadership and participation of IPLCs; incorporating natural capital into national budgets; recognising the rights of nature ${ }^{100}$, and accounting for economic prosperity through approaches that go beyond GDP towards more holistic measures (e.g. Bhutan's Gross National Happiness ${ }^{101}$ ). The removal of perverse incentives, including subsidies which undermine nature protections, and institution of safeguards (e.g. in government policy and the finance sector) would promote longer-term sustainability of PCAs. Sufficient funds to monitor adherence to and enforcement of safeguards will also be required. More detailed recommendations for resilient funding for PCAs are provided in Cumming et al. (2021). The conservation community may also consider using 'conservation basic incomes' to compensate communities on the front lines of nature stewardship (Fletcher \& Büscher, 2020). Overall, there is a need to deepen the connections between people and the rest of nature, including through experiences in PCAs, and build long-term, broad-based support for conservation efforts, along with a global reduction in overconsumption and waste - especially by the global North.

\section{CONCLUSION}

Despite evidence and arguments for more significant investment in PCAs to safeguard against future zoonoses outbreaks and pandemics, to date funding for COVID-19 economic stimulus packages more often undermines than supports conservation efforts ${ }^{1}$, increasing the risk of "subsidising the emergence of future pandemics". ${ }^{102}$ Short-term thinking and the increasing pace of rollbacks will weaken environmental protections and put nature, including ourselves, at greater risk. Instead of leaving this legacy for future generations, governments have the unique opportunity to scale up nature protection, including direct support for PCAs. This offers cost-effective solutions for climate, biodiversity, sustainable development goals and pandemic prevention, especially in rural areas where most poverty is concentrated. The global community must support conservation efforts and human, animal and environmental health now and in the longer term as humanity faces the prospect of climate change and future pandemics.

Recent commitments signal increased momentum for nature protection; for instance, dozens of countries have signed the Leaders' Pledge for Nature ${ }^{103}$, which calls for protection of at least 30 per cent of land and sea by 2030. However, more countries need to support PCAs. More funds are needed for PCA implementation, monitoring, evaluation and learning. And continued political support - following the principles of equity, diversity, inclusion and justice - is necessary to ensure successful conservation efforts in the post-COVID era and beyond. The upcoming negotiations of the Post2020 Global Biodiversity Framework of the UN Convention on Biological Diversity provide a near-term opportunity for ambitious action for PCAs. The UNFCCC COP in 2021 should be the occasion to promote natural climate solutions and how these might relate to a global carbon market under Article 6.

Post-COVID recovery is a once in a generation opportunity to deliver proper financing to PCAs, and ensure society can reap the biodiversity conservation, climate and socioeconomic benefits they provide. There is no time to waste.

\section{ENDNOTES}

See Supplementary Online Material - Endnotes

\section{SUPPLEMENTARY ONLINE MATERIAL}
1. Supplementary Methods
2. Supplementary Results
3. Endnotes

\section{DISCLAIMER}

The views and interpretations in this paper are those of the authors and they are not necessarily attributable to their organizations.

\section{ABOUT THE AUTHORS}

Rachel Golden Kroner, $\mathrm{PhD}$, is the Environmental Governance Fellow at Conservation International, and co-chairs the IUCN COVID and Protected Areas task force. Orcid: 0000-0003-1844-3398 
Edward B. Barbier, $\mathrm{PhD}$, is a University Distinguished Professor in the Department of Economics, Colorado State University. Orcid:00000002-5354-3995

Olivier Chassot, $\mathrm{PhD}$, is Deputy Vice-Chair and Central American Lead of the Connectivity Conservation Specialists Group of the WCPA. Orcid:0000-0003-3061-2203

Sunita Chaudhary, $\mathrm{PhD}$, is the Ecosystem Services Specialist at International Centre for Integrated Mountain Development (ICIMOD)

Lorenzo Cordova Jr. is the Lead Consultant for UNDP-BIOFIN in the Philippines.

Annabelle Cruz-Trinidad (Abbie) is a Senior Technical Advisor to UNDP-BIOFIN.

Tracey Cumming is Technical Advisor to UNDPBIOFIN, and a member of the CBD Panel of Experts on Resource Mobilisation

Jennifer Howard, $\mathrm{PhD}$, is Senior Director of the Blue Carbon Program at Conservation International.

Charlotte Karibuhoye Said, $\mathrm{PhD}$, is the Director of the West Africa program for the MAVA Foundation.

Zoltan Kun works with various nature conservation NGOs such as FZS, PFPI, and Wild Europe. Orcid:0000 -0002-4688-8936

Angelique Ogena is a development communicator for UNDP-BIOFIN and the Department of Environment and Natural Resources.

Florence Palla, $\mathrm{PhD}$, is Deputy Regional Vice Chair, WCPA West and Central Africa.

Rodrigo Samayoa Valiente is a Sustainable Business Development professional focused on Environmental Sustainability and Corporate Governance.

Sebastian Troëng, $\mathrm{PhD}$. is Executive Vice President of Conservation Partnerships at Conservation International.

Allan Valverde is the Dean of the Faculty of Environment and Development at the University for International Cooperation, Costa Rica.

Ramitha Wijethunga is the National Project Coordinator of UNDP-BIOFIN and other biodiversity management initiatives in Sri Lanka.
Michael Wong is Chair for the North America Region of the World Commission on Protected Areas of the IUCN.

\section{REFERENCES}

Andam, K.S., Ferraro, P.J., Pfaff, A., Sanchez-Azofeifa, G.A. and Robalino, J.A. (2008). Measuring the effectiveness of protected area networks in reducing deforestation. Proceedings of the National Academy of Sciences, 105(42): 16089-16094. https://doi.org/10.1073/pnas.0800437105

Andrijevic, M., Schleussner, C.-F., Gidden, M.J., McCollum, D.L. and Rogelj, J. (2020). COVID-19 recovery funds dwarf clean energy investment needs. Science, 370(6514): 298-300. https://doi.org/10.1126/science.abc9697

Bacon, E., Gannon, P., Stephen, S., Seyoum-Edjigu, E., Schmidt, M., Lang, B., et al. (2019). Aichi Biodiversity Target 11 in the like-minded megadiverse countries. Journal for Nature Conservation, 51: 125723. https://doi.org/10.1016/ j.jnc.2019.125723

Barbier, E.B. and Burgess, J.C. (2020). Sustainability and development after COVID-19. World Development, 135: 105082. https://doi.org/10.1016/j.worlddev.2020.105082

Barbier, E.B., Lozano, R., Rodríguez, C.M. and Troëng, S. (2020). Adopt a carbon tax to protect tropical forests. Nature, 578 (7794): 213-216. https://doi.org/10.1038/d41586-020-00324w

Basurto, X. (2018). Linking MPA effectiveness to the future of local rural fishing societies. ICES Journal of Marine Science, 75(3): 1193-1194. https://doi.org/10.1093/icesjms/fsx075

Bennett, N.J., Finkbeiner, E.M., Ban, N.C., Belhabib, D., Jupiter, S.D., Kittinger, J.N., Mangubhai, S., Scholtens, J., Gill, D. and Christie, P. (2020). The COVID-19 Pandemic, Small-Scale Fisheries and Coastal Fishing Communities. Coastal Management, 48(4): 336-347. https:// doi.org/10.1080/08920753.2020.1766937

BenYishay, A., Heuser, S., Runfola, D. and Trichler, R. (2017). Indigenous land rights and deforestation: Evidence from the Brazilian Amazon. Journal of Environmental Economics and Management, 86: 29-47. https://doi.org/10.1016/ j.jeem.2017.07.008

Brancalion, P.H.S., Broadbent, E.N., de-Miguel, S., Cardil, A., Rosa, M.R., Almeida, C.T., et al. (2020). Emerging threats linking tropical deforestation and the COVID-19 pandemic. Perspectives in Ecology and Conservation. https:// doi.org/10.1016/j.pecon.2020.09.006

Cabral, R.B., Bradley, D., Mayorga, J., Goodell, W., Friedlander, A.M., Sala, E., Costello, C. and Gaines, S.D. (2020). A global network of marine protected areas for food. Proceedings of the National Academy of Sciences, 117(45): 28134-28139. https://doi.org/10.1073/pnas.2000174117

Carnell, R., Sakpal, P., Pang, I., Mapa, N., and Patterson, W. (2020). Asia's lamentable green response to COVID-19. ING, Economic and Financial Analysis. Available at: https:// think.ing.com/articles/hold-asias-lamentable-green-covid-19response

Claes, J., Conway, M., Hansen, T., Henderson, K., Hopman, D., Katz, J., et al. (2020). Valuing nature conservation: a methodology for quantifying the benefits of protecting the planet's natural capital. McKinsey and Company. Available at: https://www.mckinsey.com/business-functions/sustainability/ our-insights/valuing-nature-conservation\# 
Corlett, R.T., Primack, R.B., Devictor, V., Maas, B., Goswami, V.R., Bates, A.E., et al. (2020). Impacts of the coronavirus pandemic on biodiversity conservation. Biological Conservation, 246, 108571. https://doi.org/10.1016/ j.biocon.2020.108571

Cumming, T., Seidl, A., Emerton, L., Spenceley, A., Golden Kroner, R., Uwineza, Y. and van Zy, H. (2021) Building sustainable finance for resilient protected and conserved areas: lessons from COVID-19. PARKS 27(Special Issue): 149-160 https:/doi.org/10.2305/IUCN.CH.2021.PARKS-27SITC.en

Deutz, A., Heal, G. M., Niu, R., Swanson, E., Townshend, T., Zhu, L., et al. (2020). Financing Nature: Closing the global biodiversity financing gap. The Paulson Institute, The Nature Conservancy, and the Cornell Atkinson Center for Sustainability. Available at: https://www.paulsoninstitute.org/ key-initiatives/financing-nature-report/

Dobson, A.P., Pimm, S.L., Hannah, L., Kaufman, L., Ahumada, J.A., Ando, A.W., et al. (2020). Ecology and economics for pandemic prevention. Science, 369(6502): 379-381. https:// doi.org/10.1126/science.abc3189

Fa, J. E., Watson, J. E. M., Leiper, I., Potapov, P., Evans, T. D., Burgess, N. D., et al. (2020). Importance of Indigenous Peoples' lands for the conservation of Intact Forest Landscapes. Frontiers in Ecology and the Environment. doi:10.1002/fee.2148

Ferreira, M.N., Elliott, W., Golden Kroner, R., Kinnaird, M.F., Prist, P.R., Valdujo, P. and Vale, M.M. (2012). Drivers and causes of zoonotic diseases: an overview, PARKS 27(Special Issue): 31-40 https:/doi.org/10.2305/IUCN.CH.2021.PARKS-27SIMNF.en

Fletcher, R. and Büscher, B. (2020). Conservation basic income: A non-market mechanism to support convivial conservation. Biological Conservation, 244: 108520. https://doi.org/10.1016/ j.biocon.2020.108520

Forest Peoples Programme, International Indigenous Forum on Biodiversity, Indigenous Women's Biodiversity Network, Centres of Distinction on Indigenous and Local Knowledge and Secretariat of the Convention on Biological Diversity (2020). Local Biodiversity Outlooks 2: The contributions of Indigenous peoples and local communities to the implementation of the Strategic Plan for Biodiversity 20112020 and to renewing nature and cultures. A complement to the fifth edition of Global Biodiversity Outlook. Moreton-inMarsh, England: Forest Peoples Programme. Available at: www.localbiodiversityoutlooks.net

Forrest, J. L., Mascia, M. B., Pailler, S., Abidin, S. Z., Araujo, M. D., Krithivasan, R., \& Riveros, J. C. (2015). Tropical Deforestation and Carbon Emissions from Protected Area Downgrading, Downsizing, and Degazettement (PADDD). Conservation Letters, 8(3), 153-161. https://doi.org/10.1111/ conl.12144

Fuchs, R., Brown, C. and Rounsevell, M. (2020). Europe's Green Deal offshores environmental damage to other nations. Nature, 586(7831): 671-673. https://doi.org/10.1038/d41586020-02991-1

Geldmann, J., Barnes, M., Coad, L., Craigie, I.D., Hockings, M. and Burgess, N.D. (2013). Effectiveness of terrestrial protected areas in reducing habitat loss and population declines. Biological Conservation, 161: 230-238. https:// doi.org/10.1016/j.biocon.2013.02.018
Gibb, R., Redding, D.W., Chin, K.Q., Donnelly, C.A., Blackburn, T.M., Newbold, T. and Jones, K.E. (2020). Zoonotic host diversity increases in human-dominated ecosystems. Nature, 584(7821): 398-402. https://doi.org/10.1038/s41586-0202562-8

Gill, D. A., Mascia, M. B., Ahmadia, G. N., Glew, L., Lester, S. E., Barnes, M. et al. (2017). Capacity shortfalls hinder the performance of marine protected areas globally. Nature, 543 (7647), 665-669. https://doi.org/10.1038/nature21708

Golden Kroner, R.E., Qin, S., Cook, C.N., Krithivasan, R., Pack, S.M., Bonilla, O.D., et al. (2019). The uncertain future of protected lands and waters. Science, 364(6443): 881-886. https://doi.org/10.1126/science.aau5525

Goldstein, A., Turner, W. R., Spawn, S. A., Anderson-Teixeira, K. J., Cook-Patton, S., Fargione, J., et al. (2020). Protecting irrecoverable carbon in Earth's ecosystems. Nature Climate Change, 10(4), 287-295. https://doi.org/10.1038/s41558-0200738-8

Hepburn, C., O'Callaghan, B., Stern, N., Stiglitz, J. and Zenghelis, D. (2020). Will COVID-19 fiscal recovery packages accelerate or retard progress on climate change? Oxford Review of Economic Policy, 36(Supplement_1): S359-S381. https:// doi.org/10.1093/oxrep/graa015

Hockings, M., Dudley, N., Elliot, W., Napolitano, M., MacKinnon, K., Pasha, M., et al. (2020). Editorial Essay: Covid-19 and Protected and Conserved Areas. PARKS, 26(1): 7-24.

ICIMOD (2020). COVID-19 impact and policy responses in the Hindu Kush Himalaya. International Centre for Integrated Mountain Development. Available at: https://lib.icimod.org/ record/34863

Kawarazuka, N. and Béné, C. (2011). The potential role of small fish species in improving micronutrient deficiencies in developing countries: Building evidence. Public Health Nutrition, 14(11): 1927-1938. https://doi.org/10.1017/ S1368980011000814

Lindsey, P., Allan, J., Brehony, P., Dickman, A., Robson, A., Begg, C., et al. (2020). Conserving Africa's wildlife and wildlands through the COVID-19 crisis and beyond. Nature Ecology \& Evolution, 4(10): 1300-1310. https://doi.org/10.1038/s41559020-1275-6

Maxwell, S.L., Cazalis, V., Dudley, N., Hoffmann, M., Rodrigues, A.S.L., Stolton, S., et al. (2020). Area-Based Conservation in the 21st Century. Preprints, https://doi.org/10.20944/ preprints202001.0104.v1

McKibbin, W., and Fernando, R. (2020). The global macroeconomic impacts of COVID-19: seven scenarios. Brookings Institute. Available at: https://www.brookings.edu/ research/the-global-macroeconomic-impacts-of-covid-19seven-scenarios/

Naidoo, R., Gerkey, D., Hole, D., Pfaff, A., Ellis, A.M., Golden, C.D., et al. (2019). Evaluating the impacts of protected areas on human well-being across the developing world. Science Advances, 5(4): eaav3006. https://doi.org/10.1126/ sciadv.aav3006

Pack, S.M., Ferreira, M.N., Krithivasan, R., Murrow, J., Bernard, E. and Mascia, M.B. (2016). Protected area downgrading, downsizing, and degazettement (PADDD) in the Amazon. Biological Conservation, 197: 32-39. https://doi.org/10.1016/ j.biocon.2016.02.004

Qin, S., Golden Kroner, R.E., Cook, C., Tesfaw, A.T., Braybrook, R., Rodriguez, C.M., Poelking, C. and Mascia, M.B. (2019). 
Protected area downgrading, downsizing, and degazettement as a threat to iconic protected areas. Conservation Biology, 33(6): 1275-1285. https://doi.org/10.1111/cobi.13365

Schuster, R., Germain, R. R., Bennett, J. R., Reo, N. J., \& Arcese, P. (2019). Vertebrate biodiversity on indigenous-managed lands in Australia, Brazil, and Canada equals that in protected areas. Environmental Science \& Policy, 101, 1-6. https:// doi.org/10.1016/j.envsci.2019.07.002

Shah, V., Shah, A. and Joshi, V. (2018). Predicting the origins of next forest-based emerging infectious disease. Environmental Monitoring and Assessment, 190(6): 337. https:// doi.org/10.1007/s10661-018-6711-6

Siqueira-Gay, J., Soares-Filho, B., Sanchez, L.E., Oviedo, A. and Sonter, L.J. (2020). Proposed legislation to mine Brazil's indigenous lands will threaten Amazon forests and their valuable ecosystem services. One Earth, 3(3): 356-362. https://doi.org/10.1016/j.oneear.2020.08.008

Stolton, S., Dudley, N., Avcıoğlu Çokçalışkan, B., Hunter, D., Ivanić, K.-Z., Kanga, E., et al. (2015) 'Values and benefits of protected areas', in G. L. Worboys, M. Lockwood, A. Kothari, S. Feary and I. Pulsford (eds) Protected Area Governance and Management, pp. 145-168, ANU Press, Canberra, Australia.

Terraube, J. and Fernández-Llamazares, Á. (2020). Strengthening protected areas to halt biodiversity loss and mitigate pandemic risks. Current Opinion in Environmental Sustainability. https://doi.org/10.1016/j.cosust.2020.08.014

Villén-Pérez, S., Moutinho, P., Nóbrega, C.C. and Marco, P.D. (2020). Brazilian Amazon gold: Indigenous land rights under risk. Elementa: Science of the Anthropocene, 8(1): 31. https:// doi.org/10.1525/elementa.427

Waithaka, J., Dudley, N., Álvarez, M., Mora, S.A., Figgis, P., Fitzsimons, J., Gallon, S., Kim, M . et al. (2021). Impacts of COVID-19 on protected and conserved areas: a global overview and regional perspectives. PARKS 27(Special Issue): 41-56 https:/doi.org/10.2305/IUCN.CH.2021.PARKS27-SIJW.en
Waldron, A., Adams, V., Allan, J., Arnell, A., Asner, G., Atkinson, S., et al. (2020). Protecting $30 \%$ of the planet for nature: costs, benefits and economic implications. Working paper analysing the economic implications of the proposed $30 \%$ target for areal protection in the draft post-2020 Global Biodiversity Framework. Available at: https:// www.conservation.cam.ac.uk/files/ waldron_report_30_by_30_publish.pdf

Walker, W. S., Gorelik, S. R., Baccini, A., Aragon-Osejo, J. L., Josse, C., Meyer, C., et al. (2020). The role of forest conversion, degradation, and disturbance in the carbon dynamics of Amazon indigenous territories and protected areas. Proceedings of the National Academy of Sciences, 117 (6), 3015-3025. https://doi.org/10.1073/pnas.1913321117

Wily, A. L. (2011). The tragedy of public lands: The fate of the commons under global commercial pressure. Rome: International Land Coalition.

World Bank Group. (2020). Mobilizing private finance for nature. Available at: http://pubdocs.worldbank.org/ en/916781601304630850/Finance-for-Nature-28-Sep-webversion.pdf

World Economic Forum. (2020). Nature risk rising: Why the crisis engulfing nature matters for business and the economy. New Nature Economy Series. Available at: http:// www3.weforum.org/docs/

WEF_New_Nature_Economy_Report_2020.pdf Wren L. (2020). The economic effects of a pandemic. In R. Baldwin and B. Weder di Mauro (Eds) Economics in the time of COVID -19, pp. 109-112. London, UK: Centre for Economic Policy Research.

Zafra-Calvo, N., Garmendia, E., Pascual, U., Palomo, I., GrossCamp, N., Brockington, D., Cortes-Vazquez, J.-A., Coolsaet, B., \& Burgess, N. D. (2019). Progress toward Equitably Managed Protected Areas in Aichi Target 11: A Global Survey. BioScience, 69(3), 191-197. https://doi.org/10.1093/ biosci/biy143

\footnotetext{
Author affiliations (continued)

${ }^{7}$ Center for Natural Climate Solutions, Conservation International, 2011 Crystal Drive, Arlington, VA, 22202, USA

8West Africa Programme, MAVA Foundation, Mamelles, Rue 21 OKM, villa F46, Dakar, Senegal

${ }^{9}$ Wildland Research Institute, University of Leeds, LS2 9J T, United Kingdom

${ }^{10}$ Observatoire des Forêts d'Afrique Centrale, Secrétariat Exécutif de la COMIFAC, Yaoundé, Cameroon 11Territorios Vivos de El Salvador, Calle Las Acacias \#No120 Colonia Vista Hermosa, San Salvador, El Salvador ${ }^{12}$ Conservation Partnerships, Conservation International, Carrera 13 No. 71-41, Bogota DC, Colombia 110231

${ }^{13}$ United Nations Development Programme Biodiversity Finance Initiative, UN Compound 202-204, Bauddhaloka Mawatha, Colombo 7, Sri Lanka

${ }^{14}$ World Commission on Protected Areas, International Union for the Conservation of Nature, 845 Des Saisons, Gatineau, Québec, J9J 3B9, Canada
} 


\section{RESUMEN}

La pandemia del COVID-19 está teniendo un gran impacto en las políticas y prácticas de conservación a múltiples escalas, incluyendo las áreas protegidas y conservadas (APC). Es necesario comprender las implicaciones para las APC de las recientes medidas, promulgadas o promovidas a raíz del COVID-19. Para llenar este vacío de conocimiento, revisamos los conjuntos de medidas de estímulo económico y otras políticas gubernamentales que fueron impulsadas o implementadas entre enero y octubre de 2020. Identificamos ejemplos positivos de apoyo a las APC en las medidas de recuperación económica (en 17 países) y casos en los que se impulsaron los compromisos contraídos antes de 2020 para ampliar las protecciones ambientales (en 22 países), pero también retrocesos ocasionados en las medidas de protección (64 casos en 22 países). En general, hasta la fecha las medidas y políticas de estímulo económico post COVID han debilitado más que apoyado las protecciones ambientales, incluso en el caso de las APC; los retrocesos pueden tener repercusiones a largo plazo cuando permiten el deterioro de la infraestructura o socavan los derechos de los pueblos indígenas. Sugerimos medidas prioritarias para una recuperación económica verde que incluyen situar a las APC en el centro de dichos esfuerzos para ayudar así a garantizar la prosperidad a largo plazo de las personas y de nuestro planeta.

\section{RÉSUMÉ}

La pandémie COVID-19 engendre des impacts majeurs sur les politiques et les pratiques de conservation à plusieurs échelles, y compris pour les aires protégées et conservées (APC). Il parait nécessaire de comprendre les implications pour les APC des actions récentes, adoptées ou promues suite à l'avènement de la COVID-19. Pour combler ce manque de connaissances, nous avons examiné les plans de relance économique et les autres politiques gouvernementales qui ont été développées ou mises en œuvre entre janvier et octobre 2020. Nous avons identifié des exemples positifs de soutien aux APC dans les programmes de relance économique (dans 17 pays) et des cas où les engagements pris avant 2020 pour renforcer les protections environnementales ont progressé (dans 22 pays), mais aussi des cas de recul de la protection (64 cas dans 22 pays). Dans l'ensemble, les politiques et les plans de relance économique post-COVID à ce jour ont plus entravé que soutenu les protections environnementales, y compris au sein des APC; les reculs de protection peuvent avoir des conséquences à long terme lorsqu'ils engendrent l'endommagement des infrastructures ou portent atteinte aux droits des populations autochtones. Nous proposons des actions prioritaires pour une reprise économique verte, notamment en plaçant les APC au centre de ces efforts, contribuant ainsi à assurer la prospérité à long terme des populations et de notre planète 


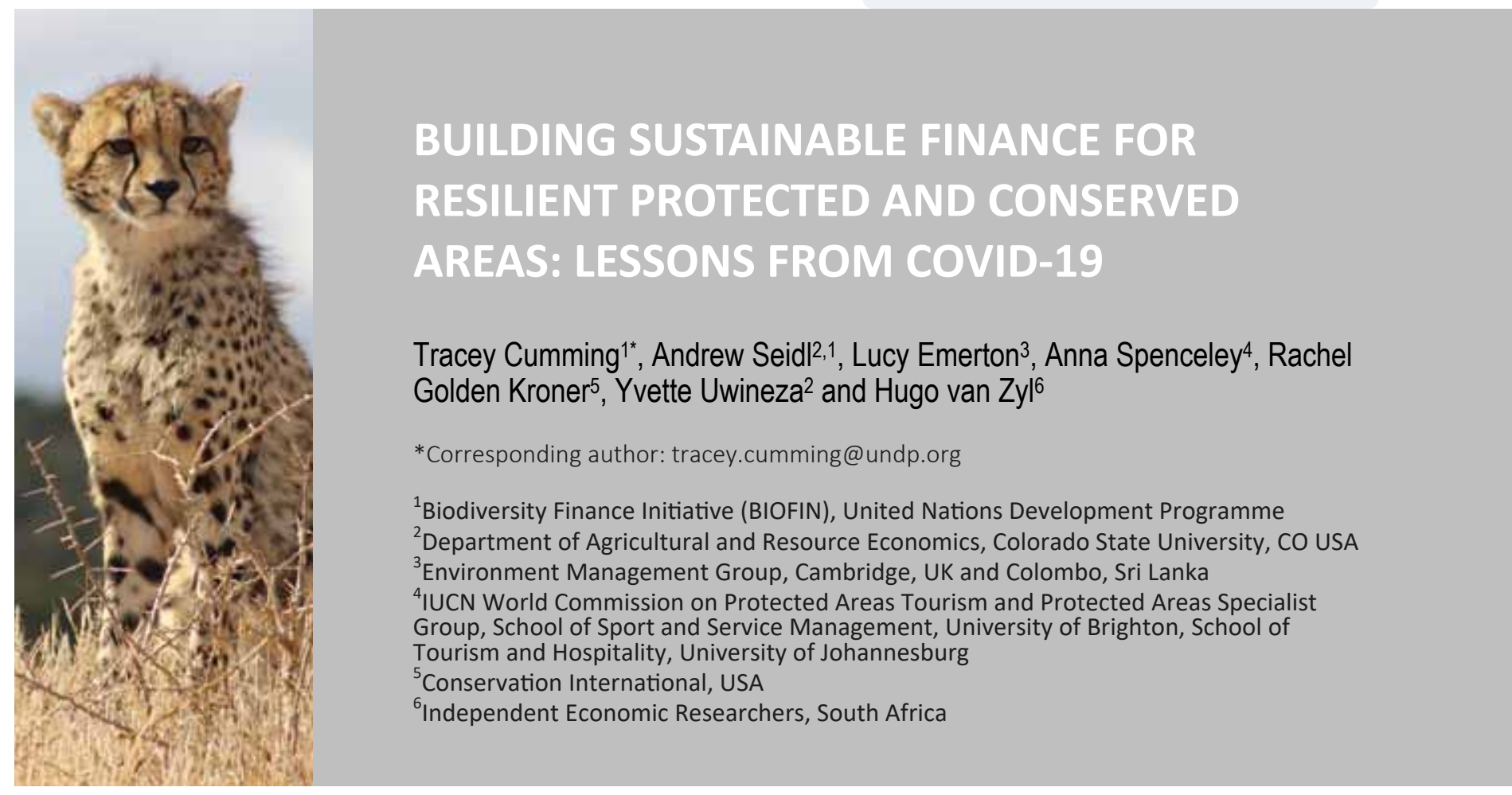

\begin{abstract}
There is widespread concern that funding for protected and conserved areas (PCAs) will decline substantially due to the COVID-19 pandemic and related economic outcomes. This paper makes the case that the impacts of the global crisis do not in themselves introduce novel financial threats to PCAs; rather, they serve to magnify, intensify and exacerbate existing structural and systemic financial constraints and weaknesses. To respond appropriately, it is therefore important to understand the status of PCA finance before COVID-19, and to address the underlying barriers and constraints to PCA financial sustainability. Based on known PCA finance challenges, and predicted effects from COVID-19, the authors present nine overarching recommendations for building a sustainable finance base for PCAs: diversify the funding base; improve spending effectiveness and efficiency; ensure domestic budgets continue to support PCAs; increase international development finance and philanthropy; strengthen revenue generation from tourism; support PCAs governed by Indigenous peoples, local communities and private actors; include local communities in PCA governance and benefits; engage the finance sector and attract private capital; and raise public support and interest in nature conservation and PCAs. Specific activities and tools are provided to support each of these recommendations, whilst respecting the current global context.
\end{abstract}

Key words: conservation finance, protected area finance, economic crisis, finance mechanisms, BIOFIN

\section{THE STATE OF PCA FINANCE PRE-COVID-19}

Estimates of the costs of maintaining an effective and globally representative system of protected and conserved areas (PCAs) have varied over the years, the most recent being US\$ 67 billion p.a. (Waldron et al., 2020). Whatever the exact figure, it is clear that PCAs faced substantial funding challenges even before the COVID-19 pandemic struck. The current global protected area network receives only approximately one -third of the funding needed for effective management (Waldron et al., 2020), and less than a quarter of terrestrial PCAs have adequate staff and budgets to achieve effective conservation (Coad et al., 2019). Data from 26 countries participating in the UNDP Biodiversity Finance Initiative (BIOFIN) indicate that every billion dollars of investment in biodiversity conservation will lead to an annual reduction in the proportion of threatened species to total species of about 0.57 per cent (Seidl et al., 2020a).

These shortfalls are most pronounced in the Global South. For example, a survey of more than 400 PCAs in South East Asia found funding gaps between 25 and 300 per cent (Castillo et al., 2015). Even PCA managers in North America report that a fifth of their budget requirements remain unmet, with the US National Park Service reporting US\$ 12 billion in deferred maintenance against an annual budget of approximately US $\$ 4$ billion (NPS, 2020).

Global calls to expand the area of land and sea under protection means funding needs will be increased 
further. While Waldron et al. (2020) make a strong economic case for the expansion of PCAs to 30 per cent of the Earth's surface by 2030, the annual cost of achieving this is estimated to be US\$ 103-178 billion (including the US\$ 68 billion required to manage the existing system effectively). This is approximately equal to the current national public sector investment in biodiversity conservation, restoration and sustainable use globally (Seidl et al., 2020b), and some four to seven times more than the estimated US $\$ 24.3$ billion that is currently being spent on PCAs (Waldron et al., 2020).

Not only was the amount of funding of concern in the pre-COVID-19 world, but also its composition and stability. The vast majority of PCAs rely on a narrow financing base. International development assistance accounts for almost a third of PCA funding in Africa, and up to 70-90 per cent in some cases. Nearly 80 per cent of the annual budget of conservation authorities in Eastern and Southern African countries comes from tourism revenues (Lindsey et al., 2020). Should one or more of these funding streams decline or fail, the entire PCA budget is placed in jeopardy.

A wide range of structural factors limit the effectiveness of conservation spending, place pressure on PCAs and their budgets, undermine investment flows and even increase conservation costs (Emerton et al., 2006). These include shortcomings in the systems and capacities to plan, manage and spend limited funds, and a lack of economic incentives for the groups that bear the costs of conservation (GIZ, 2019). A more nuanced understanding of 'financial sustainability' has replaced the simple concept of 'funding' that traditionally dominated conservation planning: "the ability to secure sufficient, stable and long-term financial resources, and

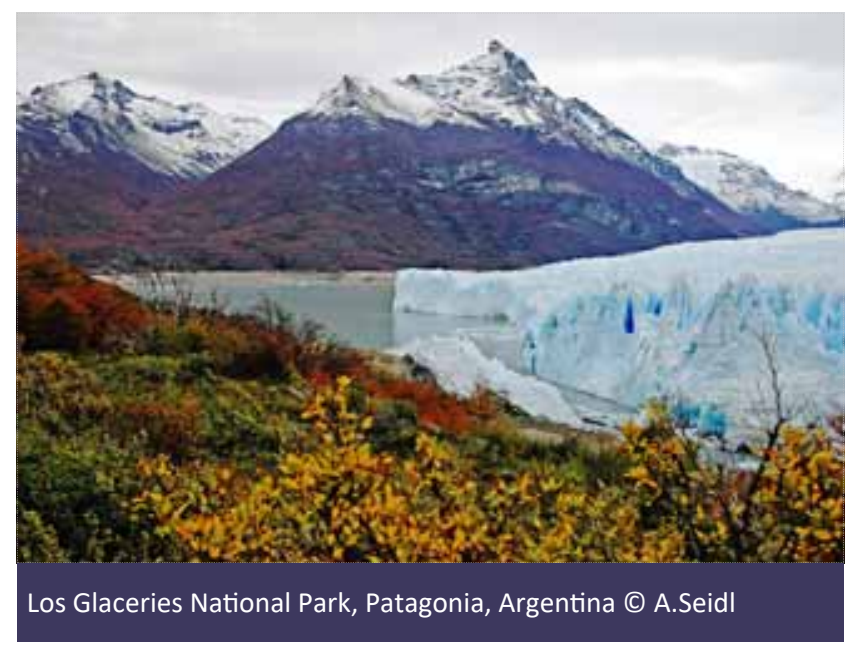

to allocate them promptly and in an appropriate form, to cover the full costs of conservation and to ensure that they are managed effectively and efficiently" (Emerton et al., 2006). Conservation finance is now understood as "mechanisms and strategies that generate, manage, and deploy financial resources and align incentives to achieve nature conservation outcomes" (Meyers et al., 2020). Financial stability now means a broader range of enabling conditions than just funding availability.

It is into this landscape of PCA finance that the COVID19 crisis emerged, and it is against these broader conditions and needs that COVID-19-related impacts on PCA finance, and proposed responses, must now be designed.

\section{THE IMPACT OF COVID-19 AND GLOBAL ECONOMIC SHOCKS ON PCA FINANCE}

Emerging literature makes dire predictions about the impacts of the COVID-19 global economic crisis on conservation funding (such as Corlett et al., 2020; Lindsey et al., 2020; Helm, 2020). Although some of these claims are as yet unsubstantiated, there are reasons to fear an imminent collapse - or at least a steep decline - in funding. Although we do not know the magnitude of this, how long it will last, or whether it will cause permanent shifts in PCA finance, lessons from recent economic crises point to some likely risks and outcomes.

\section{Reduction in tourism revenue for PCAs}

Travel restrictions have had a dramatic impact on global tourism (UNWTO, 2020). ${ }^{1}$ The World Travel and Tourism Council estimates a probable global loss of 197 million jobs and US\$ 5.5 trillion in revenue (WTTC, 2020b). ${ }^{2}$ The repercussions for tourism in protected areas include declines in revenues used for conservation finance, reduced salaries of tourism employees, and drastically less income for entrepreneurs and small businesses providing products and services (Spenceley, 2020a; Lindsey et al., 2020; Spenceley, 2021).

If, or when, a COVID-19 vaccine is developed and widely distributed, we can assume that international tourism will rebound to some extent. It was exposed to several crises over the last two decades, including four global pandemics (SARS in 2002, 'Bird flu' in 2009, MERS in 2012 and Ebola which peaked in 2013-14) and the economic recession of 2007-2009. However, only SARS and the economic crisis resulted in a sustained reduction in international arrivals (Gössling et al., 2020), and none led to a long-term decline in global tourism. Evidence does, however, suggest that it can take time for visitor confidence to return. The average 
time for tourist numbers to recover following previous major viral outbreaks was 19 months, although wellplanned interventions can cut this to 10 months or less (WTTC, 2020a). ${ }^{3}$ There can also be significant knock-on effects, even in countries that remain relatively unaffected by the disease. For example, The Gambia recorded no Ebola cases, but tourism receipts more than halved during the 2014/ 15 season (Novelli et al., 2018). Other extreme events, such as terrorism, political unrest or natural disasters, typically give rise to strong local substitution effects, with tourist demand largely sustained but shifting to other nearby sites or countries (Seabra et al., 2020). However, the global nature of the current crisis will probably cause systemic shifts in substitution - including from international to domestic tourist source markets - at least in the short and medium term (Bremmer, 2020). ${ }^{4}$ Most international wildlife and nature tourists spend more than domestic tourists, so the potentially negative effects on PCA revenues or losses due to the current pandemic may be substantial, unless managers are able to adjust their strategies, facilities and promotion strategies.

\section{Reduction in domestic public budgets}

Responding to the COVID-19 crisis and resultant economic crisis places an added demand on already overstretched public budgets. The impact of reduced tax revenue for governments will exacerbate this problem in the years to come. There is a real risk that pressure on public sector budgets will result in a reallocation away from PCAs, as has happened in the past. In the USA, for example, while the global economic recession of 2007-2009 led to public funding cuts across the board, parks and recreation were among the hardest hit, suffering both in terms of the absolute amount of funding received and in the share relative to other local government services (Barrett et al., 2017).

\section{Reduction in official development aid and philanthropy}

Official development aid and philanthropic donations targeted at PCAs are also at risk as priorities shift and the total amount of funds shrinks. The 2007-2009 economic recession saw a decline in bilateral and multilateral aid flows due to fiscal constraints in donor countries. ${ }^{5}$ Historical data show that the effects of economic recession on development funding usually come with a time-lag of one or two years; however, aid commitments respond faster than aid disbursements (Hallet, 2009), so they tend to persist for three years or more (Dabla-Norris et al., 2010). A sharp drop was also registered in charitable giving by individuals, foundations and corporations. In the US, donations fell by 10.9 per cent between 2007 and 2010, and were still well below 2007 levels in 2012 (Reich \& Wimmer, 2012). The UK registered an almost identical decline of 11 per cent, although donations picked up again relatively quickly (NCVO, 2009). However, not all causes were affected equally: in the US, there was a shift towards domestic targets and poverty-related causes (Reich \& Wimmer, 2012), while organisations implementing international development activities were among the worst affected in the UK (Charity Commission, 2010).

\section{Increase in local opportunity cost for PCA- adjacent communities}

COVID-19 may, arguably, increase the local opportunity costs of PCAs, placing an added burden on the local economy and livelihoods. Many PCA-adjacent communities and institutions, including local authorities, business and enterprises, face economic collapse, thus endangering livelihoods where jobs are strongly reliant on international tourism (World Bank Group, 2020). The result can be increased pressure on PCAs from unsustainable land and resource uses (Lindsey et al., 2020). Brazil ${ }^{6}$, Kenya ${ }^{7}$ and Uganda are among those reporting increased poaching and illegal wildlife trafficking. ${ }^{8}$

\section{Impact of economic recovery responses on PCAs}

By September 2020, about 30 per cent of economic stimulus funds of G20 nations (US\$ 3.7 trillion of US\$ 12.1 trillion) were directed toward sectors and activities that affect nature (Vivid Economics, 2020). While most green recovery initiatives have focused on renewable energy, green infrastructure and transport, some target or affect PCAs. At least ten governments have earmarked funds that do this, including increasing areas under conservation, supporting management, bolstering tourism infrastructure and creating jobs in restoration (Golden Kroner et al., 2021). New Zealand ${ }^{9}$ is investing in a jobs programme to manage public lands. Pakistan ${ }^{10}$ has committed to expand PCAs and launch the country's first National Parks Service while creating jobs. The EU's ${ }^{11}$ recovery package is the most extensive green recovery plan to-date, redoubling the commitment to scale up PCAs in line with the EU Biodiversity Strategy. At least eight other countries have earmarked additional green support in their stimulus packages that may indirectly support PCAs, through the funding of naturebased solutions, forest management and other activities. In addition, at least 13 countries have begun implementation of pre-COVID-19 commitments to scale up and further support PCAs, despite the pandemic.

In contrast, at least 24 governments have proposed or enacted more than 60 rollbacks to regulations or cuts to PCA agency budgets. These will affect PCAs and other 
environmental protections, affecting the rights of Indigenous Peoples and Local Communities (IPLC) (Conservation International, 2020). ${ }^{12}$ New regulatory rollbacks authorise mining, oil and gas, extensive infrastructure (dams, airports, housing complexes) and other environmentally damaging activities (Golden Kroner et al., 2021). Although rollbacks to PCAs are not new (Golden Kroner et al., 201913), recent decisions have been advanced under cover of a public health crisis when public engagement is limited. Ironically, they could exacerbate the risk of future pandemics by further damaging ecosystems. ${ }^{14}$ On balance, economic recovery stimulus efforts of the largest economies have to-date favoured investing in business-as-usual practices rather than in carbon-neutral and nature-positive actions, as signalled by a negative 'green stimulus index' score for 16 of the 20 G20 countries (Vivid Economics, 2020).

However, there is increasing political momentum for nature conservation, leading up to this year's CBD COP; for instance, a recent pledge signed by dozens of governments (the Leaders' Pledge for Nature) calls for a green recovery and commits to scale up the extent of, and support for, PCAs. ${ }^{15}$

\section{RESPONDING TO THE CRISIS: REBUILDING} SUSTAINABLE FINANCING FOR RESILIENT PCAS

There are therefore opportunities as well as risks in the post-pandemic situation, which calls for a renewed strategic approach to PCA finance. Drawing on lessons from past economic crises as well as emerging evidence from the current one, we present nine recommendations for creating more resilient PCA finance. These are:

1. diversifying the funding base;

2. improving spending effectiveness and efficiency;

3. ensuring domestic budgets continue to support PCAs;

4. increasing international development finance and philanthropy;

5. strengthening revenue generation from tourism;

6. supporting PCAs governed by Indigenous peoples, local communities and private actors;

7. including local communities in PCA governance and benefits;

8. engaging the finance sector and attracting private capital; and

9. raising public support and interest in nature conservation and PCAs.

While many of these recommendations can be taken up immediately, this paper does not specifically focus on the short-term COVID-19 recovery response, as this is addressed in Golden Kroner et al. (2021).

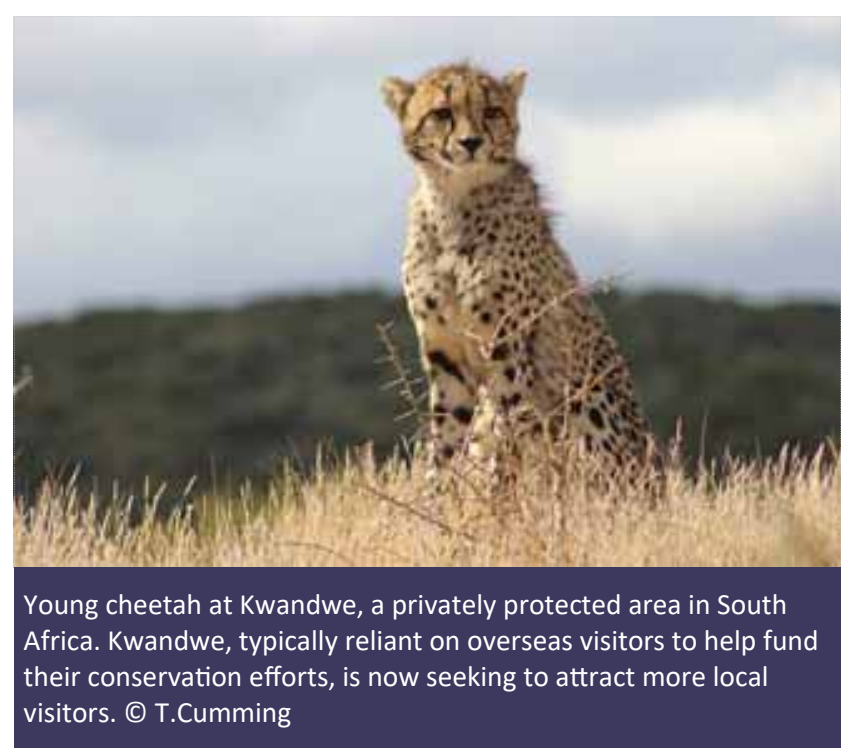

\section{Diversifying the funding base}

Even before the COVID-19 crisis, there was a realisation that over-dependence on any single funding source for PCAs was risky, often unsustainable, and frequently insufficient to meet needs (Deutz et al., 2020). The current PCA funding crisis reinforces the importance of diversifying funding and reducing risk. A diverse funding base would embrace complementary combinations of funding, for example: long-term, dependable funding for ongoing management and salaries; short-term funding efforts for specific projects; and cyclical funding, such as from seasonal tourism, to supplement budgets. Diversification also allows for mutually reinforcing funding mechanisms. For example, long-term PCA funding commitments from governments may encourage the private sector to invest in income-generating enterprises, such as private lodges, which in turn provide revenue from concessions and add value through expenditure in the local economy.

Short-term fund-raising by PCAs is not an ideal primary funding source to meet national and global PCA targets. However, they still add to the funds raised, and help increase public awareness of the PCA conservation mission. Crowdfunding is one such mechanism where increased funds go hand-in-hand with increased public awareness. Examples of COVID-19 motivated crowdfunding campaigns supporting PCAs include Belize (Hol Chan MP), Brazil (Pantanal), Ecuador (Galapagos), Thailand (Koh Tao MR) and the Philippines (Mounts IglitBaco NP). ${ }^{16}$ Similar efforts include: the Wildlife Ranger Challenge ${ }^{17}$, where members of the public and wildlife rangers across Africa run 'together' - virtually - to raise funds; the Yankari 
Game Reserve where rangers ran a marathon to raise funds for themselves; the Frankfurt Zoological Society Mission Possible: Corona relief fund for PCAs in need ${ }^{18}$; and BIOPAMA Rapid Response Grants 2020.19

There are many effective finance mechanisms that can be used to supplement or even entirely meet a PCA's funding need (see, for example, the BIOFIN Catalogue of Finance Solutions ${ }^{20}$, and Meyers et al., 2020). Many of these are suitable for a subset of PCAs, depending on context. Revenue from tourism is one such example, as is funding from carbon markets. Carbon emissions offsetting through habitat conservation and restoration can bring about benefits in PCA buffer areas and within PCAs, provided additionality can be shown. Zambia's Luangwa Community Forests Project, the largest REDD+ project in Africa, will eventually protect 944,000 ha of wildlife-rich forest in an area with high levels of deforestation, and benefit approximately 37,000 local households. ${ }^{21}$ As PCAs are often sources of essential ecosystem services, investment in 'ecological infrastructure' or 'green infrastructure' can be important in financing PCAs (Deutz et al., 2020). However, there is no one 'silver bullet' finance mechanism for PCA funding, and contexts may shift, as COVID-19 has demonstrated. The UNDP BIOFIN methodology (UNDP, 2018) includes a process for determining the most suitable 'finance solutions' for biodiversity finance at a country level, the principles of which can be applied specifically for PCAs.

\section{Improving spending effectiveness and efficiency}

The current crisis looks set to result in significant pressure on PCA budgets. So, as well as retaining and increasing budgets wherever possible, it is essential to use existing PCA resources effectively and efficiently. The revitalisation of PCA operations and budgeting in a post-COVID-19 context offers the opportunity to do this, by improving the systems and capacities for PCA planning and management. In Kazakhstan, for example, training programmes for PCA managers are being created to help improve the development and costing of PCA management plans (M. Sarsembayeva, pers. comm. 2020). In Kyrgyzstan, results-based budgeting templates are being piloted in two protected areas and 20 state-managed forest areas. ${ }^{22}$

More effective use of resources can also be achieved through collaboration between the public sector, civil society, communities and the private sector. For example, the Rhino Action Group Effort ${ }^{23}$ assembles ecologists, game reserve owners, government, media professionals and economists to channel and account for the contributions of money, material and time that they make to prevent rhino poaching in PCAs. Public Private Partnerships ${ }^{24}$ are another way of effectively utilising available resources: such long-term arrangements can allow commercial concessions in PCAs, or contract skilled private entities to assist with PCA management (Meyers et al., 2020). Channelling funding through trust funds can improve PCA management and help to ensure sustainable funding (Bonham et al., 2014). Trust funds can be a useful institutional structure to manage COVID-19-related funding efforts, and a tool to facilitate debt-for-nature swaps.

\section{Ensuring domestic budgets support PCAs}

There is currently massive pressure on public sector budgets. Hence the importance of recognising the value of the natural capital in PCAs and the role PCAs can play in job creation and rural livelihoods, water provisioning services, disaster risk reduction, domestic and international tourism, etc., alongside securing the intrinsic value of biodiversity (ten Brink et al., 2012). Public sector allocations for PCAs should be maintained or increased through the budgets of the ministry primarily responsible for PCAs, as well as by integrating biodiversity-positive actions into the plans and budgets of other ministries and programmes which benefit from intact and conserved ecosystems (CBD, 2020). This is needed both near term, within domestic recovery packages (Golden Kroner et al., 2021), and in the longer term.

Job creation public sector programmes - more important now than ever - should be designed to bring about biodiversity benefits that support labour-intensive ecosystem restoration (such as South Africa's Working for Water' programme ${ }^{25}$ ), and focused where possible on PCAs. India has recently allocated US $\$ 780$ million towards a programme designed to stimulate the rural and semi-urban economy, create biodiversity benefits, including wildlife protection and forest management, and support local communities (Vivid Economics, 2020).

There is growing evidence that supports the use of nature-based solutions (NbS), provided there are real biodiversity benefits, to achieve climate change mitigation and adaptation, as a complement, or an alternative to, grey infrastructure (Sneddon et al., 2020). There is a strong argument for Nationally Determined Contributions (NDCs) under the Paris Agreement to be used to expand the role of PCAs in support of local, national and global climate change adaptation and mitigation efforts, and for much more climate change funding to be allocated towards these 
efforts (WWF, 2019a; Deutz et al., 2020). The difficulty of measuring and predicting the effectiveness of $\mathrm{NbS}$ has held back investment in these systems; however, "highly sectoralized forms of governance" (Sneddon et al., 2020) may be a bigger barrier to integrating biodiversity and ecosystem services into sector and development planning. While NDCs are determined by governments, some commitments are conditional upon international funding, making this a cross-cutting issue which also has relevance to increasing international development finance and philanthropy (see below).

The cost of managing pressures on PCAs can also be reduced through improved and integrated planning at the national level. As countries seek to rebuild, many PCAs would benefit from more cohesive national development strategies, which recognise the full importance of biodiversity and ecosystem services. Plans should be used to avoid conflicts between natural systems and unsustainable development, and to reduce pressure on PCAs; for example, by avoiding incompatible land use around PCA boundaries. In the near term, it is important that stimulus packages exclude any relaxation of regulations that would increase pressures on PCAs (Golden Kroner et al., 2021). There are specific instruments that can help secure and channel public sector funds for PCAs. Fiscal earmarking can help to ensure funding security (Deutz et al., 2020). For example, in Estonia and Ireland fishing fees are directly used to protect fish habitats through conservation funds (Ezzine de Blas et al., 2017).

COVID-19 is having substantial economic impact on sub -national governments, so improving the long-term financial resilience of sub-national governments is crucial (OECD, 2020). Subnational governments managing PCAs may need specific support from national government. Ecological fiscal transfers, a mechanism used to channel financial support and incentives from national government to subnational governments based on biodiversity health and PCA metrics, aim to counter the high real and opportunity costs sometimes borne by sub-national governments with a high proportion of land under protection. ${ }^{26}$ This mechanism has been used successfully in Brazil and Portugal (Droste et al., 2018).

\section{Increasing international development finance and philanthropy}

International development finance and philanthropy will continue to be important sources of funding for PCAs that conserve globally significant biodiversity and secure ecosystem services (Lindsey et al., 2020; Deutz et al., 2020). But more could be done to make these funding flows more effective and durable. The impact of donor funds can be enhanced through better access to information on funding opportunities and support for potential recipients in applying for funding (CBD, 2020). Improving donor coordination can ensure that funding is targeted more strategically, from both public and private sources (CBD, 2020). The Legacy Landscapes Fund (LLF) ${ }^{27}$, for example, is a joint initiative that includes the German and French international development agencies, IUCN and WWF, and which combines public and private resources. The LLF and the project finance for permanence approach ${ }^{28}$ can help focus on the long-term management needs of PCAs of global significance.

Funding primarily allocated for achieving sustainable development and climate change adaptation and mitigation objectives can have a substantial positive impact on PCA funding (Deutz et al. 2020). The French Development Agency, for example, aims to fully integrate nature-based solutions ${ }^{29}$, bringing biodiversity benefits to all of their investment portfolios, including agriculture and urban development.

The economic impact of COVID-19 will make sovereign debt a growing challenge over the next few years. Efforts are underway to develop a new asset class for 'Nature Performance Bonds', which could provide substantial funding flows to countries in return for specific, measurable commitments to biodiversity protection and restoration. ${ }^{30}$ Linking sovereign debt to PCAs is not new. The Seychelles blue bond' was the first debt-for-nature swap focusing on expanding marine conservation and sustainable fisheries (World Bank Group, 2020). A variety of conservation bonds, including the Rhino Impact Bond, have been proposed as ways to finance PCA systems. Environmental impact bonds allow for 'pay for performance' conditions to be put in place, and can combine public funds with private funds (World Bank Group, 2020).

\section{Strengthening revenue generation from tourism}

In many cases, tourism revenues provide the major, or only, source of self-generated PCA revenues, as well as making an important contribution to local livelihoods and the national economy. While many PCAs are not in a position to self-fund through tourism, there is a subset of PCAs that can rely on tourism-related revenue as a substantial funding flow. In their analysis of the impact of tourism in PCAs amid the pandemic, Spenceley et al. (2021) describe a diversity of responses to the current crisis which allow PCAs to make the visiting experience safer. These are often provided for the growing numbers of visitors who find in nature an antidote to the stresses of lockdowns. 
Government relief packages for the tourism sector in countries that rely heavily on tourism will help keep the industry alive during the crisis, allowing it to emerge strong when restrictions are eased. Such packages should, as far as possible, incorporate sustainability criteria for biodiversity, climate change and local community benefits (Spenceley, 2020b). Kenya, for example, has announced a tourism stimulus package ${ }^{31}$ of over US\$ 58 million, with additional funds set aside for upgrading facilities. Local efforts to support local value chains that no longer have tourism income are also critically important to sustain local economies adjacent to PCAs (Spenceley, 2020a).

Some nature-based tourism operators and natural attractions are becoming more resilient through new and diversified income streams, including virtual tours and promoting their services to domestic markets (Spenceley, 2020a \& b). Examples of virtual tours include: the Grand Canyon, Yosemite and Zion national parks in the US; Sagarmartha (Mount Everest) in Nepal; Phong Nha-Ke Bang National Park in Viet Nam; the Perito Moreno glacier in Argentina; and Giant's Causeway in Northern Ireland. ${ }^{32}$ Examples of expanding markets include Mbazi Safaris, which is encouraging the South African diaspora to sponsor game drives in the Kruger National Park for neighbouring communities (Spenceley, 2020a).

As countries emerge from strict lockdowns, a review of PCA entrance and other fees could be highly beneficial, preferably guided by clear criteria. An appropriate pricing policy, where prices are updated regularly, can make a substantial difference to PCA finance flows. For example, South African National Parks now update their fees annually, whereas in neighbouring Botswana and Namibia they have remained unchanged for 20 and 15 years respectively - though both are now updating theirs. Foregone revenues are substantial in these cases, as fees will need to more than double to keep up with inflation (Van Zyl, 2019). Re-thinking the structure of tourism fees will have to balance the capacity and willingness of operators and different types of visitors to pay (Spenceley et al., 2017), while taking into account structural changes in international and domestic source markets.

Systems should be put in place that allow for the retention of fees for reinvestment in PCAs. In the Philippines, the management board of each PCA retains 75 per cent of income generated from entry charges and user fees, leases, concessions and other revenues derived from the operation of the PCA. This arrangement has generally functioned well as a way to improve PCA funding autonomy and cost recovery, and ensure that those self-sourced revenues are not mingled with core annual budget allocations (Anda \& Atienza, 2013). However, it is important to retain crosssubsidisation arrangements to support PCAs with limited revenue earning potential.

\section{Supporting PCAs governed by Indigenous peoples, local communities and private actors}

PCAs that are governed by private actors, Indigenous peoples and local communities ${ }^{33}$ remove a substantial financial burden from the public sector while helping to meet PCA targets and maintaining biodiversity and ecosystem services (Ivanova \& Cook, 2020). These nonstate PCA governance types require the right conditions to succeed and thrive, such as: mutually beneficial partnership agreements; management, scientific and technical support; recognition of efforts; and a supportive community of practice, economic incentives and enabling policy and legislation (Mitchell et al., 2018). Governments and NGOs have a role to play in supporting these initiatives. Non-state PCAs themselves need to create financial strategies that are different from many state PCAs - without domestic public budgets, they are more reliant on self-generated revenue and philanthropy. Private and community-managed PCAs are often particularly reliant on tourism revenues to finance conservation and support local communities (Lindsey et al., 2020); many will need more support now than ever.

\section{Including local communities in PCA governance and benefits}

This is the time to redouble efforts to ensure that local communities benefit from PCAs. Well-designed projects and strategies can link conservation with local economic

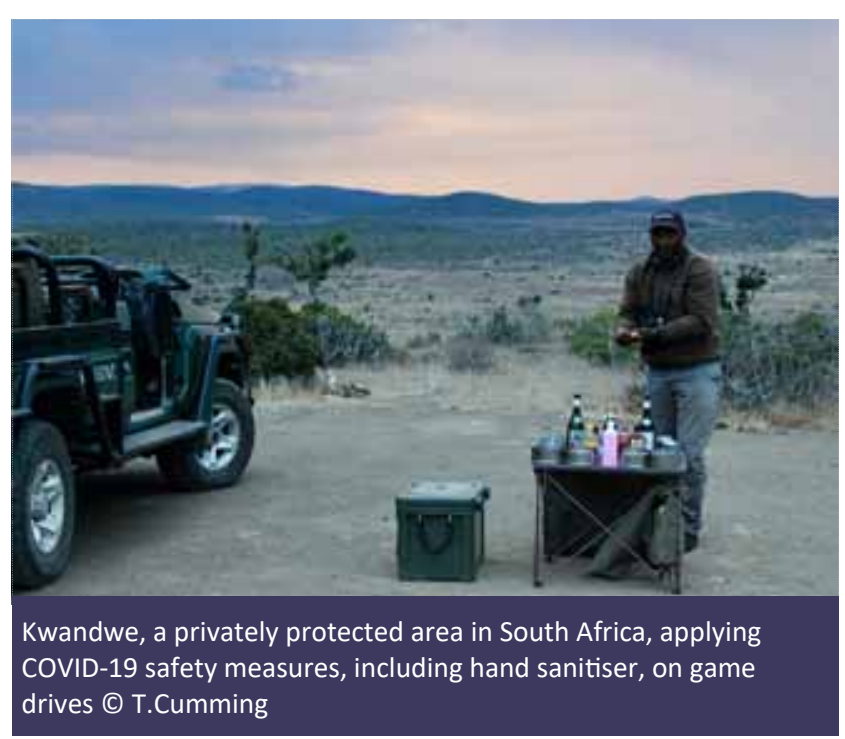


and social development. In Namibia the concept of wildlife credits is being tested, which will allow tourism businesses, tourists and others to make performancerelated payments to communities for actively conserving wildlife and habitats. ${ }^{34}$ Local enterprises and job creation for local communities need not be limited to the tourism sector. Gorongosa Coffee ${ }^{35}$ in Mozambique works with local coffee farmers around Mount Gorongosa; coffee sales support the community and Gorongosa National Park.

Shared-governance arrangements for PCAs can provide similar financial as well as socio-economic benefits for local communities. Blue Finance ${ }^{36}$ (see also Phua et al., 2021) is pioneering an approach to collaborative management of marine protected areas, facilitating agreements between government, NGOs, for-profit organisations and community groups.

\section{Engaging the finance sector and attracting private capital}

The 2020 World Economic Forum Global Risks Report rates biodiversity loss as the third most important global risk in terms of impact and the fourth in terms of likelihood (WEF, 2020). So, it is hardly surprising that the finance sector is taking an increased interest in the subject in two ways: as a potential source of revenue and as a means to reduce risk (UNDP, 2020): in doing so, its actions can greatly benefit PCA finance.

Decisions taken in the financial sector can support PCA finance through biodiversity-compatible investments. Investment managers are struggling to keep up with the public demand for green investment and environmental, social and governance (ESG) investment options. In the UK, net inflows into ESG mutual funds were 37 times higher ${ }^{37}$ in the three-year period up to J une 2020 compared to the previous threeyear period. However, it is still challenging to bring biodiversity investment opportunities to market (UNDP, 2020).

More business opportunities that benefit PCAs can be created by improving the business acumen of project developers, reducing transaction costs, providing blended finance and reducing risk for private sector investors (UNDP, 2020). The Coalition for Private Investment in Conservation (CPIC) has developed a number of 'blueprints' to guide the development of conservation projects for investment, seeking to connect project providers with support and investors. ${ }^{38}$ The Millennium BIM Bank, the largest bank in Mozambique, has established a US\$ 50 million line of credit for investors in nature-based tourism, focused on
PCAs (World Bank Group, 2020), and the European Investment Bank has created the Natural Capital Financing Facility for projects delivering biodiversity benefits and climate adaption. 39

Reducing harmful impacts from private-sector investments in and around PCAs can substantially reduce the costs associated with managing these pressures. Trillions of dollars are invested annually in infrastructure, energy, transportation and extractive industries (Deutz et al., 2020), while the negative impact of these activities on PCAs is often unregulated or unmanaged (Sloan et al., 2016; Sonter et al., 2017). Such projects frequently require support from financial institutions, such as loans from development and commercial banks. To reduce the financial burden placed on PCAs in managing pressures, all lending institutions should apply social and environmental safeguards (such as the IFC's Performance Standard $6^{40}$ ), and monitor adherence to these. The finance sector should maintain and strengthen its support for reducing illegal wildlife crime, including through the Financial Action Task Force ${ }^{41}$, thereby reducing the need for costly anti-poaching efforts.

The recent establishment of the Informal Working Group to set up a Taskforce for Nature-related Financial Disclosures in the finance sector is an indication that, even in the midst of a global crisis, the finance sector recognises the importance of shifting finance from destructive activities to biodiversity-positive activities. 42

The corporate sector also has an important role. It can help reduce illegal and unsustainable practices in food and fibre supply chains, thus controlling the excesses of intensive agriculture and fisheries. Unilever has recently committed to a deforestation-free supply chain by 2023 and to engaging more broadly on reducing large-scale deforestation. ${ }^{43}$ Walmart is working towards greening supply chains, and, together with the Walmart Foundation, is committing to help protect, manage or restore at least 50 million acres of land and one million square miles of ocean by 2030. Governments have a crucial role to play in creating the enabling policy and legislative conditions for positive change in the finance sector and businesses (CBD, 2020; Deutz et al., 2020; World Bank Group, 2020).

\section{Raising public support and interest in nature conservation and PCAs}

Public awareness of the importance of environmental issues, including biodiversity conservation, is growing and should continue to provide opportunities for increasing PCA support and finance.44 In the United 
States, WWF has grown its income from US\$ 221 million to US\$ 308 million (40 per cent of which came from individual donors) over the last 10 years (WWF, 2019b). The pandemic may have further increased public awareness of, and support for, initiatives that deliver positive social and environmental outcomes. ${ }^{45}$

Increased public support should be positive news for all forms of PCA funding. Individuals should be more willing to make donations, politicians should respond with increased budget allocations when voters place a higher value on conservation, and corporate social responsibility (CSR) spending will attempt to reflect the preferences of customers. There should therefore be opportunities for PCAs to capitalise on this, for example through crowdfunding and payments for ecosystem services.

PCA governance authorities may want to put more effort into building broader and stronger support bases that can come to their aid, particularly in times of crisis. Friends associations, honorary ranger programmes and supportive foundations, potentially with links to CSR donors, can provide direct assistance in kind and cash. The US National Park Service works closely with the National Park Foundation, which has raised US\$ 550 million for the parks system over the last five years. Subaru Motors are among the Foundation's prominent partners and have contributed more than US $\$ 20$ million since 2013, giving them defined rights to use the NPS brand and logo. ${ }^{46}$ In Singapore, the Garden City Fund is used to finance outreach, education, research and infrastructure programmes, which go beyond the basic core mandate of the National Parks. ${ }^{47}$ As public awareness of the importance of securing biodiversity and ecosystems increases, these and other tools should be used more widely to diversify the funding base of PCAs and increase their financial resilience.

\section{CONCLUSION}

The recommended actions put forward in this paper are grounded in the understanding that PCAs are fundamental to the health of natural, social and economic landscapes, a fact laid bare by the current global pandemic. As we work towards rebuilding and regenerating natural, social and economic landscapes, investing in PCAs should be deeply integrated into sustainable and green recovery responses. And, as we move from short-term responses to longer-term planning, putting biodiversity at the heart of resilient societies should be a top priority. COVID-19 and the related economic crisis have exacerbated, magnified and brought into sharp relief pre-existing challenges with PCA funding. The conservation community and its supporters need to scale up efforts to address the underlying structural and systemic financial constraints that undermine PCAs. A strategic and integrated approach to improving PCA funding is needed to: address the complexities of national and subnational development strategies, policies and budgets; build partnerships between the public, private and finance sectors, and with local communities; strengthen institutions; and invest in building capacity. This will take time, but it has never been more important.

\section{ENDNOTES}

See Supplementary Online Material - Endnotes

\section{SUPPLEMENTARY ONLINE MATERIAL} Endnotes

\section{ABOUT THE AUTHORS}

Tracey Cumming is a Technical Advisor to UNDP BIOFIN, and a member of the CBD Panel of Experts on Resource Mobilisation for the post-2020 global biodiversity framework. ORCID: 0000-0002-2147-4622

Andrew Seidl, Ph.D. is Associate Department Head and Professor of Agricultural and Resource Economics, Colorado State University, USA and Senior Technical Advisor to UNDP BIOFIN. ORCID: 0000-0002-23381307

Lucy Emerton is Director of Economics and Finance at the Environment Management Group, and works on developing innovative conservation finance solutions across the world. ORCID: 0000-0003-1626-6324

Anna Spenceley, $\mathrm{PhD}$, is an independent consultant, and Chair of the IUCN WCPA Tourism and Protected Areas Specialist Group. ORCID: 0000000228151615

Rachel Golden Kroner is the Environmental Governance Fellow at Conservation International and co - chair of the IUCN COVID and Protected and Conserved Areas task force. ORCID: 0000-0003-1844-3398

Yvette Uwineza is a research assistant in the Agricultural and Resource Economics department at Colorado State University. ORCID: 0000-0002-96757758

Hugo van $\mathbf{Z y l}, \mathrm{PhD}$, is the director of Independent Economic Researchers, a consultancy focusing on applied environmental resource economics and finance, socio-economic impact assessment and project appraisal. ORCID: 0000-0002-2810-1167 


\section{REFERENCES}

Anda, A. and Atienza, M. (2013). 'Fiscal gap and financing protected areas in the Philippines'. EEPSEA Research Report No. 2013-RR16, Economy and Environment Program for Southeast Asia, Laguna.

Barrett, A., Pitas, N. and Mowen, A. (2017). 'First in our hearts but not in our pocket books: Trends in Local Governmental Financing for Parks and Recreation from 2004 to 2014'. Journal of Park and Recreation Administration 35(3): 1-19. doi.org/10.18666/JPRA-2017-V35-I3-7674.

Bonham, C., Steininger, M.K., McGreevey, M., Stone, C., Wright, T. and Cano, C. (2014). 'Conservation trust funds, protected area management effectiveness and conservation outcomes: lessons from the Global Conservation Fund'. PARKS, 20. doi.org/10.2305/IUCN.CH.2014.PARKS-20-2.CB.en

Castillo, G., Chan, S., Li, W., Li, Y., Fatah, H., Malivarn, S., Lee, K., Anda, A., Laencharoen, P., Pham, D. and Laplante, B. (2015). 'Fiscal gaps and financing of Southeast Asia's protected areas: a cross-country analysis'. EEPSEA Research Report No. 2015-RR13, Economy and Environment Program for Southeast Asia, Laguna.

CBD. (2020). 'Contribution to a draft resource mobilization component of the post-2020 biodiversity framework as a follow-up to the current strategy for resource mobilization'. CBD/SBI/3/5/Add.3. Available at: https://www.cbd.int/ meetings/SBI-03

Charity Commission. (2010). Charities and the economic downturn. London: Charity Commission.

Coad, L., Watson, J., Geldmann, J., Burgess, N., Leverington, F., Hockings, M., Knights, K. and Marco, di. M. (2019). 'Widespread shortfalls in protected area resourcing undermine efforts to conserve biodiversity'. Frontiers in Ecology and the Environment. doi.org/10.1002/fee.2042

Corlett, R., Primark, R.B., Devictor, V., Maas, B., Goswami, V.R., Bates, A.E., et al. (2020). 'Impacts of the coronavirus pandemic on biodiversity conservation'. Biological Conservation 246 (2020) 108571. doi.org/10.1016/ j.biocon.2020.108571

Dabla-Norris, E., Minoiu, C. and Zanna, L. (2010). 'Business cycle fluctuations, large shocks, and development aid: New evidence'. IMF Working Paper 10/240, International Monetary Fund, Washington, DC. Available at: https://www.imf.org/en/ Publications/WP/lssues/2016/12/31/Business-Cycle-

Fluctuations-Large-Shocks-and-Development-Aid-NewEvidence-24303

Deutz, A., Heal, G.M., Niu, R., Swanson, E., Townshend, T., Zhu, L., Delmar, A., Meghji, A., Sethi, S.A. and Tobin-de la Puente, J. (2020). Financing Nature: Closing the global biodiversity financing gap. The Paulson Institute, The Nature Conservancy, and the Cornell Atkinson Center for Sustainability.

Droste, N., Becker, C., Ring, I. and Santos, R. (2018). 'Decentralization effects in ecological fiscal transfers: A Bayesian structural time series analysis for Portugal'. Environmental and Resource Economics 71, 1027-1051. doi.org/10.1007/s10640-017-0195-7

Emerton, L., Bishop, J. and Thomas, L. (2006). Sustainable financing of protected areas: A global review of challenges and options. World Commission on Protected Areas Best Practice Protected Area Guidelines Series No. 13. Gland,
Switzerland: International Union for Conservation of Nature (IUCN).

Ezzine de Blas, D., Kettunen, M., Russi, D., Illes, A., Lara-Pulido, J., Arias, C. and Guevara, A. (2017). Innovative mechanisms for financing biodiversity conservation: a comparative summary of experiences from Mexico and Europe. Brussels: Institute of European Environmental Policy (IEEP).

GIZ. (2019). 'Towards a strategic approach to the diagnosis, response \& delivery of sustainable biodiversity financing solutions.' Implementing the Biodiversity Convention project. Bonn: Deutsche Gesellschaft für Internationale Zusammenarbeit (GIZ).

Golden Kroner, R., Barbier, E.B., Chassot, O., Chaudhary, S., Cordova, L., Cruz-Trinidad, A. et al. (2021) COVID-era policies and economic recovery plans: are governments building back better for protected and conserved areas? PARKS 27 (Special Issue): 135-148. doi.org/10.2305/ IUCN.CH.2021.PARKS-27-SIRGK.en

Gössling, S., Scott, D. and Hall, C. (2020). 'Pandemics, tourism and global change: a rapid assessment of COVID-19'. Journal of Sustainable Tourism 2020, Ahead-of-print, 1-20. doi.org/10.1080/09669582.2020.1758708

Hallet, M. (2009). 'Economic cycles and development aid: What is the evidence from the past?'. ECFIN Economic Brief Issue 5. Brussels: Directorate-General for Economic and Financial Affairs, European Commission.

Helm, D. (2020). 'The environmental impacts of the Coronavirus'. Environmental \& Resource Economics, European Association of Environmental and Resource Economists, 76(1), 21-38. doi.org/10.1007/s10640-020-00426-z

Ivanova, I.M. and Cook, C.N. (2020). 'The role of privately protected areas in achieving biodiversity representation within a national protected area network'. Conservation Science and Practice, p.e307. doi.org/10.1111/csp2.307

Lindsey, P. Allan, J., Brehony, P., Dickman, A., Robson, A., Begg, C., et al. (2020). 'Conserving Africa's wildlife and wildlands through the COVID-19 crisis and beyond'. Nature Ecology and Evolution. https://doi.org/10.1038/s41559-020-1275-6

Meyers, D., Bohorquez, J., Cumming, T., Emerton, L., v.d. Heuvel, O., Riva, M., Swanson, E. and R. Victurine, R. (2020). 'Conservation Finance: A framework.' Conservation Finance Alliance. Available at: www.cfalliance.org

Mitchell, B.A., Stolton, S., Bezaury-Creel, J., Bingham, H.C., Cumming, T.L., Dudley, N., Fitzsimons, J.A., Malleret-King, D., Redford, K.H. and Solano, P. (2018). IUCN guidelines for privately protected areas. Best Practice Protected Area Guidelines Series No. 29. Gland, Switzerland: IUCN. doi.org/10.2305/IUCN.CH.2018.PAG.29.en

NCVO. (2009). 'The impact of the recession on charitable giving in the UK'. London: National Council for Voluntary Organisations. Available at: https://www.cafonline.org/docs/ default-source/about-us-publications/ukgivingreport2009.pdf

Novelli, M., Burgess, L., Jones, A. and Ritchie, B. (2018). "No Ebola...still doomed' - The Ebola-induced tourism crisis'. Annals of Tourism Research 70: 76-87.doi: 10.1016/ j.annals.2018.03.006

NPS. (2020). 'Budget justifications and performance information, Fiscal Year 2021.' US Department of the Interior, National Park Service. Available at: https://www.doi.gov/sites/doi.gov/ files/uploads/fy2021-budget-justification-nps.pdf 
OECD. (2020). The territorial impact of COVID-19: Managing the crisis across levels of government. Paris: Organisation for Economic Cooperation and Development (OECD).

Phua, C., Andradi-Brown, D.A., Mangubhai, S., Ahmadia, G.N., Mahajan, S.L., Larsen, K., Friel, S. et al. (2021) Marine protected and conserved areas in the time of COVID. PARKS 27 (Special Issue): 85-102. doi:10.2305/ IUCN.CH.2021.PARKS-27-SICP.en

Reich, R. and Wimmer, C. (2012). Charitable giving and the Great Recession. Stanford: Stanford Center on Poverty and Inequality.

Seabra, C., Reis, P. and Abrantes, J. (2020). 'The influence of terrorism in tourism arrivals: A longitudinal approach in a Mediterranean country'. Annals of Tourism Research 80, 102811. doi.org/10.1016/j.annals.2019.102811

Seidl, A., Mulungu, K., Arlaud, M., van den Heuvel, O. and Riva, M. (2020a). 'The effectiveness of national biodiversity investments to protect the wealth of nature'. Nature Ecology and Evolution. Forthcoming.

Seidl, A., Mulungu, K., Arlaud, M., van den Heuvel, O. and Riva, M. (2020b). 'Finance for nature: A global estimate of national biodiversity investments.' Ecosystem Services. Special Issue on Finance for nature: bridging the blue-green investment gap to inform the post-2020 global biodiversity framework. 46: December 2020. doi.org/10.1016/j.ecoser.2020.101216

Sloan, C., Bertzky, B. and Laurance, W.F. (2016). 'African development corridors intercept key protected areas'. African Journal of Ecology. doi.org/10.1111/aje.12377

Sneddon, N., Chausson, A., Berry, P., Girardin, C.A.J., Smith, A. and Turner, B. (2020). 'Understanding the value and limits of nature-based solutions to climate change and other global challenges'. Philosophical Transactions, Royal Society. 375. doi.org/10.1098/rstb.2019.0120

Sonter, L.J., Herrera, D., Barrett, D.J., Galford, G.L., Moran, C.J. and Soares-Filho, B.S. (2017). 'Mining drives extensive deforestation in the Brazilian Amazon'. Nature Communications 8, 1013 doi.org/10.1038/s41467-017-00557w

Spenceley, A. (2020a). 'COVID-19 and protected area tourism: A spotlight on impacts and options in Africa'. Report to the EU, Eurata Consortium.

Spenceley, A. (2020b). 'Building nature-based tourism back better: COVID-19 recovery, resilience and sustainability'. Report to the Luc Hoffmann Institute.

Spenceley, A., Rylance, A. and Laiser, S. (2017). 'Protected area entrance fees in Tanzania: The search for competitiveness and value for money'. Koedoe 59(1), a1442. doi.org/10.4102/ koedoe.v59i1.1442
Spenceley, A., Baez, A., Barborak, J. Blye, C-J., Bricker, K., Cahyadi, H., et al. (2021) 'Tourism in protected areas amid the COVID-19 pandemic.' PARKS 27(Special Issue): 103-118. doi:.10.2305/IUCN.CH.2021.PARKS-27-SIAS.en

ten Brink P., Mazza L., Badura T., Kettunen M. and Withana S. (2012). 'Nature and its role in the transition to a green economy'. Geneva: TEEB. Available at: http://teebweb.org/ publications/other/nature-role-in-green-economy/

UNDP. (2018). 'The 2018 BIOFIN Workbook: Finance for Nature'. The Biodiversity Finance Initiative. New York: United Nations Development Programme. Available at: https:// www.biodiversityfinance.net

UNDP. (2020). 'Moving mountains: Unlocking private capital for biodiversity and ecosystems'. New York: United Nations Development Programme. Available at: https:// www.biodiversityfinance.net/

Van Zyl, H.W. (2019). 'The Biodiversity Finance Initiative (BIOFIN) Botswana: Protected areas fee review'. Cape Town: Independent Economic Researchers. doi.org/10.13140/ RG.2.2.27421.54245.

Vivid Economics. (2020). 'Green Stimulus Index: An assessment of the orientation of COVID-19 stimulus in relation to climate change, biodiversity and other environmental impacts'. Available at: https://www.vivideconomics.com/

Waldron, A. Adams, V., Allan, J., Arnell, A., Asner, G., Atkinson, S., et al. (2020). 'Protecting $30 \%$ of the planet for nature: costs, benefits and economic implications'. Available at: https://www.conservation.cam.ac.uk/files/ waldron_report_30_by_30_publish.pdf

World Bank Group. (2020). 'Mobilizing Private Finance for Nature'. Available at: http://pubdocs.worldbank.org/ en/916781601304630850/Finance-for-Nature-28-Sep-webversion.pdf

World Economic Forum. (2020). 'Global Risks Report: World Economic Forum Global Risks Perception Survey 20192020'. Geneva: WEF. Available at https://www.weforum.org/ reports/the-global-risks-report-2020

WWF. (2019a) 'Enhancing Nationally Determined Contributions Through Protected Areas'. Washington: WWF. Available at: https://www.worldwildlife.org/publications/enhancing-nationally -determined-contributions-through-protected-areas

WWF. (2019b). '2019 WWF-US Annual Report.' Washington: WWF. Available at http://assets.worldwildlife.org/ financial_reports/37/reports/original/WWF-AR2019FINALPAGES.pdf? 1582917951\&_ga=2.184939817.183458182.1599647569249203835.1599647569 


\section{RESUMEN}

Existe una preocupación generalizada de que la financiación para las áreas protegidas y conservadas (APC) se vea reducida sustancialmente debido a la pandemia del COVID-19 y a los resultados económicos relacionados. En el presente artículo se argumenta que los efectos de la crisis mundial no suponen necesariamente nuevas amenazas financieras para las APC, sino que sirven para ampliar, intensificar y exacerbar las limitaciones y debilidades financieras estructurales y sistémicas existentes. Por lo tanto, para responder adecuadamente, es importante comprender la situación con respecto a la financiación de las APC antes del COVID-19, y abordar las barreras y limitaciones subyacentes a la sostenibilidad financiera de las APC. Con base en los desafíos conocidos en materia de financiación de las APC y los efectos previstos del COVID-19, presentamos nueve recomendaciones generales para crear una base de financiación sostenible para las APC: diversificar la base de financiación; mejorar la eficacia y la eficiencia del gasto; asegurar que los presupuestos nacionales sigan apoyando a las APC; aumentar la financiación internacional para el desarrollo y la filantropía; fortalecer la generación de ingresos procedentes del turismo; apoyar a las APC administradas por pueblos indígenas, comunidades locales y actores privados; incluir a las comunidades locales en la gobernanza y los beneficios de las APC; involucrar al sector financiero y atraer capital privado; y aumentar el apoyo e interés público en la conservación de la naturaleza y las APC. Se incluyen actividades y herramientas específicas para apoyar cada una de estas recomendaciones, respetando el contexto mundial actual.

\section{RÉSUMÉ}

Il existe une inquiétude largement répandue sur la diminution considérable du financement des aires protégées et conservées (APC) en raison de la pandémie du COVID-19 et des résultats économiques connexes. Cet article montre que les impacts de la crise mondiale n'induisent pas en eux-mêmes de nouvelles menaces financières pour les APC; ils servent plutôt à amplifier, intensifier et exacerber les contraintes et faiblesses financières structurelles et systémiques existantes. Afin d'y répondre au mieux, il est donc important de comprendre l'état du financement des APC avant COVID-19, et de s'attaquer aux obstacles et aux contraintes sous-jacents à la viabilité financière des APC. En nous basant sur les défis financiers connus des APC et les effets prévus du COVID-19, nous présentons neuf recommandations globales pour l'établissement d'une infrastructure financière durable pour les APC: diversifier la base de financement; améliorer l'efficacité et l'efficience des dépenses; veiller à ce que les budgets nationaux continuent de soutenir les APC; accroître le financement du développement international et la philanthropie; renforcer la génération de revenus du tourisme; soutenir les APC gouvernés par les peuples autochtones, les communautés locales et les acteurs privés; inclure les communautés locales dans la gouvernance et les bénéfices des APC; engager le secteur financier et attirer des capitaux privés; et susciter l'appui et l'intérêt du public pour la conservation de la nature et les APC. Des activités et des outils spécifiques sont fournis pour soutenir chacune de ces recommandations, tout en respectant le contexte mondial actuel. 


\title{
LAND USE-INDUCED SPILLOVER: PRIORITY ACTIONS FOR PROTECTED AND CONSERVED AREA MANAGERS
}

\author{
Jamie K. Reaser ${ }^{1,2,3^{*}}$, Gary M. Tabor ${ }^{1 *}$, Daniel J. Becker ${ }^{4}$, Philip Muruthi ${ }^{5}$, Arne \\ Witt ${ }^{6}$, Stephen J. Woodley ${ }^{7}$, Manuel Ruiz-Aravena ${ }^{8}$, Jonathan A. Patz ${ }^{9}$, Valerie \\ Hickey ${ }^{10}$, Peter J. Hudson ${ }^{11}$, Harvey Locke ${ }^{12}$, Raina K. Plowright ${ }^{8}$ \\ *Joint first authors: jamiekreaser@gmail.com, gary@largelandscapes.org \\ ${ }^{1}$ Center for Large Landscape Conservation, Bozeman, MT, USA \\ ${ }^{2}$ Department of Environmental Science and Policy, George Mason University, Fairfax, VA, \\ USA \\ ${ }^{3}$ Department of Natural Resources, University of Rhode Island, Providence, RI, USA \\ ${ }^{4}$ Department of Biology, University of Oklahoma, Norman, OK, USA \\ ${ }^{5}$ African Wildlife Foundation, Nairobi, Kenya \\ ${ }^{6} \mathrm{CABI}$, Nairobi, Kenya \\ ${ }^{7}$ IUCN World Commission on Protected Areas, Canada \\ ${ }^{8}$ Department of Microbiology and Immunology, Montana State University, Bozeman, MT, \\ USA \\ ${ }^{9}$ University of Wisconsin, Madison, USA \\ ${ }^{10}$ Environment, Natural Resources and the Blue Economy Global Practice, World Bank, \\ Washington, DC, USA \\ ${ }^{11}$ Department of Biology, Pennsylvania State University, State College, PA, USA \\ ${ }^{12}$ Beyond the Aichi Targets Task Force, IUCN World Commission on Protected Areas and \\ Yellowstone to Yukon Conservation Initiative, Banff, Canada
}

\begin{abstract}
Earth systems are under ever greater pressure from human population expansion and intensifying natural resource use. Consequently, micro-organisms that cause disease are emerging and the dynamics of pathogens in wildlife are altered by land use change, bringing wildlife and people in closer contact. We provide a brief overview of the processes governing land use-induced spillover', emphasising ecological conditions that foster 'andscape immunity' and reduce the likelihood of wildlife that host pathogens coming into contact with people. If ecosystems remain healthy, wildlife and people are more likely to remain healthy too. We recommend ten practices to reduce the risk of future pandemics through protected and conserved area management. Our proposals reinforce existing conservation strategies while elevating biodiversity conservation as a priority health measure. Pandemic prevention underscores the need to regard human health as an ecosystem service. We call on multi-lateral conservation frameworks to recognise that protected and conserved area managers are in the frontline of public health safety.
\end{abstract}

Key words: ecological countermeasures, ecological integrity, health, landscape immunity, land use-induced spillover, practices, protected and conserved areas, zoonotic disease

\section{INTRODUCTION}

Earth systems are under ever greater pressure from human population expansion and intensifying natural resource use. Human-induced impacts on the environment are now documented across nearly 75 per cent of the planet's land surface (Venter et al., 2016) and 66 percent of the marine realm (Diaz et al., 2019). Climate change and invasive alien species exacerbate these impacts. The consequences to human well-being of these human-driven challenges cannot be overstated; human health is inextricably linked to ecosystem health (Tabor, 2002; Patz et al., 2004; Evans et al., 2020).

This paper focuses on how land use change ${ }^{1}$ drives the emergence and spread of micro-organisms (pathogens) that infect wildlife and humans with severe consequences for environmental, animal and human health. Pathogens that originate in vertebrate animals and cause disease in humans are known as zoonotic and these diseases are collectively referred to as zoonoses. 
When a pathogen crosses from one species to another (including to humans), the process is called spillover. When a pathogen spreads among humans, an outbreak is regarded as an epidemic (widespread in a particular population) or a pandemic (prevalent at epidemic levels across multiple countries with a global distribution). Spillback occurs when humans transmit pathogens back to domestic animals or wildlife.

The COVID-19 pandemic, caused by the SARS-CoV-2 virus, demonstrates society's inability to respond in a timely and effective manner to novel pathogens. The result is mass human suffering and mortality, bringing substantial moral, ethical and economic dilemmas. The most effective, cost-efficient and humane way forward is to keep wildlife healthy by keeping landscapes healthy (Andrade et al., 2020; Dobson et al., 2020; Lovejoy, 2020). As protected and conserved areas are the most widely used approaches to securing species, habitat and ecological integrity, they have a critical role to play in safeguarding public health. Hockings et al. (2020) call upon countries and sectors to work together to ensure that protected and conserved areas facilitate planetary recovery from COVID-19, while simultaneously advancing human and economic health and well-being.

We provide a brief overview of the processes governing land use-induced spillover, placing emphasis on ecological conditions that foster landscape immunity and reduce the likelihood of infected animals coming into contact with susceptible people. From our perspective, a healthy' ecosystem is one in which wildlife-pathogen interactions are in balance and

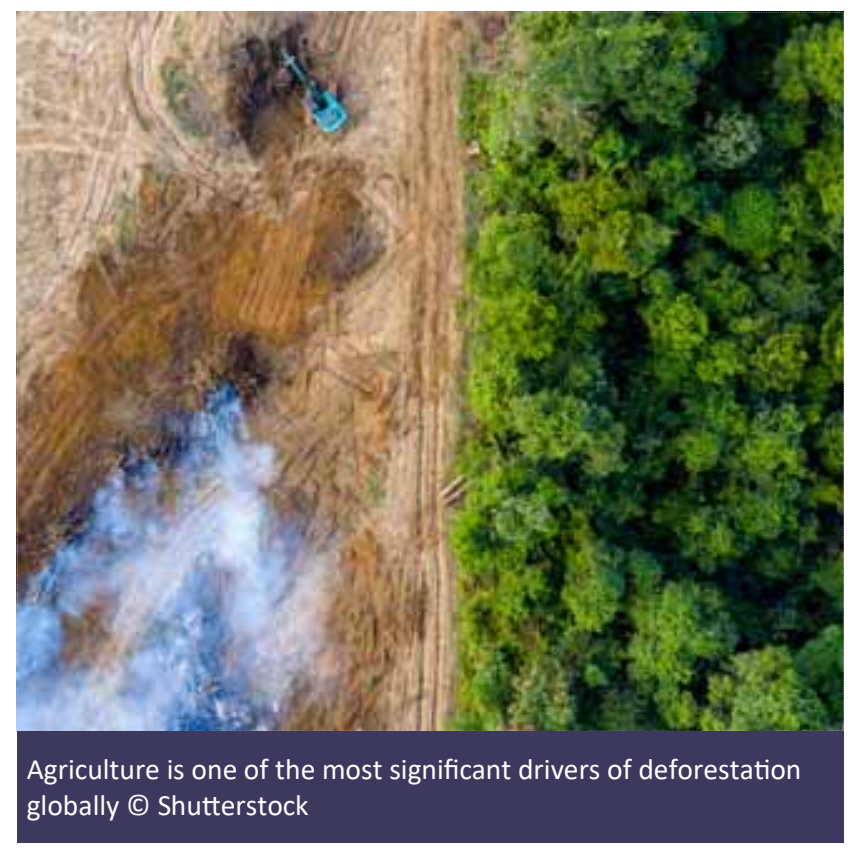

wildlife are not overly stressed or concentrated together by land use-induced changes (Patz et al., 2004). If ecosystems remain healthy, wildlife and people remain healthy. We recommend practices for reducing the risk of future pandemics through protected and conserved area management. Our proposals reinforce existing One Health principles (Gibbs, 2014) and conservation strategies while elevating biodiversity conservation as a public health service. We call on multi-lateral conservation frameworks to recognise that protected and conserved area managers are in the frontline of public health safety (Stolton \& Dudley 2010).

\section{DEFINING LAND USE-INDUCED SPILLOVER AND OTHER KEY PROCESSES}

Although pathogens (including bacteria, viruses and protozoan parasites) are a normal occurrence in biological systems and have important, perhaps undervalued, ecological functions where they have coevolved with their wildlife hosts (Hudson et al., 2006; Gómez \& Nicholas, 2013), environmental destruction and degradation can alter these established relationships. Land use change involving humaninduced ecosystem change in any kind of habitat is a major driver of the transmission of pathogens from wildlife to humans (Brearley et al., 2013; Plowright et al., 2021). All species have a range of chemical, physical and biological conditions - environmental conditions in which they thrive (or perish if conditions are insufficient or too extreme). When environmental conditions are no longer ideal, the relationship between micro-organisms and their hosts can change, sometimes leading to higher levels of infections.

Wildlife stressed by the environmental conditions associated with land use change can lose immunity and become more susceptible to zoonotic pathogen infection (Sapolsky, 2010; Becker et al., 2020; Nelson et al., 2020; Seiler et al., 2020). Stress can increase the likelihood that wildlife will release (shed) pathogens that lead to the infection of other animals of the same or different species, including humans (spillover). When land use change increases interaction between infected animals and people, it is more likely that zoonotic pathogens will cross over into human populations. The rate and scale of pathogen spread in human populations is largely driven by human social behaviour (the greater the contact rates among humans, the higher the likelihood of pathogen transmission) and pathogen biology (e.g., ability to transmit before symptoms are evident). Urbanisation and other land use changes increase human population density, thus increasing the risk of infection. Today, advances in human transport technologies and globalised consumer patterns spread 


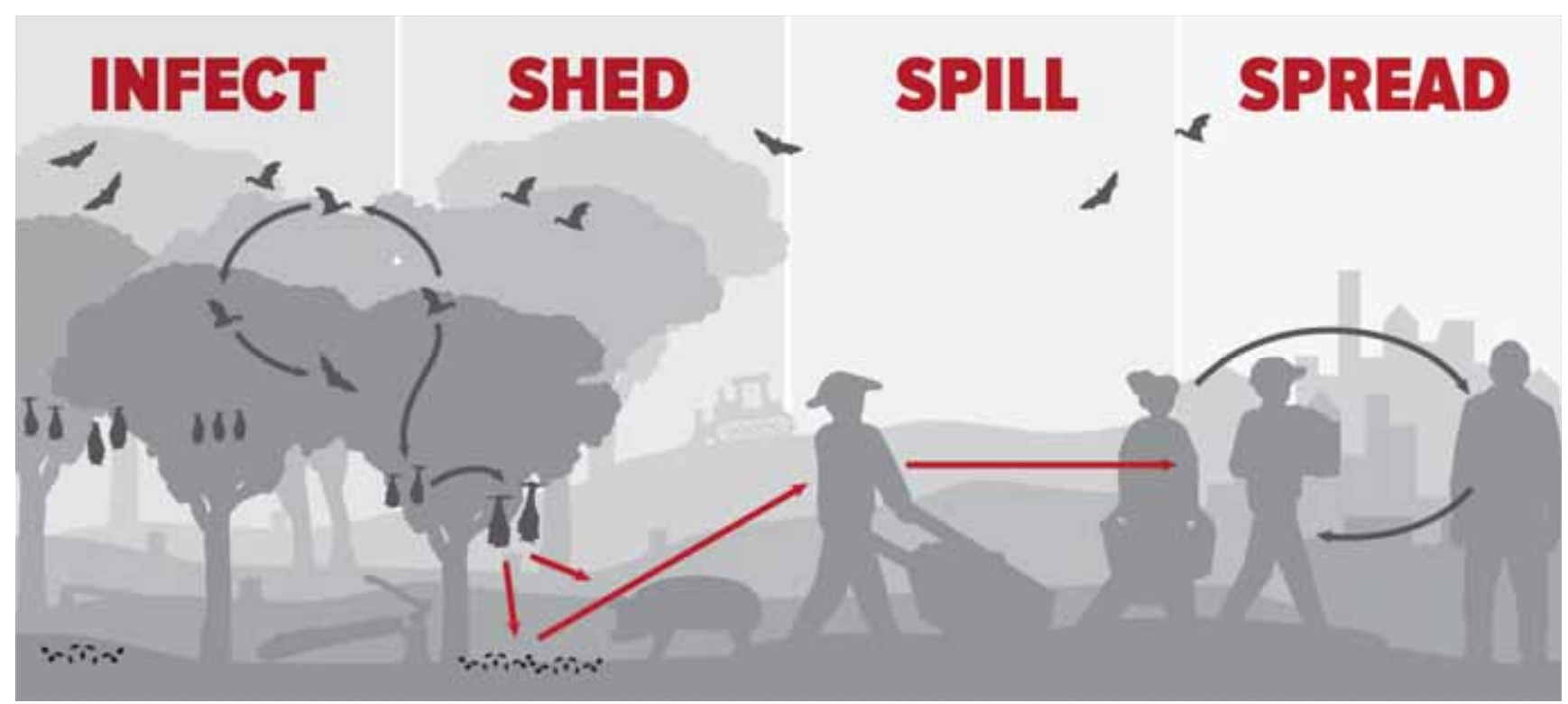

\section{Figure 1. Land Use-Induced Spillover}

Human activities that destroy and degrade ecological systems can trigger land use-induced spillover, the infect-shed-spill-spread cascade. Wildlife stressed by the environmental conditions associated with land use change can decline in immune function, thus becoming more susceptible to zoonotic pathogen infection. Stress can also increase the likelihood that wildlife will release (shed) pathogens in ways and locations that lead to the infection of other animals of the same or different species, including humans (spillover). When land use change increases interaction between infected animals and people, it is more likely that zoonotic pathogens will be transmitted into human populations. The rate and scale of pathogen spread in human populations is largely driven by patterns of human contact (social behaviour) and pathogen biology.

zoonotic pathogens faster and more extensively than before - making it possible for local land use events to have global-scale implications. Plowright et al. (2021) summarise this as the infect-shed-spill-spread cascade, and refer to it as land use-induced spillover. We provide a simple model of these pathogen dynamics in Figure 1. More elaborate models can be found in Plowright et al. (2021).

An animal or a person infected with a pathogen is referred to as a host. Pathogens shed by the host may spread to other hosts by one of three pathways (Plowright et al., 2017): 1) animal excreta (e.g., directly through saliva from a bite from an infected animal, such as in rabies, or indirectly through urine or faeces contaminating food, e.g., Nipah virus was spread by consuming date palm sap or Giardia from drinking contaminated water); 2) slaughter or butchering (e.g., Ebola virus was transmitted through preparation of bushmeat); or 3) a vector, usually an arthropod, such as a mosquito or tick, that bites an infected animal and then bites another animal (examples are dengue virus, Lyme disease and trypanosomiasis). A reservoir host is a wild animal that maintains the pathogen within its populations and serves as a source of infection, in some cases without making the animal sick (Viana et al., 2014). A recipient host receives the infection from another host. For zoonotic pathogens, recipient hosts are ultimately humans, but the infection can be transmitted via an intermediate or bridging host that has contact with the reservoir host and humans. Other species of wildlife or domestic animals, particularly livestock, can be intermediate hosts (Plowright et al., 2017).

Despite the severity of the implications for human health and well-being, land use-induced spillover is not a well-studied phenomenon across ecological systems (Reaser et al., 2020a; in press). However, research findings reveal that the relationships between land use change and wildlife disease are not easily generalised; different scenarios arise depending on the geographic location, ecosystem type, current and historical land uses, species of pathogens and animal hosts involved, the way the pathogens are transmitted, and animalhuman dynamics of proximity (Brearley et al., 2013; Plowright et al., 2021). Land use-induced spillover is evidently a complex process in which land use change can affect many parts of the infect-shed-spill-spread cascade simultaneously. For example, forest fragmentation may drive changes in the relationship among species (trophic structure), increasing the abundance of reservoir hosts or vectors, and increased prevalence of infection. At the same time, people and wildlife are brought into closer proximity (Faust et al., 2017, 2018). To better inform land use management, 
Plowright et al. (2021) call for scientists across disciplines to collaborate in studying the mechanisms driving land use-induced spillover.

Reaser et al. (2020a) define landscape immunity as the ecological conditions that, in combination, maintain and strengthen the immune function of wildlife within an ecosystem. Messing et al. (2018) and Becker et al. (2020) propose that a high degree of landscape immunity should limit pathogen prevalence (e.g., via the dilution effect; Faust et al., 2017), enable wildlife to resist pathogen infection and minimise shedding. This will reduce pathogen exposure and spread among wildlife, and between wildlife, domestic animals and humans. Landscape immunity will prevent the infectshed-spill-spread cascade, protecting animal and human health (see Figure 1 in Reaser et al., 2020a).

An ecosystem with high landscape immunity can be regarded as a healthy landscape' because it is intact enough that: a) pathogen populations are kept in check by sufficient numbers of predators and competitors; and b) wildlife can access the resources they need to remain healthy enough to resist or reduce pathogen infection (Patz et al., 2004). Although land use change is often thought of as large-scale ecological destruction, the more subtle invasion of non-native plants can also reduce animal fitness (Vilà et al., 2011). Figure 1 in Plowright et al. (2021) presents these highly complex dynamics in a relatively simple model of land useinduced spillover.

Contact patterns - the dynamics of proximity between animals and people are also influenced by land use change. They affect the extent to which infected animals will expose other animals and people to shed pathogens. Understanding the dynamics of proximity among wildlife, domestic animals and human populations in various contexts poses a major challenge, but is critical to understanding the dynamics of emerging infectious diseases (Hassel et al., 2017). Muehlenbein (2016) reviews the spillover risk factors that result from human interactions with livestock, companion animals, animal exhibits and wildlife through both nature-based tourism and consumption. Primate-human contact is particularly problematic because primates host several pathogens deadly to humans and some human-originating pathogens can decimate wild primate populations via spillback.

\section{TAKING STRATEGIC ACTION TO PREVENT LAND USE-INDUCED SPILLOVER}

The following ten practices are intended to enable countries and sectors to work together to ensure that protected and conserved area management limits the risk of future pandemics, thereby protecting human health and economic well-being, including local livelihoods. The specific roles and responsibilities for implementation of these recommendations will vary across protected and conserved areas. We, therefore, refer to 'protected and conserved area managers' in general terms, recognising that the specific activities may need to be taken up by national and local governing bodies, donor agencies, natural resource specialists, biological and social scientists, veterinarians, educators, tourism operators, food vendors, waste managers, residents, visitors and neighbouring communities, among others.

Effective responses to land use-induced spillover may require: 1) changes in human distribution and behaviour; 2) shifts in land management principles, strategies, technologies, ethics and laws; and 3) a substantial, long-term investment in protected and conserved area restoration, expansion and connectivity. Effectiveness also depends on the willingness and ability to implement the practices below. This requires an understanding of: local socio-economic and cultural conditions; geographic and ecological factors; the epidemiology of pathogens, hosts and vectors; and the capacity of education, community-based cooperation, policy and law.

In response to COVID-19, Hockings et al. (2020) establish three principles and three phases of action on which to base management decisions for protected and conservation areas. We complement their framework with additional actions that place protected and conserved area managers at the forefront in preventing land use-induced spillover. We take a landscape-scale approach to zoonotic disease prevention through protected and conserved area management, but our recommendations are consistent with the full suite of nature-based solutions to COVID-19 advocated by leading conservation organisations (Global Goal for Nature Group, 2020). We provide additional research and management guidance addressing land use induced -spillover, based on Plowright et al. (2021), Reaser et al. (2020a) and Locke et al. (2019). Landscape management approaches to spillover risk reduction are part of a wider strategy for preventing the emergence of disease, which also includes ecological, veterinary and medical interventions (e.g., Sokolow et al., 2019), and policy initiatives, notably in controlling the wildlife trade (Reaser et al., 2020a).

\section{Practice 1: Assess risk}

Protected and conserved area managers have a public responsibility to understand and manage zoonotic 
spillover risks to the extent feasible. In some parts of the world, these risks may be substantial, while in other regions they are negligible (J ones et al., 2008). Zoonotic disease risk exists across terrestrial, freshwater and marine ecosystems, but varies as a function of the local ecology and patterns of human behaviour. Although knowledge of the distribution of zoonotic pathogens, disease emergence and spillover is in its infancy, increased investments in pathogen surveillance and related studies are elucidating patterns and trends that improve risk assessment capacity. Taxonomically, we know that rodents, bats and primates tend to act as zoonotic pathogen hosts, and that mosquitoes, ticks and some other arthropod groups commonly vector zoonotic pathogens (Luis et al., 2013; Olival et al., 2017). Areas rich in a diversity and abundance of these taxa warrant spillover risk analysis - particularly when the wildlife is stressed by land use change, there are large populations of species that can host zoonotic pathogens, and there is substantial risk of human exposure to these pathogens.

Studies of zoonotic pathogen prevalence in wild mammals have revealed that the risk varies geographically and with degrees of disturbance. Han et al. (2016) report fewer mammalian zoonotic diseases in very high latitudes. Allen et al. (2017) found that the risk of emerging zoonotic diseases is greatest in forested tropical regions experiencing land use changes and where mammal species richness is high. They present a global hotspot map of emerging zoonotic disease spatial variation. J ohnson et al. (2020) found that the number of zoonotic viruses detected in mammalian species correlated with global species abundance, suggesting that virus transmission risk is higher from mammal species that have increased abundance and/or range because of changes in human-dominated landscapes. They found that domesticated mammal species, primates and bats carried the greatest risk of zoonotic virus infection. Populations of threatened wild mammal species that were reduced in number from habitat loss and exploitation carried a high diversity of zoonotic pathogens. More detailed studies of animal behaviour and biology are needed to understand the spillover mechanisms associated with these broad-scale geographical associations.

Human exposure and susceptibility to wildlife pathogens are the basis of zoonotic spillover risk. The likelihood of spillover at a particular location is thus a function of the probability that people will have direct contact with infected wildlife, indirect contact through wildlife body-fluids (e.g., excrement, saliva) or are bitten by a pathogen vector. Most often, the patterns of wildlife-human encounter at a particular protected or conserved area will vary over space and time, particularly in light of land use changes. Likewise, human susceptibility is spatio-temporally variable, and may also be influenced by socio-economic factors, for example people living in impoverished conditions may have health problems that make them particularly susceptible to pathogen infection (Muehlenbein, 2016). Estrada-Peña et al. (2014) reviewed how environmental conditions affect the distribution of zoonotic pathogens and their transmission to humans; they found that environmental change can modify the behaviour and relative importance of different pathogen host species, in turn affecting contact rates with humans. The risk of zoonotic spillover in protected and conserved areas may be affected by changes in environmental conditions at local (e.g., ecological succession or biological invasion influencing microclimate) or regional scales (e.g., climate change impacts on extreme weather events).

Human-association with domestic animals that host zoonotic pathogens, particularly certain mammal and bird species within and bordering protected and conserved areas, can greatly affect the risk of exposure to zoonotic pathogens. The presence of domestic animals that serve as intermediate hosts for zoonotic pathogens generally increases the risk of land useinduced spillover, especially if they are used for human consumption or where direct contact is routine (e.g., tuberculosis in cattle, Shury, 2015). The way domestic animals are managed can also increase host and vector populations. For example, rodents are frequently able to share animal feed, water and shelter (Stenseth et al., 2003). Standing water provided for domestic animals, or that forms in the hoof ruts or wallows created by domestic animals, can support mosquito larvae (Imbahale et al., 2011). Ways of using domestic animals to reduce zoonotic spillover risk are addressed under Practice 5.

Where agriculture is practised within and at the margins of protected and conserved areas, crop raiding by wildlife that host zoonoses can expose humans to zoonotic pathogens. Some primates are notorious crop raiders. Siljander et al. (2020) found that most farms in southeast Kenya experienced primate crop raids on a weekly basis. The primate species, crop type and distance from the forest to the nearest farm determined raiding patterns. In Uganda, crop raiding by primates was associated with transmission of gastrointestinal pathogens (Escherichia coli) to humans and livestock (Goldberg et al., 2008). In Australia, Flying Foxes (Pteropus bats) that have lost their winter nectar resources due to deforestation have begun feeding on fruit and other food in agro-urban landscapes, 
increasing the risk of Hendra virus spillover (Plowright et al., 2015). Land transformation that leads to grasses can increase the number of rodents and raise the risk of zoonotic diseases such as tularemia, hantavirus pulmonary syndrome and Lassa fever (Young et al., 2017). Where human food supplies are limited, people may hunt wildlife for supplemental protein thus becoming exposed to pathogens during butchering and consumption. In some cases, food scarcity drives people to consume diseased poultry and livestock, leading to outbreaks of disease caused by pathogens such as Bacillus anthracis (Katani et al., 2019).

The Food and Agriculture Organization of the United Nations (FAO), the World Organisation for Animal Health (OIE) and the World Health Organization (WHO) share responsibility to minimise the human health, animal welfare and socio-economic impacts associated with zoonotic disease. One of their goals is to mitigate potential health threats at the human- animalecosystem interface through early warning and robust risk assessments, provided through the Global Early Warning System for Major Animal Diseases Including Zoonosis (GLEWS). ${ }^{2}$ Protected and conserved area managers can benefit from the early warning risk assessment guidance, tools and notifications made available nationally through GLEWS and the three administrating organisations. For example, the OIE has published guidelines for assessing the risk that nonnative animals (including potential zoonotic hosts) may become invasive. ${ }^{3}$

\section{Practice 2: Conduct surveillance}

Surveillance involves the systematic collection, analysis, interpretation and dissemination of information about the occurrence of pathogens, or their clinical diseases, in animal or human populations. Effective surveillance is crucial for early detection and rapid response to emerging diseases, but is inadequate globally. For example, surveillance for zoonotic disease has focused on livestock or humans, rather than wildlife populations (Grogan et al., 2014), so knowledge of intervention opportunities is biased towards the 'downstream' elements of the infect- shed-spill-spread cascade.

The COVID-19 pandemic demonstrates the need for governments, donors and research institutions to overcome the social, technical and financial barriers to surveillance of wildlife species that serve, or may serve, as zoonotic pathogen hosts. The U.S. Agency for International Development's Emerging Pandemic Threats PREDICT program ${ }^{4}$, which ran from 2009 to 2019, aimed to identify and map wildlife pathogens with

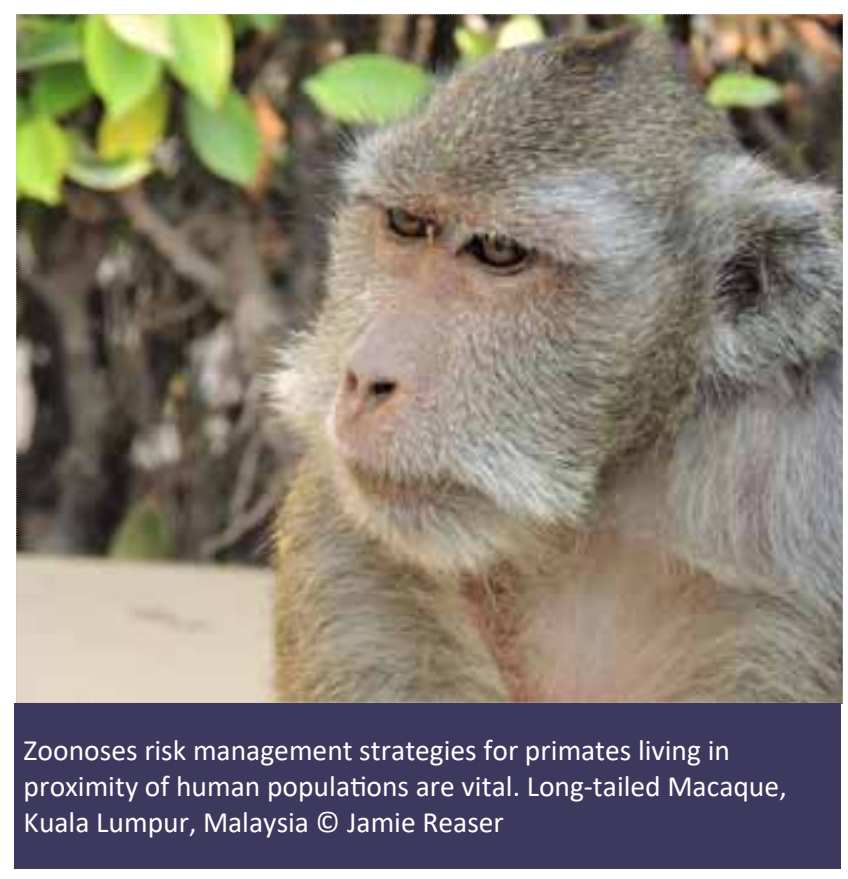

zoonotic potential (Carlson, 2020). Protected and conserved area managers will be hampered in their ability to make risk-informed decisions unless priority is given to surveillance programmes, especially those that address the ecological dynamics of pathogens (Plowright et al., 2019) and the mechanisms driving land useinduced spillover. ${ }^{5}$

Protected and conserved area managers have vital roles to play in disease surveillance. Their intimate knowledge of the landscapes and species they manage can improve sampling rigour and help collaborating scientists to tease apart the complex ecological and social factors that influence pathogen distributions and biology (see Practice 10). It is thus vital that they are actively encouraged to report disease outbreaks to the appropriate veterinary and medical authorities as a standard task. Humans are put at risk if the fear of losing tourist income discourages such reporting and agencies need policies to stop this happening.

\section{Practice 3: Protect protected and conserved areas}

For reasons explained above, the highest levels of landscape immunity are likely to be associated with the least-disturbed landscapes (Reaser et al., 2020a). Fostering landscape immunity in protected and conserved areas should focus on ensuring a wide range of ecological structures and functions. This includes retaining a full complement of native species and their inter-relationships. For example, Terraube (2019) recommends the use of protected and conserved areas to 
mitigate Lyme disease risk by encouraging a diverse array of tick predators (discussed further below).

Protected and conserved areas thus need to be protected in practice, not just in concept. Due to the increasing pressures on natural resources and limited budgets for protected and conserved area management, this may be difficult (J oppa et al., 2008), but it remains a necessary goal from environmental, animal and human health perspectives. Landscape-level conservation in which wildlife roams freely across protected and conserved areas helps gain natural space, maintain ecological connectivity, build ecological resilience and improve livelihoods of local communities. The most extensive assessments of the opportunities and challenges for landscape-scale conservation planning, with its implications for zoonotic pathogen spillover, may be those undertaken in Africa (e.g., Didier et al., 2011; Henson et al., 2009; Muruthi, 2004). However, a region-by-region assessment is warranted to synthesise findings and identify information gaps.

Effective site protection may require bold conservation targets and the prohibition of some land use activities within protected and conserved areas, especially logging and mining: such large-scale extractive resource uses require substantial infrastructure and often have longterm disturbance implications (Maron et al., 2018). Smaller scale activities - from tourism to wildlife poaching - may also need to be controlled within and around protected and conserved areas (discussed further below).

Protected areas and conserved areas are nested in a wider landscape and thus subject to ecological pressures that transcend their boundaries (reviewed in Hansen \& DeFries, 2007). Invasive alien species can act as ecological stressors by adversely impacting the resources needed by native species of wildlife, for example, by outcompeting them for food, and making them more susceptible to pathogen infection and shedding. Invasive alien species (e.g., non-native rodents) can also become hosts of zoonotic pathogens or vectors (e.g., for non-native mosquitoes). Protected and conserved areas should therefore take preventative measures against the introduction and spread of invasive alien species, especially where there is substantial human presence (Dayer et al., 2020; Liu et al., 2020). Tu (2009) provides guidance for assessing and managing invasive alien species within protected and conserved areas.

Climate change is another stressor that transcends protected and conserved area boundaries. Elsen et al. (2020) point out that, at least in the terrestrial context, these static boundaries may actually undermine the potential to protect species under climate change scenarios. Protected and conserved area managers therefore need to develop adaptive management strategies to address the shifting capacity of their areas to maintain biodiversity, whilst taking into consideration that zoonotic pathogen, host and vector dynamics are expected to change within and around protected and conserved areas. Research thus far indicates that climate change is expanding the range of many zoonotic pathogens, particularly those vectored by mosquitoes (Manore et al., 2020).

\section{Practice 4: Restore ecosystem health}

Many protected and conserved areas are susceptible to anthropogenic pressures, mainly due to insufficient financial resources, lack of management capacity and poor governance (see review in Geldmann et al., 2019). Protected and conserved areas that have a history of land use disturbance and/ or have suffered invasive alien species impacts may require strategic restoration interventions to secure biodiversity and human health. Restoration planning should include ecological and human health goals, with an emphasis on restoring landscape immunity. Aronson et al. (2016) review the needs and opportunities for restoration ecology to serve public health needs, emphasising the importance of the medical, veterinary and environmental sectors collaborating in this work. Plowright et al. (2021) also call for interdisciplinary collaboration to arrest land useinduced spillover by fostering greater landscape immunity. Social scientists should be included in such efforts so that the human dimensions of protected and conserved area management are properly addressed. For example, through cost-benefit analysis, Morlando et al. (2011) demonstrated that habitat restoration can pay for itself via the reduction of tick-borne disease. Similar analyses conducted in other zoonotic systems are needed to promote the value of protected and conserved area restoration to policy makers and donor agencies.

Keenleyside et al. (2012) provide extensive guidance for ecological restoration within protected and conserved areas. Here we emphasise two points that are likely to have substantial implications for landscape immunity, but are not typically addressed in protected and conserved area restoration strategies from the zoonotic disease perspective:

A. The size of the protected and conserved area at functional ecological scales is important in establishing landscape immunity and delivering ecosystem services, including the protection of human health. Ideally, protected and conserved area 
conservation should be integrated with the management of surrounding landscapes and with land use strategies, and supported by local communities (Lopoukhine et al., 2012). Over time, land use and climate change will require larger areas to be managed for ecological viability (Hanson \& DeFries, 2007). Protected and conserved areas may need to be expanded to maintain landscape immunity within their borders.

In the context of zoonotic spillover, there are, however, at least two important caveats. First, the larger the landscape to be protected, the greater the likelihood that local human populations will need to be an integral part of the protected and conserved area management. Land use zonation can help address these issues. Further discussion is provided under Practices 6 and 7. Second, the expansion of protected and conserved areas may benefit some zoonotic pathogen host and/or vector populations by providing them with ideal habitat. For example, disease vectors like Tsetse Flies (Glossina morsitans morsitans) thrive in intact landscapes rather than landscapes which have been cleared of vegetation (Ducheyne et al., 2009).

B. Protected and conserved areas need to be managed to reduce the edge effects that occur at the boundary of two or more habitats. Edge effects are influenced by the geographic layout of protected and conserved areas and the land uses occurring at their margins. Increased edge effect (from a patchwork of varied land uses) can promote interaction among pathogens, vectors and hosts (Patz et al., 2004; Faust et al., 2018). In Uganda, the reduction of core areas and increased density of edges of forest patches were correlated with increased contact between humans and non-human primates in the communities around Kibale National Park (Bloomfield et al., 2020). Glass et al. (1995) have shown that edge effects can increase the prevalence of Lyme disease. Despommier et al. (2006) reviewed the role of ecological system boundaries (ecotones) on emerging infectious diseases, including zoonoses, and concluded that the human-created or modified ecotones may increase disease risks.

\section{Practice 5: Maintain and restore connectivity}

Many zoonotic pathogen hosts are highly adapted to human modified landscapes and may thrive in disturbed areas (Ostfeld \& LoGiudice, 2003). For example, Langlois et al. (2001) found that infection by Sin Nombre virus (Hantavirus) in Deer Mice
(Peromyscus maniculatus) was higher in fragmented habitats at more than 100 sites across Canada. In addition, Deer Mice moved faster across the landscape where there are patches of low-quality habitat, so increasing virus transmission. In Panama, Gottdenker et al. (2011) found that forest remnants within highly disturbed areas of the landscape may be sources for Rhodnius pallescens, a vector of Chagas disease. A similar pattern exists in India where Kysanur forest disease is associated with fragmentation that drives increased contact with ticks and greater incidence of disease (Purse et al., 2020). ${ }^{6}$

Since protected and conserved areas often provide species with resources that exceed what is available in the bordering landscape, wildlife diversity, abundance and density may be unnaturally high in isolated reserves, particularly if these areas are fenced. Where this happens, intra- and inter-species competition and crowding may increase the risk of zoonotic pathogens emerging and transmitting (Lebarbenchon et al., 2006). However, restoring ecological connectivity would allow organisms to meet their resource needs, with more space to move in response to the weather - and indeed the changing climate. This will avoid many of the issues associated with small populations, such as low genetic diversity. Hilty et al. (2020) provide guidance for conserving connectivity through ecological networks and corridors. On behalf of the Convention on Biological Diversity, Ervin et al. (2010) established guidance for integrating protected and conserved areas into wider landscapes and seascapes, as well as sectoral plans and strategies. Examples of how this has been actualised within protected and conserved area networks are available in Worboys et al. (2010) and Fitzsimons et al. (2013), for example.

However, there is also a risk that increased connectivity may facilitate pathogen spread through the increased mobility of their hosts and vectors (Hess, 1996). The effect of connectivity on pathogen spread depends on many factors, such as host movement rates in relation to pathogen infectious periods (Cross et al., 2005). High connectivity has facilitated the spread of wildlife diseases (e.g., pneumonia in Bighorn Sheep (Ovis canadensis); Cassirer et al., 2013), whereas low connectivity has been proposed as a driver of high Hendra virus prevalence in Pteropodid bats (Plowright et al., 2011). Fergusan and Hanks (2012) note that the use of park and veterinary fences to reduce zoonotic disease risk by separating wildlife, people and livestock is fragmenting African rangelands. However, when fences are removed, more widely roaming wildlife can 
spread zoonoses that cause hardship to rural communities and harm national livestock exports.

In South Africa, where genetic diversity has decreased in species of conservation concern due to population isolation, animals are sometimes translocated between protected and conserved areas. While this is intended to benefit the species, it may place the animals at increased risk of contracting zoonotic disease through interaction with wildlife at other localities. And unless they are shown to be disease-free before translocation which can be difficult and expensive to do - there is a risk that the translocated species may transmit pathogens to wildlife in the destinations they are sent to (Cassirer et al., 2018).

\section{Practice 6: Manage human activity in wildlife habitat}

Recent research indicates that human activity in protected and conserved areas can have a greater impact on ecological integrity, and thus landscape immunity, than previously supposed. For example, Betts et al. (2017) found that the first acts of deforestation in tropical ecosystems can push a diversity of species closer to extinction due to loss of habitat and the land use activities that deforestation facilitates (e.g., hunting, farming, mining). These issues are largely addressed in the previous 'Practices'.

Since protected and conserved areas often support a higher diversity and abundance of wildlife than humandominated landscapes, human activity within these areas may increase people's exposure to wildlife pathogens, as well as potentially transmitting human pathogens to wildlife (spillback), as in the case of gorillas infected by tourists or neighbouring communities (Dunay et al., 2018), and the possibility that humans may transmit SARS-CoV-2 to local bat communities (Olival et al., 2020). Other risks may also be associated with direct human-animal contact (e.g., rabies) or pathogen transmission via vector bites. In Colombia, increased human activity in forest habitats appears to be a major risk factor for leishmaniasis infection, which is spread via Sand Flies (Phlebotomus perniciosus; Weigle et al., 1993). In the northeastern United States, Lyme disease (Borrelia burgdorferi), transmitted by Blacklegged (Deer) Ticks (Ixodes scapularis), presents a risk to those who work and recreate outdoors (Mead et al., 2018). A university collaboration in the eastern United States ${ }^{7}$ is underway to evaluate if tick bite frequency increases as people spend more time outdoors trying to avoid COVID-19 infection.
Domestic animal management is also an important part of mitigating the risk of human exposure to zoonotic pathogens. In the highest exposure risk situations, prohibitions on the possession of certain types of domestic animals may be warranted (e.g., non-human primates as pets or for tourist exhibition). Tethering ('leash') and containment (e.g., fencing, coops/sheds) may be sufficient for managing dogs, cats, livestock and poultry. When rodents are attracted to the food and structures associated with human activity, people may be exposed to zoonotic pathogens. Controls are needed on the feed and grain provided to domestic animals, and rodent trapping and euthanasia programmes may be necessary. In Ecuador's Galapagos Islands, Island Conservation and partners have worked with Floreana Island residents to control non-native rodent and cat populations that posed zoonotic disease risks, including toxoplasmosis, leptospirosis, cat scratch disease, cutaneous larva migrans, lymphocytic choriomeningitis, plague, hantavirus and salmonellosis (Hanson \& Campbell, 2013).

There may also be opportunities to use domestic animals to reduce the risk of human exposure to zoonotic pathogens, a practice known as zooprophylaxis (Dobson et al., 2006). For example, Keesing et al. (2018) found that integrating livestock and wildlife in African savannahs can reduce tick abundance, thus protecting pastoralists and tourists from tick-borne diseases. Duffey et al. (1992) found that Helmeted Guinea-fowl (Numida meleagris) significantly reduced populations of Blacklegged Ticks in suburban lawns in New York State (USA): maintaining this species as domestic fowl may provide a relatively low-cost way to reduce Lyme disease risks. Landowners at the margins of Shenandoah National Park in central Virginia (USA) are increasingly interested in using Guinea-fowl to control tick populations on their properties (Reaser, pers. obs.). Care must be taken, however, that the domestic animals employed to reduce the risk of one disease do not amplify another by serving as hosts or becoming invasive, so driving environmental change and associated stress.

Often, education and social marketing are sufficient to help humans protect themselves from direct contact with wildlife or their bodily fluids (see Practice 9). However, protected and conserved area planning and policy also plays an important role. Protected and conserved area zoning can be used to define geographic areas for specific purposes, such as species conservation or recreation (Rotich, 2012). Zonation can be used to reduce zoonotic disease risk by reducing the likelihood of contact between animal hosts (wild and 
domestic) and people. For example, if human facilities associated with the protected and conserved area are concentrated near the reserve boundaries, this can help prevent human access and associated disturbance (wildlife stress) in core areas. It could also assist in limiting and concentrating trail and road infrastructure to protected and conserved area margins, thereby discouraging illegal entry for hunting (e.g., bushmeat; van Velden et al., 2020) or other purposes, and minimising the spread of invasive alien species.

\section{Practice 7: Prevent wildlife from being drawn towards people}

In order to reduce the risk of wildlife transmitting zoonotic pathogens to park managers, tourists and people living within and at the margins of protected and conserved areas, measures should be taken to prevent wildlife from being drawn to human activity, especially localities providing food and water for people. Although bites, crop raiding and the occupation of human dwellings by zoonotic pathogen hosts present obvious spillover risks, numerous more subtle but equally health -threatening issues arise from indirect contact with the saliva and excrement of wildlife. For example, on the Caribbean Island of Saint Kitts, Gallagher et al. (2019) found that invasive African Green Monkeys (Chlorocebus aethiops sabaeus) carried faeces containing zoonotic parasitic organisms on their hands and/ or feet. Trichuris spp. eggs, Hookworm larvae and eggs, and Pinworm eggs were recovered from picnic tables frequented by tourists. A similar situation has arisen with free-ranging Baboons (Papio cynocephalus and P. anubis) in Kenya (Hahn et al., 2003).

Common measures taken within protected and conserved areas include: prohibiting visitors from feeding wildlife, requiring visitors to remain in vehicles, making sure that human food waste and excrement is not accessible to wildlife, and fencing wildlife out of agricultural, business and dwelling areas. In the case of Great Ape tourism, minimum viewing distances and requirements to wear N95 masks are employed (MacFie \& Williamson, 2010). At Boabeng-Fiema Monkey Sanctuary in Ghana, Agyei et al. (2019) found that compensation from sanctuary proceeds, education and arresting poachers was an effective way of mitigating human-monkey conflict for all but the poorest communities. Hockings and Humle (2009) provide guidance for reducing conflict and disease between humans and Great Apes.

Establishment and fencing of protected areas to isolate biodiversity from human activities is one of the most popular methods for achieving this protection.
Although fencing protected and conserved areas to isolate wildlife from human activity is widely used to reduce human- wildlife conflict (Massey et al., 2014), fencing poses pros and cons for zoonotic disease management. Some fences function as environmental stressors, facilitating land use-induced spillover (see Practice 4). In other situations, they may be an effective approach to mitigating zoonotic exposure risk from large mammals, but other approaches (e.g., chemical and biological control) will be needed to prevent vector bites. Protected and conserved areas could employ ecological fencing analogues using native vegetation. Jakes et al. (2018) review fencing as an animal management tool globally: they argue that managers need to understand the implications of 'fence ecology'.

It is also possible to use buffer zones to minimise human - wildlife interactions. Creative buffer zone designs can support protected and conserved area disease risk minimisation goals. Land management zoning regulations can limit human activities within and at the margins of protected and conserved areas (SchonewaldCox \& Bayless, 1986; Dudley, 2008).

\section{Practice 8: Employ ecological countermeasures}

There are a growing number of ecological management interventions that can prevent or reduce zoonotic disease outbreaks (Sokolow et al., 2019). Reaser et al. (in press) regard ecological countermeasures as highlytargeted, landscape-based interventions to arrest one or more of the elements of the land use-induced spillover infect-shed-spill-spread cascade. They believe that ecological countermeasures should complement reactive public health responses to disease emergence, such as quarantine and vaccines.

Plowright et al. (2021) propose strategic tree planting as an ecological countermeasure to prevent Hendra virus spillover in Australian agricultural landscapes. This project is made feasible because the Hendra virus system has been studied for decades and the process of pathogen transmission among primary hosts (fruit bats; Pteropus spp.), intermediate hosts (horses) and humans has been identified. The bats experience winter nutrition stress due to the loss of winter-flowering Eucalyptus trees and move into human-dominated landscapes to feed. Horses, the intermediate host of Hendra virus, become infected when they feed on grass contaminated by bat urine. Humans are then infected through contact with the horses (Plowright et al., 2015). Replanting trees that produce winter nectar, while protecting existing winter flowering habitats, will allow bats to feed away from agricultural areas, reducing the risk of pathogen spillover. Protected and conserved areas can 


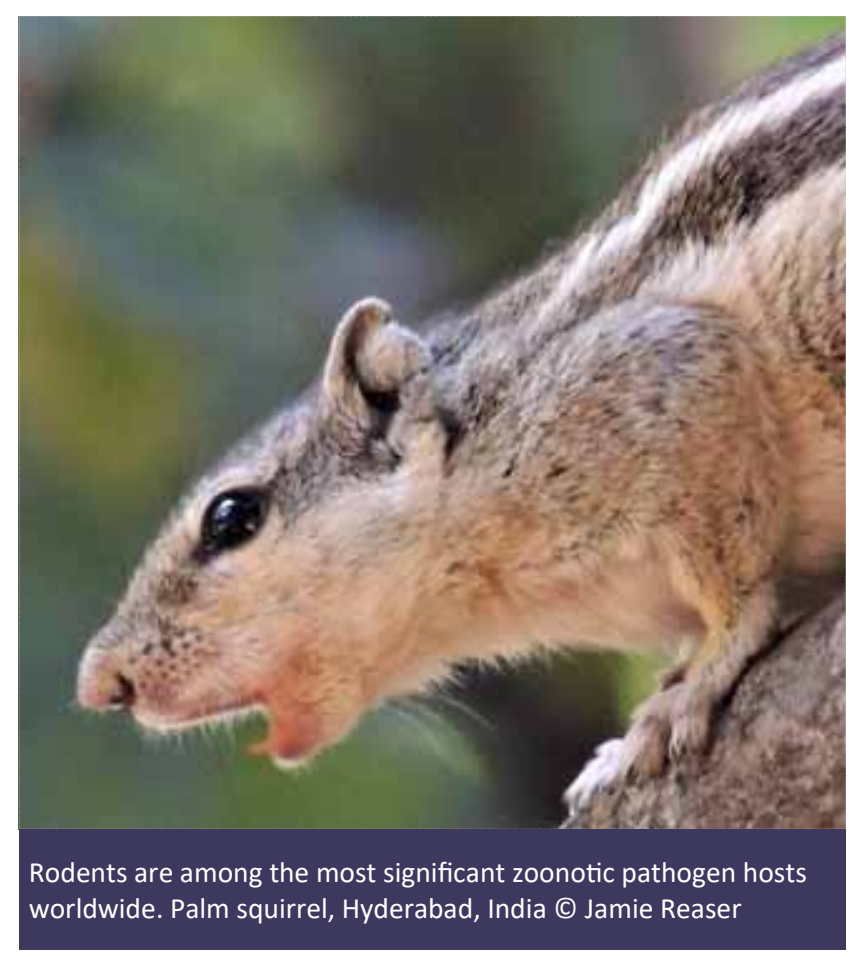

complement these restoration efforts and amplify largescale rewilding initiatives that support landscape immunity benefits.

The strategic removal of invasive plants that support populations of zoonotic pathogens, vectors or hosts can also function as an ecological countermeasure (Reaser et al., in press). In Mauritius, invasive alien plants have reduced the habitat quality of the Mauritian Flying Fox (Pteropus niger), resulting in increased foraging in agricultural lands and urban environments. Krivek et al. (2020) showed that non-native plant invasions reduced native fruit production and that weeded forests provide a better habitat for Flying Foxes. They conclude that their study lends support to invasive alien plant control as a management strategy in mitigating human- wildlife conflicts.

Japanese Barberry (Berberis thunbergii), a woody understory shrub, was introduced to the United States from Asia in 1875 for ornamental landscaping. It is now widespread outside of cultivation, invading natural areas (especially meadows, forest and wetlands) throughout much of the United States and eastern Canada (USDA/NRCS, 2020). Japanese Barberry is worrisome from a zoonotic disease perspective for two reasons: the plant infestations provide microclimates favourable to Blacklegged Ticks, the vector responsible for several human diseases, including Powassan virus and Lyme disease (Williams \& Ward, 2010); and they provide nesting areas for White-footed Mice (Peromyscus leucopus) and other rodents that function as reservoir hosts (Linkske et al., 2018). Ward et al. (2013) found that the number of Blacklegged Ticks averaged 297 per hectare in barberry-infested forests compared to 25 per hectare in forests without Barberry. Linkske et al. (2018) found that management of Barberry stands reduced contact opportunities between Blacklegged Ticks and White-footed Mice; they encouraged eradication and control of the invasive shrub to reduce the number of $B$. burgdorferi-infected Blacklegged Ticks. The Kestrel Land Trust of Amherst, Massachusetts (USA) has prioritised control of J apanese Barberry on multiple properties under its conservation management with some success in controlling earlystage infestations. ${ }^{8}$

\section{Practice 9: Educate and change human behaviour}

Human-driven problems require human-targeted solutions. The effectiveness of measures that address human behaviour depends on an understanding of the prevailing socio-economic factors and how they change over time. Muehlenbein (2016) points out that social scientists must play a central role in understanding differing cultural attitudes towards other species, as well as perceived risks when humans interact with animals. He argues that the management of emerging infectious diseases is best accomplished through human behavioural changes rather than disease surveillance.

Messages that promote the value of wildlife while discouraging contact between humans and wildlife are essential in preventing land use-induced spillover, as well as the conservation of biodiversity in protected and conserved areas. Educational efforts by public health officials that blame people for disease outbreaks and/or fail to instill a value in native wildlife can lead to wildlife culling and the destruction of wildlife habitats.

Social marketing approaches have been used successfully to work with communities to identify and implement the human behaviour changes necessary to support conservation and human health goals, separately and combined (MacDonald et al., 2012). For example, in Bangladesh, Hassan et al. (2020) used a standard knowledge and values survey to understand community perceptions and knowledge of bats as they relate to the transmission of Nipah virus. Their findings enabled them to recommend interventions to raise awareness of the zoonotic disease issues and improve local people's knowledge and acceptance of the role of bats. 
In Sri Lanka, Dittus et al. (2019) used a similar approach to understand the social dynamics associated with human-monkey conflicts. They found that 80 per cent of people surveyed in the local community wanted troublesome monkeys translocated from their properties to protected and conserved areas; an impractical solution: very few $(<1 \%)$ wanted them destroyed. They concluded that the combination of a feeding ban, possibly contraceptive intervention at localised conflict spots, and extensive education may provide a benign alternative to the destruction of wild primates favoured by a powerful minority.

\section{Practice 10: Invite interdisciplinary collaborations}

Since protected and conserved areas typically provide strong ecological contrasts between non-disturbed core areas and moderate- to highly-disturbed zones at the periphery, they may serve as natural laboratories for studies of land use-induced spillover. Within the One Health and Planetary Health contexts, Plowright et al. (2020) discuss the need for interdisciplinary collaboration to study the environmental stressors that trigger the infect-shed-spill-spread cascade. Protected and conserved area managers can forge collaborations by, for example, facilitating or undertaking:

A. The surveillance of wildlife for pathogens, particularly birds and mammals likely to come into contact with people (e.g., Uhart et al., 2015) (see Practice 2);

B. Cataloguing protected and conserved area species in research accessible databases. Particular effort should be made to document animal species that can act as zoonotic pathogen hosts or vectors, as well as plant species that provide habitat, food or other resources for these animals. Both native and nonnative species should be included in the databases (see Plowright et al., (2021) and Reaser et al., (2020b) for relevant discussion);

C. Collection of serum samples from wild host species to characterise wildlife health under various environmental conditions (Demas et al., 2011; Plowright et al., 2019); and

D. Data collection on the behavioural and socioeconomic factors that influence wildlife-human proximity (e.g., Dittus et al., 2019) (see Practice 9).

Such work can increase our knowledge of pathogen diversity and distribution, pathogen circulation in wildlife populations, how environmental conditions influence wildlife immune status and infection dynamics, and the drivers of human exposure to zoonotic pathogens. For example, a workshop funded by the Bill and Melinda Gates Foundation in Africa brought mosquito experts together with invasion biologists to discuss the links between invasive alien plants, mosquitoes and associated diseases. The interdisciplinary dialogue identified and facilitated several new paths of research..$^{9}$ In Australia, sampling of Pteropodid bats for Hendra virus has been conducted in collaboration with staff managing several protected and conserved areas. Researchers working with staff from the Queensland Department of Natural Resources were able to locate animals during a food shortage and show a relationship between nutritional stress and Hendra virus seropositivity (Plowright et al., 2008).

\section{CONCLUSION}

The COVID-19 pandemic has shown the staggering global costs of this zoonotic disease outbreak in human lives and money. As pressures on ecological systems mount around the globe, the next pandemic is already in the making. We know protecting nature benefits human health. We also know that protected and conserved areas can be managed to diminish the risk of land useinduced spillover by fostering landscape immunity and preventing contact between animals that host zoonotic pathogens and people. As far as possible, protected and conserved area managers need to keep systems intact, restore degraded ecosystems and facilitate ecological connectivity. Protected and conserved area managers also need to be attentive and responsive to zoonotic disease risk when integrating the needs of wildlife with those of the human communities that live in and around protected and conserved areas.

Nations can no longer treat conservation as a second order priority. The Post-2020 Global Biodiversity Framework that includes decadal revisions of the Convention on Biological Diversity targets, the United Nations Framework Convention on Climate Change, and aligned multi-lateral environmental agreements must now adopt Post-COVID-19 strategies in their forwardlooking agendas, including the aim to place at least 30 per cent of the world in protected and conserved areas by 2030.10 COVID- 19 shows that - as part of these strategies - we should now recognise that protected and conserved areas are at the frontline of public health infrastructure and that their managers are vital to disease prevention. It is now readily apparent that investments in protected and conserved areas are investments in humanity. Looking ahead, we have to conserve nature as if our lives depended on it.

\section{ENDNOTES}

${ }^{1}$ Although zoonotic pathogens have been documented across a diversity of ecosystems, this paper largely focuses on terrestrial and freshwater environments. This reflects the greater depth of knowledge and risks associated with these systems, as well as 
the disciplinary expertise of the authors. We encourage greater attention to zoonotic pathogen dynamics in marine environments.

${ }^{2}$ http://www.glews.net/, accessed 12 November 2020

${ }^{3}$ Guidelines for Assessing the Risk of Non-native Animals Becoming Invasive: https://www.oie.int/fileadmin/Home/eng/ Our_scientific_expertise/docs/pdf/

OIEGuidelines_NonNativeAnimals_2012.pdf, accessed 12 November 2020

${ }^{4}$ https://www.usaid.gov/ept2, accessed 12 November 2020

${ }^{5}$ For example: http://www.batonehealth.org, accessed 12 November 2020

${ }^{6}$ The points made is this paragraph are also applicable to fragment size (Practice 4A)

${ }^{7}$ https://ugaticks.weebly.com/, accessed 12 November 2020

${ }^{8}$ https://www.kestreltrust.org/controlling-invasive-plants-62019/, accessed 12 November 2020

${ }^{9}$ A. Witt, pers. com. Held at Lake Naivasha, near Nairobi, Kenya under CABI contract CPT009350

${ }^{10}$ https://www.cbd.int/doc/c/efb0/1f84/

a892b98d2982a829962b6371/wg2020-02-03-en.pdf, accessed 12 November 2020

${ }^{11}$ https://www.cabi.org/about-cabi/who-we-work-with/key-

donors/, accessed 12 November 2020

\section{ACKNOWLEDGEMENTS}

We thank Robyn Egloff for help developing Figure 1, Eliza Krause for formatting references, and Abi Tamim Vanik for sharing insights and reference material. We are grateful to Brent Mitchell and Adrian Phillips for the invitation to contribute to this special issue, as well as editorial, reviewer, and copyediting contributions that improved the final product. RKP was supported by NSF DEB-1716698, DARPA PREEMPT D18AC00031, and the USDA NIFA Hatch 1015891. HL was supported by a Gordon and Betty Moore Foundation grant to the Yellowstone to Yukon Conservation Initiative which sponsors the IUCN World Commission on Protected Areas Beyond the Aichi Targets Task Force. For CABI, AW acknowledges core support from various agencies. ${ }^{11}$

\section{ABOUT THE AUTHORS}

Jamie K. Reaser is President of Giving Voice to Resilience and adjunct faculty at George Mason University. https:// orcid.org/ 0000-0003-3879-0100

Gary M. Tabor is President of the Center for Large Landscape Conservation and Chair, IUCN/WCPA Connectivity Conservation Specialist Group https:// orcid.org/ 0000-0003-4711-1018

Daniel J. Becker is an assistant professor at the University of Oklahoma. https:// orcid.org/ 0000-00034315-8628

Philip Muruthi is Vice President for Species Conservation and Science at the African Wildlife Foundation.
Arne Witt is CABI's Regional Coordinator (Africa and Asia) for Invasive Alien Species. https:// orcid.org/ 0000-0003-2257-4411

Stephen J. Woodley is Vice-Chair for Science and Biodiversity with IUCN's World Commission on Protected Areas. https:// orchid.org/0000-0003-30746578

Manuel Ruiz-Aravena is a postdoctoral researcher at Montana State University (USA). https:// orcid.org/ 0000-0001-8463-7858

Jonathan A. Patz is Professor and John P. Holton Chair of Health and the Environment at the University of Wisconsin-Madison. https:// orchid.org/ 0000-0002-7131-9698

Valerie Hickey is an environmental scientist working at the World Bank Group.

Peter J. Hudson is the Willaman Professor of Biology at Penn State University. https:/ / orcid.org/ 0000-00030468-3403

Harvey Locke is co-founder and strategic advisor of the Yellowstone to Yukon Conservation Initiative and Chair of the IUCN World Commission on Protected Areas Beyond the Aichi Targets Task Force. https:/ orcid.org/ 0000-0003-3882-5852

Raina K. Plowright is an associate professor of epidemiology at Montana State University. https:// orcid.org/ 0000-0002-3338-6590

\section{REFERENCES}

Agyei, F.Y., Afrifa, A.B. and Agyei-Ohemeng, J. (2019). Humanmonkey conflict and community wildlife management: The case of the Boabeng-fiema monkey sanctuary and Fringed communities in Ghana. International Journal of Biosciences, 14(6): 302-311. doi: 10.12692/ijb/14.6.302-311.

Allen, T., Murray, K.A., Zambrana-Torrelio, C., Morse, S.S., Rondinini, C., Di Marco, M., Breit, N., Olival, K. J. and Daszak, P. (2017). Global hotspots and correlates of emerging infectious zoonotic diseases. Nature Communications, 8 (1124). doi: 10.1038/s41467-017-00923-8.

Andrade, A., Zambrana-Torrelio, C., Vasseur, L., Nelson, C., Carver, S. and Convery, I. (2020). Rewilding for human health. Ecologist, 3 July. https://theecologist.org/2020/jul/03/ rewilding-human-health?fbclid=IwAR3YqdnKtQVEjZfYdBKiLxMY21d013ruse6lqqs4Ul6voU7IrcHf12OK_g; (accessed 23 July 2020).

Aronson, J.C., Blatt, C.M. and Aronson, T.B. (2016). Restoring ecosystem health to improve human health and well-being: physicians and restoration ecologists unite in a common cause. Ecology and Society, 21(4): 39. doi: 10.5751/ES08974-210439.

Becker, D.J., Albery, G.F., Kessler, M.K., Lunn, T.J., Falvo, C.A., Czurják, G.A., Martin, L.B. and Plowright, R.K. (2020). Macroimmunology: The drivers and consequences of spatial 
patterns in wildlife immune defence. Journal of Animal Ecology, 89(4): 972-995. doi: 10.1111/1365-2656.13166.

Betts, M.G., Wolf, C., Ripple, W.J., Phalan, B., Millers, K.A., Duarte, A., Burchart, S.H.M. and Levi, T. (2017). Global forest loss disproportionately erodes biodiversity in intact landscapes. Nature, 547: 441-444. doi: 10.1038/nature23285.

Bloomfield, L.S.P., McIntosh, T.L. and Lambin, E.F. (2020). Habitat fragmentation, livelihood behaviors, and contact between people and nonhuman primates in Africa. Landscape Ecology, 35: 985-1000. doi: 10.1007/ s10980-020-00995-w.

Brearley, G., Rhodes, J., Bradley, A., Baxter, G., Seabrook, L., Lunney, D., Liu, Y. and McAlpine, C. (2013). Wildlife disease prevalence in human-modified landscapes. Biological Review, 88(2): 427-442. doi: 10.1111/brv.12009.

Carlson, C.J. (2020). From PREDICT to prevention, one pandemic later. The Lancet Microbe, 1(1): E6-E7. doi: 10.1016/S26665247(20)30002-1.

Cassirer, E.F., Manlove, K.R., Almberg, E.S., Kamath, P.L., Cox, M., Wolff, P., Roug, A., Shannon, J., Robinson, R., Harris, R.B. and Gonzales, B.J. (2018). Pneumonia in bighorn sheep: Risk and resilience. The Journal of Wildlife Management, 82 (1): 32-45. doi: 10.1002/jwmg.21309.

Cassirer, E., Plowright, R., Manlove, K., Cross, P., Dobson, A., Potter, K. and Hudson, P. (2013). Spatio-temporal dynamics of pneumonia in bighorn sheep. Journal of Animal Ecology, 82(3): 518-528. doi: 10.1111/1365-2656.12031.

Convention on Biological Diversity (2018). Decision adopted by the Conference of the Parties to the Convention on Biological Diversity. 14/8 Protected areas and other effective-area based conservation measures. 30 November 2018, Sharm ElSheikh, Egypt. https://www.cbd.int/doc/decisions/cop-14/cop14-dec-08-en.pdf (accessed 22 October 2020).

Cross, P.C., Lloyd-Smith, J.O., Johnson, P.L. and Getz, W.M., (2005). Duelling timescales of host movement and disease recovery determine invasion of disease in structured populations. Ecology Letters, 8(6): 587-595. doi: 10.1111/ j.1461-0248.2005.00760.x.

Dayer, A.A., Redford, K.H., Campbell, K.J., Dickman, C.R., Epanchin-Niell, R.S., Grosholz, E.D., Hallac, D.E., Leslie, E.F., Richardson, L.A. and Schwartz, M.W. (2020). The unaddressed threat of invasive animals in U.S. National Parks. Biological Invasions, 22: 177-188. doi: 10.1007/s10530 -019-02128-0.

Demas, G.E., Zysling, D.A., Beechler, B.R., Muehlenbein, M.P. and French, S.S. (2011). Beyond phytohaemagglutinin: assessing vertebrate immune function across ecological contexts. Journal of Animal Ecology, 80(4): 710-730. doi: 10.1111/j.1365-2656.2011.01813.x.

Despommier, D., Ellis, B.R. and Wilcox, B.A. (2006). The role of ecotones in emerging infectious disease. EcoHealth, 3(4): 281-289. doi: 10.1007/s10393-006-0063-3.

Díaz, S., Settele, J., Brondízio, E.S., Ngo, H.T., Guèze, M., Agard, J., Arneth, A., et al. (2019). Summary for policymakers of the global assessment report on biodiversity and ecosystem services of the Intergovernmental Science-Policy Platform on Biodiversity and Ecosystem Services. Paris: IPBES Secretariat, 2. doi: 10.5281/zenodo.3553579.

Didier, K.A., Cotterill, A., Douglas-Hamilton, I., Frank, L., Georgiadis, N.J., Graham, M., Ihwagi, F., et al. (2011). Landscape-Scale Conservation Planning of the Ewaso Nyiro: A Model for Land Use Planning in Kenya? Smithsonian
Contributions to Zoology, 632: 105-123. doi: 10.5479/ si.00810282.632.105.

Dittus, W.P.J., Gunathilake, S. and Felder, M. (2019). Assessing public perceptions and solutions to human-monkey conflict from 50 years in Sri Lanka. Folia Primatologica, 90(2): 89-108. doi: 10.1159/000496025.

Dobson, A.P., Pimm, S.L., Hannah, L., Kaufman, L., Ahumada, J.A., Ando, A.W., Bernstein, A., et al. (2020). Ecology and economics for pandemic prevention, Science, 369(6502): 379381. doi: 10.1126/science.abc3189.

Dobson, A., Cattadori, I., Holt, R.D., Ostfeld, R.S., Keesing, F., Krichbaum, K., Rohr, J.R., Perkins, S.E. and Hudson, P.J. (2006). Sacred Cows and Sympathetic Squirrels: The Importance of Biological Diversity to Human Health. PLoS Medicine, 3(6): e231. doi: 10.1371/journal.pmed.0030231.

Ducheyne, E., Mweempwa, C., De Pus, C., Vernieuwe, H., De Deken, R., Hendrickx, G. and Van den Bossche, P. (2009). The impact of habitat fragmentation on tsetse abundance on the plateau of eastern Zambia. Preventive Veterinary Medicine, 91(1): 11-18. doi: 10.1016/ j.prevetmed.2009.05.009.

Dudley, N. (2008). Guidelines for Applying Protected Area Management Categories. Gland, Switzerland: IUCN.

Duffey, D.C., Downer, R and Brinkley, C. (1992). The effectiveness of Helmeted Guineafowl in the control of the deer tick, the vector of Lyme disease. The Wilson Bulletin, 104(2): 342-345

Dunay, E., Apakupakul, K., Leard, S., Palmer, J.L. and Deem, S.L. (2018). Pathogen transmission from humans to great apes is a growing threat to primate conservation. EcoHealth, 15(1): 148-162. doi: 10.1007/s10393-017-1306-1.

Elsen, P.R., Monahan, W.B., Dougherty, E.R. and Merenlender, A.M. (2020). Keeping pace with climate change in global terrestrial protected areas. Science Advances, 6(25): eaay0814. doi: $10.1126 /$ sciadv.aay0814.

Ervin, J., Mulongoy, K.J., Lawrence, K., Game, E., Sheppard, D., Bridgewater, P., Bennett, G., Gidda, S.B. and Bos, P. (2010). Making Protected Areas Relevant: A guide to integrating protected areas into wider landscapes, seascapes and sectoral plans and strategies. $44^{\text {th }}$ edn. Montreal, Quebec, Canada: Convention on Biological Diversity.

Estrada-Peña, A., Ostfeld, R.S., Peterson, A.T., Poulin, R. and de la Fuente, J. (2014). Effects of environmental change on zoonotic disease risk: an ecological primer. Trends in Parasitology, 30(4), 205-214. doi: 10.1016/j.pt.2014.02.003

Evans, T., Olson, S., Watson, J. Gruetzmacher, K., Pruvot, M., Jupiter, S., Wang, S., Clements, T. and Jung, K. (2020). Links between ecological integrity, emerging infectious diseases originating from wildlife, and other aspects of human health an overview of the literature. https://c532f75abb9c1c021b8ce46e473f8aadb72cf2a8ea564b4e6a76.ssl.cf5.rackcdn.com/2 020/05/22/8zqrkmzuna_Links_between_ecological_integrity_a nd_EIDs_originating_from_wildlife.pdf (accessed 21 October 2020).

Faust, C.L., McCallum, H.I., Bloomfield, L.S., Gottdenker, N.L., Gillespie, T.R., Torney, C.J., Dobson, A.P. and Plowright, R.K. (2018). Pathogen spillover during land conversion. Ecology Letters, 21(4): 471-483.

Faust, C.L., Dobson, A.P., Gottdenker, N., Bloomfield, L.S., McCallum, H.I., Gillespie, T.R., Diuk-Wasser, M. and Plowright, R.K. (2017). Null expectations for disease 
dynamics in shrinking habitat: dilution or amplification? Philosophical Transactions of the Royal Society B, 372(1722): 20160173.

Ferguson, K. and Hanks, J. (2012). The effects of protected area and veterinary fencing on wildlife conservation in southern Africa. PARKS, 18(1): 49-60.

Fitzsimons, J., Pulsford, I. and Wescott, J. (eds.)(2013). Linking Australia's Landscapes: Lessons and Opportunities from Large-scale Conservation Networks. Melbourne: CSIRO Publishing.

Gallagher, C., Beierschmitt, A., Cruz, K., Choo, J. and Ketzis, J. (2019). Should monkeys wash their hands and feet: A pilotstudy on source of zoonotic parasite exposure. One Health, 7: 100088A. doi: 10.1016/j.onehlt.2019.100088.

Geldmann, J., Manica, A., Burgess, N.D., Coad, L. and Balmford, A. (2019). A global-level assessment of the effectiveness of protected areas at resisting anthropogenic pressures. Proceedings of the National Academy of Sciences, 116(46): 23209-23215. doi: 10.1073/pnas.1908221116.

Gibbs, E.P.J. (2014). The evolution of One Health: a decade of progress and challenges for the future. Vet Record 174: 8591.

Glass, G.E., Schwartz, B.S., Morgan III, J.M., Johnson, D.T., Noy, P.M. and Israel, E. (1995). Environmental risk factors for Lyme disease identified with geographic information systems. American Journal of Public Health, 85(7): 944-948. doi: 10.2105/ajph.85.7.944.

Global Goal for Nature Group (2020). COVID-19 Response and Recovery: Recommendations for Policy Makers. Washington, DC: World Resources Institute.

Goldberg, T.L., Gillespie, T.R., Rwego, I.B., Estoff, E.L. and Chapman, C.A. (2008). Forest fragmentation as cause of bacterial transmission among nonhuman primates, humans, and livestock, Uganda. Emerging Infectious Diseases, 14(9): 1375-1383. doi: 10.3201/eid1409.071196.

Gómez, A. and Nicholas, E. (2013). Neglected wild life: parasitic biology as a conservation target. International Journal of Parasitology: Parasites and Wildlife, 2: 222-227. doi: 10.1016/ j.ijppaw.2013.07.002.

Gottdenker, N.L., Calzada, J.E., Salañda, A. and Carroll, C.R. (2011). Association of Anthropogenic Land Use Change and Increased Abundance of the Chagas Disease Vector Rhodnius pallescens in a Rural Landscape of Panama. The American Journal of Tropical Medicine and Hygiene, 84(1): 70-77. doi: 10.4269/ajtmh.2011.10-0041.

Grogan, L.F., Berger, L., Rose, K., Grillo, V., Cashins, S.D. and Skerratt, L.F. (2014). Surveillance for Emerging Biodiversity Diseases of Wildlife. PLoS Pathogens, 10(5): e1004015. doi: 10.1371/journal.ppat.1004015.

Hahn, N.E., Proulx, D., Muruthi, P.M., Alberts, S. and Altmann, J. (2003). Gastrointestinal Parasites in Free-Ranging Kenyan Baboons (Papio cynocephalus and P. anubis). International Journal of Primatology, 24: 271-279. doi: 10.1023/ A:1023092915171.

Han, B.A., Kramer, A.M. and Drake, J.M. (2016). Global patterns of zoonotic disease in mammals. Trends in Parasitology, 32 (7): 565-577. doi: doi.org/10.1016/j.pt.2016.04.007.

Hanson, A.J. and DeFries, R. (2007). Ecological mechanisms linking protected areas to surrounding lands. Ecological Applications 17(4): 974-988. doi: 10.1890/05-1098.

Hanson, C. and Campbell, K. (2013). Floreana Island Ecological Restoration: Rodent and Cat Eradication Feasibility Analysis.
Island Conservation, 6. https://www.cbd.int/doc/lifeweb/ Ecuador/images/FeasibilityAnalysis.pdf.

Hassan, M.M., Kalam, M.A., Alam, M., Shano, S., Al Faruq, A., Hossain, M.S., Islam, M.N., Khan, A.S. and Islam, A. (2020). Understanding the community perceptions and knowledge of bats and transmission of Nipah virus in Bangladesh. Animals, 10(10): 1814. doi:10.3390/ani10101814.

Hassel, J.M., Begon, M., Ward, M.J. and Fèvre, E.M. (2017). Urbanization and disease emergence: Dynamics at the wildlife -livestock-human interface. Trends in Ecology and Evolution, 32(1): 55-67. doi: 10.1016/j.tree.2016.09.012.

Henson, A., Williams, D., Dupain, J., Gichohi, H. and Muruthi, P. (2009). The Heartland Conservation Process: enhancing biodiversity conservation and livelihoods through landscapescale conservation planning in Africa. Oryx, 43(4): 508-519. doi: $10.1017 /$ S0030605309990536.

Hess, G. (1996). Disease in metapopulation models: implications for conservation. Ecology, 77(5), 1617-1632. doi: $10.2307 / 2265556$.

Hilty, J., Worboys, G.L., Keeley, A., Woodley, S., Lausche, B., Locke, H., Carr, M., Pulsford I., Pittock, J.,

White, J.W., Theobald, D.M., Levine, J., Reuling, M., Watson, J.E.M., Ament, R. and Tabor, G.M. (2020).

Guidelines for conserving connectivity through ecological networks and corridors. Gland: IUCN. doi: 10.2305/ IUCN.CH.2020.PAG.30.en

Hockings, M., Dudley, N., Elliott, W., Ferreira, M., MacKinnon, K., Pasha, M., Phillips, A., et al. (2020). Editorial essay: COVID19 and protected and conserved areas. PARKS, 26(1): 7-24. doi: 10.2305/IUCN.CH.2020.PARKS-26-1MH.en

Hockings, K. and Humle, T. (2009). Best Practice Guidelines for the Prevention and Mitigation of Conflict Between Humans and Great Apes. Gland: IUCN/SSC Primate Specialist Group (PSG), 37. doi: 10.2305/IUCN.CH.2009.SSC-OP.37.en

Hudson, P.J., Dobson, A.P. and Lafferty, K.D. (2006). Is a healthy ecosystem one that is rich in parasites? Trends in Ecology \& Evolution, 21(7): 381-385. doi: 10.1016/j.tree.2006.04.007.

Imbahale, S.S., Paaijmans, K.P., Mukabana, W.R., Van Lammeren, R., Githeko, A.K. and Takken, W. (2011). A longitudinal study on Anopheles mosquito larval abundance in distinct geographical and environmental settings in western Kenya. Malaria Journal, 10(81). doi: 10.1186/1475-2875-1081.

Jakes, A.F., Jones, P.F., Paige, C.L., Seidler, R.G. and Huijser, M.P. (2018). A fence runs through it: A call for greater attention to the influence of fences on wildlife and ecosystems. Biological Conservation, 227: 310-318. doi: 10.1016/j.biocon.2018.09.026.

Johnson, C.K., Hitchens, P.L., Pandit, P.S., Rushmore, J., Evans, T.S., Young, C.C.W. and Doyle, M.M. (2020). Global shifts in mammalian population trends reveal key predictors of virus spillover risk. Proceedings of the Royal Society B: Biological Sciences, 287(1924). doi: 10.1098/rspb.2019.2736.

Jones, K.E., Patel, N.G., Levy, M.A., Storeygard, A., Balk, D., Gittleman, J.L. and Daszak, P. (2008). Global trends in emerging infectious diseases. Nature, 451: 990-993. doi: 10.1038/nature06536.

Joppa, L.N., Loarie, S.R. and Pimm, S.L. (2008). On the protection of "protected areas". Proceedings of the National Academy of Sciences, 105(18): 6673-6678. doi: 10.1073/ pnas. 0802471105 
Katani, R., Schilling, M.A., Lyimo, B., Tonui, T., Cattadori, I.M., Eblate, E., Martin, A., et al. (2019). Microbial Diversity in Bushmeat Samples Recovered from the Serengeti Ecosystem in Tanzania. Scientific Reports, 9: 18086. doi: 10.1038/s41598-019-53969-7.

Keenleyside, K.A., Dudley, N., Cairns, S., Hall, CM. and Stolton, S. (2012). Ecological Restoration for Protected Areas: Principles, Guidelines and Best Practices. Gland, Switzerland: IUCN.

Keesing, F., Ostfeld, R.S., Okanga, S., Hucket, S., Bayles, B.R., Chaplin-Kramer, R., Fredericks, L.P., et al. (2018). Consequences of integrating livestock and wildlife in an African savanna. Nature Sustainability, 1: 566-573. doi: 10.1038/s41893-018-0149-2.

Krivek, G., Florens, F.B.V, Baiderd, C., Seegobinc, V.O. and Haugaasena, T. (2020). Invasive alien plant control improves foraging habitat quality of a threatened island flying fox. Journal for Nature Conservation, 54: 125805.

Langlois, J.P., Fahrig, L., Merriam, G. and Harvey, A. (2001). Landscape structure influences continental distribution of hantavirus in deer mice. Landscape Ecology, 16: 255-266. doi: 10.1023/A:1011148316537.

Lebarbenchon, C., Poulin, R., Gauthier-Clerc, M. and Thomas, F. (2006). Parasitological consequences of overcrowding in protected areas. EcoHealth, 3: 303-307. doi: 10.1007/s10393006-0067-z.

Linske, M.A., Williams, S.C., Ward, J.S. and Stafford, K.C.3rd. (2018). Indirect Effects of Japanese Barberry Infestations on White-Footed Mice Exposure to Borrelia burgdorferi. Environmental Entomology, 47(4): 795-802. doi: 10.1093/ee/ nvy079.

Liu, X., Blackburn, T.M., Song, T., Wang., X., Huang, C. and Li, Y. (2020). Animal invaders threaten protected areas worldwide. Nature Communications, 11. doi: 10.1038/s41467-020-16719 -2 .

Locke, H., Ellis, E.C., Venter, O., Schuster, R., Ma, K., Shen, X., Woodley, S., Kingston, N., Bhola, N., Strassburg, B.B.N., Paulsch, A., Williams, B. and Watson, J.E.M. (2019). Three global conditions for biodiversity conservation and sustainable use: An implementation framework. National Science Review, 6(6): 1080-1082. doi: 10.1093/nsr/nwz136.

Lopoukhine, N., Crawhall, N., Dudley, N., Figgis, P., Karibuhoye, C., Laffoley, D., Londoño, J.M., MacKinnon, K. and Sandwith, T. (2012). Protected areas: providing natural solutions to $21^{\text {st }}$ Century challenges. Surveys and Perspectives Integrating Environment \& Society, 5(2). https://journals.openedition.org/ sapiens/1254\#entries (accessed 21 October 2020).

Lovejoy, T. (2020). To prevent pandemics, stop disrespecting nature. National Geographic, https:/l www.nationalgeographic.com/science/2020/05/to-preventpandemics-stop-disrespecting-nature/ (accessed September 2020).

Luis, A.D., Hayman, D.T.S., O'Shea, T.J., Cryan, P.M., Gilbert, A.T., Pulliam, J.R.C., Mills, J.N. et al. (2013). A comparison of bats and rodents as reservoirs of zoonotic viruses: are bats special? Proceedings of the Royal Society B: Biological Sciences, 280(1756). doi: 10.1098/rspb.2012.2753.

MacDonald, L., Cairns, G., Angus, K. and Stead, M. (2012). Evidence review: social marketing for the prevention and control of communicable disease. European Centre for Disease Prevention and Control (ECDC). https:// dspace.stir.ac.uk/handle/1893/10391\#.X6rw-5NKiqA.
Macfie, J.E. and Williamson, E.A. (2010). Best Practice Guidelines for Great Ape Tourism. Gland, Switzerland: IUCN/SSC Primate Specialist Group (PSG).

Manore, C., Xu, C. and Fair, J.M. (2020). Climate change is driving expansion of zoonotic disease. Research OUTREACH. https://researchoutreach.org/articles/climate-change-drivingexpansion-zoonotic-diseases/ (accessed 21 October 2020).

Maron, M., Simmonds, J.S. and Watson, J.E.M. (2018). Bold nature retention targets are essential for the global environment agenda. Nature Ecology \& Evolution, 2: 11941195. doi: 10.1038/s41559-018-0595-2.

Massey, A.L., King, A.A. and Foufopoulos, J. (2014). Fencing protected areas: A long-term assessment of the effects of reserve establishment and fencing on African mammalian populations. Biological Conservation, 176: 162-171. doi: 10.1016/j.biocon.2014.05.023.

Mead, P., Hook, S., Niesobecki, S., Ray, J., Meek, J., Delorey, M., Prue, C. and Hinckley, A. (2018). Risk factors for tick exposure in suburban settings in the Northeastern United States. Ticks and Tick-borne Diseases, 9(2): 319-324. doi: 10.1016/j.ttbdis.2017.11.006.

Messina, S., Edwards, D.P., Eens, M. and Costantini, D. (2018). Physiological and immunological responses of birds and mammals to forest degradation: A meta-analysis. Biological Conservation, 224: 223-229. doi: 10.1016/ j.biocon.2018.06.002.

Morlando, S., Schmidt, S. and Logiudice, K. (2011). A habitat restoration that pays for itself via reduction in tick-borne disease risk. Restoration Ecology, 20(4): 498-504. doi: 10.1111/j.1526-100X.2011.00796.x.

Muehlenbein, M.P. (2016). Disease and human/animal interaction. Annual Review of Anthropology, 45: 396-416. doi: 10.1146/ annurev-anthro-102215-100003.

Muruthi, P.M. (2004). African Heartlands: A Science-Based and Pragmatic Approach to Landscape Level Conservation in Africa. Nairobi: African Wildlife Foundation. https:// www.awf.org/sites/default/files/media/Resources/Books $\%$ 2520and\%2520Papers/AWF_Heartlands_paper.pdf

Nelson, R.J., Demas, G.E., Klein, S.L. and Kriegsfeld, L.J. (2020). Seasonal Patterns of Stress, Immune Function, and Disease. Cambridge: Cambridge University Press.

Olival, K.J., Cryan, P.M., Amman, B.R., Baric, R.S., Blehert, D.S., Brook, C.E., Calisher, C.H. et al. (2020). Possibility for reverse zoonotic transmission of SARS-CoV-2 to free-ranging wildlife: A case study of bats. PLoS Pathogens, 16(9): e1008758. doi: 10.1371/journal.ppat. 1008758 .

Olival, K.J., Hosseini, P.R., Zambrana-Torrelio, C., Ross, N., Bogich, T.L. and Daszak, P. (2017). Host and viral traits predict zoonotic spillover from mammals. Nature, 546(7660): 646-650.

Ostfeld, R.S. and LoGiudice, K. (2003). Community disassembly, biodiversity loss, and the erosion of an ecosystem service. Ecological Society of America, 84(6): 1421-1427. doi: 10.1890/02-3125.

Patz, J.A., Daszak, P., Tabor, G.M., Aguirre, A.A., Pearl, M., Epstein, J., Wolfe, N.D. et al. (2004). Unhealthy landscapes: Policy recommendations on land use change and infectious disease emergence. Environmental Health Perspectives, 112 (10): 1092-1098.

Plowright, R.K., Becker, D.J., McCallum, H. and Manlove, K.R. (2019). Sampling to elucidate the dynamics of infections in 
reservoir hosts. Philosophical Transactions of the Royal Society, 374(1782). doi: doi.org/10.1098/rstb.2018.0336.

Plowright, R.K., Eby, P., Hudson, P.J., Smith, I.L., Westcott, D., Bryden, W.L., Middleton, D. et al. (2015). Ecological dynamics of emerging bat virus spillover. Proceedings of the Royal Society B: Biological Sciences, 282(1798). doi: 10.1098/rspb.2014.2124.

Plowright, R.K., Field, H.E., Smith, C., Divljan, A., Palmer, C., Tabor, G.M., Daszak, P. and Foley, J.E. (2008). Reproduction and nutritional stress are risk factors for Hendra virus infection in little red flying foxes (Pteropus scapulatus). Proceedings of the Royal Society of London B: Biological Sciences, 275(1636): 861-869. doi: 10.1098/rspb.2007.1260.

Plowright, R.K., Foley, P., Field, H.E., Dobson, A.P., Foley, J.E., Eby, P., and Daszak P. Urban habituation, ecological connectivity and epidemic dampening: the emergence of Hendra virus from flying foxes (Pteropus spp.). (2011) Proceedings of the Royal Society B: Biological Sciences, 278 (1725): 3703-3712. doi: 10.1098/rspb.2011.0522.

Plowright, R.K., Parish C.R., McCallam, H., Hudson, P.J., Ko, A.I., Graham, A.L. and Lloyd-Smith, J.O. (2017). Pathways to zoonotic spillover. Nature Reviews Microbiology, 15: 502-510. doi: 10.1038/nrmicro.2017.45.

Plowright, R.K., Reaser, J.K, Locke H., Woodley S.J., Patz, J.A., Becker, D., Oppler, G. et al. (2021). Land use-induced spillover: A call to action to safeguard environmental, animal, and human health. The Lancet Planetary Health https:// doi.org/10.1016/S2542-5196(21)00031-0

Purse B.V, Darshan, N., Kasabi, G.S., Gerard, F., Samrat, A., George, C., Vanak, A.T. et al. (2020). Predicting disease risk areas through co-production of spatial models: The example of Kyasanur Forest Disease in India's forest landscapes. PLOS Neglected Tropical Diseases, 14(4): e0008179. https:// doi.org/10.1371/journal.pntd.0008179

Reaser, J.K., Guala, G.F., Simpson, A., Morisette, J.T. and Fuller, P. (2020a). A national invasive species information framework. Biological Invasions, 22: 21-36. doi: 10.1007/ s10530-019-02141-3.

Reaser, J.K., Hunt, B.E., Ruiz-Aravena, M., Tabor, G.M., Patz, J.A., Becker, D., Locke, H., et al., (2020b). Reducing land use-induced spillover risk by fostering landscape immunity: policy priorities for conservation practitioners. Preprint: https:// ecoevorxiv.org/7gd6a/.

Reaser, J.K., Witt, A., Tabor, G.M., Hudson, P.J. and Plowright, R.K. (in press). Ecological countermeasures for preventing zoonotic disease outbreaks: when ecological restoration is a human health imperative. Restoration Ecology doi: 10.1111/ rec. 13357

Rotich, D. (2012). Concept of zoning management in protected areas. Journal of Environment and Earth Sciences, 2(10): 173 -183. doi: 10.1.1.850.5207\&rep=rep1\&type=pdf.

Sapolsky R. (2010). Stress and your body: course guidebook. Palo Alto, CA: Stanford University.

Schonewald-Cox, C.M. and Bayless, J.W. (1986). The boundary model: a geographical analysis of design and conservation of nature reserves. Biological Conservation, 38(4): 305-322. doi: 10.1016/0006-3207(86)90057-1.

Seiler A., Fagundes C.P. and Christian L.M. (2020). The Impact of Everyday Stressors on the Immune System and Health. In: Choukèr A. (eds) Stress Challenges and Immunity in Space (pp. 71-92). Cham, Switzerland: Springer. https:// doi.org/10.1007/978-3-030-16996-1_6

(accessed 23 July 2020).

Shury, T. (2015). The Epidemiology of Bovine Tuberculosis (Mycobacterium Bovis) in the Greater Riding Mountain Ecosystem (Doctoral dissertation, University of Saskatchewan).

Siljander, M., Kuronen, T., Johansson, T., Nziza Munyao, M. and Pellikka, P.K.E. (2020). Primates on the farm - spatial patterns of human-wildlife conflict in forest-agricultural landscape mosaic in Taita Hills, Kenya. Applied Geography, 117: 102185. doi: 10.1016/j.apgeog.2020.102185

Sokolow, S.H., Nova, N., Pepin, K.M., Peel, A.J., Pulliam, J.R.C., Manlove, K., Cross, P.C. et al. (2019). Ecological interventions to prevent and manage zoonotic pathogen spillover. Philosophical Transactions of the Royal Society B: Biological Sciences, 374(1782). doi: 10.1098/rstb.2018.0342.

Stenseth, N.C., Leirs, H., Skonhoft, A., Davis, S.A., Pech, R.P., Andreassen, H.P., Singleton, G.R. et al. (2003). Mice, rats, and people: the bio economics of agricultural rodent pests. Frontiers in Ecology and the Environment, 1(7): 367-375. doi: 10.1890/1540-9295(2003)001[0367:MRAPTB]2.0.CO;2.

Stolton, S. and Dudley, N. (2010). Vital sites: The contribution of protected areas to human health. Washington, DC: World Wildlife Fund and Equilibrium Research. http:// d2ouvy59p0dg6k.cloudfront.net/downloads/vital_sites.pdf (accessed 22 October 2020).

Tabor, G.M. (2002). Defining conservation medicine. In: R. Ostfeld, M.C. Pearl, A.A. Aguirre, G.M. Tabor and C. House (eds), Conservation Medicine: Ecological Health in Practice (pp. 8-16). New York: Oxford University Press.

Terraube, J. (2019). Can protected areas mitigate Lyme disease risk in Fennoscandia? EcoHealth, 16(2): 184-190. doi: 10.1007/s10393-019-01408-4.

Tu, M. (2009). Assessing and managing invasive species within protected areas: A quick guide for protected area managers. Arlington, Virginia: The Nature Conservancy. https:// www.cbd.int/invasive/doc/ias-tnc-guide-2009-en.pdf

Uhart, M., Pérez, A., Rostal, M., Robles E.A., Mendoza, A.P., Nava, A., de Paula, C.D. et al. (2015). A 'One Health' approach to predict emerging zoonoses in the Amazon. One Health, 3: 65-73. doi: 10.13140/RG.2.1.3549.1609.

USDA, NRCS. (2020). The PLANTS Database, http:// plants.usda.gov, National Plant Data Team (19 October 2020).

van Velden, J.L., Wilson, K., Lindsey, P.A., McCallum, H., Moyo, B.H.Z and Biggs, D. (2020). Bushmeat hunting and consumption is a pervasive issue in African savannahs: insights from four protected areas in Malawi. Biodiversity and Conservation, 21: 1443-1464. doi: doi.org/10.1007/s10531020-01944-4

Venter, O., Sanderson, E.W., Magrach, A., Allan, J.R., Beher, J., Jones, K.R., Possingham, H.P. et al. (2016). Sixteen years of change in the global terrestrial human footprint and implications for biodiversity conservation. Nature Communications, 7(1): 1-11. doi: 10.1038/ncomms12558.

Viana, M., Mancy, R., Biek, R., Cleaveland, S., Cross, P.C., LloydSmith, J.O. and Haydon, D.T. (2014). Assembling evidence for identifying reservoirs of infection. Trends in Ecology \& Evolution, 29(5): 270-279. doi: 10.1016/j.tree.2014.03.002.

Vila, M., Espinar, J.K., Hejda, M., Hulme, P.E., Jarosik, V., Maron, J.L., Pergl, J, et al. (2011). Ecological impacts of invasive alien plants: a meta-analysis of their effects on species, 
communities and ecosystems. Ecology Letters: 702-708. doi: 10.1111/j.1461-0248.2011.01628.x.

Ward, J.S., Williams, S.C. and Worthley T.E. (2013). Japanese barberry control methods. University of Connecticut, available at, https://portal.ct.gov/-/media/CAES/DOCUMENTS/ Publications/Special_Bulletins/ SpecialBulletinFeb2013Wardpdf.pdf

Weigle, K.A., Santrich, C., Martinez, F., Valderrama, L. and Saravia, N.G. (1993). Epidemiology of cutaneous leishmaniosis in Colombia: a longitudinal study of the natural history, prevalence, and clinical manifestations. Journal of Infectious Diseases, 168(3): 699-708. doi: 10.1093/ infdis/168.3.699.

Williams, S.C. and Ward, J.S. (2010). Effects of Japanese Barberry (Ranunculales: Berberidaceae) Removal and
Resulting Microclimatic Changes on Ixodes scapularis (Acari: Ixodidae) Abundances in Connecticut, USA. Environmental Entomology, 39(6): 1911-1921. doi: 10.1603/EN10131.

Worboys, G.L., Francis, W.L. and Lockwood, M. (2010). Connectivity conservation management: a global guide. London and Washington, DC: Earthscan.

Young, H.S., McCauley, D.J., Dirzo, R., Nunn, C.L., Campana, M.G., Agwanda, B., Otarola-Castillo, R.R., et al. (2017). Interacting effects of land use and climate on rodent-borne pathogens in central Kenya. Philosophical Transactions of the Royal Society B Biological Sciences 372(1722). doi: 0.1098/ rstb.2016.0116

\section{RESUMEN}

Los sistemas terrestres están sometidos a una presión cada vez mayor debido a la expansión de la población humana y la intensificación del uso de los recursos naturales. En consecuencia, los microorganismos que causan enfermedades están surgiendo a medida que la dinámica de los patógenos en la fauna silvestre se ve alterada por el cambio de uso de la tierra, propiciando un mayor contacto entre la fauna silvestre y las personas. Ofrecemos una breve visión general de los procesos que rigen las "repercusiones inducidas por el uso de la tierra", haciendo hincapié en las condiciones ecológicas que fomentan la "inmunidad del paisaje" y reducen la probabilidad de que la fauna silvestre que alberga los patógenos entre en contacto con las personas. $\mathrm{Si}$ los ecosistemas permanecen saludables, es más probable que la vida silvestre y las personas también lo hagan. Recomendamos diez prácticas para reducir el riesgo de futuras pandemias mediante la gestión de áreas protegidas y conservadas. Nuestras propuestas refuerzan las estrategias de conservación existentes, elevando al mismo tiempo la conservación de la biodiversidad como medida sanitaria prioritaria. La prevención de pandemias subraya la necesidad de considerar la salud humana como un servicio de los ecosistemas. Hacemos un llamamiento para que los marcos de conservación multilaterales reconozcan que los administradores de áreas protegidas y conservadas están en la primera línea de la seguridad y salud públicas.

\section{RÉSUMÉ}

Les systèmes terrestres subissent de plus en plus de pressions en raison de l'expansion de la population humaine et de l'intensification de l'utilisation des ressources naturelles. Par conséquent, les micro-organismes qui causent des maladies émergent à mesure que la dynamique des agents pathogènes dans la faune est modifiée par le changement d'utilisation des terres, mettant davantage en contact la faune et les personnes. Nous donnons un bref aperçu des processus régissant les «conséquences induites par l'utilisation des terres» et mettons l'accent sur les conditions écologiques qui favorisent «l'immunité du paysage», réduisant ainsi la probabilité que la faune qui héberge des agents pathogènes n'entre en contact avec les humains. Si les écosystèmes restent sains, cela sera le cas pour la faune et les humains également. Nous recommandons dix pratiques pour réduire le risque de futures pandémies grâce à la gestion des aires protégées et conservées. Nos propositions renforcent les stratégies de conservation existantes tout en faisant de la conservation de la biodiversité une mesure sanitaire prioritaire. La prévention de la pandémie souligne la nécessité de considérer la santé humaine comme un service écosystémique. Nous appelons les cadres de conservation multilatéraux à reconnaître que les gestionnaires d'aires protégées et conservées se trouvent en première ligne pour la protection de la santé publique. 


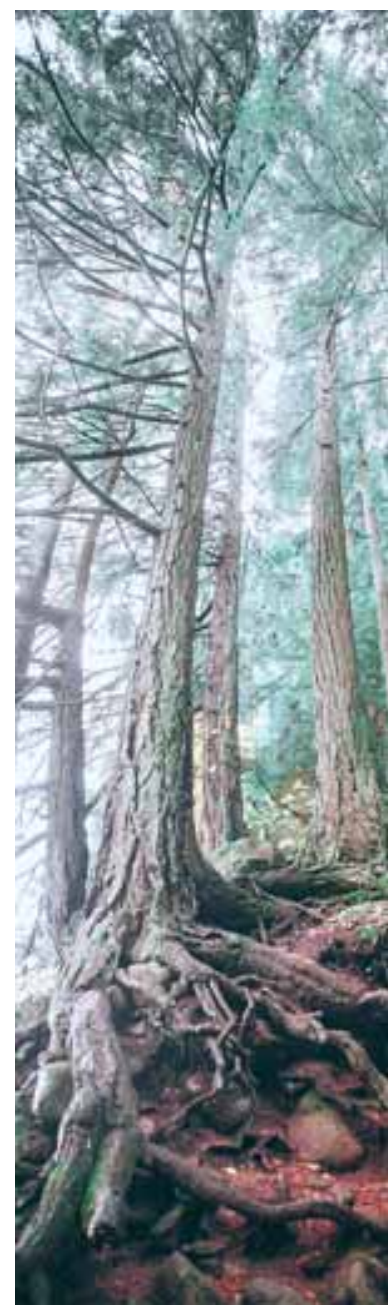

\title{
REFRAMING THE PROBLEM AND SOLUTIONS: TWELVE PERSPECTIVES FROM AROUND THE WORLD
}

\author{
Adrian Phillips'1, Brent A. Mitchell1,2, Gilles Boeuf3, Emily Bohobo N'dombaxe \\ Dola $^{4}$, Yolanda Kakabadse ${ }^{5}$, Ashok Khosla ${ }^{6}$, Richard Louv ${ }^{7}$, Freya Matthews ${ }^{8}$, \\ Elizabeth Maruma Mrema ${ }^{9}$, Mark Poznansky ${ }^{10}$, Fiona Reynolds ${ }^{11}$, Mary \\ Robinson ${ }^{12}$, Richard Roberts ${ }^{13}$, Juan Manuel Santos ${ }^{12}$ and Josefa Cariño \\ Tauli14
}

Corresponding authors: brentmitchell@qlf.org, adrian.phillips@gmx.com

${ }^{1}$ IUCN World Commission on Protected Areas

${ }^{2}$ QLF Atlantic Center for the Environment , USA

${ }^{3}$ Pierre-et-Marie-Curie University, Sorbonne University, France

${ }^{4}$ Youth4Nature

${ }^{5}$ Fundación Futuro Latinoamericano, Ecuador

${ }^{6}$ Development Alternatives, India

${ }^{7}$ Children \& Nature Network, USA

${ }^{8}$ La Trobe University, Australia

${ }^{9}$ Convention on Biological Diversity, Montréal, Canada

${ }^{10}$ Massachusetts General Hospital, USA

${ }^{11}$ Emmanuel College, Cambridge, UK

${ }^{12}$ The Elders

${ }^{13}$ New England Biolabs, USA

${ }^{14}$ Global Youth Biodiversity Network, Philippines

\begin{abstract}
A dozen short essays in the form of personal reflections by distinguished people, the authors of which were all asked to consider the deeper implications of the pandemic and its significance for humanity's relationship with nature. The authors include former Presidents of two countries, two Nobel prize winners, two former Presidents of IUCN, several leading academics, and leaders of international conventions, national and international NGOs, Indigenous Peoples and global youth. Together, they cover every aspect of human endeavour from economics to ethics, and address the roles of the international community, governments, industry, civil society and individuals.
\end{abstract}

Key words: leadership, philosophy, humanity, vision, youth, inter-generational responsibility, nature, global

\section{INTRODUCTION}

When we put together this special issue, we decided to complement the peer-reviewed articles with a collection of voices of distinguished people who have been thinking about the deeper implications of the pandemic and its significance for humanity's relationship with nature.

We asked them all this question:

As we come out of the COVID-19 pandemic, how do you think our ideas about the place of nature in society will have changed and what might that mean for the development of more effective approaches to its conservation, and especially the role of protected areas?
We requested brief, 600-word answers to this question from environmental leaders and scientists around the world. As far as possible, we wanted personal reflections rather than institutional answers.

We were delighted by the responses we received and are grateful for the time and thought that busy people gave to this question. We reproduce their replies below between short bridging commentaries.

There were some clear common themes which came up time and again:

- COVID-19 has reminded us of humanity's dependence on nature. We need it, collectively and as individuals, for our happiness, well-being and survival. 


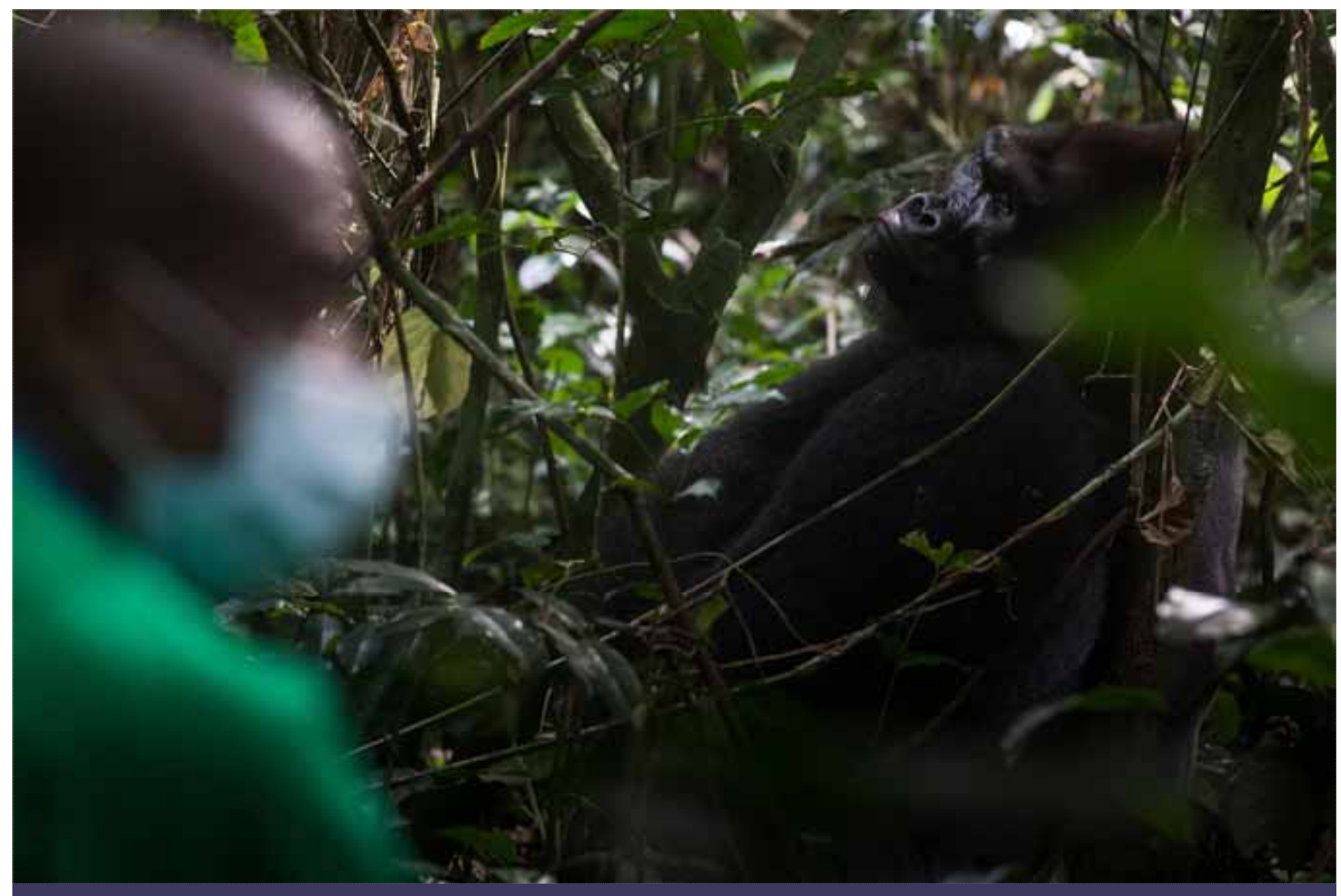

Humans are of course not the only species vulnerable to viruses. A silverback Western Lowland Gorilla known as Kingo. Nouabale-Ndoki National Park, Democratic Republic of Congo, near the border with the Central African Republic. @ Jerome Starkey

- The pandemic is a symptom of our disrupted relationship with nature: it occurs against the background of the only great extinction in our planetary history that has been caused by one species.

- The worldwide abuse of nature that led to the pandemic is paralleled and exacerbated by other alarming global, human-induced changes: climate change and pollution of air, land and water. All stem from the same cause: the excessive demands we make on the planet.

- While the pandemic has been a profound shock, it can also be a once-in-a generation opportunity to reset humanity's relationship with the natural world.

- To do so, we must learn the lessons of the pandemic - above all, the dangers of continuing along the current path of pillaging and destroying nature.

- We should also learn from our response to COVID19. We have shown that we can, with some difficulty, organise society - nationally and globally - for a common purpose.

- But 'Building Back Better' post-COVID cannot mean a return to 'Business as Usual'. Now is the time to address the root causes of our ills: many aspects of our economic system, our unsustainable exploitation of nature and the gross inequalities between peoples.

- All this calls for a spiritual and philosophical renaissance, in which we re-discover our individual and collective dependence on nature, and which puts nature at the heart of how we organise our economy and society in future.

- This is demanding but we have the necessary knowledge - from global plans and targets to Indigenous wisdom; from national conservation strategies to creating and managing protected and conserved areas. The challenge is to make use of what we know.

- If we use that wisdom, learn the lessons of COVID-19 
and act with our descendants in mind, we can make this awful pandemic a turning point towards a fairer, greener, more sustainable world.

Now let our guest writers speak for themselves. Adrian Phillips and Brent Mitchell

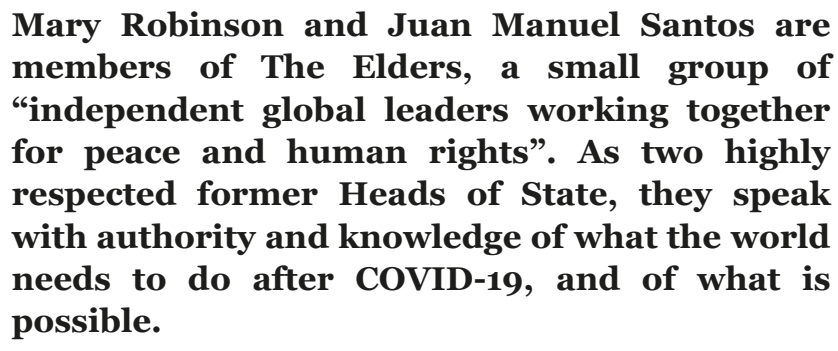

Mary Robinson and Juan Manuel Santos are members of The Elders, a small group of "independent global leaders working together for peace and human rights". As two highly respected former Heads of State, they speak with authority and knowledge of what the world needs to do after COVID-19, and of what is possible.

Mary Robinson was the first woman president of Ireland, a former UN High Commissioner for Human Rights, and is chair of The Elders, an independent group of global leaders working together for peace, justice and human rights.

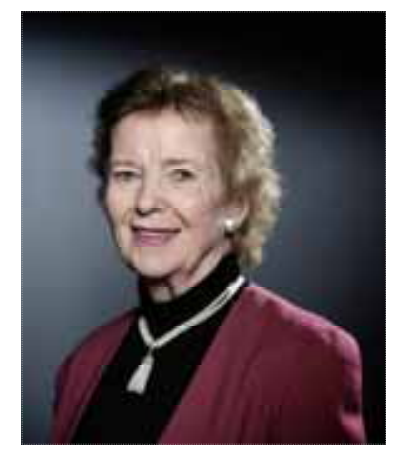

The COVID-19 crisis has created chaos leaving no nation untouched, but it has also taught us lessons. Compliance with social distancing measures has shown us the collective power of changes in our behaviour, when combined with responsible political leadership and effective systems of governance. Just as we can change our behaviour to protect the most vulnerable to a virus, we can also promote a paradigm shift to better protect nature and those most vulnerable to climate change.

The pandemic has underscored the close connections between people, nature and climate. Firstly, we know that to reduce the likelihood of future pandemics and zoonotic threats we must halt the rapid environmental decline we have seen in recent decades. Secondly, in our own lives, the pandemic has acted as a reminder of how completely dependent we all are on healthy and vibrant ecosystems for our well-being, for our medicines, our water and our food.

We have an opportunity to forge a new relationship with nature grounded in good governance, science and compassion. This new approach must recognise that efforts to tackle the climate crisis and biodiversity loss are inextricably linked. Protecting and restoring nature is also key to meeting climate goals, as the loss of biodiversity and extinction of species is one of the many layers of injustice created by the climate crisis. We already have a solid foundation for building back better. Both the 2030 Agenda for Sustainable Development and the Paris Accord should act as cornerstones of a green, healthy, resilient recovery.

In my role on the Global Steering Committee for the Campaign for Nature, I have joined a call on world leaders to protect at least 30 per cent of the planet's land and oceans by 2030 . While the task of protecting these 'Green and Blue Belts' may seem daunting, the science tells us that this is the minimum effort needed to halt global biodiversity loss. However, the last decade has shown us that targets alone are not enough in the face of powerful economic interests driving the destruction of nature, particularly in the industrial agriculture sector. J ust as important are the means of implementation to translate these into real-world change. The Science Based Targets initiative is developing a methodology for companies and cities to internalise environmental limits into their own operations, and set quantifiable, sciencebased, specific goals across their value chains. This is the kind of standard we need for companies and cities to be part of the solution.

As we consider our economic rescue plans in response to the emerging global recession, I believe now is a good time to ask: How can we make this target of 30 per cent tangible? How can we develop standards that governments, the private sector and others can work with? How do we protect nature while simultaneously protecting local communities who live in protected areas? How can we bolster the rights of local and Indigenous communities so they can continue protecting territories that they have been guardians of for generations?

For too long, we have seen ourselves as 'outside of nature'. This separation has become entrenched in every aspect of our lives, and our economic and political systems have been built on extraction at any cost. Indigenous people and many communities in the Global South have much to teach us about a different way of doing things. If we are to truly 'build back better' from the COVID-19 crisis, we must recognise it is only through our connection with nature, and one another, that we have hope of creating a safe, fair, liveable future for us all. This shift in thinking will be huge, but if we are to take some hope from the coronavirus pandemic, it is that we are capable of change. 
Juan Manuel Santos $a$ Conservation International Arnhold Distinguished Fellow, was president of Colombia and the sole recipient of the 2016 Nobel Peace Prize. He is also one of The Elders, an independent group of global leaders working together for peace, justice and human rights.

The current pandemic is remarkable not only for its economic shockwaves but for its impact in galvanising solidarity for 'green recoveries' and emerging recognition that our global economy relies on nature to thrive. Our world remains divided on how we deliver solutions to address global challenges. We are experiencing extraordinary strides forward, such as Europe's historic breakthrough with its ambitious Green Deal, as well as significant setbacks, with countries around the world rolling back environmental protections so that previously protected areas can be used for mining, drilling and accelerated deforestation.

Looking beyond the pandemic, our best hope of unifying all sectors of society and bringing nations together around areas of mutual interest lies in recognising the value of collaborative, science- and nature-based approaches to solving critical global threats. Protected and conserved areas are some of the most effective tools for conservation, and are crucial for sustaining plant and wildlife species, securing livelihoods and mitigating climate change. Well aware of this, we increased natural protected areas in Colombia from 13 million to 43 million hectares, equivalent to the area of Sweden.

As major economies assemble enormous economic packages to cushion the shock of the coronavirus pandemic, investors, politicians and businesses need to integrate the value of our relationship with nature into their decision making to save ourselves and the planet. Our well-being is dependent on healthy, vibrant ecosystems. My home country Colombia is the second most biodiverse nation in the world, but also one of the most vulnerable countries to climate change. In Latin America, the Amazon's Indigenous population is under siege from the impacts of the pandemic and increased deforestation and unprecedented fires that have destroyed massive areas of the world's largest rainforest. Not only has the pandemic taken countless lives, it has also crippled the livelihoods of people that rely on protected areas for income.
There is no pathway to a safe climate which does not also involve significant upscaling of nature-based solutions. According to the UN's biodiversity science body IPBES, global warming is the third biggest factor driving species extinction. And healthy ecosystems are vital in the Earth's ability to absorb CO2. It has been estimated that as much as 37 per cent of the costeffective carbon emissions reductions needed to meet the Paris Agreement can come from the natural climate solutions of stopping deforestation, restoring degraded lands and better managing the way we use land.

I believe these solutions are essential for a sustainable future, which is why we need to support and work with Indigenous peoples and other partners to expand adoption of natural climate solutions. The world's Indigenous peoples have been living in harmony with nature for centuries. They still sustain many of the healthiest ecosystems on Earth. Although today they make up only 5 per cent of the global population, Indigenous peoples effectively manage more than a quarter of all land on Earth and protect about 80 per cent of global biodiversity.

A true 'green recovery' cannot leave behind the communities connected to the very ecosystems we seek to protect. Together with fellow members of The Elders, I have been calling for the ratification of the Escazú Agreement, an historic treaty guaranteeing environmental rights for communities in Latin America and the Caribbean, and providing special protections for environmental human rights defenders.

In the wake of the COVID-19 pandemic, protected and conserved areas and the rights of Indigenous peoples must be at the heart of our future plans to build back better and restore a more sustainable global economy.

Elizabeth Maruma Mrema focuses on the role of the Convention on Biological Diversity, stressing the need for international action on lines that are already widely agreed. She appeals for global solidarity at this critical time.

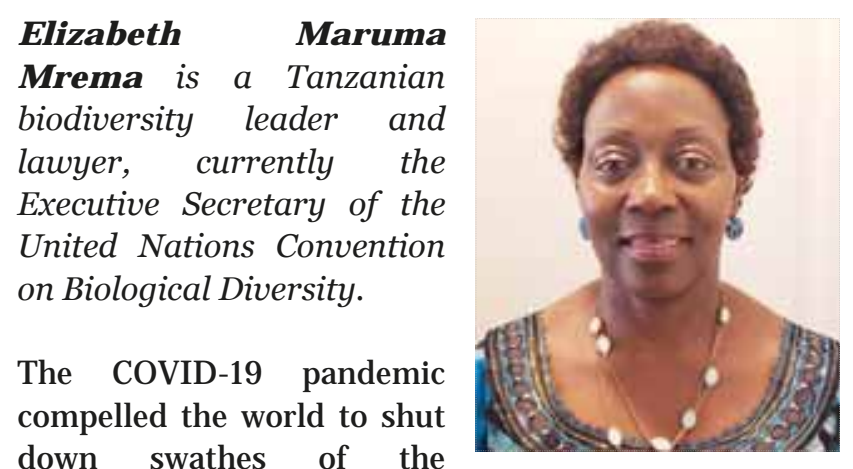


economy and has demonstrated that the foundations of prosperity are precarious. Disasters long talked about, and long ignored, can come upon us with no warning, turning life upside down and shaking all that seemed stable. The COVID-19 pandemic may have ushered in a new kind of war, which could confront humanity with a range of threats for many years yet. Responding to these will call for a more just global order and a determination to deliver far better outcomes for future generations.

One such threat is the biodiversity crisis. Extinction rates are estimated to be 1,000 times the background rate and future rates could soon become 10,000 times higher. In response, the Intergovernmental SciencePolicy Platform on Biodiversity and Ecosystem Services (IPBES) recently launched its 'Global Biodiversity Outlook 5' report. It describes how biodiversity loss, compounded by land degradation, desertification and climate change, now threaten life on Earth in an unprecedented way. These forces reinforce each other. Unless this vicious circle is broken, they will undermine all efforts towards sustainable development and create a dark future for humanity.

In the face of this challenge, the Post-2020 Global Biodiversity Framework is our road map and its implementation a necessity for our survival. The next 10 years will be the most critical of our generation. Without much more determined action, nature will be destroyed on an appalling scale, with ever greater environmental threats and climate-related impacts, including floods, storms, drought, desertification, food shortages, water scarcities, wildfires, sea level rise and depletion of the oceans. To avoid this nightmare future and realise instead the 2050 Vision of Living in Harmony with Nature, the nations of the world must deliver on the 2030 Agenda for Sustainable Development.

The Parties to the Convention on Biological Diversity recognise that protected and conserved areas are cornerstones of biodiversity conservation. They constitute important stocks of natural, cultural and social capital and yield economically valuable goods and services that benefit human populations. If they are to function well, they must be effectively managed and governed with inclusiveness, transparency and equity, and encourage the participation of Indigenous peoples and local communities, and youth, among others.

There is some good news. We are on track to exceed Aichi Target 11 - of 17 per cent of terrestrial areas under protection, and 10 per cent of marine and coastal waters. Almost 20 million $\mathrm{km} 2$ in protected land and sea areas have been added over the last decade. With coherent and concerted effort, globally agreed targets can be achieved.

The COVID-19 pandemic taught us that by working together and in solidarity, we can end the pandemic, tackle its consequences and build resilience against future pandemics. We should transfer that lesson to the challenge of biodiversity by implementing the Post2020 Global Biodiversity Framework. Moving into the post-2020 period, we will need increased ambition and implementation, as well as a greater focus on protected area quality. By leading humanity away from its current destructive course, we can achieve the 2050 Vision of Living in Harmony with Nature. But that will require a concerted effort from all stakeholders: governments; global, regional and sub-regional organisations; nongovernmental organisations, civil society, the private sector, academia and others. If we take one message from COVID-19, it is this: we are all in this together. So, let's all resolve to implement the Post-2020 Global Biodiversity Framework and the 2030 Agenda for Sustainable Development in full and on time. There is no alternative.

As former presidents of IUCN, Yolanda Kakabadse and Ashok Khosla both bring a lifetime of high level experience of international environmental politics. Both are concerned that our relationship with nature urgently needs repair. Unless we act soon, address the faults in the global economic system and begin to value nature properly, the future for both people and nature will be dark indeed.

Yolanda Kakabadse is a former president of both IUCN and WWFInternational, and Ecuador's former minister of the environment.

Pandemics shed light on the fragility of social structures created by human societies to function and interact in

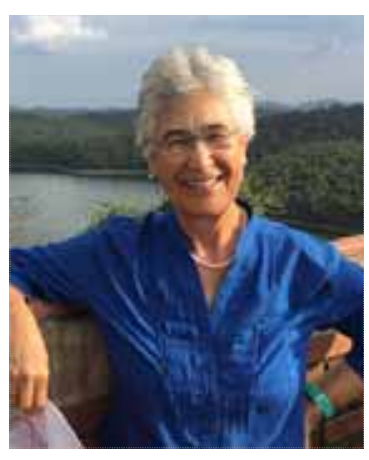
national, regional or global spaces. Pandemics provide evidence of the risks we must face when the links between nature and we humans are broken to prioritise economic or political wins, when the value of biodiversity is not recognised, when protected areas are not considered as a savings account of humanity.

While the coronavirus has brought a great deal of harm to global and national economies, and to the most 
vulnerable sectors of society, it has certainly given us the time to reflect on the links between this crisis and nature, the environment and the natural resources on which life depends. These links have always been there, but we have not done much to recognise their importance.

The direct relationship between the health of humanity and of nature, and the value of this relationship, have not been properly incorporated in economic analyses and projections of human development, nor have they been given the necessary weight in the planning of sustainable development. We have the opportunity now to review this approach and build something different, where nature and especially protected areas are at the centre. The stability of nature is our long-term insurance policy and protected areas are an important part of the balance between humanity's growing needs and desires and the capacity of the planet to meet them. In many parts of the world, protected areas have not been more than lines on a map, and often regarded only as an obstacle to conventional development. The COVID -19 crisis is the perfect opportunity to re-evaluate their importance and recognise the need to invest in programmes that guarantee their integrity. But that will not happen unless they are explored and enjoyed by the common citizen. That's our challenge now: to invest much more in familiarising citizens with the values of nature and the importance of keeping exceptional areas as reserves. We will only protect what we know, understand and care about. The importance of nature and its services to humanity are suddenly a conversation topic, a theme as important as health or job creation. They are being discussed by decision makers and not only by the conservation community. This decade must rescue and strengthen the concept of solidarity: between us and nature, between generations, between countries, between peoples. The discussion has started; it must continue.

Ashok Khosla is the chair of Development Alternatives and former co-chair of the United Nations Environment Programme's International Resource Panel (UNEP-IRP), and a former president of both IUCN and the Club of Rome.

The first priority facing the

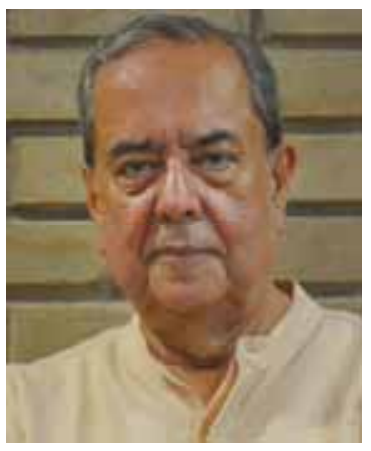
world today must undoubtedly be to place the wellbeing of people and the productivity of nature, now and for the future, at the core of post-COVID-19 economic recovery plans. This is the quickest and surest way to revive the health of our fellow citizens, speed revitalisation of our economies and accelerate the creation of jobs. It will also rebuild the resilience of our economies, ecosystems and institutions to cope more effectively with such emergencies - and prevent them in the future.

Beyond the current COVID-19 pandemic, our world faces many even deeper, more intractable and persistent crises, rooted in a number of interconnected global challenges. Some are manifested locally, such as pervasive poverty and marginalisation, pollution, land use change, and species and habitat loss; others are national or regional, such as deforestation, human and wildlife trafficking, unsustainable trade practices and resource depletion; and some are global, like threats to the climate, biodiversity and oceans - and collapsing international financial and trading systems.

We now understand that the pandemic, along with these other challenges, results from the lopsided value systems and institutional arrangements that underlie our current economic policies and practices. Events like the Dotcom bubble of 2000, the Sub-Prime Mortgage meltdown of 2008 and the current Coronavirus contagion are just the triggers, the proximate causes of our economic crises - the ultimate causes lie hidden from today's governance institutions by the false promises of neo-classical economics and neo-liberal economic policies. If, post-pandemic, these remain and we return to 'business as usual', the world cannot achieve the levels of social justice, resource efficiency and environmental health that all nations say they aspire to.

As most of these threats transcend national or physical borders, international cooperation and a new kind of global solidarity are essential to restore the balance between people and nature and to build future resilience to the existential threats that we will face with increasing regularity and force. Strong new institutional networks and nodal agencies need to be built up at the regional and national levels to act as bridges between global entities such as the UN, WHO, FAO, Red Cross/ Red Crescent, etc., and local institutions working on the ground and on the front line.

The dreaded virus gives us a cruel but serendipitous and critically needed opportunity to press the button to reset the system. Governments, business and civil society must respond by fulfilling their national and global commitments to maximise social and economic equity, minimise greenhouse gas emissions, conserve 
biodiversity, raise resource efficiency and reduce wastes and pollution. We know what needs to be done: we now need to introduce serious policies and practices to replace fossil fuels with renewable energy; protect nature and restore our forests, rivers and degraded lands; and adopt nature-based solutions to replace mechanised, resource-guzzling ones.

Investments in eradicating poverty - and thus completing the demographic transition to a stable world population - and building the resilience of ecosystems that deliver among the highest returns to the economy, now and in the future, are also the lowest cost means for preventing future disasters, natural or manmade. As the recent report on the 'Future of Nature and Business' from the World Economic Forum shows, there is a very strong business and economic case for taking a proactive, bottom-up, systemic approach to addressing such planetary emergencies.

Above all, we must secure the future of our food, water, energy and soil supplies and meet the basic needs of all. We need to: create safe and sustainable food systems by adopting regenerative agriculture; decentralise and revitalise local production systems; and shift to a more inclusive, green and circular economy. Most important of all, we need to protect, regenerate and conserve biodiversity and ecosystem services which are now under greater threat than at any time since an asteroid hit the Earth some 65 million years ago.

E.O. Wilson's call for protecting half the Earth from human predation may not be easy to achieve but it dramatically underlines the gravity of our collective predicament and the urgent need to expand our natural and wilderness areas.

Josefa Cariño Tauli brings an Indigenous perspective. She reminds us that in many places the conservation of nature depends on using Indigenous knowledge and that a pre-requisite is the recognition of Indigenous people's rights.

\footnotetext{
J osefa Cariño Tauli is an Ibaloi-Kankanaey Igorot Indigenous youth from the Cordillera Region in the Philippines. She serves on the Steering Committee of the Global Youth Biodiversity Network (GYBN), the official youth constituency to the UN Convention on Biological Diversity (CBD).
}

The pandemic presents society with a grim and unprecedented crisis. It is a crisis that affects everyone, yet the hardest hit are once again the poor and those who bear the brunt of structural inequality, including Indigenous peoples, children and youth, and women. We see the failings of the unjust systems that have brought us to this situation. But we also see that a massive mobilisation of capacity and resources to solve a pressing global crisis is possible - and we demand that the same effort be urgently extended to fight the looming ecological collapse, for the sake of future generations.

To learn from this pandemic, we must become acutely aware of connectedness: of our connectedness with all other people and places; of the links between past generations and ourselves, and our place as future ancestors to the coming generations; and of the quality of our own connections with nature. We also need to be aware of the inextricable links among the problems we face today: from biodiversity loss and climate breakdown, to inequality and the infringement of human rights, to the loss of cultural diversity and diverse knowledge systems. Thinking in silos is hindering us from addressing the root causes of these crises, with young people shouldering many of the longterm consequences.

Fundamental to building back to a more sustainable world is rebuilding lost connections with nature. Nature thrives where these connections remain strong - and such has been the case in many Indigenous peoples' territories around the world, despite the continuing and often targeted attacks against them. We must shift the conservation paradigm to recognise this and learn from it.

State-recognised protected areas have played a significant role in shaping society's perception of, and relationship with nature. Many people continue to look at protected areas as fortresses-protecting nature from the destructive force that is humanity. Thus, in many parts of the world, they are established, governed and managed in a strict, authoritarian manner, forcefully displacing communities who live within nature in the name of keeping biodiversity-rich areas 'pristine'. This has contributed to the breakdown of people's relationship with nature: rather than seeing ourselves as part of nature with the responsibility to care for our entire home and the basis of our survival and well-being, many have begun to think that, as long as we keep people away from certain beautiful areas, we can keep on wilfully yet blindly exploiting the rest of the Earth. 
Moving forward, we must then take steps to completely cut ties with the colonial and oppressive history of protected areas - towards an area-based conservation that is socially and politically feasible and morally just. First and foremost, we must secure the rights of Indigenous peoples to their collective territories, better enabling them to govern these areas on their own terms through Indigenous and local knowledge, practices and innovations. We must support and stand alongside them in their defence of these territories of life against external threats and destructive industries. We must build legitimacy for a new kind of protected area by proving that it is possible for them to be established and managed in ways that put human rights at the centre, including self-determination and free, prior and informed consent. And we must correct historical wrongs, establishing grievance and accountability measures for past instances of violations such as displacement and territorial capture in the name of conservation.

Indigenous peoples and local communities have the wisdom and knowledge to lead us towards a better path. Mainstream societies who have lost sight of humanity's inherent connections with nature must listen to and learn from them.

Fiona Reynolds offers an essentially national perspective. She reminds us that it is at the national level that action is often most critical and where nature must not only be defended but given scope to expand.

\section{Dame Fiona Reynolds is Master of Emmanuel College, Cambridge, United Kingdom, and is a former Director-General of the National Trust.}

If we ever questioned the dependence of the human spirit on nature, fresh air and beauty, the coronavirus

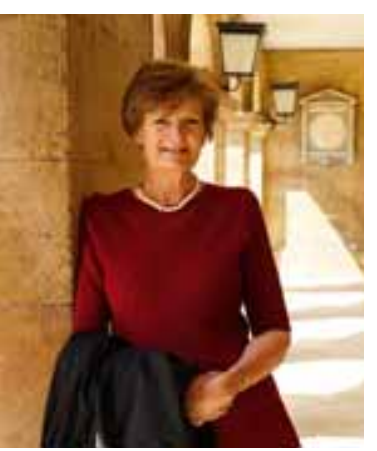
crisis has surely laid an end to it. The sight of people flooding to their local parks, National Parks, tourist hotspots and beaches in one of the sunniest summers on record, in spite of COVID-19 restrictions, sent a clear message. We need fresh air, we need to get outdoors and close to nature, and we'll do almost anything to achieve it.

At a time when many of us were forced to be still, we saw nature in all its glory: perhaps properly for the first time. We watched the first spring flowers unfurl, heard birds sing in the unnatural quiet of an aeroplane-free sky, and because we were advised to take exercise regularly, we exposed ourselves to the fascinating minutiae of daily changes in our surroundings. It made many of us really appreciate nature, close up.

There were downsides too, as we know. Sadly many National Park and local authority rangers had to deal with the pressures caused by mass invasions of beauty spots, littering (and worse), and the casual abandonment of tents and camping gear as if these were festival sites in the worst throw-away society. Yet for many people, unable or unwilling to risk a holiday abroad, this was their first experience of holidaying at home, and it would be wrong to condemn everything about this burst of enthusiasm for the beauty of Britain. Indeed the Glover Review of protected landscapes in England (which reported in September 2019, and on which I sat) argued specifically that we must ensure that more people in Britain get to experience these extraordinary, beautiful places. We have designated 20 per cent of England as either National Parks or Areas of Outstanding Natural Beauty (AONBs) and they are rightly popular, but millions of people from poorer and ethnic minority backgrounds have never been to one. Indeed many have never visited the countryside at all.

We made our recommendations alongside an urgent plea for protected landscapes also to play a stronger role in nature recovery. Since around the 1950s, we have presided over a catastrophic decline in nature, exploiting it faster than its capacity to regenerate, and failing utterly to value the fundamental contribution it makes to our lives and collective future.

Shockingly nature has fared no better within protected landscapes than the wider countryside, yet these are areas where conservation is already a stated objective, where farmers and landowners are primed to play their part, and where authorities exist to support a proactive nature recovery programme, alongside well managed public access to these special places.

Imagine a fifth of England - the whole family of National Parks and AONBs - dedicated to nature recovery, leading the charge in restoring and connecting fragmented habitats; restoring peatland, wetlands, meadows and grassland; and creating new habitats by planting trees, letting field boundaries burgeon and slowing the flow of rivers. Along with land already under nature protection, that would help our country meet the 30 per cent international target for biodiversity conservation already proposed in the draft Post-2020 
Global Biodiversity Framework and accepted by the UK Government.

COVID-19 has given us an unprecedented opportunity to put things right. As David Attenborough has said, we only protect what we care about and only care about what we have experienced. Now we have experienced nature, it's time to prioritise the health of our planet alongside that of our people. To establish new norms to ensure we live within our environmental means, to safeguard nature and stabilise the climate, alongside measures to ensure social and economic well-being for all.

There's never been a better time to re-set our priorities and reverse nature's decline. Because not only do we, as people, need nature; but nature needs us: to value and restore it, for its own and our collective benefit.

Mark Poznansky and Rich Roberts are respectively an immunologist and a molecular biologist. Impressed as they are by the rapid production of successful vaccines to counter the spread of COVID-19, they believe that an even greater achievement would be the avoidance of many future pandemics altogether through the effective protection of nature.

\section{Mark Poznansky is Director of the Vaccine and Immunotherapy Center and Attending Physician in Infectious Diseases Medicine at Massachusetts General Hospital directly involved in the acute care of patients with COVID-19 infection. He is also the Steve and Debbie Gorlin MGH Research

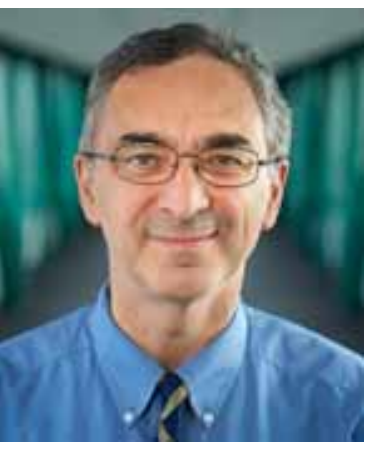 Scholar at MGH and an Associate Professor of Medicine at Harvard Medical School.}

Sir Richard Roberts is Chief Scientific Officer at New England Biolabs, a world leader in the discovery and production of enzymes for molecular biology. Rich was awarded the Nobel Prize in Physiology or Medicine in 1993 for his contribution to the discovery of introns in eukaryotic DNA and the mechanism of gene-splicing.
It seems as if our human species must constantly learn the same lesson over and over again - that human life on planet Earth is inextricably linked with nature and the multitude of animal and plant species that live with us and amongst us in ways that both support and occasionally threaten our survival as a species. Nature nurtures us through its marvellous ecosystems, which support life on the planet, provide us with food and help stabilise the climate. However, nature can also threaten us, as when pathogens that thrive in animal species cross over and cause potentially deadly human infections.

It is likely that the COVID-19 outbreak resulted from markets in which wild animals were bought and sold to large numbers of people in Wuhan, China. We have been aware for decades of the dangers that arise when people live next to wild animals from which viruses can be transmitted. That threat has grown with expanding human populations and greater interference with natural environments.

People are coming to understand the climatic changes caused by the devastation of rainforests and the consequences of mining and burning fossil fuels without limit. Unless we also learn to protect and preserve the natural world that exists alongside us, we face the daunting prospect of a 'pandemic century' where manmade encroachments into the natural world leads to ever more transmission of pathogens from animals to humans.

Usually, when we invent a process that leads to problems, we invent something new to address the problem - when the wheel turns too fast and the object it carries runs out of control, we develop brakes, safety belts and a steering wheel. When fire burns out of control, we invent fire extinguishers and fireproof materials. Inventions beget further inventions. In the case of infectious diseases, the traditional response has been to isolate diseased individuals and - more recently - to make vaccines, which we are now doing with impressive speed. This is a natural human response that is good. But it avoids looking for solutions that address the root cause of the problem.

That is where we, an immunologist and a molecular biologist, believe we find ourselves. The greatest and most impactful healthcare measure - the vaccine - is still only one part of the solution. A vaccine is useful once a pandemic is growing - or, in the case of COVID19 , raging. Safe and effective vaccines prevent the spread of disease, but do not eradicate the source of it. We need also to take the preventative measures to protect, nurture and preserve our natural environment wherever 
possible, and limit the ever-expanding interaction between humans and animals that provokes the transmission of pandemic infections. The old adage applies: "an ounce of prevention is worth a pound of a cure". If civilisation is to avoid a pandemic century, we must educate the public and politicians about zoonoses and act quickly to eliminate the risks inherent in the destruction of natural habitats.

Gilles Boeuf, Richard Louv and Freya Mathews - three thinkers who argue that COVID-19 challenges us to think anew about humanity's often damaged relationship with nature approach this topic from, respectively, biological, philosophical and spiritual standpoints. Theirs is a moving call for us to reawaken our respect for the natural world, upon whose health our own health depends.

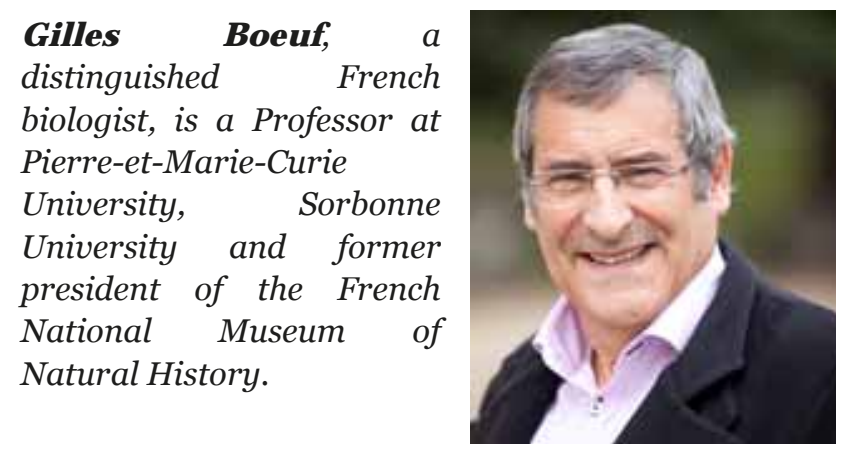

We are not at war against a virus, but against our own failings, our own actions, our own irresponsibility towards the planet. We are, after all, our own enemy. This is due to our culpable servility to dogmas - liberal economics, growth, consumption, property, hurry, and of course profit - in the name of which humanity, blinded by its anthropocentric arrogance, believes itself authorised and even incited to overexploit 'nature' capital to the point of its annihilation. When will there be a real questioning: a sense of what one initiates, builds, spreads; of what one creates, undertakes, shares? And precisely, what should we 'do with' this nature? Or, rather than 'doing with', what can we 'do with respect for' this biodiversity that is now in danger? What can we 'do while being inspired by' this wonder of living species, animals and plants, to which humans belong - humans, who, in their scientific intoxication, believe they possess it? What 'to do', in the end, so that humans' relationship with nature, humans' consideration for nature, no longer cements humanity in the suicide it has programmed, and interrupts the progression of ecocide?
In this period of lockdown and reflection that favours introspection, everyone can rethink the way they interact with other species, their relationships with living things, and the impact of their daily actions on the future. To prepare for the 'day after', let us draw inspiration from living things. When it is sufficiently preserved and in good condition, the diversity of living things amazes us, nourishes us, heals us, maintains us, reassures us, inspires us. In good condition - hence the value of protected areas - it protects us against pathogens (when biodiversity is present, it protects us against pathogens by a 'dilution' effect) and resists the encroachment of invasive plants. How can we escape from this myopia of disaster? Ecologists and epidemiologists have been warning of these possible pandemics since 2003. And it will come back if we continue as before. The acceleration of climate change is acutely challenging our behaviour. March 2020 was the hottest March in 160 years, and the heat waves will follow one another. This COVID-19 crisis is indeed linked to the mistreatment of biodiversity!

So today we have a short window of opportunity to overcome the challenges of the current crisis and avoid sowing the seeds of future ones. Will we be able to take advantage of it? When will we see the end of these markets for living animals in filthy conditions in Asia, an end to the unbridled extirpation of trees and animals in all the world's ecosystems, including tropical forests, and an end to constantly and systematically flouting the thresholds of renewability of life on land and at sea? An end to the perpetual wasting and polluting of water. An end to the 'ecological wheel' that transports everything everywhere, triggering explosions of invasive species and anarchic releases of pathogens of all kinds, viruses and bacteria, responsible for pandemics and so much suffering?

We even need to care, quite viscerally, for the biodiversity within our own bodies - micro biota - since the virus targets people already weakened by a bad relationship between their human cells and symbiotic microbes.

We are biodiversity. We consume it for our food and must cooperate with it for our survival! Yet we constantly forget our dependence on nature. Therefore, let's not go back to the system of an unbridled economy that aims to build a profit on the destruction or overexploitation of our capital: nature and biodiversity. Let us always remember: we are water, salts and cells! Can a small virus composed of only fifteen genes cause the collective electroshock we need? 
Richard Louv is the author of 'Last Child in the Woods: Saving Our Children from NatureDeficit Disorder', 'Our Wild Calling', 'The Nature Principle', 'Vitamin $N$ ' and other books. He is chair emeritus of the Children \& Nature Network.

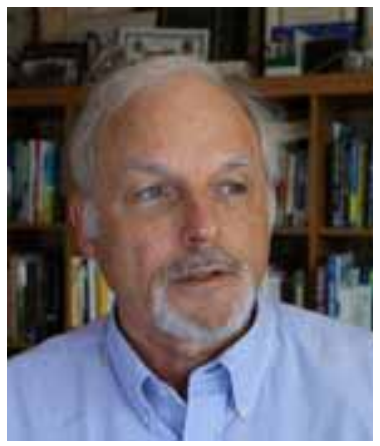

Last year, during Australia's devastating fires, many of us were moved by the images of scorched forests and suffering animals. We watched burned koalas climb onto human laps to reach bottles of water held by people who had lost their own home. They had headed out "with only the clothes on their backs to help injured and burned animals", as an NGO reported.

These images reminded us that we belong to a larger family of animals.

What will it take to move our species to act on the environmental challenges of our time? Science is essential. But data alone will never sufficiently move hearts and minds. We must muster the power of two additional forces. One element is love, a deep emotional attachment to the nature around us. The second is hope - not blind hope, but imaginative hope.

The Australian eco-philosopher Glenn Albrecht argues that only "a shift in the baseline of emotions and values has worked" to transform facts into action in other movements, including feminism, samesex marriage and racial inequities. Each of these causes revolved around the power of relationship. And love.

Human loneliness now ranks with obesity and smoking as an indicator of early death. The breakdown of the extended family, unwalkable cities, anti-social media and the dominance of screens - these are among the reasons for the parallel pandemic of human isolation. But I believe the rise of human loneliness is rooted in something older, deeper - our species loneliness.

We humans are desperate to feel that we are not alone in the universe. And yet, we are surrounded by a great conversation that unites us with other species. If we pay attention.

Today, an expanding body of research suggests that a direct bond with the natural world is fundamental to emotional, physical, cognitive and social health. Partly as a result of that research, a new nature movement has emerged, one that works to connect children, families and communities to the natural world. A growing number of paediatricians are now writing prescriptions for nature time. Biophilic architects are weaving natural elements into workplaces - for aesthetics, but also for increased productivity and reduced sick time.

What if whole cities could be transformed through biophilic design?

As policymakers draw blueprints for a pandemic-altered future, they should envision communities with equitable distribution of parks, wildlife corridors and natural schoolyards, with room for social distancing.

Hope is more realistic if we view climate disruption, biodiversity collapse, zoonotic pandemics and human isolation as a single existential threat with shared solutions. The seeding of vast new multi-species forests and other wildlands could reduce the rate of biodiversity collapse, absorb a substantial amount of $\mathrm{CO} 2$, help slow or reduce global warming and improve human wellbeing. Our species can thrive only if we attend to the health of wildlife and the planet. This is the guiding principle of a public health approach called One Health.

As part of an enlarged environmentalism, positive nature connection should be recognised for what it is: a human right. In 2012, the IUCN World Conservation Congress passed a pioneering resolution called The Child's Right to Connect with Nature and to a Healthy Environment'. For people of all ages, full acknowledgement of that right will require an additional recognition of the rights of nature.

The children of all species may yet live in a nature-rich future, but only if people and countries galvanise the full powers of science, love and imaginative hope.

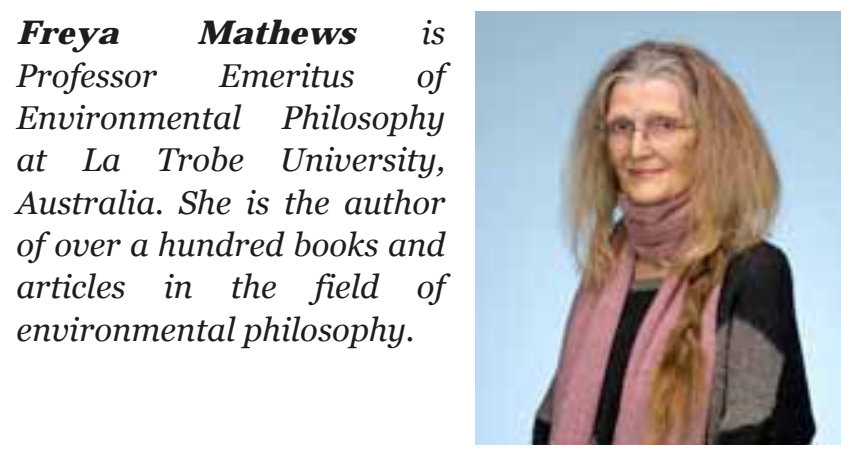

With ecological catastrophe now on a continental scale witness fires in the Arctic, Amazon, Australia and the American West - and the global spread of COVID-19, humanity faces a future in which the certainties that have undergirded civilisation are crumbling. 
To respond to this epochal shift, we will need to convert civilisation itself from biosphere-antagonist to agent of biosphere self-repair. We must create an ecological civilisation: one imbued with ecological consciousness and economically organised around forms of material production and consumption that enhance the richness and diversity of the biosphere.

Different cultures will understand and articulate ecological consciousness in different ways. In Western societies, such consciousness will involve repudiation of the old mechanistic premises of modern industrial civilisation and rest instead on affirmation, in new, scientifically literate ways, of the irreducible agency of living systems, including that of the Earth-system as a whole. As a self-realising system in its own right, organised in such a way as to preserve and increase its own integrity, the biosphere may be seen as embodying self-purpose and self-value. Its integrity is never assured but must be continuously adjusted and renewed via the system's own efforts. When the components of the system all play their own distinctive parts in its ongoing self-configuration, the system flourishes. If some of them fail to do so - or if the system is subject to external impacts to which it is not adapted - then its integrity may be impaired: the system may fall ill, as is currently the case.

The pandemic has taught us, in a way that the prospect of a sixth great extinction event evidently did not, that we ourselves inevitably become embroiled in global processes of ecological dis-integration: such processes not only render the planet progressively uninhabitable but can end up infiltrating the very tissue of our bodies. The COVID-19 virus has revealed that our individual identity as organisms is more attenuated than we perhaps realised. Life on Earth might now appear not merely as a jigsaw of intersecting, co-conforming parts but as an actual 'plasma', a pattern of flows and interflows of living particles in which larger life forms configure themselves as only superficially distinct and stable eddies. Viewed from this perspective, the biosphere presents not merely in relational terms, as a systemic unity in whose webwork we are inextricably enmeshed, but also in such plasmic terms, as a higher order Body or, as ecophilosopher Arne Naess puts it, a larger Self.

Our own telos, as members of an ecological civilisation, will be to discover and then play our distinctive speciesrole in assuring the ongoing unfolding and flourishing of this larger Earth-Self. This will require adherence to core ecological principles of reciprocal accommodation

or biosynergy in every aspect of our lives, including every aspect of our productive praxis. Ecology as an axis for civilisation is in this sense normative: as members of an ecological civilization, we will share a core purpose and a common template for meaning, beyond the contingencies of our various historical cultures and religions.

The Earth-guided process of biosphere self-repair will require protection of all those areas in which the myriad micro- and macro-agents and catalysts of biosphere metabolism remain active. These protected areas are the repositories of information, the 'increase sites', to use the idiom of Aboriginal Australia, from which biosphere integrity can begin to be recovered: within these increase sites, Earth can begin the process of its selfreconstitution. One of our first steps towards ecological civilisation will accordingly be to expand these areas as much as we can, encouraged by the Half-Earth goal that E.O. Wilson has dared to set.

Creating ecological civilisation will be an inter-cultural endeavour drawing on deep cultural synergies across societies. It will articulate itself differently in different parts of the world but converge around this idea: that our purpose, as humans, is to contribute to the ongoing unfolding and flourishing of the living Earth, our larger Self.

Finally, the voice of the next generation. In her 'Urgent Message from Youth', Emily Bohobo N'Dombaxe Dola sets down a challenge to the decision makers of today. Her "tenacious generation" of young people are, she says, committed to fighting for success in both the climate and nature arenas - but asks whether world leaders are ready too.

\section{Emily Bohobo N'Dombaxe Dola is the Storytelling Programme Director at Youth4Nature and a member of the global youth climate- nature movement, focused on agri-food systems, adaptation and resilience, and social/ economic justice.}

In 2019, young people were instrumental in bringing climate and environmental issues to the forefront of international and national politics. From youth-led climate strike marches and online mobilisation efforts to 
a visible and vocal presence at key agenda-setting events, the message from young activists and organisers in 2019 was clear: we need to act now, not only to avoid a menacing future, but also because of existing threats to lives and livelihoods. And we owe it to Planet Earth to put right the harms we have committed in the past.

The voice of youth in 2019 emerged at the same time as nature was being mainstreamed as a solution to climate change. Silos were at last broken down as politicians and organisations acknowledged the importance of integrating climate action with biodiversity action, and with broader work around social and human well-being challenges. By the end of 2019, the 'climate-nature' movement had seemingly gained an unstoppable momentum. The next step was to seize the decisionmaking opportunities presented by the '2020 Super Year for Nature' by acting on the reports from the IPBES and the IPCC.

Little did we know then that the COVID-19 pandemic would dramatically highlight the interplay not only between climate change and the overexploitation of nature and wildlife but also with global issues of precarious employment, poverty, food insecurity, and above all an array of inequalities in terms of health, gender, race, geography, income and urban access to green space. The need for interconnected solutions to these interrelated problems is inescapable. Governments and organisations need to adopt holistic plans in responding to the pandemic, and in building back better' once it is under control.

Youth and civil society movements have long called for all-encompassing approaches and 'systems change' to deal with the climate and biodiversity crises. Not only are these two linked but they cannot be solved without addressing social and economic issues. This has significant implications for climate- and nature-related policies and targets: for example, expanding protected areas and area-based conservation must take account of the voices, rights, knowledge and livelihoods of Indigenous and local communities.

Responding to COVID-19 demands a cross-sectoral and integrated way of seeing the global challenges. While it is disheartening that climate and nature action was somehow relegated to a supporting role in 2020, the pandemic has also been a source of focus, motivation and energy for young activists in the climate-nature space.

With important international gatherings scheduled for 2021, and as post-pandemic plans are drafted, young people strongly feel the responsibility to ensure that the climate-nature momentum is maintained. We need scalable solutions and systemic transformation towards a more just world based on ecological principles. Solidarity and cooperation are being built among young activists from diverse backgrounds working in previously siloed issues like biodiversity, climate, human rights, health and social justice.

Having been part of this hopeful and urgent work during 2020, I can attest that youth are ready for the decisions, conversations and challenges that 2021 will bring. The question now is whether world leaders are ready too: whether they will mirror - or overlook - the courage, collaborative spirit and boldness displayed by our tenacious generation.

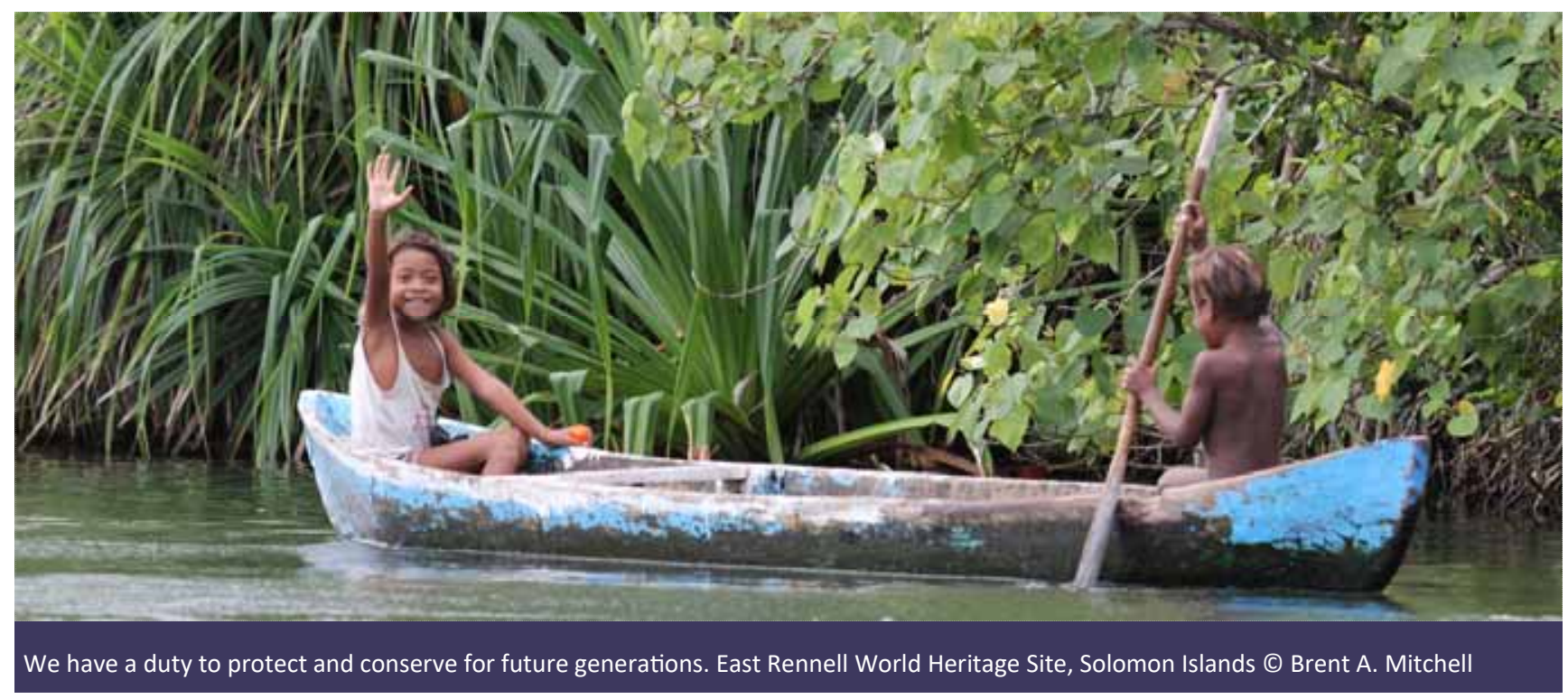




\section{RESUMEN}

Una docena de ensayos cortos en forma de reflexiones personales de un distinguido grupo de personas, a quienes se les pidió que consideraran las implicaciones más profundas de la pandemia y su importancia para la relación de la humanidad con la naturaleza. Entre los autores se encuentran expresidentes de dos países, dos galardonados con el Premio Nobel, dos expresidentes de la UICN, varias personalidades del mundo académico y líderes de convenios internacionales, ONG nacionales e internacionales, pueblos indígenas y representantes de la juventud mundial. J untos, abarcan todos los aspectos del quehacer humano, desde la economía hasta la ética, y abordan el papel de la comunidad internacional, los gobiernos, la industria, la sociedad civil y los individuos.

\section{RÉSUMÉ}

Nous présentons une douzaine de courts essais sous forme de réflexions personnelles par des personnalités éminentes, dont les auteurs ont été invités à se pencher sur les implications plus profondes de la pandémie et son importance pour les relations de l'humanité avec la nature. Parmi les auteurs figurent d'anciens présidents de deux pays, deux lauréats du prix Nobel, deux anciens présidents de l'UICN, plusieurs universitaires de premier plan et des dirigeants de conventions internationales, d'ONG nationales et internationales, de peuples autochtones et de jeunes du monde entier. Ensemble, ils couvrent tous les aspects de l'activité humaine, de l'économie à l'éthique, et abordent les rôles de la communauté internationale, des gouvernements, de l'industrie, de la société civile et des individus. 


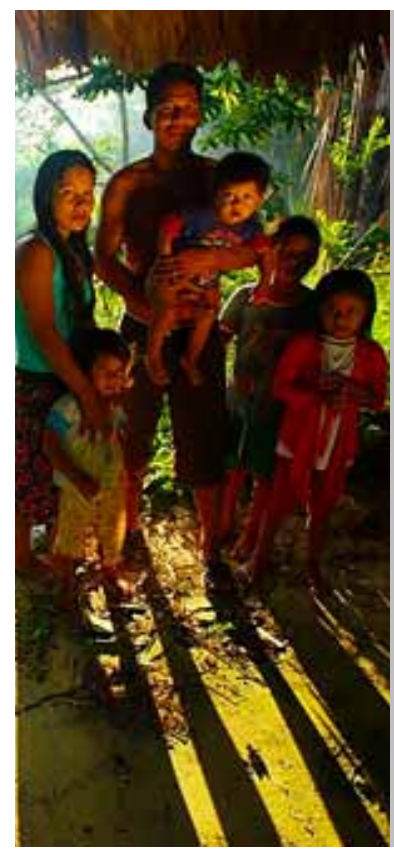

\title{
VITAL SITES: PROTECTED AND CONSERVED
} AREAS OFFER SOLUTIONS FOR BUILDING BACK BETTER

\author{
Bruno Oberle ${ }^{1}$, Kathy MacKinnon² and Trevor Sandwith ${ }^{3^{*}}$ \\ *Corresponding author: Trevor.SANDWITH@iucn.org \\ ${ }^{1}$ IUCN-International Union for the Conservation of Nature, Gland, Switzerland \\ ${ }^{2}$ IUCN World Commission on Protected Areas, UK \\ ${ }^{3}$ IUCN Global Protected and Conserved Areas Programme, Gland, Switzerland
}

\begin{abstract}
The COVID-19 pandemic presents both challenges and opportunities for nature conservation. This paper reviews the social and economic values of protected and conserved areas-in water supply, food security, carbon storage, climate change adaptation, and human health. IUCN is well placed to advocate for a green recovery with protected and conserved areas playing a critical role as cost-effective nature-based solutions, along with better ecosystem management and ecological restoration. The Post-2020 Global Biodiversity Framework of the Convention on Biological Diversity offers a unique moment in time to agree on new priorities for biodiversity conservation and a more sustainable future.
\end{abstract}

Key words: biodiversity, green recovery, nature-based solutions, IUCN, WCPA

The year 2020 has been both extraordinary and worrying. The global COVID-19 pandemic has exposed humankind's critical dependence on nature and healthy ecosystems and what can go wrong when we abuse our natural environment. This has been a wake-up call to humankind that we need to reset our relationship with the natural world. There is good evidence that the pandemic is linked to environmental degradation and we are beginning to see a new understanding of the importance of retaining intact, natural ecosystems and the value of protected and conserved areas (PCAs).

As discussed elsewhere in this volume, the COVID-19 pandemic presents both challenges and opportunities for nature conservation. There is a new appreciation of nature and natural settings as places for physical and mental respite during lockdown, especially in cities and towns. At the same time the pandemic has curtailed travel and tourism to PCAs and other wild places, severely restricting tourism revenues which are vital for employing staff, funding management operations and providing livelihoods for surrounding communities. Paradoxically, the contrasting value and vulnerability of PCAs exposed by the pandemic allows for much better understanding of their potential as a foundation for human security and social, economic and environmental sustainability.

Over the past decades, science and practice have underlined two fundamental truths:

- Natural ecosystems conserve biodiversity and deliver ecosystem services that underpin human health, welfare and well-being. These processes help to maintain a stable climate, water provision, food security, protection against disaster risk, and also contribute to human health and well-being, and even to peace and security.

- Protected and conserved areas when governed and managed effectively are able to maintain intact, functioning and resilient natural ecosystems, halt the loss of biodiversity and maintain essential ecosystem processes and services.

The social and economic values of PCAs have been well documented (Dudley et al., 2010; Stolton \& Dudley, 2010). Many major cities, including New York, Melbourne, Sydney, Karachi, Dar es Salaam and 


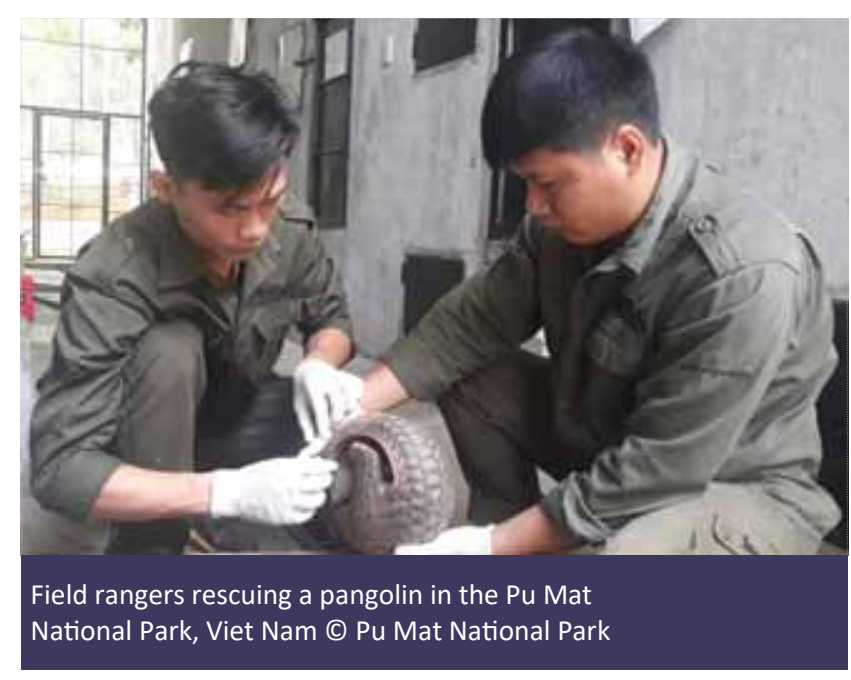

Mumbai, are dependent on PCAs for their domestic water supplies. For example, the Colombian capital Bogota, a city of 8 million people, derives most of its water from the Chingaza National Park. In South America, several water funds are funding local communities in high-altitude protected areas to enhance ecosystem management and secure water supplies. The 11 interconnected protected areas of the Australian Alps conserve catchments which deliver essential water for agriculture in Australia's food bowl, the Murray-Darling Basin, a service which benefits more than 2 million people and has an estimated worth of AU\$10 billion per annum. Marine protected areas also contribute to food security, providing recruitment zones for fish stocks and other marine harvests. Strategically expanding the existing global network of marine protected areas by just 5 per cent could improve future catch by at least 20 per cent (Cabral et al., 2020).

The role of natural ecosystems and PCAs in storing carbon and helping people to cope with climate change is now well recognised (World Bank, 2010; Dudley et al., 2010). Several countries including many in South America, and Madagascar and Mexico have recognised the valuable role that PCAs can play in storing carbon and have integrated PCAs into their climate change strategies, planning and programmes. But PCAs also deliver many other benefits, underpinning human health, well-being and welfare. Research in Victoria, Australia, has demonstrated the positive benefits of public recreation in parks and protected areas for human health and well-being with avoided health-care costs offsetting most of the costs of maintaining the protected area system (Townsend et al., 2015).

Many governments are expressing their intentions to build back greener and better in their recovery programmes post-pandemic (Golden Kroner et al.,
2021). IUCN has a key leadership role to play here, both through the work of the PCA programmes but also through promoting more sustainable nature-based solutions in production landscapes and seascapes and key development sectors. It is clear that many PCAs can deliver multiple goods and services, contributing to human health and recovery from the pandemic. These benefits depend on areas being well managed, well governed and well connected. The IUCN Green List standard provides an important tool for promoting effective management and governance, with more than 30 countries globally already involved in applying the standard. The investment required to achieve effective systems of protected and conserved areas is relatively small when compared with the estimated value of the ecosystem services they provide (Bovarnick et al., 2010).

For the moment, the world is focused on the COVID-19 pandemic, but we shouldn't forget that we are also facing two other longer term, and even more serious crises related to biodiversity and climate change. As countries try to build back better, the greatest gains will come from strategies and programmes that explore and expand the synergies between these agendas. Climate change will require new strategies for conservation and sustainable PCA networks, protecting areas important for biodiversity and carbon, maintaining habitat connectivity in the wider landscape, and encouraging more restoration and sustainable and biodiversityfriendly' practices in surrounding landscapes and seascapes. The roles and benefits of natural ecosystems as green infrastructure will become even more important with climate change.

Protected and conserved areas have a vital role to play as part of green infrastructure and a greener economic future: protecting key watersheds; incorporating riverine forests and wetlands into flood abatement strategies; maintaining and restoring natural habitats for coastal protection. But much more also needs to be done in the broader landscape and seascape to stop overexploitation and habitat degradation and promote more sustainable use. While much lip service is given to the concept of mainstreaming biodiversity, few countries consider the values of ecosystem services in national accounts, and yet the economic benefits are clear. Effective mainstreaming will require integration of nature conservation into land-use and marine spatial plans, harmonised with other development sectors. We need to promote investment and regulation to support the development of green infrastructure, address threats, halt the degradation of land and ocean ecosystems, and remove incentives for unsustainable uses. Maintaining natural ecosystems and services is a 


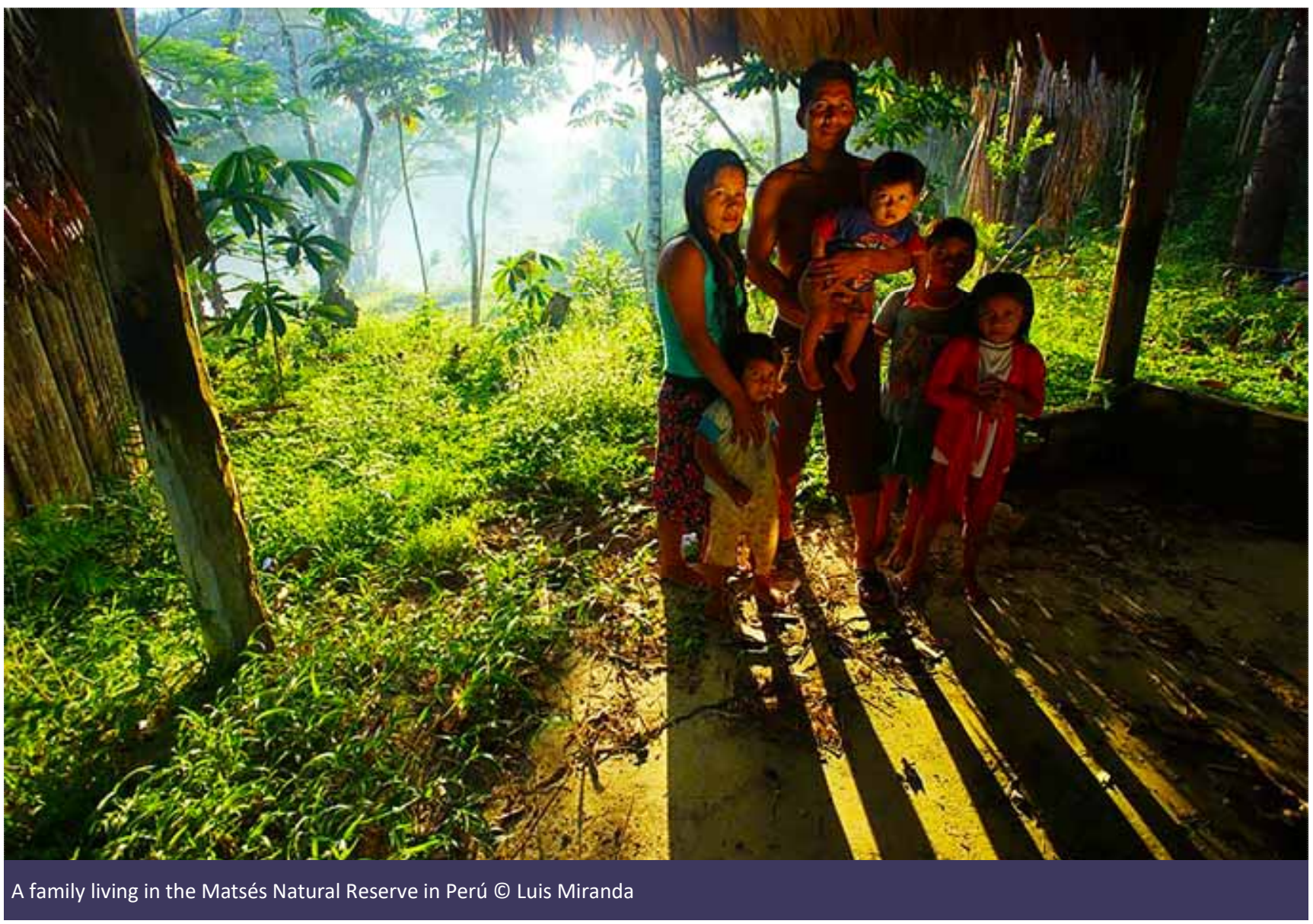

smart investment option since habitat restoration and/ or hard infrastructure are likely to be far more costly.

Achieving these ambitions will require a more rigorous understanding of the economic values of nature conservation and the conditions under which solutions for conservation and development are effective and complementary. There are already some good examples of innovative programmes that provide multiple benefits to people, livelihoods and biodiversity. The Working for Water programme in South Africa, a country faced with chronic water shortages, used levies on water consumption to invest in massive programmes to clear water-hungry invasive alien species from key watersheds. The programme not only improved both the flow and quality of water supplies for domestic use, industry and agriculture but also created new and diverse forms of employment for disenfranchised and marginalised communities, while simultaneously restoring globally significant biodiversity. The success of this approach has promoted its replication to wetlands, coasts, oceans and to the management of fire risk countrywide.
IUCN is well placed to advocate for a green recovery and to promote good practice in PCAs, ecosystem management and ecological restoration. Programmes like \#NatureForAll and the Urban Alliance can help to strengthen the relationship between people and nature. Maintaining, restoring and connecting natural spaces should be a priority for urban planning, including better understanding of cities' dependence on surrounding landscapes and the services they provide (MacKinnon et al. 2019). It will be important to have improved valuation of economic benefits from individual sites and protected and conserved area networks to underpin arguments for strengthened support and innovative conservation financing strategies, including payments for ecosystem services, additional government budgets and financing through major development projects and biodiversity offsets. It is encouraging that some countries, such as New Zealand and Finland, are already investing heavily in conservation as part of their postCOVID-19 recovery plans, strengthening conservation work and creating new employment opportunities. Pakistan, too, has announced an ambitious new project to strengthen and expand its national parks system as part of a green stimulus package designed to provide 
new employment opportunities and address climate change.

The Post-2020 Global Biodiversity Framework of the Convention on Biological Diversity offers a unique moment in time to agree on new priorities for biodiversity conservation and a more sustainable future. IUCN is ready through its Members, Commissions and Secretariat-led programmes to take a leadership role in promoting greener economies, with an emphasis on conserving and restoring healthy ecosystems for healthy societies.

\section{ABOUT THE AUTHORS}

Bruno Oberle is the Director General of the International Union for the Conservation of Nature

Kathy MacKinnon is Chair of IUCN's World Commission on Protected Areas

Trevor Sandwith is Director of IUCN's Global Protected and Conserved Areas Programme

\section{REFERENCES}

Bovarnick, A., Fernandez-Baca, J., Galindo, J. and Negret, H. (2010). Financial Sustainability of Protected Areas in Latin America and the Caribbean: Investment Policy Guidance.
New York and Arlington: United Nations Development Programme and The Nature Conservancy.

Cabral, R.B., Bradley, D., Mayorga, J., Goodell, W., Friedlander, A.M., Sala, E., Costello, C. and Gaines, S.D. (2020). A global network of marine protected areas for food. Proceedings of the National Academy of Sciences, 2020; 202000174 DOI: 10.1073/pnas.2000174117

Dudley, N., Stolton, S., Belokurov, A., Krueger, L., Lopoukhine, N., MacKinnon, K., Sandwith, T. and Sekhran, N. (eds) (2010). Natural Solutions. Protected areas helping people cope with climate change. IUCN-WCPA, TNC, UNDP, WCS, World Bank and WWF.

Golden Kroner,

MacKinnon, K., van Ham, C., Reilly, K. and Hopkins, J. (2019). Nature-Based Solutions and Protected Areas to Improve Urban Biodiversity and Health. In: M. Marseille, J. Stadler, H. Korn, K. Irvine, and A. Bonn (eds.) Biodiversity and Health in the Face of Climate Change. Springer. $481 \mathrm{pp}$.

Stolton, S. and Dudley, N. (2010). Arguments for Protected Areas. Multiple Benefits for Conservation and Use. London: Earthscan.

Townsend, M., Henderson-Wilson, C., Warner E. and Weiss, L. (2015). Healthy parks, healthy people: the state of the evidence. Melbourne: Parks Victoria.

World Bank. (2010). Convenient Solutions to an Inconvenient Truth. Ecosystem-based Approaches to Climate Change. Washington, DC: World Bank.

\section{RESUMEN}

La pandemia del COVID-19 plantea tanto desafíos como oportunidades para la conservación de la naturaleza. En el presente artículo se examina los valores sociales y económicos de las áreas protegidas y conservadas en términos del suministro de agua, la seguridad alimentaria, el almacenamiento de carbono, la adaptación al cambio climático y la salud humana. La UICN se encuentra en una posición idónea para abogar por una recuperación verde en la que las áreas protegidas y conservadas desempeñen un papel fundamental como soluciones rentables basadas en la naturaleza, junto con una mejor gestión de los ecosistemas y la restauración ecológica. El Marco Mundial de la Diversidad Biológica Posterior a 2020 del Convenio sobre la Diversidad Biológica ofrece un momento concreto en el tiempo para acordar nuevas prioridades para la conservación de la biodiversidad y un futuro más sostenible.

\section{RÉSUMÉ}

La pandémie COVID-19 présente à la fois des défis et des opportunités pour la conservation de la nature. Cet article passe en revue les valeurs sociales et économiques des aires protégées et conservées - en ce qui concerne l'approvisionnement en eau, la sécurité alimentaire, le stockage du carbone, l'adaptation au changement climatique et la santé humaine. L'UICN est bien placée pour plaider en faveur d'une restauration verte avec des aires protégées et conservées jouant un rôle essentiel en tant que solutions rentables fondées sur la nature, ainsi qu'une meilleure gestion des écosystèmes et une restauration écologique. Le Cadre mondial de la biodiversité pour l'après-2020 de la Convention sur la diversité biologique offre une occasion unique pour s'accorder sur de nouvelles priorités pour la conservation de la biodiversité et un avenir plus durable. 


\title{
EDITORS' POSTSCRIPT
}

\author{
Adrian Phillips and Brent A. Mitchell
}

This special issue of PARKS is a unique assembly of knowledge at a unique moment in time. The lessons drawn here about the relationship between COVID-19 and the natural world should be quickly learnt and acted upon. The year 2021 represents a narrow window for change.

These are the lessons from the papers we have had the honour to edit:

- the pandemic arose because a dangerous virus was allowed to spill over from wildlife into human populations;

- this was most likely because of the way we have abused and misused the natural world; and

- a local epidemic went global in a matter of weeks because of the interconnected world that we have created.

And these are the overarching messages we extract from the information we gathered:

- set against the billions of dollars that has been spent on dealing with the consequences of the pandemic, and the trillions more that will be spent to get economies moving again, the cost of securing the natural world through an effective system of protected and conserved areas is but a small fraction of that expenditure;

- if the same amount of effort that has been put - with magnificent success and in record time - into the development of vaccines to combat the disease, were to be applied to dealing with the root causes of zoonotic pandemics, we could drastically reduce the threat of future events of this kind; and

- if the shock of COVID-19 is not enough to make humanity wake up to the suicidal consequences of the destructive course of much misguided development, then it is hard to see how further calamities - far worse than the current pandemic - can be avoided.

During the coming year, governments and others will be gathering in a series of international meetings to decide how to stabilise our climate, save biodiversity, secure human health and revive the global economy. Through all these events should run this golden thread: learn the lessons of COVID-19 by protecting nature and restoring damaged ecosystems.

This is the mission that all with the power to bring about change must now pursue. 




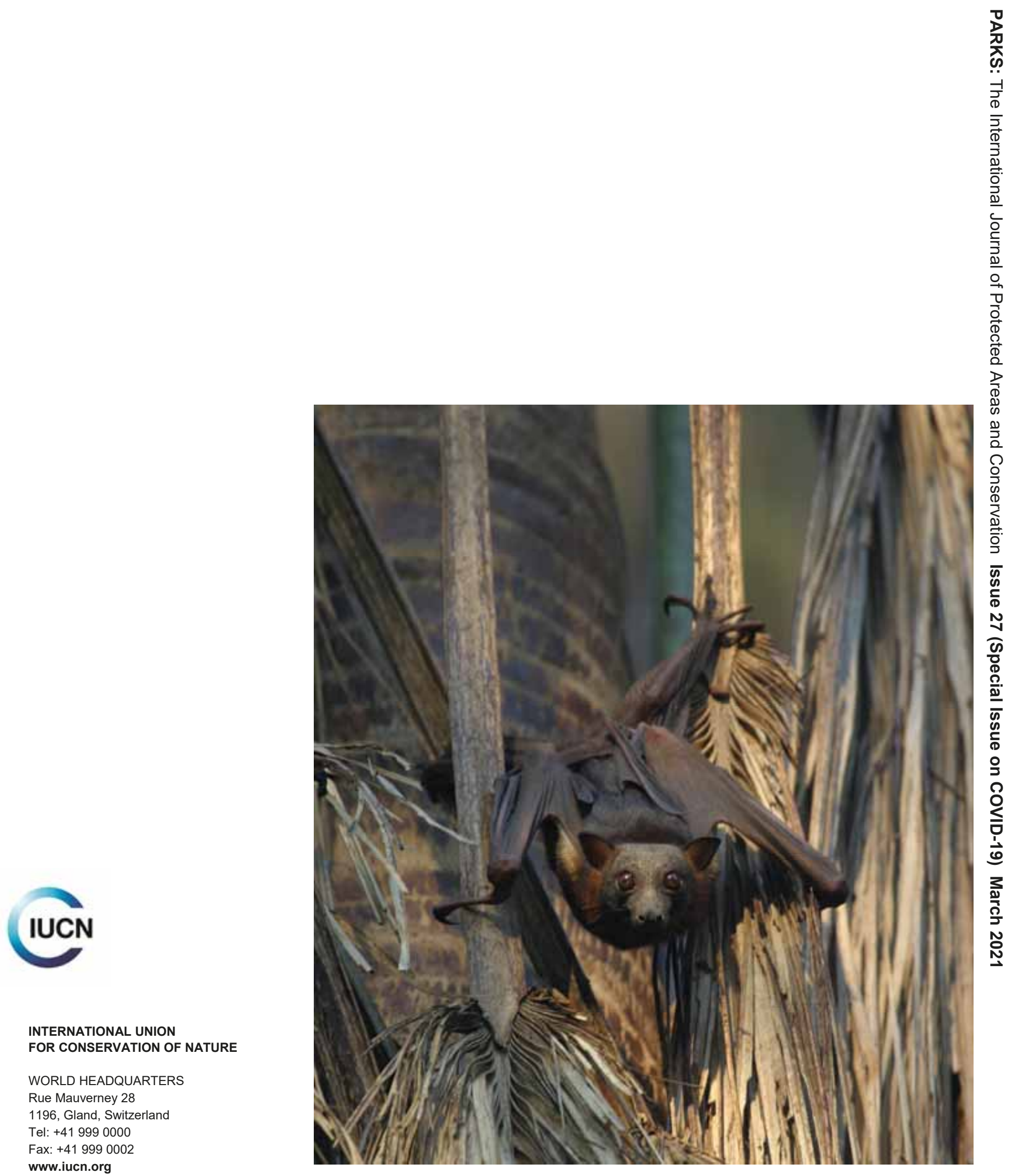

